\author{
UNIVERSIDADE DE SÃO PAULO \\ Instituto de Física \\ Instituto de Química \\ Instituto de Biociências \\ Faculdade de Educação
}

SONIA SALEM

\title{
Perfil, evolução e perspectivas da Pesquisa em Ensino de Física no Brasil
}

SÃO PAULO 

SONIA SALEM

\title{
Perfil, evolução e perspectivas da Pesquisa em Ensino de Física no Brasil
}

\author{
Tese apresentada ao Programa de Pós- \\ Graduação Interunidades em Ensino de \\ Ciências da Universidade de São Paulo, \\ como requisito parcial para obtenção do \\ título de Doutor em Ensino de Ciências. \\ Área de Concentração: Ensino de Física \\ Orientadora: Prof ${ }^{\mathrm{a}}$. Dr ${ }^{\mathrm{a}}$. Maria Regina \\ Dubeux Kawamura
}

SÃO PAULO 
Autorizo a reprodução e divulgação total ou parcial deste trabalho, por qualquer meio convencional ou eletrônico, para fins de estudo e pesquisa, desde que citada a fonte.

\section{FICHA CATALOGRÁFICA}

Preparada pelo Serviço de Biblioteca e Informação do Instituto de Física da Universidade de São Paulo

Salem, Sonia

Perfil, evolução e perspectivas da Pesquisa em Ensino de Física no Brasil. São Paulo, 2012.

Tese (Doutorado) - Universidade de São Paulo.

Faculdade de Educação, Instituto de Física, Instituto de Química e Instituto de Biociências.

Orientadora: Profa. Dra. Maria Regina Dubeux Kawamura

Área de Concentração: Ensino de Física

Unitermos: 1.Ensino; 2. Física; 3. Ciências; 4. Meta-análise 


\section{Agradecimentos}

São muitos e tantos!

Regina.

Regina foi bússola. Sempre.

Me norteou desde que nos encontramos há tanto tempo.

Me deu a mão direita, o Sul, quando o sol nascia. Levantou o austral.

Me orientou em todos os módulos, direções e sentidos. Participou, sinalizou e viveu comigo os nascentes. Me trouxe muitos levantes.

Me ocidentalizou, nos poentes dos dias cansativos, nos momentos de crise, desânimos e ânimos. Ocasionou, causou, motivou, promoveu, provocou, suscitou.

Me aguou e me agüentou!

(Se não fosse a Regina e sua empolgação, certamente não estaríamos hoje aqui.)

Menezes.

Menezes, presente em tantas etapas dessa trajetória sinuosa.

Amigo, professor, orientador e doutor da vida, da poesia, dos limites, dos desafios, dos sonhos, da aventura, do imponderável, do inimaginável. Abriu portas, frentes e diques. Apostou na minha pessoinha, acolheu e emancipou. Também confundiu e balançou!

Menezes, Regina, Yá, João, Demétrio, são parceiros desse meu percurso.

Deram colo, conhecimento e senso de noção e, mais que isso, me auxiliaram a achar minha "casinha", ainda que nesse longuíssimo trajeto quase sempre estivéssemos "fora da casinha".

O que me dá um enorme orgulho e alívio!

Não estou só nesse planeta.

Tenho grandes ícones da história da área como testemunhas e padrinhos.

Sinais de que há vida inteligente e esperanças às margens do Rio Pinheiros e da Raia Olímpica da USP.

Acrescento a eles, gentes muito importantes, relevantes, significativas, especiais, expressivas, interativas, afetivas, que estiveram comigo nos mais variados âmbitos e interfaces, dimensões e perspectivas, dentro e fora da casinha. Ontem, hoje e amanhã, dando apoio, orelha, cerveja, música, poesia, pito, cultura, humor, companhia, e tendo uma enorme paciência com meu jeito ansioso, teimoso, distraído, cansativo... de ser.

Lá vai. 
Vidal e Dulce.

Vida doce, doce vida.

Pai, mãe, amigos. Meus mestres, meus doutores. Meus livres-docentes e titulares. Minhas células, meu DNA. Meus quarks, núcleos, átomos, moléculas. Meu sangue. Meu Sol e minha Lua. Juntos, meu Big-Bang! (Manoela me inspirou nisso!)

Meus brothers, manos, filho, sobrinhos, neta, amigos do peito, da cabeça aos pés, companheiros, terapeutas, poetas, músicos, combustíveis, motores, geradores, transformadores, sinapses e sinopses, inspiradores e conspiradores. Todos orientadores! Todos no meu coração, músculos, órgãos e artérias. Cada um no meu quadrado...

Suzana, Rachel, Fernando, Fábio, Paulo, Fernanda, Manoela, Marcos, Joana, Felipe, Bel, Verônica, Kinha, Tomaz, João, Nina, Van, Leninha, Ná, Bia Auristelina, Marelena, Umbelina, Renata, Marcília, Ligia, Ivã, Gra, Gi, Fred, Bruna, Mané, Cristiano, Demétrio, Robinho (da lanchonete), Ailton, André, Iso, Yoshio, Cristiano, Mazé, Ivone, Helena, Duda, Daniel, Flor, Dô, Renato, Thaís, Maria do Carmo, Kuhn, Freud, Paulo Freire, Gustavo Galo, Beth, Mônica, Maria Augusta, Regina Cândida, Rebeca, Rose, Paulinha, Carla, Aninha, Flávia, Alexandre, Cecil, Leika, Cristina, Secretaria da Pós (Camila, Tomas, Ellen, Rosana), muitos funcionários do IF, Bia, Judith, Fernandinho, Marina, Chico, Gil, Caetano, Noel, Roberto e Erasmo, Paulinho da Viola, Zafenate, Orquestra de Berimbaus, Ambulantes, Titãs, Chá de Boldo, Mia Couto, Isabel Allende, Balzac, Guimarães Rosa, Machado de Assis, Saramago, Monteiro Lobato, Jerry Lewis, Pica-Pau, Galinha-Pintadinha, Cocoricó, Almodovar, Woody Allen, Paciência, Dona Benta, Dicionário Aurélio, Google, Ilha do Cardoso, Coimbra, Morro do Querosene, Sumaré, Ubatuba, Gonçalves, Deserto de Atacama, São Paulo, Sara.

(Sara é hoje, mais que meu nascente, crescente, levante. Sara é minha CHAVE!)

Em especial,

Dulce, ah Dulce! Apoiando hora a hora, desculpando minhas faltas, ouvindo, abraçando, mãezando do jeito mais gostoso e amigo de ser.

Rachel e Paulo pelo apoio e colo, pela força e companhia em momentos difíceis e felizes nesses tempos. Meus bi-pés. A Rachel me deu cores, luzes e letras.

Suzana, irmã solidária, companheira, amiga atenta, sempre com "olhos e coração abertos pra me compreender". (Brigada pela leitura generosa da apresentação!)

Fernando com sua arte, afeto e leituras ricas do meu viver.

Renata. Me su(portando) dia-a-dia, com orelhas antenadas, com uma calma invejável, e sempre dando contribuições, artísticas, técnicas e ternas.

Bia, no dia-a-dia, me garantindo suportes essenciais de sobrevivência e de vivência.

Todos recolhendo minhas chaves, óculos, pen-drives e celulares...

Dedico ao Vidal e à Dulce. 
Valeu, Sô.

Por todos esses muitos cotidianos, pinturas de mãos e demãos.

Múltiplas caminhadas.

Pelas muitas empreitadas compartilhadas.

Pelos becos sem saída e pelas avenidas pavimentadas.

Pelo trabalho e pelo além do trabalho.

Vivências, sonhos acordados e dormindo.

Mas, sobretudo, por ter transformado parte disso tudo nos sólidos tijolos dessas páginas.

E com eles re-construído uma "casinha".

Uma casa para todos nós que acreditamos nela.

Um jardim onde novas idéias possam crescer.

Obrigada, por mim e por todos mais.

Regina

(orientação é apenas sintonia, simetria e parceria) 

Retratos não guardam a objetividade, tampouco a nitidez que deles esperamos.

Estão sempre um pouco desfocados.

Conservam o recorte da perspectiva. Dependem de uma série de fatores externos, do acaso, do imponderável, que estão muito além das circunstâncias técnicas. Trazem manchas de luz, súbitas obscuridades, deformações. (José Velloso) 

SALEM, Sonia. Perfil, evolução e perspectivas da Pesquisa em Ensino de Física no Brasil. 2012. 385f. Tese (Doutorado) - Universidade de São Paulo, São Paulo, 2012.

Ao longo de quase quatro décadas, a área de Ensino de Física no Brasil vem se expandindo e ganhando uma identidade própria, quer como campo de pesquisa, quer como espaço de propostas, intervenções e projetos pautados e planejados segundo o conhecimento produzido na área. Acompanhar a evolução dessa trajetória é fundamental para uma demarcação da área e, sobretudo, para construir uma consciência coletiva da comunidade de pesquisa, ampliar a discussão sobre seus problemas e possíveis rumos. Nessa perspectiva, investigamos a dinâmica de evolução da área de Pesquisa em Ensino de Física no Brasil, desde suas origens até o momento atual, analisando seu desenvolvimento, focos de interesse, tendências e perspectivas. Para isso, tomamos como universo de investigação as dissertações e teses produzidas na área de Ensino de Física ao longo de sua trajetória, desde sua institucionalização, no início dos anos setenta, até o final da primeira década de 2000. Com base nos resultados da pesquisa, discutimos marcos e marcas significativas que dão identidade a essa área, sinalizando tendências e desafios atuais.

Palavras-chave: Pesquisa em Ensino de Física; Pesquisa em Ensino de Ciências; MetaAnálise. 

SALEM, Sonia. Outlines of the evolution and perspectives of Physics Education In Brazil. 385f. 2012. Tese (Doutorado) - Universidade de São Paulo, São Paulo, 2012.

In the course of the last four decades, Physics Education in Brazil has been intensively developed acquiring a proper and autonomous identity as a field, due both to researches and to a multiple set of activities, propositions and projects based in its investigations results. It seems important to follow the development and evolution of this field in order to allow teachers to be conscious of its meaning, creating collective perceptions, delimiting possible frontiers and contributing to discuss its future perspectives. With this purpose, we investigated the dynamic of the evolution of the Physics Teaching Research in Brazil, from its beginnings to present time. We analyzed a sample of Physics Teaching dissertations and theses produced along the years, in all research centers in Brazil, identifying focus of interests, approaches, arguments and major currents of the production. Our results allow a panoramic overview of its evolution, distinguishing different stages and tendencies and providing significant feedback to identify and face actual and future challenges.

Keywords: Physics Education Researches; Science Education Researches; Meta-Analysis Topics 

Sumário

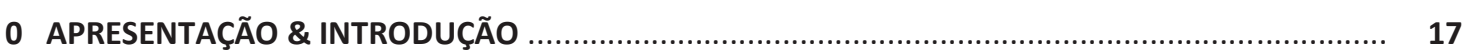

1 O ESTADO DA ARTE DOS ESTADOS DA ARTE DA PESQUISA EM ENSINO DE FÍSICA .................... 29

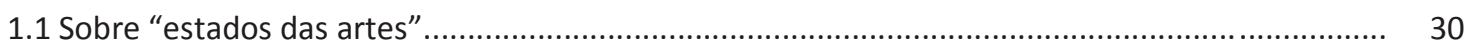

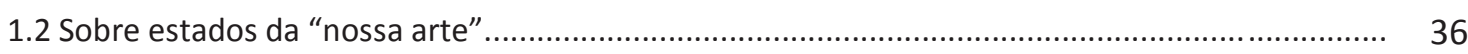

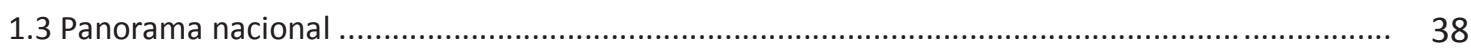

1.4 Características e tendências recentes .......................................................................... 43

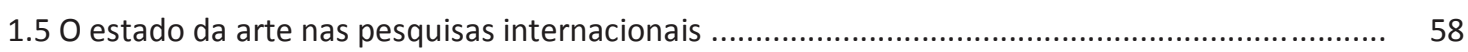

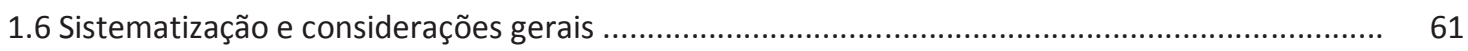

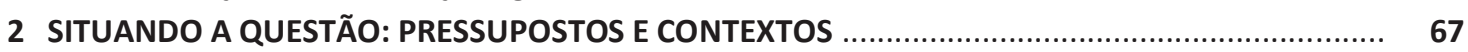

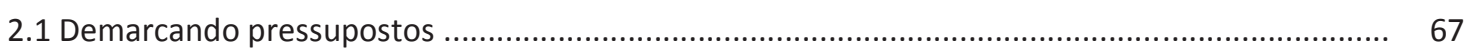

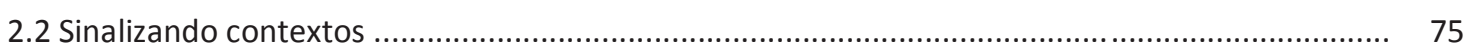

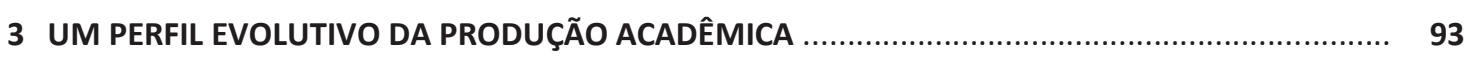

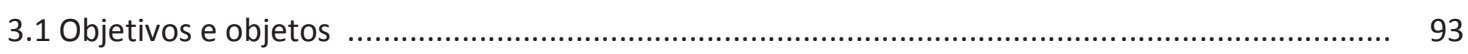

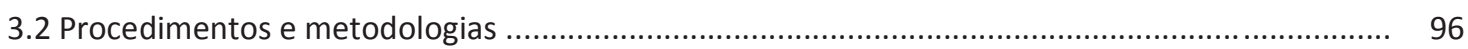

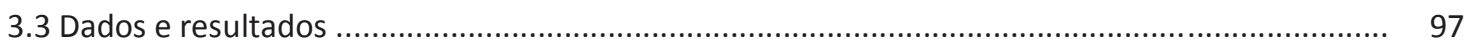

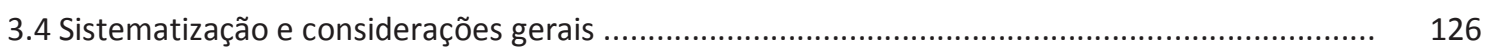

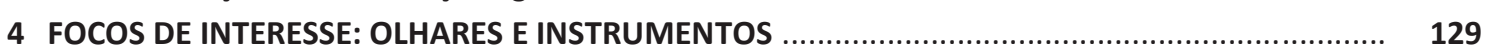

4.1 Temas, áreas e focos temáticos: vertentes de investigação ........................................................ 131

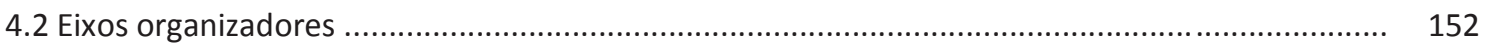

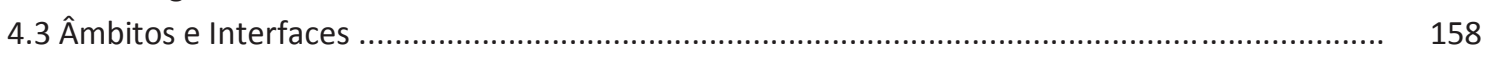

4.4 Sistematização e considerações gerais .............................................................................. 161

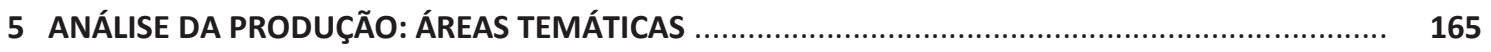

5.1 Evolução segundo áreas temáticas: aspectos gerais .............................................................. 168

5.2 Evolução segundo áreas temáticas: aspectos específicos .............................................................. 174

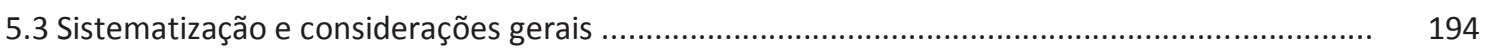

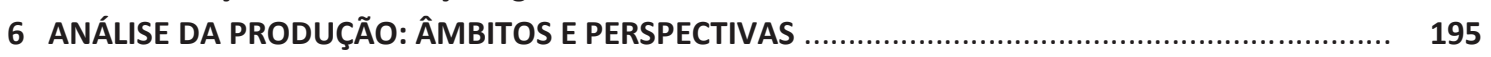

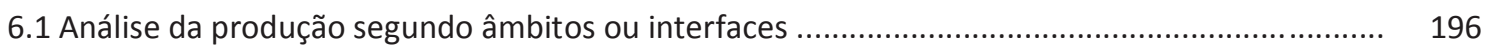

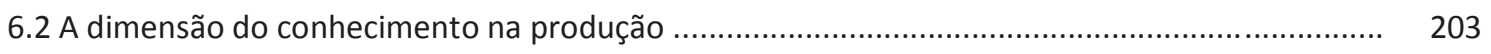

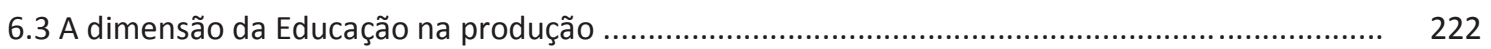

6.4 Sistematização e considerações gerais ............................................................................ 224

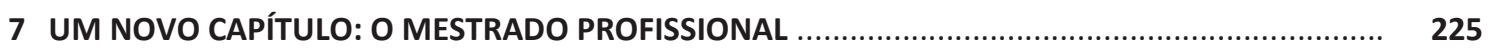

7.10 Mestrado Profissional: questões em pauta e panorama geral .................................................. 226

7.2 O Mestrado Profissional na área de Ensino de Ciências: um perfil emergente ........................... $\quad 244$

7.3 Produção do Mestrado Profissional em Ensino de Física ......................................................... 253

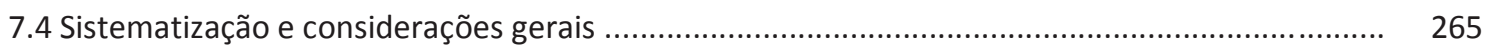

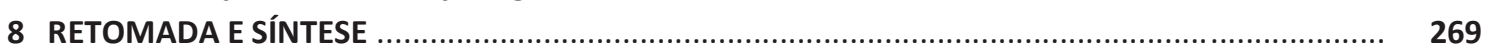

8.1 Retomando questões de pesquisa .......................................................................... 270

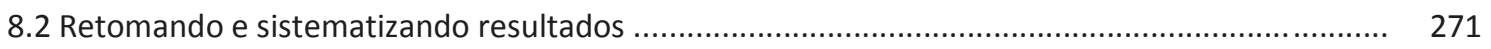

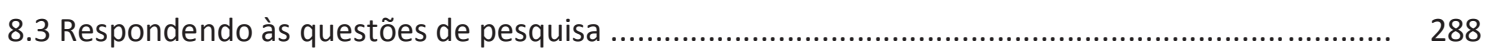

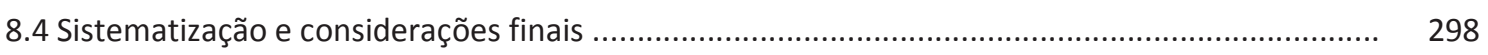

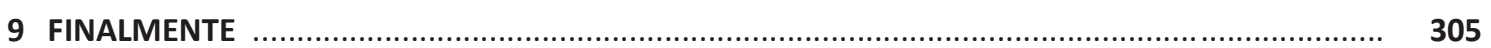

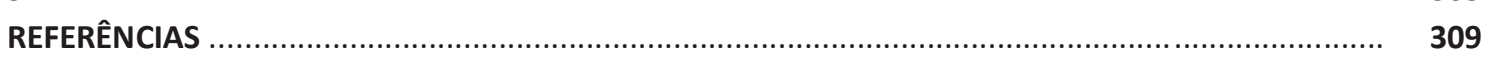

$\begin{array}{ll}\text { ANEXOS } & 317\end{array}$ 



\section{Apresentação \& Introdução}

\section{(ou vice-versa)}

O importante não é a casa onde moramos, mas onde, em nós, a casa mora. (Mia Couto)

Ao longo de muitas décadas, a área Ensino de Física no Brasil vem se consolidando e ganhando uma identidade própria, seja como campo de pesquisa, seja como espaço de produção de propostas, intervenções e projetos, pautados e planejados segundo o conhecimento produzido.

Ainda que seja difícil delimitar com precisão suas origens, na medida em que as preocupações com o ensino de Física acompanharam a presença dessa ciência na estrutura curricular, pode-se localizar sua gênese, enquanto campo de produção e pesquisa, na década de 1960, quando projetos de ensino foram desenvolvidos por docentes e pesquisadores preocupados com a melhoria da educação nesse campo, seguidos, na década de 1970, pela sua institucionalização, por meio da implantação de programas de pós-graduação nessa área.

Hoje, ano de 2012, meio século nos separa dessas origens. Ao longo desse período a área cresceu, diversificou-se, consolidou-se, e o acúmulo de experiência e conhecimento produzido indica a necessidade de reflexão e análise crítica dessa evolução. A revisão de caminhos é oportuna e, explicitando sentidos e significados, deverá sinalizar trajetórias.

Esse é o cenário em que propomos nos mover e descortinar, dentro de muitas limitações que se impõem para isso, pretendendo uma reconstrução dos percursos, motivações, interesses e desafios dessa área.

\section{“Eu na Área”}

De certo modo, foi também nesse período que "nasci e cresci" nesse campo.

O ano de 1970 marca a década em que inicio e termino a graduação: licenciatura e bacharelado em Física. Já nos primeiros anos dessa formação, antes de qualquer direcionamento profissional, começo a ter contato com a área de ensino. Como aluna no primeiro ano de graduação e monitora no segundo, participo de uma experiência 
educacional considerada inovadora no Instituto de Física da USP (IFUSP), o Curso Personalizado e Individualizado (CPI) com base no método Keller. Seguindo tendência da época, na linha comportamentalista (ainda que com algumas "transgressões"), o curso tinha "como objetivo fundamental desenvolver no aluno o comportamento de resolver problemas em Física" (Hosoume, 1978). Coordenaram e ministraram esse curso, docentes que se tornariam pesquisadores reconhecidos na área de Pesquisa em Ensino de Física, dos quais destaco Alberto Villani e Yassuko Hosoume, ainda hoje importantes protagonistas dessa peça (ou filme).

Essa minha iniciação ocorre, portanto, poucos anos depois que a área dá, no Brasil, seus primeiros passos no mundo acadêmico institucional, com uma comunidade de pesquisadores já se estabelecendo. Destacam-se, como eventos que marcaram essa década, o primeiro SNEF, no ano de 1970; a criação dos dois cursos de pós-graduação em Ensino de Física, na UFRGS e na USP, o primeiro no Instituto de Física e o segundo em um programa inter-unidades envolvendo o Instituto de Física e a Faculdade de Educação. Aqui, particularmente, cabe mencionar o Professor Ernst W. Hamburger, precursor e grande lutador na implantação dessa área no Instituto de Física da USP, com enormes resistências dos pesquisadores em "Física dura" (sobre o que retomaremos no capítulo dois).

Ao me formar na graduação, no final dessa década, já se somavam mais de 30 mestres e doutores na área. No início dos anos 80 ingresso na pós-graduação em ensino (IF/FEUSP), para defender minha dissertação de mestrado em 1986 (e, ainda que bem distante no espaço e no tempo, na temática e no contexto, percebo marcas de continuidade). Nessa fase, Manoel Robilotta, orientador do mestrado, teve grande influência em minha formação, apontando novos caminhos, pensares e saberes.

E assim, sejam quais tenham sido minhas motivações, acabei por entrar nesse "barco" e, com idas e vindas nos mares por onde vem navegando, algumas vezes na onda e outras tantas fora da onda, aqui estou, passados quase 30 anos. Um longo período em que pude, não apenas acumular conhecimentos e produções acadêmicas, mas adquirir uma vivência relativamente diversificada e intensa. Seja como estudante, como professora, como pesquisadora, e como técnica (funcionária na função "Educadora"). Algumas vezes com resistências, outras mais motivada, algumas vezes "fora da casinha" e "companheira equivocada" (expressões que peço emprestar, respectivamente da Marcília e da Joana), outras buscando me enquadrar e vestir a camisa, quer intelectual, acadêmica ou afetivamente.

Em grande parte dessa vivência, e particularmente a partir do início da década de 1990, desenvolvi, em colaboração com a Maria Regina Kawamura (mais do que orientadora, parceira e grande incentivadora de minha trajetória) projetos e trabalhos que tinham como motivação e perspectivas, reunir, sistematizar e refletir sobre nossa 
"arte". Trajetória que se iniciou com a criação de um Banco de Referências em Ensino de Física (ENFIS) ${ }^{1}$ e que refletia a preocupação de...

...reunir, sistematizar e cadastrar a produção escrita na área de Ensino de Física no Brasil ao longo das últimas décadas. Pretende-se, dessa forma, que as experiências, propostas e pesquisas realizadas possam ser compartilhadas por professores e pesquisadores da área.

De lá para cá, além da criação, implantação e disseminação desse Banco de Referências, desenvolvemos, em parceria, diversos trabalhos na perspectiva de mapear e identificar elementos que caracterizavam e sinalizavam tendências e focos de preocupação desse campo de pesquisa que se estabelecia e vinha crescendo.

Pois bem, ao longo desse percurso com significativo acúmulo de trabalhos, investigações e não poucas questões sobre nossa identidade e perspectivas, a maior motivação dessa pesquisa (e de seu registro acadêmico na forma de tese de doutorado) é sistematizar essa experiência e, sobretudo, buscar contribuir para uma reflexão sobre essa caminhada que vem marcando e demarcando a área de pesquisa em Ensino de Física.

\section{Não estamos sós}

A preocupação em analisar e refletir sobre a área de Ensino de Ciências e, particularmente de Ensino de Física, não é nova e não é apenas nossa; tem sido objeto de atenção de pesquisadores, com diferentes trabalhos nessa perspectiva, especialmente a partir década de 1980. Até então, foram poucos os relatos e registros publicados sobre as trajetórias e evolução dessa área no Brasil. Destacam-se, entre esses, referências como Almeida Junior (1979, 1980), que situa o ensino de Física em uma cronologia abrangente da educação brasileira, Pernambuco (1985) e Krasilchik (1987), que traçam panoramas gerais da área de Ensino de Ciências no Brasil, especialmente no período entre a década de 1950 e meados da de 1980, procurando demarcar e refletir sobre algumas de suas questões, motivações e identidade. Já, a partir de 1990, delineia-se e começa a crescer uma nova tendência de investigação na qual se busca caracterizar a cada vez mais diversificada produção na área, geralmente com base em mapeamentos e estudos do tipo estado da arte ou revisão bibliográfica. E nos incluímos nessa...

\footnotetext{
${ }^{1}$ O Banco de Referências em Ensino de Física (ENFIS), criado em 1990, catalogou materiais produzidos na área de Pesquisa em Ensino de Física, de diferentes naturezas - artigos de periódicos, trabalhos apresentados em eventos, dissertações e teses, pré-prints, apostilas de disciplinas da Licenciatura em Física do IFUSP, entre outras produções. Foi mantido e atualizado até o final da década de 1990. Está disponível no site do PROFIS - Espaço de Apoio, Pesquisa e Cooperação de Professores de Física (IFUSP): http://fep.if.usp.br/ profis/enfis.html (IFUSP): http://fep.if.usp.br/ profis/enfis.html
} 
Foi nesse período que publicamos o primeiro volume do Catálogo Analítico de Dissertações e Teses em Ensino de Física no Brasil (Universidade de São Paulo Instituto de Física, 1992). Nessa mesma perspectiva foi lançado pelo Centro de Documentação em Ensino de Ciências (CEDOC), da Faculdade de Educação da UNICAMP, outro catálogo de dissertações e teses abrangendo todo o ensino de Ciências (MEGID, 1998). Essas iniciativas, que tiveram continuidade, trouxeram importantes contribuições e foram instrumentos de investigações para pesquisadores da área, permitindo estudos sistemáticos dessa produção.

Entendemos que para além da necessidade de sistematizar e refletir sobre as contribuições do conjunto significativo de investigações já realizadas, há muitas questões latentes e aspectos a serem aprofundados; sempre levando em conta seus objetos de estudo e temáticas de interesse, seus problemas e procedimentos metodológicos, tanto quanto uma contextualização e localização de suas incursões e referências no cenário mais amplo da pesquisa em educação

\section{Das hipóteses e questões de pesquisa}

E é aí ou aqui que entramos. Pretendemos, nessa pesquisa, compreender a dinâmica de evolução da área de Pesquisa em Ensino de Física ao longo de sua institucionalização e desenvolvimento. No entanto, assim posto ou dito, pode parecer muito ou pode dizer muito pouco. Também pode aparentar certo distanciamento e neutralidade, o que não seria honesto, do ponto de vista pessoal ou acadêmico. Ainda que seja possível e essa é a intenção - buscar um olhar distanciado e abrangente, partindo de uma realidade concreta (mas não tanto) - essa distância é relativa, pois fazemos parte, estamos profundamente imbricados no objeto de análise e muito menos partimos de um ponto de vista neutro.

Assim, tentarei situar, nesse quadro, qual é o nosso "problema" ou nossa "tese", alguns dos caminhos já percorridos até aqui, possibilidades delineadas do que há por fazer e, certamente, questões e mais questões sobre meios e fins que nos motivam e aqui nos trazem.

Ao resgatar as origens da pesquisa em Ensino de Ciências (EC), enquanto campo de produção e pesquisa, podemos perceber que tem em sua gênese uma marca característica, algo "que corre em suas veias", "presente em seu DNA". Questão que procuraremos melhor situar histórica e socialmente no contexto em que a área se instaura e se desenvolve, mas que já podemos adiantar como uma vocação original. Trata-se do que caracterizaremos nessa pesquisa como a dimensão dos "Processos de Ensino-Aprendizagem".

Uma das motivações que entendemos estar na origem da pesquisa em educação em Ciências, e nessa a de ensino de Física, seria uma demanda pelo aprimoramento do 
aprendizado do conhecimento científico, ou seja, de fazer com que o ensino de Ciências fosse "mais eficiente". Demanda que viria responder a necessidades sociais mais amplas, particularmente nas décadas de 1950 e 60, em que a ciência teria um importante papel na superação do subdesenvolvimento, requerendo a formação de quadros que dessem suporte aos desenvolvimentos tecnológico e industrial. Nesse contexto, em que surgem os grandes Projetos Curriculares internacionais, havia uma preocupação em promover uma educação científica de qualidade, que instaura, então, um foco de interesse e uma concepção cujo eixo condutor seria dado pelos métodos, procedimentos, técnicas ou processos de ensino.

Décadas passadas, uma das questões que nos colocamos e torna-se foco de investigação dessa pesquisa é o quanto essa marca, esse registro de nascimento permanece, sobrevive e predomina. Ou ainda, seriam os meios e os processos de "eficientizar", aperfeiçoar, aprimorar o ensino (de Física), desde as suas origens, e ainda hoje, o eixo principal motivador ou condutor da trajetória da nossa área, o contorno determinante de nosso campo?

A nosso ver, tal vocação traria algumas implicações relevantes nos rumos da área de pesquisa em Ensino de Física. Do ponto de vista de seus fins, apontamos, particularmente, o seu distanciamento da perspectiva propriamente educacional. $\mathrm{Ou}$ seja, a rara atenção em refletir, explicitar, sinalizar as demandas sociais da educação em nosso mundo, em nosso país, em nossas escolas. Isso nos demarca outro recorte de análise ou dimensão investigativa. Onde, quando, de que modo na dinâmica de evolução da pesquisa em Ensino de Física o enfoque educacional se coloca? Trata-se de questão controvertida, polêmica, com múltiplos entendimentos e, portanto, envolvendo escolhas nas abordagens a serem utilizadas.

O enfoque nos "processos e meios" somado à natureza inter-trans-disciplinar de nossa área, que articula campos de conhecimento como as ciências, a sociologia, a filosofia, a linguística, a história, a psicologia, a psicanálise, a pedagogia etc., poderia também estar nos distanciando de nosso particular campo de conhecimento científico específico. Esse constituiria, então, um terceiro recorte de pesquisa: identificar de que forma a dimensão do conhecimento científico, ou a preocupação com qual física ensinar, tem estado presente nas nossas pesquisas.

Ao longo desse caminho e do desenvolvimento de uma área com características interdisciplinares, um pé na educação e outro na ciência (com seus campos derivados e associados), que enfrenta resistências de diferentes naturezas e passa a ter questões controvertidas internamente, entram em cena outras preocupações e motivações. Particularmente, a necessidade de se impor e ser reconhecida e legitimada academicamente frente às políticas de financiamento da pesquisa e da pós-graduação, de ganhar visibilidade nacional e internacional. $\mathrm{O}$ que nos apresenta outra questão: $\underline{\text { }}$ 
quanto a demanda por reconhecimento e legitimação no meio acadêmico implicou e trouxe orientações e rumos para a nossa pesquisa.

Essas questões constituem, de certo modo, os princípios e fins dessa pesquisa. E, de saída, sinalizam um olhar para a área, que será determinante no desenvolvimento do trabalho, sobretudo na seleção dos recortes de investigação: um olhar que contemple seus objetos, meios e fins.

\section{Dos objetivos e objetos}

Diante do quadro apresentado, questões como - O que caracteriza a área de Pesquisa em Ensino de Física? Quais os marcos de sua evolução? Quais as trajetórias de sua institucionalização? Quais seus objetos de investigação? Quem constitui sua comunidade? Qual o seu alcance e impacto sobre o sistema educacional do país? merecem reflexões e análises para que se possa fazer um resgate da área, identificando suas principais tendências, desafios e contribuições no âmbito da educação escolar.

Essas são questões que compõem o pano de fundo da pesquisa. Mas por serem abrangentes demais, demandam recortes de diferentes tipos: quer quanto aos objetos ou ao universo de estudo, quer quanto às delimitações que as próprias questões nos impõem.

Assim, definimos como objetivos gerais da pesquisa, identificar e analisar

- $\quad$ as principais características da área de Ensino de Física, enquanto campo de conhecimento e produção de pesquisa;

- $\quad$ os focos de interesse ao longo de sua evolução;

- $\quad$ os problemas e desafios atuais; tendências e perspectivas futuras.

No que se refere ao objeto ou corpus de investigação, optamos pela análise de dissertações e teses, dentre o conjunto que constitui a produção na área (artigos de periódicos, trabalhos apresentados em eventos, conferências, livros etc.). Opção que se justifica, em primeiro lugar, porque dissertações e teses refletem mais diretamente a produção propriamente acadêmica, foco de atenção desse trabalho. Em segundo lugar, porque é razoável supor que são as dissertações e teses que frequentemente dão origem a outras formas da produção. Acrescenta-se, ainda, o fato de que constituem trabalhos singulares, únicos, que não seriam contabilizados multiplamente, como acontece quando tomamos como objeto de estudo as comunicações em eventos e/ou artigos publicados. E finalmente, em terceiro lugar, pela extensão da produção (algo da ordem de dezenas de milhares de unidades de análise), para a qual critérios de seleção de amostragem ou recortes apresentariam grande dificuldade. 
Dentro desse universo, coloca-se, ainda, uma questão sobre a delimitação do próprio campo ou área de pesquisa - Ensino de Física - problema metodológico do qual trataremos. De um modo geral, a seleção das teses para essa pesquisa foi feita com base nos mesmos critérios que utilizamos nos catálogos analíticos mencionados:

O critério principal utilizado para a seleção das teses foi a ênfase dada por eles aos aspectos relacionados especificamente ao ensino de física. Trabalhos que tratam do ensino de ciências no primeiro grau [ensino fundamental], bem mais numerosos, foram incluídos apenas quando abordam especificidades da física. Por outro lado, trabalhos que tratam de questões gerais e abrangentes, relativas ao ensino dos conteúdos científicos como um todo também foram incluídos. (UNIVERSIDADE DE SÃO PAULO, Instituto de Física, 1992).

Ressaltamos, contudo, que à época da elaboração desse primeiro volume dos "Catálogos" (1992), ainda que houvesse dificuldade na demarcação do que se enquadrava como "pesquisa em Ensino de Física", esse campo tinha uma identificação ou fronteiras mais facilmente delimitadas que nos períodos seguintes. Fato esse que se torna motivo não só de recortes metodológicos, como de análise na dinâmica de evolução da área.

\section{Dos meios}

O perfil e a evolução de uma área de pesquisa ou campo de produção de conhecimento, por envolver um corpo diversificado, heterogêneo e complexo de aspectos, requerem a delimitação de outros recortes que delineiam ou definem a metodologia a ser utilizada. Ou seja, os meios e instrumentos para "olhar" esse corpo de conhecimentos não são dados, não são únicos, não são objetivos, não são normativos. São escolhas. Escolhas essas que dependem de uma visão e de uma perspectiva para a própria área. E, por isso, não existe uma metodologia apriori para um trabalho dessa natureza, sendo ela mesma parte do objeto de investigação e proposição.

Gamboa (1987), em um estudo sobre a produção dos programas de pós-graduação em Educação em instituições brasileiras, afirma que

Por trás de uma determinada abordagem está um interesse gnoseológico específico e a visão de mundo que o pesquisador consciente ou inconscientemente deixa, mais ou mesmo, transparecer no seu relatório, dissertação ou tese. [...] Nesse sentido, cada abordagem metodológica [da pesquisa] está vinculada a um determinado interesse de conhecimento... (GAMBOA, 1987, p.146).

Um de nossos pressupostos básicos implica trabalhar numa perspectiva que vá além de descrever os temas predominantes enfocados na área ou que se restrinja a uma reconstrução cronológica de eventos ou das linhas de pesquisa desenvolvidas em um 
dado âmbito particular. No entanto, como escolhas devem ser feitas - o quê e como olhar - impõe-se a necessidade de priorizar recortes e adotar referências.

Para isso, o ponto de partida que adotamos (e melhor justificamos no Capítulo 2) é privilegiar instrumentos, abordagens e métodos que possibilitem, de um lado, uma descrição da área do ponto de vista de seus locus e focus, apresentando um panorama geral de sua evolução, e de outro, uma análise de seus objetos de interesse e perspectivas predominantes. E é por aí que nos identificamos com alguns estudos, proposições e pesquisas nesse conjunto de possibilidades.

Nessa perspectiva, o caminho adotado envolve três momentos principais. Em um primeiro momento, trata-se de mapear diferentes estudos meta-analíticos, ou seja, de identificar de que modo pesquisadores nesse campo vêm investigando a própria área. Em um segundo momento, estabelecer uma definição do campo em estudo e de suas delimitações, através da construção de um panorama sobre quem e onde se pesquisa e como evoluem esses espaços. E finalmente, em um terceiro momento, identificar sobre o quê se pesquisa, e de como evoluem os objetos de investigação e perspectivas ao longo do tempo.

Ainda do ponto de vista metodológico, a pesquisa deverá ser desenvolvida com base em uma abordagem predominantemente qualitativa, ainda que façamos uso em alguns momentos de dados estatísticos. Em particular, ao buscarmos identificar focos de interesse, categorias temáticas, concepções ou perspectivas presentes nas dissertações e teses, não nos limitaremos a um estudo documental, ou seja, restrito ao campo da indexação e classificação, mas uma análise de conteúdo, que envolve inferências e interpretações. Nessa linha metodológica Bardin (1977) conceitua a análise de conteúdo como um conjunto de técnicas de análise das comunicações visando obter, por procedimentos sistemáticos e objetivos de descrição do conteúdo das mensagens (quantitativos ou não), a inferência de conhecimentos relativos às condições de produção/recepção destas mensagens.

Para o primeiro momento, serão analisados estudos na perspectiva de "estado da arte" que buscam caracterizar, por diferentes meios, a área de pesquisa em Ensino de Física.

No segundo momento, fazemos um levantamento das dissertações e teses produzidas nessa área, no Brasil, em todo o período de sua trajetória, que se estende de 1972 a 2009 (final esse, dado pelo ano em que terminamos a análise de dados e, ao mesmo tempo, pela disponibilização de dados em diferentes sistemas de busca atuais). Nessa fase, por se tratar de uma produção bastante extensa, contendo mais de mil títulos, a análise será, sobretudo, descritiva. 
Para a classificação dos trabalhos em áreas temáticas serão utilizados, a princípio, os resumos e palavras-chave e, nos casos em que se mostrar necessário, a leitura de partes relevantes da obra completa. Também com esse objetivo será feito um estudo de diferentes classificações temáticas propostas em outras pesquisas.

Como fontes de informação, utilizamos os já mencionados Catálogos Analíticos de Dissertações e Teses no Brasil, publicados pelo IFUSP (Universidade de São Paulo Instituto de Física, 1992, 1996 e 2009), os catálogos do CEDOC, o banco de teses da CAPES e portais ou páginas de Programas de Pós-Graduação da área de Ensino de Ciências/Física.

Tirante essa Apresentação/Introdução, o trabalho foi desenvolvido em nove capítulos.

No capítulo 1 fazemos um estudo meta-analítico sobre os trabalhos na linha de estado da arte da área de pesquisa em Ensino de Ciências / Física, buscando construir o que denominamos "um estado da arte dos estados da arte". Procuramos caracterizar o que se tem concebido, de um modo geral, como "estado da arte" ou "estado do conhecimento" em diferentes campos e, particularmente em nossa área, para melhor delimitarmos a nossa proposta de pesquisa, situando-a em relação a trabalhos já existentes.

Trata-se, assim de mapear o quê e como se está olhando para a nossa arte.

No capítulo 2 buscamos traçar um contexto mais amplo no qual essa "arte" vem se desenvolvendo. $O$ intuito é propiciar condições para que as análises a serem realizadas nesse campo de pesquisa possam ampliar seu olhar, considerando elementos para além da sua evolução interna. Ou seja, trata-se de reconhecer melhor o terreno no qual essa evolução vem se construindo. Não é o caso de análise histórica, mas de procurar justapor eventos em diferentes instâncias ou âmbitos que sejam referência e justificativa para o nosso caminhar. Nesse sentido, a reconstituição do contexto é desenvolvida em dois diferentes planos que contemplam aspectos da histórica social da educação e da instauração e desenvolvimento da pesquisa em Ensino de Ciências/Física.

Trata-se, portanto, de situar em que contexto a área de Pesquisa em Ensino de Física se situa e evolui.

No capítulo 3 construímos um perfil evolutivo da pesquisa acadêmica em Ensino de Física, desde os primórdios de sua institucionalização, no início dos anos setenta, até o final da primeira década de 2000. Apresentamos um panorama geral das dissertações e teses desenvolvidas nesse longo período de quase quatro décadas, buscando descrever e apontar elementos que marcam a expansão da área: do crescimento dessa produção de um modo geral e de aspectos mais específicos dessa evolução. Os 
resultados desse estudo contribuem, particularmente no âmbito dessa pesquisa, para definir alguns dos critérios e parâmetros na escolha dos recortes adotados para um estudo analítico da área.

Trata-se, aqui, de apresentar um desenho descritivo de como a área vem crescendo.

No capítulo 4 voltamos nossa atenção para questões de ordem metodológica. Uma vez identificada como tendência importante e predominante nos estudos de estado da arte da área de Ensino de Física, a investigação de seus focos de interesse, em diferentes épocas ou espaços, nos dedicamos a analisar e criar instrumentos de análise nessa perspectiva. Ou seja, tratamos de identificar quais têm sido os instrumentos ou metodologias utilizadas nesses estudos, para discutir os nossos próprios, apresentando e discutindo critérios e categorias de análise que temos utilizado ao longo dos diversos trabalhos realizados e que nortearam escolhas metodológicas dessa pesquisa.

O objetivo desse capítulo é, pois, apresentar um instrumento de análise para caracterizar os focos de interesse da área.

No capítulo 5 analisamos a produção acadêmica do ponto de vista de suas áreas temáticas, utilizando um dos instrumentos definidos no capítulo precedente. Tendo em vista a grandeza de nosso corpus de estudo, que é composto por mais de mil unidades (dissertações e teses), definimos uma amostra, que passa a constituir nosso universo de pesquisa, somando 470 títulos. Mapeamos esse conjunto de acordo com as categorias temáticas estabelecidas, extraindo as principais tendências da área e suas marcas predominantes, quanto a esse parâmetro.

O foco desse capítulo é, portanto, identificar de que "assuntos" ou temas nossa área vem tratando.

Ainda com a finalidade de caracterizar analiticamente o conteúdo da produção na área, no Capítulo 6 investigamos os âmbitos em que se situam as nossas pesquisas, sua natureza e perspectivas. Também com base em instrumento apresentado no capítulo quatro, analisamos como a produção se insere em uma tríade de dimensões dadas pelas perspectivas da Educação, do Conhecimento e dos Processos de Ensino e Aprendizagem.

Assim, nesse capítulo, buscamos delimitar âmbitos $e$ perspectivas que melhor caracterizam a área, ao longo de seu percurso.

O capítulo 7 constitui uma espécie de parênteses na pesquisa. Traz uma discussão sobre a criação dos Mestrados Profissionais e seus impactos na área de Ensino de Ciências. Parênteses com a finalidade de complementar a análise das atuais tendências da trajetória da pesquisa em Ensino de Ciências / Física. Retomamos os mesmos parâmetros de descrição e análise da produção acadêmica para apresentar um perfil 
dessa nova modalidade de curso de pós-graduação e seus particulares impactos em nossa área.

Procuramos complementar, aqui, o perfil da área considerando novas tendências dadas pela implantação de uma nova modalidade de pós-graduação.

No capítulo 8 fazemos uma retomada de resultados e conclusões ao longo da pesquisa, visando sistematizar o "conjunto da obra" e responder às nossas questões centrais de pesquisa, para então, no capítulo 9, finalizar o trabalho, sinalizando o que consideramos desafios e questões relevantes colocados para a comunidade e agenda de pesquisa. 


\section{1}

\section{Do Estado da Arte dos Estados da Arte da Pesquisa em Ensino de Física}

"Existirmos: a que será que se destina...?" (Cajuína, de Caetano Veloso)

O crescimento da área de Pesquisa em Ensino de Ciências no Brasil pode ser constatado pela ampliação de sua produção nas últimas décadas, seja em número de trabalhos publicados, na criação de novos periódicos, no expressivo número de participantes e trabalhos apresentados em eventos ou na expansão de seus próprios programas de pós-graduação. Do ponto de vista institucional, o reconhecimento pela CAPES da identidade dessas pesquisas constituindo uma área específica, reforça e ratifica esse movimento.

Acompanhando esse crescimento, vêm sendo intensificadas, também, as investigações e reflexões sobre a área, sua história e evolução, características e tendências. Nessa perspectiva, muitos trabalhos vêm buscando mapear o estado da arte do campo. De algum modo, iniciativas dessa natureza estiveram presentes ao longo de todo o desenvolvimento da área. No entanto, passam, agora, a ocupar a atenção de um número maior de pesquisadores e com um caráter mais diversificado e abrangente. Não é difícil perceber a pertinência dessas preocupações, especialmente a partir da variedade de rumos, objetos e metodologias que passaram a ser adotadas nas pesquisas em Ensino de Ciências.

Constituindo-se em um já expressivo e numeroso grupo de trabalhos, passam, eles mesmos, a demarcar uma linha de investigação específica. Na medida em que nessas pesquisas vêm sendo adotadas múltiplas abordagens e metodologias, além de diferentes recortes para o mapeamento do campo, torna-se relevante uma análise dos muitos estados da arte que possibilite delinear e compreender suas contribuições, além das diferentes compreensões sobre o que seja descrever uma área interdisciplinar de pesquisa, com contribuições de campos de saber diversos.

A presença de trabalhos com essa preocupação, por si só, é a expressão da importância atribuída por diversos pesquisadores à necessidade da construção de uma perspectiva mais abrangente sobre o campo. Sobre a necessidade desse tipo de investigação, Cachapuz destaca: 
A primeira orientação é de índole epistemológica e diz respeito à necessidade de desenvolver estudos de sistematização da pesquisa já desenvolvida. No fundo, corresponde a melhor precisar o estado da arte. Trata-se de levar a cabo os estudos transversais de índole meta-analítica que permitam responder, ainda que tentativamente, a questões como: Quais as perspectivas de pesquisa que são dominantes (acadêmica...)? quais os estudos teóricos de referência? Quais as linhas de pesquisa dominantes? Tais estudos são raros... (CACHAPUZ, 2003, p.1)

Com essa perspectiva, objetivamos, nesse capítulo, realizar uma investigação analítica sobre os trabalhos com essa preocupação, buscando construir o que denominamos estado da arte dos estados da arte da área de Pesquisa em Ensino de Ciências, com especial atenção à área de Pesquisa em Ensino de Física. Trata-se de investigar as diferentes contribuições nessa linha, buscando identificar: o que apresentam em comum e em que aspectos se diferenciam? Qual a natureza de suas perspectivas de análise? Quais referências adotam para suas elaborações? Como definem / nomeiam / identificam /reconhecem esse campo de pesquisa?

Esses elementos permitirão melhor delimitar nossa proposta de pesquisa, situando-a em relação a trabalhos já existentes. Como se explicitará adiante, as diferentes contribuições identificadas indicam a necessidade de melhor caracterizar o próprio campo de investigação, ou o estado "da arte" a que corresponde o campo de Pesquisas em Ensino de Física. Ainda que à primeira vista possa parecer o contrário, essa não é uma questão simples nem mesmo consensual.

\subsection{Sobre "estados das artes"}

Pesquisas denominadas "estado da arte" (EA) tratam, em geral, de reunir e sistematizar o conhecimento acumulado em dado campo ou assunto, visando reconhecer, mapear e refletir sobre o que se conhece, o que já se produziu ou vem sendo produzido nesse campo, no momento em que estão sendo realizadas. Sobre suas definições e fins não há muitas variações ou controvérsias.

Definidas como de caráter bibliográfico, elas [pesquisas conhecidas pela denominação 'estado da arte' ou 'estado do conhecimento'] parecem trazer em comum o desafio de mapear e de discutir uma certa produção acadêmica em diferentes campos do conhecimento... tentando responder que aspectos $e$ dimensões vêm sendo destacados e privilegiados em diferentes épocas e lugares, de que formas e em que condições têm sido produzidas certas dissertações de mestrado, teses de doutorado, publicações em periódicos e comunicações em anais de congressos e de seminários. (FERREIRA, 2002, p.258)

Um estado da arte ou do conhecimento é uma análise da produção acadêmica em uma determinada área que permite reconhecer e identificar o conhecimento 
produzido, as áreas de tensão e possiveis avanços na compreensão do tema em estudo... (CASTRO e WERLE, 2004, p.1045)

Os estudos de tipo estado da arte permitem, num recorte temporal definido, sistematizar um determinado campo de conhecimento, reconhecer os principais resultados da investigação, identificar temáticas e abordagens dominantes $e$ emergentes, bem como lacunas e campos inexplorados abertos à pesquisa futura.(HADDAD et al, 2000, p.9)

Algumas vezes, a denominação "EA" restringe-se mais especificamente àquilo que se conhece de mais atualizado sobre o campo em questão, à produção relativa à arte no momento atual, hoje, concepção essa mais comumente aplicada a conhecimentos tecnológicos:

O Estado da Arte é também identificado frequentemente como parte integrante de relatórios técnicos, científicos ou acadêmicos, de dissertações e teses ou de artigos de periódicos especializados em dada área acadêmica ou científica. Nessas produções, em geral, constitui um capítulo específico com o objetivo de situar a investigação em um conjunto mais amplo, por meio de levantamentos ou revisões bibliográficas a cerca da matéria ou pesquisa em desenvolvimento.

A "arte", ou o objeto da qual tratam as pesquisas dessa natureza, pode ser um campo de conhecimento abrangente (EDUCAÇÃo AmBiental, Psicologia ClínICA, ENGENHARIA GENÉTICA), um assunto específico (GERENCIAMENTO DE RECURSOS HÍDRICOS, EDUCAÇÃO DE JOVENS ADULTOS). Pode referir-se a um campo de investigação científica (PESQUISAS COM CÉLULA-TRONCO), uma tecnologia (TECNOLOGIAS PARA A PRODUÇÃO DE ENERGIA), uma técnica ou um procedimento específico (CIRURGIA DE REVASCULARIZAÇÃO CORONÁRIA), abrangendo, portanto, por parte dos autores que assim denominam ou caracterizam esses trabalhos, uma grande diversidade de assuntos, temas e áreas de saber ou de pesquisa.

De um modo geral, os autores desses trabalhos, ainda que nem sempre os denominem ou os reconheçam dessa maneira, como "estado da arte", apresentam objetivos comuns de mapear, traçar um panorama geral, apresentar tendências sobre o tema de interesse:

O objetivo deste tipo de trabalho ["estado da arte"] é descrever o estado atual de uma dada área de pesquisa: o que já se sabe, quais as principais lacunas, onde se encontram os principais entraves teóricos e/ou metodológicos. Entre as muitas razões que tornam importantes estudos com esse objetivo, deve-se lembrar que eles constituem uma excelente fonte de atualização para pesquisadores fora da área na qual se realiza o estudo, na medida em que condensam os pontos importantes do problema em questão. (LUNA, 1997, p.20) 
...A proposição adequada de um problema de pesquisa exige, portanto, que o pesquisador se situe nesse processo, analisando criticamente o estado atual do conhecimento em sua área de interesse, comparando e contrastando abordagens teórico-metodológicas utilizadas e avaliando o peso e a confiabilidade de resultados de pesquisa, de modo a identificar pontos de consenso, bem como controvérsias, regiões de sombra e lacunas que merecem ser esclarecidas. (ALVES, 1992, p.54)

Contudo, nem sempre existe nesses trabalhos uma preocupação em explicitar ou precisar o significado ou a natureza do que se está chamando por "estado da arte". Em boa parte deles pressupõe-se uma definição ou conhecimento comum, universal, sobre o que seja esse tipo de estudo. Ou seja, dizer que se está a realizar um "estado da arte" sobre dado tema, já diz tudo. Mais que isso, muitas vezes se dá a entender que o estado da arte é o estado da arte, único e absoluto.

O objetivo deste estudo é descrever o estado da arte da Sistemática Zoológica no Brasil, demonstrando seus limites e possibilidades e, partir do exposto, propor ações e metas futuras como políticas de atuação nessa área vital da Ciência. (MARQUES; LAMAS, 2006, p.141). (grifos nossos)

Há casos menos frequentes, no entanto, em que de algum modo se sinaliza o que se entende por estado da arte, descrevendo a natureza, a abordagem ou a metodologia utilizada para realizá-lo, de onde se pode perceber que esse fazer não é único e objetivo. É construção... Não é claro, até mesmo, se é considerado um tipo de investigação, uma metodologia, um procedimento, uma técnica, uma abordagem. Quanto à denominação, também há certa indefinição ou variações. Expressões como: estado do conhecimento, estado da questão, revisão crítica, revisão bibliográfica, revisão de literatura, revisão teórica, síntese, balanço, entre outras, são utilizadas indiscriminadamente para nomear ou descrever pesquisas desse tipo.

As pesquisas sobre o "estado da arte" em história da educação brasileira tem se intensificado nas últimas décadas, diante da necessidade sentida pelos historiadores da educação de um balanço crítico sobre a produção na área... (SCHELBAUER, 2006, p.1). (grifos nossos)

O presente trabalho busca fazer uma sintese integrativa do conhecimento sobre $o$ tema da formação do professor, com base na análise das dissertações e teses defendidas... (ANDRE, Marli et al, 1999, p.301). (grifos nossos)

O artigo apresenta o resultado de uma pesquisa bibliográfica cujo objetivo foi identificar tendências teóricas e metodológicas, instrumentos de coleta $e$ tratamento de dados utilizados em trabalhos cujo objeto de estudo estava relacionado com transposição didática... (JARDIM, ERROBIDART, GOBARA, 2008, p.1). (grifos nossos) 
Neste trabalho é apresentada uma revisão da literatura sobre a linha de pesquisa "Física Moderna e Contemporânea (FMC) no ensino médio" realizada com consulta a artigos em revistas, livros didáticos, dissertações, teses, projetos e navegações pela internet, que abordam essa questão. (OSTERMANN e MOREIRA, 2000, p.23). (grifos nossos)

Ainda quando tais denominações estão presentes, com descrições metodológicas ou objetivos delineados, raras são as vezes em que se procura estabelecer uma concepção de estado da arte (ou estudos similares), demarcando-a, diferenciando-a de outros trabalhos da mesma natureza, refletindo sobre seus sentidos, ou problematizando-a, como é o caso de artigo de alguns artigos sobre o tema, seja apontando objetivos e contribuições ou limitações e protestos. Quanto aos primeiros, são exemplos Romanowski e Ens (2006) em artigo sobre o estado da arte da formação de professores...

[...]Estados da arte podem significar uma contribuição importante na constituição do campo teórico de uma área de conhecimento, pois procuram identificar os aportes significativos da construção da teoria e prática pedagógica, apontar as restrições sobre o campo em que se move a pesquisa, as suas lacunas de disseminação, identificar experiências inovadoras investigadas que apontem alternativas de solução para os problemas da prática e reconhecer as contribuições da pesquisa na constituição de propostas na área focalizada [...]

[...]Esses trabalhos não se restringem a identificar a produção, mas analisá-la, categorizá-la e revelar os múltiplos enfoques e perspectivas. Segundo Soares (2000, p. 04), num estado da arte é necessário considerar "categorias que identifiquem, em cada texto, e no conjunto deles as facetas sobre as quais o fenômeno vem sendo analisado. (ROMANOWSKI e ENS, 2006, p.39)

Ou, ainda, trabalhos que têm como o próprio objeto de estudo esse problema, no âmbito da metodologia de pesquisa: o que é / para que serve / como se faz ou não se faz / um estado da arte, uma revisão de literatura etc. Nessa perspectiva, Alda Alves (ALVES, 1992) tratando do papel da revisão bibliográfica em trabalhos de pesquisa, procura explicitar a importância da análise crítica do estado do conhecimento na área de interesse do pesquisador e propõe uma tipologia para caracterizar os equívocos mais freqüentes observados nesse campo.

A revisão de bibliografia, apesar de sua indiscutível importância para o encaminhamento adequado de um problema de pesquisa, é frequentemente apontada como um dos aspectos mais fracos de teses e dissertações de pósgraduação em Educação [...] A má qualidade da revisão de literatura compromete todo o estudo, uma vez que esta não se constitui em uma seção isolada, mas, ao contrário, tem por objetivo iluminar o caminho a ser trilhado pelo pesquisador, desde a definição do problema até a interpretação dos resultados. Para isso, ela 
deve servir a dois aspectos básicos: (a) a contextualização do problema dentro da área de estudo; e (b) a análise do referencial teórico.[...](ALVES, 1992, p.54)

Também nessa direção, Nóbrega-Therrien e Therrien (2004) trazem uma reflexão de natureza teórica-metodológica sobre o estado da questão em trabalhos científicos.

Nos processos de produção científica o 'estado da questão' pode ser contraposto ao 'estado da arte' ou 'estado do conhecimento'. Importa esclarecer que este ensaio delimita o alcance do 'estado da questão' à construção do objeto de investigação pretendido pelo pesquisador. Neste caso, a busca seletiva e crítica nas fontes de informação da produção científica restringe-se aos estudos $e$ parâmetros próximos às especificidades do interesse do pesquisador o que requer consulta a documentos substanciais. Na literatura disponível, por seu lado, o 'estado da arte' ou 'estado do conhecimento' tem por objetivo "mapear e discutir uma certa produção acadêmica em determinado campo do conhecimento" (Ferreira, 2002. p.258) utilizando predominantemente fontes de consulta disponíveis em forma de resumos ou catálogos de fontes. Nesta compreensão a mesma autora associa o 'estado da arte' a uma "metodologia de caráter inventariante e descritivo da produção acadêmica e científica sobre o tema que busca investigar. (THERRIEN e NÓBREGA-THERRIEN, 2004, p.6)

Laranjeira (2002), por sua vez, protesta quanto ao termo.

Tomar o mote "Estado da Arte" como diagnóstico de algo, é, antes de tudo, data venia, tratar de uma expressão canhestra e rebuscada, que beira ao esotérico. Sua difícil compreensão advém do fato de não ser corriqueira em nossa linguagem, nem a popular nem a culta do país. Tendo sido estruturada no meio acadêmico dos Estados Unidos (State of the art), aqui nos vem sendo impingida, e copistas que infelizmente somos da cultura norte-americana, passamos a adotá-la a pouco e pouco.

Aceito utilizar o termo sob protesto, eis que o encontrei determinado pelos organismos que comandam este evento; mas não posso resistir aos comentários introdutórios para dizer que a denominação adotada não exprime um impacto imediato de apreensão do tema, e parte do equivocado pressuposto de que os espectadores de um Congresso ou os leitores de um texto com a epígrafe "Estado da Arte" já sabem o que esta significa. Pelo que já aferroei acima, ela não é de pronto entendimento, e exige uma explicação sobre o seu significado." (LARANJEIRA, 2002, p.1)

No entanto, independentemente da denominação ou do sentido atribuído a esses estudos, boa parte dos trabalhos nessa linha também parece conter implícita uma hipótese de que o objeto ou campo de estudo (a arte) é dado, estabelecido, conhecido. Não está em questão identificá-lo, reconhecê-lo ou questioná-lo enquanto tal. O estado da arte teria um caráter de um "inventário" em que são feitos levantamentos (revisões, sínteses, balanços) da produção (ou do estado atual) acerca 
desse objeto conhecido. O resultado desse tipo de trabalho, grosso modo, se assemelharia a uma "fotografia" do objeto em dado momento ou a um "filme", quando incorpora neste, uma evolução temporal, uma revisão histórica. Seria único, independente do seu criador / autor. Diferenças entre estados da arte/conhecimento/questão de um mesmo campo, realizados por diferentes autores, seriam dadas, assim, mais pela escolha da amostra, de sua extensão, dos recortes locais, temporais ou temáticos realizados do que por pontos de vista, conhecimentos, vivências ou concepções distintos acerca daquele campo, daquele objeto. $O$ objeto seria um só, podendo mudar o modo de reconstituí-lo, sistematizá-lo, retratá-lo. Mudaria a "foto", permaneceria o objeto. Assim, ao se tratar de estado da arte em "Educação Ambiental", "Psicologia Clínica", "Sistemática Zoológica" ou "Ensino de Ciências", cada um desses campos de saber seriam compreendidos inequivocamente como algo dado, indiscutível.

Essa ideia, quase caricatural, está aqui colocada como um modelo para demarcar nossa concepção e hipótese inicial de investigação: a de que em trabalhos do tipo "estado da arte, do conhecimento ou da questão", de alguma forma sempre haverão pontos de vista, perspectivas ou focos diferentes de conceber a própria arte. Os dados, o tratamento e resultados dependerão do olhar de seus autores para o objeto de pesquisa, ou seja, para o campo de conhecimento em questão. Seguindo nossa metáfora, o resultado da "foto" dependeria de fatores objetivos e subjetivos, da "câmera" e do olhar do fotógrafo. Mas não apenas isso, o próprio objeto, o que o define enquanto um dado campo ou área de saber (no caso de estados da arte sobre campos de conhecimento) não é necessariamente único e bem estabelecido. Isso é parte do que procuraremos investigar no caso de nossa área.

Desse modo, o problema que nos colocamos como um desafio não está em "fazer um estado da arte" ou em identificar/levantar trabalhos que se denominam "estado da arte", no sentido de inventário, levantamento, revisão bibliográfica. Mas em buscar nesses trabalhos, também, a própria concepção do objeto (sua delimitação, fronteiras, questões, características, metodologias...) no nosso caso, a Pesquisa em Ensino de Física.

Assumindo essa perspectiva, tomaremos aqui como pesquisas do tipo "estado da arte" os diversos olhares para essa área: como vem sendo descrita, analisada, conhecida, questionada, identificada, reconstruída. Portanto, seja qual for a denominação mais adequada para a nossa próprio investigação, de caráter meta-analítico - estado da arte, do conhecimento ou da questão - a perspectiva que adotamos aqui é a de um estudo reflexivo sobre distintas reconstruções de nossa área. 


\subsection{Sobre estados da "nossa arte"}

Há cerca de vinte anos, em meados da década de 1990, quando começávamos a nos preocupar e reconhecer a necessidade de uma sistematização da produção na área de pesquisa em Ensino de Física, podíamos praticamente "contar nos dedos das mãos" os trabalhos nessa direção, ainda que tomando o conjunto mais abrangente da pesquisa em Ensino de Ciências. No final dessa referida década, os dedos das mãos já podiam ser insuficientes, mas juntando a esses, os dos pés, praticamente dávamos conta desse levantamento. ${ }^{2}$

Passados apenas mais dez anos desse levantamento ao final da década de 1990, em 2010 registramos cerca de duas centenas de pesquisas que buscam mapear e discutir a área de Pesquisa em Ensino de Ciências. Incluem-se nesse levantamento, do qual trataremos a seguir, trabalhos mais gerais, que tratam da pesquisa em Ensino de Ciências como um todo, trabalhos com foco em recortes específicos, sejam esses relativos às particulares componentes curriculares do ensino de ciências - Biologia, Física, Matemática, Química - ou a linhas temáticas, tais como Formação de Professores, Tecnologia da Informação e Comunicação, Linguagem, Divulgação Científica, Recursos Didáticos, História e Filosofia da Ciência entre outras.

Tal como identificamos em outros campos do conhecimento, também na área de Pesquisa em Ensino de Ciências, encontramos, em um primeiro momento, descrições, justificativas e objetivos comuns ou muito semelhantes nos trabalhos do tipo estado da arte:

Buscando realizar uma revisão bibliográfica sobre pesquisas do tipo estado da arte em Educação em Ciências, procuramos identificar e descrever os artigos publicados em periódicos científicos nacionais nos últimos dez anos nesse contexto. Ou seja, verificar e discutir as características e tendências gerais dos artigos que revisam a produção científica brasileira na área, de modo global ou restrito a determinado campo temático, nível escolar, área de conhecimento, abordagem metodológica, ou outro aspecto específico. (FERNANDES e MEGID NETO, 2007, p.2).

O presente trabalho tem como objetivo a realização de um mapeamento dos trabalhos relacionados à divulgação científica... no intuito de demarcar as vertentes de pesquisa que englobam o tema e os principais referenciais teóricos a ele relacionados. (NASCIMENTO e REZENDE JR, 2006, p.1)

A pesquisa sobre o "Estado da Arte" de áreas do conhecimento tem sido objeto de estudo em programas da educação, objetivando compreender o processo de

\footnotetext{
${ }^{2}$ Em 1995 identificamos três trabalhos na perspectiva de Estado da Arte em Ensino de Ciências e oito em Ensino de Física; em 1999, nove em Ensino de Ciências e doze em Ensino de Física.
} 
instauração de um campo de saber e as transformações ocorridas ao longo da história. (LORENZETTI e DELIZOICOV, 2007, p.2)

Este artigo estuda as produções de pós-graduação brasileiras sobre formação de professores/educadores para o trabalho com Educação Sexual nos vários níveis escolares, com objetivo de conhecer e apontar as principais tendências dessa produção. (SILVA e MEGID, 2006, p.185)

Com esse quadro, o Centro de Documentação em Ensino de Ciências (CEDOC), da Faculdade de Educação da Universidade Estadual de Campinas (FE-UNICAMP), vem desenvolvendo projetos com intuito de identificar, recuperar, classificar $e$ divulgar a pesquisa acadêmica brasileira sobre Ensino de Ciências, especialmente os trabalhos produzidos sob a forma de dissertações de mestrado e teses de doutorado ou de livre-docência. (MEGID, 1999b, p.1)

Quando analisamos pesquisas de Estado da Arte na área de Ensino de Ciências desenvolvidas em outros países, podemos perceber aspectos comuns às brasileiras no que diz respeito aos objetivos mais gerais. Mas, assim como aqui no Brasil, há diversidades entre elas, quer quanto à natureza da investigação, suas metodologias e resultados. Encontramos trabalhos nessa linha que vão das revisões bibliográficas na área com identificação de temáticas dominantes (TSAI, 2005) a pesquisas de natureza meta-analítica que investigam a natureza do conhecimento produzido pela Investigação em Didática das Ciências (CACHAPUZ, 2005), passando por estudos de natureza histórica e epistemológica que focalizam a evolução e consolidação desse campo de pesquisa (GIL-PEREZ, 1996).

This study conducted a series of content analyses of the articles published by International Journal of Science Education, Science Education, and Journal of Research in Science Teaching from 1998 to 2002... Similarly, science education researchers often view the publications of research findings in academic or refereed journals as an important task for their profession. For new researchers, being aware of some important academic journals helps them to understand the field of science education more broadly. Therefore, having a systematic analysis of articles published in academic journals may assist science educators to explore the current status and future trends of research. (TSAI, 2005, p.3)

O ponto de partida do projecto referido foi a consciência da necessidade $e$ importância de reflectir sobre o estado da arte da IDC, para clarificar as suas possiveis orientações actuais e futuras. O projecto de investigação foi guiado pelas seguintes questões de investigação: Qual o sentido da IDC contemporânea, suas perspectivas dominantes, quadros teóricos, linhas de investigação dominantes $e$ metodologias? Quais deveriam ser as prioridades da IDC? Como melhorar o impacto da IDC nas práticas e nas políticas educativas? O foco do projecto não é, pois, replicar estudos do tipo já apresentado em handbooks (p.ex. Frazer \& Tobin, 1998; Perales, \& Cañal, 2000), mas sim centrar a atenção em meta-dimensões da 
IDC tendo em vista apoiar uma reconceptualização desta área do conhecimento. Este é um tipo de estudo pouco frequente na literatura. (CACHAPUZ et al, 2005, p.2) (grifos nossos)

Assim, antes mesmo de aprofundarmos na análise dessas investigações sobre o Estado da Arte da Pesquisa em Ensino de Ciências, já podemos concluir que elas compõem um conjunto com características próprias, que lhe conferem uma identidade, demarcando uma linha de pesquisa na área. E, também desde já, anuncia-se a existência (dentro dessa unidade) de uma diversidade de abordagens ou de metodologias. Possivelmente, por meio de uma análise mais pormenorizada e focada, encontremos outras unidades e diversidades, que buscaremos a seguir investigar mais cuidadosamente, em particular no panorama brasileiro, com foco na pesquisa em Ensino de Física.

\subsection{Panorama nacional}

Em uma primeira etapa da pesquisa, realizamos um levantamento detalhado da produção na área de Ensino de Ciências no Brasil, buscando identificar os trabalhos que poderíamos identificar como "estado da arte", ou "estado do conhecimento", na perspectiva acima apontada. Essa pesquisa teve como resultado um conjunto de mais de duas centenas de trabalhos que, ainda que não se auto-denominem dessa maneira ou não apresentem a intenção explícita de realizar algum tipo de estado da arte, contemplam diferentes vertentes de investigação nessa linha.

Esse levantamento compreendeu um período de vinte anos, entre 1990 e $2009^{3}$, e incluiu trabalhos

i) em diferentes formatos, como dissertações e teses, livros ou capítulos de livros, artigos de periódicos e comunicações em eventos, publicados ou apresentados no âmbito específico da área de Ensino de Ciências ou de Ensino de Física

ii) tendo como objeto de estudo a pesquisa em ensino de Ciências como um todo ou um particular recorte disciplinar ou temático.

A distribuição desses títulos segundo a área de conhecimento é apresentada na tabela 1.1.

\footnotetext{
${ }^{3}$ Esclarece-se que esse período não foi uma opção de recorte, mas resultado do levantamento efetuado.
} 


\begin{tabular}{|l|l|l|}
\hline ÁREA DE CONHECIMENTO & No. & $\%$ \\
\hline Ensino de Ciências (geral) & 100 & $50 \%$ \\
\hline Ensino de Física & 60 & $30 \%$ \\
\hline Ensino de Biologia & 14 & $7 \%$ \\
\hline Educação Ambiental & 12 & $6 \%$ \\
\hline Ensino de Química & 11 & $5,5 \%$ \\
\hline Ensino de Matemática & 3 & $1,5 \%$ \\
\hline TOTAL & 200 & $100 \%$ \\
\hline
\end{tabular}

Tabela 1.1: Distribuição de trabalhos nacionais sobre EA por área de conhecimento

Verificamos que cerca de metade do total de trabalhos tem como objeto a pesquisa em Ensino de Ciências de um modo geral, sem recorte em dada componente curricular. Dentre as áreas de conhecimento específicas, os trabalhos na área de Pesquisa em Ensino de Física têm maior concentração, constituindo 30\% do total. Trata-se de resultado esperado e justificável, em primeiro lugar, por ser, no ensino de Ciências, uma área precursora, com trajetória institucional mais longa e, portanto, com produção quantitativamente superior às demais. E, em segundo lugar, por ser a área de interesse nessa pesquisa, o que certamente levou a uma busca mais cuidadosa para dar conta de um conjunto o mais abrangente possível. Assim, no que se refere às áreas de Ensino de Biologia, Química, Educação Ambiental e Matemática, o levantamento é parcial, pois se limita às publicações no evento mais abrangente da PEC - o ENPEC - ou aos periódicos da área de Ensino de Ciências. Ou seja, não fazem parte dessa relação, trabalhos apresentados em eventos ou publicados em periódicos específicos dessas áreas (ensino de Biologia, de Química, de Matemática etc.)

Nos Anexo 1.1 e 1.2 apresentamos um panorama geral desses trabalhos.

\section{Primeiro Recorte: Pesquisa em Ensino de Física}

Em uma segunda etapa, passamos a analisar nosso primeiro recorte desse levantamento - trabalhos desenvolvidos no âmbito da Pesquisa em Ensino de Física, contendo um total de 60 títulos, os quais classificamos segundo indicadores gerais, quer quanto à própria produção (autor, título, ano e tipo de produção), quer quanto à produção analisada, ou seja, dados sobre o estado da arte realizado (tipo de produção analisada, recorte temporal e recorte temático), cujos principais dados e resultados sistematizamos a seguir. 


\section{Quanto à própria produção}

A classificação desses trabalhos no que se refere ao ano de produção confirma o esperado crescimento dessa linha de investigação, do início da década de 1990 para cá, como mostra o gráfico 1.1 .

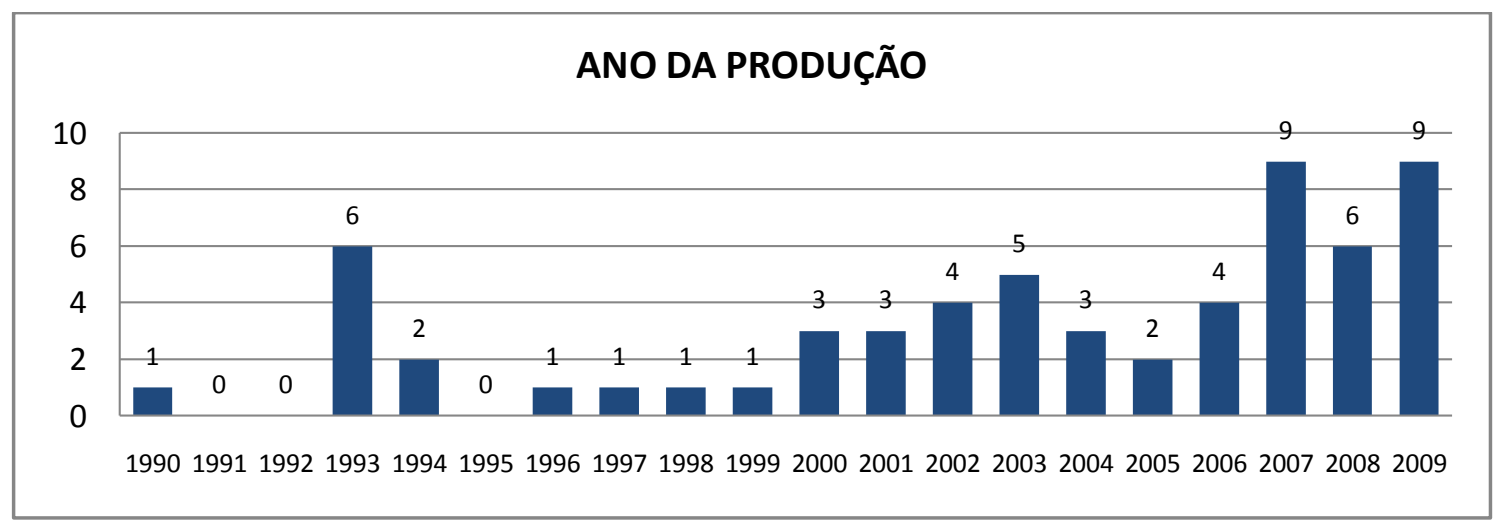

Gráfico 1.1: Evolução do número de trabalhos nacionais de EA da PEF ao longo dos anos

Não fossem os dados da década de 2000-2009, poderíamos concluir que os trabalhos nessa linha constituiriam casos isolados em nossa área, sem apresentar alguma tendência. O primeiro trabalho desse levantamento data de 1990 e nos anos seguintes dessa década observam-se poucos e dispersos títulos, com uma média de 1,3 trabalhos/ano. Ressaltamos que particularmente nos anos de 1993 e 1994, entre os oito trabalhos constantes desse levantamento, seis são de nossa autoria, que como já dissemos, a essa época a sistematização e reflexão sobre a produção na área de ensino de física já era uma preocupação e parte de nossa pesquisa. Somente a partir do início da década seguinte, observamos um crescimento no número de trabalhos, levando a média dessa nova década a cinco trabalhos/ano.

A tabela 1.2, na qual esses dados estão organizados por períodos de cinco anos, mostra que a grande maioria dos trabalhos, quase $\mathbf{8 0} \%$ do total, foi produzida após 2000 e que apenas no último quinquênio, de 2005 a 2009, concentra-se a metade do total de pesquisas nesse período de vinte anos.

\begin{tabular}{|l|l|l|}
\hline PERÍODO & No. & $\%$ \\
\hline $1990-1994$ & 9 & 15 \\
\hline $1995-1999$ & 4 & 6,5 \\
\hline $2000-2004$ & 17 & 28,5 \\
\hline $2005-2009$ & 30 & 50 \\
\hline TOTAL & 60 & 100 \\
\hline
\end{tabular}

Tabela 1.2: Evolução do número de trabalhos de EA sobre a Pesquisa em Ensino de Física 
Esse resultado é importante, pois mostra que, de fato, os estudos de estado da arte vêm se intensificando, acompanhando o crescimento da própria produção na área. 0 início da década 2000 representa um momento significativo por demarcar cerca de 30 anos de institucionalização da Pesquisa em Ensino de Física no país (I SNEF e criação dos primeiros dois Programas de Pós-Graduação na área de Ensino de Física, na USP e UFRGS), o que veio, certamente, motivar investigações e reflexões dessa natureza.

Quanto ao tipo de produção, os trabalhos foram classificados nos três formatos em que foram apresentados ou publicados: participações em eventos, artigos de periódicos, dissertações e teses, cuja sistematização encontra-se na tabela 1.3.

\begin{tabular}{|l|l|l|}
\hline TIPO DE PRODUÇÃO & No. & $\%$ \\
\hline Participação em Evento & 42 & 70 \\
\hline Artigo de Periódico & 16 & 26,5 \\
\hline Dissertação ou Tese & 2 & 3,5 \\
\hline TOTAL & 60 & 100 \\
\hline
\end{tabular}

Tabela 1.3: Distribuição dos trabalhos sobre EA da PEF quanto ao tipo de produção

Verifica-se uma predominância de trabalhos (70\%) apresentados em eventos. De certo modo, isso pode refletir e ser reflexo da própria produção na área que, por meio de seus três principais eventos bienais (SNEF, EPEF e ENPEC), com expressivo e crescente número de trabalhos, deve concentrar grande parte da produção acadêmica como um todo, considerando-se a maior agilidade de produção por esse meio do que na forma de artigos de periódicos especializados ou de dissertações e teses.

\section{Quanto à produção analisada}

Alguns dos trabalhos nessa linha tratam da área de um modo geral (aqui classificados como "Gerais") enquanto outros fazem recortes específicos, geralmente revisões bibliográficas sobre um dado tema ou objeto de interesse da pesquisa. Nesse conjunto, quase $60 \%$ dos trabalhos são "Gerais"; os demais $40 \%$ focalizam recortes temáticos, que são dispersos, sem concentrações muito expressivas em um determinado foco.

Entre esses últimos, são temas de revisão: Física Moderna e Contemporânea no Ensino Médio; Atividades Experimentais, Formação de Professores, Tecnologia da Informação e Comunicação, Ensino-Aprendizagem no nível Médio, Ensino-Aprendizagem no Nível Fundamental, Construtivismo, CTS, Divulgação Científica, História da Ciência, Metacognição, Transposição Didática, Pesquisa x Prática Docente. Alguns tratam de linhas de pesquisa que constituem a área há um longo período (tal como Formação de Professores ou História da Ciência), outros a focos mais específicos ou mais recentes na história da área (como Transposição Didática ou Tecnologia da Informação e Comunicação), com distribuição de frequências apresentada na tabela 1.4. 


\begin{tabular}{|l|l|}
\hline ESTADOS DA ARTE SOBRE TEMAS ESPECÍFICOS & PARTICIPAÇÃO \\
\hline Física Moderna e Contemporânea & $23 \%$ \\
\hline Ensino-Aprendizagem no Nível Fundamental e Médio & $16 \%$ \\
\hline Atividades experimentais & $12 \%$ \\
\hline Formação de professores & $12 \%$ \\
\hline Tecnologia da Informação e Comunicação & $12 \%$ \\
\hline Construtivismo & $4 \%$ \\
\hline CTS & $4 \%$ \\
\hline Divulgação Científica & $4 \%$ \\
\hline História da Ciência & $4 \%$ \\
\hline Metacognição & $4 \%$ \\
\hline Transposição Didática & $4 \%$ \\
\hline Pesquisa x Prática Docente & $4 \%$ \\
\hline
\end{tabular}

Tabela 1.4: Trabalhos com recortes específicos

Ainda quanto à produção analisada, outro recorte é temporal; refere-se ao estado da arte em um dado período. Uma vez feita a distribuição dos 60 trabalhos segundo esse indicador, procuramos agrupá-los segundo a década focalizada, identificando o número de trabalhos que contemplam cada uma das cinco décadas. Como há trabalhos que abarcam distintos períodos, o total não resulta em $100 \%$. A tabela 1.5 mostra essa distribuição, considerando as sobreposições.

\begin{tabular}{|l|l|l|l|}
\hline & \multicolumn{2}{|c|}{ OBJETO DE ESTUDO } & \\
\hline PERÍODO & GERAIS & RECORTES & TOTAL \\
\hline $1960-1969$ & 3 & 0 & $\mathbf{3}$ \\
\hline $1970-1979$ & 20 & 4 & $\mathbf{2 4}$ \\
\hline $1980-1989$ & 19 & 8 & $\mathbf{2 7}$ \\
\hline $1990-1999$ & 17 & 15 & $\mathbf{3 2}$ \\
\hline $2000-2009$ & 7 & 23 & $\mathbf{3 0}$ \\
\hline Gerais & 6 & 1 & $\mathbf{7}$ \\
\hline
\end{tabular}

Tabela 1.5: Evolução dos trabalhos de EA da PEF segundo período analisado

Esses dados indicam que há uma tendência de crescimento nas investigações do estado da arte relativas aos anos mais recentes e com recortes temáticos, que pode se justificar pelo crescimento e diversificação da produção de um modo geral. Ou seja, com a evolução da área, torna-se (cada vez) mais difícil dar conta de estudos com maior abrangência. Por outro lado, ao longo de sua trajetória a área vem se estruturando em torno de linhas ou áreas temáticas e no interior de cada uma, os pesquisadores procuram se situar, por meio de mapeamentos, revisões, reflexões e intercâmbio acadêmico. E nessa dinâmica esses mapeamentos tornam-se mais restritos no tempo, porque mais atualizados e focados em anos mais recentes.

Um segundo indicador que classificamos nesses estudos refere-se ao tipo de apresentação/publicação analisada: eventos, artigos de periódicos, dissertações e 
teses. Nesse caso também há combinações de dois ou mais tipos (por exemplo, periódicos e eventos), as quais categorizamos como "Diversos". Àqueles que não focalizam um tipo específico de apresentação, mas tratam da produção na área de um modo geral, foram classificados como "Produção Geral".

\begin{tabular}{|l|l|l|l|l|l|l|}
\hline & \multicolumn{2}{l|l}{ GERAIS } & \multicolumn{2}{l|}{$\begin{array}{l}\text { RECORTES } \\
\text { ESPECÍ́IICOS }\end{array}$} & \multicolumn{2}{l|}{ TOTAL } \\
\hline TIPO DE PRODUÇão & abs & $\%$ & abs & $\%$ & abs & $\%$ \\
\hline Dissertações e teses & 8 & 24 & 0 & 0 & 8 & 13 \\
\hline Periódicos & 2 & 6 & 15 & 58 & 17 & 28 \\
\hline Trabalho em evento & 4 & 12 & 6 & 23 & 10 & 17 \\
\hline Diversos & 6 & 18 & 5 & 19 & 11 & 18 \\
\hline Produção Geral & 14 & 40 & 0 & 0 & 14 & 23 \\
\hline
\end{tabular}

Tabela 1.6: Distribuição dos trabalhos de EA segundo tipo de produção analisada

No total, a distribuição é relativamente uniforme, com ligeira predominância na análise de artigos de periódicos (cerca de $30 \%$ ) e menor concentração nas dissertações e teses (cerca de 10\%).

Até aqui, podemos destacar nesse panorama geral que as investigações de natureza de estado da arte na Pesquisa em Ensino de Física:

- Vêm crescendo ao longo das duas últimas décadas, sendo que nos últimos dez anos (2000-2009) concentram cerca de $80 \%$ do total.

- Em sua maioria são trabalhos apresentados em eventos da área.

- Têm como objeto de estudo, predominantemente, a produção na área de um modo geral (sem recortes temáticos).

- No entanto, mais recentemente, focalizam recortes temáticos e períodos mais estreitos e recentes.

\subsection{Características e tendências recentes}

A sistematização desses dados acerca do estado da arte da produção na área de PEF permite situar a abrangência da questão e, ao mesmo tempo, impõe a necessidade da delimitação e construção de uma amostra mais restrita. Com esse intuito, visando o aprofundamento da análise com uma compreensão mais refinada das características e tendências dos trabalhos com esse caráter - o que têm em comum, do que vêm tratando, com que objetivos e por meio de quais metodologias, abordagens e perspectivas - selecionamos uma amostra de 12 deles (20\%) contemplando, nessa seleção, alguns dos resultados do panorama obtido na análise do conjunto. Estão 
incluídos nessa amostra, três trabalhos que não estão no âmbito específico da Pesquisa em Ensino de Física (fazem parte do levantamento da Pesquisa em Ensino de Ciências), mas que a tratam como componente especial da investigação realizada, além de ter como autores pesquisadores com tradição e produção reconhecida nessa área. Foram critérios usados na escolha da amostra, os estudos:

(i) Mais recentes (produzidos após 1999);

(ii) cuja produção analisada tratou preferencialmente da área como um todo;

(iii) identificados, em um primeiro estudo, como tendo abordagens diferenciadas;

(iv) contemplando autores que têm realizado mais sistematicamente esse tipo de investigação.

Com base nesses critérios, chegamos à seguinte amostra, sistematizada na tabela 1.7.

\begin{tabular}{|l|l|l|l|}
\hline \multicolumn{1}{|c|}{ AUTOR } & ANO & \multicolumn{1}{|c|}{ FORMA DE APRESENTAÇÃo } & \multicolumn{1}{c|}{$\begin{array}{c}\text { PERÍODO } \\
\text { ANALISADO }\end{array}$} \\
\hline BARROS & 2002 & Evento - Conferência / VIII EPEF & 1960 a 1990 \\
\hline BORTOLETTO et al & 2007 & Evento - VI ENPEC & $2000-2007$ \\
\hline CARVALHO e VANNUCHI & 1999 & Artigo Periódico - Inv. Ens. Cienc. & $1990-1995$ \\
\hline DELIZOICOV & 2004 & Artigo Periódico - Cad.Bras. Ens.Fis. & $1972-2003$ \\
\hline MEGID & 2000 & Evento - VII EPEF & $1972-1995$ \\
\hline MOREIRA & 2003 & Adaptação de Conferência & Sem delimitação \\
\hline NARDI & 2005 & Artigo Periódico - Inv. Ens.Cienc. & Sem delimitação \\
\hline PENA e FREIRE & 2003 & Evento - IV ENPEC & $1960-1979$ \\
\hline QUEIROZ e SILVA & 2008 & Evento - XI EPEF & $1997-2005$ \\
\hline REZENDE et AL & 2007 & Evento - VI ENPEC & $2000-2006$ \\
\hline SALEM e KAWAMURA & 2008 & Evento - XI EPEF & $1972-2005$ \\
\hline SOUZA FILHO et AL & 2005 & Evento - V ENPEC & $2000-2005$ \\
\hline
\end{tabular}

Tabela 1.7: Amostra de trabalhos analisados

Para a caracterização desses estudos, foi feita uma leitura na íntegra dos doze trabalhos, de modo a reconhecer e extrair, de cada um, indicadores de perfis e tendências dados por:

(i) Objetivos: como apresentam seus objetivos, intenções, motivações e justificativas para realização do trabalho.

(ii) Objeto de análise: como definem o objeto de estudo focalizado, ou seja, "a arte" em questão.

(iii) Metodologias: quais as metodologias utilizadas na pesquisa. 
(iv) Principais resultados e conclusões: qual a natureza dos resultados, as principais conclusões e recomendações ou proposições feitas.

Para cada um desses elementos, passamos a identificar tipologias que sintetizassem e representassem o conjunto. Não foram criadas categorias a priori, ou seja, agrupamentos ou categorias-síntese foram obtidos a partir dos "dados brutos", os quais, nesse caso, estão mediados por análise de conteúdo e, portanto, interpretativa.

A intenção principal dessa análise não foi contabilizar os trabalhos classificados em cada uma das categorias ou tipologias, mas reconhecer e sistematizar as características ou a natureza dessas pesquisas, aspectos que nem sempre vêm sendo explicitados e que podem contribuir para o aprofundamento de estudos da área.

\section{Dos Objetivos}

Da análise dos objetivos dos trabalhos dessa amostra, em alguns casos explícitos, em outros implícitos, pudemos extrair tendências que, agrupadas segundo características comuns, levaram à identificação de categorias não excludentes ou exclusivas de um ou outro trabalho. Ou seja, há aspectos comuns entre elas e há trabalhos que apresentam mais de um desses objetivos identificados. Desse modo, de acordo com a tendência predominante, evidenciamos quatro categorias-síntese que podem representar a natureza desses objetivos, sintetizadas no Quadro 1.1:

\begin{tabular}{|c|c|c|c|}
\hline \multicolumn{4}{|c|}{ OBJETIVOS } \\
\hline $\begin{array}{l}\text { recuperar } \\
\text { caminhos }\end{array}$ & identificar & apontar caminhos & divulgar \\
\hline preservar memória & $\begin{array}{c}\text { caracterizar focos de } \\
\text { interesse }\end{array}$ & ...tendências & compartilhar \\
\hline resgatar história & reconhecer & ...perspectivas & intercambiar \\
\hline reconstruir & compreender & superar desafios & difundir \\
\hline$\downarrow$ & $\downarrow$ & $\downarrow$ & $\downarrow$ \\
\hline MEMÓRIA & IDENTIDADE & PERSPECTIVAS & DISSEMINAÇÃO \\
\hline$\downarrow$ & $\downarrow$ & $\downarrow$ & $\downarrow$ \\
\hline como chegamos aqu & quem somos & para onde vamos & dialoguemos \\
\hline
\end{tabular}

Quadro 1.1: Natureza dos objetivos 
Na primeira dessas tendências, a natureza principal dos objetivos está relacionada à recuperação dos caminhos traçados pela área, ao resgate da sua história, ao registro de sua memória. A esse tipo, demos a designação MEMÓRIA.

Alguns trechos extraídos de trabalhos dessa amostra ilustram essa tendência.

O objetivo desta pesquisa é elaborar um perfil da comunidade brasileira de pesquisadores em ensino de física no período compreendido entre 1960 e fins da década de 70 mediante o levantamento dos professores/pesquisadores titulados ou em atividade no período, da produção intelectual desses pesquisadores, bem como a categorização dessa produção. Tal estudo visa contribuir para a elaboração de uma história da comunidade de pesquisadores em ensino de física no Brasil. (PENA e FREIRE, 2003, p.1) (grifos nossos).

Entendendo que os fatores que contribuíram para a constituição dessa área ainda não parecem estar esclarecidos nos registros até então existentes, Nardi e Almeida (2003, 2004), estabeleceram projeto de pesquisa que visa "contribuir para a preservação da memória da Educação em Ciências no país". Existe uma área de Educação em Ciências no país? Quem poderia responder a esta questão? A que se deve o início da pesquisa em Ensino de Ciências no Brasil? Que fatores foram determinantes para a constituição dessa área? Quais são suas características? (NARDI, 2005a) (grifos nossos).

Na segunda categoria de objetivo identificada, à qual denominamos IDENTIDADE, a tendência predominante é a busca de uma caracterização da área por meio de mapeamentos e análises de aspectos que a identificam, particularmente de seus âmbitos de estudo, metodologias e focos de interesse. São, assim, trabalhos que têm como perspectiva traçar um perfil ou construir um panorama da produção que situe e reconheça esse campo de pesquisa.

Alguns exemplos em que esse tipo de objetivo é explicitado:

....Descrever e analisar algumas características e tendências do conjunto de teses e dissertações em Ensino de Física, comparando ao mesmo tempo dados dessa produção com o conjunto de pesquisas nacionais no campo da educação cientifica.(MEGID, 2000, p.1).

O presente trabalho tem como foco de atenção a área de Ensino de Ciências, no sentido de contribuir ao acompanhamento de seu processo de evolução, buscando os elementos que podem constituir a identidade propriamente dessa área. (SALEM e KAWAMURA, 2005, p.2)

Na terceira categoria, à qual denominamos PERSPECTIVA, destacamos trabalhos que têm como objetivo central, a busca de tendências futuras, caminhos, desafios, limites ou perspectivas da área, em alguns casos, apresentando propostas nesse sentido. 
[...] realizar um balanço crítico do que tem sido pesquisado terá um caráter não de mero 'mapeamento' da realidade escolar, mas reflexivo sobre a evolução ao longo do período analisado da pesquisa na área, podendo ser associado às questões políticas e econômicas do país nos últimos anos. (QUEIROZ E SILVA, 2008, p.2)

Propostas são apresentadas com a finalidade de se efetivar uma maior aproximação dos problemas investigados pelo campo com aqueles enfrentados pelo ensino de ciências nas escolas brasileiras. (DELIZOICOV, 2004, p.145)

Finalmente, identificados na categoria DISSEMINAÇÃO estão os trabalhos que apontam como objetivo promover o intercâmbio entre os diversos estudos dessa natureza (de estado da arte); de compartilhar e comparar resultados ou de criar canais de diálogo e troca de informações e reflexões.

O objetivo desta comunicação é divulgar aos educadores e pesquisadores da área de ensino de Física as tendências das temáticas presentes em publicações desta área em algumas revistas nacionais e internacionais e nas atas de eventos. (SOUZA FILHO et al, 2005, p.1) (grifos nossos)

Como socializar, então, os conhecimentos oriundos dessas pesquisas? Aqui se apresenta o segundo objetivo deste artigo: discutir possiveis meios que estimulem maior difusão das pesquisas em Educação em Ciências geradas em programas de pós-graduação no país. (MEGID, 2000, p.1) (grifos nossos).

De um modo geral, pode-se também perceber que há um consenso no que se refere à importância desse tipo de investigação, seja qual for a natureza do objetivo: resgatar a memória, buscar identidade, apontar perspectivas ou divulgar e compartilhar resultados. Mas para além disso, parece haver um objetivo comum, nem sempre explícito, de demarcar a área (ou marcar território) afirmando e reconhecendo sua existência e autenticidade enquanto campo de pesquisa ou de conhecimento.

\section{Do Objeto / Arte}

Em uma primeira leitura dos trabalhos, depoimentos e falas dos protagonistas da área de Pesquisa em Ensino de Física mostram um entendimento comum, implícito, do que seja essa área (o mesmo valendo para a Pesquisa em Ensino de Ciências). Todos nós, protagonistas de seus fazeres ou de sua história, sabemos do que se trata, não é necessário definir. O objeto "Ensino de Física" ou "Pesquisa em Ensino de Física", para seus criadores ou para sua comunidade é dado, se auto-define.

Tal percepção nos levou a escolher como outro elemento a ser analisado aquilo que os autores desses trabalhos estão, implícita ou explicitamente, concebendo como "a área", ou seja, o que seria a "arte" nesses estudos de estado da arte.

Novamente, antes de qualquer busca de definições ou delimitações, existe uma insistente afirmação da existência da área, cujos componentes (ou dados "comprovadores") não variam muito significativamente de um a outro discurso. 
O Brasil tem uma tradição de Pesquisa em Ensino de Física, com várias décadas de existência, realizações de peso, programas de Pós-Graduação bem estabelecidos e muitas publicações que atestam a fertilidade da produção dessa comunidade... (BARROS, 2002, p.2)

A produção acadêmica sobre o ensino e a aprendizagem de Física no Brasil hoje é bastante visivel e deve-se à existência de um número razoável de pesquisadores que se congregam em diversos grupos de pesquisa atuantes no país e que são responsáveis pela organização e edição de revistas, pela criação e manutenção de eventos, projetos e cursos de formação continuada, pela implantação de dezenas de cursos de pós-graduação lato sensu e pelo conseqüente credenciamento junto aos órgãos normatizadores, principalmente a partir do final da década de 90, de diversos programas de pós-graduação em Educação em Ciências em nível stricto sensu existentes no país. (NARDI, 2005a, p.63)

Através de aspectos relacionados à área de ensino de ciências, tais como existência de cursos e programas de pós-graduação, de periódicos especializados na publicação de resultados de pesquisas e de eventos científicos específicos, constata-se que esta constitui um campo social de produção de conhecimento. (DELIZOICOV, 2004, p.146)

Alguns pesquisadores argumentam, contudo, que não é nessa demarcação precisamente que se deve concentrar esforços para avançar, já que as características desse campo de pesquisa estão sócio-historicamente dadas.

[...] Em síntese, podemos concluir que esse campo se associa à existência de pesquisa com características que podem ser demarcadas e que, portanto, não se trata de procurar definir o que é ou o que deveria ser pesquisa em $E C / E F$, uma vez que isto já está sócio-historicamente dado. Assim, uma perspectiva simplesmente normativa para qualificar a pesquisa em EC, além de desnecessária neste momento, seria praticamente ineficaz, uma vez que há uma construção que não pode ser facilmente descartada, desconsiderada ou alterada em nome de alguma normatização que não esteja em sintonia com o que já foi produzido. Cabe, no entanto, tirar lições dessa trajetória, de modo a prosseguir na caminhada que já iniciamos há cerca de três décadas, realizando as necessárias correções de rumo. (DELIZOICOV, 2004, p.151) (destaques do autor).

Em um segundo momento, verificamos que há uma diferença que pode parecer sutil ou casual, nas denominações para a área, que se mesclam e se confundem, mas podem ser lidas com distintos significados, quais sejam: ENSINO DE CIÊNCIAS (FÍSICA) e PESQUISA EM ENSINO DE CIÊNCIAS (FÍSICA) sendo que dependendo do sentido, uma abarcaria a outra (ou outra abarcaria a uma...). Há casos em que ambas as denominações são usadas indistintamente, e há outros em que se revela uma preocupação em diferenciar ou definir a abrangência e limites dessas concepções. 
Em uma das visões, a área "Ensino de" incluiria elementos que iriam além da "pesquisa em si" tais como: comunidade, eventos, publicações, programas de pós-graduação, projetos, cursos de formação inicial ou continuada, credenciamento por órgãos de fomento à pesquisa, ações, práticas e políticas. Ao reportar-se a ela, estaria se referindo ao conjunto de todos esses elementos. Segundo essa visão, a "PESQUISA EM ENSINO DE" seria restrita à produção de conhecimento ou à "pesquisa básica" e, diante disso, seria necessário redefinir as fronteiras entre o que é o que não é "pesquisa".

O que é pesquisa básica em educação em ciências? É produção de conhecimentos sobre educação em ciências; busca de respostas a perguntas sobre ensino, aprendizagem, currículo e contexto educativo em ciências e sobre o professorado de ciências e sua formação permanente, dentro de um quadro epistemológico, teórico e metodológico consistente e coerente, no qual o conteúdo específico das ciências está sempre presente[...] Quer dizer, pesquisa em educação em ciências é produção de conhecimento nesse campo mas, por exemplo, o desenvolvimento instrucional, a produção de equipamento de laboratório, de "softwares" educativos ou de textos e outros materiais didáticos, não está necessariamente contribuindo para o avanço do conhecimento em educação em ciências, conseqüentemente, não é pesquisa, embora possa ser muito importante para o ensino e a aprendizagem de ciências. Não é uma questão de mérito, mas sim de significado. Pesquisa e desenvolvimento podem andar juntas (e/ou devem andar juntas) mas significam coisas distintas. Há, por exemplo, muita atividade de desenvolvimento instrucional e curricular sem nenhum referencial teórico, que não se constitui, portanto, a meu ver, em atividade de pesquisa em educação em ciências. (MOREIRA, 2003, p.2) (grifos nossos)

Alguns autores, no que tange à delimitação das fronteiras ou de identidade da área, procuram precisar ou discutir a própria definição do que seja um dado campo de pesquisa, de conhecimento ou de saber. Com diferentes significados e denominações, conforme aportes distintos em que esses estudos se apóiam, encontramos noções tais como "campo de conhecimento", segundo Bourdieu (BORTOLETTO, 2007), campo de produção de conhecimento (MOREIRA, 2003), campo social de produção de conhecimento ou coletivos de pensamento, segundo Fleck (DELIZOICOV, 2004), campo científico de estudo e investigação, entre outras denominações, rótulos ou concepções.

Campo de conhecimento, conforme Bourdieu (2004), é [...] o universo no qual estão inseridos os agentes $e$ as instituições que produzem, reproduzem ou difundem a arte, a literatura ou a ciência. Esse universo é um mundo social como os outros, mas que obedece a leis sociais mais ou menos específicas' (p. 20). A análise que propomos considera um campo ou área de conhecimento específica, a área de ensino de Ciências no Brasil - um campo científico. (BORTOLETTO, 2007, p.2) (grifos nossos) 
...Esses dados são indicativos de que, de fato, há uma comunidade de pesquisadores em ensino de ciências no Brasil que vem produzindo e divulgando seus resultados de pesquisa. Franco e Sztajn (1998) argumentam que a área de Educação em Ciências, que incluí as atividades de pesquisa, constitui um campo social de produção de conhecimento. Apoiando-se em Bourdieu, caracterizam este campo como um microcosmo social autônomo na medida em que é um espaço de relações objetivas com lógicas e necessidades específicas irredutíveis àquelas que regem outros campos. (DELIZOICOV, 2004, p.151) (grifos nossos)

Fleck, nas considerações epistemológicas que faz, argumenta sobre o papel dos distintos coletivos de pensamento (FLECK, 1986) ao analisar a produção $e$ disseminação de conhecimentos. Ele caracteriza um coletivo de pensamento como constituído por um coletivo de indivíduos que é portador de um estilo de pensamento, o qual podemos compreender sinteticamente como sendo caracterizado por conhecimentos e práticas compartilhadas [...](DELIZOICOV, 2004, p.164)

Não é o caso, no momento, de buscar significados ou diferenças entre essas concepções, mas apenas destacar que existem, especialmente porque não constituem pauta de debates polêmicos ou de questão controversa na área. No entanto, é tema que abre espaço para discussões e reflexões que contribuam para as práticas e desafios impostos hoje para a pesquisa em nossa área.

Também se salienta em diversos trabalhos a natureza interdisciplinar da área, como marca importante de sua constituição e estrutura de conhecimento, bem como motivo de dificuldades na delimitação de seu universo. Nessa dimensão, alguns autores examinam o modo como a área se compõe e evolui no entrelaçamento de diferentes campos de conhecimento e seus impactos na pesquisa.

[...] nesse movimento [em meados da década de 1960], emergiu progressivamente um campo de pesquisa preocupado especificamente com aspectos ligados à Educação em Ciências, área de ensino e pesquisa que abrange estudos e ações educacionais no campo das denominadas ciências da natureza (Biologia, Física, Química e Geociências), direcionados para os diversos níveis escolares da educação básica e superior, bem como aos estudos e ações voltados para os processos educacionais não-escolares, visando a alfabetização científica, a divulgação e a popularização das ciências da natureza ao público em geral. Também estão inseridos na área os estudos no campo da Educação Ambiental, da Educação em Saúde e da Sexualidade, desde que correlacionados com o ensino das ciências da natureza em processos escolarizados ou não-escolarizados. (MEGID, 2007)

A pesquisa em Ensino e Aprendizagem de Física é [...] formada por uma comunidade eclética de físicos que utilizam metodologias oriundas da educação, psicologia, ciências sociais, história e epistemologia, psicanálise, tecnologia da 
comunicação [...] Os conteúdos e os contextos [das pesquisas] devem estar diretamente relacionados com a Física [...] Também e provavelmente devido ao seu caráter intrinsecamente interdisciplinar, a Pesquisa em Ensino de Física, utiliza um espectro de enfoques que leva à dispersão das linhas de pesquisa, como se observa nos trabalhos desenvolvidos, pelos mesmos pesquisadores. São poucos aqueles que se mantêm coerentes, dentro de um Programa de Pesquisas, pré definido por linhas temáticas/metodológicas. Assim vemos pesquisas que se sustentam dentro de referências oriundas da Psicologia, da Epistemologia, da Antropologia/sociologia como também nas pesquisas das ciências experimentais, que delimitam os conteúdos dos estudos realizados. (BARROS, 2002, p.13)

Ainda quanto à "arte" e não exatamente sobre suas fronteiras e elementos constituintes, outro aspecto que vem ocupando espaço nas reflexões de alguns pesquisadores são os seus fins, para os quais questionamentos e análises na direção de caracterizar esse objeto chamado PEF deveriam levar em conta "a que veio" para definir "o que é" ou "o que vem sendo".

A realidade é que a Pesquisa em Ensino de Física, ora desenvolvida no Brasil, possui metas próprias e se encontra atualmente num estágio de desenvolvimento sistemático, com um grau de integração direto e indireto em relação ao sistema de ensino, sendo este provavelmente um dos seus objetivos fim de maior relevância e prioridade. (BARROS, 2002, p.2)

Sem querer ser repetitiva, mas com a intenção de frisar aspecto que novamente se sobressai, o que mais se destaca nesses estudos é que seja qual for o "órgão emissor" da "certificação" de identidade da área, as dimensões de seu território ou os elementos que abarca, o fato é que existe.

\section{Das Metodologias}

Dadas as diferentes abordagens ou perspectivas de estado da arte realizadas, também suas metodologias de investigação são diversas e não muito claramente definidas.

Os estudos que buscaram fazer levantamentos, mapeamentos, revisões ou classificações, geralmente descrevem suas "metodologias" em função de como foram feitos esses levantamentos, quais as suas fontes de dados e, em alguns casos, quais as categorias utilizadas para eventuais classificações. Na maioria das vezes, são empíricos e mesclam tratamento quantitativo e qualitativo, (dados quantitativos interpretados por análise qualitativa) em uma triangulação metodológica, conforme Moreira. ${ }^{4}$

\footnotetext{
${ }^{4}$ Moreira define tendências metodológicas na Investigação em Didática da Física em três principais categorias: (i) enfoque quantitativo, científico, realista e objetivo; (ii) enfoque qualitativo, interpretativo, etnográfico, idealista e subjetivo e (iii) complementaridade, triangulação metodológica, e identifica uma progressão, ao longo do tempo, do primeiro ao terceiro enfoque (MOREIRA, 1993).
} 
Metodologicamente, iniciamos com um enfoque quantitativo/estatístico, passamos quase abruptamente para um enfoque qualitativo/etnográfico e talvez estejamos hoje em uma época de triangulação metodológica ou, pelo menos, de convivência pacífica. (MOREIRA, 2003, p.6)

Nesses trabalhos, as fontes dos dados e informações geralmente são catálogos analíticos (CEDOC, USP-IF, ANPED, CAPES), atas de eventos e periódicos da área. Nem sempre se faz referência sobre a utilização de resumos ou de trabalhos completos, sendo no caso de dissertações e teses mais frequente a primeira opção, o que é tido como um problema metodológico para alguns pesquisadores.

As interpretações que apresentamos são elaboradas a partir de procedimentos de coleta e análise de dados característicos de pesquisa "estado da arte". São analisadas pesquisas em ensino de Física considerando resumos e/ou artigos completos publicados em eventos e revistas na área no período de 2000 a 2007. [...] Ferreira (2002) ainda questiona a possibilidade de realização de "estado da arte" utilizando apenas resumos e, nessa direção, ela discorre sobre problemas $e$ proposições... (BORTOLETTO et al, 2007).

Quanto aos estudos que analisam a estrutura ou evolução da área segundo focos temáticos ou linhas de pesquisa, identificamos outro problema que merece atenção. Tem sido comum, e é o caso de alguns trabalhos dessa amostra, o uso das Áreas Temáticas (ATs) propostas nos eventos para submissão de trabalhos como categorias de análise, o que a nosso ver traz diversas limitações: uma primeira advém do fato de que algumas dessas ATs são muito abrangentes (como é o caso, por exemplo, da área "Ensino e Aprendizagem") enquadrando-se nelas um enorme número de trabalhos com conteúdos e perspectivas muito distintos, enquanto outras (como "Políticas Públicas") são específicas demais e agrupam um número muito reduzido de trabalhos. Como resultado, a identificação dos focos de interesse ou linhas de pesquisa, ao serem contabilizados os trabalhos em cada categoria, torna-se fragilizada. (Sobre isso, voltaremos no Capítulo 4).

Em segundo lugar, há um problema de ordem histórica, pois à medida que a área evolui, há temáticas que surgem e se fortalecem e outras que desaparecem ou se enfraquecem, tornando difícil a comparação e análise dessa evolução, quando se utiliza para períodos distintos as mesmas categorias, criadas em um dado momento dessa evolução.

Aos problemas advindos da escolha dessas áreas temáticas de eventos como categorias, somam-se os da própria classificação dos trabalhos nas mesmas. Algumas vezes são classificados segundo o critério de organização do próprio evento que, via de regra, tem como princípio usar a indicação do autor ao submeter o trabalho, tratandose, pois de critério subjetivo. Outras vezes, são usadas as ATs de um evento para classificar os trabalhos de outro evento, ou mesmo para classificar estudos de outra 
natureza, como teses e artigos de periódicos, sem se levar em conta as especificidades de cada evento ou de cada tipo de produção.

Enfoques de pesquisa em ensino de Física podem ser delineados a partir da análise das pesquisas publicadas nos mesmos [periódicos da área] [...] Dessa forma, podemos considerar o EPEF, em especialmente as comunicações orais, como representativos das pesquisas em ensino de Física desenvolvidas no país. (BORTOLETTO, 2007)

Finalmente, e esta é uma das mais graves limitações, é que nem sempre são explicitadas quer as definições das categorias usadas, quer os critérios de classificação. Acreditamos que entre as questões fundamentais a serem destacadas e refletidas, em relação a esse procedimento, é a não neutralidade dessas escolhas. A opção por dada estrutura classificatória está associada a uma dada concepção da área, e raríssimas vezes isso é discutido, problematizado, questionado.

Quanto aos estudos com ênfase em uma abordagem histórica, que visam resgatar a memória da área, as metodologias são predominantemente qualitativas ou interpretativas, por meio de análise de conteúdo ou de discurso, a partir de depoimentos, entrevistas ou de análise documental; tendo Bardin como referencial metodológico mais citado nos primeiro caso e no outro, Pêcheux e Orlandi.

A classificação dos trabalhos foi feita a partir da análise do conteúdo (Bardin, 1994) de seus resumos e visou, fundamentalmente, levantar seus objetos de estudo e, assim, identificar a principal temática na qual cada trabalho se encaixava. (REZENDE et al, 2007)

São muitos os procedimentos que podem ser seguidos num trabalho focado na recuperação da memória. Entre as fontes de informação possiveis está a memória falada dos que viveram situações associadas à criação dessa área. A decisão de entrevistar pessoas que vêm trabalhando na área de Ensino de Ciências no Brasil, supostamente desde o seu início, está associada ao fato de se acreditar que haja um número significativo de fatos ainda não documentados, mas deve-se também à consideração da importância de se trabalhar com o imaginário dos entrevistados através da análise de seus discursos, procurando compreender suas interpretações, manifestas nos discursos obtidos nas entrevistas, ou seja, procurando estabelecer como histórica e socialmente os sentidos dessas interpretações foram produzidos... Esses aportes, pautados na análise de discurso de linha francesa, cuja origem se deve aos trabalhos de Michel Pêcheux, apoiou-se principalmente em noções desenvolvidas no Brasil por Eni Orlandi. (NARDI, 2005a)

Para sintetizar, essa análise sugere que os trabalhos de estado da arte nesse campo não têm uma metodologia própria, característica, o que poderia ser atribuído à sua diversidade de perspectivas e conteúdos. Ou seja, nos parece que, por um lado, não existe uma metodologia única, o que a nosso ver é salutar quer com metodologias 
unívocas de um modo geral, quer com as características dessa área; sua pluralidade teórica e temática implicaria também uma pluralidade metodológica.

\section{Dos Resultados e Conclusões}

Tal como do ponto de vista metodológico, a natureza dos resultados ou conclusões desses trabalhos depende da perspectiva da investigação.

Naqueles estudos mais típicos de revisões e mapeamentos, os resultados são relativos aos levantamentos, às distribuições e classificações realizadas (evoluções do número de trabalhos ao longo do ano; distribuições temáticas, classificações por grau de ensino privilegiado etc.). Dadas as limitações já sinalizadas nas definições de categorias e critérios de classificação, esses resultados, ainda que em muitos trabalhos pareçam convergir, poderiam ser mais bem comparados e aprofundados. O que de mais relevante se pode extrair deles? Quais as convergências? Há contradições? O que apontam como desafios ou rumos para a área?

De um modo geral, as conclusões convergem para pontos comuns, especialmente no que se refere:

(i) Ao crescimento da área em relação às publicações, trabalhos em eventos, dissertações e teses, comunidade, instituições, programas de pós-graduação, projetos, etc. Essa parece ser a consideração mais destacada, presente na totalidade dos trabalhos.

A partir dos resultados obtidos até o presente momento, concluímos que a pesquisa em Ensino de Física tem passado por um evidente crescimento, com aumento no número de investigações e trabalhos publicados. Uma das explicações para isso é a criação de vários programas de pós-graduação na área. Esta expansão iniciou-se há pelo menos 20 anos, mas tem se intensificado nos últimos anos, como mostrado neste trabalho. (QUEIROZ e SILVA, 2008)

Os resultados desse panorama geral confirmam, sobretudo, que a pesquisa na área de Ensino de Física vem, de fato, se expandindo do ponto de vista quantitativo, com um número sempre crescente de dissertações e teses ao longo dessas mais de três décadas; ao lado de um crescimento e diversificação de programas, instituições e pesquisadores que compõem sua 'comunidade'. (SALEM e KAWAMURA, 2008)

(ii) À constatação de que a área existe enquanto tal tem uma história, identidade própria, produção fértil e constitui um campo particular de conhecimento e de pesquisa.

Esses dados são indicativos de que, de fato, há uma comunidade de pesquisadores em ensino de ciências no Brasil que vem produzindo e divulgando seus resultados 
de pesquisa [...] A pesquisa em EC no Brasil constitui, de fato, um campo social de produção de conhecimento, caracterizando-se como autônoma em relação a outros campos do saber, mas mantendo inter-relações, em distintos níveis de aproximação, com essas áreas. (DELIZOICOV, 2004, p.168)

A análise dos documentos levantados neste estudo e a interpretação de efeitos de sentido presentes nas falas dos pesquisadores entrevistados a respeito da origem e das características da área de ensino de ciências, algumas delas acima exemplificadas, mostram claramente que existe consolidada no país uma área de ensino de Física (e de Ciências), a qual, por sua vez, tem uma história. [...] Não obstante as convergências que possam ser mencionadas, as falas dos entrevistados mostram também uma diversidade de pontos de vista. (NARDI, 2005a, p.95)

(iii) À diversidade ou pluralidade da produção, em relação a temáticas, referenciais, metodologias, práticas e origens.

A Pesquisa em Ensino e Aprendizagem de Física é um campo relativamente novo. Com 30 anos de vida, e formada por uma comunidade eclética de fisicos que utilizam metodologias oriundas da educação, psicologia, ciências sociais, história e epistemologia, psicoanálise, tecnologias da comunicação, etc, é óbvio que o campo é complexo e aberto a muita crítica por parte dos pesquisadores ortodoxos das áreas específicas. Cada um destes grupos tem visões diferentes $e$ metodologias diferenciadas. (BARROS, 2002, p.13)

Embora essa diversidade ou pluralidade de imaginários possa ser uma rica característica da área de ensino de Física (e de Ciências), uma possível interpretação é que a área atingiu um expressivo nível de consolidação, mas, a exemplo de outras áreas que são integradas às Ciências Humanas, abriga uma pluralidade de concepções e metodologias, relacionada à diversidade da formação dos pesquisadores (o lugar de onde falam - origem acadêmica, localização geográfica, ideologia, valores etc), conforme o referencial assumido nessa pesquisa... (NARDI, 2005a, p.97)

(iv) À necessidade de investir, alargar e aprofundar esse tipo de estudo e concentrar esforços em uma intensiva troca de informações a cerca da produção na área, por meio de catálogos, bancos de dados, redes nacionais e outras formas de disseminação da pesquisa.

Daí a necessidade de se ampliar significativamente os estudos de revisão bibliográfica sobre a produção científica na área; de se incorporar novos documentos; de se vislumbrar novos modelos de descrição e análise. A rapidez com que o número de projetos e pesquisas se multiplicam, não somente aqueles restritos aos programas de pós-graduação, exige novos mecanismos de divulgação da produção nacional em Educação em Ciências e, quem sabe, a formação 
inclusive de grupos inter-institucionais para mapeamento e avaliação dessa produção... (MEGID, 2000, p.11)

Finalmente, vale ressaltar que essa e outras investigações que procuram mapear, compor e analisar a história e tendências da pesquisa ganham sentido se possibilitam mais e maiores reflexões e propostas no enfrentamento dos grandes (e pequenos) desafios envolvidos na contribuição que podem dar ao ensino de física e à sociedade. (SALEM e KAWAMURA, 2008)

Em muitas dessas conclusões, também são apontados limites, problemas e desafios para a pesquisa na área e, nesse caso, são conclusões comuns:

(i) Há fragilidades e limites dados pela própria natureza da área, geralmente associados à sua natureza interdisciplinar, que dificulta muitas vezes a sua demarcação.

Também e provavelmente devido ao seu caráter intrinsecamente interdisciplinar, a Pesquisa em Ensino de Física, utiliza um espectro de enfoques que leva à dispersão das linhas de pesquisa, como se observa nos trabalhos desenvolvidos, pelos mesmos pesquisadores... Assim vemos pesquisas que se sustentam dentro de referências oriundas da Psicologia, da Epistemologia, da Antropologia/sociologia como também nas pesquisas das ciências experimentais, que delimitam os conteúdos dos estudos realizados. (BARROS, 2002, p.11)

(ii) Grande parte dos problemas reside na formação de professores, que não vem incorporando resultados da pesquisa, o que implicaria incentivar a "pesquisaação", a maior participação dos professores na pesquisa ou ampliar a interação pesquisa-escola.

E ainda nem chegamos a falar dos professores da educação básica que menos acesso têm - quase nenhum - às pesquisas na área, exceção feita àqueles poucos que já participam de programas de pós-graduação ou de projetos de pesquisa junto às instituições de ensino superior. (MEGID, 2000, p.11)

A pesquisa em educação em ciências deve estar presente no currículo da formação inicial dos professores de ciências. Como mínimo, isso se concretizará através da inserção, na grade curricular, de uma disciplina específica, a qual deverá enfatizar a análise crítica do conhecimento produzido pela pesquisa em educação em ciências, ao invés de ser um curso de metodologia da pesquisa, e ser ministrada por um professor-pesquisador na área. (MOREIRA, 2003, p.12)

(iii) Os resultados da pesquisa têm contribuído de forma incipiente e limitada ao saber escolar, não chegando de modo efetivo aos professores e às salas de aula.

Uma das debilidades e/ou dificuldades identificadas anteriormente é que há pouca transferência do conhecimento produzido pela pesquisa em educação em ciências 
à sala de aula. Parece que na educação em ciências, na prática, na escola, na sala de aulas, passa-se muito pouco em termos de mudanças que possam ser consideradas conseqüência clara do conhecimento produzido pela pesquisa nessa área. (MOREIRA, 2003, p.10)

E, aqui, corroborado pelos trabalhos de Barros (2002) e Franco e Sztajn (1998), enfatizo a necessidade de se conceber a pesquisa em EC como estando no contexto das ciências humanas aplicadas. Significa, dentre outros aspectos, considerar o impacto dos resultados de pesquisa em EC no âmbito da educação escolar. Em outros termos, responder a questão: Qual é o retorno, em termos de usos e aplicações, dos resultados de pesquisa em EC para alterações significativas das práticas educativas na escola? (DELIZOICOV, 2004, p.152)

Isoladamente, outros aspectos são apontados como problemas ou desafios (não constituem consenso):

(i) A necessidade de maior rigor nas pesquisas, em particular na adoção de marcos teóricos e metodológicos claros, sem importação acrítica.

(ii) O enfraquecimento da presença do conteúdo científico nas pesquisas, em favor de outras dimensões e saberes (história, epistemologia, psicologia, sociologia, filosofia, pedagogia etc.).

(iii) Ausência de registros escritos por pesquisadores que vem atuando na área sobre suas visões, vivências e avaliações.

(iv) Debilidades metodológicas seja nas abordagens qualitativas, quanto nas quantitativas.

(v) Ausência de referenciais ou concepções do ponto de vista educacional, geralmente não explicitados.

(vi) Pouco diálogo com outras áreas de conhecimento ou centros de pesquisa.

Dos desafios e questões

Questões, recomendações ou desafios propostos em alguns desses trabalhos acompanham essas conclusões com focos que vão da necessidade de maior consolidação da área à sua contribuição social. Destacamos como exemplos:

Quanto aos desafios, o principal deles é o da própria consolidação da área, da identidade da área. Avançamos muito, criamos a área de educação em ciências, $e$ a pesquisa em educação em ciências, há mais ou menos trinta anos. Mas ainda temos que consolidá-la melhor, dar-lhe mais identidade. Necessitamos de mais programas de pós-graduação em educação em ciências, de mais revistas de pesquisa em educação em ciências, de mais associações de pesquisa em educação em ciências. Tudo isso em nível nacional e internacional. Necessitamos igualmente de departamentos ou centros de educação em ciências nas universidades e nas 
escolas. É claro que precisamos, também, trabalhar mais a questão da natureza epistêmica da área. Em relação às recomendações, me parece que as apresentadas na seção anterior são todas muito importantes $e$, ao invés de destacar uma ou outra, quero apenas reiterar duas: a participação dos professores na pesquisa e o diálogo com outras áreas. (MOREIRA, 2003, p.9)

Ainda que tanto a educação escolar como o ensino nela promovido pudessem ser considerados como efeitos e não causa da situação em que nos encontramos, penso que a pesquisa em EC, enquanto ciências humanas aplicadas, deve ter sólidos vínculos e compromissos com a superação dessa situação. (DELIZOICOV, 2004, p.171)

\subsection{0 estado da arte nas pesquisas internacionais}

O levantamento e a constatação aqui realizados sobre o crescimento e a variedade dos estudos na linha de estado da arte da pesquisa em ensino de Ciências / Física no Brasil é igualmente verificado em âmbito internacional. $E$ tal como verificamos no contexto brasileiro, há diferentes concepções e metodologias.

Nesse panorama, alguns trabalhos de revisão da área de Ensino de Ciência procuram analisar características de sua produção, investigando possíveis tendências. De certa forma, seus resultados podem ser interpretados também como um contexto mais geral no qual se insere a produção nacional.

Esse é o caso dos trabalhos de Tsai e Wen (2005) e Lee, Wu e Tsai (2009), que desenvolvem um estudo dos artigos publicados em três periódicos internacionais (Journal o Science Education, Science Education e Journal of Research in Science Education), nos períodos, respectivamente de (1998-2002) e (2003-2007). A metodologia e sistemática desses dois trabalhos são as mesmas, de tal forma a que se possam comparar seus resultados e acompanhar a evolução da área. São investigados a nacionalidade dos autores, os tipos e tópicos de pesquisa. Como tipos de pesquisa, classificam os trabalhos em empíricos, de autoria, teóricos ou de revisão, além de outros. Como tópicos de pesquisa, estabelecem uma classificação a partir do material analisado, de forma, em parte, equivalente ao que denominamos de temáticas.

Dentre seus resultados, destacam que mais de $60 \%$ dos artigos publicados são de autores de países de língua inglesa (Estados Unidos, Inglaterra, Austrália e Canadá) e, como tendência, apontam um possível aumento da internacionalização, representada pela diversidade da nacionalidade dos demais autores. Verificam, ainda, que predominam trabalhos empíricos com abordagens qualitativas, principalmente relacionados a tópicos de ensino. Em relação aos temas de pesquisa, apontam um declínio de trabalhos que investigam concepções alternativas, reconhecendo que isso possa estar ocorrendo por ter já se estabelecido um campo de conhecimento em relação a esses aspectos. Por outro lado, constatam uma maior atenção às questões 
relacionadas ao contexto de aprendizagem, incluindo ambientes de aprendizagem, argumentação, dimensão afetiva do aprendizado, entre outros. Enfim, reconhecem que a cooperação entre pesquisadores de diferentes contextos sócio-culturais será muito importante para o avanço do campo, embora a forma de vir a integrar esses conhecimentos venha a ser um grande desafio.

Gil-Perez (1997) faz uma atenta revisão da área de Ensino de Ciências, constatando seu reconhecimento como campo específico de conhecimento, ultrapassando a fase préparadigmática que caracterizou essa área na década de 80. Para isso, considera diferentes indicadores, tais como o número de periódicos, eventos e trabalhos publicados, além de constatar a diversidade de abordagens contempladas.

Ressalta a importância de se incorporar uma compreensão histórica da área, resgatando as contribuições de cada tempo, sem considerá-las ultrapassadas. $\mathrm{Na}$ medida em que não se buscam receitas definitivas para o ensino, o avanço da área se daria por um contínuo processo de questionamento e re-estruturação.

Identifica algumas fases na evolução do conhecimento da área e propõe algumas perspectivas. A primeira fase incluiu os trabalhos sobre concepções espontâneas, que contribuem no sentido de questionar a eficiência de um ensino baseado na transmissão de conhecimento. Em seus desdobramentos, os trabalhos de mudança conceitual apontam para um processo que envolve tornar os alunos conscientes de suas idéias, a proposição de conflitos cognitivos que gerem uma re-estruturação do conhecimento e, finalmente, a consolidação das novas idéias/conceitos através de sua aplicação. Em uma segunda fase, diversos trabalhos reconhecem as limitações de uma mudança apenas conceitual, não acompanhada de mudanças mais amplas, metodológicas e epistemológicas. A década de 90 teria trazido diversos avanços, no sentido de incorporar a importância do aprendizado da natureza da ciência, ou sobre o fazer das ciência, que implicam em superar diversas concepções dos próprios professores. Dentre as perspectivas que sinaliza, destaca a importância da superação das concepções simplistas sobre o ensino, de muitos professores, e propõe inovações curriculares centradas em programas de atividades.

Cachapuz et al (2004) discutem a constituição da Educação em Ciências como área de conhecimento interdisciplinar, do ponto de vista epistemológico, apontando a inexistência de uma teoria mais geral que permita identificar sua identidade. Ao mesmo tempo, esquematizam a construção dessa área como resultado da integração de diferentes campos: por um lado, dos conhecimentos da própria ciência, da história e filosofia da ciência e da sociologia; por outro, da psicologia, da ciência da educação e da ética. Propõe que as orientações para o Ensino possam ser compreendidas a partir de três tipos de aportes: epistemológico, processos de aprendizagem e aspectos curriculares. Com base neles, identificam três formas de integração desses elementos 
ou três dimensões que predominam na área, que são nomeadas como pós-positivista, contextualizada e sócio-construtivista. Apresentam, portanto, uma visão sincrônica da área de Ensino de Ciências, a partir dos diversos elementos que foram sendo integrados às suas investigações ao longo dos anos.

Cachapuz et al. (2008), ao buscar um estudo do estado da arte da pesquisa em Educação em Ciências, procuram sistematizar e reorganizar os resultados de diferentes trabalhos que partem da análise da produção da área, tal como configurada em trabalhos publicados em alguns periódicos reconhecidos pela comunidade. Identificam onze linhas de pesquisa diferentes, comparando sua incidência nos trabalhos correspondentes a dois períodos (1993-1997) e (1998-2002). Na classificação dessas linhas, são utilizados como elementos tanto temáticas, como abordagens ou ênfases, ou seja, parâmetros de naturezas diferentes. Seu quadro apresenta uma grande dispersão das linhas, com predominância significativa apenas da Filosofia da Ciência e da Aprendizagem de Conceitos que, juntas, correspondem a pouco mais de $40 \%$ da produção da área. Além dessas, algumas tendências podem ser constatadas, como o expressivo aumento das pesquisas na linha CTS.

Enfim, podemos apreender desses estudos que há uma certa convergência com os nossos, brasileiros. O que não se trata, obviamente, de uma coincidência. Mas, tal como iremos perceber em outros aspectos da evolução da área de pesquisa em ensino de Ciências, reflete uma propensão que vem acentuando-se cada vez mais, de "globalização" desse campo de pesquisa. 


\subsection{Sistematização e considerações gerais}

Cresço, logo existo...

1) A ÁREA ESTÁ crescendo, crescendo, crescendo...

É DIVERSIFICADA (temas / focos de interesse, referenciais)

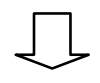

LOGO, EXISTE! (tem história, identidade, volume de produção...)

2) MAS O QUE É? O que a define / caracteriza?

Origens, comunidade, locus de produção, objeto de pesquisa, focos temáticos, metodologias...

3) LIMITES, PROBLEMAS

Fragilidades e limites dados pela própria natureza

Questão da interdisciplinaridade, das origens, das influências e demandas.

Da pesquisa para a sala de aula...

4) TENDÊNCIAS, PERSPECTIVAS

Consolidação

Divulgação / trocas / aprofundamentos

Penetração social

Quadro 1.2: Uma sistematização dos Estados da Arte na área

A investigação permite concluir que os estudos na linha de Estado da Arte referentes à Pesquisa em Ensino de Física apresentam pontos em comum, mas também diversidades.

\section{EXISTIMOS...}

Quanto aos pontos em comum, destaca-se a constatação do crescimento da área, seja quantitativo, seja qualitativo. Há praticamente unanimidade no reconhecimento de que cresce a produção acadêmica, seja de artigos em periódicos especializados, dissertações e teses, participações e trabalhos apresentados em eventos ao mesmo tempo em que seus focos de interesse e linhas de pesquisa vêm se diversificando. Ou seja, há inegavelmente um entendimento comum de que a Pesquisa em Ensino de Física no Brasil, em suas várias décadas de existência, atingiu um razoável grau de maturidade e pode ser vista como uma área consolidada. Tem uma história, uma produção acadêmica significativa, uma comunidade definida, focos de interesse comuns. Tem identidade. 


\section{QUEM SOMOS...}

No que concerne, entretanto, à identificação da área enquanto um campo de pesquisa ou de produção de conhecimento (quando é o caso de se colocar essa questão), há diferentes compreensões quer sobre nosso "DNA" quer sobre o lugar que ocupamos em um universo maior que abrange o campo da pesquisa em educação, das ciências naturais, da filosofia e da história, da psicologia e das ciências sociais.

No caso dessa amostra, em que poucos problematizam a questão, destacam-se duas linhas ou referências distintas (aparentemente não antagônicas). Segundo uma delas, que se apóia em Bourdieu, a área de Pesquisa em Ensino de Ciências (PEC) comporia um campo social de produção de conhecimento - um campo científico - caracterizado pela sua autonomia e especificidades irredutíveis a outros campos. A outra compartilha da idéia de ser a PEC um campo social de produção de conhecimento e, fundamentada em Fleck, caracteriza-a como um coletivo de pensamento ou como coletivos de pensamentos afinados com as ciências humanas, "que investigam problemas relativos à disseminação sistematizada de conhecimentos científicos, que é caracterizada como um processo complexo de interação entre três grandes círculos sócio-culturais" (DELIZOICOV, 2004).

Há, ainda, uma definição do campo que enfatiza em especial a presença do conhecimento científico como marca da pesquisa básica em educação em ciências:

É produção de conhecimentos sobre educação em ciências; busca de respostas a perguntas sobre ensino, aprendizagem, currículo e contexto educativo em ciências e sobre o professorado de ciências e sua formação permanente, dentro de um quadro epistemológico, teórico e metodológico consistente e coerente, no qual o conteúdo específico das ciências está sempre presente. Será este o significado que usarei daqui para frente quando me referir à pesquisa em educação em ciências. (MOREIRA, 2003). (grifos nossos)

Sobre essa discussão, feita em um âmbito maior da Investigação em Didática das Ciências, também trataremos mais adiante nos capítulos dois e cinco, mas destacamos aqui mais uma fala, que poderia ser acrescentada a essas outras duas.

Cachapuz e colaboradores expressam que: considerar a Didática das Ciências uma simples aplicação prática das Ciências da Educação pode fazer com que ignoremos a importância da epistemologia da ciência para uma melhor aprendizagem das ciências [...] Aliás, é a existência de um corpo próprio de conhecimentos sobre o ensino e a aprendizagem das ciências que torna possível a integração de conhecimentos adquiridos da Psicologia da Educação (p.161). [...] Em outras palavras, a identidade dessa nova área de investigação é marcada pela especificidade do conhecimento científico, que está na raiz dos problemas de ensino e de aprendizagem investigados, implicando pesquisas sobre métodos 
didáticos mais adequados ao ensino daquele conhecimento e investigações sobre processos que melhor dêem conta de necessárias reelaborações conceituais ou transposições didáticas para o ensino daquele conhecimento em contextos escolares determinados. (SCHNETZLER, 2002, p.14-15).

Enfim, em primeiro lugar fica evidente não haver uma preocupação predominante em definir essa nossa identidade: somos o que somos, pelo que produzimos, pelo que fazemos, pela nossa história etc.. Entre os que têm essa questão como um problema a ser estudado / pesquisado / refletido, há visões diferentes. Não é possível concluir agora se por meio desses diferentes olhares enxergam a mesma coisa, facetas da mesma coisa, ou coisas distintas...

\section{TEMOS PROBLEMAS...}

Comum também em alguns desses trabalhos é o reconhecimento de problemas e fragilidades da área. Entre eles, destacam-se limitações ou desafios dados pela própria natureza da pesquisa, especialmente à sua composição interdisciplinar, que impõe dificuldades metodológicas, dispersão de linhas de pesquisa e de resultados, diversidade de referenciais teóricos. Enfim, uma pluralidade que torna difícil a própria demarcação desse campo. Somos um coletivo plural, eclético ou, talvez não seja impróprio dizer, um coletivo "ecumênico".

Além das dificuldades na delimitação de linhas de investigação, objetos de interesse ou focos temáticos, essa característica da área também traz problemas de ordem metodológica, ao se buscar uma combinação de metodologias das ciências "duras" e "moles", "exatas" e "humanas", quantitativas e qualitativas, estatísticas e interpretativas.

Realça-se nas conclusões desses estudos (e não raramente tem sido motivo de discussões e reflexões nessa comunidade) é a ausência ou a pouca "penetração", intercâmbio ou diálogo entre a pesquisa e a sala de aula, entre a produção de conhecimento sobre o ensino e o próprio ensino, entre a teoria e a prática, entre o pesquisador e o professor. Em última instância, trata-se de um questionamento sobre o papel social desse campo, de suas contribuições quer para a formação de professores, quer para o saber escolar ou, para alguns autores mais claramente, para a democratização do acesso ao conhecimento. De onde surgem recomendações que apresentam alternativas diversas para a superação desse problema, particularmente no âmbito da formação de professores.

Outras dificuldades ou desafios são apontados de modo disperso e nem sempre compartilhados, tais como a necessidade de maior rigor nas pesquisas, a redução da presença de conhecimento científico (nesse caso, conhecimento físico), a ausência de referenciais ou perspectivas educacionais, a importação acrítica de referenciais 
teóricos, o fraco diálogo com outras áreas, a falta de critérios de avaliação ou de progressividade da área e a necessidade de mais estudos do tipo estado da arte.

Fundamentalmente, essa análise revela ou confirma que, ainda que existam muitas convergências quanto ao que se entende pela área de PEF nos trabalhos que aqui identificamos como "estados da arte" - o que a identifica, quais as suas principais linhas de pesquisa ou seus desafios - as abordagens e perspectivas sobre como fazê-los são diversas. $E$, de certo modo, essas diferenças podem estar associadas a concepções diferentes sobre a própria área. Queremos dizer com isso que não há neutralidade nas reconstruções, em suas maneiras de olhar para esse campo de pesquisa, em suas escolhas metodológicas e epistemológicas. O que implica, mais do que resultados diversos, perfis e panoramas distintos. Não há um retrato único e não há como compôlos em um único retrato, mesmo que em alguns aspectos sejam complementares. Ou seja, assim como se dá na própria escolha de linhas de pesquisa, de metodologias, temáticas e referenciais teóricos ou na compreensão e demarcação da área, há formas de reconstruí-la ou descrevê-la com perspectivas e concepções distintas.

Uma forma de reconhecimento desses vários retratos pode ser dada pela natureza dessas diferentes abordagens ou perspectivas na construção de um estado da arte.

\section{Perspectivas na construção do estado da arte}

A partir da amostra de trabalhos analisada, identificamos estudos em três grandes agrupamentos que representariam tendências ou olhares sobre a construção de um estado da arte.

A primeira dessas tendências que poderíamos reconhecer como uma perspectiva é de natureza histórico-social, identificada sobretudo nos estudos que buscam recuperar a memória da área a partir de registros diversos, enfatizando aspectos históricos ou sócio-culturais da área: suas origens e evolução, constituição de sua comunidade, programas de pesquisa, eventos, publicações, projetos, políticas etc..

A segunda tendência, que estamos identificando como de natureza teóricometodológica ou conceitual pode ser reconhecida nas investigações sobre a pesquisa na área com foco em seu domínio epistemológico, gnosiológico ou metodológico: buscam reconhecer referenciais adotados (educacionais, filosóficos, psicológicos, epistemológicos), metodologias de pesquisa, ênfases conceituais, lógica interna e validade do campo de conhecimento.

E, finalmente, uma terceira tendência seria a dos estudos de natureza predominantemente temática, que investigam os objetos de interesse da pesquisa na área, com foco em suas áreas temáticas. Procuram identificar quais têm sido os "assuntos" da produção e/ou como se distribuem em dado período ou ao longo do 
tempo. Parte dos estudos nessa linha trata da produção na área como um todo, outra parte elege um dado recorte temático específico, para o qual apresenta revisões bibliográficas ou estudos similares.

Trata-se, é claro, de uma categorização possível (como todas...) e não excludente. Em cada um dos diferentes trabalhos uma dessas tendências ou perspectivas é dominante.

$E$, novamente, uma questão que se coloca é se, por meio dessas diferentes lentes ou focos de iluminação ("spots") o que se vê são objetos distintos ou diferentes facetas de um mesmo objeto. Aparentemente, há muitos traços em comum no perfil reconstruído. Não parecem ser antagônicos ou muito diferentes entre si. No mínimo, primos de segundo grau... Talvez seja um caso análogo, mas não precisamente o mesmo, ao de uma "gestalt", como é o conhecido exemplo da velha-moça: alguns vêem a velha, outros a moça, ou podemos ver uma e outra, mas nunca ao mesmo tempo. Conforme o olhar, conforme a perspectiva, ou é moça ou é velha. No caso que aqui estamos identificando como distintos olhares, parece ocorrer que todos vêem a moça ou a velha, mas com traços e perfis diferentes...

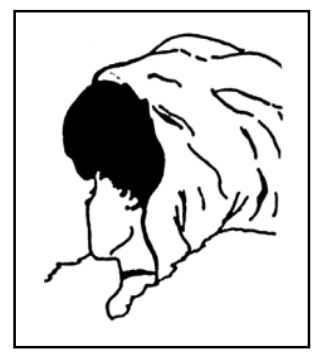

A marca desses estudos é uma busca, ainda que implícita, pelo reconhecimento e demarcação da área, por uma delimitação de quem somos, a que viemos, como chegamos aqui, para onde vamos. Isso é bastante significativo e compreensível, uma vez que se por um lado a Pesquisa em Ensino de Ciências, diferentemente de outros campos de saber, tem história relativamente recente, por outro lado, ao longo de quatro décadas essa evolução tem trazido novas e diversificadas linhas de pesquisa, agregado novos campos de conhecimento e marcos teóricos, novas instituições formadoras de pesquisadores e intercâmbios internacionais. Constitui uma área interdisciplinar, envolvendo uma pluralidade de temas e metodologias, tornando bastante difícil essa demarcação: o que nos une e nos diferencia de outras áreas, notadamente da Pesquisa em Educação ou da Pesquisa em Ciência, em suma, o que nos identifica.

No âmbito da própria Pesquisa em Ensino de Ciências (PEC), começam a se delinear intersecções e combinações entre as várias áreas específicas de conhecimento que abarca - Biologia, Física, Química, Educação Ambiental, Geociências, entre outras, tornando-se também muitas vezes difícil diferenciá-las ou demarcá-las. Desse modo, 
essa busca por "demarcação de território" pode ser atribuída à própria natureza da área que se pretende mapear, identificar e se fazer reconhecida.

Por outro lado, qualquer área de conhecimento, em sua evolução, envolve um processo de complexificação, em que cada vez mais novos conteúdos, enfoques, dinâmicas de pesquisa e demandas vão se estabelecendo e se transformando, tornando cada vez mais difícil a identificação de seus limites. Ao mesmo tempo em que alarga suas fronteiras, que se expande, também se diversifica e se ramifica. Por essa razão, mapeamentos, revisões bibliográficas, relatos históricos ou estudos similares de uma área de conhecimento com essas características, não devem resultar em um perfil ou "fotografia" únicos. Mesmo havendo objetivos e resultados comuns, é importante perceber que os mapas e reconstruções são qualitativamente diferentes. Não apenas há diferentes compreensões dessa evolução, como dos meios, métodos e perspectivas para sua reconstrução histórica, epistemológica, conceitual, metodológica. Ou, no fundo do fundo, conforme as ênfases adotadas, as diferentes reconstruções de nossa área refletem, particularmente no momento atual, diferentes concepções sobre quais são nossos desafios, caminhos a percorrer e agendas de pesquisa fundamentais a serem contempladas. 


\title{
Situando a questão: pressupostos e contextos
}

\author{
"A história é o hoje de cada atualidade, que nos fornece os conceitos, \\ da mesma forma que a natureza, natural ou artificial, nos dá as \\ categorias. Sabemos que o permanente não o é porque as visões \\ sucessivas tornadas possiveis pelo conhecimento desmancham a \\ nossa construção as coisas, até mesmo daquelas que consideramos \\ eternas. E sabemos que o hoje não o abarcamos todo, mas é nossa \\ tarefa, entretanto, a busca do seu entendimento". (Milton Santos)
}

Como vimos, a difícil tarefa de caracterizar a área de Pesquisa em Ensino de Física no Brasil e sua evolução envolve diferentes abordagens ou planos de análise, que se sobrepõem e se interpenetram.

Nesse sentido, e para possibilitar responder às questões que movem esse trabalho, é indispensável situar os pressupostos sobre os quais implicitamente construímos nossas indagações. Elas são movidas por preocupações ou hipóteses sobre o próprio desenvolvimento da área e suas perspectivas, a partir de uma certa compreensão do sentido do Ensino de Física, que é, delimitando melhor, o sentido de uma educação científica mais ampla.

Além disso, e para além das diferentes formas de tratar a evolução da área, é indispensável não desconsiderar o contexto em que os diversos momentos se instauram e desenvolvem. Essa evolução é parte de um processo histórico muito mais amplo, inserido no quadro das profundas mudanças sociais observadas nos últimos cinqüenta anos.

Nesse capítulo pretendemos situar essas duas dimensões da pesquisa - pressupostos e pano de fundo, como forma de definir as escolhas para o encaminhamento do restante do trabalho.

\subsection{Demarcando pressupostos e recortes}

Diante da diversidade de estudos acerca da produção da área, apresentadas no primeiro capítulo, impõem-se escolhas. E as opções de pesquisa devem procurar atender aos percursos necessários para responder às questões e inquietações 
manifestadas inicialmente. Trata-se, portanto, de escolher as lentes adequadas para as leituras desejadas, como em qualquer trabalho de pesquisa.

Nesse mesmo sentido, ao discutir a produção científica da área de Educação como objeto da epistemologia, Gamboa $(1998)^{5}$ chama atenção para a especificidade de cada investigação.

O objeto do conhecimento não pode ser entendido como uma entidade autônoma e independente do sujeito. Entre o sujeito e o objeto de dá uma relação dialética e dinâmica. Nesse sentido, dizemos que o conhecimento é conhecimento de alguma coisa e por alguém. (GAMBOA, 1998, p.39).

Esse mesmo autor reitera, ainda, que a percepção do objeto, no nosso caso a produção da pesquisa em Ensino de Física, não decorre de uma simples leitura dos dados, mas requer uma manifestação ativa do sujeito-pesquisador (nós), e de suas intenções em relação ao que se quer conhecer, ou aos aspectos que prioriza em sua concepção sobre o objeto.

A intenção não é apenas de constatar e referir as diferentes conotações epistemológicas assumidas pelos autores, mas de propor instrumentos de avaliação da produção cientifica, no interior do desenvolvimento social. Subjaze a esta abordagem um conceito critico da ciência, segundo o qual, a produção cientifica deve ser entendida tanto como produção social, influenciada pelas condições históricas, quanto como impulso renovador destas mesmas condições. Aplicando-se isto à educação, significa que a prática da pesquisa educacional traz em si a marca da realidade sócio-histórica, mas também que é chamada a contribuir para a melhoria desta realidade. Neste sentido, os trabalhos científicos não devem apenas ser analisados como fatos decorrentes $e$ inseridos em determinadas circunstâncias mas também devem ter seus resultados avaliados à luz de necessidades e objetivos sociais (GAMBOA, 1998, p.5)

Em outras palavras, e para além de uma objetividade inexistente, que supostamente se deduziria apenas e unicamente dos dados empíricos, tal como desejariam abordagens positivistas, é preciso explicitar de partida alguns pressupostos que poderão guiar nossa análise.

Essa não é uma tarefa trivial, já que nos faltam referências suficientemente gerais para dar conta da complexidade das pesquisas e ações educativas. De certa forma, a diferença de natureza entre os estudos sobre estado da arte, como identificamos na revisão de trabalhos realizados no capítulo anterior, podem fornecer algumas pistas. Mas, ainda assim, essas são insuficientes. Na análise daqueles trabalhos, nosso

\footnotetext{
${ }^{5}$ SANCHEZ, Silvio Gamboa (1998) é a referência do livro publicado com base em sua tese de doutorado, cuja referência é GAMBOA (1997). Ainda que tenhamos utilizado o livro como referência, nos remeteremos a esse como GAMBOA (1998) por ser o nome pelo qual é reconhecido mais largamente o autor desse trabalho.
} 
interesse esteve mais centrado na forma como caracterizaram seus objetos/objetivos, a natureza da reconstrução que empreenderam e os resultados a que chegaram. No entanto, do ponto de vista dos procedimentos metodológicos utilizados, a análise ficou prejudicada pelo fato de nem sempre serem explicitadas as categorias utilizadas, ou de como essas são construídas. Essas limitações, de certa forma, decorrem do tipo de trabalhos analisados, em sua maioria artigos ou comunicações em congressos.

Inspiração mais significativa pode advir, por outro lado, de trabalhos que, a exemplo do nosso, adotaram como objeto de estudo a produção de teses e dissertações em diferentes áreas. Um rápido olhar sobre alguns desses trabalhos pode trazer contribuições sobre as compreensões que desenvolvem acerca de seus objetos e para a explicitação de métodos e/ou categorias de análise que foram utilizados.

Gamboa (1998), por exemplo, realiza um extenso e profundo estudo da produção dos programas de pós-graduação em educação, procurando caracterizar as diferentes naturezas desses trabalhos, do ponto de vista de suas epistemologias, ou seja, da forma como encaminham a construção de conhecimento no campo. Essas epistemologias são identificadas a partir de um conjunto de categorias dialéticas, inspiradas na teoria marxista e na Teoria Crítica (Escola de Frankfurt), que dão estrutura a um esquema paradigmático. Dessa forma, consegue caracterizar a pesquisa da área em três grandes grupos: abordagens empírico-analíticas, fenomenológicohermenêuticas e crítico-dialéticas.

Slongo (2006) analisa a produção acadêmica na área de Ensino de Biologia, também a partir de teses e dissertações. Para isso, constrói um referencial baseado nas propostas da epistemologia de Fleck (1986), utilizando como elementos de análise, dentre outros, os problemas investigados, os referenciais teóricos e procedimentos metodológicos utilizados pelos autores, em que a circulação de informação entre diferentes coletivos de pensamento assim como os próprios estilos de pensamento ganham destaque. Procura caracterizar esses estilos de pensamento a partir de concepções de conhecimento, de educação, das práticas de pesquisa e linguagem utilizadas, assim como de seus referenciais teóricos.

Lemgruber (1999), analisando a produção em Ensino de Ciências Físicas e Biológicas, faz um recorte mais específico que resulta em categorias que, de certa forma, privilegiam os referenciais teóricos adotados nas pesquisas. Nesse caso, identifica e classifica as dissertações e teses nas categorias Construtivismo, referenciais inspirados em Bachelard, em Freire e trabalhos na perspectiva Ciência, Tecnologia e Sociedade (CTS).

Esses exemplos de forma alguma esgotam o universo de trabalhos dessa natureza, nem é essa nossa intenção. Há outros, ainda, como as análises realizadas por Megid, sobre a pesquisa em Ensino de Física no 2‥ Grau (1990) e sobre a pesquisa em Ensino 
de Ciências no nível fundamental (1999), cujos encaminhamentos serão retomados, com maior detalhe, mais adiante.

Ainda que brevemente, esses trabalhos apontam a diversidade de possibilidades e podem nos auxiliar a melhor caracterizar nossa proposta e demarcar pressupostos.

No caso do trabalho desenvolvido por Gamboa (1998), há um campo suficientemente bem definido, sobre o qual interessa caracterizar a natureza da própria pesquisa, ou as formas de construção da pesquisa no campo. O ponto de partida é uma dada concepção de educação, no sentido amplo, e de como se constroem as pesquisas no campo, de forma associada às compreensões mais gerais de ação do sujeito, das compreensões sobre ciência e educação, e de diferentes entendimentos acerca das relações dicotômicas tais como sujeito/objeto, real/ concreto, dentre outras. Em sua investigação, privilegia os processos pelos quais as pesquisas na área de Educação foram se constituindo, analisando diversos elementos das teses que compõem seu universo de estudo.

O estudo epistemológico da pesquisa educacional preocupa-se com as principais abordagens metodológicas, opções paradigmáticas ou modos diversos de interpretar a realidade; interessa-se pelas diferentes formas ou maneiras de construção do objeto científico, formas de relacionar o sujeito e o objeto, ou de tratar o real, o abstrato e o concreto no processo do conhecimento; está também interessado nos critérios de cientificidade nos quais se fundamentam as pesquisas etc. (GAMBOA, 1998, p. 48)

No nosso caso, trata-se de um campo, a pesquisa em Ensino de Física, que não é só da área de educação nem das diversas áreas de conhecimento em ciências ou física, mas da articulação entre ambas, que envolve muitos outros campos de saber. Ou seja, o próprio campo não nos serve de referência, na medida em que ele mesmo está em processo de demarcação.

Além disso, de certa forma, nos interessa menos discutir em que sentido e como essa produção está (ou não) se configurando como campo específico de conhecimento, a partir de uma perspectiva metodológica, mas de como esse movimento está respondendo às demandas educacionais que Ihe deram origem. Ainda que esses dois aspectos estejam profundamente interligados, optamos por tomar como ponto de partida o segundo. Assim, e ainda que as questões epistemológicas de construção do campo sejam fundamentais e que esse processo decorra da interação de coletivos e estilos de pensamento, a preocupação central desse trabalho volta-se para a natureza da produção de conhecimento que estão sendo priorizados.

Nesse sentido, partimos do reconhecimento de que se trata de um processo de construção e consolidação de uma área, movido por determinadas demandas sociais, em busca de uma melhoria da educação científica em diferentes níveis. Trata-se, 
então, de investigar de que forma essas demandas vêm sendo colocadas, de como diferentes aspectos de sua complexidade vêm sendo contemplados e em que medida supostamente movem a área e vão sendo respondidas. Ou melhor, em que sentido vão sendo buscadas possíveis respostas.

Responder às demandas não significa, no contexto em que estamos refletindo, aportar necessariamente em propostas para a sala de aula. Não significa necessariamente desenvolver pesquisa aplicada, se essa for entendida meramente como elaborar propostas, materiais e recursos para a escola, ou adentrar no campo da chamada "pesquisa-ação". Mas, no campo da pesquisa em ensino significa, sobretudo, produzir conhecimento que tenha, em última instância, intenções educacionais e formativas, seja visando a educação formal ou não-formal, a escola básica ou o ensino superior. Em particular, no âmbito da pós-graduação na área, construir aportes para a formação de formadores de professores.

E é claro que essa demarcação ainda é ampla demais e abre um amplo "guarda-chuva" de objetivos e práticas, de concepções de educação e de ciência, de valores e éticas, ideologias e metodologias.

O que nos interessa é buscar decifrar, no interior de nossa área, como essas intenções, práticas e valores vêm se expressando (ou não). E, como já dissemos, os meios para tal investigação podem ser diversos: seja do ponto de vista das epistemologias ou metodologias de pesquisa, seja dos referenciais e modelos teóricos, dos resultados e produtos, das temáticas ou linhas de pesquisa. E, mais uma vez, cada um desses olhares é articulado aos demais, são interdependentes. Metodologias e epistemologias, referenciais, temáticas e linhas de pesquisa dialogam entre si. Contudo, cada um deles pode ser privilegiado, nucleando a pesquisa.

A opção que fizemos foi a de buscar uma caracterização dos focos de interesse da pesquisa por meio do que definimos como "áreas temáticas", entendendo que essas áreas estão mais proximamente ligadas a um núcleo central que dá sentido e conduz a produção. Particularmente no caso da pesquisa em ensino de Ciências, as metodologias adotadas não se reportam necessariamente a um foco de interesse, tendo em vista as suas finalidades, ainda que estejam associadas a visões e concepções de ensino e de Ciência. Referenciais teóricos, apesar de serem também sinalizadores dessas concepções, se olhados em si mesmos, trazem complicadores. De um lado, porque nem sempre são condizentes com o desenvolvimento da pesquisa. Tanto há casos em que essas referências são explicitadas e consistentemente utilizadas, como explicitadas, mas não consistentes com o trabalho e, ainda, casos em que não são explicitadas, mas norteiam e conduzem a pesquisa. De outro lado por que, mais recentemente, a presença de tais referenciais tornou-se um critério de avaliação da produção acadêmica, que passa a incorporá-los por exigência metodológica, seguindo 
ditames ou modismos que, de certo modo, refletem-se nas próprias escolhas temáticas.

Nesse sentido, partimos da hipótese de que cada trabalho é movido por um interesse próprio que, ainda que implicitamente, sinaliza um campo ou um âmbito privilegiado em que os autores pretendem contribuir para a melhoria do ensino/educação. Tal campo, por sua vez, demarca focos ou temas de pesquisa. Serão, portanto, as temáticas privilegiadas na produção da área de Ensino de Física que constituirão nosso ponto de partida e instrumento de análise, procurando por meio dessas, situar a pesquisa na área sob a ótica de seus interesses, convicções e perspectivas.

Gamboa, no trabalho já mencionado, dentre os elementos de síntese que utiliza, aponta a visão de mundo, como categoria que explicita o nexo entre conhecimento e interesse.

... visão de mundo, entendida como uma percepção organizada da realidade que orienta a produção da pesquisa, se constrói através da prática cotidiana do pesquisador e das condições concretas de sua existência. Isto é, a visão de mundo que organiza, como categoria mais complexa e abrangente, os diversos elementos implícitos na concreticidade de uma determinada opção epistemológica, é a responsável pelas opções de caráter técnico, metodológico, teórico, epistemológico e filosófico que o pesquisador faz durante o processo da investigação. Embora essa visão apareça muitas vezes implícita, ela se forma através da incidência de determinadas condições históricas de caráter psicológico, sociológico e político. (GAMBOA, 1998, p.131)

Embora não tenhamos a pretensão de utilizar visão de mundo como categoria de análise, dada a sua complexidade, o que queremos salientar é a relação dessa visão com os interesses dos pesquisadores, com suas preocupações últimas. Nesse caso, o tema de sua atenção é um dos elementos que expressa, ainda que de forma implícita, uma perspectiva de contribuição para a educação. Mesmo tendo em conta que essas escolhas são dadas por um conjunto amplo de "matrizes e determinantes" ou de "condições de contorno", que não decorrem apenas de uma opção individual, do pesquisador, mas de instâncias maiores que orientam a pesquisa ao longo de sua evolução.

Assim, o pano de fundo que irá orientar nossa investigação são algumas convicções sobre o que seja relevante em uma educação científica, ou seja, alguns pressupostos ou preocupações que, em última análise, movem essa pesquisa.

Para isso, poderíamos buscar diferentes concepções, modelos e referenciais de educação e nos filiarmos a uma ou outra. Mas optamos por manter esse entendimento de uma forma ampla, como entendimento pessoal do investigador, para que não se 
perca de vista a identidade própria e limitada do ponto de vista do qual nos colocamos.

De um modo geral, educação científica é um campo muito mais amplo que ensino de Física. E não se trata apenas, e principalmente, de uma abrangência que transcende o espaço escolar. No próprio âmbito das práticas escolares cotidianas, dos currículos, dos materiais e propostas didático-pedagógicas, podem ser identificados sinais dessa diferença. Ou seja, as especificidades do "ensino de", de suas práticas, em si mesmas constituem ou refletem uma concepção de educação. Nesse sentido, entendemos que a educação científica é mais do que uma transmissão cultural do conhecimento acumulado pela ciência e vai além da promoção de habilidades e competências individuais específicas. É algo que aponte os caminhos para a inserção dos sujeitos em um coletivo social mais amplo, no qual possam viver, compreender, atuar, sonhar e, eventualmente, transformar.

E tais quais as práticas e ações e educativas, a pesquisa em ensino de Ciências/Física, por meio de suas escolhas acerca "do quê" pesquisar reflete uma concepção de educação científica, ou seja do "para quê".

Queremos, em síntese, buscar compreender de que forma a produção nessa área vem, de algum modo concebendo e buscando contribuições para uma educação científica ao longo de sua evolução. Sendo assim, nos interessa o tipo de aporte que cada trabalho ou seu conjunto traz.

Tal perspectiva nos levou a buscar possíveis instrumentos metodológicos ou categorias de análise, de forma a encaminhar a investigação dentro do quadro dos focos de interesse dos pesquisadores. É conveniente sinalizar que nossa ênfase central não é a educação em seu sentido amplo, mas uma educação escolar, inscrita em uma dada estrutura, portanto, de uma perspectiva em muitos aspectos curricular. Para isso, nos interessa articular os objetos de pesquisa, traduzidos pelas suas temáticas, com dimensões da educação científica escolar que permitam uma compreensão que vá além de uma descrição e de dados estatísticos sobre essas categorias temáticas em si mesmas.

Para aprofundar as dimensões envolvidas na abordagem da educação escolar, diversos autores nos orientam em uma mesma direção, sinalizando a possibilidade de considerar três perspectivas diferentes.

Forquin (1992), por exemplo, ao discutir as relações entre escola e cultura, chama atenção para o fato de que, ao tratar das questões curriculares no âmbito escolar, três aspectos se fazem presentes na construção de propostas e no entendimento das práticas. Por um lado, todo currículo empreende uma seleção de conhecimentos, a partir do patrimônio acumulado pela humanidade. Esse é um campo que se 
institucionalizou fortemente, de tal forma que o conhecimento escolar de uma dada disciplina já tem delimitações reconhecidas pela comunidade científica. Em grande parte dos currículos, são esses aspectos, de natureza epistemológica, que adquirem preponderância. Por outro lado, os conhecimentos a serem transmitidos são reorganizados segundo os imperativos didáticos, ou seja, as condições de aprendizagem. Essas incluem tanto os pré-requisitos conceituais na construção do conhecimento e de seu aprendizado, como os tempos escolares, ou a forma de organização das atividades, etc. Finalmente, um terceiro conjunto de aspectos diz respeito às demandas sociais, ou as expectativas em relação à escola e seu papel social. São, portanto, dimensões que destaca, os aspectos epistemológicos (ligados ao conhecimento científico), os imperativos didáticos (relacionados aos processos de ensino-aprendizagem) e as demandas sociais (expressão de propósitos educacionais).

Da mesma forma, Garcia (1998) propõe para a escola o objetivo de complexificar o conhecimento dos alunos, a partir de seus saberes de senso comum, através da incorporação de aspectos do conhecimento científico, cultural e artístico. Nesse processo, sinaliza a existência de três critérios a serem levados em conta na organização curricular: aspectos epistemológicos, relacionados aos conhecimentos reconhecidos por uma determinada disciplina; aspectos psicológicos, relacionados às estruturas cognitivas e às características dos alunos e, finalmente, aspectos sociológicos, relacionados a perspectivas sociais de maior relevância a serem trabalhados pela escola.

Delizoicov, Angotti e Pernambuco (2002), no encaminhamento das reflexões e propostas educativas, em uma releitura de Paulo Freire, também sinalizam a necessidade de atentar para três focos de considerações. Com a dimensão epistemológica, chamam a atenção para o conhecimento a ser apropriado, conhecimento esse que requer significados próprios. Com a dimensão didáticopedagógica, apontam para as questões de ensino e aprendizado e de sala de aula, enfatizando ser essencial a dialogicidade nas interações e com o conhecimento, além das necessárias rupturas pelas quais o conhecimento dos alunos vai sendo construído. Com a dimensão educacional, articuladora das demais, reiteram a importância de temas geradores, com significado social, que permitam se distanciar da educação bancária.

Diversos outros autores, ainda que utilizando denominações diferentes, também se referem à possibilidade de compreender a prática educativa a partir de três dimensões, relacionadas, respectivamente, à proposta educacional, aos conhecimentos a serem construídos e às questões de ensino-aprendizado. Essas dimensões ganham, assim, uma força de estruturação, especialmente porque, como vimos, diferentes autores atribuem a cada uma delas significados ou 
encaminhamentos diferentes, o que reforça a ideia de dimensões de fundo estrutural, articuladas entre si.

No desenvolvimento da análise das temáticas da pesquisa, visando articulá-las em um pano de fundo maior, que lhe atribui sentidos e perspectivas, buscamos sistematizações que contemplam essas dimensões. Particularmente, adotamos o tratamento proposto por Menezes, Kawamura e Hosoume (1997) em que buscam situar a pesquisa e as práticas na área de Ensino de Ciências, em âmbitos dados por essas três dimensões (aos quais voltaremos no capítulo quatro, ao detalhar melhor o instrumento de análise que adotamos).

As ciências, enquanto objeto do aprendizado escolar, os objetivos educacionais, como as competências e valores que se pretende desenvolver, e os processos de aprendizagem, com seus recursos e estratégias, constituem três âmbitos distintos, frequentemente tratados independentemente ou considerados aos pares, em suas interfaces. As três interfaces entre esses âmbitos, ou seja, entre objetivos e áreas, entre áreas e processos e objetivos constituem, tomadas em seu conjunto, um complexo espaço de conceitos, de práticas e de intenções formativas. (MENEZES; KAWAMURA; HOSOUME, p.308) (grifos nossos).

Em síntese, nosso ponto de vista (ou, mais exatamente nossa "vista do ponto"...) é melhor compreender ou explicitar, a partir dos focos de interesse da produção acadêmica, analisados e articulados à luz dessas dimensões, as contribuições da pesquisa para a melhoria da educação ao longo de seu percurso.

Dessa maneira, entendemos que o campo vai sendo desenhado a partir do conjunto de contribuições de toda uma comunidade de pesquisadores, que interagem entre si e com o conjunto maior das idéias e ideologias dos espaços em que estão inseridos. $\mathrm{Na}$ medida em que esse processo é dinâmico, porque inserido em uma realidade que está ela também em contínua transformação, o contexto é um elemento importante. Não se trata de olhar para a evolução da área, e de suas temáticas, com os referenciais de hoje. Mas de reconhecer que suas diferentes compreensões foram elas mesmas evoluindo, em função de demandas de ordens diversas. E foi a própria evolução dessas demandas que contribuiu para construir o campo.

\subsection{Sinalizando contextos}

Os acontecimentos que sinalizam o percurso da área, e sua constituição em uma comunidade de pesquisa, ocorrem dentro de um vasto e heterogêneo cenário de preocupações educacionais bem mais abrangentes. Esse, por sua vez, corresponde ao panorama social, econômico e político de seu tempo. Paralelamente, no campo das ideias, diferentes ênfases e prioridades locais também se delineiam, em correspondência a preocupações mais gerais, de cunho transnacional. 
Isso significa que os diferentes recortes também delineiam diferentes planos de caracterização do contexto temporal, com ênfase, por exemplo, no âmbito social, educacional, econômico ou ideológico, no qual as ideias, ações e práticas evoluem e se transformam.

Como já vimos no capítulo inicial, muitos trabalhos foram já desenvolvidos, ao longo dos últimos anos, com a preocupação de caracterizar a constituição e evolução da área. Uma análise mais detalhada revelou que até mesmo a natureza das preocupações nessas caracterizações foi também se transformando. Para reforçar esse aspecto, destacamos dois conjuntos de estudos nessa direção com preocupações diferentes. O primeiro, reunindo trabalhos elaborados na década de 1980, acompanha o que hoje reconhecemos como os passos iniciais da evolução das pesquisas em ensino de ciências e que também busca caracterizar sua natureza ou identidade. Já o segundo, com trabalhos publicados a partir do início da década de 2000, portanto, quase vinte anos depois, ainda repercute a difícil tarefa de identificar a natureza das pesquisas da área, só que em um contexto diferente, tomando como ponto de partida a análise da produção já desenvolvida. Ou seja, num contexto em que a pesquisa estava começando a se consolidar, tratava-se de compreender e melhor demarcar a área. Mais recentemente, partindo do pressuposto que essa demarcação já está feita, trata-se de olhar para a própria produção.

Podemos exemplificar as preocupações expressas na década de 80 através dos trabalhos de Almeida Júnior $(1979,1980)$. Com ênfase em dados históricos, esse autor tem como foco o ensino de Física do ponto de vista de sua inserção no contexto dos programas curriculares, em diferentes níveis e âmbitos, traçando um panorama que vai desde o final do século XIX até a década de 1970. Destaca, de forma especial, a constituição da Faculdade de Filosofia Ciências e Letras da USP, e de sua contribuição na formação de profissionais e professores de física. Através da recuperação dos diagnósticos e discussões ocorridos nos três primeiros Simpósios de Ensino de Física (SNEF) traça um interessante panorama de como eram percebidos os problemas relacionados ao ensino, muitos dos quais permanecem atuais.

Quase na mesma época, mas de um ponto de vista em claro contraponto, Villani $(1981,1982)$ tem como principal preocupação caracterizar a então recente pesquisa em Ensino de Física como área interdisciplinar. Busca situá-la como campo de identidade próprio, apresentando as características que distinguem, por um lado, as pesquisas em Ensino das pesquisas em Física, e, por outro, sua especificidade frente às pesquisas em Educação. Destaca, em especial, a diferença entre o que denomina "pesquisa fundamental", caracterizada por "um conjunto de atividades de reflexão, análise e experimentação sistemática sobre o conteúdo e/ou a prática do Ensino de Física" (Villani, 1981, p.72) daquelas que envolvem práticas em Ensino de Física e têm a preocupação "de resolver um problema prático sem inseri-lo no contexto do 
aprofundamento das características do Ensino de Física, e sem se preocupar com a sua eventual reprodutibilidade e com a análise e a avaliação crítica da comunidade científica" (idem, p.73), o que denomina "pesquisa latu sensu ou indireta"

Aproximações como essas foram rapidamente incorporadas às perspectivas do conjunto de participantes da área de ensino, de tal forma que Pernambuco (1985), poucos anos depois, aponta em seu balanço tanto a identificação das principais linhas de pesquisa, como os condicionantes estruturais e as influências externas sobre as atividades que vinham sendo desenvolvidas. No campo de pesquisa, a autora identifica três linhas principais: as abordagens cognitivistas, as ênfases na História e Filosofia da Física e abordagens que denomina como sociológicas, tendo como centro a escola.

Um panorama bem mais abrangente, analisando o Ensino de Ciências no período 1950-1985, é apresentado por Krasilchik (1987). Trata-se de uma análise histórica, mais do que factual, em que são apresentadas, paralelamente, a evolução do Ensino de Ciências e a evolução da pesquisa, por uma professora que vivenciou intensamente ambos os campos. Além disso, apresenta um diagnóstico dos problemas e das condições para o aperfeiçoamento do ensino de ciências.

Vinte anos depois, um quadro bem diferente emerge dos trabalhos de pesquisadores com preocupações equivalentes. Como constatamos no primeiro capítulo, em todos eles há uma preocupação explícita e clara em atestar e mapear o significativo crescimento das pesquisas em Ensino de Física, reconhecendo esse desenvolvimento como exigência para sua demarcação. Ou seja, não se trata tanto mais de uma caracterização intrínseca, de natureza mais teórica, a partir de seus métodos, objetos etc., mas de um reconhecimento pelo seu percurso e institucionalização. Nessa perspectiva, também como vimos, são mapeados diferentes aspectos, como a expansão de seus eventos, criação e difusão de seus periódicos, desenvolvimento dos centros de produção e projetos institucionais, enfatizando o significativo aumento de programas de pesquisa e de docentes envolvidos, constituindo uma comunidade. No entanto, diante desse crescimento, ainda assim, colocam-se com diferentes olhares.

São exemplos dessa preocupação, estudos e reflexões já apresentados no primeiro capítulo, como os de Barros (2002), que ao tecer reflexões sobre os trinta anos de pesquisa em Ensino de Física no Brasil, procura demarcar a identidade dessa área não em contraponto com outras (como Física ou Educação), mas a partir de critérios de delimitação da pesquisa, por seus objetivos, práticas e enfoques adotados, ou da caracterização dos principais temas abordados. Nardi (2005), juntamente com Almeida e outros pesquisadores, fazem um resgate histórico da área de Ensino de Ciências, sistematizando fatos, eventos e publicações e visam identificar nos discursos dos pesquisadores, os fatores que teriam sido determinantes na constituição dessa área. Delizoicov (2004) também parte do princípio de que a pesquisa em Ensino de Ciências 
está já demarcada pela trajetória dos últimos anos, mas preocupa-se com a explicitação do vínculo entre essas pesquisas e a área de ciências humanas aplicadas, como condição para compreender a relação dos resultados de pesquisa e seus impactos na realidade escolar. É em um quadro dessa natureza que propõe que sejam recolocadas as questões de identidade da área e dos resultados de pesquisa.

Essa mesma preocupação está presente em estudos de pesquisadores de outras áreas afins, como no Ensino de Biologia e Ensino de Química. Schnetzler (2002) apresenta o que denomina um possível estado da arte da pesquisa em ensino de Química, realizando um amplo retrospecto das atividades dessa área nos vinte e cinco anos anteriores. Em suas palavras: “...busquei identificar o que tem sido pesquisado em ensino de química, contextualizando as investigações às tendências internacionais, para apontar conquistas e perspectivas da área em nosso país" (Schnetzler, 2002, p. 14). Para além do resgate de publicações, encontros e resultados de pesquisa, acompanha as tendências das Didáticas das Ciências no plano internacional, reconhecendo sua importante influência no país.

Concomitantemente, ganham densidade os trabalhos internacionais nessa linha, que visam caracterizar e sistematizar as pesquisas no campo, como os realizados por GilPerez (1996), Cachapuz (2003, 2004, 2005, 2008), Tsai (2005) e Lee , Wu, Tsai (2009) entre outros.

Esse conjunto de investigações demonstra a dificuldade em construir um contexto histórico no qual situar os acontecimentos e desdobramentos da área de Ensino de Ciências, dada a variedade de aspectos e ênfases diferentes a serem contemplados.

Diante dessa diversidade, podemos encontrar três planos de identificação histórica que situam o contexto de evolução da área.

Em primeiro lugar, será preciso situar os acontecimentos no plano social e educacional mais amplo, que inclui aspectos da história social da educação. Nesse sentido, o contexto histórico deve permitir acompanhar a evolução das políticas educacionais e ações de governo, as legislações e reorganizações sucessivas das estruturas escolares, assim como os movimentos mais abrangentes em favor da educação científica, com suas diferentes motivações, objetivos e significados.

Sobre esse cenário, procuramos posicionar, em um segundo plano, os acontecimentos que marcaram a constituição específica da comunidade em Ensino de Ciências, o que inclui a criação de seus núcleos, revistas, encontros, circulação de informações, fóruns de debates, interlocuções, etc.

E, por fim, seria preciso caracterizar a evolução das ideias da área de Ensino tanto no plano internacional como nacional, uma vez que, com a crescente globalização, as influências internacionais passam a repercussões cada vez mais diretas e imediatas no plano nacional. 
Essas ideias, a partir da década de 1980, influenciam fortemente a constituição da área, em todos os campos de ensino de, iniciando-se com os estudos de concepções espontâneas e evoluindo, na última década, para uma ampla diversidade de abordagens de pesquisa.

Quanto a esse terceiro plano, das ideias e aportes teóricos na área, trata-se justamente de objeto de estudo dessa pesquisa, a ser desenvolvido em capítulos posteriores, além de não ser propriamente contextual, ainda que situando e situado em contextos diversos ao longo do tempo. Por esse motivo, não o desenvolvemos aqui. Mas, ao final do trabalho, buscaremos retomar e articular os dois primeiros planos, aos resultados e conclusões acerca desse outro.

Reconhecendo a complexidade dessa tarefa, a construção desses contextos, embora necessária, extrapola em muito o âmbito do presente trabalho. No entanto, é indispensável estabelecer pelo menos alguns parâmetros de referência para a investigação a ser realizada. Assim, o que nos propomos aqui é a apenas mapear a cronologia dos acontecimentos, sem a preocupação com seu aprofundamento nem com as interconexões entre os dois planos delineados. A proposta é reconstruir um cenário de fragmentos, como quadros impressionistas, a partir do qual possam ser possíveis diferentes olhares.

Trata-se, portanto, de recolher, da ampla bibliografia sobre o tema, e em parte já citada, os eventos considerados marcantes da evolução da área, separando-os e situando-os nesses dois distintos planos. Não se pretende uma perspectiva analítica, mas, na medida do possível, predominantemente descritiva.

Considerando as informações sobre a evolução da área, optamos por delimitar como período de atenção os acontecimentos a partir da década de 1970, cobrindo assim os últimos quarenta anos. A partir de análises preliminares, optamos por apresentar os acontecimentos sistematizados em alguns períodos, no que diz respeito ao panorama educacional brasileiro amplo e à evolução da área de Ensino de Ciências.

Além disso, é importante observar que muitos dos acontecimentos e ênfases mencionados passam a ter influência por intervalos de tempo diferentes, com sobreposições a outros, resultando em um quadro nem sempre muito nítido, como todo contexto histórico, longe de qualquer determinismo.

\subsubsection{Evolução na perspectiva da história da educação no Brasil}

Traçar um quadro, ainda que descritivo, dos principais acontecimentos e propostas no âmbito educacional brasileiro, nas últimas décadas, é tarefa quase impossível. Não existe, ainda, um distanciamento temporal que permita uma delimitação clara das ênfases, das intenções e nem mesmo uma identificação bem delineada do que seriam as ações mais marcantes e relevantes em cada período. Um panorama amplo requereria um estudo histórico aprofundado, não condizente com a natureza de nosso 
trabalho. Além disso, sobretudo nas décadas mais recentes, diferentes posicionamentos ideológicos levam a compreensões também diferentes, muitas vezes em flagrante contraposição. É o caso, por exemplo, dos muitos entendimentos quanto ao sentido e impacto dos Parâmetros Curriculares Nacionais (PCN), propostos pelo MEC a partir da LDB/96. Em oposição, já em períodos mais distantes, os elementos característicos de uma determinada década, particularmente no âmbito do ensino de Ciências, parecem encontrar maior consenso, mesmo que sob óticas distintas.

Igualmente ou ainda mais difícil é delimitar quais aspectos educacionais mais amplos têm maior relação com aqueles relacionados à educação científica já que os âmbitos, políticas e sistemas educacionais constituem-se em um todo complexo, com muitos níveis de entrelaçamento.

Ainda que reconhecendo essas limitações, pareceu-nos importante traçar alguns marcos e fatos que possam, pelo menos, contribuir para sinalizar que o Ensino de Física e sua pesquisa são apenas uma pequena parte de um contexto educacional, social e econômico muito amplo. Acreditamos que seria uma lacuna deixar de mencionar alguns traços desse pano de fundo no qual se desenrolaram os demais aspectos já mencionados e aqueles outros que serão tratados nesse trabalho.

Às dificuldades já apontadas, soma-se uma outra. Mesmo sem a pretensão de uma análise histórica, ficando nos limites da descrição, sabemos que essas mesmas não são neutras. Impossível descrever uma tal evolução histórica sem assumir concepções que fazem os recortes, privilegiando certos fatos em detrimento de outros. Na própria escolha dos autores, ou seja, das fontes que utilizamos para fazer resgatar esse pano de fundo, estamos nos comprometendo, de certo modo, com determinados olhares para essa história. Nesse sentido, e dadas as minhas próprias limitações quanto ao assunto, vou adotar nesse tópico o panorama construído por Kawamura (2011) sobre perspectivas da educação científica no Brasil, inseridas no contexto de eventos e políticas educacionais.

Para a seleção de alguns dos principais acontecimentos nesse plano, Kawamura (2011) utiliza reconstruções desenvolvidas por Aranha (2003), Saviani (2008), Souza (2008), Romanelli (2008) e Freitas e Biccas (2009).

Começa por situar brevemente alguns acontecimentos anteriores à década de 70, no qual o conflito mundial, de diferentes formas, explicitou a importância do conhecimento científico e tecnológico como elemento estratégico para a segurança, a partir do uso de armamentos e tecnologias nunca antes utilizados, sobretudo do impacto das bombas atômicas lançadas no Japão.

Ao mesmo tempo, o posicionamento dos países vencedores em dois campos ideológicos opostos, que os levaram à chamada guerra fria, reforçava a necessidade de 
uma nova corrida armamentista, do estar permanentemente pronto para a guerra. Nessa mesma perspectiva, instaura-se um discurso que reconhece uma divisão do mundo em países desenvolvidos e subdesenvolvidos. Independente das implicações conceituais dessa divisão, emerge uma valorização da possível contribuição da ciência para a superação do subdesenvolvimento, especialmente no que diz respeito à formação de quadros que dêem suporte aos desenvolvimentos tecnológico e industrial. Dessa forma, a formação de cientistas passa a ser uma meta mundial.

Nesse cenário, é promulgada no Brasil a primeira lei de diretrizes e bases nacional, a LDB/61, resultado de longos anos de discussão e conflitos latentes entre diferentes visões de educação, especialmente quanto ao papel do Estado e a contrapartida entre educação pública e privada. A partir dela, é extinto o exame de admissão para o então curso ginasial, criando-se para uma nova estrutura, na qual tanto nesse no ensino secundário, as ciências ganham destaque. De forma especial, são organizados dois currículos, o clássico e o científico, sendo esse último a novidade, ou seja, o espaço onde parte do saber até então reconhecido como acadêmico passa a dar lugar a conhecimentos das ciências na formação básica. Paralelamente, surgem diversos movimentos em prol de incentivos à educação no país, especialmente no combate ao analfabetismo e através de iniciativas voltadas à ampliação da escola. Para tratar desse cenário educacional no Brasil, Kawamura (2011) utiliza a periodização reproduzida a seguir.

\section{Período I - Do início da década de 70 a meados da década de 80}

A década de 70 é marcada pelas ações da ditadura, implantada no Brasil a partir do golpe militar em 1964. Os movimentos estudantis estiveram no foco das ações repressivas, especialmente a partir de 1968, em alguns aspectos decorrentes de questões relacionadas ao sistema educacional, questionando-se o funil de acesso ao ensino superior.

Nesse período, no entendimento das cúpulas de governo, a ciência persiste em sua condição de status maior, como condição imprescindível para o desenvolvimento, com reflexos na educação. Assim, em 1971, é imposta uma nova reforma (Lei 5692/71) que, entre outras medidas, estabelece o ensino de segundo grau com uma estrutura única, superando a divisão anterior entre clássico e científico. No entanto, comparando os planos de curso da nova proposta frente aos anteriores, é clara a preponderância do antigo científico, respondendo à importância atribuída à ciência. Da mesma forma, o ensino com ênfase profissionalizante é objeto de seguidas regulamentações. $O$ ensino superior também é objeto de novas propostas e reformas, marcadas principalmente pela influência dos acordos MEC/USAID. A chamada reforma universitária, empreendida no início da década, faz surgir um conjunto de novas universidades, com estruturas de atuação moldadas no modelo americano, passando a 
requerer de parte de seus docentes dedicação exclusiva e ampliando as possibilidades de pesquisas nessas instituições. Com o incentivo à pesquisa acadêmica em novos moldes, regulamentam-se os cursos de pós graduação e surge a CAPES.

Enfim, e de diferentes pontos de vista, o conhecimento científico é reconhecido definitivamente como fundamental aos planos de desenvolvimento.

\section{Período II - De meados da década de 80 a meados da década de 90}

A partir do início da década de 80, passam a soprar novos ventos, sinalizando o final do desgastado regime ditatorial, e dando início a um processo gradual de abertura democrática. Embora do ponto de vista econômico, a década de 80 seja por muitos reconhecida como uma década perdida, não é isso que ocorre do ponto de vista dos movimentos da sociedade civil.

Em decorrência, a grande marca desse período é a eleição de uma assembléia constituinte e a promulgação, em 1988, de uma nova Constituição brasileira. Nela, a educação ganha um espaço muito especial, sendo reconhecida como um direito de todos. Em especial, a educação infantil recebe atenção privilegiada, passando a ser também obrigação do Estado. A preocupação com a criança e o adolescente vai motivar, nos anos seguintes, a elaboração de uma regulamentação específica própria, o Estatuto da Criança e do Adolescente (ECA/91).

Esse período é também marcado pelos movimentos de mobilização e reorganização da sociedade civil, em busca dos espaços democráticos cuja existência tinha sido, nos anos anteriores, cerceada. Como frutos desses movimentos surgem diversas associações e centros, como ANDES (Associação Nacional dos Docentes do Ensino Superior), ANPED (Associação Nacional de Pós-Graduação e Pesquisa em Educação) e CEDES (Centros de Estudos de Educação e Sociedade), por exemplo, além da realização das Conferências da Educação Brasileira (CEBS), que representaram um importante marco nas discussões educacionais.

Alguns autores apontam, ainda, a proposição de diversas iniciativas locais inovadoras, dentro de uma perspectiva de resistência e reconcepção dos espaços educacionais. Ainda que pontuais, sinalizavam novas possibilidades da educação como instrumento de transformação e democratização. Exemplo disso, dentre outros, foram os projetos desenvolvidos na gestão Erundina, à frente da prefeitura da cidade de São Paulo, entre 1989 e 1992.

Persiste nesse período uma atenção especial ao ensino profissionalizante e à formação de técnicos, reiterando a importância desse tipo de formação para as necessidades do país, sendo esses elementos incorporados aos muitos planos estratégicos de desenvolvimento da época. 
Um grande marco pós constituinte, fruto de discussões e confrontos que se desenvolveram ao longo de muitos anos, foi a promulgação, em 1996, da Lei de Diretrizes e Bases da Educação Brasileira (LDB/96). Em um extenso documento, sinalizavam-se diretrizes gerais que viriam a ser objeto de atenção e legislações específicas nos anos seguintes.

Especificamente no que diz respeito à educação básica, a LDB reconhece o ensino médio como etapa final da educação, propondo que esse estágio venha a empenhar-se em uma educação para a cidadania, retirando seu forte caráter de preparação para o ensino superior. Nessa perspectiva, várias ações e documentos foram desenvolvidos nos anos seguintes. Em especial, no que diz respeito à educação científica, os parâmetros curriculares nacionais (PCNs) para os vários graus de ensino procuraram traduzir as perspectivas da LDB em diretrizes mais próximas da realidade. Em muitos casos, foram o motor de reformulações curriculares significativas. Esses parâmetros e documentos também sinalizam uma perspectiva mais cultural e humanista para o ensino de ciências, contrapondo-se às exigências que vinham sendo impostas nos anos anteriores, voltadas para a formação de profissionais. Da mesma forma, a proposta de um exame nacional para os concluintes do ensino médio, nos moldes em que veio a se concretizar o ENEM, reforça essas ênfases.

Nesse período, buscou-se uma expansão da escola básica, de forma a torná-la accessível a toda a população de jovens, tal como apontado pela própria constituição. Esse movimento envolveu projetos e formas de financiamento, como o FUNDEF (Fundo de Manutenção e Desenvolvimento do Ensino Fundamental e de Valorização do Magistério), além de ações que visavam a permanência dos jovens na escola, através de experiências de promoção automática, estabelecimento de ciclos e as chamadas classes de aceleração.

De uma forma geral, e acompanhando os movimentos de globalização e de transformação do papel do Estado em todo o mundo, busca-se instaurar um modelo neoliberal. No caso dos sistemas educacionais, trata-se de uma relativa desregulamentação, acompanhada de sistemas de avaliação paralelos, como o SAEB (Sistema Nacional de Avaliação da Educação Básica), voltado para educação básica, e o PROVÃO (terminologia que passou a ser adotada para o ENC - Exame Nacional de Cursos), dirigido aos alunos concluintes dos cursos superiores, transformado em 2004 no ENADE (Exame Nacional de Avaliação do Desempenho de Estudante).

Período IV - De meados dos anos 2000 até o presente (2005-2011)

A descrição de um período contemporâneo é, certamente, passível de muitas e diferentes interpretações. Segundo Kawamura, do ponto de vista educacional, 
estamos presenciando um amplo esforço nacional, tanto no sentido de democratização como de inclusão, através de ações de diferentes níveis, com resultados ainda de difícil avaliação. Assim, vem ocorrendo, nos últimos anos, uma expansão do ensino público superior, e, paralelamente, maiores oportunidades de acesso ao ensino superior privado, através de diferentes estímulos e financiamentos. Essa mesma expansão vem ocorrendo através do estímulo ao ensino a distância, e de projetos de formação de professores voltados para comunidades com pouco acesso às universidades.

Do ponto de vista da educação científica, ao que tudo indica, ela estaria voltando a disputar espaços com uma educação mais humanista, que procura (re)incorporar conhecimentos de filosofia, sociologia, música, etc. nas grades curriculares escolares, de forma institucionalizada. Paralelamente, cresce o aporte de financiamentos para ações de inserção da ciência em um universo cultural mais amplo (museus, centros de ciência, divulgação científica, etc.). O papel da formação de profissionais para o desenvolvimento começa a ser retomado, assim como os programas de incentivo à inovação tecnológica.

Destaca-se nesse cenário de um pretendido incentivo à expansão do ensino superior, ações diversas que, ainda que polêmicas e com leituras diversas, estão na pauta desse final da década de 2000. Isso se dá seja por meio das formas de acesso ao ensino superior, como o PRO-UNI, o SISU e o "Novo ENEM" (esse último passa a ter caráter de avaliação para ingresso nas universidades, diferentemente de sua vocação original), seja pela abertura de novas vagas e cursos em instituições públicas federais, com destaque para a educação profissional e tecnológica. A criação dos IFET (Institutos Federais de Educação, Ciência e Tecnologia) em 2008, com a implantação de novos cursos de licenciatura, é também polêmica e tem grandes impactos, particularmente em nossa área. Novos concursos são abertos nessas instituições, absorvendo um contingente não desprezível de mestres e doutores (muitos do quais com títulos em "Ensino de") para lecionar nas licenciaturas em Física, uma das áreas privilegiadas nessas mudanças.

No âmbito da pós-graduação, instauram-se e crescem os mestrados profissionalizantes dirigidos à formação de "profissionais qualificados" e, também aqui, nossa área é "privilegiada" (o que deixarei para tratar adiante, em capítulo específico sobre essa questão).

Com base nesse cenário, apresentamos um quadro-síntese (Quadro 2.1) no qual estão privilegiados alguns dos aspectos considerados mais marcantes em cada um dos quatro períodos delimitados e descritos por Kawamura. 


\begin{tabular}{|c|c|c|c|}
\hline Início de 70 até meados de 80 & Meados de 80 até meados de 90 & Meados de 90, início dos 2000 & A partir de 2005 \\
\hline $\begin{array}{c}\text { Ditadura Militar, início do } \\
\text { processo de abertura }\end{array}$ & $\begin{array}{c}\text { Processo de abertura política } \\
\text { Constituição: } 1988 \\
\text { Eleições Diretas } \\
\text { (Collor, 1990-1992) }\end{array}$ & $\begin{array}{c}\text { Governo } \\
\text { Fernando Henrique Cardoso } \\
(1995-2002)\end{array}$ & $\begin{array}{l}\text { Governo } \\
\text { Lula } \\
\text { (2003-2010) }\end{array}$ \\
\hline $\begin{array}{l}\text { Formação de cientistas } \\
\text { (quadros) para o } \\
\text { desenvolvimento } \\
\text { (perspectiva tecnicista) }\end{array}$ & $\begin{array}{l}\text { Educação como direito para todos. } \\
\text { Educação Infantil, Estatuto da } \\
\text { Criança e Adolescente. }\end{array}$ & $\begin{array}{l}\text { Ensino profissionalizante, } \\
\text { Educação de Jovens e Adultos } \\
\text { (ENCEJA). Base humanista. }\end{array}$ & $\begin{array}{l}\text { Ciência também é cultura. } \\
\text { Diversificação: Inclusão de } \\
\text { sociologia, filosofia, etc. }\end{array}$ \\
\hline $\begin{array}{l}\text { Reforma Universitária } \\
\text { Pós graduação }\end{array}$ & $\begin{array}{l}\text { Mobilização e novas formas de } \\
\text { organização dos setores } \\
\text { educacionais (ANDE, ANPED, etc.) }\end{array}$ & $\begin{array}{c}\text { LDB (1996), } \\
\text { PCNs, PCNs + } \\
\text { (Novas ênfases) } \\
\text { Educação neoliberal. } \\
\text { Sistemas de avaliação: SAEB, } \\
\text { Provão. } \\
\text { ENEM }\end{array}$ & $\begin{array}{l}\text { Sistemas de avaliação: Prova } \\
\text { Brasil, ENADE. } \\
\text { Novo ENEM }\end{array}$ \\
\hline $\begin{array}{l}\text { Reforma de 71: ensino de } \\
\text { segundo grau (único): } \\
\text { Ênfase no "científico" }\end{array}$ & $\begin{array}{l}\text { Experiências locais (Prefeitura de São } \\
\text { Paulo 88-93) } \\
\text { Formação técnica e formação } \\
\text { profissional. }\end{array}$ & $\begin{array}{c}\text { Ensino médio como etapa final da } \\
\text { educação básica. Inclusão e } \\
\text { universalização. }\end{array}$ & $\begin{array}{l}\text { Expansão do ensino superior, } \\
\text { ProUni, FIES, etc. } \\
\text { Universidade aberta, Ensino a } \\
\text { distância }\end{array}$ \\
\hline Reformas de base & $\begin{array}{c}\text { Abertura: Reestruturações e } \\
\text { reorganizações }\end{array}$ & $\begin{array}{l}\text { Expansão da educação básica, } \\
\text { liberalização e controle }\end{array}$ & $\begin{array}{c}\text { Expansão do ensino superior } \\
\text { e democratização }\end{array}$ \\
\hline
\end{tabular}

Quadro 2.1: Marcos na perspectiva histórica da educação no Brasil 


\subsubsection{Evolução na perspectiva da história da área de Ensino de Ciências no Brasil}

Ainda tendo como referência principal o texto de Kawamura (2011), passamos a descrever marcos mais específicos da evolução da área de Ensino de Ciências, tendo em conta as principais ações e motivações, políticas, eventos e práticas ao longo de sua consolidação.

Muitos autores apontam como um marco importante na evolução das atenções ao Ensino de Ciências no Brasil a influência dos projetos americanos, desenvolvidos na década de 60 , e que tinham como principal intenção a formação de cientistas. Essa foi a principal resposta educacional à importância do conhecimento científico demonstrada na Segunda Guerra, estendida para os confrontos da Guerra Fria que então se iniciava.

Esses aspectos foram já extensamente apontados em diferentes trabalhos, sinalizando a influência dos movimentos internacionais pela educação em ciências na realidade brasileira. Dentre as iniciativas que resultaram dessa influência estão tanto a criação do IBECC (Instituto Brasileiro de Educação, Ciência e Cultura), como a criação de centros de ciências, entre 1963 e 1965, pelo MEC, em diversos estados do país, assim como a tradução do PSSC (Physical Science Study Committee) para o português (1965).

Para caracterizar o contexto da evolução da área de Ensino de Ciências a partir da década de 70, utilizamos as reconstituições e análises dos trabalhos já acima mencionados, além de outros, como Moreira (1993), Rodrigues e Hamburger (1993) e Almeida (2003). Trata-se, portanto, sempre de fontes secundárias, cujas informações não foram consolidadas, mas que, no nosso entender, constituem-se em material suficiente para o panorama que visamos apresentar.

Analisando em conjunto esse quadro, ou seja, dos acontecimentos que se sucedem a partir da década de 70, pareceu-nos possível identificar quatro períodos temporais com características diferentes. Não se trata de períodos muito bem definidos, nem as ações em cada um deles apresentam objetivos comuns. Essa caracterização, certamente, só é possível a posteriori, confrontando as ações desses diferentes momentos e reconhecendo movimentos demarcados em determinados conjuntos.

Utilizando a mesma periodização do tópico anterior, apresentamos alguns dos acontecimentos que marcaram esses períodos, sistematizados em um quadro final.

\section{Período I - Do início da década de 70 a meados da década de 80}

A década de 70 pode ser considerada como um marco do início da identificação institucional de um determinado conjunto de conhecimentos como sendo de Ensino de Física, de forma diferenciada dos conhecimentos da própria Física. Assim, em 1970 é realizado o primeiro Simpósio Nacional de Ensino de Física, que passa a ter 
regularidade, inicialmente, de três em três anos. É também em 1971 que surge uma seção dedicada especialmente ao ensino, na revista da Sociedade Brasileira de Física. Nos departamentos de Física de algumas universidades se constituem Grupos de Ensino, integrados por físicos preocupados com as questões de ensino. Dois desses grupos evoluem para a formação das primeiras pós-graduações em Ensino de Física no país, respectivamente no Instituto de Física-USP (São Paulo) e no Instituto de FísicaUFRGS (Porto Alegre), sendo que a primeira se constitui como Pós Graduação em Ensino de Ciências (modalidade Física), em parceria do Instituto de Física com a Faculdade de Educação, enquanto a segunda como Pós Graduação em Física (modalidade Ensino de Física).

No decorrer dessa década, esse movimento vai se acentuando, com o aporte de recursos do MEC através do PREMEM (Projeto de Expansão e Melhoria do Ensino Médio) para diversos projetos de ensino, estando na origem dos projetos brasileiros como o PEF (Projeto de Ensino de Física) e o FAI (Física Auto-Instrutiva), desenvolvidos pelos grupos de ensino das universidades. Paralelamente, disseminam-se disciplinas de Instrumentação para o Ensino, nos Cursos de Licenciatura, ministradas pelos físicos de departamentos de Física das universidades. Os Simpósios de Ensino vão consolidando e articulando as diversas iniciativas, dando lugar ao surgimento de novas revistas da área. A REF (Revista de Ensino de Física) dá identidade e independência à anterior seção de ensino da RBF, sendo editada entre 1979 e 1986. A partir de 1983, surge, também, o Caderno Catarinense de Ensino de Física, editado por docentes da UFSC (a partir de 2002, Caderno Brasileiro de Ensino de Física).

Assim, esse período corresponde aos primeiros passos do Ensino de Física como área de atuação e pesquisa, sendo a relação entre esses dois âmbitos muito estreita. Podemos dizer que se trata, de certa forma, da busca por um espaço institucional do Ensino de Física na comunidade dos físicos.

\section{Período II - De meados da década de 80 a meados/final da década de 90}

Os esforços e atividades do período anterior vão se consolidando, acumulando uma produção própria e se estendendo para novas iniciativas que, em conjunto, vão dando mais identidade para o Ensino de Física. Nesse período, há uma notável expansão das Pós-Graduações da área de Educação, sendo que docentes de Física contratados nos departamentos e institutos de educação vão trazer importantes contribuições para a identidade da área, seja na pesquisa, seja no movimento pelo reconhecimento de uma Didática de Ciências, como campo específico no interior da própria didática.

Surgem novos núcleos de Ensino de Física, de forma disseminada em todo o país, muitos deles originados de projetos governamentais de apoio à melhoria do Ensino de Ciências, como o SPEC/PADCT (Sub-Programa de Educação para Ciência do Programa de Apoio ao Desenvolvimento Científico e Tecnológico), que atuou marcadamente no 
período entre 1987 e 1995, incentivando projetos de formação continuada de professores de ciências/física, elaboração de materiais didáticos e também viabilizando publicações e encontros nacionais na área de Ensino de Ciências. Dentre esses, vale ressaltar o GREF (Grupo de Reelaboração do Ensino de Física), criado em 1984, de cujas atividades resulta um projeto renovador de grande amplitude desenvolvido em uma parceria entre professores de ensino médio da rede pública estadual de São Paulo e docentes do IFUSP.

O período é marcado, ainda, pela realização do primeiro Encontro de Pesquisa em Ensino de Física (EPEF), em 1986, promovido pela SBF (Sociedade Brasileira de Física), tal qual o SNEF, que depois institucionaliza e passa a ser bienal. Paralelamente, a REF é extinta e transformada em RBEF (Revista Brasileira de Ensino de Física), editada pela $\mathrm{SBF}$, o que lhe dá maior estabilidade.

Podemos constatar, portanto, que esse período corresponde a uma institucionalização da pesquisa em Ensino de Física, de tal forma que os âmbitos da pesquisa propriamente ditos vão ganhando identidade própria, e se distinguindo da proposição, prática e desenvolvimento de atividades de ensino.

\section{Período III - De meados/final da década de 90 a meados dos anos 2000}

Embora estejamos acompanhando apenas os aspectos relativos ao Ensino de Física, preocupações semelhantes, ainda que não equivalentes, também se desenvolveram em outras áreas do ensino de Ciências, em uma determinada época. Destaca-se nesse âmbito, a realização, em 1997, do I ENPEC (Encontro Nacional de Pesquisa em Educação em Ciências, estabelecendo um fórum de articulação entre as áreas das ciências da natureza, incentivando o desenvolvimento de trabalhos e debates mais gerais. Esses encontros, que passam também a ser bianuais, vêm acompanhados da criação da ABRAPEC (Associação Brasileira de Pesquisadores em Ensino de Ciências).

Outro marco importante, nessa mesma época, e em ressonância com esse movimento, é a criação, pela CAPES (Coordenação de Aperfeiçoamento de Pessoal de Nível Superior), de uma área específica de Pesquisa em Ensino de Ciências e Matemática (Área 46), permitindo, com esse reconhecimento institucional, uma série de novas possibilidades de apoio, financiamento e incentivo.

Também na direção de uma maior abrangência, no entorno de 2000, surgem inúmeras novas revistas e publicações voltadas para o Ensino de Ciências. É o caso, por exemplo, das revistas Ciência e Ensino (UNICAMP), Ensaio (UFMG), Ciência e Educação (UNESP), Investigações em Ensino de Ciências (UFRGS), dentre outras. A partir de 2001, o antigo Caderno Catarinense de Ensino de Física ganha abrangência nacional e passa a ser designado como Caderno Brasileiro de Ensino de Física. Essa e outras publicações 
inicialmente mais restritas ao ensino de Física passam a ter abrangência cada vez maior, tratando de questões que perpassam todas as áreas científicas.

Paralelamente a esses movimentos, ganham atenção na educação científica os espaços não formais e os empreendimentos de divulgação, tais como museus, centros de ciência e outros espaços culturais, em uma tentativa de buscar maior aproximação da sociedade com o conhecimento científico.

Período IV - De meados dos anos 2000 até o presente

A segunda metade dos anos 2000 vem representando uma consolidação maior da área de Ensino de Ciências, através da diversificação de focos, iniciativas, revistas, programas e ações. Por tratar-se de um período muito recente, não é possível o necessário distanciamento para sua caracterização, o que, em geral, ocorre por contraste com épocas seguintes.

Talvez um dos aspectos mais marcante desse período seja a proliferação dos Mestrados Profissionais. Sua implantação permite agregar, em torno do Ensino de Ciências, um número bastante significativo de docentes e suas respectivas instituições, dentro de uma proposta de desenvolvimento de pesquisas mais diretamente relacionadas com a produção de materiais didáticos. Ao mesmo tempo, e respondendo a políticas do MEC, vem ocorrendo uma significativa expansão dos cursos de licenciatura, no âmbito da expansão do próprio ensino superior em instituições federais. E aqui, novamente se destaca a ênfase dada à formação de quadros para a educação científica e tecnológica, e a criação dos IFETs.

Paralelamente, a questão da utilização das novas tecnologias de informação, da mesma forma que para as demais áreas educacionais, é o agente motor de inúmeras iniciativas, aportes, projetos e financiamentos. De forma mais específica, os cursos de ensino a distância, tanto como cursos de graduação e de especialização, voltados à formação continuada de professores, vêm colocando novas formas de trabalhar as questões relacionadas ao Ensino de Ciências.

Todo esse movimento vem acompanhado por uma grande proliferação de eventos temáticos, com enfoques e objetos mais localizados, como, por exemplo, educação ambiental, CTS, letramento científico, dentre outros, com participação significativa dos mesmos pesquisadores da área de Ensino de Ciências. É bem evidente, também, uma presença representativa de pesquisadores brasileiros em eventos de Ensino de Ciências internacionais, permitindo concluir que uma internacionalização está em curso. Diante de tantas novas propostas, as publicações da área estão também passando por um amplo processo de crescimento e diversificação, movimento indispensável para permitir a difusão da crescente produção da área. 
As diversas considerações apresentadas acima estão reunidas em um quadro-síntese apresentado a seguir, tal qual no anterior, privilegiando aspectos mais marcantes de cada um dos quatro períodos delimitados. 


\begin{tabular}{|c|c|c|c|}
\hline Início de 70 até meados de 80 & $\begin{array}{l}\text { Meados de } 80 \text { até } \\
\text { meados/final de } 90\end{array}$ & Final dos 90, início dos 2000 & A partir de 2005 \\
\hline $\begin{array}{l}\text { "Grupos de Ensino" } \\
\text { Primeiras Pós-Graduações em Ensino } \\
\text { de Física (IF/FEUSP e IF-UFRS) }\end{array}$ & $\begin{array}{c}\text { Expansão das pós graduações } \\
\text { especialmente na área de } \\
\text { Educação }\end{array}$ & $\begin{array}{l}\text { Criação de uma Área de Pesquisa e } \\
\text { Ensino na CAPES (Área 46) }\end{array}$ & $\begin{array}{l}\text { Proliferação dos Mestrados } \\
\text { Profissionalizantes }\end{array}$ \\
\hline $\begin{array}{l}\text { Disciplinas de instrumentação nos } \\
\text { Cursos de Licenciatura }\end{array}$ & $\begin{array}{c}\text { Didática das Ciências nas Fac. } \\
\text { Educação } \\
\text { Projetos SPEC/PADCT, Núcleos de } \\
\text { Ensino, } \\
\text { GREF }\end{array}$ & $\begin{array}{l}\text { Ações de extensão e divulgação se } \\
\text { deslocam para a pós graduação }\end{array}$ & $\begin{array}{c}\text { Expansão das Pós-Graduações } \\
\text { em Ensino de Ciências, nos } \\
\text { Dept.e FEs } \\
\text { Ensino a distância }\end{array}$ \\
\hline $\begin{array}{c}\text { Seção de Ensino RBF }(71 / 78) \\
\text { REF }(79 / 86) \\
\text { Cad. Cat. Ens. Fis. }(83) \\
\operatorname{SNEF}(70,7376, \ldots)\end{array}$ & $\begin{array}{l}\text { RBEF (a partir de } 87) \\
\operatorname{EPEF}(86,88,90 \ldots)\end{array}$ & $\begin{array}{c}\text { Novas publicações (p.ex. Ciência e } \\
\text { Ensino, Ciência e Educação) } \\
\text { ABRAPEC } \\
\text { Cad.Bras.Ens.Fis (2001) } \\
\text { ENPEC }(97, \ldots)\end{array}$ & $\begin{array}{l}\text { Diversificação das publicações } \\
\text { (Alexandria,...) } \\
\text { Diversificação de encontros } \\
\text { temáticos }\end{array}$ \\
\hline
\end{tabular}

Quadro 2.2: Marcos na evolução da área de Ensino de Ciências 
Como já adiantamos, esses quadros não pretendem esgotar a diversidade de aspectos que essas "histórias" poderiam permitir, nem tampouco serem lidos com rigor metodológico ou histórico, o que demandaria toda uma tese. Outra tese... Juntos, o que nos mostram são fragmentos ou tendências que de certa forma se articulam e, se não convergem, dialogam entre si.

Diferentes aspectos e marcos apontados na perspectiva da evolução do Ensino de Ciências certamente estão intimamente associados e situados no quadro ou contexto mais amplo da demarcação evolutiva das questões mais abrangentes das políticas educacionais no Brasil.

Deixamos para o capítulo oito, uma análise sistematização das articulações entre esses planos, de forma a incorporar o terceiro, em que buscamos sistematizar a evolução das ideias, aportes teóricos e focos de pesquisa na área. 


\section{Um perfil evolutivo da produção acadêmica}

Se a gente cresce com os golpes duros da vida, também podemos crescer com os toques suaves na alma. (Cora Coralina)

Nesse capítulo apresentamos um panorama geral da Pesquisa em Ensino de Física, segundo diferentes parâmetros que podem descrever como vem evoluindo. Entre esses, o crescimento da produção de dissertações e teses e das instituições e programas de pós-graduação em que essas vêm se desenvolvendo.

\subsection{Objetivos e objetos}

A evolução da área de Pesquisa em Ensino de Física (PEF) pode ser analisada segundo diferentes dimensões: uma delas, da qual trataremos nesse capítulo focaliza sua expansão do ponto de vista "quantitativo", na qual são consideradas variáveis que sinalizam como, onde e em que níveis ela vem ocorrendo. Outra trata de focalizar, mais qualitativamente, o desenvolvimento e as transformações de seus objetos de estudo, seus focos e temas de interesse, referenciais e outros recortes acerca de sua natureza. Desse segundo aspecto, trataremos em capítulos posteriores.

Com uma abordagem predominantemente descritiva ("cinemática") nesse capítulo apresentamos um panorama da produção acadêmica na área de Ensino de Física, visando construir um perfil de sua evolução, desde sua institucionalização, no início da década de 1970 até os anos mais recentes.

A criação de tal panorama já se justificaria por si mesma, uma vez que registra e sistematiza dados relevantes para reconstruções da área, fornecendo uma visão ampla de sua evolução. Particularmente na perspectiva dessa pesquisa, justifica-se também como instrumental para definir e analisar recortes do nosso estado da arte. Pode, ainda, ter outro papel importante no embasamento e sinalização de características e tendências sobre a inquestionável e recorrentemente constatada expansão dessa área. Podemos ir um pouco além da constatação e procurar compreender algo mais sobre a natureza desse crescimento, de forma a termos elementos para uma reflexão sobre a "dinâmica" da área: suas bases, suas políticas institucionais e públicas, suas transformações e perspectivas. 
Por se tratar da construção de um perfil da pesquisa na área, optamos por adotar como objeto de estudo as dissertações e teses, que refletem mais fiel ou proximamente as características da produção acadêmica. Não coincidentemente, mas como fator também preponderante nessa escolha, há cerca de vinte anos acumulamos um extenso trabalho de sistematização dessa produção. Trabalho esse que teve origem no início da década de 1990, com a criação de um banco de dados da área $(E N F I S)^{6}$ e, a partir desse, com a elaboração dos Catálogos Analíticos de Dissertações e Teses de Ensino de Física no Brasil. (UNIVERSIDADE DE SÃO PAULO - INSTITUTO DE FíSICA, 1992; 1996 e 2009).

Os Catálogos compõem uma coleção, até o momento em três volumes, onde estão sistematizadas as dissertações e teses em ensino de Física abrangendo, respectivamente, os períodos 1972-1992 (Volume 1), 1992-1995 (Volume 2) e 19962006 (Volume 3), reunindo um total de 891 títulos. Para cada tese apresentam as principais referências bibliográficas, além de indicadores criados para caracterizar seus conteúdos (palavras-chaves, nível de ensino focalizado, foco temático e resumos). A elaboração desses Catálogos, nos três momentos, envolveu um extenso e árduo trabalho, com uma série de dificuldades, tanto de caráter prático, quanto metodológico ou teórico (quiçá filosófico...), algumas das quais descrevemos aqui pelo fato de refletirem as limitações que encontramos na criação desse perfil.

Do ponto de vista prático, os desafios e problemas foram (ou são) inumeráveis.

Especialmente na elaboração dos dois primeiros volumes, o acesso a essa produção era extremamente limitado. Inicialmente, essa busca foi feita por meio de cartas enviadas pelos correios, viagens a instituições diversas do país e contatos com pesquisadores; mais tarde, por email ou pelo acesso a bancos de dados e páginas da web de instituições e programas de pós-graduação na área, além das trocas de dados e materiais com autores, orientadores e instituições. Assim, o sucesso dessa empreitada dependeu da boa vontade e disponibilidade de pessoas ou instituições, além de nossos próprios esforços e insistências. A maior parte dessa produção não era encontrada nos acervos de bibliotecas, não estava digitalizada e, em não poucos casos os próprios autores não eram localizáveis.

Mais recentemente, esse acesso foi bastante facilitado pelas redes e sítios na internet, pelas versões eletrônicas que passaram a ser disponibilizadas em páginas institucionais e por bancos de dados. Ainda assim, permanece um trabalho de "formiguinha" na localização das teses, cada vez mais dispersas em inúmeras instituições do país.

\footnotetext{
${ }^{6}$ ENFIS é uma base de dados de Referências Bibliográficas em Ensino de Física, na qual durante um largo período foram catalogadas publicações nacionais dessa área. Inclui uma produção bastante diversificada, incluindo-se teses e dissertações.
} 
Do ponto de vista metodológico a principal dificuldade reside na identificação e categorização de parâmetros para a análise desses trabalhos, sobretudo quanto a seu conteúdo: atribuição de palavras-chave (e, para isso, indexação de vocabulário da área), identificação de focos temáticos, de níveis de ensino privilegiados e elaboração de resumos. Dificuldade essa advinda, de um lado, da falta de material, ou seja, das teses na íntegra e, de outro, da ausência de instrumentais e referências para esse tipo de análise em nosso campo. Tarefa que demanda conhecimentos técnicos especializados (por exemplo, da área de biblioteconomia e documentação), que envolve aspectos associados a concepções de estrutura e desenvolvimento da área, ou ainda de cunho histórico, sobre sua contextualização e evolução, quer no âmbito educacional do país, quer na sua inserção em um panorama internacional.

Tanto quanto possível, procuramos nos basear nos resumos das teses elaborados pelos próprios autores, mas nem sempre eles são adequados e/ou suficientes, o que demanda o acesso dos textos completos. Entretanto, em se tratando de um volume excessivamente grande de títulos (centenas, milhares), esse procedimento torna-se praticamente impossível. Assim, apenas em casos de maior necessidade e, quando possível, realizamos essa leitura mais completa.

Do ponto de vista teórico (com desdobramentos metodológicos) reside o que reconhecemos como um problema bastante especial, associado ao núcleo central dessa pesquisa. Trata-se da delimitação do campo (a arte!). $\mathbf{0}$ que é, o que define, $\mathbf{o}$ que caracteriza, identifica, carimba uma produção da área de Ensino de Física? Desde sempre, mas agora bem mais que nos primórdios da institucionalização da área, tivemos que nos defrontar com essa questão, criando, recriando e aperfeiçoando critérios de seleção para o levantamento de "nosso universo", dadas as suas tênues fronteiras. Lá em suas origens, na década de 1970, tratava-se de um território relativamente bem delimitado, com trabalhos desenvolvidos e orientados pelos "desbravadores" da área, pesquisadores oriundos de Institutos de Física preocupados com questões educacionais e mais tarde, mesmo que alocados em Departamentos ou Faculdades de Educação, também físicos. ${ }^{7}$ Mais que isso, a maior parte desses trabalhos tinha abordagens específicas, com foco em processos de ensino e aprendizagem do conhecimento físico, que davam uma identidade bastante reconhecível a esse campo. Ou seja, em sua gênese e nos primeiros anos de vida a área possuía um perfil inequívoco, bem delineado.

Hoje, mais madura, essa produção está inserida em um universo bastante amplo, abarcado pela pesquisa em Educação como um todo, com interfaces com diferentes áreas do saber. Seus trabalhos são menos "pontuais", mais abrangentes. Enquanto

\footnotetext{
${ }^{7}$ Sobre esse aspecto, Suzana de Souza Barros (BARROS, 2002) uma das percussoras da área faz uma análise interessante em retrospectiva da área apresentada na conferência de abertura do XVIII SNEF.
} 
cresceu numericamente, enquanto se expandiu geograficamente, a área também alargou fronteiras nos campos de conhecimento e pesquisa. Essa é, talvez, a nossa principal dificuldade metodológica, à qual voltaremos a focalizar adiante.

Ao conjunto de 891 títulos somados nos três volumes dos Catálogos, incluímos, para fins dessa pesquisa, as dissertações e teses defendidas em 2007, 2008 e 2009, o que resulta em um total de 1330 teses $^{8}$. Esse "pacote" constitui o objeto de estudo desse capítulo, no qual tratamos, como foi dito, sobretudo de aspectos quantitativos e de parâmetros objetivos que descrevem e caracterizam o que estamos denominando "perfil evolutivo" da pesquisa na área.

No Anexo 3.1 apresentamos uma Tabela Geral contendo as principais referências bibliográficas do conjunto completo de teses: autor, orientador, instituição, grau acadêmico e ano de defesa.

\subsection{Procedimentos e metodologias}

Procedimentos metodológicos utilizados para a construção do panorama desse conjunto de dissertações e teses envolvem o levantamento geral de títulos, suas classificações segundo os parâmetros definidos para caracterizar o perfil evolutivo, a sistematização dos dados obtidos e a análise dos resultados.

\section{Do levantamento dos trabalhos}

Dadas as dificuldades já apontadas na identificação do nosso objeto de investigação, seja na busca, seja na seleção das dissertações e teses da área, estabelecemos alguns critérios que nortearam esse levantamento, que resultou nesse universo de 1330 dissertações e teses. Compuseram esse conjunto trabalhos que:

i) Tratam explicitamente de Ensino de Física em qualquer nível escolar.

ii) Tratam do Ensino de Ciências de uma maneira geral, abrangendo, do ponto de vista temático, o Ensino de Física. Incluem-se aqui, por exemplo: trabalhos sobre Formação de Professores na área de Ciências Naturais; História e Filosofia da Ciência; abordagem CTS no ensino de Ciências; Divulgação Científica; Tecnologias de Informação e Comunicação (TIC); Processos Cognitivos de Ensino e Aprendizagem; Atividades Experimentais.

iii) Focalizam o Ensino de Ciências no Nível Fundamental II (6․ ao 9‥ ano), desde que abarcando algum conhecimento físico. São exemplos de conteúdos inclusos: Água, Energia, Universo (Astronomia e Cosmologia), Radiações, Clima

\footnotetext{
${ }^{8} \mathrm{Na}$ data em que encerramos o levantamento de dados, o banco de teses da CAPES, assim como outros bancos de dissertações e teses de Programas de Pós-Graduação tinham sua última atualização em 2009.
} 
e Meio Ambiente (além dos convencionais tópicos de Física como Calor, Movimento, Luz, Som etc.).

Tais critérios não são excludentes. Há intersecções e complementaridades. Ou seja, existem interfaces entre uns e outros. Também há casos de difícil demarcação, para os quais, combinado a esses, utilizamos critérios secundários, como o Programa de Pesquisa onde foi desenvolvida a pesquisa ou características da orientação.

Como fontes de informação para esse levantamento, utilizamos sites ou páginas disponíveis na web de instituições e programas de pós-graduação que trazem relações de teses defendidas nos mesmos, o banco de teses da CAPES $^{9}$ o catálogo de dissertações e teses em Ensino de Física no Brasil (USP-Instituto de Física), o catálogo de dissertações e teses em ensino de Ciências do Centro de Documentação em Ensino de Ciências $(C E D O C)^{10}$ além de contatos pessoais com autores, orientadores e outros pesquisadores da área de Ensino de Ciências ou de Ensino de Física.

\subsection{Dados e resultados}

Tendo em vista a construção desse primeiro panorama geral, classificamos e sistematizamos os trabalhos segundo as principais referências bibliográficas: autor, título, ano de defesa, orientador, instituição (e/ou unidade da instituição e/ou programa de PG) e local (cidade/estado).

Essas informações foram classificadas e analisadas em três tópicos ou agrupamentos:

- Evolução geral

- Evolução por grau acadêmico

- Evolução institucional

- Distribuição regional

Para cada um desses indicadores de classificação, construímos distribuições gerais e evolutivas (ao longo do tempo).

\subsubsection{Evolução geral da produção}

O conjunto de títulos levantados foi primeiramente organizado segundo o ano de defesa, possibilitando uma análise de sua evolução quantitativa ao longo do tempo,

\footnotetext{
${ }^{9}$ Banco de teses - CAPES disponível em http://www.capes.gov.br/servicos/banco-de-teses (último acesso em 15/03/2012)

${ }^{10}$ O catálogo "O ensino de ciências no Brasil: catálogo analítico de teses e dissertações (1972-1195)" foi editado pelo CEDOC, Faculdade de Educação da UNICAMP, sob coordenação do Prof. Jorge Megid Neto.
} 
sem distinções específicas. Os resultados dessa sistematização estão apresentados na Tabela 7.1 e correspondente Gráfico 3.1.

\begin{tabular}{|c|c|c|c|}
\hline ANO & No. TESES & ANO & No. TESES \\
\hline 1972 & 04 & 1991 & 17 \\
\hline 1973 & 03 & 1992 & 10 \\
\hline 1974 & 00 & 1993 & 19 \\
\hline 1975 & 03 & 1994 & 19 \\
\hline 1976 & 11 & 1995 & 28 \\
\hline 1977 & 07 & 1996 & 29 \\
\hline 1978 & 05 & 1997 & 32 \\
\hline 1979 & 04 & 1998 & 22 \\
\hline 1980 & 13 & 1999 & 35 \\
\hline 1981 & 09 & 2000 & 50 \\
\hline 1982 & 10 & 2001 & 45 \\
\hline 1983 & 10 & 2002 & 57 \\
\hline 1984 & 03 & 2003 & 67 \\
\hline 1985 & 17 & 2004 & 79 \\
\hline 1986 & 09 & 2005 & 101 \\
\hline 1987 & 16 & 2006 & 117 \\
\hline 1988 & 11 & 2007 & 111 \\
\hline 1989 & 23 & 2008 & 158 \\
\hline 1990 & 22 & 2009 & 154 \\
\hline
\end{tabular}

Tabela 3.1: Evolução anual do número de dissertações e teses

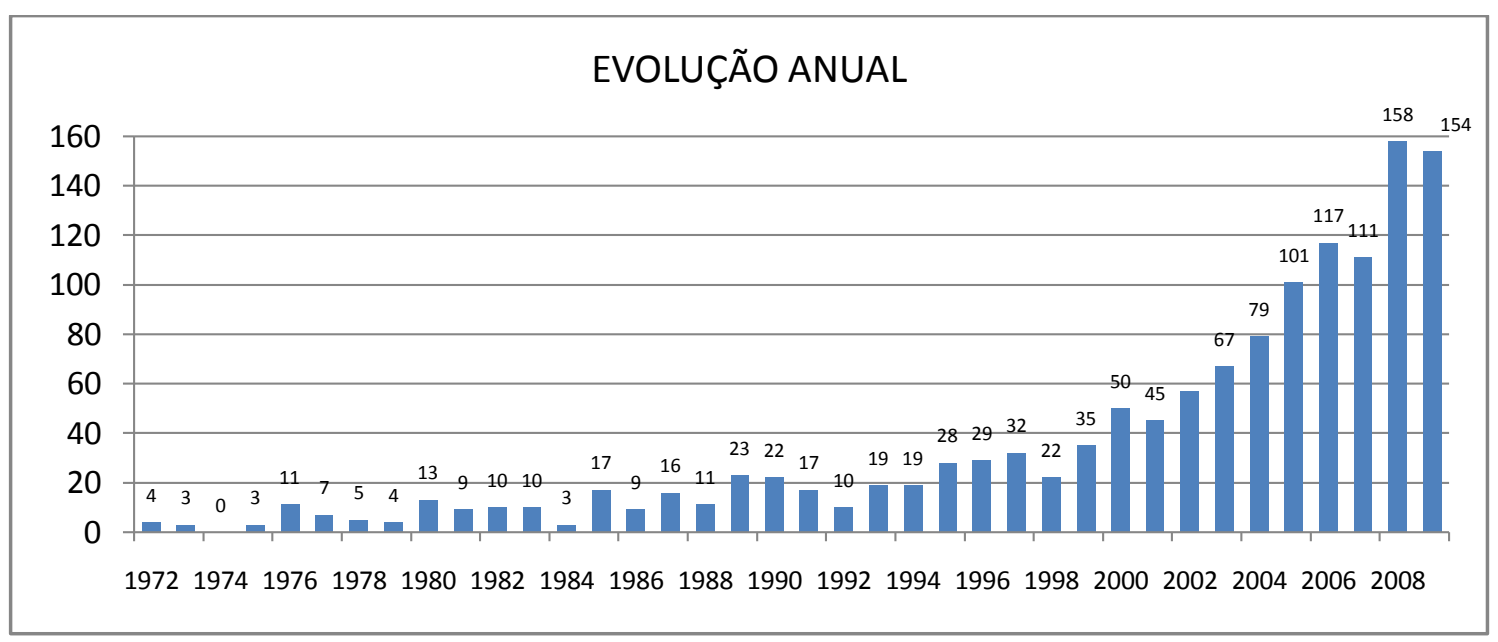

Gráfico 3.1: Evolução anual do número de dissertações e teses 
Dentre as dez primeiras dissertações e teses obtidas na área, no período 1972-1975, quatro foram apresentadas na UFRGS (Instituto de Física), três na UnB (Instituto de Ciências Exatas), duas na USP (uma na Faculdade de Educação e uma no Instituto de Física), e uma na UNESP - Rio Claro. A tabela 3.2 apresenta a relação dessa produção "pioneira".

\begin{tabular}{|c|c|c|c|c|}
\hline AUTOR & ANO & INSTITUIÇÃO & $\begin{array}{l}\text { GRAU } \\
\text { ACADÊMICO }\end{array}$ & ORIENTADOR \\
\hline MOREIRA, Marco Antonio & 1972 & UFRGS-IF & Mestrado & Fernando C. Zawislak \\
\hline BEZERRA, Paulo Cesar & 1972 & UnB-ICE & Mestrado & Luis Carlos Gomes \\
\hline CARVALHO, Anna Maria P. de & 1972 & USP-FE & Doutorado & $\begin{array}{l}\text { Amélia Domingues de } \\
\text { Castro }\end{array}$ \\
\hline DIB, Claudio Zaki & 1972 & USP-IF & Doutorado & Ernst W. Hamburger \\
\hline SCHREINER, Wido Herwig & 1973 & UFRGS-IF & Mestrado & Anildo Bristol \\
\hline MENDES FILHO, Josué & 1973 & UnB-ICE & Mestrado & Luis Carlos Gomes \\
\hline CANIATO, Rodolpho & 1973 & UNESP-R.Claro & Doutorado & José Goldenberg \\
\hline $\begin{array}{l}\text { LEVANDOWSKI, Carlos } \\
\text { Ernesto }\end{array}$ & 1975 & UFRGS-IF & Mestrado & Ialo R. Bonilla \\
\hline BUCHWEITZ, Bernardo & 1975 & UFRGS-IF & Mestrado & Anildo Bristol \\
\hline QUINTAS, José Silva & 1975 & UnB-ICE & Mestrado & Carlos Alberto S. Lima \\
\hline
\end{tabular}

Tabela 3.2: Relação das dez primeiras teses na área de Ensino de Física

Destaca-se que todos esses autores e trabalhos têm origem em Institutos ou Departamentos de Física, quadro que acaba se transformando. Ao longo do tempo, surgem pesquisadores da área vinculados a Faculdades, Centros ou Departamentos de Educação e nos anos mais recentes crescem os Programas de Pós-Graduação em Ensino de Ciências e similares, de naturezas inter ou multidisciplinares.

Para analisar com mais detalhes como se comporta essa evolução, os trabalhos foram agrupados por períodos, primeiramente de cinco e depois de dez anos. 


\section{Evolução por quinquênios}

A tabela e os gráficos mostram a evolução do número de teses tomando-se períodos de cinco anos, a partir de $1975^{11}$ : estão indicados também o percentual da contribuição de cada qüinqüênio no total da produção e o número médio de teses por ano, para cada período.

\begin{tabular}{|l|l|r|r|r|}
\hline \multicolumn{2}{|l|}{ PERÍODO } & $\begin{array}{r}\text { NÚMERO } \\
\text { ABSOLUTO }\end{array}$ & MÉDIA/ANO \\
\hline P1 & $1975-1979$ & 30 & 2,3 & 6,0 \\
\hline P2 & $1980-1984$ & 45 & 3,4 & 9,0 \\
\hline P3 & $1985-1989$ & 76 & 5,7 & 15,2 \\
\hline P4 & $1990-1994$ & 87 & 6,6 & 17,4 \\
\hline P5 & $1995-1999$ & 146 & 11,0 & 29.2 \\
\hline P6 & $2000-2004$ & 298 & 22,5 & 59,6 \\
\hline P7 & $2005-2009$ & 641 & 48,5 & 128,2 \\
\hline TOTAL & & 1323 & 100 & $\mathbf{3 4 , 8}$ \\
\hline
\end{tabular}

Tabela 3.3: Evolução do número de dissertações e teses a cada cinco anos

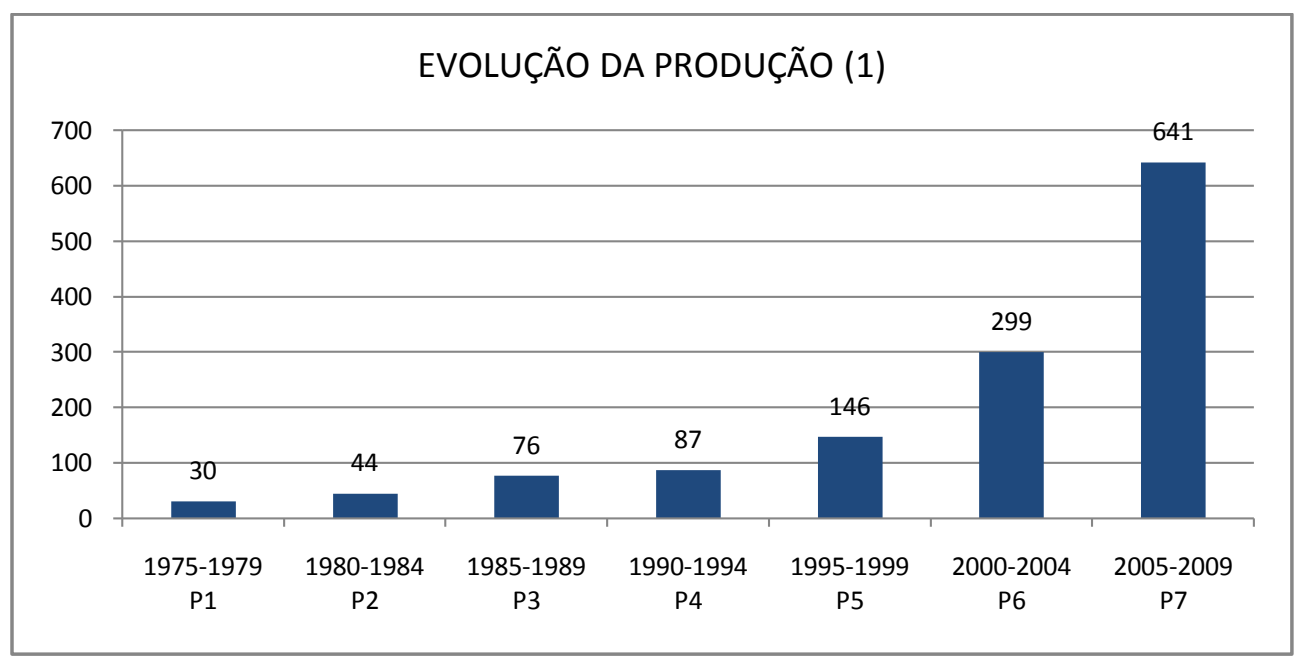

Gráfico 3.2: Evolução do número de dissertações e teses a cada cinco anos

\footnotetext{
${ }^{11}$ Descartados os anos de 1972 a 1974 para se tomar períodos de 5 anos. Nesses três anos somam-se 7 teses, número pouco expressivo no conjunto.
} 


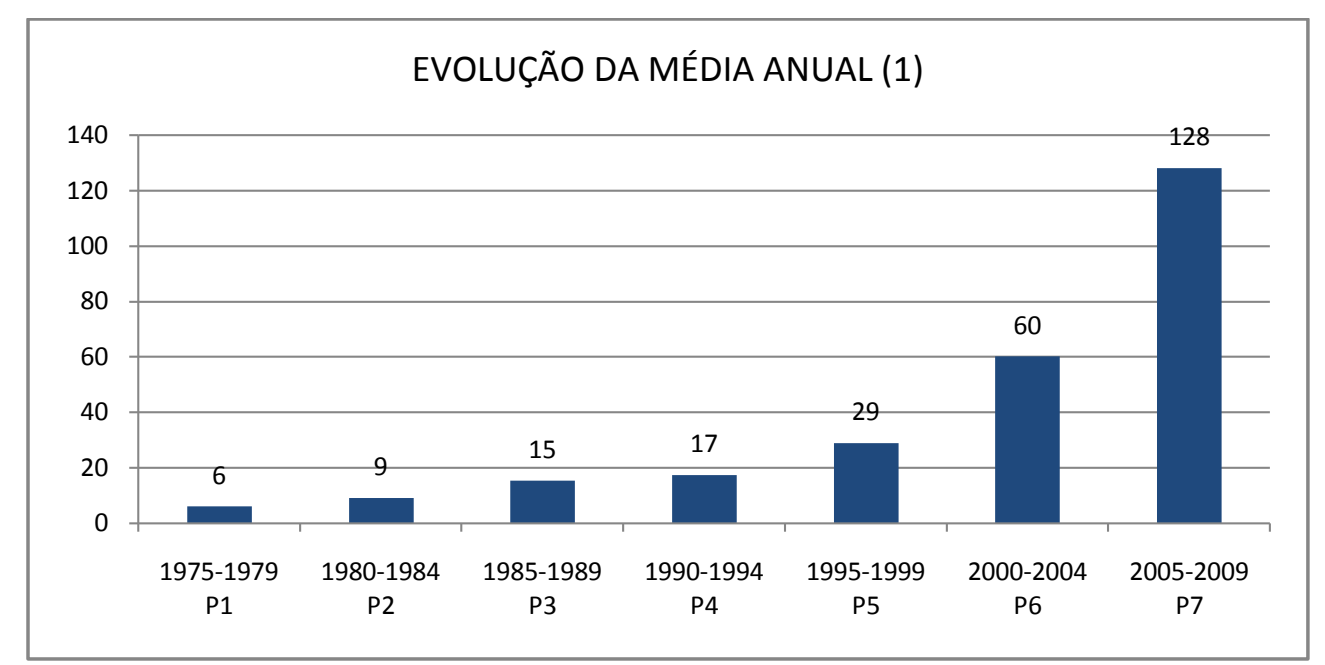

Gráfico 3.3: Médias anuais do número de dissertações e teses ao longo de períodos de cinco anos

Quanto às taxas de crescimento, também nos períodos finais são mais elevadas, sendo nos intervalos entre os dois últimos quinquênios maior que 100\%, como ilustram a Tabela 3.4 e o Gráfico 3.4 a seguir.

\begin{tabular}{|l|r|r|}
\hline $\begin{array}{r}|c| \\
\text { INTERVALOS ENTRE } \\
\text { PERIOODOS }\end{array}$ & \multicolumn{2}{|c|}{ TAXA DE CRESCIMENTO } \\
\hline P1-P2 & 1,5 & $50 \%$ \\
\hline P2-P3 & 1.7 & $67 \%$ \\
\hline P3-P4 & 1.1 & $13 \%$ \\
\hline P4-P5 & 1.7 & $71 \%$ \\
\hline P5-P6 & 2.0 & $107 \%$ \\
\hline P6-P7 & 2.2 & $113 \%$ \\
\hline
\end{tabular}

Tabela 3.4: Taxas de crescimento entre quinquênios consecutivos

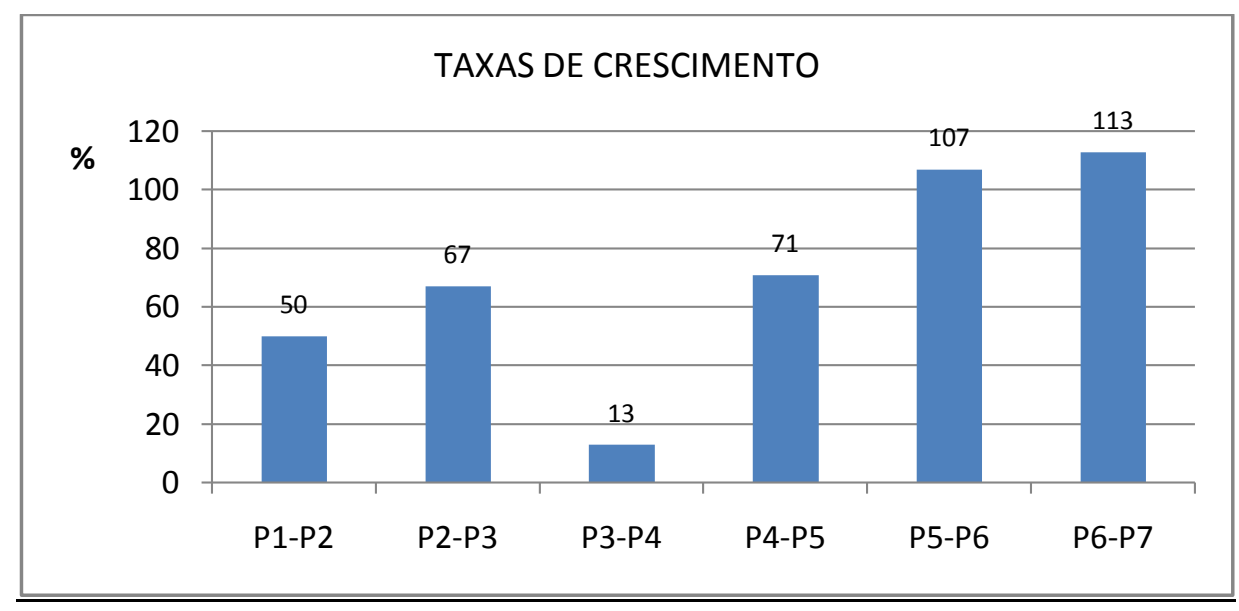

Gráfico 3.4: Taxas de crescimento entre quinquênios consecutivos 


\section{Evolução por décadas}

Um agrupamento desses dados nas quatro décadas que compreendem o período geral - entre 1972 e 2009 - permite uma visualização mais concentrada dessa evolução, reafirmando o padrão de crescimento e, em particular, o salto dado na última década. A tabela e os gráficos a seguir representam os dados dessa evolução em períodos de dez anos, a partir de 1972.

\begin{tabular}{|l|c|c|c|}
\hline & TOTAL & $\%$ & MÉDIA/ANO \\
\hline $1972-1979$ & 37 & 2,8 & 4,6 \\
\hline $1980-1989$ & 121 & 9,1 & 12,1 \\
\hline $1990-1999$ & 233 & 17,5 & 23,1 \\
\hline 2000-2009 & 939 & $\mathbf{7 0 , 6}$ & 92,1 \\
\hline TOTAL & $\mathbf{1 3 3 0}$ & $\mathbf{1 0 0}$ & $\mathbf{3 4 , 5}$ \\
\hline
\end{tabular}

Tabela 3.5: Evolução do número de trabalhos a cada dez anos

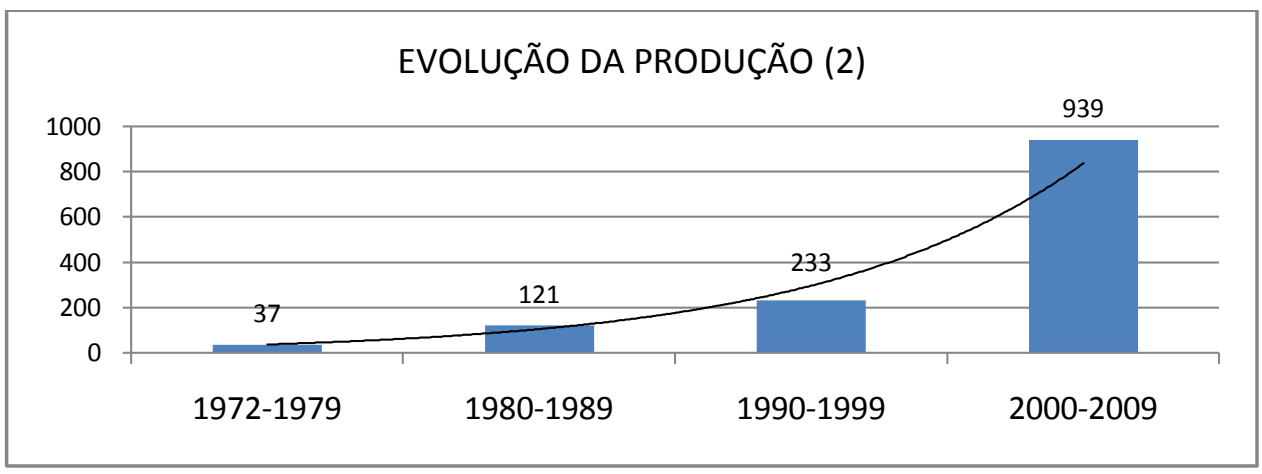

Gráfico 3.5: Evolução do número de dissertações e teses a cada dez anos (com linha de tendência exponencial como referência)

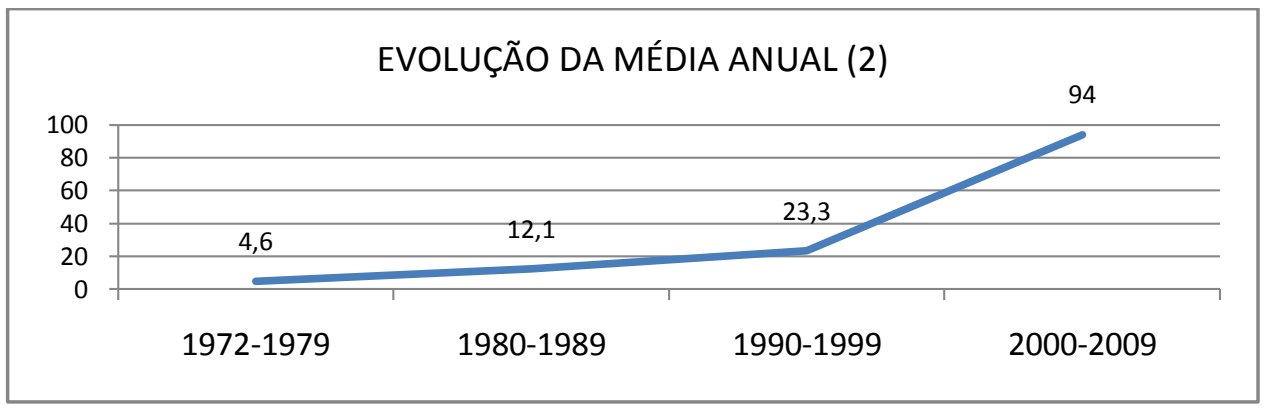

Gráfico 3.6: Médias anuais do número de trabalhos ao longo de períodos de dez anos 
Essas diferentes sistematizações mostram que qualquer critério, período ou parâmetro de crescimento que se tome, é evidente, sistemático e expressivo o aumento da produção de teses na área. Médias anuais aumentam de valores inferiores a uma dezena, nos anos setenta, para valores da ordem de uma centena, na primeira década de 2000. Números absolutos crescem de uma dezena nas décadas de 1970 e 1980 para duas a três dezenas na década de 1990, e para uma centena e meia no final da primeira década de 2000. Como já ressaltado, esse último período é o que mais chama a atenção. Vejamos...

Na primeira década de 2000, a produção é cerca de 25 vezes maior que na década de 1970. Em uma faixa mais estreita e próxima, da década de 1990 para essa última, a produção quadriplicou. $E$, em uma faixa ainda mais estreita e mais recente, tomandose apenas os últimos 10 anos (2000-2009), os cinco primeiros (2000-2004) somam 298 teses e os quatro últimos (2005-2009) somam 641, ou seja, um aumento superior a $100 \%$ da primeira para a segunda metade dessa década! Chegamos a 2009 com algo em torno de 1300 títulos, sendo cerca de 900 apenas nos últimos dez anos, o que representa aproximadamente $70 \%$ do total, nessas quase quatro décadas.

\section{Observações, ponderações e questões...}

Até determinado momento (aproximadamente início dos anos noventa) as fronteiras ou delimitações da área eram mais definidas, identificáveis; nos últimos anos crescem os trabalhos de natureza mais geral, em Ensino de Ciências, que de algum modo englobam a área de Ensino de Física. Os números acabam por refletir essa tendência (a ser discutida nos próximos capítulos). Poderíamos nos perguntar: será que deveríamos fazer os mesmos cálculos tomando-se apenas as teses estritamente de Ensino de Física? Se assim feito, em primeiro lugar voltaríamos à velha e difícil questão: quais são? Quais critérios? Quais fronteiras? Uma pesquisa em Ensino de Física seria caracterizada apenas se o conhecimento físico estivesse explicitamente contemplado? Ou, ainda, deveríamos arbitrariamente delimitar esse universo apenas às pesquisas em que o Ensino de Física é diretamente tratado como foco? Em segundo lugar, é que com tal delimitação estaríamos deixando de levar em conta justamente um aspecto essencial da evolução da área, ou seja, uma expansão que extrapola o crescimento vertical ou numérico, mas que se alastra na horizontal, abarcando novos focos de investigação e ampliando fronteiras.

O que podemos afirmar, com base nesses resultados, sobre tendências futuras? Ao que tudo indica, ou nada indica o contrário até aqui, as tendências continuam a ser de crescimento acelerado da produção. O que nos remete a outra questão: de que depende essa perspectiva? Quais os fatores que impelem uma (ou essa em particular) área de pesquisa à expansão ou a fazem retrair? Seriam seus objetivos/fins realizados? Seria a natureza das suas transformações? Seriam fatores políticos? Ou acadêmicos? 
Seria a demanda social? Acreditamos que o conjunto dessa obra possa nos indicar algumas possíveis respostas e caminhos.

\subsubsection{Evolução segundo o Grau Acadêmico}

O segundo indicador analisado para a construção desse perfil evolutivo foi o grau acadêmico. Até meados da primeira década de 2000, a produção se distribuía entre dissertações de Mestrado, teses de Doutorado e algumas poucas de Livre-Docência. Mais recentemente, entram em cena os Mestrados Profissionais (implantados na área de Ensino de Ciências em 2002) com as primeiras dissertações defendidas em 2004.

Nesse conjunto de títulos que abarca o período 1972-2009 temos 962 dissertações de Mestrado (M), correspondendo a $72 \%$ do total. As teses de Doutorado (D) representam $16 \%$ da amostra, $11 \%$ são Mestrados Profissionais (P) e 1\%, teses de Livre-Docência (LD), dados representados no Gráfico 3.7.

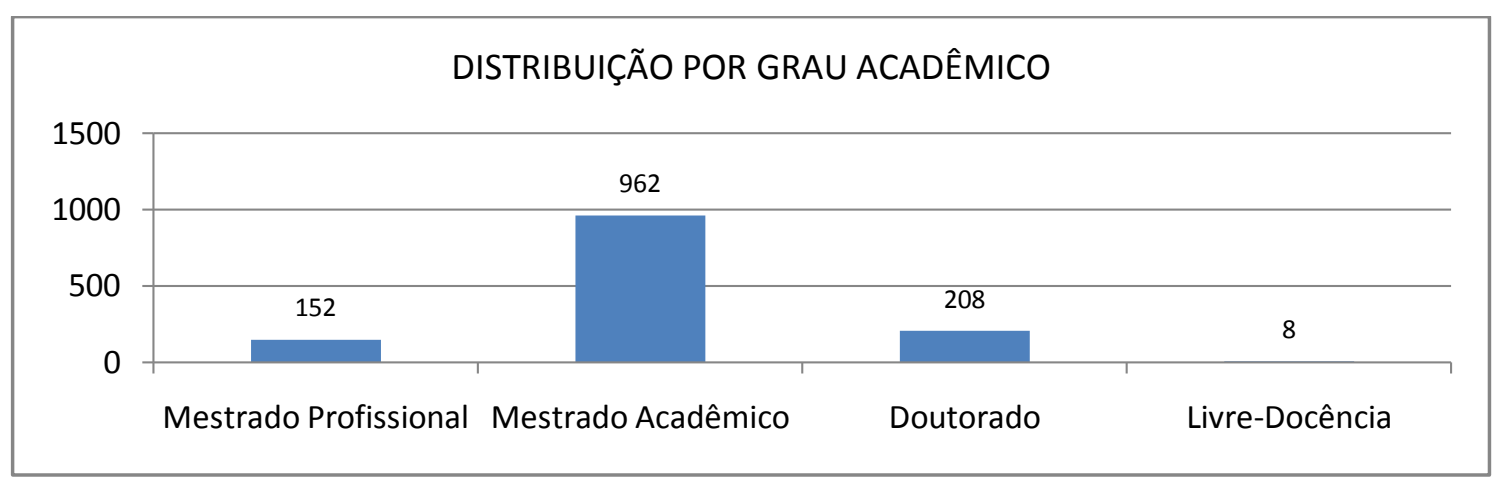

Gráfico 3.7: Distribuição da produção por Grau Acadêmico em valores absolutos

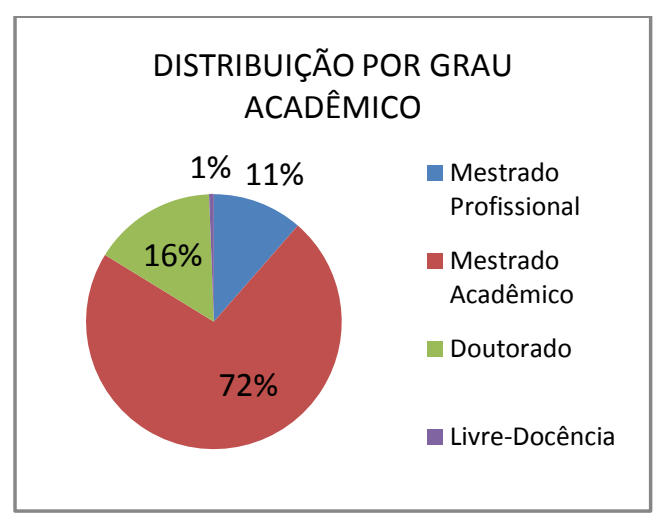

Gráfico 3.8: Distribuição percentual da produção por Grau Acadêmico

Destaca-se nesses dados a predominância dos Mestrados no conjunto geral e a porcentagem de Mestrados Profissionais (pouco mais que 10\%), considerando-se sua recente introdução na área (início da década de 2000). 
O comportamento dessa distribuição ao longo do tempo pode nos acrescentar algumas informações, sinalizar tendências e melhor caracterizar nosso perfil. Também colocam questões, tais como: os mestrados sempre predominaram com percentuais como esse da distribuição geral? Mestrados e doutorados vêm crescendo a taxas semelhantes? Doutorados aumentam a taxas mais elevadas ao longo do tempo, ou seja, o crescimento de mestrados leva necessariamente ao de doutorados? Há períodos de retração de um ou outro título acadêmico?

O número reduzido de teses de livre-docência se justifica especialmente por se tratar de título concedido apenas em universidades paulistas e, por esse motivo, não é relevante nessa análise.

Os gráficos a seguir mostram de que modo vem evoluindo a produção do ponto de vista desse indicador. No primeiro deles, temos um panorama geral da distribuição dos quatro títulos no período 1972-2009.

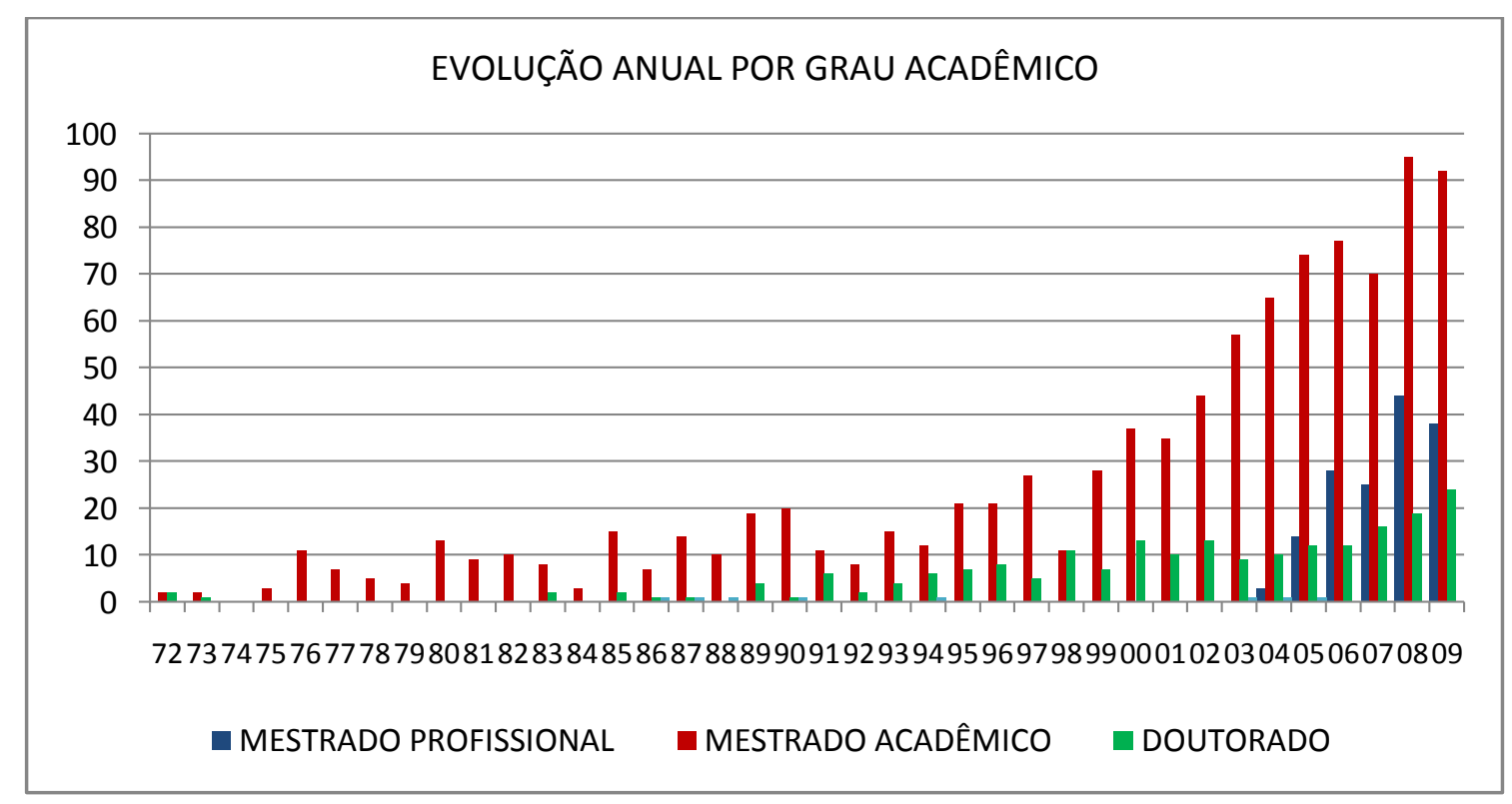

Gráfico 3.9: Evolução anual do número de teses por Grau Acadêmico

Uma visualização melhor desses dados pode ser dada pela subdivisão em períodos de cinco anos, representada a seguir. 


\begin{tabular}{|c|c|c|c|c|c|c|c|c|c|c|c|}
\hline & RíODO & Mes & rado & Dout & ado & $\begin{array}{l}\text { Lis } \\
\text { Doc }\end{array}$ & & Profis & onal & & \\
\hline P1 & $1975-1979$ & 30 & 100 & 0 & 0 & 0 & 0 & 0 & 0 & 30 & 100 \\
\hline P2 & $1980-1984$ & 43 & 96 & 2 & 4 & 0 & 0 & 0 & 0 & 45 & 100 \\
\hline P3 & $1985-1989$ & 65 & 86 & 8 & 10 & 3 & 4 & 0 & 0 & 76 & 100 \\
\hline P4 & $1990-1994$ & 66 & 76 & 19 & 22 & 2 & 2 & 0 & 0 & 87 & 100 \\
\hline P5 & 1995-1999 & 108 & 74 & 38 & 26 & 0 & 0 & 0 & 0 & 146 & 100 \\
\hline P6 & $2000-2004$ & 238 & 80 & 55 & 18 & 2 & 1 & 3 & 1 & 298 & 100 \\
\hline P7 & 2005-2009 & 408 & 65 & 83 & 12 & 1 & 0,2 & 149 & 23 & 641 & 100 \\
\hline & TOTAL & 958 & 73,0 & 205 & 15,0 & 8 & 0,6 & 152 & 11,4 & 1323 & 100 \\
\hline
\end{tabular}

Tabela 3.6: Evolução do número de teses por Grau Acadêmico em períodos de cinco anos

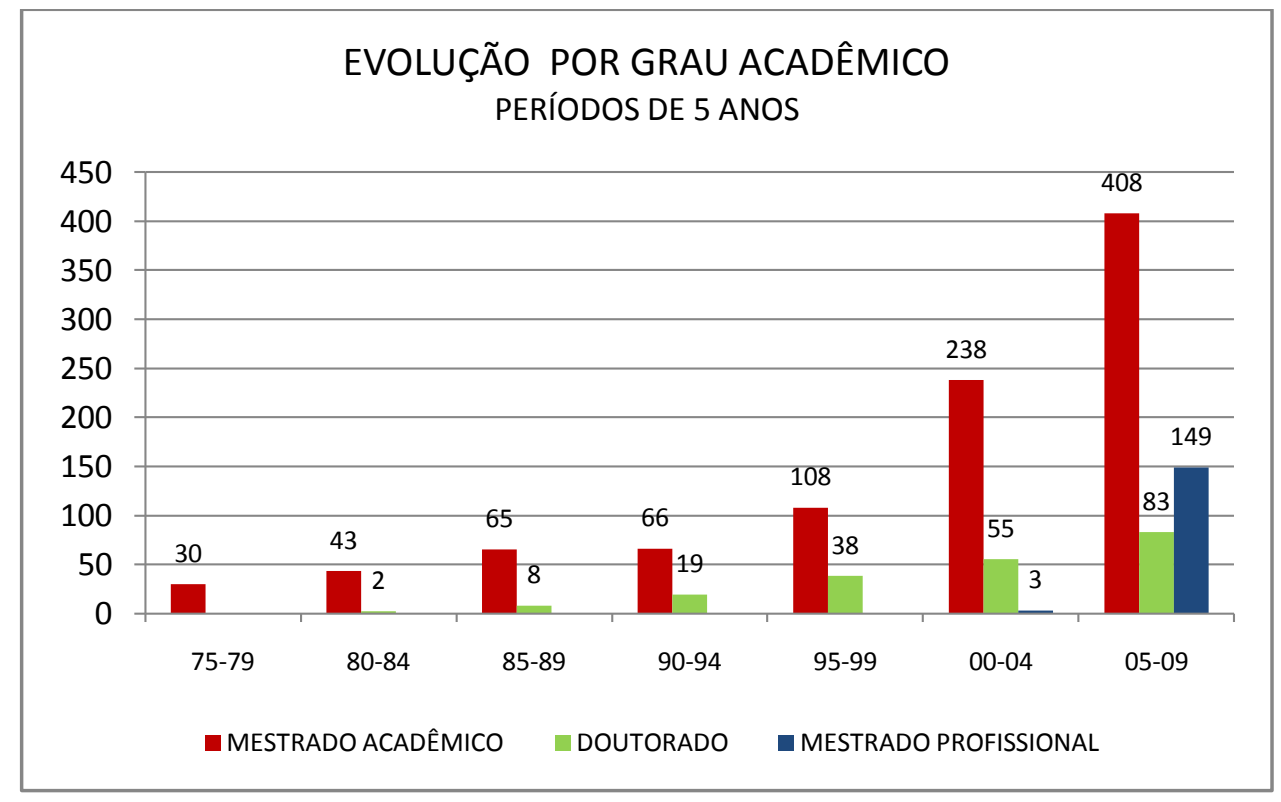

Gráfico 3.10(a): Evolução do número de teses por Grau Acadêmico em períodos de cinco anos 


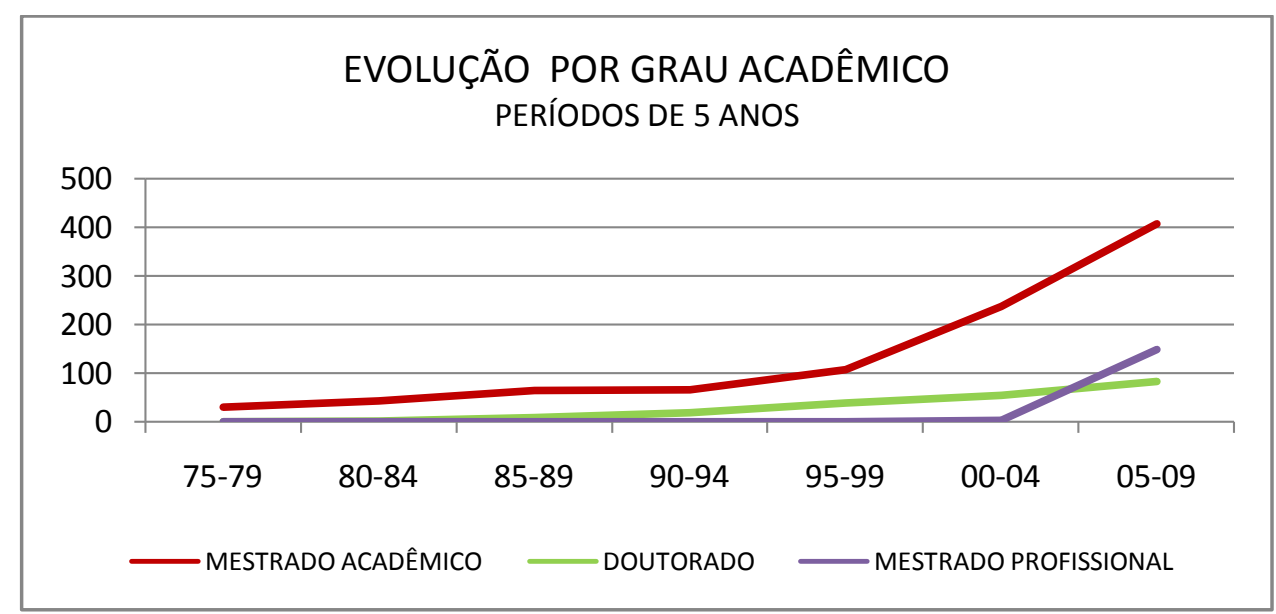

Gráfico 3.10 (b): Evolução do número de teses por Grau Acadêmico em períodos de cinco anos

As taxas de crescimento dos Mestrados e Doutorados entre períodos de cinco anos consecutivos, representadas na Tabela 3.7 (valores aproximados), indicam que até o início dos anos 2000 as teses de doutorado cresceram muito mais que as dissertações de mestrado. Nos dois quinquênios finais do período 2000-2009, essa relação se inverte, os mestrados tiveram taxas de crescimento mais elevadas que os doutorados.

\begin{tabular}{|l|l|l|l|l|l|l|}
\hline & P1-P2 & P2-P3 & P3-P4 & P4-P5 & P5-P6 & P6-P7 \\
\hline Mestrado & $45 \%$ & $50 \%$ & $2 \%$ & $65 \%$ & $120 \%$ & $\mathbf{7 0 \%}$ \\
\hline Doutorado & - & $\mathbf{3 0 0 \%}$ & $\mathbf{1 4 0 \%}$ & $\mathbf{1 0 0 \%}$ & $\mathbf{4 5 \%}$ & $\mathbf{5 0 \%}$ \\
\hline Profissional & - & - & - & - & - & $\mathbf{5 0 0 0 \%}$ \\
\hline
\end{tabular}

Tabela 3.7: Taxas de crescimento por grau acadêmico em quinquênios consecutivos

Observamos, a partir desses dados que:

A participação de mestrados ao longo do tempo tem um ligeiro declínio a partir de meados dos anos oitenta. Até início da década de 1990 representam em torno de 80 a $100 \%$ do total; de meados da década de 1990 a meados da década de 2000 passam para 75 a $80 \%$ e ao final dessa última década, cerca de $60 \%$. Naturalmente, nos períodos iniciais tinha elevada contribuição, uma vez que estávamos no começo da institucionalização da área, com os primeiros programas de pós-graduação.

A participação de doutorados no conjunto total cresce até final dos anos noventa e, a partir de 2000 passa a decrescer. Relativamente aos mestrados, também tiveram taxas de aumento muito superiores até o início de 2000, com inversão desse movimento desde então. Ou seja, até a virada de século a produção de teses acompanhou o crescimento da área o que não ocorre mais recentemente.

Ainda que pudéssemos supor que o título de mestre teria um caráter terminal, esse dado indicaria que o crescimento da área foi acompanhado, até então, por uma 
evolução na carreira acadêmica. O deslocamento, a partir de 2000, de maior crescimento relativo dos mestrados poderia ser um reflexo da própria evolução da área, com novos programas de pós-graduação. Mas pode indicar também um represamento nessa evolução, com um grande contingente de mestres que não prosseguiram na carreira. Fato que seria reflexo de uma redução de fomento à área e de bolsas ofertadas, acompanhada de uma queda da demanda, dada pela absorção de pós-graduados em instituições de ensino superior e redução dos concursos para docentes com título de doutor. Esse conjunto de fatores se aplica, em particular, nas universidades públicas federais nos anos 90 e início de 2000.

Não podemos deixar de relembrar que há um deslocamento no tempo entre o ingresso no mestrado e no doutorado e as respectivas defesas de dissertações e teses. Período que pode variar e que nos anos mais recentes vem caindo. De todo modo, esse deslocamento indica, por exemplo, que essa inversão de movimento na evolução de mestrados e doutorados a partir do início da década de 2000 reporta-se a ingressos nos correspondentes cursos em meados dos anos 90 . O que reitera a hipótese acerca desses dados, como reflexo do represamento ocorrido nas universidades públicas, com redução com redução de postos para novos formandos.

Com isso posto, não podemos afirmar que essa involução no crescimento de doutores caracterize uma tendência, mas um fato localizado nesse período. A partir de meados de 2000, com a criação de novos cursos e abertura de concursos, sobretudo nas universidades federais, é possível que haja uma retomada no aumento de doutorados, dado que ainda não se reflete em nossos dados, uma vez que se limitam até 2009.

Outra hipótese não de todo descartável é a grande formação de mestres nos anos mais recentes que, de fato, têm esse título como terminal, sem perspectivas ou vocação de prosseguir na carreira acadêmica.

Também chamamos atenção ao fato de que se comparamos as participações dos mestrados acadêmicos e doutorados sem a inclusão dos mestrados profissionais, o declínio do percentual de doutorados em relação ao de mestrados no último período é menor, como mostramos nos gráficos 3.11(a) e 3.11(b) 

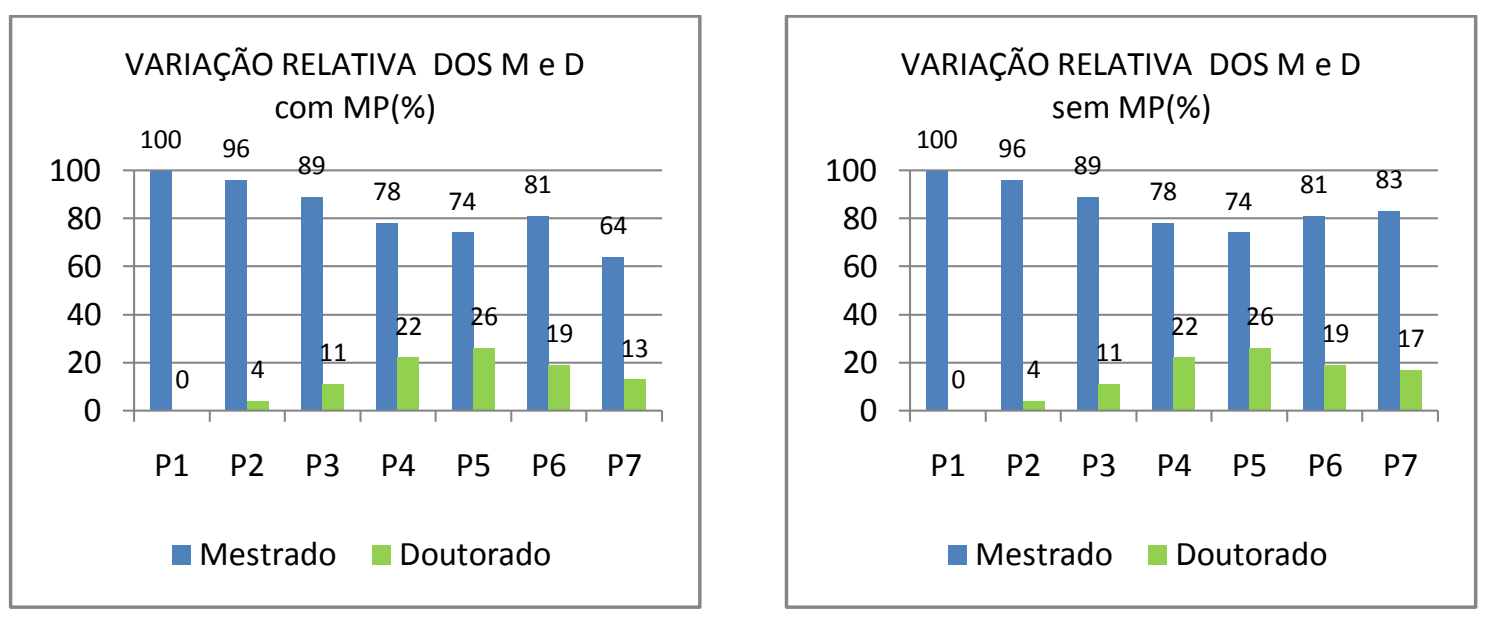

Gráficos 3.11: Comparação dos percentuais de mestrados e de doutorados no conjunto da produção (a) incluídos os mestrados profissionais e (b) sem a inclusão dos mestrados profissionais

Outro importante resultado é dado justamente pela entrada dos mestrados profissionais a partir de meados da década de 2000, que em pouquíssimo tempo após sua implantação no país atingiu $10 \%$ do conjunto de pós-graduados, e cerca de $20 \%$ do total na segunda metade dessa década. Essa é uma nova tendência que se acrescenta ao perfil da área, impulsionada pelas diretrizes atuais dos órgãos financiadores, que em 1998 regulamentam os mestrados profissionais (Portaria CAPES 080/98) e passam a incentivá-los fortemente na área de pesquisa em Ensino de Ciências. Dessa questão trataremos no Capítulo 7.

\section{$\underline{\text { Intervalos de Tempo Médio ente Mestrado e Doutorado }}$}

Ainda no que diz respeito a esse parâmetro, buscamos verificar outro dado que pode acrescentar um pouco mais ao nosso perfil:

- Quantos dos pós-graduados na área obtiveram o título de Mestre e de Doutor?

- Dentre esses, como se distribui o intervalo de tempo entre a obtenção de um título e outro?

Do total de 1330 dissertações e teses de nosso panorama geral, 135 autores (cerca de $10 \%$ ) têm ambos os títulos na área, no país. Supõe-se que os demais $90 \%$, distribuemse em casos diversos, tais como a obtenção de um dos títulos em outra área (incluindo Ensino de Ciências e Educação) ou na mesma área, fora do país. Há, ainda, os mestres que estariam realizando o doutorado sem tê-lo concluído em 2009. Mas a hipótese mais razoável que podemos fazer é a de que a maior parte de nosso conjunto representa um grande contingente de mestres que não prosseguiram na carreira acadêmica, dada as distribuições já apresentadas dos números de mestrados e doutorados.

O gráfico a seguir mostra a distribuição do tempo entre a conclusão do mestrado e a do doutorado desses autores: 


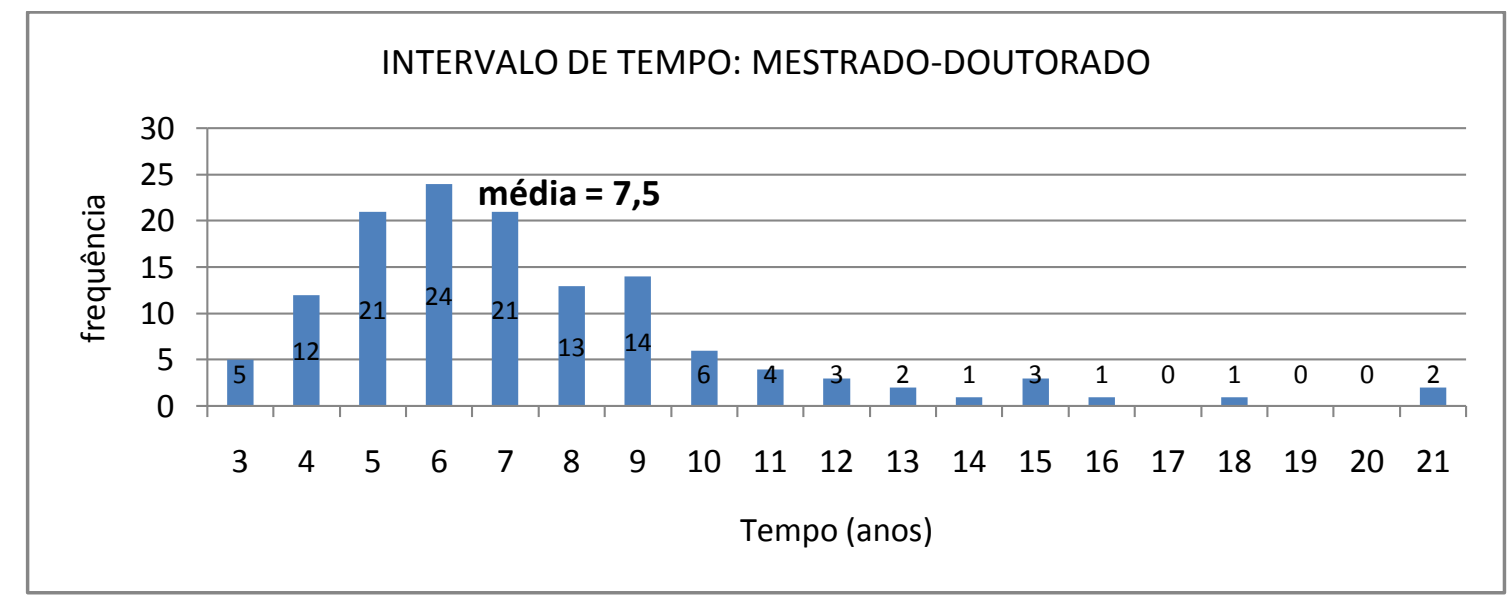

Gráfico 3.12: Intervalo de tempo entre obtenção do título de Mestre e de Doutor (135 autores)

O valor médio desses intervalos de tempo é cerca de 8 anos. No entanto, por se tratar de uma média geral, pouco revela sobre seu comportamento ao longo do tempo. Verificamos, então, de que modo essa média se altera, associando o referido intervalo de tempo ao período em que foi defendida a dissertação de mestrado, o que resultou no gráfico a seguir.

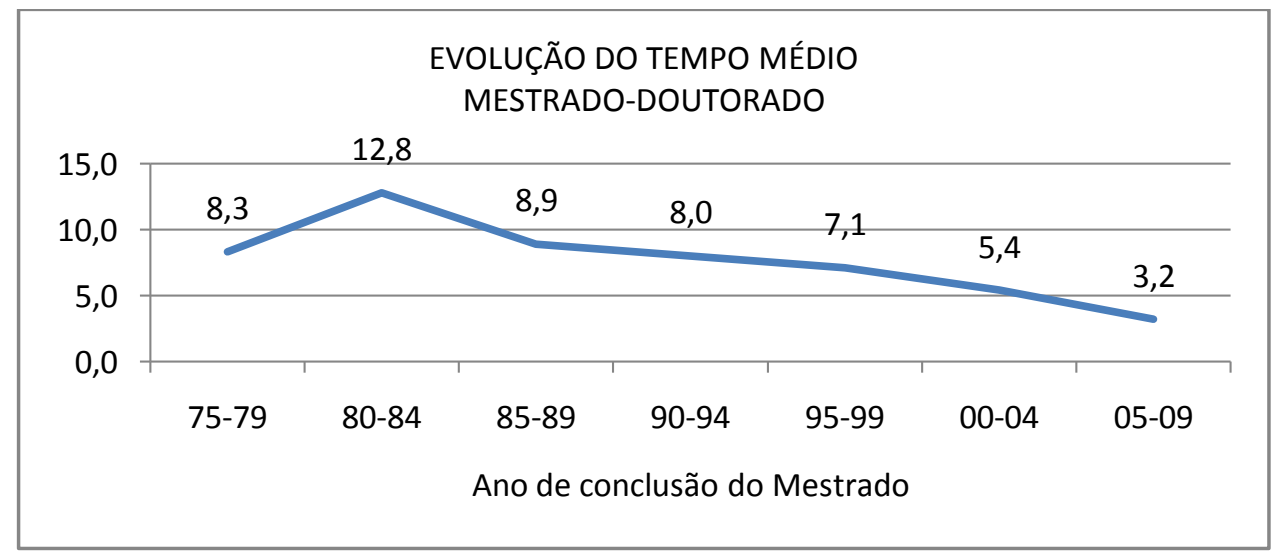

Gráfico 3.13: Evolução do tempo médio entre o título de mestre e de doutor

Uma vez que os nossos dados referem-se ao ano de conclusão do mestrado e ao do doutorado, não se pode inferir muito a respeito desses valores, ou seja, sobre o tempo, de fato, em que o doutorado foi desenvolvido. Não é possível saber, por exemplo, quantos dos casos correspondem a indivíduos que iniciaram o doutorado imediatamente após o mestrado (a menos daqueles em que o tempo é inferior a 4 anos) ou qual foi o tempo entre o término de um e início do outro. ${ }^{12}$ No caso do último período, entre 2005 e 2009, a média obtida certamente é inferior à real, uma vez que

\footnotetext{
${ }^{12}$ Se supusermos o tempo de realização do doutorado de 4,5 $\pm 0,5$ anos, e a média de 7,5 $\pm 2,5$ anos entre o final das duas titulações, estimativas levam, grosso modo, a um valor entre 0 e 3 anos no intervalo de tempo correspondente à interrupção entre o fim do mestrado e início do doutorado.
} 
muitos dos que obtiveram título de mestre nesse período e ingressaram no doutorado, ainda não concluíram esse grau.

De todo modo, é interessante observar que o intervalo de tempo entre as obtenções desses dois títulos vem caindo ao longo dos anos. O gráfico 3.13 mostra que se tomamos períodos de quatro anos, esse decréscimo é sistemático a partir de meados da década de 1980. Do que se pode concluir: ou vem diminuindo o intervalo de tempo em que o doutorado é desenvolvido ou o intervalo entre o fim do mestrado e início do doutorado. É razoável supor que ambos os casos ocorram, já que vem se reduzindo o prazo exigido para a obtenção do título de doutor (e de mestre) na maioria dos programas, além do fato de que algumas instituições que até certo momento tinham apenas programas de mestrado passaram a ter também os de doutorado, favorecendo a continuidade mais imediata de um para outro grau.

Uma questão que fica é o cruzamento entre esse resultado e o obtido acima, acerca da queda no crescimento de doutorados. No entanto, não nos arriscamos a muitas outras hipóteses e estimativas, pois essas dependem de dados e fatores a que não temos acesso, especialmente se considerarmos que estamos contando aqui apenas os casos daqueles que fizeram o mestrado e o doutorado nessa área. Também é questão a ser destacada essa parcela obtida, de (apenas) $10 \%$ do conjunto de mestres que obtiveram o título de doutor.

Em síntese, destacamos os dados mais importantes quanto à evolução da área do ponto de vista do grau acadêmico:

- Tanto o número de mestrados quanto o de doutorados vem crescendo sistematicamente em valores absolutos.

- A participação relativa dos mestrados cai ligeiramente nos primeiros períodos com a inclusão e aumento dos doutorados, situação que se inverte a partir de meados da década de 1990, quando o percentual de doutorados passa a decrescer.

- Em termos de taxas de crescimento entre qüinqüênios consecutivos, nos primeiros períodos, até meados de 1990, as de doutorado são substancialmente mais elevadas que as de mestrados. A partir de então, até meados de 2000, o crescimento de doutorados é refreado.

- Mestrados Profissionais emergem na última década, têm participação e crescimento elevados nesse período, alterando o panorama geral dessa evolução.

- Vem se reduzindo o intervalo de tempo entre a obtenção do grau de mestre e de doutorado. 


\subsubsection{Evolução institucional}

Mesmo antes de contabilizar, poderíamos supor que um fator importante a contribuir para a evolução da produção acadêmica na área seria o aumento do número de instituições ou de programas de pós-graduação que abarca. Para analisar se e de que modo isso ocorre, classificamos e obtivemos a distribuição desses trabalhos segundo os seguintes parâmetros:

- Instituição propriamente (Universidade)

- Área ou Programa (de acordo com a classificação CAPES)

- Número de orientadores

- Dependência Administrativa das Instituições

\section{Evolução da participação institucional}

No que se refere à distribuição dos trabalhos por Instituição, contabilizamos no conjunto geral ao longo de todo o período de 1972-2009, um total de 78 instituições no país ${ }^{13}$. Para cada uma, relacionamos o número de trabalhos e o tempo (anos) em que teve produção nesse período total de 38 anos (1972-2009), de modo a identificar em quais instituições essa produção tem se desenvolvido mais sistematicamente ou mais pontualmente e como tem se dado esse crescimento ao longo do tempo. Os resultados obtidos estão sistematizados a seguir.

- Total de Instituições no período 1972-2009: 78 (No Anexo 3.2 apresentamos uma relação completa dessas Instituições)

- Distribuição ao longo do tempo

\begin{tabular}{|l|l|l|l|l|l|l|l|l|l|l|l|l|l|l|l|l|l|l|l|}
\hline ANO & 72 & 73 & 74 & 75 & 76 & 77 & 78 & 79 & 80 & 81 & 82 & 83 & 84 & 85 & 86 & 87 & 88 & 89 & 90 \\
\hline $\begin{array}{l}\text { No. } \\
\text { Inst. }\end{array}$ & 3 & 3 & 0 & 2 & 6 & 5 & 3 & 2 & 4 & 3 & 5 & 3 & 3 & 5 & 4 & 7 & 5 & 6 & 9 \\
\hline
\end{tabular}

\begin{tabular}{|l|l|l|l|l|l|l|l|l|l|l|l|l|l|l|l|l|l|l|l|}
\hline ANO & 91 & 92 & 93 & 94 & 95 & 96 & 97 & 98 & 99 & 00 & 01 & 02 & 03 & 04 & 05 & 06 & 07 & 08 & 09 \\
\hline $\begin{array}{l}\text { No. } \\
\text { Inst. }\end{array}$ & 6 & 7 & 7 & 7 & 10 & 13 & 12 & 7 & 16 & 18 & 17 & 20 & 21 & 20 & 22 & 36 & 34 & 40 & 43 \\
\hline
\end{tabular}

Tabela 3.8: Evolução do número de Instituições com dissertações e teses na área

\footnotetext{
${ }^{13}$ Nesse caso, estamos considerando Instituição a Universidade ou centro produtor (Centros Universitários, CEFETs, IFETs) sem distinção de Programa ou Curso de Pós-Graduação, de Institutos e Unidades de uma mesma Universidade.
} 


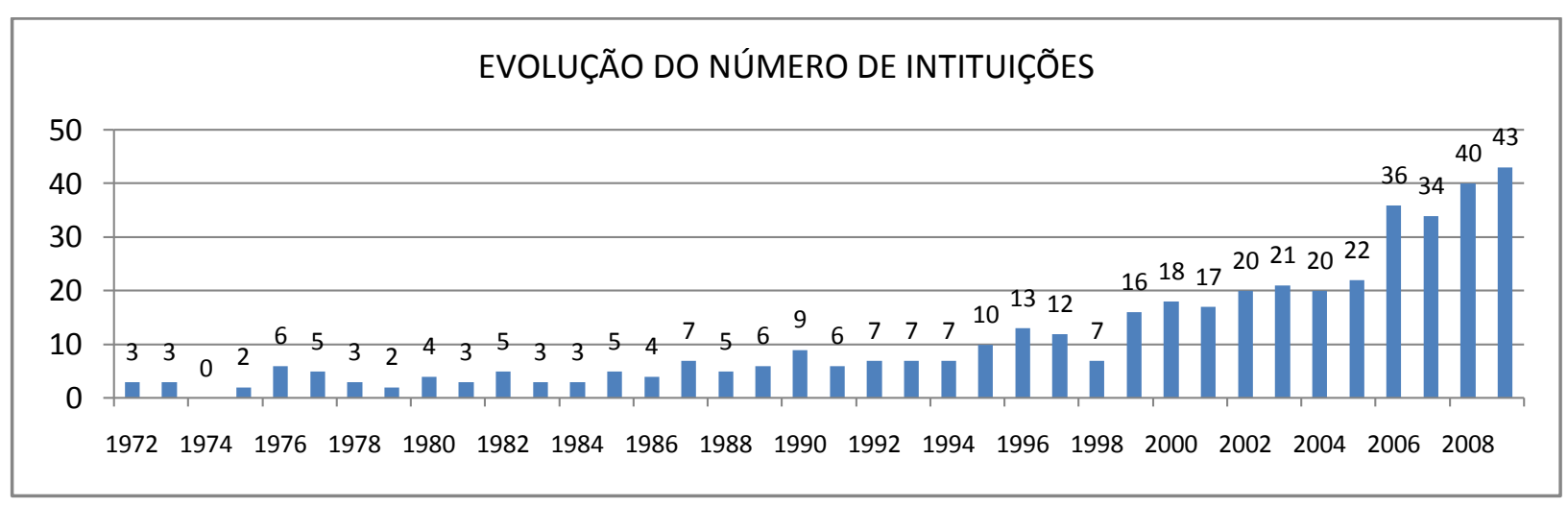

Gráfico 3.14: Evolução anual do número de instituições com teses na área

O crescimento de instituições com produção de teses na área é notável: de cerca de algumas poucas unidades nas primeiras duas décadas, para algo da ordem de duas a quatro dezenas na década de 2000. Especialmente na segunda metade dessa primeira década de 2000 esse aumento é ainda mais acentuado.

Esses números mostram tendências de evolução em quatro períodos: o primeiro que se estende desde o início dos anos 70 até final dos 80 (média de quatro instituições); o segundo correspondendo aos anos 90 (entre 1990 e 1998, com oito instituições em média); o terceiro segue do final dos anos 90 a meados de 2000 (média de 20 instituições) e finalmente o último, correspondendo à segunda metade da década de 2000 (média de quase 40 instituições).

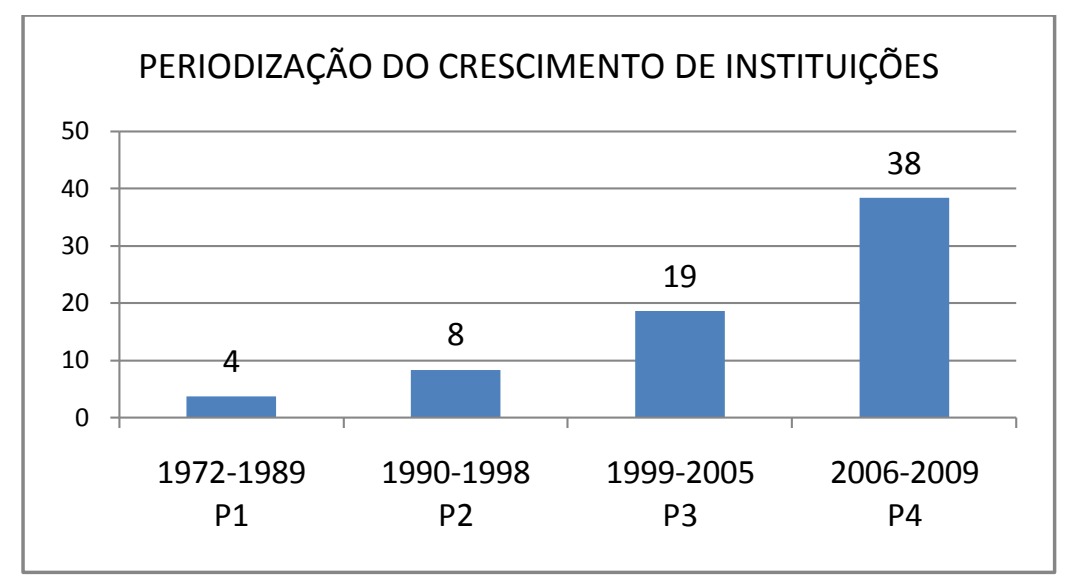

Gráfico 3.15: Distribuição do número médio de Instituições segundo periodização típica dessa evolução

Outra periodização desse crescimento está representada no gráfico 3.16 por meio da média do número instituições participantes em períodos de cinco anos. 


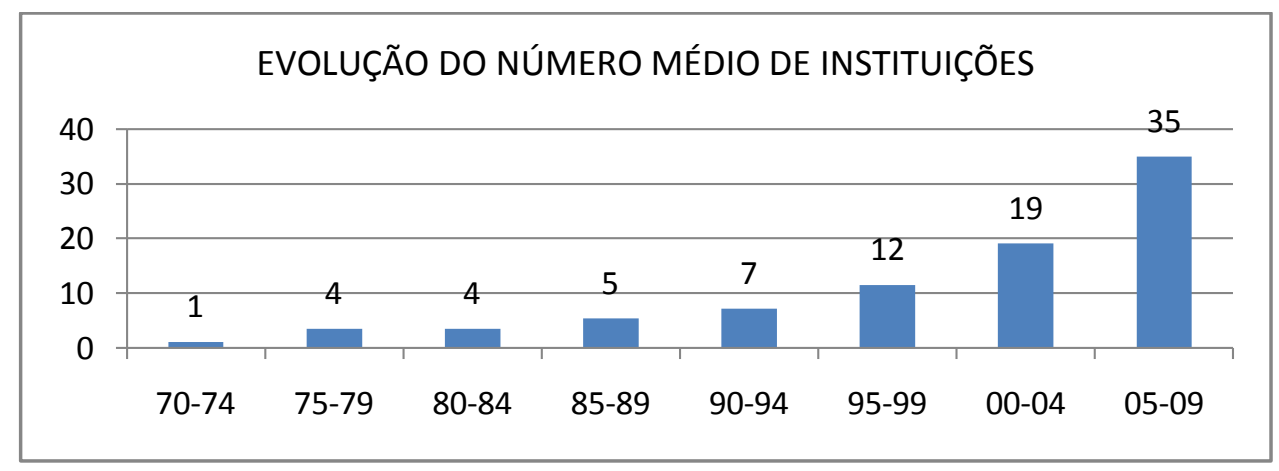

Gráfico 3.16: Evolução da média quinquenal do número de instituições

Seja representado por uma ou outra periodização, o crescimento da participação institucional é inequívoco. Contudo a questão que se coloca é se de fato representa uma maior distribuição da produção em instituições diversas, em todo o país e ao longo desses anos todos. Em outras palavras, queremos responder: "Todo mundo cresce junto?"

Já de início, com esses dados, verificamos que o crescimento não é ordenado ou equitativo. Vejamos a sistematização apresentada no Gráfico 3.15. Ao longo desses quatro períodos há uma concentração cada vez maior do número de instituições em um tempo cada vez menos. O primeiro se estende por 18 anos, com média de 4 instituiçoes; o segundo por 9 anos, 9 instituições; o terceiro por sete anos, com 130 instituições (!) e o quarto, apenas 4 anos com 153 instituições (!!!).

Na direção de melhor explicitar esse resultado, procuramos identificar de que modo esse aumento vem se dando, quer do ponto de vista da produção individual de cada uma dessas instituições, quer pelo tempo em que vêm produzindo dentro desse período de quase quatro décadas.

\section{Produção por Instituição}

O resultado dessa primeira classificação, do número de trabalhos produzidos por instituição reforça e revela como se dá a concentração da produção. (Gráfico 3.17) 


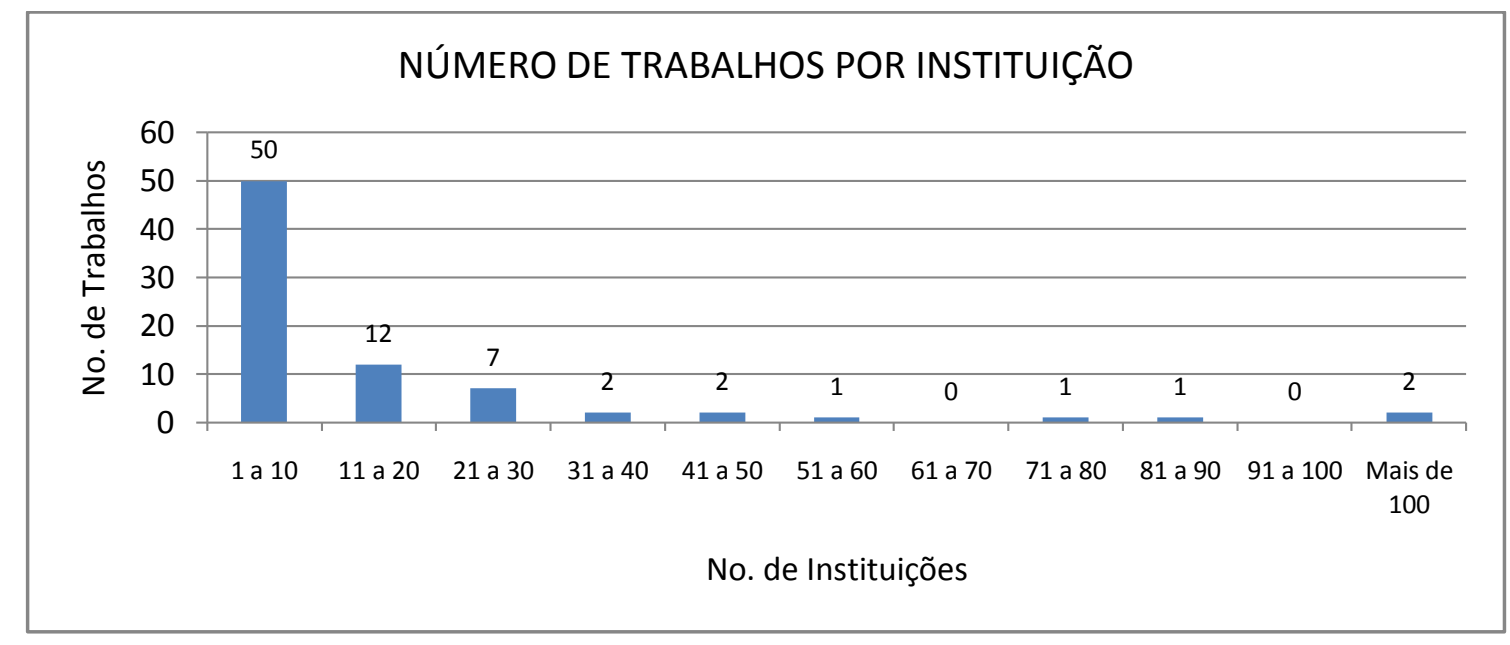

Gráfico 3.17: Relação da produção de dissertações e teses por Instituição
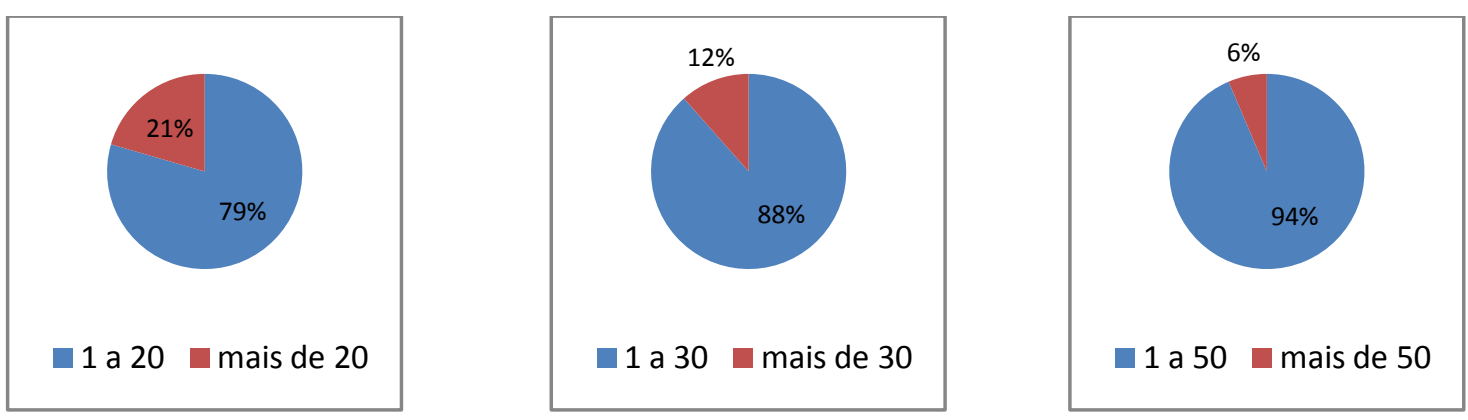

Gráficos 3.18: Distribuições de trabalhos por número de instituições

Observa-se que desse total de 78 instituições:

- 50 têm uma produção inferior a dez trabalhos (cerca de $65 \%$ )

- 62 têm produção inferior a 20 trabalhos (cerca de 80\%)

- 69 têm produção inferior a 30 trabalhos (cerca de 90\%)

- 5 têm produção maior que 50 trabalhos (6\%)

- 25 têm um único trabalho $(30 \%)$

Enfim, qualquer que seja a conta, a parcela tomada, o que se evidencia é uma enorme concentração de trabalhos em um número pequeno de centros produtores.

Dentre as Instituições com maior volume de trabalhos, as quatro que se destacam com mais de 50 teses cada são: USP (354; 27\%), UFRGS (109; 8\%), UFSC (80;6\%) e UNICAMP (71; 5\%): quatro universidades públicas do eixo sul-sudeste, duas federais, duas estaduais. Apenas a primeira delas concentra quase $30 \%$ do total; as quatro juntas, $46 \%$. Ou seja, quase metade da produção está concentrada em apenas 4 das 78 Instituições. 
Entre as dez instituições com maior número de dissertações e teses, estão:

\begin{tabular}{|c|c|c|c|c|c|}
\hline INSTITUIÇÃO & DISS & $\begin{array}{l}\text { No. DE } \\
\text { AÇÕES } \\
\text { E TESES }\end{array}$ & INSTITUIÇÃO & DIS & $\begin{array}{l}\text { No. DE } \\
\text { TAÇÕES } \\
\text { E TESES }\end{array}$ \\
\hline USP $^{14}$ & 354 & $27 \%$ & UFMG & 48 & $4 \%$ \\
\hline UFRGS & 109 & $8 \%$ & UFRJ & 44 & $3 \%$ \\
\hline UFSC & 80 & $6 \%$ & UnB & 32 & $2 \%$ \\
\hline UNICAMP & 71 & $5 \%$ & PUC-RS & 31 & $2 \%$ \\
\hline UNESP-Bauru & 57 & $4 \%$ & UFBA & 29 & $2 \%$ \\
\hline
\end{tabular}

Tabela 3.9: Dez instituições com maior produção de dissertações e teses

\section{Estabilidade da Instituição}

Outra faceta dessa distribuição pode ser observada pelo tempo (número de anos) em que a instituição esteve presente nesse período de 38 anos. A sistematização desses dados está apresentada na tabela e no gráfico a seguir, em que foram somados as instituições com produção entre 1 e mais de 20 anos.

\begin{tabular}{|c|c|c|}
\hline $\begin{array}{r}\text { TEMPO COM } \\
\text { PRODUÇÃO (anos) }\end{array}$ & $\begin{array}{r}\text { No. de } \\
\text { INSTITUIÇÕES }\end{array}$ & $\%$ \\
\hline 1 a 5 & 54 & $70 \%$ \\
\hline 6 a 10 & 12 & $15 \%$ \\
\hline 11 a 15 & 5 & $6 \%$ \\
\hline 16 a 20 & 4 & $5 \%$ \\
\hline 21 a 25 & 1 & \\
\hline 26 a 30 & 1 & $4 \%$ \\
\hline 31 a 35 & 1 & \\
\hline TOTAL & 78 & $100 \%$ \\
\hline
\end{tabular}

Tabela 3.10: Tempo (anos) em que a Instituição tem produção

\footnotetext{
${ }^{14}$ Importante lembrar que na produção dessas Instituições estão sendo contabilizados programas ou unidades diversas. No caso da USP, ainda que considerássemos os programas separadamente, o resultado não seria significativamente alterado. Os dois programas com maior participação na área - Ensino de Ciências (Interunidades) e Educação (FE) - constituem $94 \%$ da produção nessa Universidade.
} 


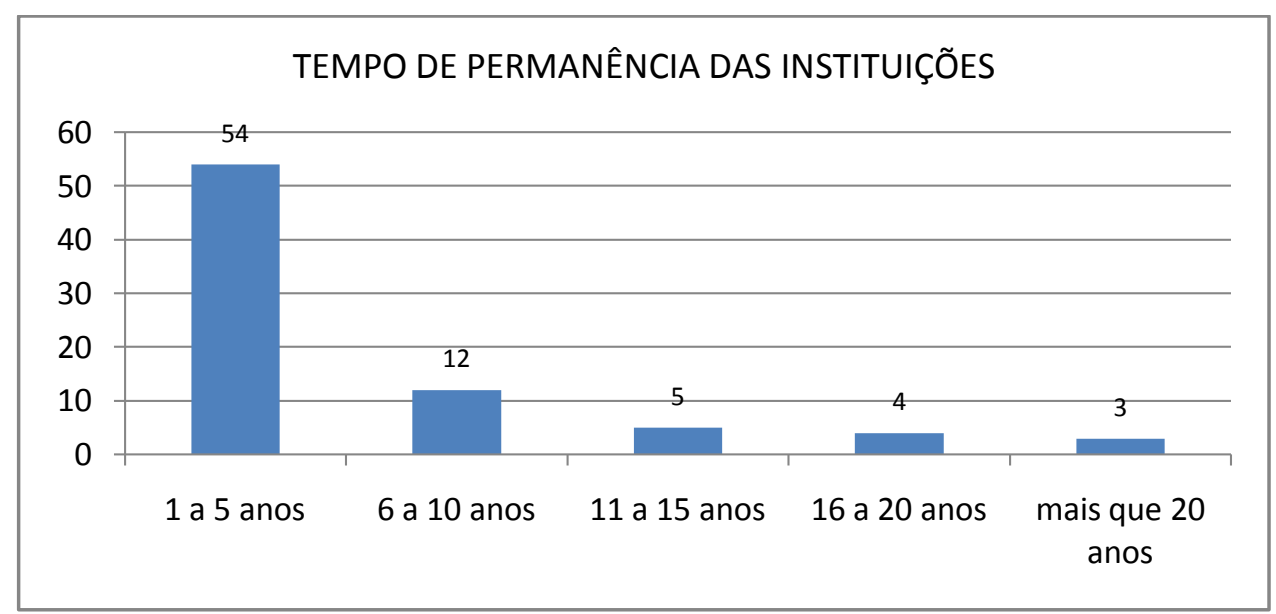

Gráfico 3.19: Tempo (anos) em que a Instituição tem produção

Novamente, chegamos a um resultado que reforça a dispersão de um grande número de instituições com produções isoladas ou pontuais, nesse caso, ao longo do tempo. No período completo de 38 anos (1972-2009),

- $70 \%$ das insitituições tiveram produções em menos de 5 anos (não necessariamente consecutivos)

- $15 \%$ estiveram presentes em mais de dez anos

- Somente $3(4 \%)$ estiveram presentes em mais de 20 anos, correspondente a cerca de metade desse período.

Entre as 15 instituições com produção em um tempo maior ou igual a 10 anos estão:

\begin{tabular}{|l|l|l|l|l|}
\hline INSTITUIÇÃO & (anos) & & INSTITUIÇÃO & (anos) \\
\cline { 1 - 1 } USP & 34 & PUC-RS & 12 \\
\hline UFRGS & 29 & UnB & 11 \\
\hline UNICAMP & 25 & PUC-SP & 11 \\
\hline UFRJ & 19 & UFSCar & 11 \\
\hline UFSC & 18 & UFBA & 10 \\
\hline UFF & 17 & UFMT & 10 \\
\hline UFSM & 16 & UNESP-Bauru & 10 \\
\hline UFMG & 12 & & \\
\cline { 1 - 1 } & & \\
\hline
\end{tabular}

Tabela 3.11: Instituições com produção em tempo igual ou maior a dez anos

De um modo geral, com poucas variações, há uma intersecção entre esses dois conjuntos: instituições com maior volume de produção e com presença mais sistemática. Parece lógico e previsível, mas tal correspondência não é necessária. Há casos, ainda que não muitos, de grande produção concentrada em poucos anos ou, inversamente, de pequena produção espalhada em longo período. Por exemplo, a UNESP-Bauru, entre as cinco unidades com maior número de trabalhos (57), teve essa produção desenvolvida em dez anos, ou seja, de modo relativamente mais 
concentrado (média de 5,7 por ano). A situação inversa é mais rara (grande permanência com volume pequeno), tendo como um exemplo a PUC-RJ, com 7 trabalhos produzidos em 7 anos (média de 1 por ano).

Tomando-se o período mais recente (primeira década de 2000), encontramos 24 instituições presentes em cinco ou mais desses dez anos.

\begin{tabular}{|c|c|c|c|c|c|}
\hline INSTITUIÇÃO & $\begin{array}{l}\text { PERMANÊNCIA } \\
\text { 1a. DÉCADA DE } \\
2000 \text { (anos) }\end{array}$ & INSTITUIÇÃO & $\begin{array}{l}\text { PERMANÊNCIA } \\
\text { 1a. DÉCADA DE } \\
2000 \text { (anos) }\end{array}$ & INSTITUIÇÃO & $\begin{array}{l}\text { PERMANÊNCIA } \\
\text { 1a. DÉCADA DE } \\
2000 \text { (anos) }\end{array}$ \\
\hline USP & 10 & $\begin{array}{l}\text { UNESP- } \\
\text { Bauru }\end{array}$ & 9 & UFSM & 7 \\
\hline UFSC & 10 & PUC-RS & 7 & UnB & 6 \\
\hline UNICAMP & 10 & UFPR & 7 & ULBRA & 6 \\
\hline UFRJ & 10 & UFRN & 7 & UFF & 6 \\
\hline UFMG & 9 & UFSCar & 7 & UFPA & 5 \\
\hline UFRGS & 9 & PUC-SP & 7 & UFU & 5 \\
\hline UFES & 9 & UEL & 7 & UFMT & 5 \\
\hline UFRPE & 9 & UFBA & 7 & UNIJUI & 5 \\
\hline
\end{tabular}

Tabela 3.12: Instituições com produção em mais de 5 anos na primeira década de 2000

Entre essas 24 instituições com produção sistemática nos últimos anos, em duas predominam os mestrados profissionais (UFRN e UnB); em onze (UNESP-Bauru, UFES, UFRPE, UFPR, UEL, UFBA, PUC-SP, ULBRA, UFPA e UFU, UNIJUI) trata-se de nova produção com mestrados acadêmicos, ou seja, de inserção na área (algumas delas já com produção em anos anteriores, mas muito isoladamente); as demais onze (em negrito na Tabela 3.12) são as de maior permanência ao longo de um período maior (com produção anterior a 2000). Portanto, cerca de metade desses centros produtores são "ingressantes" na área nessa década.

Esses dados indicam que uma característica importante da expansão da área é a crescente dispersão ou pulverização dos centros produtores ao longo dos anos, que ocorre par e passo com a concentração da produção em um número muito reduzido de instituições. Trata-se de um dado que se articula à própria dinâmica de evolução da área, com grande expansão nacional especialmente após a virada do século. Particularmente nesses anos mais recentes uma parcela considerável da produção (50\%) se dá em instituições ou programas novos, o que em grande medida se deve à criação, em 2000, da área de Pesquisa em Ensino de Ciências na CAPES, ou seja, a uma política de incentivo à pós-graduação nesse campo de pesquisa.

Outro aspecto que buscamos analisar é como se dá a particular evolução no tempo da produção nas instituições com maior volume de trabalhos e permanência mais sistemática na área. Para investigar esse dado, tomamos os dois casos mais típicos com esse perfil: USP e UFRGS. 
Dados referentes às duas Instituições de maior produção e maior permanência: USP e $\underline{\text { UFRGS }}$

Nos gráficos 3.20 a 3.22 apresentamos a evolução dessas duas instituições com maior participação no conjunto geral, seja no número de dissertações e teses, seja no tempo de permanência dessa produção, comparativamente à evolução geral.

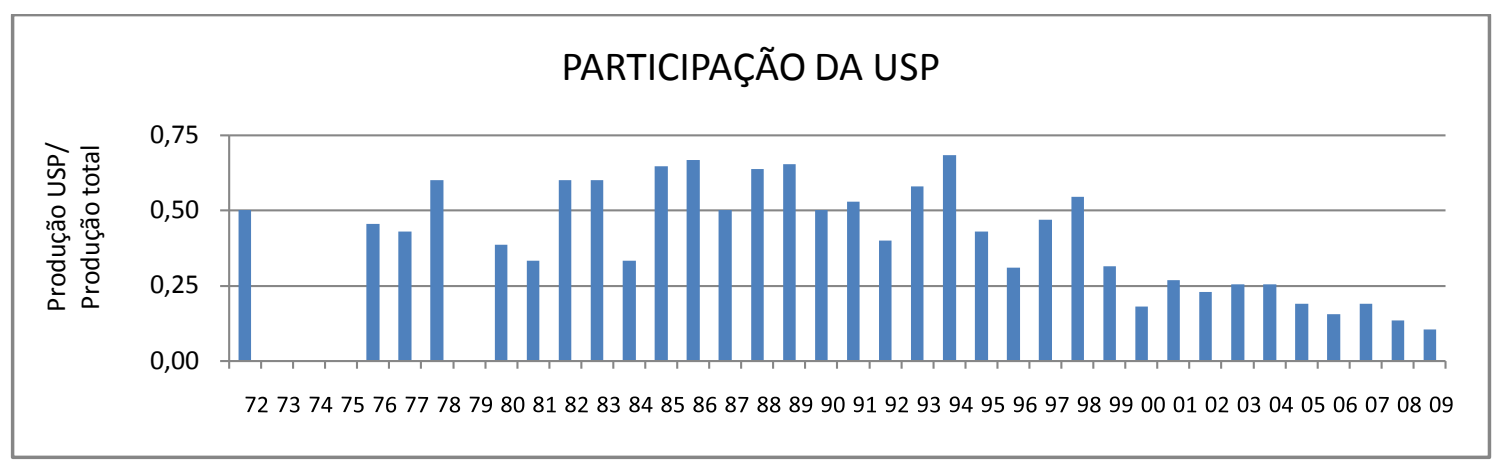

Gráfico 3.20: Participação da USP no conjunto da produção ao longo do tempo

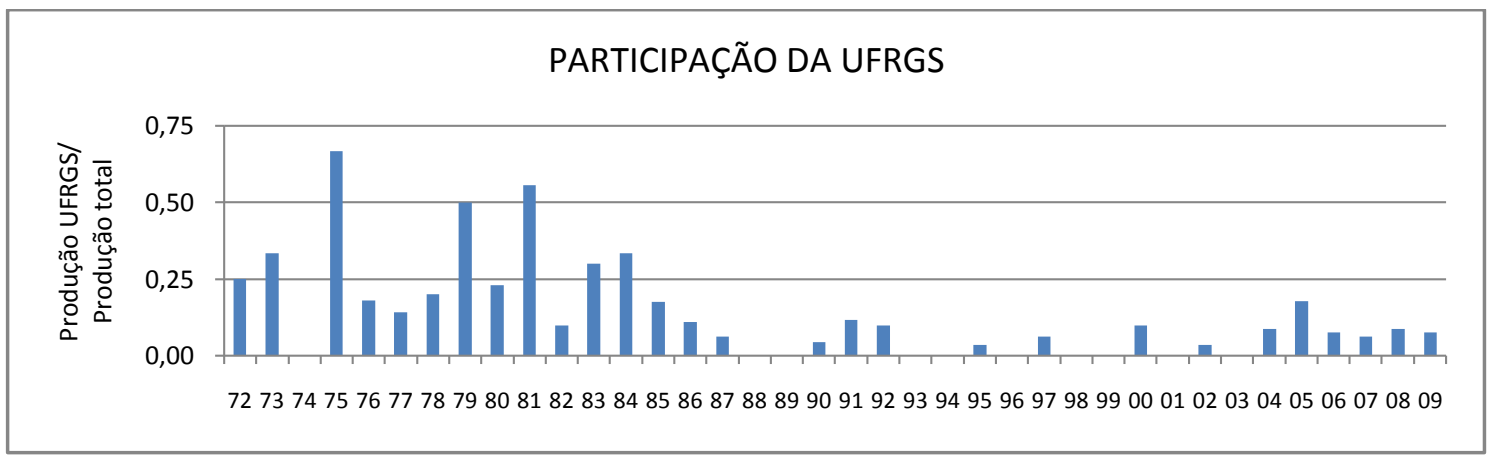

Gráfico 3.21: Participação da UFRGS conjunto da produção ao longo do tempo

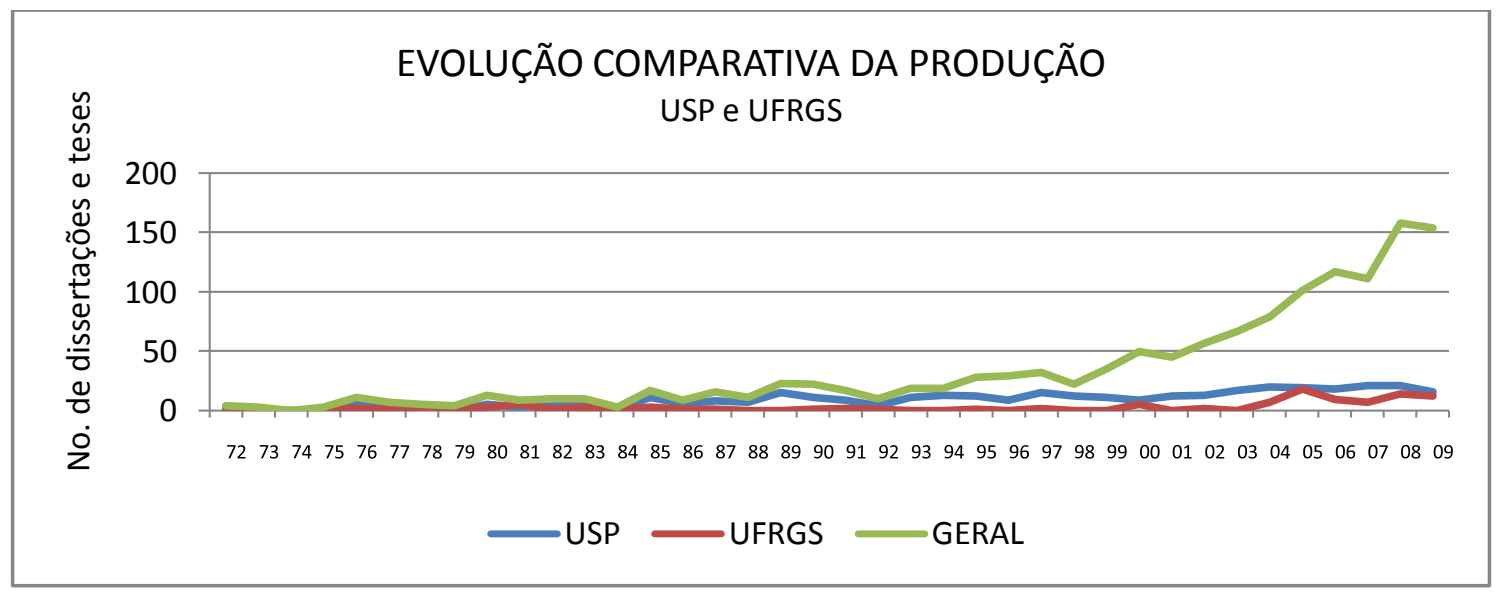

Gráfico 3.22: Evolução comparativa da participação da USP e da UFRGS na produção geral (número absoluto) 
Quanto a esses dados, observa-se que:

- Até final da década de 1990 (1998) na maior parte do tempo, a USP tem participação acima de $50 \%$ da produção total. A partir do final dos anos noventa, início de 2000 , essa participação cai e mantém-se abaixo de $30 \%$. $\mathrm{Na}$ última metade do período mais recente, concentra, em média, não mais que $10 \%$ da produção.

- Até meados da década de 1980, a UFRGS tem participação relativamente expressiva, mantendo-se acima de $20 \%$ do conjunto total, atingindo e superando a metade em alguns anos dessa fase inicial. Do final dos anos 80 até meados da primeira década de 2000 , a produção relativa cai significativamente, sendo nula em vários períodos. Na segunda metade dessa década (2005-2009) volta a contribuir com parcela em torno de $10 \%$, o que se atribui principalmente ao início dos mestrados profissionais.

Em síntese, durante as primeiras décadas de existência, a produção acadêmica na área de pesquisa em Ensino de Física é ancorada substancialmente por duas ou três instituições, que, a partir de então passam a ter participação cada vez menor no conjunto. No caso da UFRGS, esse declínio se dá desde o final dos anos 80 e, no caso da USP, no final dos anos noventa.

Uma questão que fica em aberto é se esses programas teriam atingido um limite de crescimento, com poucas renovações, enquanto outros estariam se expandindo, de modo a resultar em uma distribuição menos concentrada (uma democratização da produção ou um crescimento consistente). No caso da USP, os dados sinalizam tendência de menor contribuição no conjunto, mas mantendo o aumento da produção. A recém criação de cursos de doutorado em ensino de Física e de Química (2009) no Programa Interunidades de Ensino de Ciências da USP podem levar a um maior crescimento da produção nessa universidade. No caso da UFRGS, não é possível inferir perspectivas. Não fossem contabilizados os mestrados profissionalizantes, poderíamos concluir que de fato, sua contribuição ao conjunto passou a ser bastante reduzida, com tendência a uma estagnação ou até extinção.

* Principais conclusões até aqui:

O número de Instituições vem aumentando significativamente. No entanto esse aumento tem se dado predominantemente (até o momento) por produções isoladas. Cerca de $70 \%$ das instituições presentes têm menos de 10 títulos. Quase $40 \%$ da produção concentrada em apenas 2 Instituições. 30\% têm apenas 1 trabalho.

Cerca de $15 \%$ tem mais de 10 anos com produção de teses, mas dessas, apenas 3 (4\%) estão presentes na área em um tempo superior à metade do período total de 38 anos. 
Quanto a tendências: incorporação de número expressivo de novas Instituições e programas, contabilizando ou não os mestrados profissionais.

\section{Distribuição segundo a natureza do programa (ou unidade da Instituição)}

Do ponto de vista dos Programas e/ou das Áreas em que vêm sendo desenvolvidas as dissertações e teses no país, utilizamos a classificação em áreas da CAPES. A primeira é a própria área de Ensino de Ciências e Matemática (área 46 até 2011), que abriga o maior número de programas de pós-graduação com produção em Ensino de Física. Outras parcelas da produção têm origem em programas na área de Educação ou da própria Física. Há ainda casos dispersos em diferentes áreas, para os quais criamos a categoria "Outras", a exemplo de cursos de Psicologia, Engenharia, Letras, Energia, Educação Ambiental, Ciências Sociais, Química, Informática.

A distribuição das dissertações e teses de acordo com essa classificação está representada na tabela e gráfico a seguir.

\begin{tabular}{|c|c|c|c|c|c|}
\hline & \multicolumn{4}{|c|}{ ÁREA CAPES } & \multirow[b]{2}{*}{ TOTAL } \\
\hline & $\begin{array}{r}\text { ENSINO DE } \\
\text { CIÊNCIAS E } \\
\text { MATEMÁTICA }\end{array}$ & EDUCAÇÃO & FÍSICA & OUTRAS & \\
\hline No. Abs. & 739 & 472 & 35 & 84 & 1330 \\
\hline$\%$ & $56 \%$ & $35 \%$ & $3 \%$ & $6 \%$ & $100 \%$ \\
\hline
\end{tabular}

Tabela 3.13: Distribuição das dissertações e teses segundo áreas de conhecimento da CAPES

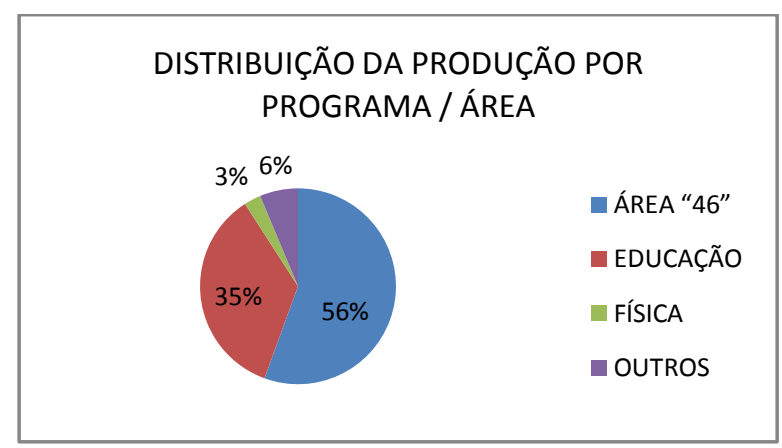

Gráfico 3.23: Distribuição das dissertações e teses segundo áreas de conhecimento da CAPES

Verifica-se que mais da metade da produção na área de Ensino de Física tem origem em programas de Ensino de Ciências e Matemática, de acordo com a classificação da CAPES. A parcela desenvolvida em programas da área de Educação também é expressiva, pouco acima de um terço. 
Utilizando essas mesmas áreas, classificamos os cursos depositários da produção. Para isso, identificamos entre as 78 instituições participantes, em quais áreas (CAPES) os programas ou cursos se encontram.

\begin{tabular}{|l|c|c|c|c|c|}
\hline & $\begin{array}{c}\text { ENSINO DE } \\
\text { CIÊNCIAS E } \\
\text { MATEMÁTICA }\end{array}$ & EDUCAÇÃO & FÍSICA & OUTROS & TOTAL \\
\hline No. Abs. & 45 & 62 & 9 & 41 & 157 \\
\hline$\%$ & $29 \%$ & $39 \%$ & $6 \%$ & $26 \%$ & $100 \%$ \\
\hline
\end{tabular}

Tabela 3.14: Distribuição dos cursos/programas por área de conhecimento da CAPES

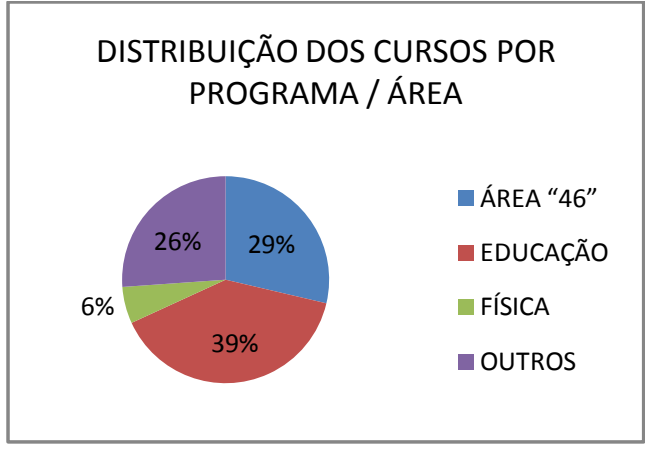

Gráfico 3.24: Distribuição dos cursos/programas por área de conhecimento da CAPES

Interessante notar que enquanto a área de Ensino de Ciências e Matemática congrega maior produção de dissertações e teses, os cursos em que essa produção se desenvolve estão majoritariamente sediados em programas da área de Educação. Fato que poderia ser interpretado como resquício das origens da pesquisa em Ensino de Física, cuja aceitação no campo acadêmico se deu mais amplamente pelas Faculdades de Educação do que pelos Institutos de Física, como observa Barros (2002) ao refletir sobre a constituição da comunidade de pesquisadores em Ensino de Física.

Todos os pesquisadores em ensino de física, com raras exceções, são oriundos dos cursos de graduação em física (licenciatura ou bacharelado). Sua pós-graduação tem nichos diferentes, assim como os locais onde desenvolvem sua vida profissional. Por diversas razões este grupo teve melhor recepção nas Faculdades de Educação, tendo sido poucos os Institutos de Física que abriram as portas para grupos interessados na pesquisa em ensino de física (podemos citar 3 ou 4) como UFRGS, UFES, UFF (na década dos 80's), permitindo que linhas de pesquisa em ensino de física fossem implantadas com a consequente possibilidade de mestrados em ensino de física, desenvolvidos inteiramente dentro dos Institutos. (BARROS, 2002, p.6)

Trata-se de um resultado que poderia ser investigado com mais atenção, por exemplo, acompanhando a natureza da produção em uma ou outra área. Fica como sugestão... 


\section{Evolução do número de orientadores}

A relação do número de orientadores em função do número de teses orientadas pode ser outro parâmetro relevante da distribuição desse nosso conjunto. Contabilizamos um total de $\mathbf{4 8 5}$ orientadores no universo das 1330 dissertações e teses, o que representa uma média geral de cerca de 3 teses por orientador. No entanto, temos novamente uma distribuição pulverizada com grande número de orientadores em pequeno número de dissertações e teses, como mostramos no Gráfico 3.25.

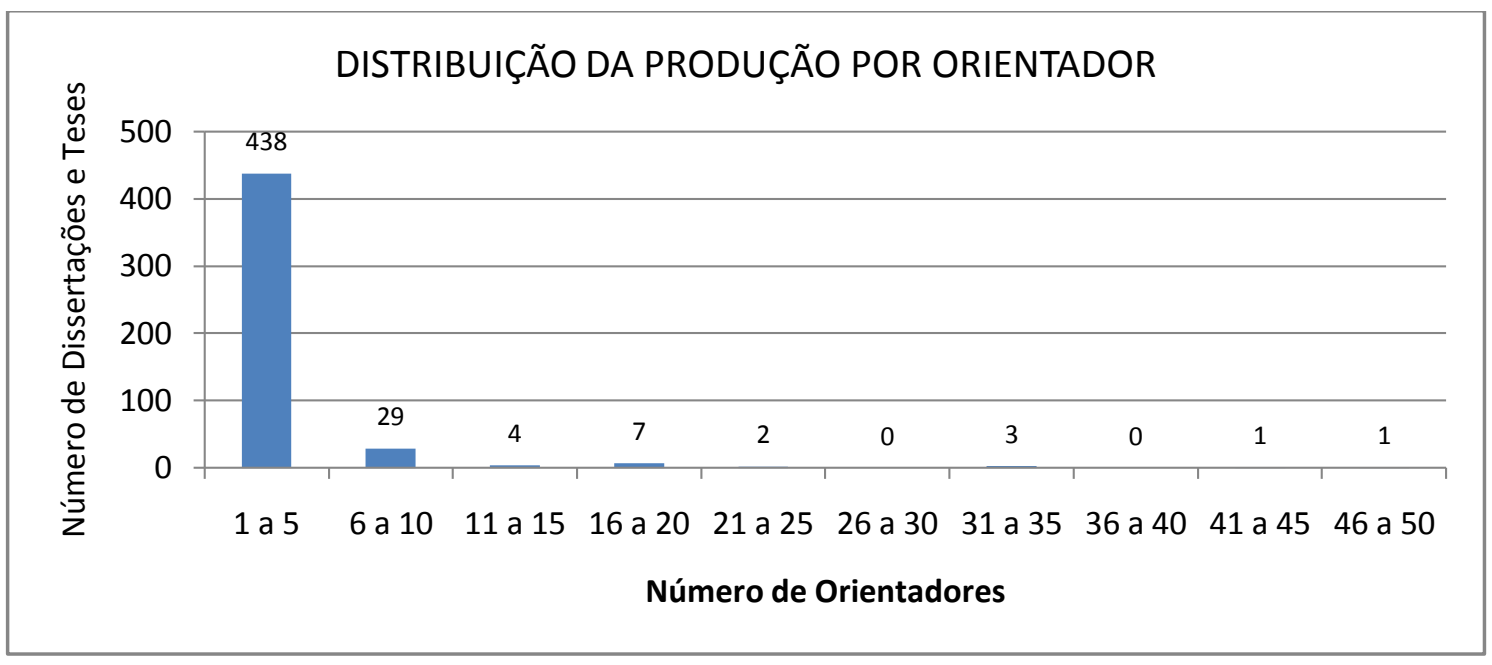

Gráfico 3.25: Distribuição do número de dissertações e teses pelo número de orientadores

Verifica-se que dentre esse total de 485 orientadores:

- 295 (61\%) orientaram apenas 1 tese

- $438(90 \%)$ orientaram menos de 5 teses

- 467 (96\%) orientaram menos de 10 teses

- 20 (4\%) orientaram mais de 10 teses

Dentre os 20 orientadores com mais de 10 dissertações e teses, temos a seguinte distribuição: 11 da USP, 3 da UFSC, 2 da UNICAMP, 1 da UNESP-Bauru, 1 da UFSM, 1 da UFRGS, 1 da UFMG.

Juntos, esses 20 orientadores têm uma produção de 389 teses. O que significa que $5 \%$ do total de orientadores concentram cerca de um terço da produção de dissertações e teses na área. 
Tal como na distribuição do número de Instituições com produção na área, há um grande aumento do número de orientadores ao longo do tempo. E, novamente, acompanhando todos os demais parâmetros da evolução da área, esse aumento é pronunciado na segunda metade da década de 2000.

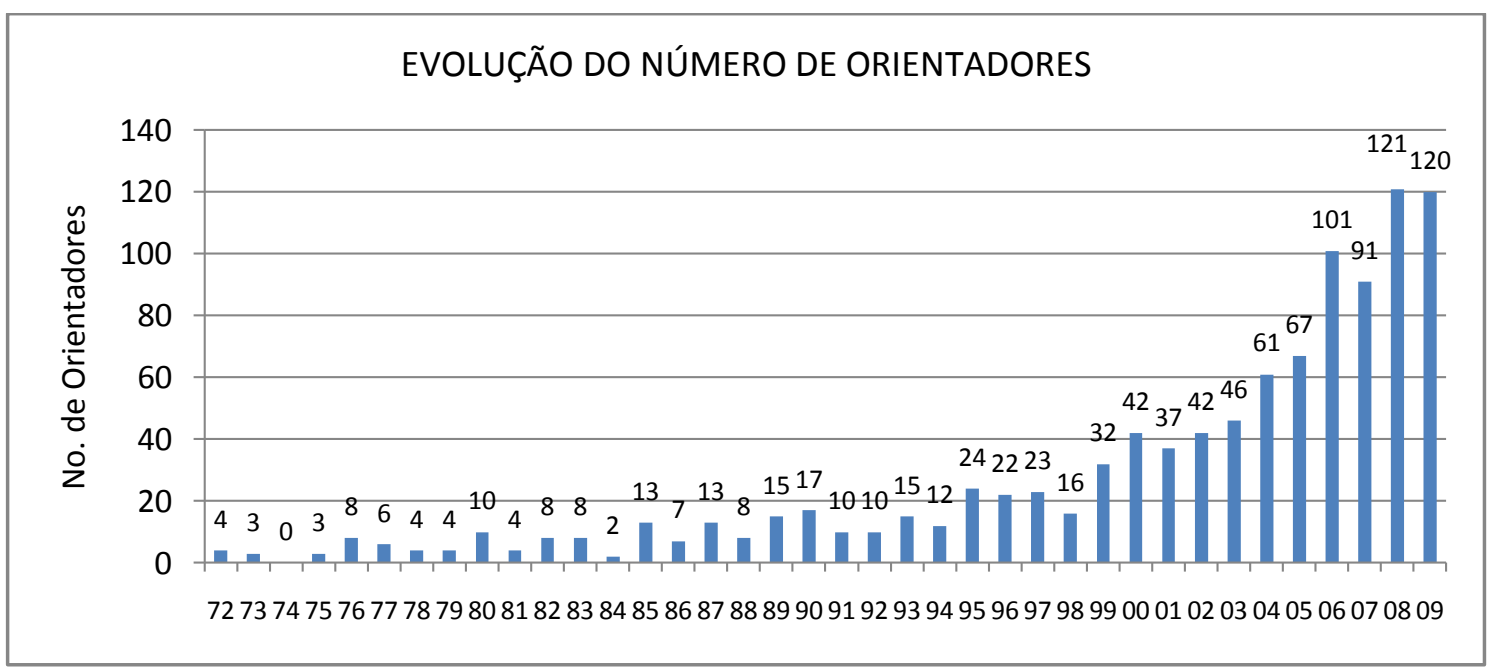

Gráfico 3.26: Evolução anual do número de orientadores

Esses dados reiteram um crescimento da área marcado por uma pulverização/dispersão cada vez maior, com concentração cada vez maior da produção em um reduzido número de instituições e orientadores.

\section{Distribuição segundo Dependência Administrativa}

Quanto à Dependência Administrativa das instituições depositárias das dissertações e teses na área, verificamos que a maior parcela concentra-se em instituições públicas (cerca de 60\%) e, dentre essas as Universidades Federais são predominantes. Mostramos essa distribuição na tabela e nos gráficos a seguir.

\begin{tabular}{|l|r|r|}
\hline $\begin{array}{r}\text { DEPENDÊNCIA } \\
\text { ADMINISTRATIVA }\end{array}$ & $\begin{array}{r}\text { NÚMERO } \\
\text { ABSOLUTO }\end{array}$ & PERCENTUAL \\
\hline Federal & 33 & $42 \%$ \\
\hline Estadual & 14 & $18 \%$ \\
\hline Municipal & 1 & $1 \%$ \\
\hline Total Públicas & $\mathbf{4 8}$ & $\mathbf{6 2 \%}$ \\
\hline Total Privadas & $\mathbf{3 0}$ & $\mathbf{3 8 \%}$ \\
\hline Total Geral & $\mathbf{7 8}$ & $\mathbf{1 0 0 \%}$ \\
\hline
\end{tabular}

Tabela 3.15: Distribuição das Instituições por Dependência Administrativa 

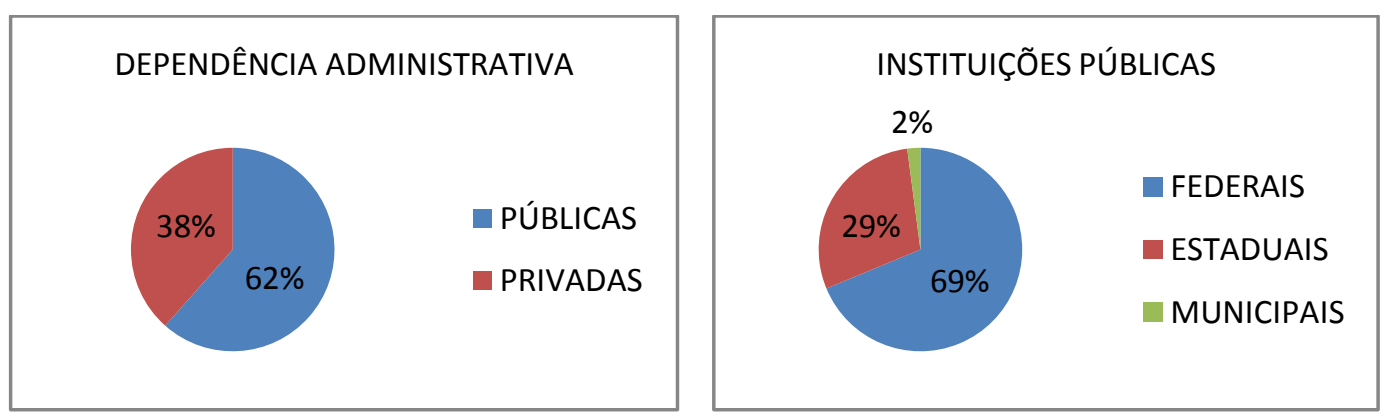

Gráficos 3.26: (a) Distribuição das Instituições por Dependência Administrativa;

(b) distribuição das instituições públicas

\subsubsection{Distribuição regional}

Finalmente, quanto à origem geográfica da produção, verificamos a seguinte distribuição:

\begin{tabular}{|c|c|c|c|c|c|}
\hline \multicolumn{3}{|c|}{ SUL } & \multicolumn{3}{|c|}{ NORDESTE } \\
\hline PR & 55 & & $\mathrm{AL}$ & 6 & \\
\hline RS & 193 & & $\mathrm{BA}$ & 31 & \\
\hline $\mathrm{SC}$ & 82 & & CE & 4 & \\
\hline TOTAL S & 330 & $25 \%$ & $\mathrm{PE}$ & 35 & \\
\hline \multicolumn{3}{|c|}{ SUDESTE } & $\mathrm{PI}$ & 2 & \\
\hline ES & 11 & & $\mathrm{RN}$ & 27 & \\
\hline MG & 84 & & SE & 2 & \\
\hline $\mathrm{RJ}$ & 131 & & TOTAL NE & 107 & $8 \%$ \\
\hline SP & 580 & & \multicolumn{3}{|c|}{ CENTRO-OESTE } \\
\hline TOTAL SE & 806 & $61 \%$ & DF & 33 & \\
\hline \multicolumn{3}{|c|}{ NORTE } & G0 & 7 & \\
\hline AM & 8 & & MS & 5 & \\
\hline $\mathrm{PA}$ & 17 & & MT & 17 & \\
\hline TOTAL N & 25 & $2 \%$ & TOTAL CO & 62 & $5 \%$ \\
\hline
\end{tabular}

Tabela 3.15: Distribuição do número de dissertações e teses por região geográfica

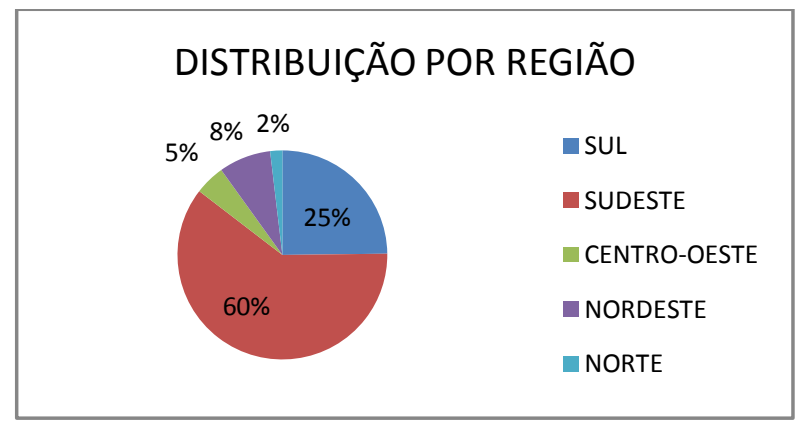

Gráfico 3.27: Distribuição do número de dissertações e teses por região geográfica 


\subsection{Sistematização e Considerações Gerais}

Como síntese desses dados e resultados, ressaltamos os seguintes aspectos:

$\checkmark$ O crescimento da produção na área, nesse universo de dissertações e teses, é sistemático e expressivo ao longo de toda sua evolução, com médias anuais que vão de algumas poucas unidades para valores da ordem de uma centena.

$\checkmark$ Os mestrados representam maior parte do conjunto, 75\% na soma cumulativa, e acompanham o crescimento geral. Os doutorados crescem a taxas superiores às dos mestrados até início de 2000 , quando passam a ter participação e crescimento menores.

$\checkmark$ Na década de 2000 entram em cena os mestrados profissionais, que se expandem muito rápida e intensivamente, representando nova tendência, que merece atenção especial.

$\checkmark$ Há uma redução no tempo de obtenção dos títulos entre a conclusão do mestrado e a do doutorado.

$\checkmark$ O crescimento da produção se dá de forma concentrada em um número relativamente reduzido de instituições se comparado ao total delas, quer seja pelo volume, quer pelo tempo de existência ou de produção na área. Cresce o número de instituições com pequena produção. Não é possível, contudo, afirmar que essa seja uma tendência. Na última década, novas instituições e programas de pós-graduação na área surgem com produção elevada. Além disso, com a introdução dos mestrados profissionais, é possível que outras instituições passem a ter participação maior.

$\checkmark$ As instituições com maior produção e maior tempo de produção, que de certa forma deram sustentação a esse crescimento, começam a ter participação no conjunto menor do que tiveram, sinalizando, se não uma inflexão, uma estabilização. O mesmo se pode concluir quanto ao número de Orientadores.

$\checkmark$ Cerca de $60 \%$ das Instituições depositárias das dissertações e teses são Universidades Públicas e, dentre essas, 70\% são Universidades Federais.

$\checkmark$ Mais de $80 \%$ da produção concentra-se nas regiões Sudeste e Sul, sendo $60 \%$ na região Sudeste.

Enfim, o crescimento da área, ainda que expressivo e cada vez mais acentuado, não aponta tendências futuras evidentes. Todos os parâmetros analisados nessa evolução mostram que numericamente "tudo cresce": volume da produção, instituições, programas, orientadores. No entanto, o futuro não pode ser inferido por tais números. Pois depende de um amplo e complexo conjunto de fatores. Quanto a isso, colocamos algumas questões.

Teria a área atingido a sua "capacidade-limite" de crescimento? Pode ainda crescer nesse ritmo exponencial? Quais seriam os indicadores? Novas instituições 
e programas irão se consolidar com aumento de produção, ou essa dispersão tende a se manter?

Se tomarmos por base apenas os números, gráficos e estatísticas, a natureza do crescimento parece mais indicar que estamos longe do "fim", sem indicações de diminuição nas taxas de "crescimento vegetativo". No entanto, os números são governados por políticas. Crescimento ou declínio, grande ou pequeno, rápido ou lento, dependem de fatores não apenas internos à própria área, mas principalmente de condicionantes externos.

Haveria demanda (profissional/social) para um grande (e crescente) contingente de mestres e doutores na área de Ensino de Ciências? Na área de Ensino de Física? De um lado, há que se considerar as políticas de apoio, avaliação e financiamento de programas de pós-graduação nessa área. Certamente determinam esse panorama, mas também são ditadas por outras políticas que podem vir a alterar esse panorama. O próprio Ensino de Física, antes de sua pesquisa, pode sofrer mudanças substanciais que poderiam desviar o curso dessa história.

São questões em aberto que merecem ser refletidas, se queremos orientar ações futuras. O curso da história não está definido, é imprevisível, e conduzi-lo em qualquer direção que seja depende de nossas ações no presente. Voltamos a isso no Capítulo 8. 


\section{Focos de interesse: olhares e instrumentos}

Não tenho um caminho novo. O que tenho de novo é um jeito de caminhar. (Thiago de Mello)

Para complementar o panorama geral iniciado, que visa retratar como vem evoluindo a área de PEF, coloca-se a necessidade de investigarmos aspectos que melhor caracterizem sua produção. Isso significa que é preciso investigar seus conteúdos ou objetos de estudo. Ou seja, focalizar de quê ela vem tratando, quais os temas ou linhas de pesquisa mais (ou menos) privilegiados ao longo de sua trajetória, quais os seus focos de interesse. No entanto, essa não é uma tarefa simples, pois demanda, já de início, compreender e definir o quê tomar como parâmetro para identificar esses conteúdos, objetos, focos de interesse, temas ou linhas de pesquisa: o quê olhar para enxergar isso! E o que mesmo é isso?!

Ocorre que não estamos partindo do zero, de tábula rasa. Como já pudemos ver, há um conjunto notável de trabalhos que tem se voltado para a área de Ensino de Ciências / Física com esse objetivo, de identificar, sistematizar, analisar sua produção em diferentes momentos ou espaços (que inclui os estudos de estado da arte abarcados no Capítulo 1). Pudemos também verificar que quando se trata de mapear os objetos de investigação, não raro se tem adotado como procedimento, o levantamento e a classificação da produção segundo Áreas ou Focos Temáticos. Nós mesmas temos assim procedido em trabalhos anteriores.

Com o propósito, então, de verificar como tem sido analisada a produção na área de PEF segundo categorias temáticas, fizemos um levantamento das pesquisas mais expressivas nessa linha. Uma análise preliminar desse levantamento chamou atenção para a existência de tratamentos ou procedimentos metodológicos distintos, o que passou a constituir um novo problema de investigação: quais são, de onde vêm, em que se baseiam, em que se assemelham ou se diferenciam as categorias utilizadas para classificar e analisar a produção acadêmica na área? Que critérios são adotados para classificá-la, quais os dados ou conclusões mais significativos? Dessas questões procuraremos tratar no presente capítulo.

Mesmo com o crescimento do número de trabalhos dessa natureza no nosso campo, não foi criado nem existe um instrumento ou referencial que oriente e embase uma 
definição de "área, foco ou categoria temática". O que podemos encontrar são propostas e estudos diversos, mas fragmentados, com diálogo e intercâmbio ainda incipientes no que tange a concepções, métodos ou resultados. São investigações empíricas e não se pode afirmar sequer se convergem, divergem ou se complementam. Na verdade, por não utilizarem os mesmos instrumentos ou, em alguns casos, sequer explicitá-los, ou ainda, por não "medirem" ou "olharem" os mesmos objetos, uma análise comparativa fica comprometida. Não queremos afirmar, com isso, que essas investigações deveriam seguir as mesmas regras, utilizar os mesmos procedimentos metodológicos ou chegar a resultados semelhantes. Até porque estamos tratando de um campo de pesquisa relativamente jovem, cuja natureza ainda é motivo de interrogações, reflexões e polêmicas, com compreensões e olhares diferenciados.

Particularmente no que tange a metodologias, quer da pesquisa em ensino, quer da pesquisa da pesquisa (metapesquisa), não há sequer uma visão consensual do que seja uma metodologia de pesquisa nessa área. Linhas de pesquisa, referenciais teóricos e procedimentos técnicos de seleção e tratamento de dados são uns ou outros, por uns ou outros, entendidos como "metodologia de pesquisa". E ainda, dado seu caráter interdisciplinar, nas investigações em Ensino de Ciências há tendências diversas, que dependem do olhar para o próprio campo de saber ou das finalidades da pesquisa. Há quem empreste metodologias mais típicas das ciências humanas ou da educação, há quem busque métodos denominados "científicos", emprestados das ciências duras. E nesse intervalo, há mesclas de uma ou outra vertente ou, ainda, há quem desconsidere a necessidade de definir com rigor uma dada metodologia de pesquisa.

Ainda quanto a esse aspecto, as tendências metodológicas "mudam conforme a música", assim como na evolução da própria área. Houve momentos, por exemplo, que dada a necessidade de legitimação da pesquisa em ensino diante das objeções de pesquisadores em Física, surgiram tendências de preocupação com o "rigor científico" nos métodos e procedimentos de análise. Ou seja, uma busca de validar a pesquisa em educação como pesquisa científica. Sobre essa tendência, Villani (1981) pondera que...

[...] A ausência de um instrumental teórico tão preciso como a matemática tem sido objeto de questionamento e até de propostas tendentes a reformular a natureza dos experimentos, das teorias e das metodologias em Educação; no entanto, o efeito líquido dessa pressão tem sido o aumento e o refinamento do tratamento estatístico com evidente desconhecimento de algumas características dos fenômenos educacionais. Nesse sentido acreditamos que a tentativa de considerar como científica a pesquisa educacional somente a partir de um grau de precisão quantitativa, que permita uma formulação bem próxima da matemática, seja destinada a fracasso...] (VILLANI, 1981, p.77) 
Ao mesmo tempo, devemos ter em conta que metodologias, assim como tantos outros parâmetros de pesquisa, não são neutras. Certamente refletem o olhar do pesquisador (como já pontuamos antes) que é conduzido por visões mais do que meramente no "acerto" da investigação ou de sua qualidade.

No caso específico da metapesquisa, nosso particular interesse nesse momento, o que queremos destacar é não só a ausência de orientações metodológicas e, portanto, de se tratar mais acentuadamente de escolha ou criação do pesquisador, mas, sobretudo, o fato de que tais escolhas via de regra não são explicitadas. Ou seja, mesmo não focalizando os objetos de estudo (a pesquisa) por meio das mesmas lentes, (nesse caso, os instrumentos utilizados para identificar do que a área trata ou vem tratando), o problema central está na ausência de explicitação das opções e critérios utilizados. Daí a dificuldade de uma interlocução mais efetiva entre os diversos estudos.

Entendemos, por esse motivo, que a principal dificuldade e uma meta importante nessa perspectiva de pesquisa consiste em criar, elucidar, discutir e validar instrumentos de análise que possibilitem atingir os objetivos a que vieram: identificar focos de interesse e tendências da área para sinalizar desafios e perspectivas. Para tanto, é essencial que técnicas, abordagens, critérios e referências sejam discutidos com maior amplitude e transparência, de modo a criar enfoques convergentes de análise, agregar conhecimento e construir referências para futuras investigações.

Por tal motivo nossa intenção, nesse capítulo, não é, ainda, analisar a produção na área, no que se refere a seus "assuntos" ou às suas "temáticas", mas, antes disso, apresentar e discutir instrumentos com essa finalidade. Para isso, inicialmente discutimos algumas características metodológicas predominantes nos trabalhos que vêm sendo desenvolvidos para, em seguida, apresentar uma proposta de instrumento que usaremos nos capítulos seguintes com o objetivo de caracterizar as dissertações e teses segundo essa perspectiva.

\subsection{Temas, áreas e focos temáticos: vertentes de investigação}

Linhas, enfoques, campos, áreas, focos ou categorias temáticas vêm sendo criados ou utilizados ao longo dos anos tendo em vista identificar e analisar as principais tendências da pesquisa em nossa área. Novamente, chamamos a atenção para o fato de que essas diferentes denominações têm sido usadas indistintamente e sem definições. "Foco temático" ou "área temática", por exemplo, as nomenclaturas mais empregadas, têm sido compreendidas com o mesmo sentido, que seria dado pelos próprios termos, sem necessidade de maiores explicações. Em princípio, seriam instrumentos de classificação "neutros" ou "naturais", no sentido de não demandarem grandes (ou pequenas) definições, de não parecerem emergir de escolhas claras e fundamentadas ou de pouco dialogarem com outras escolhas. 
Em uma primeira aproximação, distinguimos dois procedimentos metodológicos utilizados para realizar esse tipo de investigação. Um deles tem como referência categorias temáticas criadas ou dadas a priori. No outro, as categorias são criadas $a$ posteriori, a partir da análise dos dados brutos, da própria produção, para depois serem reorganizadas, estruturadas e utilizadas como critérios de classificação e análise. Seja por meio da primeira ou da segunda metodologia, na maioria dos casos adota-se como instrumento de classificação da produção, os denominados focos ou áreas temáticas.

No panorama das investigações de estado da arte analisado no capítulo 1, uma das vertentes identificadas (e que compõe parcela expressiva) analisa a produção da área segundo seus focos temáticos. Como vimos, dentre esses, alguns tomam como categorias de classificação, as Áreas Temáticas em que são organizados os eventos principais da área de Ensino de Física / Ciências: EPEF, SNEF e ENPEC. Ou seja, justificadamente ou não, de forma explícita ou não, as áreas temáticas desses eventos têm sido adotadas por parte de pesquisadores, como referência das linhas de pesquisa em Ensino de Física, a partir da qual se procura levantar e delinear as principais tendências em um dado período ou ao longo do tempo.

Por esse motivo, optamos por trazer inicialmente um breve panorama desses eventos, no que se refere às suas organizações temáticas, com foco particular no EPEF, por ser o fórum que promove e congrega as discussões tópicas e os trabalhos de pesquisa na área de EF.

\subsection{1 Áreas Temáticas dos Eventos e seus usos como categorias de análise}

A proposição de Áreas Temáticas (ATs) na estruturação dos eventos tem sido uma prática cada vez mais comum em suas organizações. No momento da inscrição, os participantes do evento devem escolher entre as Áreas propostas, aquela que considera mais apropriada para submeter seus trabalhos. No entanto, não há uma explicitação de critérios e definições de como são concebidas, o que é pertinente a cada uma delas, ficando a cargo do autor essa escolha.

A definição dessas ATs reflete, de um modo geral, as tendências concebidas pelos organizadores do evento por meio de suas vivências (ou pela sugestão dos eventos anteriores) sobre quais sejam as linhas de investigação da área, o que pode implicar definições diferentes de um evento para outro. Por outro lado, há uma espécie de entendimento tácito - as ATs são compreendidas pelos participantes do evento a partir de um "rótulo", de uma denominação, segundo certa tradição ou tendência que vem se estabelecendo ao longo dos eventos. Contudo, por se tratar de uma escolha relativamente subjetiva e arbitrária, nem sempre os trabalhos inscritos em cada uma das áreas têm as mesmas características ou tratam de temas afins, e nem sempre as 
ATs, em seu conjunto, esgotam as possibilidades, demandando que autores se enquadrem de algum modo em uma delas.

No Anexo 4.1 encontra-se uma relação das Áreas Temáticas dos SNEF, EPEF e ENPEC, nas diversas edições em que foram propostas e constam de seus anais.

Uma breve análise das áreas temáticas propostas nesses três eventos, desde a década de 1980 revela:

\section{Áreas comuns (desde a Década de 1980)}

- Ensino e Aprendizagem

- Formação de Professores

- História, Filosofia e Sociologia da Ciência

Áreas Comuns (desde a Década de 1990)

- Ensino e Aprendizagem

- Formação de Professores

- História, Filosofia e Sociologia da Ciência

- Tecnologia da Informação

- Divulgação Científica e Educação Não-Formal

- Alfabetização Científica e Tecnológica

- Ciência, Tecnologia e Sociedade

- Linguagem e Cognição

No que se refere especificamente aos EPEFs:

Em sua primeira edição (I EPEF, 1986), os poucos (12) trabalhos apresentados foram classificados de acordo com linhas de pesquisa dominantes à época; na segunda edição (II EPEF, 1998), apenas duas áreas temáticas, relativamente específicas, compuseram a organização do evento e, na terceira edição (III EPEF, 1990), não houve organização temática. O IV EPEF (1994) foi estruturado a partir de quatro temas relacionados à natureza da pesquisa na área (Metapesquisa) e no V EPEF (1996), foram propostos três temas de grande abrangência (Quadro 4.1) 


\section{EPEF (1986)}

- Física INTUITIVA EM UM REFERENCIAL PIAgetiano

- concepções alternativas

- reEstruturação curricular

- ensino diagnóstico

- ABORDAGENS METODOLÓGICAS

II EPEF (1988)

- FORMAÇÃO do PROFESSOR

- CONCEITOS ALTERNATIVOS/INTUITIVOS/ HISTÓRICOS/CIENTíFICOS

III EPEF (1990)

(sem registro)

IV EPEF (1994)

- fundamentos da PESQUISA EM ENSINO de físICA

- objetIVOS DA PESQUisa e CONHECIMENTO

- metodologias de pesquisa

- RELAÇÃo eNTRE AS PESQUISAS E O ENSINO de FísICA/CIÊNCIAS NA EDUCAÇÃo esColar

V EPEF (1996)

- SISTEMAS CONCEITUAIS E HISTÓRIA DA CIÊNCIA

- FORMAÇÃo de PROFESSORES E POLÍTICAS EDUCACIONAIS

- Metodologia e CuRRí́culo

Quadro 4.1: Áreas Temáticas das cinco primeiras edições do EPEF

A partir do sexto encontro (VI EPEF, 1998) começam a ser definidas áreas temáticas mais específicas, que já sinalizam uma preocupação em estruturar e dar corpo ao conjunto das linhas de investigação predominantes na área. Desde então, as seguintes áreas mantiveram-se presentes, sistematicamente, ainda que com denominações ligeiramente diversas, apresentadas no quadro 4.2. 


\title{
ÁREAS TEMÁTICAS PERMANENTES DESDE O IV EPEF, 1998
}

\author{
ENSINO E APRENDIZAGEM \\ ENSINO E APRENDIZAGEM DE FÍSICA $(1998,2002,2004,2008)$ \\ APRENDIZAGEM EM FÍSICA (2006) \\ ENSINO/APRENDIZAGEM/AVALIAÇÃO EM FÍSICA (2010)
}

\section{DIDÁTICA, CURRÍCULO E AVALIAÇÃO}

INOVAÇÕES CURRICULARES E O ENSINO DE FÍSICA $(1996,1998)$

INOVAÇÕES DIDÁTICO-PEDAGÓGICAS PARA O ENSINO DE FÍSICA $(1996,1998)$

O CURRÍCULO NO ENSINO DE FÍSICA ( 1998)

DIDÁTICA DA FísICA ( 1998)

CURRÍ́CULO E INOVAÇÃO EDUCACIONAL (2000)

DIDÁTICA, CURRÍCULO E AVALIAÇÃO NO ENSINO DE FÍ́SICA $(2002,2004,2006,2008)$

DIDÁTICA, CURRÍCULO E INOVAÇÃO EDUCACIONAL NO ENSINO DE FÍSICA (2010)

\section{FILOSOFIA, HISTÓRIA E SOCIOLOGIA DA CIÊNCIA}

FILOSOFIA E HISTÓRIA DA CIÊNCIA: IMPLICAÇÕES E DECORRÊNCIAS PARA O ENSINO DE FÍSICA (1998) FILOSOFIA, HISTÓRIA E SOCIOLOGIA DA CIÊNCIA E O ENSINO DE FÍSICA (2002, 2004, 2006, 2008, 2010)

Questões históricas, filosóficas e epistemológicas (2000, em CURRÍCULO E INOVAÇÃo EDUCACIONAL)

\section{FORMAÇÃO DE PROFESSORES}

FORMAÇÃO INICIAL E CONTINUADA DE PROFESSORES PARA A ÁREA DE FÍSICA E DE CIÊNCIAS (1998)

FORMAÇÃO DO PROFESSOR DE FÍSICA $(2000,2002)$

FORMAÇÃO E PRÁTICA PROFISSIONAL DE PROFESSORES $(2004,2006,2008)$

FORMAÇÃO E PRÁTICA PROFISSIONAL DO PROFESSOR DE FÍSICA (2010)

\section{EDUCAÇÃO EM ESPAÇOS NÃO-FORMAIS}

A CIÊNCIA E A FÍSICA EM ESPAÇOS NÃO FORMAIS DE ENSINO $(1996,1998)$

EDUCAÇÃO EM ESPAÇOS NÃO-FORMAIS E DIVULGAÇÃO CIENTÍFICA (2002)

DIVULGAÇÃO E COMUNICAÇÃO DE CIÊNCIAS: FÍSICA EM ESPAÇOS ESCOLARES E NÃO ESCOLAR (2004)

DIVULGAÇÃO E COMUNICAÇÃO DE Fí́ICA EM ESPAÇOS FORMAIS E NÃO FORMAIS (2006)

FíSICA E DIVULGAÇÃO CIENTÍFICA EM ESPAÇOS EDUCATIVOS FORMAIS E NÃO FORMAIS (2008)

FíSICA E COMUNICAÇÃO EM PRÁTICAS EDUCATIVAS FORMAIS, INFORMAIS E NÃO-FORMAIS (2010)

Quadro 4.2: Áreas Temáticas permanentes desde o IV EPEF

A partir do VIII EPEF, em 2002, a essas áreas, se somam e são mantidas até o mais recente Encontro (XII EPEF, 2010) as seguintes áreas temáticas: 


\section{ÁREAS TEMÁTICAS PERMANENTES A PARTIR DO VIII EPEF, 2002}

\section{TECNOLOGIA DA INFORMAÇÃO}

TECNOLOGIA DA INFORMAÇÃO, INSTRUMENTAÇÃO E DIFUSÃO TECNOLÓGICA (2002)

TECNOLOGIA DA INFORMAÇÃO E INSTRUMENTAÇÃO NO ENSINO DE FÍSICA (2004)

TECNOLOGIA DA INFORMAÇÃO, DIFUSÃO TECNOLÓGICA E O ENSINO de física (2006)

TECNOLOGIAS E NOVAS ABORDAGENS NO ENSINO DA FÍSICA (2008)

TECNOLOGIAS DA INFORMAÇÃO E COMUNICAÇÃO E O ENSINO DE FÍSICA (2010)

\section{CIÊNCIA, TECNOLOGIA E SOCIEDADE}

CIÊNCIA, SOCIEDADE E ENSINO DE FÍSICA (2000)

CIÊNCIAS, TECNOLOGIA E SOCIEDADE $(2002,2004)$

CIÊNCIA, TECNOLOGIA E SOCIEDADE E O ENSINO DE FÍ́IICA (2006)

CTSA E O ENSINO DE FÍ́SICA $(2008,2010)$

\section{ALFABETIZAÇÃO CIENTÍFICA E TECNOLÓGICA}

ALFABETIZAÇÃO CIENTÍFICA E TECNOLÓGICA E ENSINO DE FíSICA (2002)

ALFABETIZAÇÃO E LETRAMENTO EM FÍSICA E TECNOLOGIA (2004)

COGNIÇÃO, ALFABETIZAÇÃO E LETRAMENTO EM FíSICA (2008)

\section{PRÁTICAS E POLÍTICAS EDUCACIONAIS}

COMUNIDADE, PRÁTICAS E POLÍTICAS EDUCACIONAIS (2002)

POLÍTICAS PÚBLICAS E ENSINO DE FÍSICA $(2004,2006,2008)$

POLÍTICAS PÚBLICAS EM EDUCAÇ̃̃O E O ENSINO DE FÍSICA (2010)

Não sistematicamente, ainda foram áreas inclusas:

\section{LINGUAGEM E COGNIÇÃO}

LINGUAGEM E COGNIÇÃO NO ENSINO DE FÍSICA E TECNOLOGIA (2004)

LINGUAGEM E COGNIÇÃO NO ENSINO DE Fí́ICA $(2006,2010)$

\section{PESQUISA EM ENSINO DE FÍSICA}

BALANÇO CRÍTICO DAS PESQUISAS E NOVAS DEMANDAS DE INVESTIGAÇÃO (2000)

QUESTÕES TEÓRICO-METODOLÓGICAS DA PESQUISA EM ENSINO DE FÍSICA $(2006,2008)$

QUESTÕES TEÓRICO-METODOLÓGICAS E NOVAS DEMANDAS NA PESQUISA EM ENSINO DE FíSICA (2010)

Quadro 4.3: Áreas Temáticas permanentes desde o VIII EPEF (2002-2010) 
Ao longo dos anos e décadas as áreas temáticas vão se recompondo, acompanhando, como é de se esperar, a evolução da área e dos referenciais mais amplos que a embasam ou a orientam. No entanto, uma vez que não há registros e reflexões sobre como são definidas e redefinidas, quais as linhas de trabalho ou de pesquisa que abrangem, torna-se difícil compreender a lógica dessa evolução, a menos de alguns aspectos mais evidentes, que procuramos destacar.

\section{i. Estrutura lógica e evolução das Áreas Temáticas}

Nos primeiros quatro EPEFs não parece haver uma preocupação clara no sentido de se estabelecer uma estrutura temática para a área, ainda que esses encontros tenham sido organizados em torno de temas que, à época, representavam focos privilegiados de interesse da pesquisa. São tentativas fragmentadas, pontuais, aparentemente sem uma perspectiva de continuidade que visasse futuros encontros ou que buscasse a criação de uma composição lógica e abrangente das linhas de pesquisa na área. De certo modo, cada evento refletia, em sua estruturação, concepções e escolhas das comissões organizadoras.

A partir do VI EPEF (1998), algumas áreas começam se estabelecer: Ensino $e$ Aprendizagem; Didática e Currículo; Formação de Professores; História e Filosofia da Ciência. De certo modo, essas quatro grandes áreas permanecem até a última edição do EPEF (2010). A partir do VIII EPEF (2002), somam-se a essas, também até o mais recente encontro, outras cinco ATs: Educação em Espaços Não-Formais e Divulgação Científica; Tecnologia da Informação e Comunicação; CTSA; Alfabetização Científica e Tecnológica; Comunidade, Práticas e Políticas. Uma última área, presente esporadicamente nos primeiros encontros e, sistematicamente nas três últimas realizações do EPEF, recebe a denominação Questões Teórico-Metodológicas da Pesquisa em Ensino de Física.

Esses dados mostram, sobretudo, que a partir do VII EPEF (2000) e, mais nitidamente, do VIII EPEF (2002), começa a se cristalizar um conjunto de áreas temáticas que estariam, agora sim, procurando representar os principais enfoques ou linhas de pesquisa da área (Ver Anexos 4.2 e 4.3), cada vez mais abarcando seu caráter pluridisciplinar. Contudo, é importante destacar a ausência de qualquer registro, seja nas atas dos eventos, seja em qualquer outra publicação da área, em que se apresente, explicite ou discuta essa questão: como e porque são escolhidas e definidas as ATs dos Encontros da área, como vêm evoluindo, o que representam, que pesquisas abarcam.

No quadro 4.4, apresentamos uma síntese dessa evolução, já numa tentativa de esboçar uma possível reconstrução lógica, de certa forma antecipando uma proposta de organização temática que estaremos apresentando adiante. 


\begin{tabular}{|c|c|c|c|c|c|c|c|c|c|c|c|c|c|c|c|}
\hline \multirow{2}{*}{\multicolumn{4}{|c|}{$\begin{array}{l}\text { EPEFS: } \\
\text { TEMÁTICA X EDIÇÃO }\end{array}$}} & \multicolumn{12}{|c|}{ EDIÇÃO / ANO } \\
\hline & & & & \multirow{2}{*}{$\begin{array}{c} \\
1986 \\
X\end{array}$} & \multirow[t]{2}{*}{$\begin{array}{c}\text { II } \\
1988\end{array}$} & $\begin{array}{c}\text { III } \\
1990\end{array}$ & $\begin{array}{c}\text { IV } \\
1994\end{array}$ & $\begin{array}{c}V \\
1996\end{array}$ & \multirow{2}{*}{$\begin{array}{c}\mathrm{VI} \\
1998 \\
X\end{array}$} & \multirow{2}{*}{$\begin{array}{l}\text { VII } \\
2000 \\
X\end{array}$} & \multirow[t]{2}{*}{$\begin{array}{c}\text { VIII } \\
2002 \\
y\end{array}$} & $\begin{array}{c}\mathrm{IX} \\
2004\end{array}$ & $\begin{array}{c}X \\
2006\end{array}$ & $\begin{array}{c}X I \\
2008\end{array}$ & $\begin{array}{c}X I I \\
2010\end{array}$ \\
\hline \multirow{12}{*}{$\begin{array}{l}\text { Á } \\
R \\
E \\
A\end{array}$} & 1 & 1 & ENSINO - APRENDIZAGEM - AVALIAÇÃO (geral) & & & - & & & & & & $\mathrm{x}$ & $\mathrm{x}$ & $\mathrm{x}$ & $\mathrm{X}$ \\
\hline & & 2 & $\begin{array}{l}\text { CONCEPÇÕES ALTERNATIVAS / ENSINO } \\
\text { DIAGNÓSTICO }\end{array}$ & $x$ & $\mathrm{x}$ & - & & & & & & & & & \\
\hline & & 3 & LINGUAGEM E COGNIÇÃO NO ENSINO DE FÍSICA & & & - & & & $\mathrm{x}$ & $\mathrm{X}$ & & $\mathrm{x}$ & $\mathrm{x}$ & & $\mathrm{x}$ \\
\hline & II & 4 & $\begin{array}{l}\text { DIDÁTICA, CURRÍCULO E INOVAÇÃO } \\
\text { EDUCACIONAL NO ENSINO DE FÍSICA }\end{array}$ & $\mathrm{X}$ & & - & & $\mathrm{X}$ & $\mathrm{x}$ & $\mathrm{x}$ & $\mathrm{x}$ & $\mathrm{x}$ & $\mathrm{x}$ & $\mathrm{X}$ & $\mathrm{x}$ \\
\hline & III & 5 & FORMAÇÃO DE PROFESSORES & & $\mathrm{x}$ & - & & $\mathrm{x}$ & $\mathrm{x}$ & $\mathrm{x}$ & $\mathrm{x}$ & $\mathrm{x}$ & $\mathrm{x}$ & $\mathrm{x}$ & $\mathrm{x}$ \\
\hline & IV & 6 & $\begin{array}{l}\text { FILOSOFIA, HISTÓRIA E SOCIOLOGIA DA CIÊNCIA } \\
\text { NO ENSINO DE FÍSICA }\end{array}$ & & & - & & $\mathrm{x}$ & $\mathrm{x}$ & $\mathrm{x}$ & $x$ & $x$ & $\mathrm{x}$ & $\mathrm{x}$ & $\mathrm{x}$ \\
\hline & $\mathrm{V}$ & 7 & $\begin{array}{l}\text { EDUCAÇÃO EM ESPAÇOS NÃO-FORMAIS E } \\
\text { DIVULGAÇÃO CIENTÍFICA }\end{array}$ & & & - & & & & $\mathrm{X}$ & $\mathrm{x}$ & $\mathrm{x}$ & $\mathrm{x}$ & $\mathrm{x}$ & $x$ \\
\hline & $\mathrm{VI}$ & 8 & $\begin{array}{l}\text { TECNOLOGIAS DA INFORMAÇÃO E } \\
\text { COMUNICAÇÃO E O ENSINO DE FÍSICA }\end{array}$ & & & - & & & & & $\mathrm{x}$ & $\mathrm{x}$ & $\mathrm{x}$ & $\mathrm{x}$ & $\mathrm{x}$ \\
\hline & VII & 9 & CTSA E O ENSINO DE FÍSICA & & & - & & & & & $\mathrm{x}$ & $x$ & $\mathrm{x}$ & $\mathrm{x}$ & $\mathrm{x}$ \\
\hline & VIII & 10 & $\begin{array}{l}\text { ALFABETIZAÇÃO CIENTÍFICA E TECNOLÓGICA E } \\
\text { ENSINO DE FÍSICA }\end{array}$ & & & - & & & & & $x$ & $x$ & & $\mathrm{x}$ & \\
\hline & IX & 11 & $\begin{array}{l}\text { COMUNIDADE, PRÁTICAS E POLÍTICAS } \\
\text { EDUCACIONAIS }\end{array}$ & & & - & & & & $\mathrm{X}$ & $x$ & $x$ & $\mathrm{x}$ & $\mathrm{x}$ & $\mathrm{x}$ \\
\hline & $x$ & 12 & PESQUISA EM ENSINO DE FÍSICA & & & - & $X$ & & & $x$ & & & $x$ & $x$ & $x$ \\
\hline
\end{tabular}

Quadro 4.4: Síntese da Evolução de Áreas Temáticas dos EPEF 
ii. Classificação e distribuição dos trabalhos

Uma vez que as ATs foram sendo criadas (e abandonadas) em função de escolhas de linhas de pesquisa consideradas referências da área, elas não representam necessariamente a frequência ou a distribuição de trabalhos que podem ser nelas enquadrados. As áreas definidas ou são abrangentes e genéricas demais, abarcando um grande número de trabalhos, ou são muito específicas, reunindo um número pouco expressivo deles. Há temas que podem ser considerados "tradicionais", permanentes, enquanto outros vão sendo incorporados ao longo do tempo.

Particularmente, chama atenção o tema "Ensino e Aprendizagem", um clássico, com tal abrangência que o faz ser o "número 1" em matéria de opções dos autores no enquadramento de seus trabalhos. Temática com presença expressiva nesses eventos, congregou, durante certo período, trabalhos diversificados sobre cognição e construção do conhecimento, métodos, abordagens e estratégias de ensino, recursos didáticos, currículo e avaliação. Mais recentemente se ramificou, de modo que linhas antes abarcadas nessa área ganharam uma identidade própria, enquanto categoria temática. São exemplos de desdobramentos ou novas categorias: Didática: Materiais, Métodos, Estratégias e Avaliação (SNEF, 2003, 2005, 2007, 2009); Didática, Currículo e Avaliação no Ensino de Física (EPEF, 2002, 2004, 2006 e 2008; SNEF, 2011); Didática, Currículo e Inovação Educacional no Ensino de Física (EPEF, 2000); Ensino por Investigação, Experimentação e Aprendizagem de Habilidades Científicas (ENPEC, 2009), Aprendizagem de Conceitos Científicos (ENPEC 2009). Em alguns eventos essas novas categorias foram acrescentadas, mantendo-se a tradicional "Ensino $e$ Aprendizagem": Ensino-Aprendizagem de Física (EPEF 2008); Ensino/Aprendizagem/Avaliação em Física (EPEF 2010); Aprendizagem em Física (SNEF, 2011). Ver Quadro 4.2.

Também por conta da ausência de demarcações mais explícitas das áreas propostas, e da relativa arbitrariedade de escolha ou enquadramento dos trabalhos em cada uma delas (via de regra feita pelos seus autores segundo critérios próprios) ficam comprometidas as comparações do ponto de vista da frequência ou da predominância de tendências, em um dado evento, ou das transformações e evolução dessas tendências no decorrer do tempo, em diferentes eventos.

iii. Áreas temáticas, enquadramento e identidade

As questões acima apontadas levantam a necessidade de uma reflexão sobre implicações e sentidos dessa possível tendência de "cristalização" de um conjunto de linhas temáticas da área. Por um lado, traz aspectos positivos no sentido de construir um mapeamento abrangente dos seus focos de investigação, com suas especificidades, criando uma espécie de "retrato" do que fazemos, do que pesquisamos, do que buscamos. Ou seja, seria uma forma de reforçar o que já antes 
constatamos, um desejo de afirmação de identidade. Por outro lado, especialmente porque essa construção não é abertamente debatida pelos seus protagonistas, há outra implicação questionável, já que pode levar a um "enquadramento" das possíveis questões e focos de investigação, impossibilitando ou dificultando que novas frentes aflorem.

Finalmente, ainda que tais definições sejam feitas empiricamente, sem a clara intenção de constituir um meio ou ferramenta para futuras investigações, merecem atenção especial nas coordenações desses eventos, não apenas com essa finalidade de pesquisa, mas também para melhor orientar e situar os seus participantes no "conjunto da obra". Soma-se a isso, o fato bastante significativo de que as áreas temáticas dos eventos passaram a constituir referências importantes em investigações sobre estado da arte ou, de modo geral, sobre a produção na pesquisa em Ensino de Física (ou em Ensino de Ciências, no caso dos ENPEC).

\section{Áreas Temáticas dos Eventos como Categorias de Análise}

Como já dissemos, uma das vertentes metodológicas nas investigações do tipo estado da arte, estado do conhecimento, metapesquisa ou similares, analisa a produção acadêmica a partir de categorias previamente definidas. Nessas investigações, com ou sem justificativas, de modo explícito ou não, tem se buscado delinear características e tendências da nossa produção acadêmica (seja em artigos de periódicos, dissertações e teses ou trabalhos apresentados em eventos) adotando-se em muitos casos, como categorias de análise, as áreas temáticas de eventos.

São alguns exemplos dessa vertente:

Bortoletto e colaboradores analisam artigos publicados na Revista Brasileira de Ensino de Física (RBEF) e no Caderno Brasileiro de Ensino de Física (CBEF) e trabalhos apresentados nos SNEF e EPEF no período 2000 a 2007. Utilizam como categorias temáticas, as áreas propostas no VI ENPEC, justificando:

O ENPEC reúne pesquisadores de diversas disciplinas e possui comissão organizadora e comitê de avaliação de trabalhos constituídos por pesquisadores com importantes trabalhos desenvolvidos na área de ensino de Ciências; tais pesquisadores estariam envolvidos na explicitação dos elementos constitutivos de uma pesquisa e no delineamento de enfoques de pesquisa. Neste sentido, destacamos as áreas temáticas propostas no VI ENPEC como uma representação desses enfoques de pesquisa. (BORTOLETTO et al, 2007) (grifos nossos)

Como resultado dessa análise concluem que...

...Em ambos os eventos examinados, a área temática Formação de Professores de Ciências apresentou o maior número de trabalhos de pesquisas. Em ambos os 
periódicos examinados, a área temática Aprendizagem de Conceitos Científicos é que teve o maior número de publicações. (BORTOLETTO et al, 2007)

Souza Filho et al têm como objeto de análise artigos publicados em periódicos nacionais e internacionais (Revista Brasileira de Ensino de Física, Caderno Brasileiro de Ensino de Física, International Journal of Science Education, Enseñanza de las Ciencias, Physics Education, Science Education e Studies in Science Education), além de trabalhos apresentados em eventos nacionais (EPEF e SNEF), tomando o período 2000-2005. Para classificar essa produção de modo padronizado, utilizam "grupos temáticos" que, pudemos verificar, correspondem às áreas definidas no VIII EPEF (2002), sem, contudo, explicitar essa adoção.

Os três encontros, anteriormente mencionados, apresentam grupos temáticos que variam consideravelmente de um encontro para outro, o que dificultaria a análise. Assim sendo, optamos, então, por utilizar uma categorização padronizada para estes eventos, enquadrando os trabalhos na temática de maior afinidade. (SOUZA FILHO et al, 2005) (grifos nossos)

Dessas classificações, concluem que, no caso dos trabalhos apresentados nos eventos...

...É inegável a hegemonia do grupo temático "Ensino/Aprendizagem", sendo a área mais explorada dos eventos, seguida pelos trabalhos relacionados à "Formação de Professores. (SOUZA FILHO et al, 2005)

O mesmo se repete para as publicações nos periódicos, tomados em seu conjunto:

A temática mais predominante nestes periódicos analisados é aquela relacionada à questão do "Ensino/Aprendizagem de Física", tendo sido publicados 177 artigos, muito embora outros artigos poderiam também se alocar nesta temática. (SOUZA FILHO et al, 2005)

Rezende et al investigam periódicos nacionais da área, no período de 2000 a 2006, analisando artigos que focalizam o ensino e aprendizagem de Física no nível médio.

...o universo de trabalho foi classificado segundo um conjunto de temáticas definidas a partir de uma composição das temáticas utilizadas nas últimas edições do Encontro de Pesquisa em Ensino de Física e do Simpósio Nacional de Ensino de Física, resultando em um total de doze categorias. (REZENDE et al, 2007). (grifos nossos)

Considerando que "a classificação do universo de trabalhos selecionados segundo as categorias definidas mostrou que a grande maioria das publicações nos periódicos da área está dirigida a questões relacionadas ao ensino-aprendizagem de Física" (cerca de dois terços do total) os autores fazem nova classificação em sub-temas por eles 
criados: Referenciais teóricos para o ensino e aprendizagem; Resolução de problemas; Metodologias/Estratégias de ensino-aprendizagem; Levantamento de concepções; Avaliação da aprendizagem; Recursos didáticos; Laboratório didático; Conteúdos reelaborados para o ensino médio.

Terrazzan e colaboradores (um grupo de pesquisadores de larga experiência na área, de instituições diversas do país) apresentaram, no VII EPEF, um projeto de trabalho visando uma reflexão das investigações em nossa área. Para isso, os campos temáticos do VII EPEF seriam utilizados na análise de uma vasta produção nacional, abrangendo todas as edições dos SNEF, EPEF e ENPEC, as publicações da RBEF, do CCEF, IEC, CE e Ensaio, além das bases de dados ENFIS/IFUSP e CEDOC/FE-UNICAMP.

A escolha das linhas de pesquisa, vertentes de investigação ou campos temáticos certamente é arbitrária e serve apenas para iniciar o processo de coleta das informações, sendo que a categorização final surge usualmente de várias releituras do material devidamente coletado e organizado, tendo em vista uma melhor compreensão do todo...Para esta análise preliminar adotamos, basicamente, os campos temáticos apontados pela comissão organizadora no próprio boletim do VII EPEF, ou seja: 1. Ensino-Aprendizagem-Avaliação: Espaços Formais e Não-Formais; 2. Formação do Professor de Física; 3. Currículo e Inovação Educacional; 4. Balanço Crítico das Pesquisas; 5. Ciência, Sociedade e Ensino. (TERRAZZAN et al, 2000, p.137) (grifos nossos)

Queiroz e Silva (QUEIROZ e SILVA, 2008) analisam cerca de 305 trabalhos das atas do EPEF, referentes aos anos de 1998 a 2004, utilizando as ATs dos EPEF como base para classificações temáticas. Apesar de não explicitarem, as dez categorias tomadas possivelmente são uma composição de diferentes eventos, já que não correspondem a um EPEF em particular.

Seus dados mostram, como nos demais trabalhos, a supremacia da categoria "Ensino e Aprendizagem" sobre a qual, na explicitação de suas características e delimitações, as próprias autoras tecem as considerações:

Algumas áreas temáticas são bem amplas, como Ensino Aprendizagem de Física, onde trabalhos de naturezas bem diversas são incluídos tais como concepções alternativas, modelos mentais, aprendizagem significativa, resolução de problemas, além de revisões bibliográficas, reflexões sobre o ensino de física, aplicação de metodologias como subsídio para o ensino, entre outros. (QUEIROZ e SILVA, 2008)

Em relação a essa tendência metodológica, apontamos alguns aspectos que merecem reflexão. 


\section{i. Categorias definidas apriori}

O primeiro deles refere-se à adoção de categorias de análise definidas apriori. Ou seja, olhar para um dado objeto de análise segundo uma estrutura de classificação construída previamente, não necessariamente com base nesse objeto, na própria produção. Tal metodologia pode levar a uma análise com vícios ou lacunas, já que toda e qualquer produção deverá ser "enquadrada" em uma dessas categorias, impedindo o surgimento de novas possibilidades.

\section{ii. Diferentes nomes ou diferentes coisas}

As denominações para as categorias definidas nas diversas classificações são utilizadas indiscriminadamente. Apenas nessa amostra, encontramos "rótulos" como: campo temático, foco temático, área temática, grupo temático, categoria temática, linha de pesquisa, enfoque de pesquisa, vertente de investigação. E aí coloca-se a questão: estaríamos todos falando da mesma "coisa"? Ainda que os objetos de estudo sejam os mesmos (a produção na área), considerando-se as diversas escolhas temporais ou tipo de produção (artigo, trabalho em evento, tese...), o instrumento para classificá-los só mudaria de nome? Ou os diferentes nomes representam olhares diferentes? Não é possível saber. O que se pode afirmar é que essa preocupação parece ausente.

\section{iii. Áreas de eventos como referência genérica}

Será que as ATs definidas nos eventos podem ter o status de "referências genéricas" para toda a produção? Ou seja, são suficientemente abertas / abrangentes para dar conta de trabalhos de naturezas distintas, como comunicações em (diferentes) eventos, artigos de (diferentes) periódicos ou teses? Nesse caso teriam um caráter mesmo de "linhas de pesquisa" na área? Só prá exemplificar: as ATs dos EPEF são referência para organizar / classificar / analisar trabalhos apresentados no SNEF? Ou para artigos de periódicos? Nesse último caso, observa-se que há periódicos com linhas editoriais diversas, alguns deles já voltados para determinadas temáticas ma is específicas e para os quais essas categorias não se adequariam.

\section{iv. Áreas que não discriminam}

Os resultados desses e de outros trabalhos reforçam o problema já levantado de que há áreas muito abrangentes que não discriminam linhas ou tendências da produção. Frequentemente conclui-se que predominam os focos temáticos "Ensino e Aprendizagem" ou "Formação de Professores", o que é inerente a uma área de pesquisa em ensino. Em alguns casos, os autores reconhecem a necessidade de criar ou compor categorias de modo a melhor identificar ou discriminar essas tendências.

v. Desneutralização ou desnaturalização 
Outro risco que se corre ao adotarmos temáticas pré-estabelecidas como categorias de análise da produção é a falsa ideia de que se tratem de escolhas neutras, objetivas, sem trazerem uma concepção de nossa área de pesquisa: porque essas e não outras linhas, o que abarcam, porque essa metodologia etc.. Seriam essas escolhas "naturais"? De onde vêm? Têm uma lógica própria da evolução da pesquisa em nosso país? Trata-se de importação ou modismo? Existe alguma hierarquia nas estruturas temáticas propostas?

A nosso ver não são escolhas neutras e naturais, ainda que expressem essa ideia. Refletem uma compreensão do que sejam questões inexoráveis ou relevantes na pesquisa. Claro que de certo modo fundamentadas na "realidade" do que se vem pesquisando. Mas é aí que pode se estar criando um ciclo vicioso ou viciado.

\subsubsection{Definição de temáticas com base na produção da área}

Em outra forma de tratar metodologicamente os campos temáticos, na qual nos enquadramos em trabalhos diversos, categorias de análise são definidas a partir do material bruto analisado - na produção em artigos de periódicos, trabalhos apresentados em eventos ou dissertações e teses.

As primeiras investigações na área de Ensino de Ciências / Física nessa linha foram desenvolvidas no início da década de 1990 por Megid (MEGID, 1990) e Salem e Kawamura (SALEM e KAWAMURA, 1993a; 1993b; 1994a; 1994b).

Megid, em sua dissertação de mestrado (MEGID, 1990) investiga as dissertações e teses em Ensino de Física com foco no segundo grau, defendidas até 1987, dedicando um capítulo às temáticas dessa produção. Para isso, cria, apresenta e classifica essa produção segundo categorias próprias.

As categorias, que classificam tais temáticas, foram concebidas a partir da identificação do tema central de cada pesquisa, de modo a envolverem todos os trabalhos, e cuja denominação (de cada categoria) mostrasse, explicitamente, o assunto principal tratado. Desta forma, não configuramos categorias bem delimitadas, com fronteiras definidas e não superpostas. Se isto ocorresse, poderíamos obter um número muito reduzido de categorias em virtude do aglutinamento de temas afins ou correlatos no conjunto de pesquisas acadêmicas sobre ensino de Física do $2^{\circ}$ Grau. Porém, pelo fato de cada tema apresentar peculiaridades próprias, essas categorias não apontariam, com clareza, a temática central de cada tese ou dissertação. (MEGID, 1990, p. 86) 


\section{MEGID 1990}

Concepções Espontâneas

Projetos de Ensino

Desenvolvimento Intelectual

Ensino Experimental

Currículo

Material Didático

Caracterização de Situação

Educacional

Métodos de Ensino

Cursos Específicos

Vestibular

\section{MEGID 1999}

Currículos e Programas

Conteúdo-Método

Recursos Didáticos

Características do Professor

Características do Aluno

Formação de Conceitos

Formação de Professores

Políticas Públicas

Organização da Escola

Organização da Instituição/Programa

de Ensino não-Escolar

Filosofia da Ciência

História da Ciência

História do Ensino de Ciências

Outro

Posteriormente, em sua tese de doutorado, Megid tem como universo as dissertações e teses em Ensino de Ciências no nível fundamental (MEGID, 1999). Entre diversos parâmetros, novamente procura identificar as tendências da pesquisa acadêmica segundo um conjunto de focos temáticos constituídos com base na literatura na área e na produção analisada.

O conjunto de descritores específicos com respeito ao foco temático das teses e dissertações foi estabelecido tendo por base três estudos sobre as pesquisas acadêmicas na área de Ensino de Ciências... (os trabalhos citados são MEGID, 1990; FRACALANZA, 1993; IFUSP, 1992 e 1995)

... De um modo ou de outro, os três estudos exprimem um conjunto de aspectos a serem considerados na classificação e descrição dos temas da produção acadêmica em Ensino de Ciências, constituído a partir da literatura na área e da análise dos próprios documentos a serem classificados. Nesses estudos não se configuram, pois, elencos de descritores estabelecidos a priori. Também se reconhece a existência de sobreposições parciais entre alguns descritores dos temas das pesquisas, não havendo uma delimitação precisa das fronteiras entre os mesmos, nem uma ordenação hierárquica. Ressaltam ainda que muitos aspectos temáticos considerados possuem naturezas distintas, além de uns serem mais abrangentes e outros mais especificos. (MEGID, 1999)(grifos nossos)

Essas mesmas categorias vêm sendo adotadas em diversos estudos posteriores para diferentes produções em Ensino de Ciências, alguns recentes, do próprio autor (MEGID, 2000; TEIXEIRA e MEGID, 2009) e também por outros pesquisadores, a exemplo de Lemgruber (1999). 
Também desde o início da década de 1990, desenvolvemos e apresentamos um número expressivo de investigações, visando caracterizar a produção na área de Ensino de Física (e em Ensino de Ciências), adotando metodologia similar à de Megid. Nossos primeiros trabalhos com tal perspectiva foram desenvolvidos quando da estruturação do Banco de Dados de Referências em Ensino de Física em 1990 (base de dados ENFIS) e, a partir deste, a elaboração do primeiro volume do Catálogo Analítico de Dissertações e Teses.

A primeira publicação em que apresentamos uma proposição de categorias temáticas foi feita para as dissertações e teses compreendidas no período 1972-1992 (USPInstituto de Física, 1992). A segunda foi apresentada em trabalho onde analisamos o conjunto da produção na área catalogada no Banco de Referências, incluindo artigos, teses, projetos, eventos e outras publicações (SALEM; DEL CARLO; KAWAMURA, 1993).

\section{USP-IF 1992 (SALÉM \& KAWAMURA)}

1. História e filosofia da ciência

2. Concepções espontâneas

3. Abordagens piagetianas

4. Estrutura conceitual

5. Ensino experimental

6. Recursos didáticos

7. Métodos de ensino

8. Projetos de ensino

9. Formação do professor

10. Currículo / Programas de disciplinas

11. Características institucionais

12. Vestibular

13. Ensino de ciências / física

para o $1^{\circ}$ Grau

14. Abordagens gerais

15.Outros

\section{SALÉM \& KAWAMURA 1993b}

1. Aprendizagem/cognitivismo

2. Concepções espontâneas

3. Métodos de ensino

4. Recursos didáticos

5. Ensino experimental

6. Currículo

7. Formação do Professor

8. Questões institucionais

9. Avaliação

10. Vestibular

11. Ciências de 1‥ Grau

12. História da Educação

13. Educação e Sociedade

14. Política educacional

15. Educação-concepção

16. História e Filosofia da Ciência

17. Ciência e Sociedade

18. Ciência e Tecnologia

19. Divulgação Científica

20. Pesquisa em Ensino

\section{SALEM E KAWAMURA 1994}

1. Psicologia e Aprendizagem

2. Métodos e Abordagens

3. Recursos Didáticos

4. Ensino Experimental

5. Projetos de Ensino

6. Currículo

7. Avaliação

8. Física no Ensino Fundamental

9. Pós-Graduação e Pesquisa

10. História e Filosofia da Ciência

11. Formação do Professor

12. Educação e Sociedade

13. Educação não Formal

14. Educação - concepções

15. História da Educação

16. Questões Institucionais

17. Ciência e Sociedade

Quadro 4.6: Temáticas I (Salem e Kawamura)

Esses primeiros trabalhos resultaram em "Listas" de temas, ainda que com certa organização hierárquica, não configuravam propriamente uma estrutura, tal como os focos temáticos de Megid. (Quadro 4.6). A partir desses estudos, mantivemos um trabalho sistemático de classificação e estruturação de categorias temáticas, 
envolvendo amostras bastante diversas, e já com uma clara intenção de chegar a uma estrutura organizada, com abrangência que pudesse dar conta dessa diversificada produção na área, ao mesmo tempo em que refletir as tendências que vinham se configurando ao longo de sua evolução. (Quadro 4.7)

\section{SALEM E KAWAMURA 2005}

1. Cognição e Construção do Conhecimento

2. Métodos, Abordagens e Estratégias de Ensino

3. Recursos e Materiais Didáticos

4. Tecnologia da Informação

5. Formação de Professores

6. Divulgação Científica

7. Diretrizes e Ênfases Educacionais

8. Evolução da Pesquisa em EC

9. História e Filosofia da Ciência

10. Seleção e Organização do Conhecimento

11. Educação Ambiental

12. Educação em Saúde

\section{SALEM E KAWAMURA 2008}

1. Processos Cognitivos de Ensino-Aprendizagem

2. Materiais, Métodos e Estratégias de Ensino

3. Diretrizes, Seleção e Organização do Conhecimento

4. Formação de Professores

5. História, Filosofia e Sociologia da Ciência

6. Ciência, Tecnologia e Sociedade

7. Educação em Espaços Não-Formais

8. Tecnologias da Informação e Comunicação

9. Ciência e Cultura

10. Pesquisa em Ensino de Ciências

11. Outros

\section{SALEM E KAWAMURA 2007}

1. Processos de ensino-aprendizagem: cognição

2. Materiais, métodos e estratégias de ensino

3. Currículo: diretrizes, seleção e organização do conhecimento

4. Formação inicial e continuada de professores

5. História, filosofia e sociologia da ciência

6. Ciência, tecnologia, sociedade e ambiente

7. Divulgação científica e educação em espaços não formais

8. Tecnologias da informação no ensino

9. Física e cultura

10. Pesquisa em ensino de física

11. Questões institucionais e políticas públicas

12. Temas diversificados

\section{SALEM E KAWAMURA 2009}

1. Processos Cognitivos de Ensino-Aprendizagem

2. Materiais, Métodos e Estratégias de Ensino

3. Seleção e Organização do Conhecimento

4. Formação de Professores e Prática Docente

5. História, Filosofia e Sociologia da Ciência

6. Ciência, Tecnologia e Sociedade

7. Divulgação Científica e Educação em Espaços Não-Formais

8. Tecnologias da Informação e Comunicação

9. Ciência, Educação Científica e Cultura

10. Educação, Política e Sociedade

11. Pesquisa em Ensino de Ciências / Física

Quadro 4.7: Temáticas II (Salem e Kawamura)

O procedimento adotado nas classificações da produção incluiu a atribuição de um tema central e, eventualmente, de um sub-tema. Esses temas e sub-temas deveriam ter uma definição específica clara, mas, ao mesmo tempo, abrangência suficiente para permitir análises mais gerais. Para se chegar a uma estrutura final, foram realizadas diversas classificações e comparações entre pares, a partir da leitura do resumo e/ou do trabalho completo, sempre que disponível, e assumindo definições 
de forma independente da classificação eventualmente proposta pelos próprios autores dos títulos em estudo.

Como relatamos no primeiro desses trabalhos (1992), quando da definição de temas na elaboração do primeiro volume do catálogo de teses,

O conjunto de temas não contempla, por esse motivo, todas as áreas de pesquisa e não apresenta uma estrutura lógica ou hierárquica. Alguns temas são abrangentes, outros mais especificos, além de terem naturezas diferentes. As fronteiras entre os temas não são bem delimitadas, havendo, inclusive, algumas sobreposições. A ordem em que estão apresentados também não segue qualquer hierarquia...

...Essas características são consequência do critério utilizado para classificação e devem-se essencialmente à natureza da área em questão. Identificar o tema central de uma pesquisa acadêmica em uma área interdisciplinar e abrangente como a de ensino de física nem sempre é tarefa fácil.

Um exemplo disso é a criação de uma categoria para a Física do Primeiro Grau (Categoria 13) e não equivalentes para o Segundo ou Terceiro graus. Isso se deve à marcante especificidade guardada pelo ensino de física no primeiro grau, parte do ensino de Ciências, sendo frequentemente tratado nas teses de uma forma bem delimitada e à parte dos outros níveis de ensino. O segundo e o terceiro graus, ainda que também tenham claramente suas particularidades, não são em geral tratados enquanto temas globais, mas aparecem dispersos nos diferentes aspectos e problemáticas pelos quais podem ser abordados... (UNIVERSIDADE DE SÃO PAULO - Instituto de Física, 1992, p.81)

Ao longo dos anos e da evolução da área, buscamos acompanhar as transformações da produção e passamos e estabelecer categorias temáticas mais definidas, utilizando como critérios os inúmeros e diversificados trabalhos já anteriormente analisados, mas já levando em conta as linhas ou enfoques de pesquisa tradicionalmente estabelecidos. Chegamos, desse modo, a uma proposição que representa uma combinação entre o objeto concreto (a produção de fato, tendo em conta as suas unidades e diversidades) e as referências dadas pela comunidade acadêmica. As duas últimas dessas composições (SALEM E KAWAMURA, 2008 e 2009), por nós utilizadas em trabalhos recentes, constituem, hoje, uma proposta de instrumento de análise dos focos ou áreas temáticas da PEF, que será utilizada nessa pesquisa, sistematizada no Quadro 4.8. 


\section{ESTRUTURA TEMÁTICA}

1. Processos Cognitivos de Ensino-Aprendizagem

2. Materiais, Métodos e Estratégias de Ensino

3. Seleção de Conteúdos e Organização do Conhecimento

4. Formação de Professores e Prática Docente

5. História, Filosofia e Sociologia da Ciência

6. Ciência, Tecnologia e Sociedade

7. Divulgação Científica e Educação em Espaços Não-Formais

8. Tecnologias da Informação e Comunicação

9. Ciência, Educação Científica e Cultura

10. Educação, Política e Sociedade

11. Pesquisa em Ensino de Ciências / Física

\section{Temas e Sub-temas}

1. Processos Cognitivos de Ensino-Aprendizagem

1.1 Construção conceitual (modelos, propostas e diagnósticos de ensino-aprendizagem e construção de conhecimento do aluno; concepções de alunos; perfil conceitual; estruturas conceituais / campo conceitual)

1.2 Interações sócio-afetivas no processo de ensino-aprendizagem (relação professor-aluno / aluno-aluno; interação dialógica; psicanálise e ensino...)

1.3 Linguagem e cognição

1.4 Avaliação da aprendizagem

\section{Materiais, Métodos e Estratégias de Ensino}

2.1 Recursos didáticos (à exceção de livros, experimentos e TIC)

2.2 Metodologias e estratégias de ensino (projetos de ensino, metodologias, estratégias e atividades didático-pedagógicas, resolução de problemas)

2.3 Laboratório didático e atividades experimentais

2.4 Livro Didático e textos paradidáticos

\section{Seleção e Organização do Conhecimento}

3.1 Currículo e programas (propostas, reflexões, análise de estrutura curricular de cursos ou programas de disciplinas mais gerais, ênfases curriculares)

3.2 Física Moderna e Contemporânea no Ensino Médio e na Formação de Professores

3.3 Seleção de conteúdos e temas para dado curso, disciplina ou área de conhecimento

3.4 Abordagens e critérios na organização do conhecimento (interdisciplinaridade, contextualização, problematização, habilidades e competências, abordagens temáticas ou integradoras, física do cotidiano...)

3.5 Conhecimento escolar x Conhecimento científico e Ciências como disciplina

\section{Formação de Professores e Prática Docente}

4.1 Formação inicial de professores (discussões, proposições, reflexões, relatos sobre cursos de licenciatura e respectivas disciplinas)

4.2 Formação continuada de professores (discussões, proposições, reflexões sobre formação continuada / aperfeiçoamento / atualização / capacitação / especialização / extensão)

4.3 Perfil profissional e prática docente (diagnósticos de condições profissionais, perfil de professores, relatos e avaliação de prática docente, papel do professor)

4.4 Concepção de professores sobre temas diversos 
5. História, Filosofia e Sociologia da Ciência

5.1 História e Filosofia da Ciência no ensino de Física (propostas, avaliações, reflexões sobre o uso de temas, materiais ou estratégias de ensino com enfoque na HFSC nos diferentes níveis de ensino)

5.2 Concepções e Representações de Ciência

5.3 Estudos abrangentes sobre História e Filosofia da Ciência (não diretamente ligados ao ensino)

5.4 Características e modelos sobre conhecimento científico/físico

5.5 História da Física, dos físicos e/ou do ensino de Ciências / Física no Brasil

6. Ciência, Tecnologia, Sociedade

6.1 Abordagens CTSA no ensino (explícitas ou não)

6.2 Alfabetização científica e tecnológica

6.3 Discussões e concepções sobre Ciência e Tecnologia

7. Divulgação Científica e Educação em Espaços Não-Formais

7.1 Divulgação científica (discussões, análise do papel ou características da DC em diferentes espaços; disseminação e popularização da Ciência)

7.2 Museus e Centros de Ciências

7.3 Educação não-formal (de modo mais geral)

8. Tecnologias da Informação e Comunicação (TIC)

8.1 TIC propriamente dita (uso no ensino formal / presencial)

8.2 TIC no Ensino a Distância

9. Ciência, Educação Científica e Cultura (ou Ciência e Cultura)

9.1 Ciência e Cultura no Ensino (Ciência e Arte; Ciência e Literatura...)

10. Educação, Política e Sociedade

10.1Políticas Educacionais (políticas públicas para educação e/ou educação científica; legislação educacional; avaliação institucional...)

10.2 Educação - concepções e finalidades

10.3 História da Educação

10.4Questões Institucionais (perfil e memória institucional / evasão / vestibular)

11. Pesquisa em Ensino de Ciências / Física (metapesquisa)

QUADRO 4.8: Estrutura temática ( Salem e Kawamura, 2008)

\subsubsection{Considerações sobre as duas vertentes e novas demandas metodológicas}

No que se refere à primeira vertente, para a qual já apontamos algumas questões (definições de categorias aprióri e uso das áreas temáticas dos eventos), não é possível extrairmos algum tipo de síntese, uma vez que são trabalhos isolados, sem muito diálogos e intercâmbios entre si. No que se refere a resultados dessas investigações, esses são pontuais e, frequentemente, têm como conclusão a supremacia das áreas "Ensino e Aprendizagem" e "Formação de Professores", o que, a princípio não diz muito sobre quais conteúdos, abordagens ou olhares para o Ensino de Física abarcam. Para isso, seriam necessárias maiores explicitações e 
discussões sobre esses conteúdos e olhares, identificados com concepções da área, de sua evolução e perspectivas.

Quanto à segunda vertente, entendemos que traz como contribuição, quadros sintéticos das categorias temáticas melhor demarcadas, e fruto de uma construção elaborada a partir do material bruto, da própria produção. No entanto, também apresenta problemas e desafios. Dentre esses, apontamos dois aspectos que merecem destaque e reflexão.

O primeiro refere-se a uma questão de ordem temporal, que implica dificuldades na análise da evolução da pesquisa. As categorias estabelecidas ao longo do tempo e "cristalizadas" em dado momento, nem sempre se adequam quando queremos voltar a analisar a produção ao longo de seu desenvolvimento, em períodos diferentes.

Tomando como exemplo o conjunto de focos temáticos propostos por Megid (MEGID, 1999) e utilizados posteriormente por outros pesquisadores, podemos identificar lacunas quanto a enfoques ou temas presentes em anos posteriores (como Divulgação Científica, abordagem CTSA, Tecnologias de Informação e Comunicação, relações Ciência e Cultura), o que requereria, para analisar a produção atual, acréscimos ou adaptações.

Por outro lado, se tomarmos a nossa versão mais recente (SALEM E KAWAMURA, 2009), algumas das temáticas incluídas não teriam trabalhos representantes do "passado", como é o caso exatamente das temáticas citadas acima, no exemplo da proposta de Megid.

No que se refere, contudo, a essa última proposta, destacamos uma importante distinção em relação à de Megid. Uma vez que procuramos dar à estrutura temática uma lógica própria, que não constituísse apenas um rol de temas, é possível enquadrarmos diferentes trabalhos, desenvolvidos em períodos distintos, ou de naturezas distintas, nas áreas temáticas propostas. Enfoques como "Concepções Espontâneas", muito presentes na década de 1980, estão abarcados pela área denominada "Processos Cognitivos de Ensino e Aprendizagem". Investigações sobre "Laboratório ou Atividades Experimentais", explorados com intensidade nas décadas de 1970 e parcialmente na de 1980, são contemplados pela área "Materiais, Métodos e Estratégias de Ensino". Propostas de programas de cursos e disciplinas do tipo "Física para Engenharia" ou "Astronomia no Primeiro Grau", focalizadas em períodos anteriores, são representadas pela área "Seleção e Organização do Conhecimento", assim como questões atuais pertinentes a esse campo, tais como "Física Moderna e Contemporânea no Ensino Médio".

Assim, tal estrutura, com áreas abrangentes e demarcadas, permite mais adequadamente o enquadramento e a análise da produção na área em épocas 
distintas. A ausência de enfoques em dado campo temático, ontem ou hoje, em teses, artigos ou eventos, no Norte ou no Sul, em dissertações de Mestrado ou Teses de Doutorado, por exemplo, tem um significado, seria sinalizadora de algum tipo de evolução, de focos de interesse na área temporal ou espacialmente.

Finalmente, um outro desafio apresentado por qualquer das vertentes ou propostas metodológicas, refere-se à necessidade, ainda que com demarcações e abrangências, de agrupar, sintetizar e, sobretudo significar esses focos ou áreas temáticas, como categorias de análise de nossa produção. Desafio esse que nos levou a dar um passo além da estrutura de temas proposta, buscando sistematizar o conjunto de categorias e criar um instrumento que permitisse identificar perspectivas mais amplas abarcadas por diferentes áreas temáticas. É o que tratamos a seguir.

\subsection{Eixos organizadores}

Ao longo do tempo passamos a buscar uma sistematização das categorias dos muitos conjuntos de trabalhos, procurando identificar perspectivas temáticas comuns. Para isso, procuramos reestruturar nossos conjuntos de focos temáticos em eixos organizadores, que comporiam a totalidade das pesquisas desenvolvidas na área, assim como compõem a própria prática em que o aprendizado das ciências se dá, segundo diferentes perspectivas.

Conforme acenamos no segundo capítulo, nos interessa olhar para esse campo com uma abrangência que dê conta das multi-dimensões em que uma área de Ensino como a nossa pode situar-se. Para isso, consideramos que a atuação na área envolve três dimensões ou eixos organizadores, conforme propõem Menezes e colaboradores, (MENEZES et al, 1997).

Esses autores identificam, nas atividades de ensino de ciências e da formação de professores, a existência de três âmbitos distintos, frequentemente tratados independentemente ou considerados aos pares, que, em seu conjunto constituem um espaço complexo de conceitos, de práticas e de intenções formativas: o âmbito científico propriamente, relacionado às áreas científicas e ao objeto de aprendizado escolar, o âmbito educacional, dos objetivos e intenções formativas e o âmbito dado pelo conjunto dos processos de aprendizado, com seus recursos e estratégias.

As ciências, enquanto objeto do aprendizado escolar, os objetivos educacionais, como as competências e valores que se pretende desenvolver, e os processos de aprendizagem, com seus recursos e estratégias, constituem três âmbitos distintos, frequentemente tratados independentemente ou considerados aos pares, em suas interfaces. As três interfaces entre esses âmbitos, ou seja, entre objetivos e áreas, entre áreas e processos e entre processos e objetivos 
constituem, tomadas em seu conjunto, um complexo espaço de conceitos, de práticas e de interações formativas. (MENEZES, KAWAMURA, HOSOUME, 1997)

Compartilhando essa análise, assumimos a identificação desses três âmbitos com as ênfases ou perspectivas da produção na área: (i) objetivos da educação, (ii) processos de ensino-aprendizagem e (iii) conhecimento científico focalizado. Tais ênfases compõem, então, três eixos, denominados de forma abreviada, respectivamente por Educação (E), Processos de Ensino-Aprendizagem (P) e Conhecimento (C). Embora sejam complementares e estejam presentes em menor ou maior grau na pesquisa em ensino, pode-se identificar quase sempre uma ênfase predominante em um deles, associados, respectivamente, a preocupações com o para quê ensinar (perspectiva educacional), com o como ensinar (meios e processos de ensinoaprendizagem) e com o quê ensinar (seleção e organização do conhecimento).

Se consideradas como eixos cartesianos, essas três dimensões definem o espaço das práticas e das perspectivas de investigação da área. Suas múltiplas combinações, dois a dois, constituem "planos" ou interfaces onde mais frequentemente os trabalhos de pesquisa se situam.

\subsubsection{Eixos, temas e sub-temas}

Tendo em vista a busca de perspectivas comuns para sistematizar e significar os trabalhos de pesquisa na área, tomamos como referência esses três eixos, aos quais procuramos associar as áreas temáticas então definidas no tópico anterior, de modo a compor um conjunto de enfoques temáticos, ao mesmo tempo abrangente e sintético, aperfeiçoando o instrumento a ser utilizado para análise da produção e identificação de suas tendências ou focos de interesse. Apresentamos a seguir essa organização nos três eixos, identificando as áreas temáticas e respectivos subconjuntos de temas abarcados por eles.

\begin{tabular}{l} 
EIXOS ORGANIZADORES \\
PROCESSOS DE ENSINO-APRENDIZAGEM \\
Processos Cognitivos de Ensino-Aprendizagem \\
Materiais, Métodos e Estratégias de Ensino \\
Tecnologias da Informação e Comunicação \\
CONHECIMENTO \\
Seleção e Organização do Conhecimento \\
História, Filosofia da Ciência e Sociologia da Ciência \\
Ciência, Educação Científica e Cultura \\
CTS \\
EDUCAÇÃo \\
Formação de Professores e Prática Docente \\
Educação, Política e Sociedade \\
Divulgação Científica e Educação não-formal \\
Pesquisa em Ensino de Ciências \\
\hline
\end{tabular}

Quadro 4.5: Eixos organizadores das áreas temáticas de pesquisa 


\section{EIXO I. Processos de Ensino-Aprendizagem}

Nesse eixo, destacam-se os meios, as práticas e os fazeres de estudantes e professores - materiais, métodos, recursos e estratégias - que compõem os meios, procedimentos ou processos de ensino e aprendizagem. Abarca, assim, trabalhos cujo enfoque predominante está nos aspectos cognitivos e metodológicos do aprender e ensinar. Têm como perspectiva predominante, ou como foco principal os meios ou o "como ensinar".

Envolve temas ou aspectos como: cognição e construção do conhecimento (concepções de estudantes, mudança conceitual, estrutura cognitiva, perfil conceitual); métodos, abordagens e estratégias de ensino; materiais e recursos didáticos; avaliação da aprendizagem e/ou dificuldades dos estudantes; interações sócio-afetivas.

Temas predominantes:

PROCESSOS COGNITIVOS DE ENSINO-APRENDIZAGEM: Trabalhos que abordam aspectos do processo de ensino-aprendizagem relativos à construção do conhecimento e à formação conceitual. Tratam de modelos, propostas e diagnósticos de aprendizagem na construção do conhecimento, das concepções conceituais dos estudantes, das suas dificuldades e de mudanças produzidas pelo ensino; das inter-relações sócio-afetivas; da avaliação e dos aspectos lingüísticos na formação conceitual ou nos discursos de estudantes e professores. Tem como principais sub-temas:

- Aprendizagem e/ou Construção conceitual: modelos, propostas e diagnósticos de ensinoaprendizagem e construção de conhecimento do aluno (concepções de alunos / concepções espontâneas / perfil conceitual / mudança conceitual / estruturas conceituais...)

- Interações sócio-afetivas no processo de ensino-aprendizagem (relação professor-aluno / interação dialógica / psicanálise e ensino...)

- Linguagem e cognição

- Avaliação da aprendizagem

MATERIAIS, MÉTODOS E ESTRATÉGIAS DE ENSINO: Trabalhos que têm como foco principal diferentes métodos, estratégias, abordagens ou recursos didáticos. Abrange uma grande diversidade de propostas metodológicas ou relatos e resultados de atividades e intervenções em sala de aula, análise ou propostas de utilização de recursos didáticos. São alguns dos subtemas:

- Recursos didáticos: filme / ficção científica / jornais / jogos... (à exceção das TICs)

- Metodologias e estratégias de ensino: estratégias e atividades didáticas, metodologias de ensino, projetos de ensino, atividades lúdicas...

- Laboratório didático e atividades experimentais 
- Livro Didático

- Resolução de Problemas / Aprendizagem Baseada em Problemas

TECNOLOGIAS DA INFORMAÇÃO E COMUNICAÇÃO (TIC): Ainda que, em muitos casos, as tecnologias de informação no ensino tenham o caráter de "recurso didático", esse tema está sendo destacado à parte, pelas características próprias que o fazem hoje uma linha de pesquisa em nossa área. Trata do uso de diferentes recursos tecnológicos no ensino, especialmente da internet e outras aplicações da informática, como simulações e applets. Como sub-temas, distinguimos dois âmbitos que fazem uso das TICs:

- TIC como recurso no ensino formal/escolar

- TIC como instrumento para a Educação a Distância.

\section{EIXO II. Conhecimento}

Eixo centralizado no objeto do ensino, na dimensão disciplinar, em que se destacam trabalhos centrados nos conteúdos, temas, formas de organização, seleção e abordagem do conhecimento. Focalizam mais marcadamente "o quê ensinar".

Temas predominantes:

SELEÇÃO E ORGANIZAÇÃO DO CONHECIMENTO: Propostas, reflexões e relatos de pesquisas sobre opções na seleção do conhecimento: seleção e organização de conteúdos e temas para o ensino de Ciências/Física, tais como currículos e programas de cursos ou disciplinas, inserção e tratamento de tópicos e temas nos diferentes níveis de ensino. Engloba os subtemas:

- Currículo e programas (propostas e discussões sobre conteúdos ou temas em cursos / programas / grades curriculares / ênfases curriculares)

- Física Moderna e Contemporânea (no Ensino Médio e na Formação de Professores)

- Seleção de conteúdos para dado conhecimento ou área científica (que não FMC): Ensino de Astronomia / Ensino de Óptica / Energia /...

- Transposição Didática

- Interdisciplinaridade / Contextualização / Problematização / Abordagens integradoras / Complexificação / Cotidiano / Competências e Habilidades (na perspectiva do Conhecimento)

- Conhecimento escolar x Conhecimento científico / ciências como disciplina

- Ensino Superior - Bacharelado / formação do Pesquisador

- Ensino profissionalizante / cursos técnicos

HISTÓRIA E FILOSOFIA DA CIÊNCIA: Investigações, discussões ou propostas relativas a aspectos históricos, filosóficos ou sociológicos da ciência e suas implicações no ensino em diferentes níveis ou abordagens. Incluem-se aqui, particularmente, as concepções de ciência presentes em textos didáticos ou nos discursos de alunos e professores. Sub-temas: 
- História e Filosofia da Ciência no ensino de Física: propostas / avaliações / reflexões sobre o uso de temas, materiais ou estratégias de ensino com enfoque na HFC nos diferentes níveis de ensino

- Concepção / Representação de Ciência (em materiais ou de alunos e professores)

- HFSC da Ciência + abrangente / genérico, não diretamente ligada ao ensino

- Características do conhecimento físico: física x matemática / modelos e modelagens

CIÊNCIA, EDUCAÇÃO CIENTÍFICA E CULTURA: em uma interface Ciência e Educação, mas com ênfase no conhecimento, encontram-se trabalhos que discutem abordagens ou tratamentos do conhecimento científico, estabelecendo vínculos desse com aspectos sociais, ambientais ou tecnológicos, com o cotidiano e contexto sócio-cultural, ou com outras áreas do saber. Privilegiam, na escolha de conteúdos, temas que promovem vínculos da Ciência e Cultura, em diferentes manifestações, como a literatura, as artes etc... . Mais acentuadamente tratam do conhecimento científico como dimensão da cultura humana ou social. Sub-temas:

- Abordagens CTSA no ensino de ciências / física em diferentes níveis

- Alfabetização científica e tecnológica

- Discussões / concepções sobre Ciência \& Tecnologia

- Ciência e Cultura / Ciência e Artes / Ciência e Literatura

\section{EIXO III. Educação}

Eixo no qual a perspectiva educacional - objetivos, valores, concepções - é priorizada. Agrupa temas que privilegiam concepções, diretrizes e finalidades da educação ou da formação de educadores. Têm como foco principal o "para quê ensinar".

Temas predominantes:

FORMAÇÃO DE PROFESSORES: Trabalhos voltados a propostas, análises ou relatos de vivências na formação inicial ou continuada de professores de ciências, para os diferentes níveis de ensino, incluindo programas e projetos de aperfeiçoamento, capacitação ou especialização de professores, avaliação (ou auto-avaliação) de práticas pedagógicas em processos de formação em serviço ou, ainda, avaliações e propostas de cursos e programas específicos das licenciaturas ou magistério. Em alguns casos, incluem-se, nesse conjunto, diagnósticos das condições de trabalho de professores, perfil sócio-econômico ou concepção de professores sobre assuntos diversos. Muitos desses trabalhos têm um tema secundário relativo a um determinado aspecto do ensino (sobretudo processos de ensinoaprendizagem), mas destacamos nesta classificação aqueles que têm a Formação de professores como foco e não como locus da pesquisa.

Sub-temas:

- Formação inicial de professores (discussões / proposições / reflexões / relatos sobre cursos de licenciatura ou disciplinas; estágios supervisionados...) 
- Formação continuada de professores (discussões / proposições / reflexões sobre formação continuada / aperfeiçoamento / atualização / capacitação / especialização / extensão etc...)

- Perfil profissional e prática docente (diagnósticos de condições e características profissionais / perfil sócio-econômico / relatos e avaliação de prática docente / pesquisaação / prática reflexiva...

- Concepções e representações de professores sobre temas diversos

EDUCAÇÃO, POLÍTICA E SOCIEDADE: Análises, reflexões e propostas que têm como enfoque principal, orientações e finalidades da educação, em seus aspectos políticos, sociais e culturais (política educacional, ética e cidadania, educação para o trabalho, educação popular etc), abrangendo parâmetros curriculares, reformas educacionais e diretrizes relativas à formação profissional. Abarca os sub-temas:

- Política(s) Educacional(is): políticas públicas para educação e/ou para educação científica; legislação educacional / diretrizes / parâmetros (gerais e na perspectiva da Educação)

- Educação - concepções

- História da Educação e/ou do Ensino de Ciências / Física

- Questões Institucionais (perfil / evasão / vestibular...)

DIVULGAÇÃO CIENTÍFICA E EDUCAÇÃO NÃO-FORMAL: Trabalhos que discutem propostas e instrumentos de educação científica produzidos e veiculados em espaços não-formais, como museus e centros de ciências, livros e periódicos de divulgação científica e seus usos e potenciais no ensino das ciências formal ou não-formal. Destacamos os sub-temas:

- Divulgação científica (discussões, análise do papel ou características da DC em diferentes espaços; disseminação / popularização da Ciência)

- Museus e centros de ciência

- Divulgação científica no ensino: caráter ou vertentes da DC no ensino escolar

- Discussões sobre educação não formal em geral

PESQUISA EM ENSINO DE CIÊNCIAS / FÍSICA: Trabalhos que apresentam análise da evolução das pesquisas na área de Ensino de Ciências ou Física, de um modo geral, em relação a uma particular linha de pesquisa, ou, ainda os que discutem aspectos metodológicos dessa pesquisa.

Essa demarcação nos três eixos tem como finalidade identificar tendências das pesquisas segundo perspectivas predominantes, tendo claro que não são independentes e isoladas. A escolha de objetos, conteúdos e tópicos de ensino (eixo do Conhecimento) ou dos meios, práticas e procedimentos (eixo dos Processos de Ensino-Aprendizagem) certamente não é feita sem uma concepção de objetivos e valores educacionais, sociais ou culturais que se pretende promover (eixo da Educação). Assim, também, os meios dependem e implicam dadas opções no âmbito do conhecimento científico a ser priorizado e, na outra mão, a seleção e organização do conhecimento têm decorrências práticas e metodológicas. 


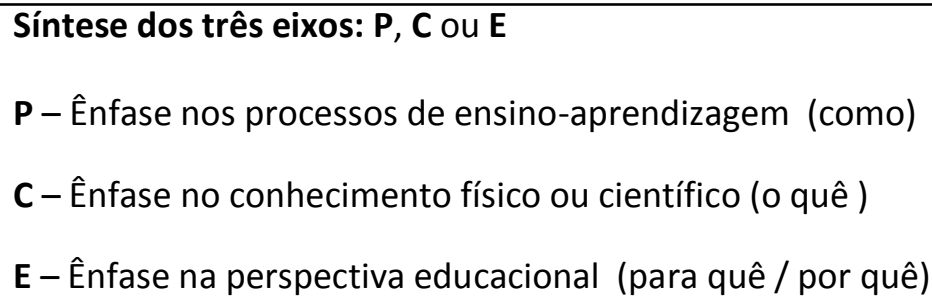

\section{3 Âmbitos e Interfaces}

Como já dissemos, ainda que possamos identificar perspectivas predominantes nos trabalhos de pesquisa, dadas por esses três eixos, mais comumente elas são melhor identificadas pelas diferentes combinações ou intersecções entre eles, definidas pelos planos ou interfaces dois a dois.

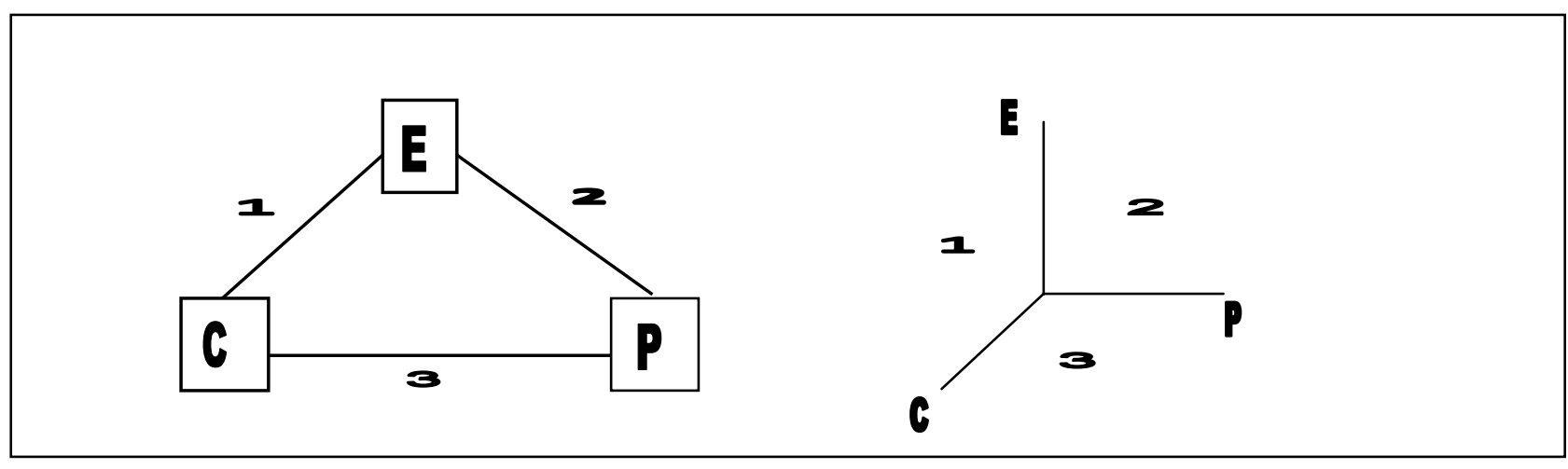

Fig. 4.1: Interfaces e planos definidos pelos Eixos E, C, P

\section{INTERFACE 1: Educação e Conhecimento (EC)}

Objetivos educacionais e conteúdos do ensino compõem uma interface (EC) dada pela intersecção entre a seleção e organização do conhecimento a ser ensinado (em dado momento / para determinado contexto) e as finalidades do ensino. Nesse plano enquadramse diferentes áreas temáticas, assim como diferentes concepções, quer de ciência, quer de educação. Segundo Menezes e colaboradores,

Há uma ampla intersecção entre as ciências e os objetivos da educação, desde a perspectiva da compreensão da ciência como atividade fim do ser humano, assim como na visão de ciência como instrumental para a vida produtiva e para a cidadania contemporânea. Como plano de definições pedagógicoepistemológicas, essa interface é percorrida em diferentes direções, dependendo do ponto de partida. (MENEZES; KAWAMURA; HOSOUME, 1997) 
Como exemplos dessas diferentes direções, Menezes cita os educadores ditos conteudistas na linha da pedagogia crítico-social dos conteúdos (Libâneo, 1989), que partem de uma concepção ampla ou abstrata de educação, e no sentido de sua concretização, incorporam os conteúdos científico. Também nessa direção, há aqueles que, a exemplo do Grupo de Reelaboração do Ensino de Física (GREF 1990, 1991, 1993), já pressupõem a essencialidade do ensino de ciências, tratando de situála em proposta educacional mais ampla, tendo o diálogo como elemento essencial. Ou podem ser incluídas, ainda, as propostas de abordagens temáticas de inspiração freireana.

Na vasta produção da PEF, encontramos pesquisas que podem ser identificadas nessa interface, nas quais, ainda que os objetivos educacionais não sejam claramente explicitados, apresentam concepções, propostas ou abordagens de ensino em que o conhecimento científico tem um sentido formativo. Incluem-se aqui, trabalhos que enfatizam a importância da abordagem histórica e filosófica no ensino das ciências ou de aspectos sócio-culturais, buscando ressaltar a dimensão humana e social da construção do conhecimento científico. Inserem-se, ainda nesse campo trabalhos que destacam a necessidade da inserção de conteúdos da Física Moderna e Contemporânea tendo em vista uma formação cidadã mais ampla, ou ainda algumas das chamadas abordagens Ciência-Tecnologia-Sociedade (CTS) ou de Alfabetização Científico-Tecnológica. Trata-se de um campo de idéias e proposições, no qual

....as ciências são tomadas como instrumentos de compreensão do mundo, com toda a sua contemporaneidade, buscando a integração do indivíduo ao processo de transformação por que passa o mundo tecnológico e a possibilidade de compreensão e intervenção nesse mundo. (MENEZES, KAWAMURA, HOSOUME, 1997)

A marca distintiva de trabalhos nessa interface é, pois, a explicitação através de seleções, escolhas ou tratamentos do conhecimento científico em âmbito escolar, de uma dada compreensão de ciência e uma perspectiva educacional, sendo um ou outro aspecto mais enfatizado.

\section{INTERFACE 2: Conhecimento e Processos (CP)}

Nessa interface situam-se os trabalhos que tratam de uma combinação entre conteúdos e meios (conhecimento e processos), com maior ênfase em um ou em outro.

Pela maior tradição em investigação científico-pedagógica, o ensino de física no Brasil constitui área específica onde, em qualquer época, se podem identificar vários projetos ou propostas claramente situados nesse plano. (MENEZES et al, 1997) 
Situam-se nesse campo diferentes visões dos processos de ensino-aprendizagem que vem se sucedendo historicamente, a exemplo das propostas fundadas na psicologia comportamentalista, muito presentes na década de 1970, ou as tendências na linha construtivista, predominantes nas décadas de 1980 e 1990. Como exemplo da primeira tendência, no Brasil, podemos citar o projeto "Física Auto-Instrutiva" (GETEF 1973) e seus percussores ou afiliados e, da segunda, o "Projeto de Ensino de Física" (PEF 1974) além de, posteriormente, as inúmeras investigações sobre concepções espontâneas, seguidas pelos trabalhos de mudança conceitual e perfil conceitual. Incluem-se, também aqui, uma enorme diversidade de trabalhos que tratam de propor e analisar métodos e estratégias de ensino, recursos didáticos (laboratório e atividades experimentais, livros didáticos, filmes, textos, uso de computador, atividades lúdicas etc.). Mais frequentemente, as pesquisas em ensino de Física situadas nessa interface partem de uma visão tacitamente consensual dos conteúdos a serem ensinados, e tratam de compô-los quer com as estratégias e métodos de promovê-los da maneira mais "eficiente" ou com os estudos de natureza psicopedagógica sobre formas em que ocorre o aprendizado ou o conhecimento é construído pelo aluno. Ou seja, predominam aqui os trabalhos que enfatizam os meios, tendo o conteúdo como dado, não problematizado. Como afirma Menezes e colaboradores

Para este campo do pensar pedagógico, as ciências são tomadas como conhecimento não problematizado, assim como os objetivos educacionais são aqueles estabelecidos pela matriz construtivista mais ampla. Essas características permite, sem sombra de dúvida, situar nesse plano a grande maioria dessas propostas e investigações. (MENEZES; KAWAMURA; HOSOUME, 1997)

\section{INTERFACE 3: Educação e Processos (EP)}

Nessa interface em que se dá a intersecção de objetivos educacionais e processos de ensino-aprendizagem, as investigações se dão no plano mais abstrato ou teórico entre as finalidades formativas e os meios para alcançá-las. Assim, mais frequentemente as pesquisas em ensino de física situadas nesse plano estão focalizadas sobretudo nos processos, ficando implícitas as perspectivas educacionais.

Nesse campo das pesquisas em ensino, são exemplos relativamente típicos dessa interface os trabalhos sobre "Formação de Professores", em seus mais diversos aspectos. Desde aqueles centrados em questões institucionais mais amplas, até os que focalizam as práticas, os saberes docentes ou o perfil do professor, via de regra não se preocupam ou não levam em conta o objeto de conhecimento, em nosso caso a ciência ou o conteúdo físico. Ou seja, são discussões ou propostas que se fazem independentemente da dimensão disciplinar: cabem ao professor de física, de geografia ou de inglês. Assim, tanto quanto alguns dos trabalhos situados na 
interface Conhecimento e Processos (CP), parece haver um pressuposto de que o conhecimento é dado, é universal ou não problematizável. Formar o professor de física pressuporia uma física dada, estabelecida.

\section{O conjunto das interfaces contemplado (ECP)}

Ainda que mais tipicamente as pesquisas em ensino de física situem-se em uma dessas interfaces, quando não em um eixo específico, não se descarta a possibilidade de existirem investigações apoiadas nesse tripé, lidando com toda a dimensionalidade. No entanto, enquanto instrumento de análise, entendemos que a identificação de uma interface predominante revela um perfil mais demarcado da pesquisa.

\subsection{Sistematização e considerações gerais}

Ao iniciar esse capítulo, tínhamos como questão central procurar mapear e compreender alguns meios de identificar de que tratam as pesquisas da área de ensino de física. Para responder a essa questão, vem junto uma outra, anterior, que diz respeito a como sistematizar essa produção, que instrumentos e abordagens utilizar, quais categorias de classificação adotar. Isso é tão mais complexo quando se constata a enorme diversidade de trabalhos da área, e da natureza também diversificada do que se pesquisa. Complementada pelo fato de que, na medida em que essa produção evolui com o tempo, parece necessário que a própria forma de sistematização também evolua. Assim, certamente seriam muitas as possibilidades de apresentação daquilo que se produz na área. Algumas das quais optamos por descartar, a exemplo de seguir alguns referenciais ou linhas de pesquisa bem demarcadas ou acompanhar a produção de alguns grupos mais antigos.

Tomando por base os trabalhos anteriores de estado da arte ou semelhantes, podese verificar que há duas abordagens predominantes quanto à forma de sistematização dessa produção. Novamente, abrimos mão de uma delas, qual seja a de partir de categorias temáticas definidas a priori, tendo por base aquelas utilizadas nos eventos da área, mas priorizando a que desenvolvemos, também compartilhada por outros pesquisadores. Trata-se de sistematizar a produção a partir da própria produção.

O instrumento utilizado nessa abordagem foi a definição de categorias temáticas que identificam o foco principal do trabalho. Essas categorias, de fato, evoluíram com o tempo. Mas se mostraram insuficientes, na medida em que correspondiam a uma listagem de temas de naturezas muito diferentes. Daí, nossa proposta de sistematização dos focos temáticos, primeiro em uma estrutura lógica de temas e sub-temas delimitados, depois em torno de eixos estruturadores, que evidenciam as diferentes dimensões presentes nos trabalhos e, finalmente pela identificação de 
planos representados pelas intersecções duas a duas entre os eixos. Esse movimento teve em conta uma hipótese de trabalho, dada pela experiência anterior desenvolvida com essa ambição analítica, de esse ser um instrumento mais adequado à nossa produção.

Esses eixos e interfaces funcionam como uma forma de estruturação em uma ordem hierárquica, mais ampla, que pode contribuir para uma percepção panorâmica da natureza da pesquisa, suas temáticas e recortes, das dimensões que vêm sendo tratadas ou daquelas relegadas. Mas reforçamos que a contribuição essencial desse esforço é trazer à tona não só a complexidade de uma análise dessa natureza, mas as diferentes possibilidades e escolhas envolvidas nesse esforço. Pois, na medida em que toda a sistematização dessa natureza tem limitações, explicitá-las é, além de uma forma de compreender melhor o que foi realizado, possibilitar o diálogo e o aprofundamento das pesquisas com esse interesse.

Algumas questões, em particular, mereceriam aprofundamento nesse possível e salutar intercâmbio.

É o caso, por exemplo, da própria definição do que sejam focos, áreas ou categorias temáticas. Ou de contrapor possíveis tratamentos metodológicos, de buscar colocar em evidência semelhanças e diferenças, contribuições e limitações, das duas principais abordagens para a sistematização da produção (temáticas de encontros $x$ temáticas da produção acadêmica). $E$, finalmente, um terceiro aspecto diz respeito às especificidades da construção por nós desenhada, buscando refletir sobre o quanto o próprio instrumento influencia no panorama obtido.

Tomando brevemente essas questões uma por vez.

Ao utilizar a denominação foco temático nessas classificações, pareceu-nos dispensável uma definição mais precisa, e, nesse sentido, tema, foco, campo ou área temática foram designações utilizadas como equivalentes. No entanto, no decorrer da análise, surgiram alguns problemas, especialmente quanto à priorização de temas que podem se confundir com linhas ou abordagens de pesquisa. Há diferenças entre TEMA (ÁREA, CAMPO OU FOCO TEMÁTICO) e LINHA DE PESQUISA (ou REFERENCIAL)? É possível diferenciar essas instâncias? Há confusões e não ficam claras, explicitadas. E, de certa forma, essa questão está relacionada ao que se privilegiou como temas principais e secundários.

Um exemplo é "Tecnologias de Informação e Comunicação (TIC)". Do ponto de vista da estrutura lógica que construímos, esse tema estaria enquadrado em "Materiais, Métodos e Estratégias de Ensino" como outros recursos didáticos foram. No entanto, recebeu destaque enquanto categoria principal pelo caráter de linha de pesquisa que conquistou na área. De um ponto de vista um pouco diferente, também é o caso da 
Divulgação Científica (DC) enquanto tema. Investigações com enfoque mais abrangente sobre o caráter ou o papel da DC no ensino de Ciências seriam identificadas nesse foco temático. No entanto, trabalhos que tratam de um uso localizado de textos e materiais de DC como recurso didático, ficariam classificados em Materiais, Métodos e Estratégias de Ensino. Essas e outras disposições e demarcações fazem parte desse jogo de quebra-cabeças no qual essa complexa produção / área toma parte.

A segunda questão relaciona-se ao panorama da produção que é obtido através das duas (ou mais) diferentes abordagens metodológicas. Ou seja, em que medida fornece perspectivas, fotografias, radiografias, filmes diferentes ou semelhantes. $\mathrm{Ou}$ tratar-se-ia apenas de ângulos, focos ou gestalts? Assim, de certo modo, voltamos à questão levantada no início... Pudemos verificar, por exemplo, que investigações diferentes, usando instrumentos e objetos de análise diversos, chegam a alguns resultados aparentemente comuns. Particularmente revelam a hegemonia dos trabalhos que tratam dos processos de ensino-aprendizagem e da formação de professores. Seria importante ir adiante nisso.

Um terceiro aspecto refere-se, ainda, à comparação de diferentes formas de sistematizar a produção segundo suas temáticas. Que significados têm? Que diferenças? Como ler cada uma das "listas de temas" propostas ou utilizadas nas pesquisas ou eventos? Não porque não tenham necessariamente uma lógica interna, mas porque essa lógica não é explicitada.

Enfim, o que buscamos em nossas diversas sistematizações e, em particular com a proposição desse instrumento (áreas, eixos e interfaces) foi uma forma de estruturar os focos de interesse de nossa pesquisa que possa ser compreendida / lida / discutida / trocada / criticada / repensada. Outras podem ser tentadas, mas o que nos orientou foi essencialmente a necessidade de um novo nível de sistematização que possbilite explicitar ou recuperar uma totalidade conceitual da área de pesquisa em Ensino de Física com suas multidimensões. 


\section{Análise da produção: áreas temáticas}

Tendo por base o instrumento proposto no capítulo precedente, pretendemos analisar a produção na área de PEF, do ponto de vista de seus focos de interesse, já previamente delimitados por Temas, Eixos e Interfaces. O propósito dessa análise é, como já anunciamos, complementar o panorama mais amplo da área, visando caracterizar algumas de seus marcos no que tange as questões de investigação. Existem, de fato, marcas que identificam a nossa produção acadêmica? O que seria tradição e o que seria episódico em sua trajetória? Quais as principais transformações nessas quatro décadas de existência?

Dado o extenso conjunto de trabalhos de nosso universo, caracterizado no capítulo 3 (1330 títulos), para viabilizar essa análise foi necessário delimitar uma amostra. De início, excluímos as teses de livre-docência (LD) e os mestrados profissionais (MP). As primeiras, muito poucas (oito no total), não só não interferem no conjunto da evolução da área, como se trata de uma titulação presente apenas nas universidades paulistas. Os mestrados profissionais, por sua vez, por terem características próprias, com objetivos distintos do acadêmico, serão analisados separadamente (Capítulo 7). O total de títulos com essas exclusões passa a ser 1170 .

Para contemplar diferentes momentos da evolução da produção no intervalo coberto, de 1972 a 2009, construímos uma amostra com trabalhos desenvolvidos em sete períodos, conforme mostra a Tabela 5.1.

Com esse segundo recorte, nosso corpus de estudo passa a compor 470 títulos, o que corresponde a $40 \%$ do universo total.

Os agrupamentos em cada período foram feitos de forma a abarcarem números absolutos de trabalhos da mesma ordem de grandeza (cerca de cinquenta) até o ano 2000, a partir de quando, em cada ano, esse número passou a ser maior. Quatro dos sete grupos selecionados para análise estão nessa primeira década de 2000 (2000, 2003, 2006 e 2009). Essa foi uma opção intencional dada a preocupação em considerar tanto a diversidade de linhas que supostamente a área passaria a ter na passagem da década de 1990 para a de 2000, como investigar as tendências mais recentes. Tal escolha, juntamente com o próprio crescimento numérico nesse período implicou, portanto, uma maior participação dos anos finais no conjunto total 
da amostra (o que se pode verificar na quinta coluna da tabela 5.1 onde se apresenta o percentual de trabalhos em cada período em relação ao conjunto total). Ainda que esse período mais recente tenha um peso maior na amostra, não compromete a análise, uma vez que a metodologia predominante adotada foi o tratamento dos dados a cada período, utilizando os totais cumulativos apenas como referência quando necessário.

\begin{tabular}{|c|c|c|c|c|}
\hline \multicolumn{2}{|c|}{ PERÍODO } & \multirow{2}{*}{$\begin{array}{l}\text { AMOSTRA } \\
48\end{array}$} & \multirow{2}{*}{$\begin{array}{l}\text { \% (em relação à } \\
\text { amostra) } \\
10 \%\end{array}$} & \\
\hline P1 & 1979-1984 & & & \\
\hline P2 & 1989-1990 & 44 & $9 \%$ & \\
\hline P3 & 1995-1996 & 57 & $12 \%$ & \\
\hline P4 & 2000 & 50 & $11 \%$ & \\
\hline P5 & 2003 & 66 & $14 \%$ & \\
\hline P6 & 2006 & 89 & $19 \%$ & \\
\hline \multirow[t]{2}{*}{ P7 } & 2009 & 116 & $25 \%$ & \\
\hline & TOTAL & 470 & $100 \%$ & \multirow[b]{2}{*}{$\begin{array}{l}40 \% \text { do total de } \\
\text { títulos }=1170\end{array}$} \\
\hline & Tabela 5.1: & mostra e & & \\
\hline
\end{tabular}

Os primeiros anos de produção, na década de 1970 (1972 a 1979) não foram incluídos, por constituírem trabalhos mais pontuais, ainda não frutos propriamente da área já institucionalizada em um programa de pesquisa. Ainda assim, realizamos um levantamento breve das temáticas principais nesse período, visando identificar alguns marcos importantes na passagem dos anos 70 para os 80 .

A amostra final compõe um conjunto de 470 títulos, $40 \%$ do total. Para ilustrar a seleção feita, no gráfico 5.1 , identificamos os sub-conjuntos representados pela amostra, no universo total.

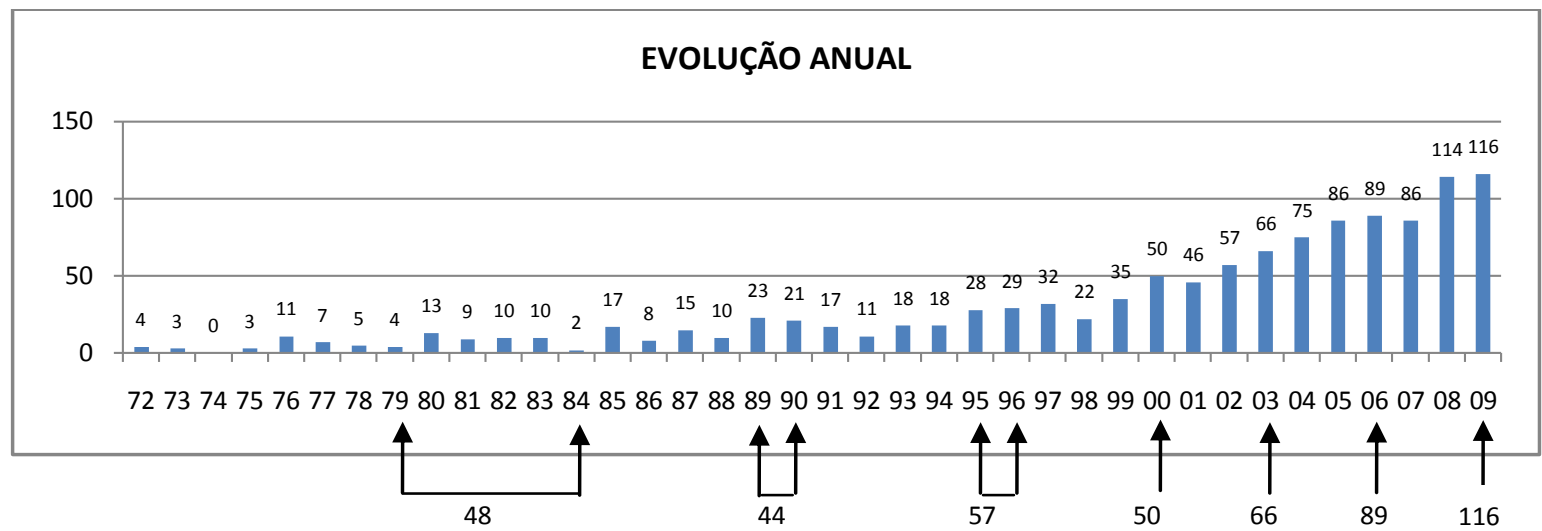

Gráfico 5.1: Evolução do número de dissertações e teses (excluídas Livres-Docências e Mestrados Profissionais) com destaque para os sub-conjuntos da amostra selecionada 
Uma vez que pretendemos compreender de que modo as temáticas e as perspectivas da pesquisa em Ensino de Física evoluem, quais a tendências principais e o que sinalizam, centralizamos a análise em duas frentes. Na primeira, objeto desse capítulo, focalizamos os temas dos trabalhos, classificando-os de acordo com as categorias temáticas propostas no capítulo quatro. Na segunda, a ser desenvolvida no capítulo seis, nos voltamos para as dimensões e âmbitos da pesquisa, representados pelos eixos Conhecimento, Educação e Processos e seus planos de interfaces também caracterizados no capítulo quatro.

Dado o expressivo número de títulos da amostra, as classificações foram feitas com base, sobretudo, nos seus resumos. Quanto a esse aspecto, é importante ressaltar que os resumos das dissertações e teses, junto aos títulos e palavras-chaves, apesar de algumas vezes limitados e não muito claros, contêm elementos básicos que permitem, em uma primeira aproximação, classificar as temáticas principais e os enfoques ou perspectivas da investigação. No entanto, sempre que necessário, quando os resumos se mostraram insuficientes, procuramos recorrer ao trabalho na sua versão completa. Para isso, utilizamos fontes diversas, como os catálogos de dissertações e teses do IFUSP ${ }^{15}$ e do CEDOC $^{16}$, o acervo de teses do ProFis/IFUSP ${ }^{17}$, o Banco de Teses da CAPES $^{18}$, os sites dos Programas de Pós-Graduação que disponibilizam esses documentos, a Biblioteca Digital Brasileira de Teses e Dissertações (BDTD) ${ }^{19}$, entre outros bancos de teses e sistemas de busca. Mas ressaltamos que ainda que com essas possibilidades providas pela Internet, é grande a dificuldade de acesso aos trabalhos completos de inúmeras instituições, mesmo as produzidas em anos mais recentes.

\footnotetext{
${ }^{15}$ UNIVERSIDADE DE SÃO PAULO - Instituto de Física, 1992, 1996, 2009. Esses três volumes do Catálogo Analítico de Dissertações e Teses em Ensino de Física no Brasil, por nós elaborados, cobrem o período de 1972 a 2006.

${ }^{16}$ O ensino de Ciências no Brasil: catálogo analítico de teses e dissertações (1972-1195). Catálogo do Centro de Documentação em Ensino de Ciências (CEDOC) sediado na UNICAMP e coordenado por Jorge Megid Neto (MEGID, 1998)

${ }^{17}$ O PROFIS - Espaço de Apoio, Pesquisa e Cooperação de Professores de Física - do qual participamos e coordenamos, é um espaço de investigação científico-pedagógica, sediado no Instituto de Física da Universidade de São Paulo (IFUSP), para promover projetos de inovação e aperfeiçoamento do ensino, com a participação de alunos da Licenciatura, estudantes da pós-graduação do Programa Interunidades em Ensino de Ciências, professores do ensino médio e docentes universitários. Entre outros projetos e iniciativas, mantém um Acervo de Dissertações e Teses em Ensino de Física no Brasil.

${ }^{18}$ Banco de Teses da CAPES, que disponibiliza referências de teses e dissertações defendidas a partir de 1987 (tais referências incluem Autor, Título, Orientação, Data, Composição da banca e Resumo. http://www.capes.gov.br/servicos/banco-de-teses

${ }^{19}$ Coordenada pelo IBICT, o projeto da Biblioteca Digital Brasileira de Teses e Dissertações (BDTD) integra os sistemas de informação de teses e dissertações existentes nas instituições de ensino e pesquisa brasileiras.
} 
Como dissemos, nossa primeira frente de análise foi uma investigação dos temas dos trabalhos, por meio da classificação nas Áreas Temáticas, cuja descrição e fundamentação encontram-se no Capítulo 4.

Todas as dissertações e teses da amostra foram inicialmente classificadas nessas áreas temáticas de acordo com seu foco principal de estudo, para termos um primeiro mapeamento geral (o que apresentamos no tópico 5.1) Para identificar as tendências ou ênfases dentro de cada uma dessas áreas e como foram evoluindo ao longo do tempo, passamos a uma caracterização mais refinada dada pelos sub-temas (tópico 5.2). Embora as categorias temáticas não sejam excludentes entre si ou, ainda, que os trabalhos não raramente possam ser abarcados por mais de uma delas, optamos por classificar e analisar apenas as suas temáticas predominantes, de modo que a cada um coube uma única categoria.

\subsection{Evolução segundo áreas temáticas: aspectos gerais}

No quadro 5.1 reproduzimos as categorias ou áreas temáticas definidas no capítulo quatro e utilizadas na classificação dos trabalhos.

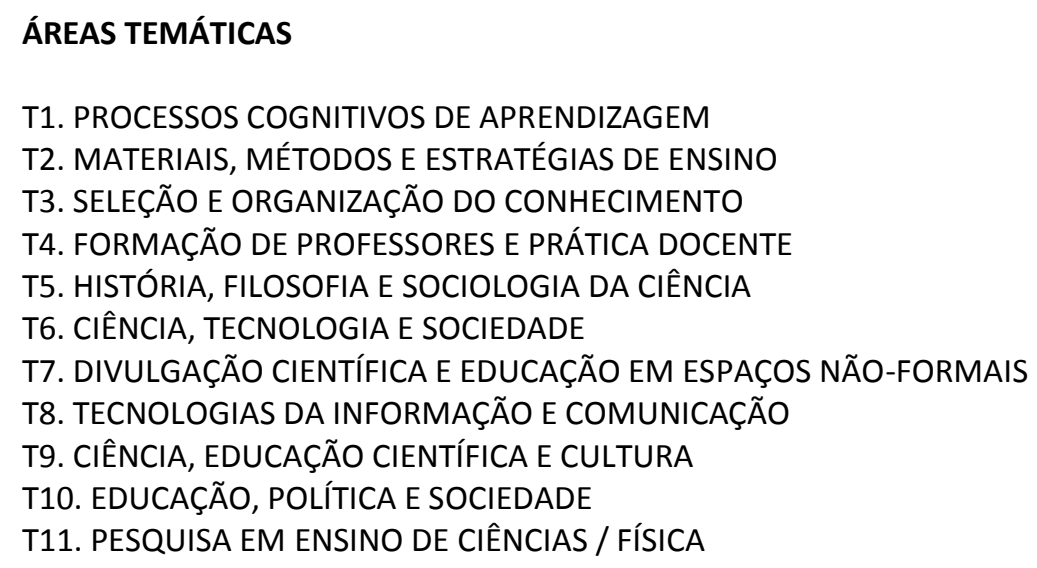

Quadro 5.1: Áreas Temáticas (AT)

Os conjuntos de gráficos a seguir representam o resultado das classificações dessa amostra nas áreas temáticas, em cada período. 
ÁREA TEMÁTICA X PERÍODO (valores absolutos)
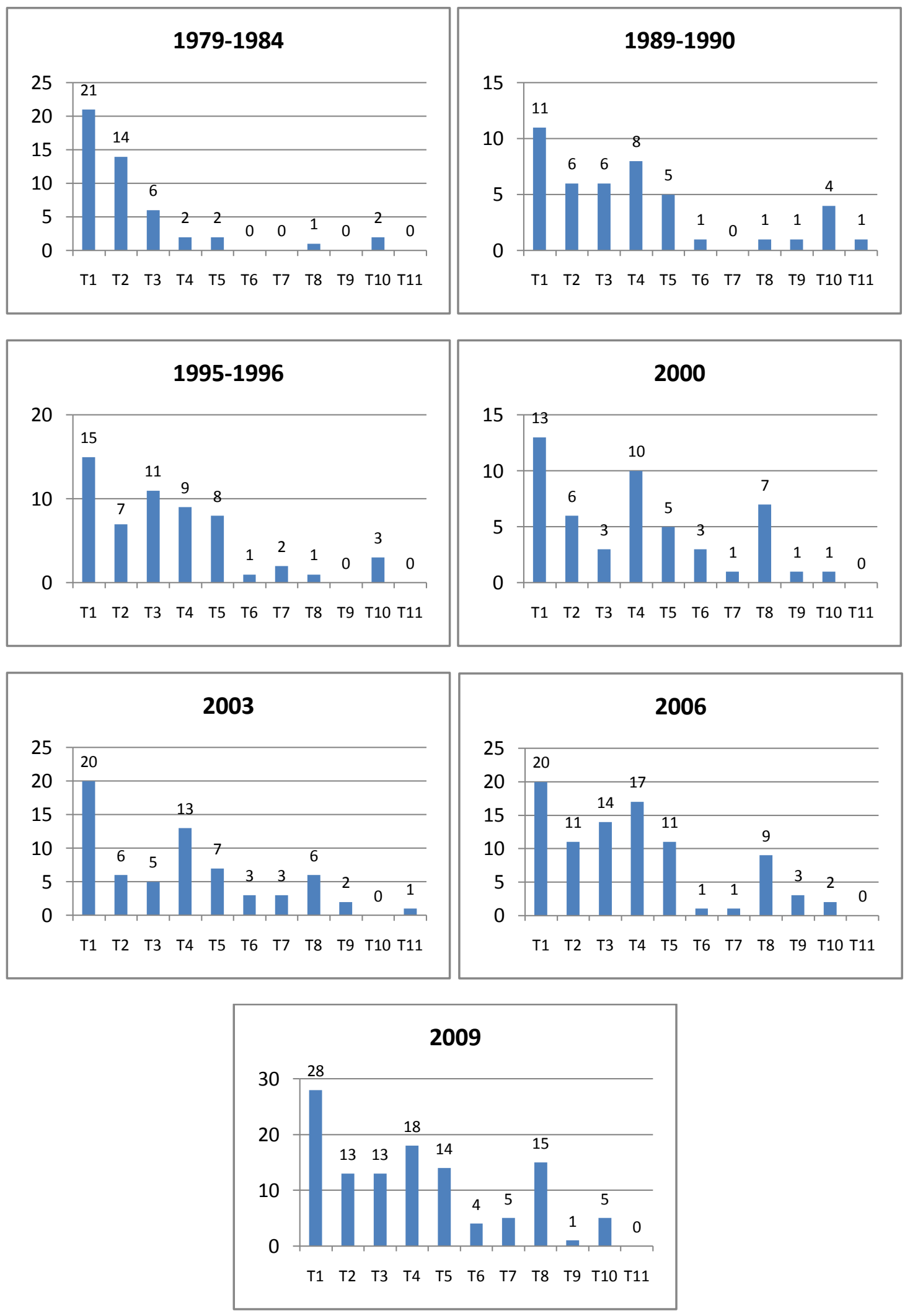

Gráficos 5.2: Distribuições das áreas temáticas por período (números absolutos) 

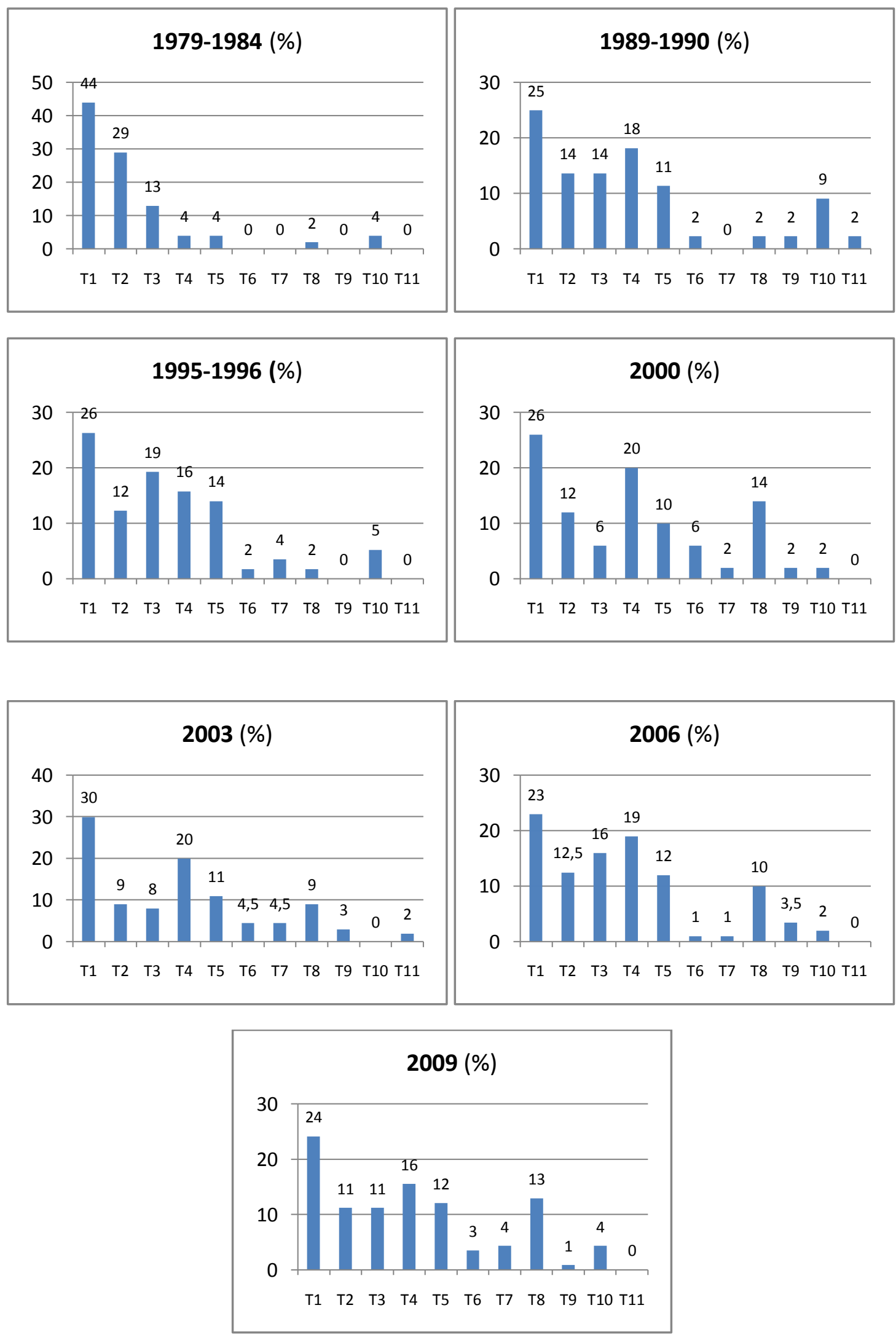

Gráficos 5.3: Distribuições das áreas temáticas por período (percentuais) 
A sistematização desses dados, apresentada por meio de um único gráfico (nas duas formas 5.4 a e 5.4b), permite uma visualização geral da evolução temática nesses períodos. Na primeira forma, pode-se "observar" a evolução de cada tema ao longo do tempo e na segunda, inversamente, como os temas se distribuem em cada período.

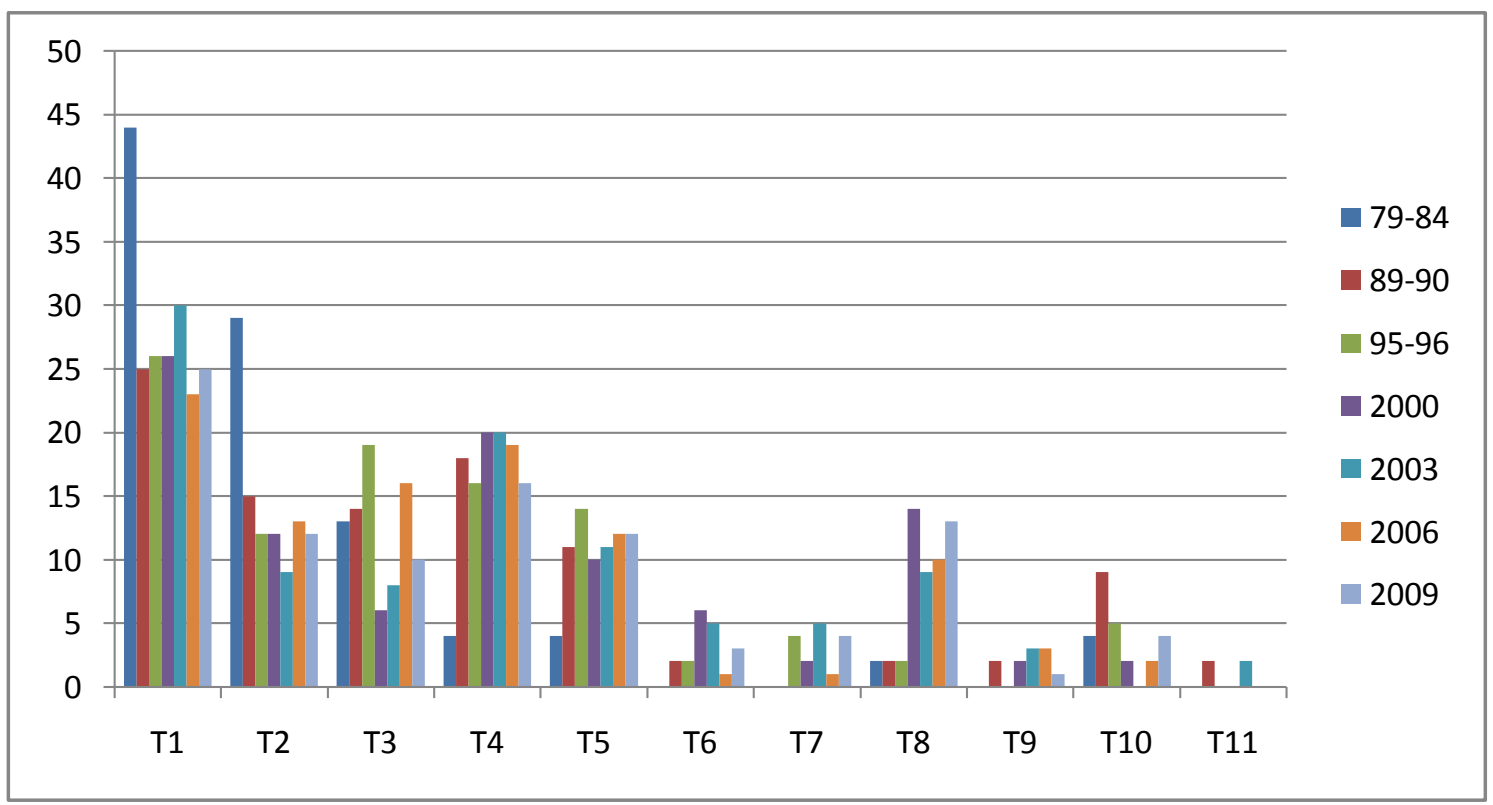

Gráfico 5.4 (a): Distribuições temporal por área temática (percentuais)

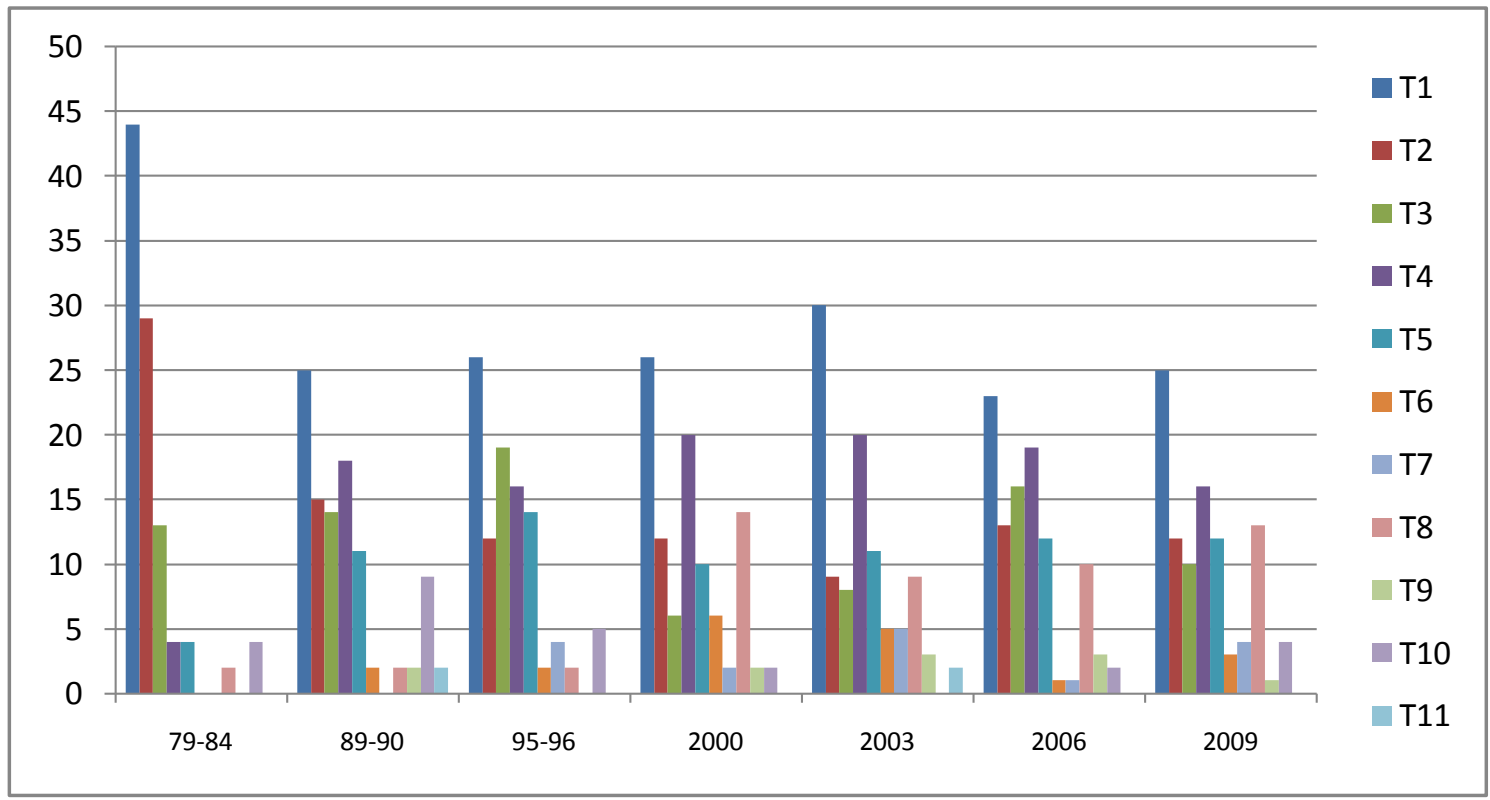

Gráfico 5.4 (b): Distribuições das áreas temáticas por período (percentuais)

Quanto a esses dados, é importante lembrar que as dissertações e teses são produtos de projetos que têm alguns anos de duração (que podem variar bastante conforme a época, grau acadêmico, instituição e outros fatores). Isso significa que nas leituras e análises que vierem a ser apresentadas, relativas a cada período, deve- 
se ter em conta que tratam de trabalhos com origem alguns anos antes de sua publicação, ou seja, podem corresponder a um período defasado em relação ao indicado.

O gráfico 5.5 mostra a distribuição cumulativa dos temas, em percentuais, no conjunto da amostra, independentemente do período de produção, que será comentada ao longo da análise desenvolvida a seguir.

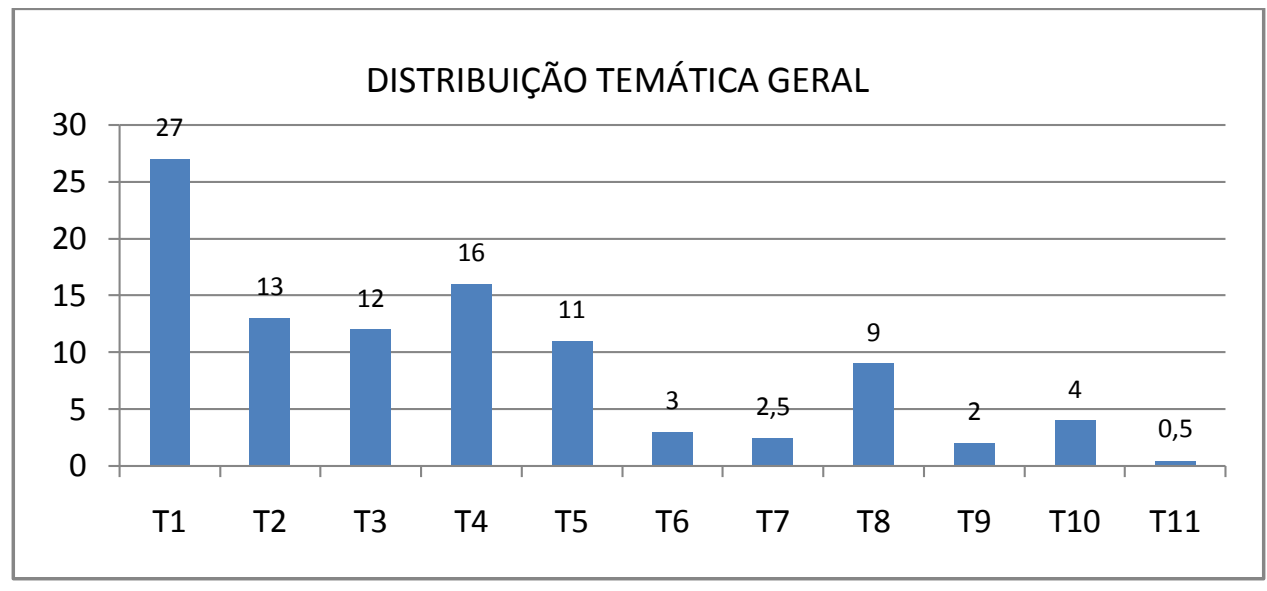

Gráfico 5.5: Distribuição cumulativa das Áreas Temáticas na amostra

Trazemos, inicialmente, alguns resultados que se destacam tanto nas distribuições por períodos (gráficos 5.3 e 5.4) como na distribuição cumulativa geral (gráfico 5.5), portanto, que dizem respeito ao conjunto da produção. No próximo item, apresentaremos aspectos mais específicos da evolução de algumas temáticas.

\section{i. Temáticas dominantes}

O primeiro deles, que salta à vista, é o peso, no conjunto, das cinco primeiras áreas temáticas: T1 a T5, em relação a todas as demais. A lembrar:

T1. PROCESSOS COGNITIVOS DE APRENDIZAGEM

T2. MATERIAIS, MÉTODOS E ESTRATÉGIAS DE ENSINO

T3. SELEÇÃO E ORGANIZAÇÃO DO CONHECIMENTO

T4. FORMAÇÃO DE PROFESSORES E PRÁTICA DOCENTE

T5. HISTÓRIA, FILOSOFIA E SOCIOLOGIA DA CIÊNCIA

Na distribuição geral cumulativa, $80 \%$ da amostra está concentrada nesse "setor esquerdo" do gráfico. Se olharmos período a período, essa parcela é igual ou superior a 75\% em todos eles. No início da década de 1980 essas áreas concentravam 95\% da amostra. Esses dados estão sistematizados na tabela 5.2. 


\begin{tabular}{|l|l|c|}
\hline \multicolumn{2}{|c|}{ PERÍODO } & SOMA T1 A T5 (\%) \\
\hline P1 & $79-84$ & 94 \\
\hline P2 & $89-90$ & 82 \\
\hline P3 & $95-96$ & 85 \\
\hline P4 & 2000 & 75 \\
\hline P5 & 2003 & 78 \\
\hline P6 & 2006 & 83 \\
\hline P7 & 2009 & 75 \\
\hline \multicolumn{2}{|c|}{ Total Cumulativo } & $80 \%$ \\
\hline
\end{tabular}

Tabela 5.2: Parcela correspondente à soma das áreas temáticas T1 a T5 por período

As demais áreas (T6 a T11), setor "direito" dos gráficos, têm uma representação de $20 \%$ da amostra geral e oscilam (na soma), em torno dos $25 \%$ ao longo do tempo (como vimos, no primeiro período representam apenas $5 \%$ do conjunto). São elas:

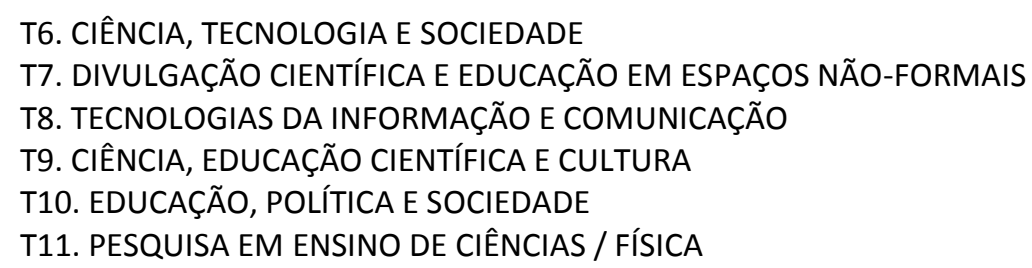

À exceção da área temática T8 - Tecnologias da Informação e Comunicação - todas aparecem com menos de $5 \%$ do total de trabalhos.

Tal resultado não é de todo surpreendente, uma vez que, de fato, as cinco primeiras áreas temáticas (e não por coincidência são as nossas primeiras) se identificam com linhas mais "tradicionais" ou estáveis em nosso campo de pesquisa, em todos os tempos. No entanto, já é um registro importante (uma primeira foto) do que vem a ser uma de nossas marcas registradas.

\section{ii. Ainda sobre temáticas dominantes}

No que se refere, ainda, ao primeiro conjunto que agrega as cinco áreas principais, não podemos deixar de ressaltar que os processos cognitivos de aprendizagem (T1), a formação de professores (T4) e os métodos, estratégias e recursos didáticos (T2), nessa ordem, são os três "líderes" na distribuição cumulativa. Ao mesmo tempo, trata-se de tendência predominante nos períodos.

As áreas temáticas T1 e T2 têm perspectivas semelhantes e complementares. Enquanto a primeira tem como objeto de estudo essencialmente a aprendizagem, a segunda está voltada ao ensino. As duas juntas, centradas nos processos de ensino $e$ aprendizagem, concentram cerca de $40 \%$ das pesquisas no conjunto da amostra $(27 \%$ na primeira e $13 \%$ na segunda) como se pode verificar no gráfico 5.5 . Soma-se a isso, o fato de que a área T8 que congrega os trabalhos sobre as Tecnologias de Informação e Comunicação (TIC), é da mesma natureza que a segunda, uma vez que trata de recursos didáticos para o ensino. Ganhou esse "status" de categoria 
temática em função de sua consolidação na área de EC como linha de pesquisa. Pois bem, se somarmos essa área às duas primeiras, chegamos a um resultado bastante significativo: $\mathbf{5 0 \%}$ das teses e dissertações estão concentrados nesse foco dos processos de ensino e aprendizagem. Adiante apresentamos mais detalhes sobre esses dados e suas evoluções no tempo.

\section{iii. Estabilidade das distribuições}

Outro dado a se ressaltar resulta da comparação das distribuições nos períodos e entre esses e a distribuição cumulativa. Num primeiro momento, podemos perceber que as mais recentes, de 2006 e 2009, são muito próximas da geral, o que seria de se esperar, uma vez que a amostra teria esse "desvio", com maior peso nos últimos anos. No entanto, se tomarmos os demais períodos, essa semelhança está presente já em períodos anteriores, como é o caso do segundo (1989-1990), em que a distribuição é também bem próxima às finais e à geral. Ou seja, a menos de alguns casos mais pontuais, o comportamento (o "desenho") dessas distribuições é relativamente estável.

Trata-se, assim, de um resultado que reforça o anterior, de que as linhas ou os focos temáticos da pesquisa na área, do ponto de vista macro, têm uma estabilidade ao longo do tempo.

\subsection{Evolução segundo áreas temáticas: aspectos específicos}

Passamos, aqui a analisar aspectos mais específicos de cada área temática, os diferentes enfoques ou referenciais (dados pelos sub-temas) que abarcam. Dadas as características já apontadas da existência dos dois conjuntos que marcam tendências predominantes: T1 a T5 e T6 a T11, dividimos a análise nesses dois blocos, conferindo atenção especial ao primeiro.

\section{BLOCO 1: Áreas Temáticas T1 a T5}

\section{Área Temática 1: Processos Cognitivos de Aprendizagem}

A predominância sistemática da Área Temática 1 - Processos Cognitivos de Aprendizagem - com maior participação nas distribuições temáticas em todos os períodos analisados é um dos primeiros resultados importantes que extraímos desses dados. De um modo geral, congrega uma parcela superior a $25 \%$ do total de trabalhos da amostra. No início da década de 1980, chega a quase 50\%. Na tabela 5.3 reproduzimos os percentuais dessa área temática em cada período. 


\begin{tabular}{|l|l|l|}
\hline & & T1/TOTAL (\%) \\
\hline P1 & $79-84$ & 44 \\
\hline P2 & $89-90$ & 25 \\
\hline P3 & $95-96$ & 26 \\
\hline P4 & 2000 & 26 \\
\hline P5 & 2003 & 30 \\
\hline P6 & 2006 & 23 \\
\hline P7 & 2009 & 24 \\
\hline \multicolumn{2}{|c|}{ Total Cumulativo } & $27 \%$ \\
\hline
\end{tabular}

Tabela 5.3: Percentual da Área Temática T1 em cada período

Esse resultado é também percebido pela representação cumulativa do número de trabalhos com esse foco, apresentada no gráfico 5.5 : cerca de $30 \%$ do total da amostra (128 em 470).

Nessa área temática estão agrupados os trabalhos que abordam aspectos do processo de ensino-aprendizagem relativos à construção do conhecimento e à formação conceitual. Tratam de modelos, propostas e diagnósticos de aprendizagem na construção do conhecimento; das concepções conceituais dos estudantes, das suas dificuldades no aprendizado e de mudanças produzidas pelo ensino, das interrelações sócio-afetivas; da avaliação e dos aspectos lingüísticos na formação conceitual. Ou seja, têm como foco principal os estudos acerca da aquisição ou construção de conhecimento com contribuições da psicologia cognitiva e desenvolvidos segundo diferentes referências, abordagens ou concepções dos processos de ensino-aprendizagem nas ciências ou na física e também, de modo indireto, a diferentes correntes epistemológicas.

Extraímos daqui, portanto um primeiro resultado relevante a ser sinalizado: os processos cognitivos de aprendizagem constituem 0 foco de investigação predominante em nosso campo de pesquisa desde os períodos iniciais de sua institucionalização.

Uma análise do conjunto de dissertações e teses classificadas nessa área temática, dada pela classificação dos trabalhos em sub-temas mostra de que modo, ao longo do tempo, vêm mudando os enfoques adotados nessas pesquisas. Apresentamos uma sistematização dessa análise, segundo quatro sub-temas identificados nessa área e utilizados como categorias de análise:

1.1- Construção conceitual

1.2- Interações sócio-afetivas

1.3- Linguagem e cognição

1.4- Avaliação da aprendizagem 
A distribuição nesses sub-temas é apresentada nos gráficos 5.6(a) e 5.6(b)
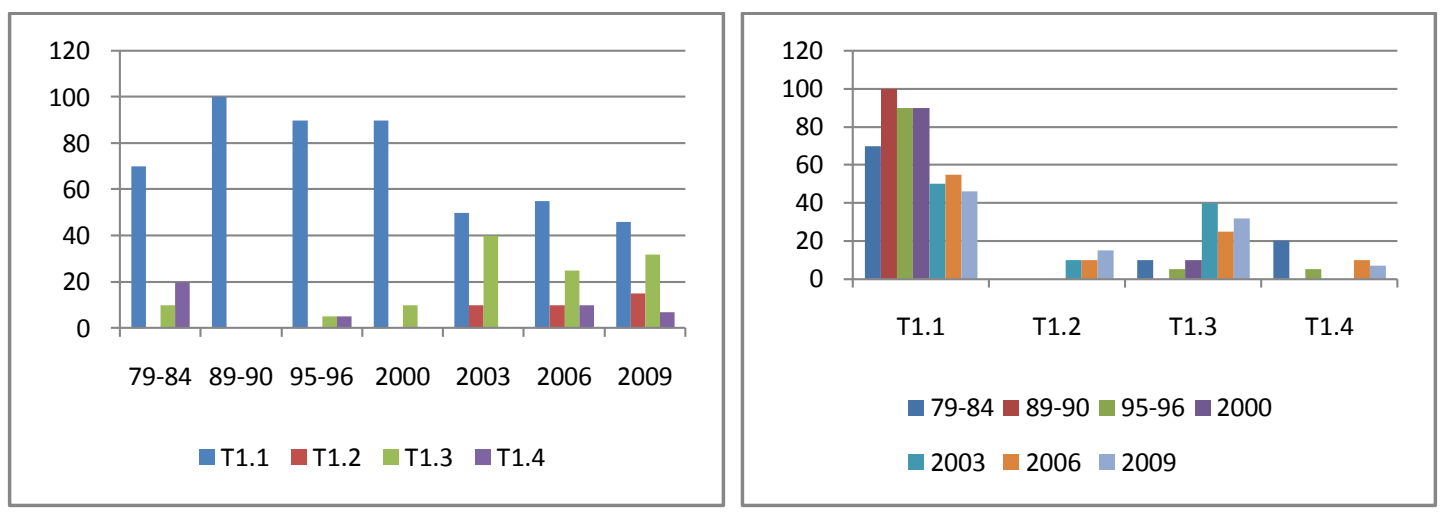

Gráfico 5.6(a) e 5.6(b): Distribuição dos sub-temas na Área Temática T1

De um modo geral, o que se destaca na evolução temporal no interior dessa área é um deslocamento, ainda que não muito acentuado, mas significativo, do sub-tema 1.1 (construção conceitual) para 1.2 e 1.3 (interações sócio-afetivas e linguagem), sendo um pouco maior nesse último. Ou seja, do ponto de vista da cognição, há uma redução da abordagem na construção conceitual (a ser detalhada a seguir) e um crescimento na dimensão sócio-afetiva e no papel da linguagem.

Mesmo com essa tendência se revelando, predominam em todos os períodos as investigações que focalizam mais especificamente o que denominamos por "construção conceitual", cuja preocupação central é estudar de que forma os alunos aprendem ou constroem conceitos científicos (sub-tema 1.1).

Por esse motivo, analisamos, dentro desse particular sub-tema, quais são as ênfases, abordagens ou referenciais adotados dentro dessa linha, de onde pudemos identificar cinco tendências principais, descritas a seguir:

1.1A - Estrutura conceitual (Ausubel)

1.1B - Desenvolvimento cognitivo e psicogênese (Piaget)

1.1C - Conhecimentos prévios / Concepções espontâneas ou alternativas

1.1D - Modelos mentais / Mudança conceitual

1.1E - Perfis conceituais / Representação social/ Abordagens sócio-culturais

$1.1 \mathrm{~F}$ - Outros (dificuldades conceituais, aprendizagem $\mathrm{x}$ metodologia, concepções $\mathrm{x}$ epistemologia; percepção/imaginação, campo conceitual) 
Em relação a essas tendências, obtivemos o seguinte mapeamento:
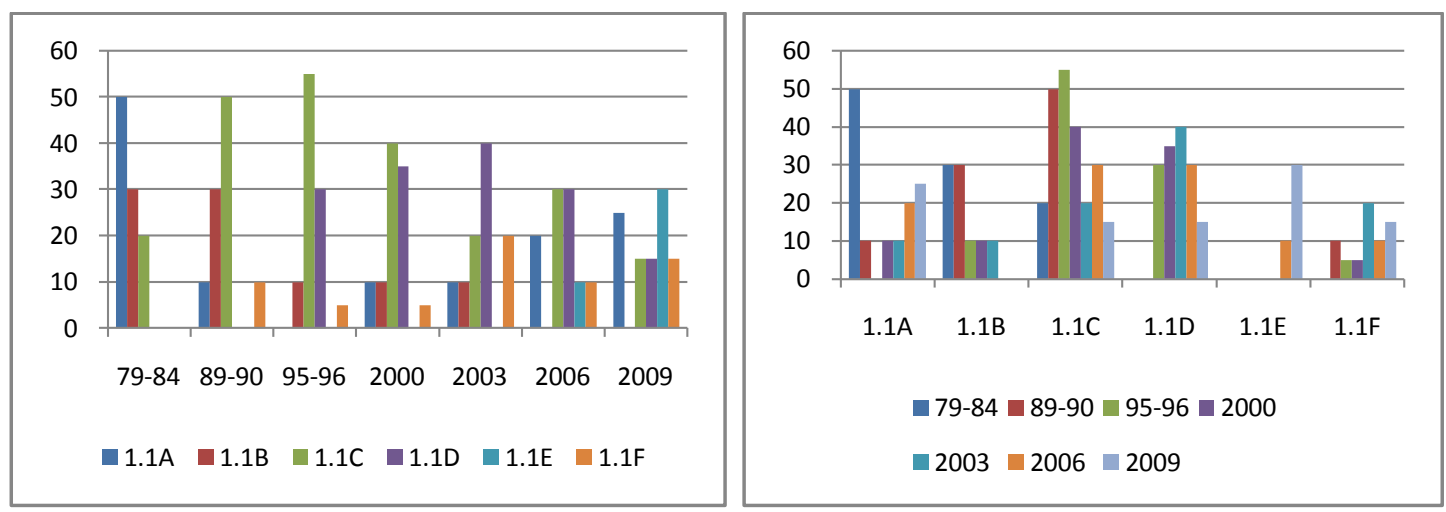

Gráficos 5.7(a) e 5.7(b): Distribuição dos enfoques no sub-tema "Construção Conceitual”

Observa-se que, na década de 1980, predominaram as ênfases nos estudos e teorias sobre desenvolvimento intelectual e cognitivo, com referencial em Piaget e sobre estruturas cognitivas e conceituais, tendo Ausubel como referência principal. 0 primeiro, com contribuições da epistemologia genética e enfoque psicológico, analisando as representações de mundo da criança no decurso de seu desenvolvimento intelectual que dariam sentido às suas experiências pessoais; o segundo, enfatizando as estruturas cognitivas e organização de ideias que favorecem o que chama de "aprendizagem significativa".

No final dessa década (1980), e na seguinte (1990), surgem e crescem de modo significativo as pesquisas com foco nas concepções de estudantes - espontâneas, alternativas ou intuitivas - com base, sobretudo, nos estudos de Viennot (1979). A partir de meados da década de 1990 e adentrando a primeira década de 2000 as investigações dessa natureza começam a se deslocar para os estudos de modelos mentais, mudanças conceituais e perfis conceituais. Já na segunda metade dessa década de 2000, instauram-se as abordagens sócio-culturais que incorporam uma dimensão sócio-interacionista e abrem espaço para linhas de investigação em que os contextos, a linguagem e as interações sócio-afetivas passam a ter especial importância nos processos de aquisição de conhecimento.

Há alguns aspectos importantes para os quais é necessário chamar a atenção, no que se refere a esses resultados, ou seja, à supremacia dessa área temática nas dissertações e teses e à evolução que se dá internamente a esta, que acreditamos ser possível estender à pesquisa na área de um modo geral.

O primeiro deles é que a predominância de pesquisas nessa linha, aqui tomada como uma área temática pode também ser percebida quando analisamos estudos diversos do tipo estado da arte sobre a pesquisa em ensino de ciências. Frequentemente tais estudos têm essa linha de investigação como eixo norteador principal na reconstrução histórica ou teórico-metodológica da área. Ou seja, para muitos 
pesquisadores, implícita ou explicitamente, a área de Pesquisa em Ensino de Ciências, do ponto de vista de suas tendências e objetos de investigação, tem como "carrochefe" esse foco dos processos de ensino e aprendizagem, centrados na cognição ou na construção de conhecimento. Não que desconsiderem outros focos e linhas, mas esses vêm, de certo modo, como decorrência ou desdobramentos do primeiro. Queremos dizer com isso, que para além e também por conta da predominância dessa linha temática, ela muitas vezes é tomada como "a própria área", aspecto que retomamos mais à frente.

Em alguns desses estudos e a partir de dado momento, esse conjunto de investigações passa a ser identificado por alguns pesquisadores com a chamada "Didática das Ciências" ou "Didática da Física" como é o caso de trabalhos já citados de Cachapuz (2004, 2005, 2008), Schnetzler (2002) e Moreira (1993, 2002, 2003), entre outros.

O segundo aspecto, que nossos dados não revelam por si próprios, é como ocorre a evolução dessas diferentes ênfases identificadas. Se de modo linear ou não, se com ou sem rupturas e conflitos. Quanto a isso, percebe-se em diferentes estudos analíticos sobre o percurso da área, que a gênese, a evolução e as transformações dessas tendências cognitivistas (concepções alternativas, modelos de mudança conceitual, perfil conceitual e abordagens sócio-culturais ou sócio-interacionistas) vão sendo substituídas umas pelas outras na medida em que vão apresentando limitações para responder a novas questões e passam a ser vistas criticamente. No entanto, não nos parece tratar-se propriamente de mudanças paradigmáticas, no sentido kuhniano aplicado às Ciências, ou seja, de "revoluções" nas quais uma teoria é abandonada, dando lugar a outra que the é incomensurável. Ainda que não seja nosso objetivo e que não nos aprofundamos nessa questão, arriscaríamos dizer que parece mais próprio compreender tais mudanças de linhas e referenciais do ponto de vista cumulativo, com sobreposições de ideias, sem rupturas na visão central sobre os focos da pesquisa ou sobre as finalidades do Ensino de Ciências. Talvez, sim, como analisa Martins (2004 e 2007) com mudanças de caráter epistemológico.

Não são poucas, na literatura da área de pesquisa em Ensino de Ciências, as análises ou descrições sobre as transições de uma a outra tendência ao longo das últimas décadas: dos enfoques piagetianos para o movimento de concepções alternativas, desses para os modelos de mudança conceitual, seguidos das proposições de perfil conceitual (ou epistemológico) e abordagens socioculturais. Estudos que a princípio parecem convergir de um modo geral, mesmo que com profundidades diversas.

Entre esses, Schnetzler (2002), em artigo que analisa tendências de investigações em "Didática das Ciências" aponta algumas características da evolução dessa linha de pesquisa. 
Sobre a passagem das concepções baseadas no behaviorismo para as contribuições da psicologia cognitivista, e a entrada em cena das pesquisas sobre concepções alternativas e mudança conceitual (dos anos 70 para 80):

...A principal crítica a esse movimento e às pesquisas por ele geradas era a de que se fundamentavam em uma concepção empirista de ciência que, associada aos resultados pouco promissores de avaliação dos projetos curriculares, levou os educadores em Ciências, no final dos anos 70, a desenvolverem investigações sobre como os alunos aprendem conceitos científicos, visando que os resultados orientassem o desenvolvimento de propostas curriculares mais eficazes. [...] os pesquisadores passaram a se fundamentar em contribuições da psicologia cognitivista, concebendo a aprendizagem como evolução, reorganização ou mudança das concepções dos alunos, cabendo ao ensino a sua promoção (SCHNETZLER, 2002, p.15)

...mudança conceitual foi o termo empregado para designar a transformação ou a substituição de crenças e idéias ingênuas (concepções prévias, alternativas) de alunos sobre fenômenos sociais e naturais por outras idéias, mais sofisticadas e cientificamente aceitas, no curso do processo de ensino-aprendizagem. Durante alguns anos, pareceu haver um certo consenso entre pesquisadores quanto às condições para a ocorrência de tal mudança. Uma delas era que o aluno deveria se sentir insatisfeito ou "em conflito" com sua concepção a fim de mudá-la ou substituí-la. Nesse sentido, ao ensino cabia promover tal conflito principalmente pelo confronto entre as concepções dos alunos e os resultados de atividades experimentais. (SCHNETZLER, 2002, p.16)

Sobre os problemas e desafios da linha nas concepções alternativas:

...Durante alguns anos, pareceu haver um certo consenso entre pesquisadores quanto às condições para a ocorrência de tal mudança [concepções espontâneas para científicas]. Uma delas era que o aluno deveria se sentir insatisfeito ou "em conflito" com sua concepção a fim de mudá-la ou substituí-la. Nesse sentido, ao ensino cabia promover tal conflito principalmente pelo confronto entre as concepções dos alunos e os resultados de atividades experimentais [...] No entanto, como as concepções dos alunos podem ser antagônicas às idéias cientificamente aceitas, porque construídas conforme características do senso comum e, portanto, comportando características dessa forma de pensar... há visões distintas entre aluno e professor que precisam ser expressas e negociadas. (SCHNETZLER, 2002, p.16)

Ainda sobre os desafios colocados e problemas resultantes dos movimentos de concepções alternativas (MCA) e de mudança conceitual (MMC), Martins (2007) em revisão histórica sobre esses movimentos, observa que

O MCA revelou uma profusão de concepções alternativas. Mas a intenção do ensino de ciências - como não poderia deixar de ser - é a busca da superação 
dessas condições, na medida em que elas se afastem daquilo que é considerado "conhecimento cientificamente aceito". Daí que tenham surgido modelos de ensino que pretendiam promover uma 'mudança conceitual', dos quais o MMC é o mais representativo...

... A resistência e tenacidade das concepções foi amplamente verificada. Desse modo, houve um 'relativização' das propostas de mudança conceitual, que passou a ser vista como um processo complexo de 'longo-termo'. O que diversos trabalhos também apontam é que, ao longo desse processo, há uma 'convivência de diferentes concepções' na estrutura cognitiva dos sujeitos. (MARTINS, 2007, P.56)

Retomamos a análise de Schnetzler, no que tange ao surgimento da nova tendência sóciointeracionista ou sociocultural,

...Nesses termos, pesquisadores na área passam a adotar posições epistemológicas mais racionalistas e contemporâneas de ciência, constatandose, desde o início da década de 90, a realização de trabalhos que também incorporam a dimensão sócio-interacionista à análise do processo de ensinoaprendizagem. Nesse âmbito, interações discursivas e a negociação social de significados são consideradas fundamentais na construção de conhecimentos. (SCHNETZLER, 2002, p.16)

Sobre esse movimento mais recente no qual se passa a valorizar ou enfatizar uma abordagem sociocultural na construção de conhecimento, Mortimer e Scott (2002) ressaltam algumas mudanças significativas em relação aos modelos anteriores embasados nas mudanças conceituais.

Essa 'nova direção' para a pesquisa em educação em ciências (Duit and Treagust, 1998) sinaliza um deslocamento dos estudos sobre o entendimento individual dos estudantes sobre fenômenos específicos para a pesquisa sobre a forma como os significados e entendimentos são desenvolvidos no contexto social da sala de aula. Muitas dessas pesquisas têm adotado, como perspectiva teórica, aquela relacionada à corrente socio-histórica ou sociocultural. Nessa tradição, o processo de conceitualização é equacionado com a construção de significados (Vygotsky, 1987), o que significa que o foco é no processo de significação. Os significados são vistos como polissêmicos e polifônicos, criados na interação social e então internalizados pelos indivíduos. Além disso, o processo de aprendizagem não é visto como a substituição das velhas concepções, que o indivíduo já possui antes do processo de ensino, pelos novos conceitos científicos, mas como a negociação de novos significados num espaço comunicativo no qual há o encontro entre diferentes perspectivas culturais, num processo de crescimento mútuo. As interações discursivas são consideradas como constituintes do processo de construção de significados. (MORTIMER e SCOTT, 2002) 
Ainda, nessa direção, Moreira (1993) em artigo sobre o estado da arte na "Investigação em Didática da Física" (IDF), para distingui-la do "desenvolvimento instrucional e curricular em Física" a define como "uma atividade de busca sistemática, fundamentada teórica e metodologicamente, de respostas para perguntas sobre aprendizagem, ensino e currículo de Física, dentro de um determinado contexto". Ao analisar os referenciais que fundamentam a IDF, afirma que

... No que se refere ao domínio conceitual, à fundamentação teórica, a investigação em didática da Física passou, também, de maneira progressiva, de um referencial basicamente behaviorista, nas décadas de sessenta e setenta, para o enfoque cognitivista/ construtivista dominante nos dias de hoje. Esse enfoque, no entanto, parece apresentar sinais de ser insuficiente para explicar alguns resultados da pesquisa e para guiar novas investigações. Em função disso, um referencial mais amplo começa a ser delineado: o da ciência cognitiva, uma nova ciência ainda forjada a partir de contribuições da psicologia, da filosofia, da ciência da computação, da lingüística e da neurociência. (MOREIRA, 1993).

Quanto às temáticas pesquisadas na IDF e suas mudanças, em outro artigo, sintetiza as diferentes fases e as identifica com tendências internacionais:

Sem muito rigor, pode-se dizer que a década de sessenta foi a dos grandes projetos curriculares, a de setenta foi a das concepções alternativas e a de oitenta a da mudança conceitual. Contudo, fica mais difícil caracterizar da mesma maneira a década de noventa pois houve uma maior diversificação nos temas de pesquisa. Surgiram muitos estudos sobre professores, sobre o papel da linguagem no ensino e na aprendizagem de Física, sobre analogias, História da Física, novas tecnologias, modelos mentais. Tudo em nível internacional, quer dizer, são esses, de um modo geral, os temas pesquisados no Brasil, na Espanha, na Inglaterra, na Argentina ou em qualquer outro país onde a área de pesquisa em Ensino de Física esteja desenvolvida. (MOREIRA, 2002b, p.1) (grifos nossos)

Esses e outros estudos, ao analisarem a evolução da pesquisa em Ensino de Ciências, além de terem predominantemente como foco central o domínio conceitual (cognição), enfatizam ainda, que mesmo havendo nesse percurso conflitos que demandaram novos modelos ou referenciais, esses se dão sobretudo internamente, de modo compartilhado pela comunidade de pesquisadores que desenvolvem investigações nessa perspectiva.

\section{Área Temática 2: Materiais, Métodos e Estratégias}

A Área Temática 2 - Materiais, Métodos e Estratégias de Ensino - também merece especial destaque. Ainda que não seja a segunda, mas a terceira em termos de percentual no conjunto total da amostra (14\%), como se pode ver no gráfico 5.5 , os trabalhos que foram nela classificados tendo esse tema foco como principal não só 
têm participação expressiva em muitos dos períodos analisados, como historicamente têm papel importante em nossa pesquisa. Nos primeiros anos da década de 1980 , agrupava $30 \%$ das dissertações e teses, passa para $15 \%$ no início dos anos 90 e, nos demais períodos, até o final da primeira década de 2000, estabiliza-se em torno dos $10 \%$

\begin{tabular}{|l|l|l|}
\hline \multicolumn{2}{|l|}{ PERÍODO } & T2/TOTAL (\%) \\
\hline P1 & $79-84$ & 29 \\
\hline P2 & $89-90$ & 15 \\
\hline P3 & $95-96$ & 12 \\
\hline P4 & 2000 & 12 \\
\hline P5 & 2003 & 9 \\
\hline P6 & 2006 & 12 \\
\hline P7 & 2009 & 12 \\
\hline \multicolumn{2}{|l|}{ Total cumulativo } & $14 \%$ \\
\hline
\end{tabular}

Tabela 5.4: Percentual da Área Temática T2 em cada período

Essa temática congrega as investigações que têm como foco os diferentes métodos, estratégias, abordagens ou recursos didáticos. Abrange uma grande diversidade de propostas metodológicas ou relatos e resultados de atividades e vivências em sala de aula, análise ou propostas de utilização de recursos didáticos diversos visando o aperfeiçoamento do ensino.

Em termos de natureza da linha de pesquisa, as TIC (Área Temática T8 - Tecnologias de Informação e Comunicação) estariam aqui enquadradas, como já observamos anteriormente.

O que significa que desse ponto de vista, a incidência de trabalhos com essa perspectiva cresce bastante, particularmente a partir do início dos anos 2000, como mostra a tabela 5.5, em que refazemos a anterior, com os percentuais, em cada período, somadas essas duas áreas.

\begin{tabular}{|l|l|l|}
\hline \multicolumn{2}{|l|}{ PERÍODO } & $\begin{array}{l}\text { T2+T8/TOTAL } \\
(\%)\end{array}$ \\
\hline P1 & $79-84$ & 30 \\
\hline P2 & $89-90$ & 19 \\
\hline P3 & $95-96$ & 18 \\
\hline P4 & 2000 & 26 \\
\hline P5 & 2003 & 17 \\
\hline P6 & 2006 & 23 \\
\hline P7 & 2009 & 25 \\
\hline Total cumulativo & $23 \%$ \\
\hline
\end{tabular}

Tabela 5.5: Percentual da soma das Áreas Temáticas T2 e T8 em cada período

Olhando por essa perspectiva, o foco nos estudos sobre estratégias, recursos e métodos de ensino passaria a constituir o segundo foco temático com maior incidência, praticamente se equiparando à primeira área temática na segunda metade da década 2000-2009. Na distribuição cumulativa (gráfico 5.5) concentraria 
$23 \%$ dos trabalhos, quase um quarto do total da amostra, participação bem pouco inferior à área temática $\mathrm{T} 1$, com $27 \%$.

Uma análise mais refinada, levando-se em conta os sub-temas identificados nessa área, mostra quais são os enfoques presentes e como evoluem no tempo. São os principais sub-temas identificados nas pesquisas e utilizados como categorias de análise:

2.1 - Recursos didáticos (à exceção de livros, experimentos e tecnologias de informação e comunicação)

2.2 - Metodologias e estratégias de ensino (projetos de ensino, metodologias de ensino, estratégias e atividades didático-pedagógicas, resolução de problemas)

2.3 - Laboratório didático e atividades experimentais

2.4 - Texto didático e/ou paradidático

Nos gráficos 5.9(a) e 5.9(b) pode-se observar a evolução dos trabalhos classificados nessa AT segundo esses sub-temas.
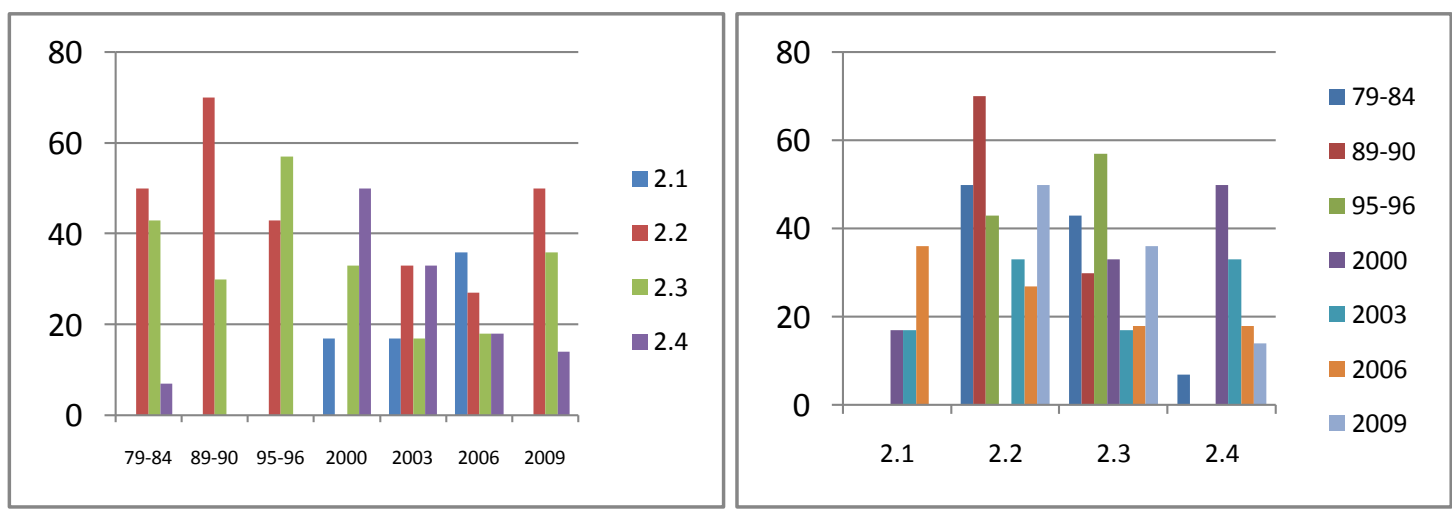

Gráfico 5.9(a) e 5.9(b): Distribuição dos trabalhos na Área Temática 2

Nos dois primeiros períodos analisados (década de 1980), há uma predominância do sub-tema 2.2 (metodologias e estratégias) com participação de 50 a 70\%, respectivamente. Nos períodos seguintes essa tendência diminui (some em 2000) e cresce outra vez, voltando aos 50\% dos trabalhos nessa linha em 2009.

Os estudos sobre laboratório e atividades experimentais - sub-tema 2.3 - também têm maior contribuição nos períodos iniciais, começam a diminuir na década de 2000, mas ao seu final (2009) crescem novamente. Já os trabalhos sobre livro didático têm movimento inverso: praticamente ausentes até o início da década de 2000, quando surgem e constituem $50 \%$ dos trabalhos, passam a decrescer ao longo dessa mesma década (com participação de 15\% em 2009). A pouca expressividade do primeiro sub-tema - recursos didáticos - pode ser compreendida pelo fato de que, entre esses recursos, as atividades experimentais, o livro didático e as TICs, meios privilegiados nas pesquisas, constituíram categorias à parte. 


\section{Áreas temáticas 1 e 2: Processos de ensino-aprendizagem}

Como já observamos, outro resultado importante a ser destacado vem da análise dessas duas primeiras áreas temáticas juntas. No primeiro período, 1979-1984, 73\%, portanto quase $3 / 4$ dos trabalhos estão concentrados nessas duas áreas. A partir do início da década de 1990 , em todos os períodos, somam cerca de $40 \%$. Isso sem contar a inclusão das "TICs", pois se também acrescidas nesse conjunto, a partir de 2000 esse agrupamento está representado por cerca de metade do total da amostra. Esses resultados estão sistematizados na Tabela 5.6 e no Gráfico 5.10 correspondente.

\begin{tabular}{|l|l|l|l|l|l|}
\hline \multicolumn{2}{|l|}{ PERÍODO } & $\begin{array}{l}\text { T1/TOTAL } \\
(\mathbf{\%})\end{array}$ & $\begin{array}{l}\text { T2/TOTAL } \\
(\mathbf{\%})\end{array}$ & $\begin{array}{l}\text { T1+T2/TOTAL } \\
(\%)\end{array}$ & $\begin{array}{l}\text { T1+T2+T8/TOTAL } \\
(\%)\end{array}$ \\
\hline P1 & $79-84$ & 44 & 29 & 73 & $\mathbf{7 5}$ \\
\hline P2 & $89-90$ & 23 & 15 & 38 & $\mathbf{4 0}$ \\
\hline P3 & $95-96$ & 26 & 12 & 38 & $\mathbf{4 0}$ \\
\hline P4 & 2000 & 26 & 12 & 38 & $\mathbf{5 2}$ \\
\hline P5 & 2003 & 30 & 9 & 39 & $\mathbf{4 8}$ \\
\hline P6 & 2006 & 23 & 12 & 35 & $\mathbf{4 5}$ \\
\hline P7 & 2009 & 25 & 12 & 37 & $\mathbf{5 0}$ \\
\hline
\end{tabular}

Tabela 5.6: Participação do enfoque nos Processos de Ensino-Aprendizagem

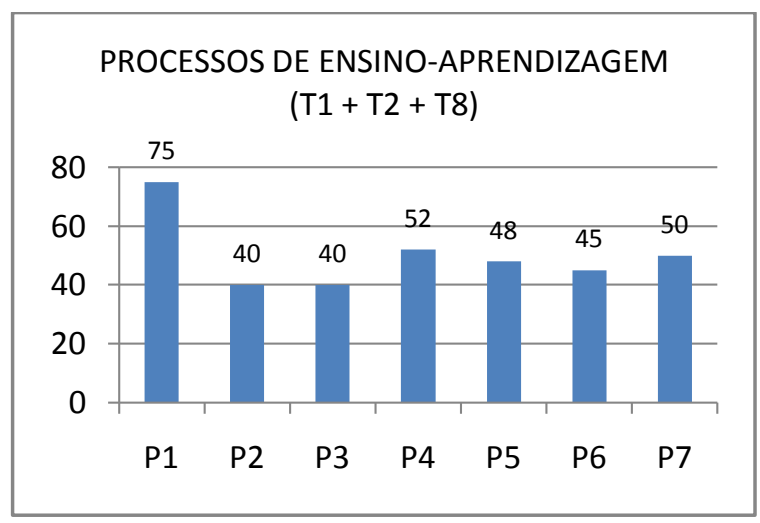

Gráfico 5.10: Participação do enfoque nos Processos de Ensino-Aprendizagem

Mais uma vez achamos importante "iluminar" esse resultado, já assinalado há algumas páginas. As pesquisas com foco nos processos de ensino-aprendizagem ocupam em nossa área, segundo os dados dessa amostra, parcelas em torno de $50 \%$.

Finalmente, é necessário considerar um dado histórico relevante, que nos faz trazer para aqui os primeiros anos não incluídos em nossa amostra, anteriores à década de 1980. No período inicial das primeiras dissertações e teses em Ensino de Física, entre 1972 e 1978, 90\% enquadram-se nessas duas primeiras áreas, sendo 75\% na Área Temática T2. (Gráfico 5.11) 


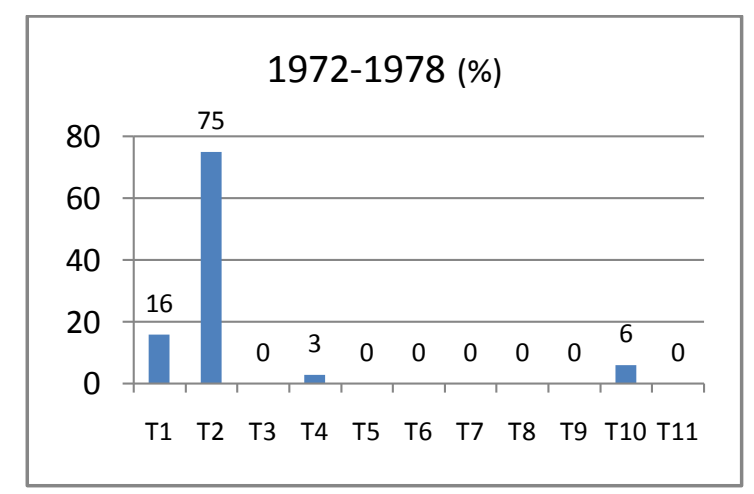

Gráfico 5.11: Distribuição das Áreas Temáticas no período inicial de constituição PEF

O que se verifica, quando comparamos os dados relativos a esse período inicial com os seguintes, é uma transição de foco, do "ensino", no qual os projetos, métodos e estratégias para aperfeiçoar o ensino concentravam maior atenção das pesquisas, para o foco na "aprendizagem", quando a preocupação das pesquisas se desloca para os processos de aquisição ou construção de conhecimentos científicos, referenciados na psicologia cognitiva e que abrem campo para diversas linhas de investigação.

\section{Área temática 3: Seleção e Organização do Conhecimento}

Na amostra geral, $12 \%$ dos trabalhos foram classificados na Área Temática 3 - Seleção e Organização do Conhecimento. Trata-se do quarto tema em termos de participação na classificação cumulativa.

São trabalhos cuja ênfase principal recai sobre o conhecimento a ser ensinado: conteúdos, temas e formas de organizá-los. Podem tratar de propostas e ênfases curriculares e para diferentes níveis de ensino (fundamental, médio ou superior) e podem focalizar um dado curso, disciplina ou área de conhecimento. Incluem-se investigações que tratam de "abordagens" ou critérios na organização do conhecimento, tais como interdisciplinaridade, contextualização e problematização ou, ainda, da relação entre o conhecimento científico e o escolar.

\begin{tabular}{|l|l|l|}
\hline \multicolumn{2}{|c|}{ PERÍODO } & $\begin{array}{l}\text { T3/TOTAL } \\
(\%)\end{array}$ \\
\hline P1 & $79-84$ & 13 \\
\hline P2 & $89-90$ & 14 \\
\hline P3 & $95-96$ & 19 \\
\hline P4 & 2000 & 6 \\
\hline P5 & 2003 & 8 \\
\hline P6 & 2006 & 16 \\
\hline P7 & 2009 & 10 \\
\hline \multicolumn{2}{|l|}{ Total Cumulativo } & $12 \%$ \\
\hline
\end{tabular}

Tabela 5.7: Participação da Área Temática T3 em cada período

Os períodos analisados na década de 1980 concentram uma parcela próxima à média geral (13 e 14\%). Cresce um pouco nos períodos 1995-1996 e 2006 (19 e 16\%, 
respectivamente). No entanto, em 2000 e 2003, anos que estão no intervalo entre esses dois períodos, são bem reduzidos os trabalhos com esse enfoque, $6 \%$ e $8 \%$ respectivamente. No último período, 2009, aglutina $10 \%$ dos trabalhos, valor também próximo à média geral. Ou seja, enquanto enfoque ou linha de pesquisa, não parece haver alguma tendência de crescimento ou de declínio das dissertações e teses com esse foco.

No que se refere às tendências internas dessa área temática, também buscamos analisar como se distribuem os diferentes enfoques, dados pelos sub-temas aqui identificados, a saber:

3.1 Currículo e programas

3.2 Física Moderna e Contemporânea no Ensino Médio e na Formação de Professores

3.3 Seleção de conteúdos e temas para dado curso, disciplina ou área de conhecimento

3.4 Abordagens e critérios na organização do conhecimento

3.5 Conhecimento escolar x Conhecimento científico

Resultados dessas classificações estão apresentados nos gráficos 5.12(a) e 5.12(b).
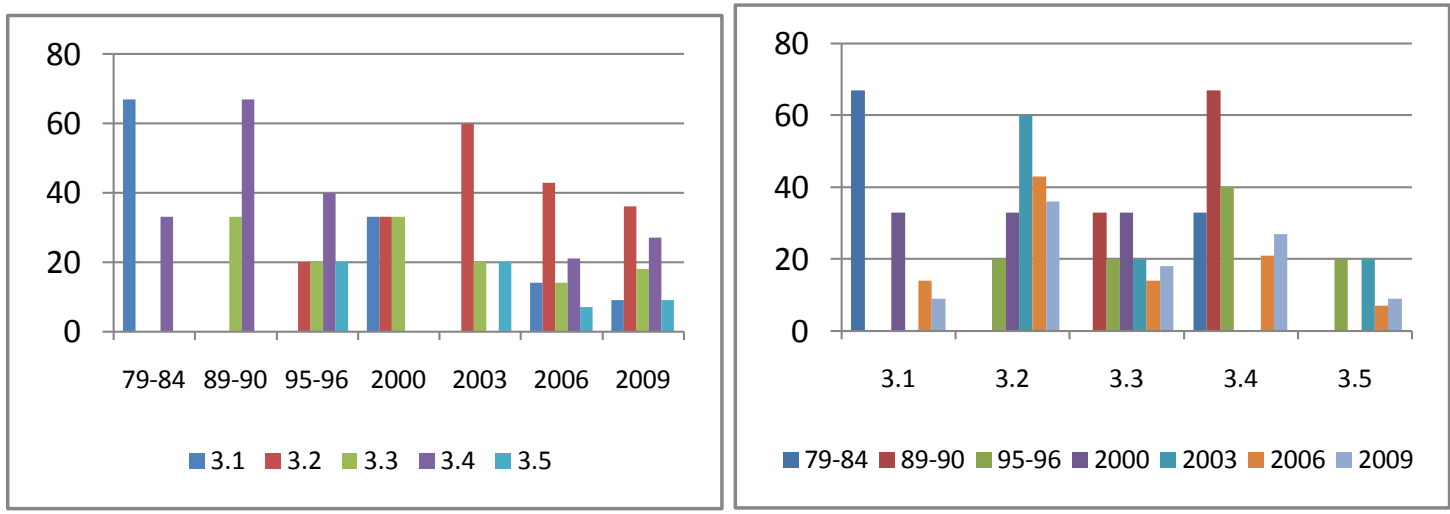

Gráficos 5.12 (a) e (b): Distribuição dos enfoques na Área Temática T3.

Observa-se, nessas distribuições, que não parece haver um enfoque privilegiado nas pesquisas dentro dessa área temática. As diferentes abordagens ou olhares para esse campo da seleção e organização curricular se alternam ao longo do tempo. Tratam-se de temas complementares e, mesmo internamente a cada um, há perspectivas diferenciadas.

São alguns dados significativos:

- A diminuição e presença reduzida do sub-tema 3.1, que trata de estudos sobre propostas curriculares. Sua predominância no primeiro período - 1979-1984 deve-se, sobretudo, a trabalhos mais pontuais sobre programas de disciplinas, particularmente no ensino superior; e sua participação mais expressiva em 2000, possivelmente seria um reflexo das reflexões e propostas que convergiram nas novas 
diretrizes curriculares, como a Lei de Diretrizes e Bases (LDB-1996) e os Parâmetros Curriculares Nacionais (PCN-1998).

- O surgimento (em meados de 1990), o aumento (com topo em 2003) e o declínio dos estudos sobre inserção da Física Moderna e Contemporânea no ensino médio ou na formação de professores, sub-tema 3.2.

- O sub-tema 3.4 é, de todos o de maior diversidade, uma vez que os critérios ou abordagens na seleção e organização do conhecimento são muito diversos variam ao longo do tempo, tais como abordagens unificadoras, "física do cotidiano", uso de problematizações, interdisciplinaridade, complexificação, inserção de temáticas contemporâneas e seus tratamentos, entre outros. Sua presença relativamente elevada no final dos anos 80, início dos 90 se deu, em especial, pelo surgimento de algumas pesquisas na linha "freireana"; em meados da década de noventa, marcam presença os trabalhos que discutem e analisam, particularmente a proposta "GREF".

\section{Área Temática 4: Formação de professores}

No conjunto geral da amostra, a Área Temática 4 - Formação de Professores - ocupa a segunda posição, aglutinando $16 \%$ dos trabalhos (Gráfico 5.5). Incluem-se aqui investigações sobre formação inicial e continuada de professores, perfil profissional, práticas e saberes docentes e concepções de professores sobre temas diversos.

\begin{tabular}{|l|l|l|}
\hline \multicolumn{2}{|l|}{ PERÍODO } & $\begin{array}{l}\text { T4/TOTAL } \\
(\%)\end{array}$ \\
\hline P1 & $79-84$ & 4 \\
\hline P2 & $89-90$ & 18 \\
\hline P3 & $95-96$ & 16 \\
\hline P4 & 2000 & 20 \\
\hline P5 & 2003 & 20 \\
\hline P6 & 2006 & 19 \\
\hline P7 & 2009 & 16 \\
\hline \multicolumn{2}{|r|}{ Total cumulativo } & $16 \%$ \\
\hline
\end{tabular}

Tabela 5.8

Até final da década de 1980, quando as pesquisas estavam predominantemente voltadas aos processos de ensino-aprendizagem, a linha de pesquisa sobre a formação de professores não tinha muita expressão. De 4\% das dissertações e teses, no período 1979-1984, passam para 18\% no início da década de 1990 (1989-1990), parcela em torno da qual se mantém ao longo de toda a primeira década de 2000.

Segundo esses dados, a partir dos anos 90, a formação de professores passa a ser foco de pesquisa na área, mantendo-se relativamente estável, e com parcela bastante significativa (em torno de $20 \%$ ) ao longo de todos os períodos subseqüentes. 
Para identificar as ênfases desenvolvidas nessa linha, classificamos os trabalhos segundo os quatro sub-temas identificados nessa área temática, cujos resultados estão sistematizados nos gráficos 5.11(a) e 5.11(b).

4.1 - Formação inicial de professores

4.2 - Formação continuada de professores

4.3 - Perfil profissional e prática docente

4.4 - Concepção de professores sobre temas diversos
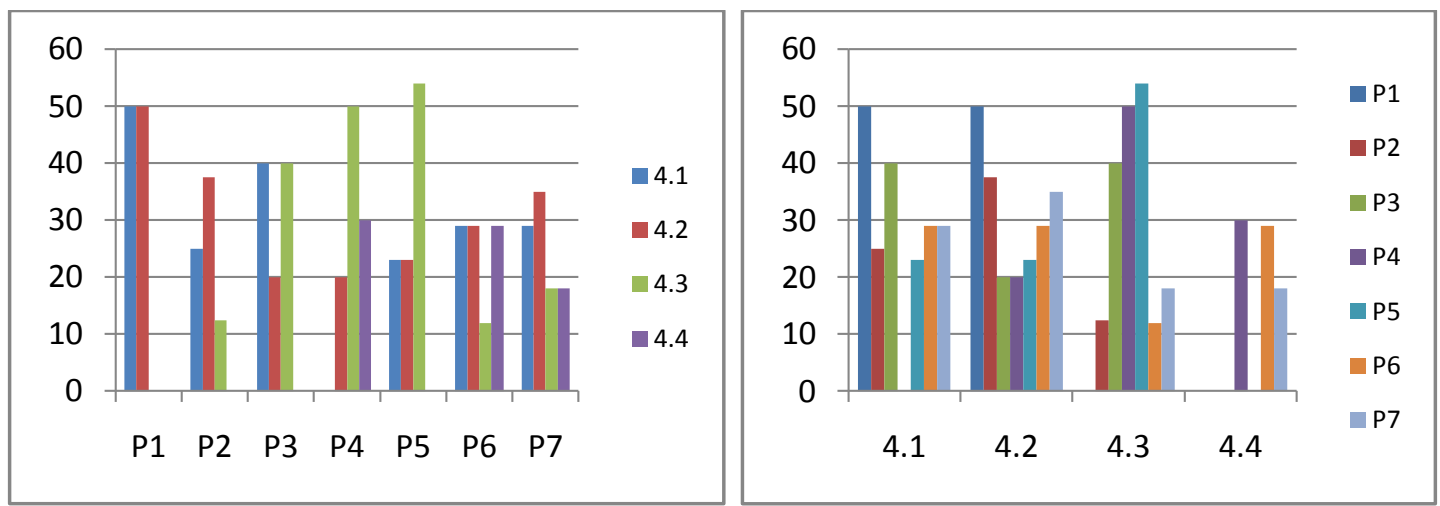

Gráficos 5.13(a) e 5.13(b)

Na década de 1980 - dois primeiros períodos - predominam os trabalhos que tratam da formação inicial e continuada de professores, em geral relatos, reflexões e análises de cursos de licenciatura em Física e seus componentes curriculares ou sobre cursos e iniciativas de aperfeiçoamento, capacitação, especialização e extensão, formação inicial e continuada, respectivamente. No início da década de 1990 entram em cena investigações sobre perfil profissional de professores e práticas docentes, nas quais se incluem perfis sócio-econômicos e outras caracterizações de professores. Em especial, nesse momento começam a se esboçar investigações sobre as práticas e saberes docentes e sobre as intervenções do tipo pesquisa-ação ou reflexão na ação. Tais estudos ganham maior atenção em meados da década de 1990, tendo um crescimento expressivo no início dos anos 2000, sendo em 2000 e 2003 o foco privilegiado das teses nessa linha temática. Nos dois últimos períodos, 2006 e 2009, novamente a formação inicial e continuada voltam a predominar. Também se verificam, nos anos 2000, trabalhos com o olhar para concepções de professores sobre temas diversos: científico-conceituais, sócio-culturais, históricofilosóficos ou didático-pedagógicos (à exceção de 2003).

Quanto a esses dados, levantamos algumas hipóteses e questões que merecem (futuras) investigações. 
- Uma delas seria verificar as influências da nova LDB (1996) ou, mais adiante, das diretrizes curriculares para a formação de professores (2002): como repercutiram nos enfoques da pesquisa sobre a formação de professores.

- Outra seria a relação dessas tendências com os movimentos nos processos de ensino-aprendizagem. Em determinado momento, após os inúmeros estudos sobre concepções espontâneas e a entrada em cena dos modelos de mudança conceitual (anos 80/90) começa a se perceber a necessidade de analisar e reconceber a formação de professores para dar conta da "transposição" desses modelos para a prática escolar.

- Ao mesmo tempo essas tendências passariam a demandar estudos sobre concepções de professores tanto sobre aspectos científicos, quanto pedagógicos. Nesse último caso, talvez fosse o caso de investigar quais foram os temas sobre os quais se analisaram essas concepções ao longo do tempo. Uma hipótese que poderíamos arriscar quanto a esse aspecto, seria a ocorrência de um deslocamento dos focos pedagógicos e científico-conceituais para os epistemológicos e filosóficos e sócioculturais (fazendo uso das análises de discurso) acompanhando a evolução das demais temáticas.

- Finalmente, outro estudo nessa "agenda de pesquisa", seria a análise de como evoluem as ideias sobre papel do professor, par e passo com a evolução mais geral da área.

\section{Área temática 5: História e Filosofia da Ciência}

A área temática História e Filosofia da Ciência fecha esse primeiro bloco das cinco primeiras "áreas principais" com presença relativamente expressiva.

Foram aqui classificadas as produções que tratam de aspectos históricos, filosóficos ou sociológicos da ciência e suas relações mais ou menos diretas com o ensino de Física.

Segundo os dados aqui obtidos, enquanto tema de pesquisa, a "História e Filosofia da Ciência" passa a ter presença no final da década de 1970 e, ao final dos anos 80, se estabelece e se mantém até os dias atuais de modo relativamente estável.

Na distribuição do conjunto de trabalhos tem participação de $11 \%$. À exceção do primeiro período (1979-1984), em que é representada por $4 \%$ da amostra, a partir do final da década de 1980 atinge cerca de $10 \%$ dos trabalhos, parcela em torno da qual se mantém até o final da primeira década de 2000 (Tabela 5.9). 


\begin{tabular}{|l|l|l|}
\hline \multicolumn{2}{|l|}{ PERÍODO } & T5/TOTAL \\
\hline P1 & $79-84$ & 4 \\
\hline P2 & $89-90$ & 11 \\
\hline P3 & $95-96$ & 14 \\
\hline P4 & 2000 & 10 \\
\hline P5 & 2003 & 11 \\
\hline P6 & 2006 & 12 \\
\hline P7 & 2009 & 12 \\
\hline \multicolumn{2}{|c|}{ Total cumulativo } & $11 \%$ \\
\hline
\end{tabular}

Tabela 5.9: Participação da Área Temática T5 nos períodos

Identificamos, nessa linha, os seguintes enfoques:

5.1 História e Filosofia da Ciência no ensino de Física

5.2 Concepção e representação de Ciência

5.3 Aspectos abrangentes sobre História e Filosofia da Ciência, não diretamente ligados ao ensino

5.4 Características e modelos sobre conhecimento científico/físico;

5.5 História da Física, dos físicos e/ou do ensino de Ciências / Física no Brasil.

Quanto a esses enfoques, encontramos as seguintes distribuições dos trabalhos nos períodos:

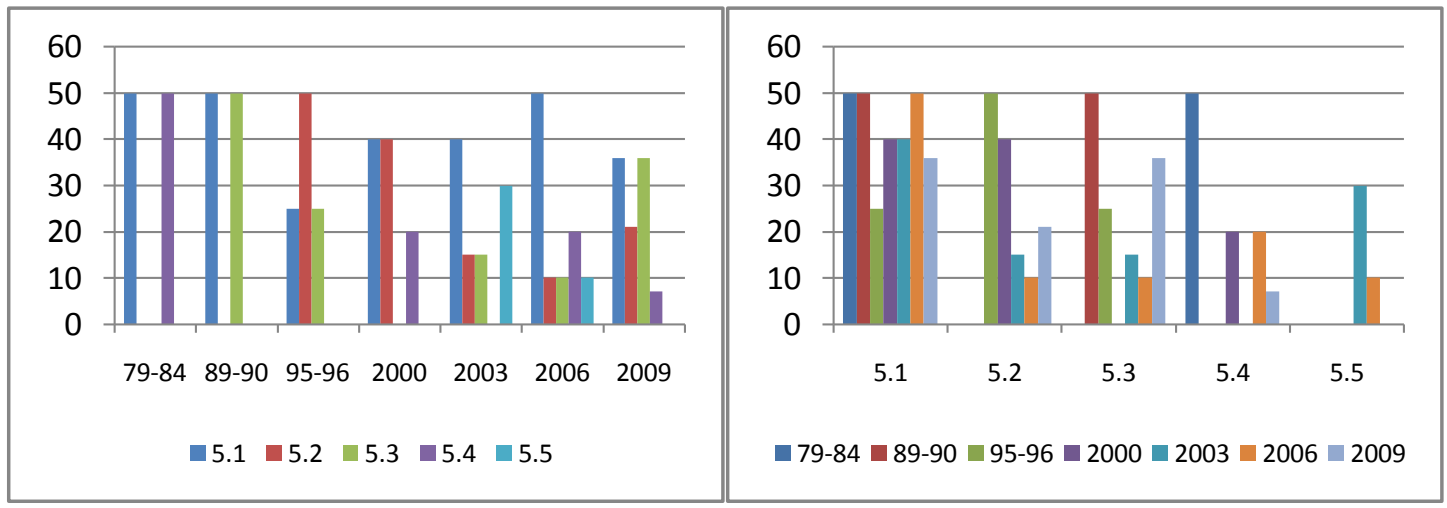

Gráficos 5.14(a) e (b): Distribuição dos enfoques na Área Temática T5

O resultado mais expressivo nesses dados é a predominância do sub-tema 5.1 , que agrega os trabalhos que investigam o uso de aspectos históricos e filosóficos da ciência (ou da Física) no ensino: propostas, reflexões sobre temas, materiais ou estratégias de ensino com enfoque na HFC nos diferentes níveis de ensino. Trata-se, de fato, da vocação principal dessa temática, desde suas origens.

Em praticamente todos os períodos esse é o foco dominante, à exceção de 19951996, quando surgem e sobressaem as análises sobre concepções ou representações de Ciência, de alunos, em materiais didáticos ou em propostas e diretrizes de cursos, temática que permanece com presença expressiva no início dos anos 2000. 
Também aqui, nessa linha temática, as concepções e perspectivas são variadas: de trabalhos que adotam referências históricas ou filosóficas mais como "ilustrativas" ou complementares ao ensino sem alterações significativas nas perspectivas educacionais, até os que têm uma concepção mais crítica quanto ao conhecimento científico e a forma de tratá-lo no ensino. Entre uma e outra possibilidade, claro que existem gradações diversas. Há, ainda, trabalhos que focalizam estudos históricos ou filosóficos, mas pouco ou nada adentram no ensino e aqueles que procuram contemplar aspectos didático-pedagógicos.

\section{Bloco 2: Áreas Temáticas 6 A 11}

Como já assinalamos, esse segundo grupo de temáticas tem uma representação relativamente reduzida nas dissertações e teses, praticamente não superando, em conjunto, a marca dos $25 \%$ ao longo do tempo. Excetuando-se o primeiro período, a partir do final da década de 1980 não parece haver qualquer tendência de crescimento ou diminuição nesse conjunto, que oscila em torno dos $20 \%$, valor de sua frequência na distribuição cumulativa das temáticas.

\begin{tabular}{|l|l|c|}
\hline \multicolumn{2}{|l|}{ PERÍODO } & $\begin{array}{c}\text { SOMA T6 A T11 } \\
\text { (\%) }\end{array}$ \\
\hline P1 & $79-84$ & 6 \\
\hline P2 & $89-90$ & 18 \\
\hline P3 & $95-96$ & 15 \\
\hline P4 & 2000 & 26 \\
\hline P5 & 2003 & 22 \\
\hline P6 & 2006 & 17 \\
\hline P7 & 2009 & 25 \\
\hline
\end{tabular}

Tabela 5.10: Participação das Áreas Temáticas T6 a T11 nos períodos

Também há que se tratar de modo particular, nesse conjunto, da área temática T8 (TIC) com distribuição de freqüências que se difere das demais em número e evolução e, de certo modo, também na sua natureza.

Dada a pequena representatividade desse bloco, não faremos uma análise de tema a tema, destacando apenas alguns aspectos mais gerais.

Algumas hipóteses prévias que poderíamos fazer sobre a contemplação desses temas em nossas pesquisas seriam:

- estão surgindo agora e ainda podem crescer e se estabelecer na pesquisa;

- inversamente ao caso anterior, já estiveram presentes em dado momento e declinaram;

- são episódicos, entram em cena e rapidamente saem;

- $\quad$ por serem ainda recentes ou por vocação própria não estão presentes na pesquisa (nas dissertações e teses) mas em trabalhos de eventos ou artigos de periódicos; 
- são desdobramentos de outros temas "tradicionais" e passaram a ter uma identidade própria;

- não se identificam ou não constituem uma linha de pesquisa da área;

- tratam de questões "marginais", com menor adesão ou aceitação pela comunidade de pesquisa ou, ainda, pela própria natureza, não são incorporados por essa.

O quadro que sistematiza a evolução ao longo do tempo de cada uma dessas áreas temáticas já revela algumas dessas possibilidades.

\begin{tabular}{|l|l|l|l|l|l|l|l|}
\hline \multicolumn{2}{|c|}{ PERÍODO } & T6 & T7 & T8 & T9 & 10 & T11 \\
\hline P1 & $79-84$ & 0 & 0 & 2 & 0 & 4 & 0 \\
\hline P2 & $89-90$ & 2 & 0 & 2 & 2 & 9 & 2 \\
\hline P3 & $95-96$ & 2 & 4 & 2 & 0 & 5 & 0 \\
\hline P4 & 2000 & 6 & 2 & 14 & 2 & 2 & 0 \\
\hline P5 & 2003 & 5 & 5 & 9 & 3 & 0 & 2 \\
\hline P6 & 2006 & 1 & 1 & 10 & 4 & 2 & 0 \\
\hline P7 & 2009 & 3 & 4 & 13 & 1 & 4 & 0 \\
\hline
\end{tabular}

\begin{tabular}{|c|}
\hline SOMA T6 \\
A T11 $(\%)$ \\
\hline 6 \\
\hline 18 \\
\hline 15 \\
\hline 26 \\
\hline 22 \\
\hline 17 \\
\hline 25 \\
\hline
\end{tabular}

Para auxiliar a leitura, reproduzimos novamente essas áreas temáticas:

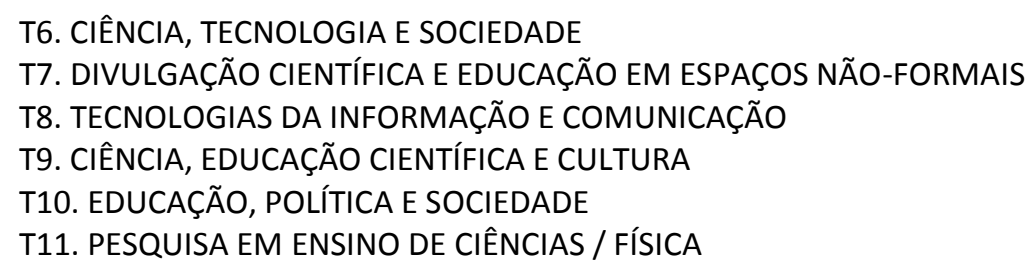

Observa-se que temas como CTS (T6), e Divulgação Científica e Educação em Espaços não Formais (T7) surgem em dado momento - anos noventa - e permanecem relativamente estáveis, com participação no conjunto que oscila em torno de 1 a $5 \%$. Ou seja, estariam mais próximos da nossa última hipótese, tratam-se de temáticas "marginais" ou "paralelas", não incorporadas (ainda) na pesquisa, o que não exclui sua presença mais elevada nos eventos (EPEF, ENPEC e SNEF) e em artigos de periódicos.

As questões relativas ao tema Ciência e Cultura (T9), além de também bastante reduzidas, também não apresentam alguma tendência de evolução. O que poderia sinalizar um tímido crescimento a partir dos anos 2000, não se confirma com os dados de 2009, impossibilitando inferências sobre perspectivas futuras.

A área temática Educação, Política e Sociedade (T10) abarca questões ou abordagens diferentes sobre aspectos relacionados a políticas e perspectivas educacionais e a aspectos institucionais relacionados ao ensino de Física. Nos anos setenta e oitenta, 
trabalhos dessa natureza tratavam mais do segundo aspecto, analisando perfis de instituições, evasão em cursos ou disciplinas ou de exames vestibulares. Já, a partir da década de 90 e entrando nos anos 2000, há uma tendência maior em reflexões sobre políticas ou concepções de educação.

Quanto à temática T11, que trata de aspectos teóricos, históricos ou metodológicos da própria Pesquisa em Ensino de Ciências ou de Física (metapesquisa), é praticamente ausente nas dissertações e teses, ainda que como bem apontamos e analisamos em nosso primeiro capítulo, venham crescendo muito nos últimos anos, mas ainda estão circunscritas no âmbito das publicações em periódicos e nos eventos. Poderíamos nos questionar sobre sua inclusão no rol de áreas ou categorias temáticas, não a deixando, como em outros casos em uma categoria que poderíamos chamar de "Outros". Quanto a isso, justificamos. A categoria "Outros" não foi adicionada porque poucas contribuições dariam a essa pesquisa, uma vez tratarem de questões pontuais e dispersas (a exemplo de trabalhos sobre Educação Especial). No entanto, a metapesquisa foi intencionalmente criada por se tratar da nossa área de pesquisa, portanto com um interesse particular. Ou seja, apenas está aqui representada, para indicar sua participação extremamente reduzida nas dissertações e teses. Estão presentes apenas nos período $89-90$ e 2003, com parcelas de $2 \%$, que correspondem, em ambos os casos a um único trabalho.

Propositalmente, deixamos por último a área temática das "TICs" (T8), pelo fato assinalado de que tem natureza diferente das demais, situando-se, enquanto perspectiva, quase que integralmente na categoria das estratégias de ensino e recursos didáticos, portanto dos processos de ensino-aprendizagem (no Bloco 1). São algumas poucas exceções, trabalhos que tratam aqui das novas tecnologias no ensino, particularmente no ensino a distância (EAD), alguns dos quais vão além dos aspectos puramente didáticos (tecnologias enquanto recurso para o ensino), abordando questões educacionais mais abrangentes.

Ainda quanto a essa área temática, vemos que dá um salto (parece surgir das cinzas) em 2000 e se mantém até 2009, com parcelas próximas dos $10 \%$ no conjunto da amostra. Quanto aos prognósticos para os próximos anos, poderíamos supor que, junto com a entrada das pesquisas sobre $E A D$, essa linha de investigação venha a crescer ainda mais, deslocando-se, contudo do foco ensino-aprendizagem para o de questões mais amplas sobre educação de um modo geral.

Poderíamos dizer, finalmente, que de um modo geral, a presença das áreas temáticas desse bloco poderiam representar preocupações ainda incipientes, que ultrapassam os limites de interesse da área de ensino de Ciências/Física nos processos de ensinoaprendizagem, sinalizando uma possível (?) transição de foco no século XXI. Para 
auxiliar essa compreensão, mais afeita às perspectivas das nossas pesquisas, tratamos no próximo capítulo da análise dos âmbitos em que vêm se dando.

\subsection{Sistematização e considerações gerais}

Os resultados obtidos nessa primeira frente de análise - temáticas da pesquisa apontam, portanto, para a predominância de pesquisas no conjunto caracterizado pelas cinco primeiras categorias temáticas (T1 a T5) somadas à categoria T8. Juntas, essas temáticas concentram em torno de 80 a $90 \%$ da produção analisada, nos diferentes períodos.

Dentro desse conjunto, sobressai a presença das três temáticas identificadas pela ênfase nos processos de ensino e aprendizagem (T1, T2 e T8). Com uma freqüência relativamente estável ao longo do tempo, elas representam cerca de metade da produção. E, ainda, nesse agrupamento, destaca-se uma expressiva concentração nos processos cognitivos de aprendizagem.

Não podemos dizer que tais resultados sejam surpreendentes, mas tampouco afirmaríamos que sejam naturais ou óbvios. Poderia se dizer que é natural ou esperado que uma área de pesquisa em ensino de... tenha como seu principal foco de interesse os meios, os procedimentos, as estratégias para tornar o ensino de... e, portanto a aprendizagem de... mais adequados ou mais eficientes. No entanto, é justamente esse dado que consideramos importante investigar, sinalizar e problematizar. Trata-se de um resultado que confirma uma das nossas hipóteses nucleares de pesquisa, já apontada anteriormente, acerca do "DNA" da área de Pesquisa em Ensino de Ciências, particularmente em Ensino de Física. Ainda que com mudanças e avanços dados pelas limitações identificadas em cada momento, o foco permanece, deixando lacunas e preterindo outras tendências de pesquisa. Esse aspecto se justificaria também por demandas de outras ordens, às quais voltaremos no capítulo oito.

Tendo em vista complementar essa análise, passamos à segunda frente de investigação, relativa à natureza e perspectivas da produção, dadas pelas dimensões e âmbitos (eixos e interfaces) em que se situam e de como evoluem, a ser desenvolvida no próximo capítulo. 


\section{Análise da produção: âmbitos e perspectivas}

Com o objetivo de complementar a análise iniciada no capítulo cinco, passamos a investigar as tendências da produção quanto a seus âmbitos e perspectivas. "Âmbitos e perspectivas" estão aqui sendo entendidos particularmente à luz do instrumento proposto no capítulo quatro, dado pela sistematização e articulação das temáticas da área de Ensino de Física nos três eixos organizadores Educação, Conhecimento e Processos de Ensino-Aprendizagem.

Retomando... Esses eixos foram tomados como referências para articular as três dimensões ou perspectivas formativas do Ensino de Ciências/Física e os focos de interesse e temáticas da pesquisa na área: os objetivos de se ensinar-aprender na dimensão da Educação (E); os conteúdos a serem ensinados ou o objeto do aprendizado (qual Ciência/ qual Física) na dimensão do Conhecimento (C) e os meios, estratégias e recursos de ensino para promoção da aprendizagem, na dimensão dos Processos de ensino e aprendizagem (P). Respectivamente, indicam tendências associadas ao para quê, o quê e como ensinar/aprender Física. Não se trata, como já dissemos de um "instrumento" ou "metodologia" arbitrário ou neutro (como nunca são os instrumentos e metodologias), mas criado a partir de nossos interesses e questões de pesquisa: situar a produção na área e identificar focos privilegiados nessa tríade " $E, C, P$ ".

Também partimos do pressuposto (e da verificação) de que frequentemente, na pesquisa em ensino, essas três dimensões são tratadas aos pares e mais adequadamente caracterizadas pelos seus planos de intersecção ou interfaces: Educação -Conhecimento (EC); Conhecimento - Processos (CP) e Educação Processos (EP).

... Tomadas duas a duas, as três dimensões produzem três planos de interface. Um destes planos liga a dimensão disciplinar, das ciências em nosso caso, com a dos objetivos educacionais; um segundo plano liga a dimensão das ciências com a dos processos e meios de aprendizagem; o terceiro plano relaciona objetivos da educação a seus processos. Cada um desses planos de interface corresponde a uma problemática específica, abrigando diferentes visões e tendências. É claro que é no espaço global, que encompassa todos os planos e dimensões, que se realiza o aprendizado. No entanto, o aprendizado pode sofrer deformações, sempre que alguma de suas dimensões estiver sub-representada.(MENEZES,....) 
É certo que não estamos partindo do zero, de página em branco. Ao longo dos capítulos precedentes, explicita ou implicitamente, incluindo os resultados obtidos na análise das temáticas (capítulo cinco) já consideramos que nesse espaço multidimensional há dominâncias e lacunas, com dimensões e interfaces sobre e subvalorizadas. O propósito desse capítulo é, pois, melhor identificar e demarcar de que modo a pesquisa vem se situando nesse "complexo espaço de conceitos, práticas e intenções formativas" (Menezes, Kawamura, Hosoume) que lhe conferem identidade quanto à sua natureza e perspectivas.

No primeiro tópico desse capítulo (Tópico 6.1) fazemos uma análise dos trabalhos segundo essas interfaces, utilizando a mesma amostra selecionada no capítulo 5, na análise das Áreas Temáticas. Uma vez caracterizadas as pesquisas nessas interfaces, tratamos de estudar mais especificamente de que modo dimensões específicas, particularmente o conhecimento científico (dimensão disciplinar) e as finalidades do ensino (dimensão educacional) vêm sendo contemplados. (Tópicos 6.2 e 6.3).

\subsection{Análise da produção segundo âmbitos ou interfaces}

Utilizando as três interfaces definidas (CP, EC e EP), classificamos as dissertações e teses da nossa amostra (o conjunto de 470 títulos definido no capítulo cinco). Embora não totalmente excludentes e havendo casos de trabalhos identificados mais especificamente em um dos três eixos e outros que de certo modo contemplam os três, utilizamos essas categorias como único critério de classificação, situando cada trabalho em uma dessas interfaces, conforme a tendência predominante.

No quadro a seguir reapresentamos sinteticamente as características dos trabalhos situados em cada uma dessas interfaces.

Conhecimento-Processos (CP): Foco na articulação entre o objeto de aprendizado (dimensão do Conhecimento ou das Ciências) com os métodos de promovê-lo ou as formas sob as quais ocorre o aprendizado (dimensão dos Processos), não explicitando finalidades formativas. Prevalece o "como" ensinar/aprender Física.

Educação-Conhecimento (EC): Foco na combinação entre as finalidades do ensino (dimensão da Educação) e a seleção e/ou organização do conhecimento a ser ensinado / aprendido em determinado contexto (dimensão do Conhecimento). Ainda que possam implícita ou explicitamente contemplar os processos, esse não é o foco.

Educação-Processos (EP): Foco na articulação entre finalidades do ensino (dimensão Educacional) e os meios para alcançá-las (dimensão dos Processos) não tendo os objetos do ensino - o conhecimento específico - como aspecto relevante a ser tratado.

Quadro 6.1: Características dominantes das Interfaces 
$\mathrm{Na}$ tabela 6.1 e no conjunto de gráficos 6.1 apresentamos uma síntese das classificações nas interfaces em cada um dos sete períodos da amostra definida e usada no capítulo cinco.

\begin{tabular}{|l|l|l|l|l|l|l|l|l|}
\hline \multicolumn{2}{|l|}{ PERÍODO } & \multicolumn{2}{l}{ INTERFACE CP } & \multicolumn{2}{l}{ INTERFACE EC } & \multicolumn{2}{l}{ INTERFACE EP } & TOTAL \\
\hline P1 & $79-84$ & 37 & 77 & 11 & 23 & 0 & 0 & 48 \\
\hline P2 & $89-90$ & 26 & 59 & 15 & 34 & 3 & 7 & 44 \\
\hline P3 & $95-96$ & 37 & 65 & 15 & 26 & 5 & 9 & 57 \\
\hline P4 & 2000 & 32 & 64 & 14 & 28 & 4 & 8 & 50 \\
\hline P5 & 2003 & 40 & 61 & 16 & 24 & 10 & 15 & 66 \\
\hline P6 & 2006 & 60 & 67 & 23 & 26 & 6 & 7 & 89 \\
\hline P7 & 2009 & 71 & 61 & 34 & 29 & 11 & 10 & 116 \\
\hline TOTAL & 303 & 65 & 128 & 27 & 39 & 8 & 470 \\
\hline
\end{tabular}

Tabela 6.1: Distribuição dos trabalhos nas Interfaces em cada período

Seguem os Gráficos correspondentes a essas distribuições. 
Distribuição das interfaces por período (em percentuais)
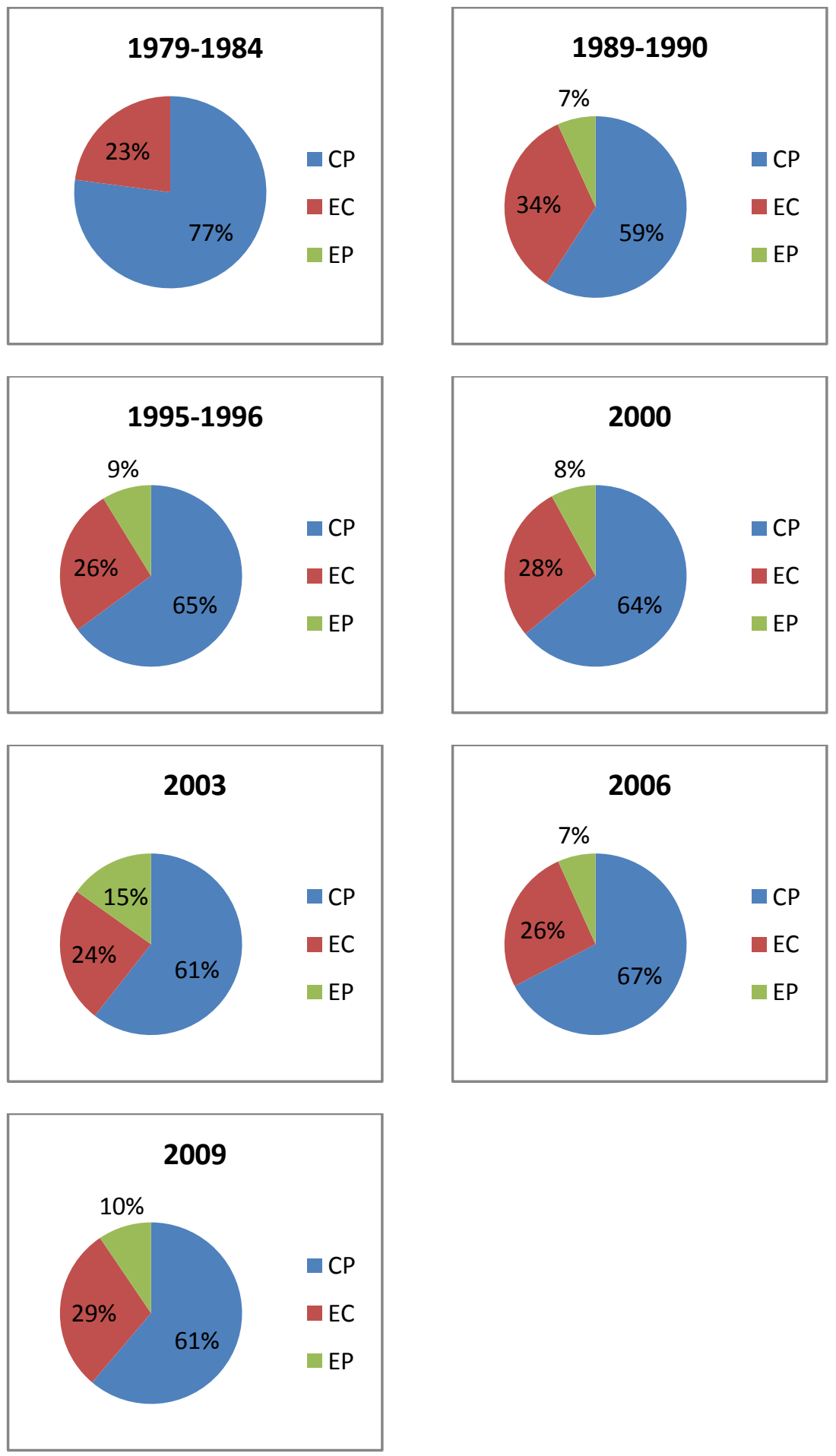

Gráficos 6.1: Distribuições das interfaces por períodos (percentuais) 
Sintetizamos esse conjunto de gráficos em um único, nas formas 6.2(a) e 6.2(b) para dar uma visão geral da evolução dos trabalhos segundo as categorias (interfaces) propostas.

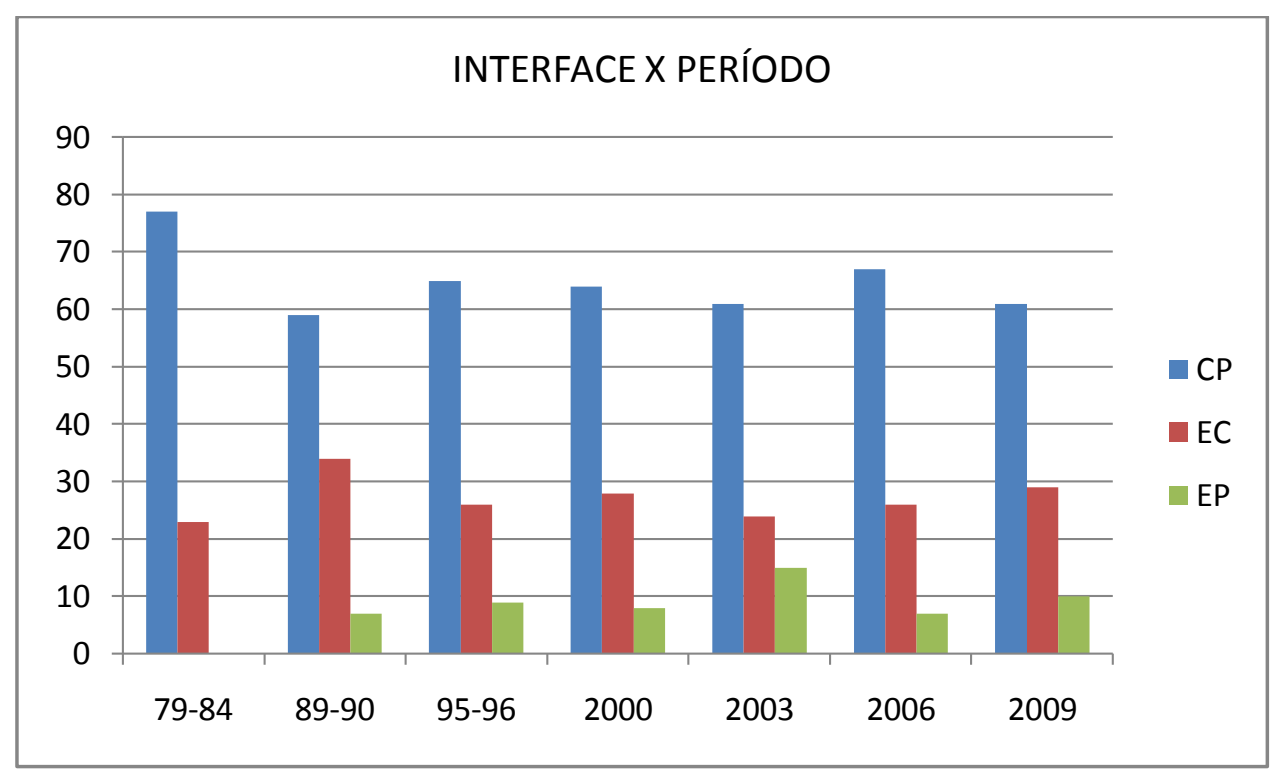

Gráfico 6.2(a): Distribuição das interfaces por período (\%)

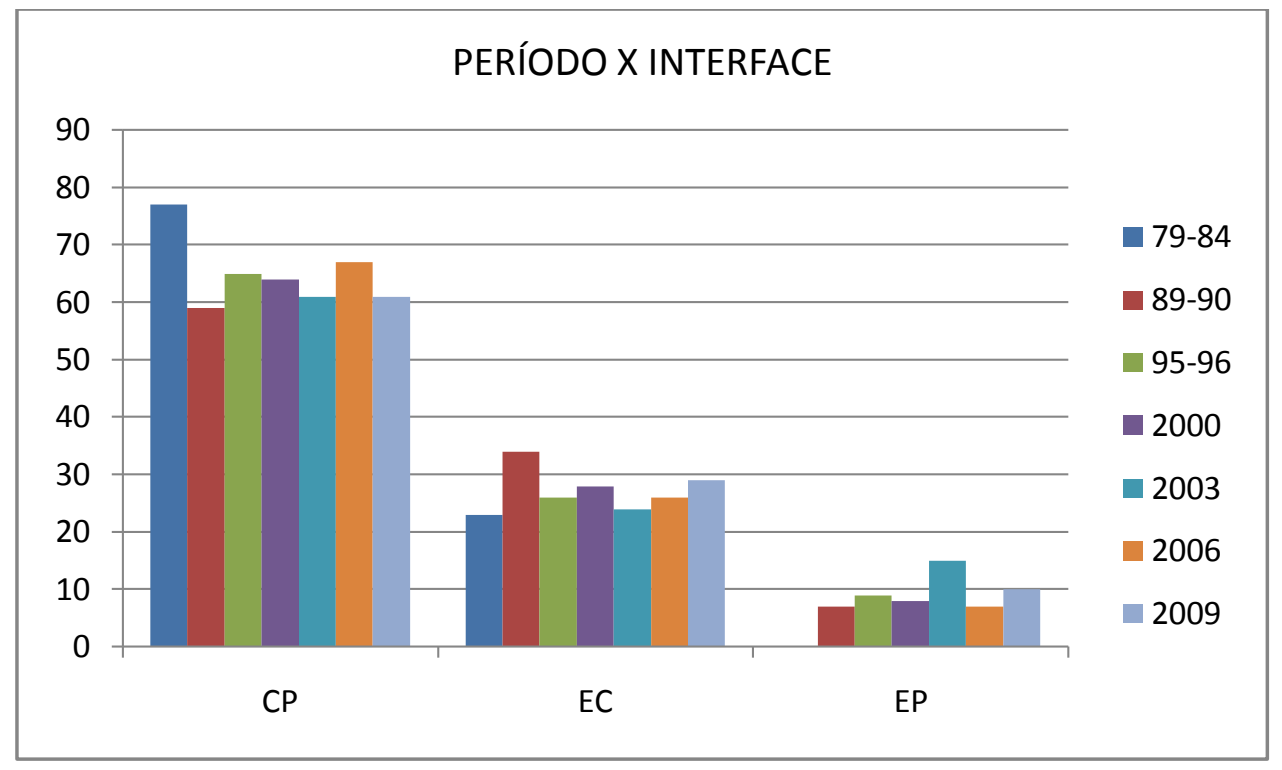

Gráfico 6.2(b): Distribuição dos períodos por interface (\%) 
A distribuição cumulativa (geral) de frequências das interfaces no conjunto da amostra está representada no gráfico 6.3.

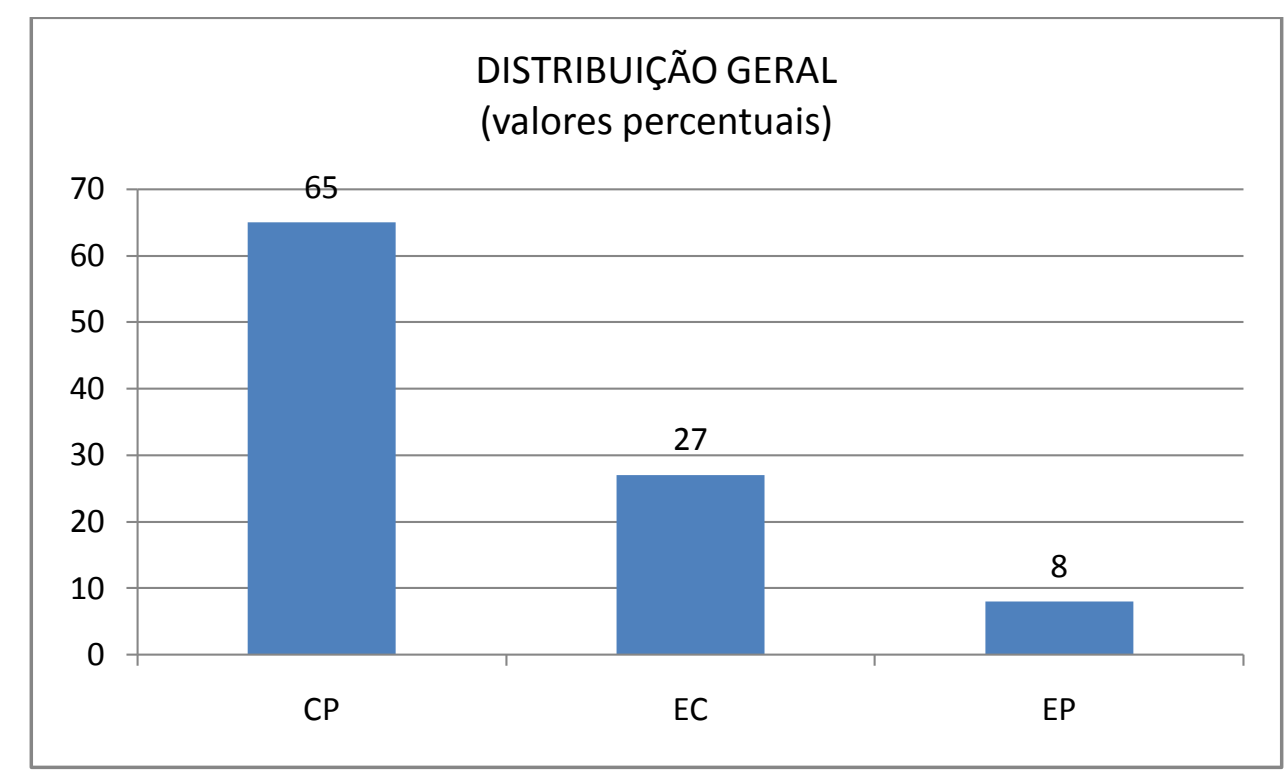

Gráfico 6.3: Distribuição cumulativa da amostra nas interfaces

Entre os resultados apontados por essas distribuições, o mais importante é a significativa predominância, em todos os períodos analisados, da interface Conhecimento-Processos (CP). Sua participação na amostra oscila em torno de 60 a $70 \%$, sendo superior no primeiro período (1979-1984), no qual quase $80 \%$ dos trabalhos estão aí situados. Seguem, respectivamente as interfaces EducaçãoConhecimento (EC), oscilando em torno de 25 a 30\%, e Educação-Processos (EP), com menor concentração em todos os períodos, variando entre 0 e 15\%. Na distribuição geral, cumulativa, essas interfaces correspondem a, respectivamente, $65 \%$ (CP), $27 \%$ (EC) e $8 \%(E P)$ do total.

De um modo geral, não há grandes discrepâncias nessas distribuições ao longo dos sete períodos. Nas categorias CP e EC há poucas variações em torno das respectivas médias ou dos valores na distribuição cumulativa. Na interface EP, essa variação em torno da média é maior nos períodos 1979-1984 e 2003, concentrando, respectivamente 0 de $15 \%$ dos trabalhos.

Com relação a esses dados, fazemos algumas hipóteses e observações:

A incidência significativamente maior de trabalhos na interface $C P$, no primeiro período da amostra, final dos anos 70 / início dos 80, seguramente está associada às características da área de Pesquisa em Ensino de Física em suas origens, já parcialmente evidenciadas na análise temática do capítulo precedente no que diz respeito a uma maior preocupação com os meios de promover o ensino, 
especialmente com ênfase nos processos (eixo "P"). Nesse período, como vimos, quase $3 / 4$ da produção se alinha a pesquisas identificadas às duas primeiras áreas temáticas, fortemente associadas aos processos de ensino e aprendizagem. Nessa interface conhecimento-processos, a ênfase está, portanto, nos processos.

O salto de zero para $7 \%$ na classificação de trabalhos identificados na interface EP, no início dos anos noventa estaria relacionado ao surgimento, nesse período, dos estudos sobre a Formação de Professores (identificado no capítulo cinco). Parte significativa das pesquisas com enfoque nessa temática privilegia as finalidades e/ou os meios na formação docente, não tendo a dimensão disciplinar, o conhecimento científico, como foco relevante. À parcela mais elevada dessa interface em 2003, atribuímos também a presença dessa temática, com maior índice de trabalhos, nos quais o conhecimento físico é preterido.

Em síntese:

- O principal âmbito no qual se situa a produção analisada está na interface do Conhecimento com os Processos de ensino e aprendizagem (CP).

- A interface Educação-Conhecimento (EC) tem presença homogênea ao longo do tempo, sem tendências de crescimento ou de declínio.

- A interface Educação-Processo (EP) tem participação mais irregular ao longo dos períodos analisados e é relativamente pequena, oscilando em torno dos $10 \%$.

Em primeiro lugar, esses dados apontam e confirmam o resultado já obtido por meio da análise temática acerca da presença dominante do foco nos processos de ensino e aprendizagem, identificada aqui pela predominância da interface ConhecimentoProcessos, ao longo de toda a trajetória da área. Mostram, ainda, que o plano da interseção entre os objetivos educacionais e o conhecimento, na interface EducaçãoConhecimento tem representação menor, mas também significativa.

A hegemonia das duas interfaces Conhecimentos-Processos (CP) e EducaçãoConhecimento (EC) que, juntas, aglutinam cerca de $90 \%$ da produção, revela, ainda, que as pesquisas em nosso campo, de um ou de outro modo, vêm contemplando a dimensão disciplinar, o conhecimento científico / físico. Ou seja, não parece haver, sob essa ótica, alguma sinalização de crescimento ou decréscimo dessa dimensão na produção acadêmica. Um dado revelador, mas que demanda análise mais cuidadosa, já que não estamos entrando no mérito de como o conhecimento está presente ou é tratado em diferentes momentos da evolução da área.

No que diz respeito à perspectiva educacional, explicita ou implicitamente presente nas interfaces EC e EP, não podemos igualmente extrair daqui muitas informações, já 
que também não está caracterizada nessa análise o modo como essa dimensão se coloca nas pesquisas, como evolui ou se transforma.

No que tange ao eixo dos Processos, entendemos que, pela sua predominância e importância nas pesquisas, está bem caracterizado na análise das áreas temáticas realizada no capítulo anterior.

Em função disso, procuramos melhor investigar as dimensões do conhecimento físico, os objetos de ensino, e das finalidades educacionais, os objetivos do ensino. Ou seja, analisar como esses aspectos vêm sendo contempladas nas pesquisas e como evoluem ao longo do tempo.

\subsection{A dimensão do conhecimento na produção}

Tal como constatamos no tópico anterior, a dimensão disciplinar, do conhecimento científico, parece estar representada expressivamente no conjunto de trabalhos situados nas interfaces que têm esse eixo em comum (CP e EC). Como também já assinalamos, esse dado, a princípio, surpreende. Especialmente diante de considerações que vêm sendo feitas por alguns pesquisadores acerca da tendência de "desaparecimento gradual" do conhecimento específico na pesquisa em Ensino de Física.

Não analisamos até aqui, contudo, de quê conhecimento se trata ou como vem sendo olhado, concebido em diferentes momentos ou em diferentes linhas de investigação. As pesquisas nessa área podem contemplar a física ou o conhecimento científico de diferentes formas, com diferentes abordagens, em diferentes níveis, profundidades, extensão e natureza.

Dado que estamos em um campo de saber onde aspectos científicos são tratados ao lado de outros - didático-pedagógicos, psicológicos, sócio-culturais, históricos, filosóficos, epistemológicos, institucionais, a tarefa de estabelecer critérios de análise dessa dimensão é complexa. Não é possível isolar ou dissociar completamente o conhecimento dessas outras dimensões e focalizá-lo de um modo "puro". Fator que implica uma dificuldade ainda maior de se extrair e classificar dados dessa natureza, com categorias únicas, números e estatísticas, como foi possível em análises anteriores.

Ainda que cientes dessas dificuldades, procuramos identificar mais qualitativa que quantitativamente, mas também verificando tendências e predominâncias, algumas características sobre a presença e a natureza da física ou da ciência nos trabalhos de nosso universo de estudo, já tendo como ponto de partida e como problema de investigação, algumas especificidades acenadas anteriormente. Entre essas, sabemos de antemão que algumas vezes esse conhecimento está presente e é tratado 
explicitamente; outras, menos diretamente e, em outras, é praticamente ausente. Também partimos da premissa de que, mesmo presente, o conhecimento específico pode ser inserido e investigado segundo concepções ou abordagens distintas. Pode ser visto segundo uma ótica mais tradicional e conservadora ou mais inovadora, crítica e transformadora. Pode ser tido como saber unívoco, natural e dado de realidade, ou como fruto de uma seleção, organização e problematização sobre qual física ensinar, com quais contornos ou tratamentos.

Diante disso, dividimos a análise acerca dessa dimensão em duas etapas, sob duas óticas distintas. No primeiro, procuramos identificar a presença do conhecimento nas pesquisas e, no segundo, buscamos caracterizar melhor a natureza desse conhecimento.

\subsubsection{A presença do conhecimento específico}

Com a finalidade de caracterizar as diferentes gradações com que o conhecimento científico na produção acadêmica é contemplado, selecionamos e analisamos as pesquisas de nossa amostra de modo a extrair alguns critérios de análise. Identificamos, nesse levantamento prévio, quatro gradações que caracterizariam a extensão ou o "nível de presença" do conhecimento nas pesquisas. Essas gradações, ainda que com fronteiras tênues, abarcam desde os trabalhos que de fato tratam diretamente algum conhecimento físico (que denominamos Tipo 3 ) até aqueles em que este é praticamente ausente (Tipo 0), passando por dois níveis intermediários (Tipo 1 e Tipo 2), os quais caracterizamos a seguir. Para exemplificar, apresentamos alguns resumos ou trechos dos mesmos que permitem ilustrar como identificamos os trabalhos nessas tipologias.

\section{Tipo 3}

$\mathrm{Na}$ primeira gradação, situamos os trabalhos que contemplam e utilizam um conhecimento físico explicitamente, enquanto objeto científico. A Física é foco do problema de pesquisa. Ou seja, incluem-se aqui as investigações em que a estrutura conceitual da Física é trabalhada, em tal medida que, em sua ausência, a pesquisa não se sustentaria.

Alguns exemplos:

As noções de espaço: ponte entre a física geométrica e o conhecimento construído. UFRGS-FE, 1990

Discute as relações entre as noções de espaço e os conceitos elementares de Física. Utiliza princípios propostos por Kant e Berkeley. Analisa os princípios que permitiram definir a teoria da relatividade do espaço e do tempo. Afirma que, de certo modo, existe uma relação entre as transformações espaciais - operadas pela atividade perceptiva (principalmente nas crianças) - $e$ as equações que descrevem as contrações/dilatações sofridas pelos objetos num universo 
einsteniano como está definido na relatividade restrita[...] Tem a finalidade de aprofundar uma questão específica na disciplina de Física referente ao tipo de realidade - os objetos, sua conservação e as relações possíveis atribuídas a estes mesmos objetos - em que se situa a criança com a qual estamos "acostumados" a trabalhar em sala de aula ou em laboratório prático e as diferenças existentes entre o que o educador "enxerga" e o que o aluno realmente "vê". (TRECHO DE RESUMO EXTRAÍDO DE CEDOC...)

A contextualização do ensino de ondas sonoras por meio do corpo humano. UFMS, 2009.

Esta dissertação apresenta os resultados de um projeto de mestrado que teve como objetivo propor e testar uma metodologia de ensino contextualizada para o ensino de ondas sonoras. Trata-se de uma atividade de manipulação de alguns objetos e de observação do próprio corpo no momento em que estão produzindo som. Os alunos foram solicitados a explicar o processo de emissão do som em cada situação proposta. A atividade possibilita a utilização e aplicação dos conceitos físicos sobre ondas e acústica na compreensão do processo de produção do som da voz pelo sistema fonatório[...] Essa atividade foi elaborada para auxiliar o aluno a construir um modelo explicativo coerente com o modelo consensual (conceitual) para produção do som $e$ da voz[...] A análise das respostas dos alunos sugere que houve uma evolução no modelo explicativo externado pelos alunos e que a atividade elaborada e contextualizada no corpo humano contribuiu para que a maioria dos alunos investigados reelaborasse um modelo explicativo coerente com o modelo consensual para produção da voz. (TRECHO DE RESUMO DO AUTOR)

Nesses dois exemplos observa-se que um determinado conhecimento - conceito de espaço (relatividade) e ótica geométrica - respectivamente, é foco de análise da pesquisa, ainda que com abordagens e tratamentos distintos. O desenvolvimento da pesquisa demanda o tratamento conceitual desses conhecimentos específicos. A investigação, a princípio, não seria a mesma se o conhecimento tratado fosse distinto, mesmo que os referenciais teóricos ou linhas de investigação se mantivessem.

\section{Tipo 2}

$\mathrm{Na}$ segunda categoria situam-se investigações que contemplam o conhecimento, mas sem entrar propriamente na sua estrutura conceitual, enquanto ciência. Podem tratar de questões relativas ao ensino de física, no entanto o conhecimento não é predominantemente o foco, mas locus da pesquisa. Mais frequentemente são estudos nos quais a Física (e seu ensino) mesmo tendo relevância e não sendo substituível por outro saber, está presente dentro de um panorama de problemáticas mais gerais. Sejam questões institucionais, curriculares, didático-pedagógicas ou mesmo científicas, situam-se no âmbito do ensino de Física, mas não se reportam diretamente a especificidades do conhecimento científico, como no caso do "Tipo 3". Exemplos: 


\section{O que há por trás do laboratório didático? USP,1995.}

Investiga o problema do laboratório didático no ensino de física, especialmente em nível universitário. Visando a compreensão da inércia existente quanto a mudanças no laboratório e o grau de complexidade envolvido nessa questão, faz, inicialmente, um levantamento e análise da produção na área de ensino de física referente a esse tema, ao longo das últimas duas décadas[...] Desse levantamento, verifica que o laboratório é um dos principais temas de pesquisa na área, com presença constante e significativa. Paralelamente, procura caracterizar a visão de alunos e professores universitários sobre o papel do laboratório e suas respectivas expectativas. Desse conjunto de dados, chega a diferentes representações para o laboratório, nas quais identifica algumas dicotomias nas relações prática-discurso; instrumentaçãoformação e processo-produto. Entende que a explicitação dessas dualidades deva contribuir para a formação de professores, recuperando a trajetória já percorrida e avançando em direção à transformação de práticas e teorias. (TRECHO DE RESUMO EXTRAÍDO DE UNIVERSIDADE DE SÃO PAULO, INSTITUTO DE FÍSICA, VOL.2, 1996)

\section{A atitude do estudante do Ensino Médio em relação à Física. PUC-RS, 2006}

A presente pesquisa apresenta uma abordagem educacional, principalmente para o Ensino de Física, considerando princípios pedagógicos que poderão ser analisados e seguidos pelos educadores que buscam promover melhorias na ação educativa e, obviamente, na aprendizagem. Visamos explicitar os sentimentos, atitudes e expectativas de estudantes do Ensino Médio quanto à prática educativa utilizada pelo professor, frente à relação entre professor e aluno e aos conteúdos trabalhados na disciplina de Física[...]Percebemos que grande parte dos alunos investigados considera interessantes e importantes os assuntos estudados pela Física, porém os problemas de aprendizagem ocorrem, normalmente, quando o professor não contextualiza os conteúdos trabalhados, quando não considera o conhecimento que o aluno já possui, quando não possibilita a comunicação interativa do aluno ou quando não acolhe o aluno segundo sua condição humana[...] (TRECHO DE RESUMO DO AUTOR)

Nesses dois exemplos o conhecimento físico não é foco da pesquisa, mas têm o ensino de Física como lócus. A pesquisa não é transponível para o ensino de outro campo. No primeiro caso o foco é a questão do laboratório didático especificamente inserido no contexto do ensino e da pesquisa em ensino de Física. O segundo, igualmente, não trata diretamente de um saber físico, mas ao investigar atitudes dos alunos perante o ensino, o faz também em um âmbito que problematiza esse objeto disciplinar.

\section{Tipo 1}

$\mathrm{Na}$ terceira categoria, situamos os estudos que inserem o conhecimento físico / científico basicamente como ilustração ou exemplo para discutir ou validar um referencial teórico, para analisar uma proposição didático-metodológica, problematizar espaços de educação científica, refletir sobre uma concepção educacional. Nesse caso, o trabalho, ainda que no espaço do ensino de Ciências, prescinde do conhecimento. Ou seja, se retirada a dimensão científica, ou se substituída por qualquer área de conhecimento das ciências naturais, o trabalho se 
sustenta. Tem, portanto, como locus um grau de generalidade maior que o do tipo anterior.

Exemplos:

Do ensino de Ciências como mudança conceitual à fronteira de uma abordagem afetiva. UFSC, 1996.

Análise do Construtivismo implementado na pesquisa em Ensino de Ciências e dedicado ao estudo das concepções dos estudantes e elaboração de novos modelos de ensinoaprendizagem. Discussão crítica do modelo de Mudança Conceitual de Posner et al (1982). Estudo de outros modelos significativos nesse campo de pesquisa e análise do papel da afetividade no ensino e aprendizagem de ciências, objetivando uma escola preocupada com a formação integral do indivíduo. (RESUMO EXTRAíDO DE...)

\section{A formação continuada de professores em Centros e Museus de Ciências no Brasil. 2006}

Esta pesquisa teve por intuito investigar as ações de formação continuada de professores em centros e museus de ciências no Brasil, na atualidade, e caracterizar os modelos de formação adotados por esses núcleos de divulgação científica[...] Foram analisados catorze programas oferecidos pelos núcleos, sendo que seis foram classificados como pertencentes ao modelo clássico de formação de professores, outros seis se enquadraram no modelo prático-reflexivo, $e$ dois no modelo emancipatório-político. Assim, observa-se que enquanto nos anos 60 e 70 a grande maioria dos programas de formação de professores nos centros e museus de ciências pertencia ao modelo clássico, atualmente, há uma maior incidência em ações formativas centradas no modelo prático-reflexivo, e inclusive algumas no modelo emancipatório-político. (TRECHO DE RESUMO EXTRAÍDO DE...)

Os dois trabalhos aqui trazidos como exemplos dessa categoria tratam de análises ou discussões sobre modelos teóricos de pesquisa em ensino de ciências, respectivamente sobre ensino-aprendizagem no âmbito do construtivismo e sobre formação continuada de professores em núcleos de divulgação científica, nas quais o conhecimento científico não é foco, nem tem relevância especial enquanto lócus. Poderiam ser aplicados a diferentes ciências, disciplinas ou conhecimentos específicos. Estão situados no âmbito do ensino de Ciências, mas têm como principal finalidade a discussão desses modelos em que estão alicerçados.

Finalmente, há trabalhos que prescindem quase que totalmente do conteúdo científico, seja como foco ou como locus de pesquisa. Tratam de aspectos educacionais, sociais, institucionais ou outros, sem entrar no âmbito da dimensão científica ou do ensino de Ciências / Física mesmo quando aí situados. Na ausência dessa dimensão ou na substituição por qualquer campo de saber, a pesquisa se sustenta plenamente. (TIPO 0)

Exemplos: 
A criatividade na fala de professores de física do ensino médio. UFMG, 2003.

Com base na entrevista semi-estruturada gravada e transcrita, elaborou-se esta pesquisa que estuda a fala sobre criatividade de cinco professores singulares de Física do ensino médio da Escola Estadual Governador Milton Campos de Belo Horizonte. Para a análise utilizaram-se parâmetros teóricos dos ciclos profissionais estabelecidos por Huberman et al (1993) e tarefas com características de design estabelecidas por Schön (2000). As categorias de análise partiram da construção de um quadro analítico do conceito de criatividade estabelecido por Rhodes (1961), acrescentando o ponto de vista do tetraedro dos derivados de Vaz (1989) de aspectos pedagógicos, filósoficos, psicólogicos e sociológicos de seu profissionalismo docente. Identificamos as características da criatividade em professores considerados criativos pela comunidade escolar à qual pertencem e, em conseqüência, estabelecermos relações entre a prática docente desses professores. Como resultado encontrou-se indicadores sobre o sujeito criativo e o processo de produção da sua obra .(RESUMO DO AUTOR)

Grupos de monitoria discente de Física: a trajetória de um projeto inovador. USP, 2009

Numa escola particular da cidade de São Paulo, em 2002, o professor de Física propôs um novo projeto: desenvolver uma monitoria com seus alunos do $1^{\circ}$ ano do Ensino Médio. Alguns alunos foram selecionados e convidados a atuarem como monitores de seus colegas de turma na disciplina de Física. Sua função era estar sempre à disposição dos colegas para ajudá-los, coordenar plantões de dúvidas em horários previamente definidos e participar de outras atividades ligadas à monitoria propostas pelo professor ao longo do ano[...] Assim, nos propusemos a investigar o processo de ascensão e declínio do projeto de monitoria identificando as dinâmicas grupais estabelecidas em cada uma das suas cinco edições. Para tanto, utilizamos como referencial teórico a teoria de grupos operativos de Enrique PichonRivière, que leva em conta aspectos subjetivos que permeiam o trabalho coletivo[...] Constatamos que fatores como a mudança de contexto do projeto (do primeiro para o terceiro ano do ensino médio), as relações afetivas estabelecidas entre os membros do grupo e o envolvimento da instituição são fatores importantes para a implantação de um projeto inovador no ambiente escolar. (TRECHO DE RESUMO DO AUTOR)

Nota-se, nesses exemplos, que a dimensão científica, quer do ponto de vista de conhecimentos específicos ou da ciência de um modo geral, quer do ponto de vista do locus de investigação - Ensino de Ciências / Física, não tem relevância. Criatividade do professor e monitoria discente, mesmo que ambos investigados no locus do ensino de Física são os focos centrais dessas pesquisas, cabendo a qualquer campo de saber na área educacional. A pesquisa caberia para o professor, no primeiro caso e o monitor, no segundo de português, matemática ou geografia.

Em resumo, caracterizamos quatro graduações em que o conhecimento específico pode estar presente nas produções, que voltamos a sistematizar: 
TIPO 3: Trabalhos que contemplam e utilizam um conhecimento físico explicitamente, enquanto objeto científico. A Física é foco do problema de pesquisa. Conhecimento físico é foco.

TIPO 2: Trabalhos que contemplam o conhecimento, mas sem entrar propriamente na sua estrutura conceitual, enquanto ciência. Podem tratar de questões relativas ao ensino de física, mas o conhecimento não é predominantemente o foco, mas locus da pesquisa.

\section{Conhecimento físico é lócus.}

TIPO 1: Trabalhos que utilizam o conhecimento físico / científico como ilustração ou exemplo para discutir ou validar um referencial teórico, para analisar uma proposição didáticometodológica, refletir sobre uma concepção educacional ou formativa no ensino de Ciências. Ainda que mencione o objeto disciplinar, prescinde do conhecimento. Conhecimento científico é exemplo.

TIPO ZERO: trabalhos que prescindem quase que totalmente do conteúdo científico, seja como foco ou como locus de pesquisa. Tratam de aspectos educacionais, sociais, institucionais ou outros, sem entrar no âmbito da dimensão científica ou do ensino de Física.

\section{Conhecimento científico é ausente.}

Utilizando esse critério, classificamos as dissertações e teses de nossa amostra. No entanto, é importante destacar que essa caracterização não é, como já apontamos, simples e precisa. Há nuances e fronteiras tênues entre um tipo e outro. Mas no conjunto permite traçar um perfil aproximado e, acreditamos que fiel, das pesquisas diante do problema colocado.

A tabela 6.2, com as correspondentes distribuições gráficas 6.4 (a) e $6.4(\mathrm{~b})$ apresentam os resultados dessa classificação.

\begin{tabular}{|l|l|l|l|l|l|l|l|l|l|l|}
\hline & \multicolumn{3}{l}{$\mathbf{3}$} & $\mathbf{2}$ & $\mathbf{1}$ & \multicolumn{2}{l}{$\mathbf{0}$} & \multicolumn{2}{l|}{ TOTAL } \\
\hline & abs & $\%$ & abs & $\%$ & abs & $\%$ & abs & $\%$ & abs & $\%$ \\
\hline $79-84$ & 24 & 50 & 20 & 42 & 4 & 8 & 0 & 0 & 48 & 100 \\
\hline $89-90$ & 29 & 66 & 14 & 32 & 0 & 0 & 1 & 2 & 44 & 100 \\
\hline $95-96$ & 31 & 54 & 21 & 37 & 4 & 7 & 1 & 2 & 57 & 100 \\
\hline 2000 & 27 & 54 & 15 & 30 & 4 & 8 & 4 & 8 & 50 & 100 \\
\hline 2003 & 26 & 39 & 24 & 36 & 6 & 10 & 10 & 15 & 66 & 100 \\
\hline 2006 & 36 & 40 & 35 & 39 & 12 & 13 & 6 & 7 & 89 & 100 \\
\hline 2009 & 41 & 35 & 47 & 40 & 18 & 16 & 10 & 9 & 116 & 100 \\
\hline TOTAL & $\mathbf{2 1 4}$ & - & $\mathbf{1 7 6}$ & - & $\mathbf{4 8}$ & - & $\mathbf{3 2}$ & - & $\mathbf{4 7 0}$ & $\mathbf{1 0 0}$ \\
\hline
\end{tabular}

Tabela 6.2: Distribuição dos trabalhos quanto à presença do conhecimento específico

As distribuições percentuais estão apresentadas no gráfico 6.4(a) e 6.4(b) 

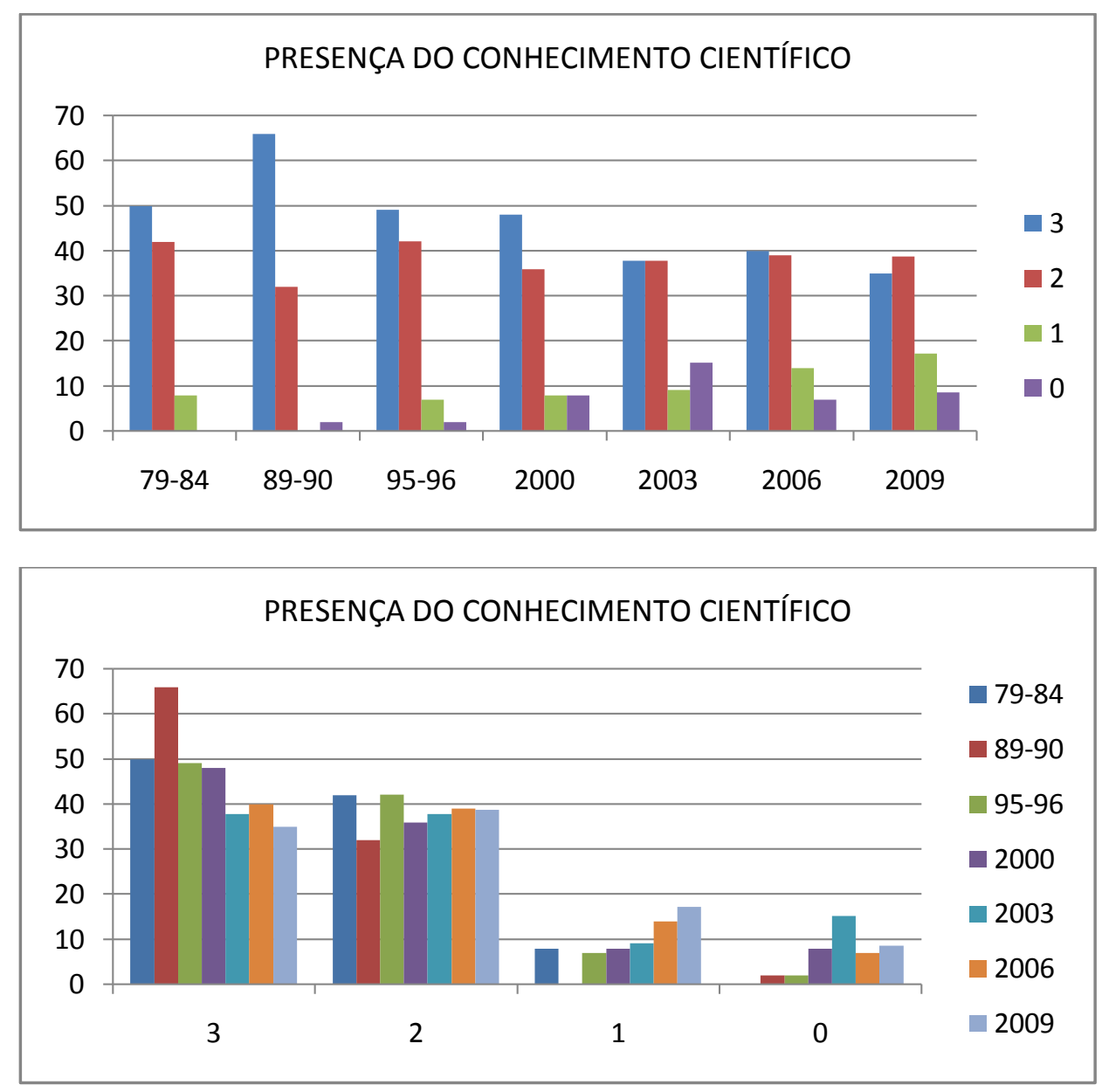

Gráficos 6.4(a) e 6.4(b): Presença do conhecimento específico por período

Do ponto de vista dessa classificação, verifica-se:

- $\mathrm{Na}$ categoria 3 (tratamento explícito do conhecimento físico) caem percentualmente a partir do início de 2000;

- Na categoria 2 (ensino do conhecimento físico como locus privilegiado) permanecem estáveis;

- $\mathrm{Na}$ categoria 1 (dimensão disciplinar como exemplo) crescem percentualmente a partir do início de 2000;

- Na categoria 0 (ausência do conhecimento científico) também crescem a partir de 2000.

Ou ainda,

- Nos primeiros períodos, até o início dos "anos 2000", predominam expressivamente os trabalhos identificados na categoria 3: inclusão explícita e uso do conhecimento físico.

- Nos períodos seguintes, compreendidos entre 2003 e 2009, esses passam a se distribuir sem muitas diferenças entre a as categorias 3 e 2: uso e tratamento explícito do conhecimento + presença predominantemente como lócus. 
- Também a partir de 2000 crescem os trabalhos identificados nas categorias 1 e 0: presença restrita (como exemplo que poderia ser substituído por outro conhecimento científico) e ausência, respectivamente.

Esses primeiros resultados dão um indicativo de que a pesquisa vem, em uma parcela relativamente importante, contemplando conteúdos da ciência, particularmente da física, direta ou indiretamente, como foco ou lócus. Na soma cumulativa, do início da década de 1980 ao final da primeira década de 2000, as duas primeiras categorias juntas somam cerca de $80 \%$ das dissertações e teses, dados destacados na tabela 6.3 e correspondentes distribuição gráficas 6.4 (a) e 6.4 (b).

\begin{tabular}{|l|r|r|r|r|r|}
\hline & $\mathbf{3}$ & $\mathbf{2}$ & $\mathbf{1}$ & $\mathbf{0}$ & TOTAL \\
\hline $\begin{array}{l}\text { TOTAL } \\
\text { CUMULATIVO }\end{array}$ & 214 & 176 & 48 & 32 & 470 \\
\hline $\begin{array}{l}\text { \% TOTAL } \\
\text { CUMULATIVO }\end{array}$ & 46 & 37 & 10 & 7 & 100 \\
\hline $\begin{array}{c}\text { PARCELAS } \\
(3+2) \text { E (1 + })\end{array}$ & $83 \%$ & \multicolumn{2}{|c|}{$17 \%$} & $100 \%$ \\
\hline
\end{tabular}

Tabela 6.4(a): Presença do conhecimento no total cumulativo
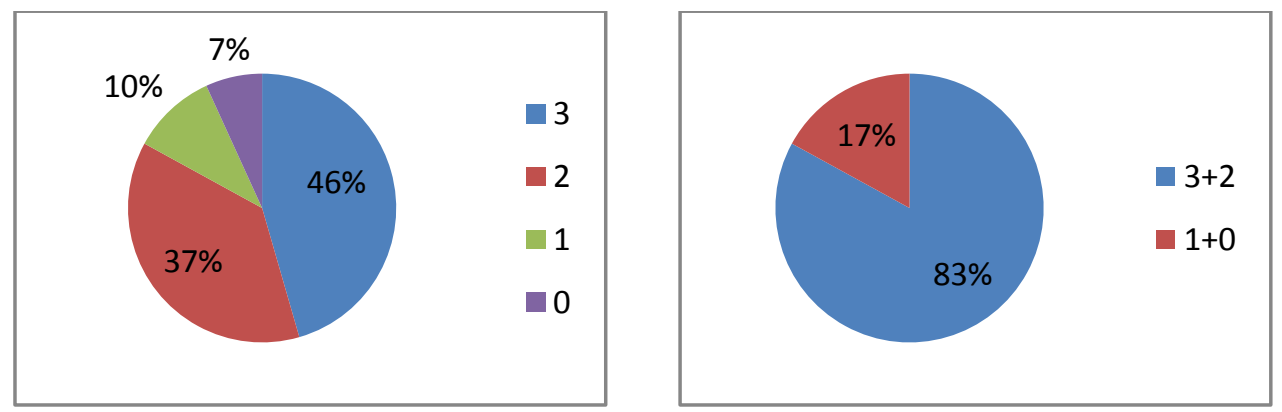

Gráficos 6.4(a) e 6.4(b): Participação do Conhecimento na soma cumulativa

Poderíamos agrupá-las de outro modo, distinguindo os dois extremos ( 3 e 0 ) e reunindo o "miolo" constituído pelas categorias 1 e 2 , o que resulta nos dados da tabela 6.4(b).

\begin{tabular}{|c|c|c|c|c|}
\hline & 3 & 2 & 0 & TOTAL \\
\hline $\begin{array}{l}\text { TOTAL } \\
\text { CUMULATIVO }\end{array}$ & 214 & 224 & 32 & 470 \\
\hline $\begin{array}{l}\text { \% TOTAL } \\
\text { CUMULATIVO }\end{array}$ & 46 & 47 & 7 & 100 \\
\hline
\end{tabular}

Tabela 6.4(b): Presença do conhecimento no total cumulativo

Seja qual for a forma de agrupar esses dados, o principal resultado é a parcela de $50 \%$ das pesquisas que identificamos no terceiro tipo, ou seja, em que a participação da física e do tratamento de seus conteúdos e tópicos conceituais está representada por cerca de metade dessa produção $\mathrm{E}$, ainda que... 
- tomando-se o primeiro agrupamento, em que agregamos a essa parcela, as pesquisas que se reportam a esse conhecimento, mesmo sem tratá-los conceitualmente, chegamos a um conjunto próximo dos $80 \%$ (Categorias $3+$ 2).

- tomando-se o segundo agrupamento, vemos um retrato não muito distinto, mas por outro ângulo, no qual pesquisas que tratam o conhecimento científico explicita e diretamente e aquelas que o fazem implícita ou indiretamente dividem-se igualmente, ocupando $90 \%$ do conjunto.

Finalmente, ainda vale ressaltar que o conjunto caracterizado pelas categorias 1 e 0 (juntas) evolui notavelmente também a partir dos anos 2000.

\begin{tabular}{|l|r|r|r|}
\hline & $\begin{array}{r}\mathbf{1} \\
(\%)\end{array}$ & $\begin{array}{r}\mathbf{0} \\
(\%)\end{array}$ & $\begin{array}{r}\mathbf{1 + 0} \\
(\%)\end{array}$ \\
\hline $79-84$ & 8 & 0 & $\mathbf{8}$ \\
\hline $89-90$ & 0 & 2 & $\mathbf{2}$ \\
\hline $95-96$ & 7 & 2 & $\mathbf{9}$ \\
\hline 2000 & 8 & 8 & $\mathbf{1 6}$ \\
\hline 2003 & 10 & 15 & $\mathbf{2 5}$ \\
\hline 2006 & 14 & 7 & $\mathbf{2 1}$ \\
\hline 2009 & 17 & 9 & $\mathbf{2 6}$ \\
\hline
\end{tabular}

Tabela 6.3: Freqüência dos trabalhos nas categorias 1 e 0

Claro que são todos os mesmos dados, os mesmos resultados. E o que refletem, ao final, é que a produção acadêmica (nas dissertações e teses) ainda que em sua maior parcela venha focalizando o seu objeto disciplinar - a Física - enquanto conhecimento, a outra parcela em que essa dimensão é parcial ou completamente prescindida vem crescendo e, ao final da década de 2000, ocupa um espaço considerável. Quanto ao primeiro resultado, poderíamos dizer que se trata do esperado e previsível. Pois seria de estranhar se a pesquisa em ensino de Física não estivesse respondendo de modo privilegiado a questões do ensino de Física...

Não podemos afirmar se o crescimento da outra parcela, em detrimento da redução na primeira, é tendência que permanece. Como em tantos outros momentos dessa pesquisa, o futuro não pode ser inferido pelos dados do presente, uma vez que fatores imprevisíveis na evolução da área podem mudar o curso da trajetória. De qualquer forma, extraímos uma conclusão importante: há um relativo crescimento na produção acadêmica de investigações que vêm se distanciando do foco em seu objeto de ensino. 


\subsubsection{Natureza do conhecimento contemplado}

Os resultados dessa primeira análise são relevantes e sinalizam aspectos importantes sobre a presença da dimensão científica nas pesquisas em nossa área. Dizem muito, porém, como já adiantamos, não dizem sobre. Ou seja, não ponderam sobre a natureza do conhecimento tratado, em uma ou outra gradação.

Ao utilizar o termo "natureza do conhecimento", estamos nos referindo mais especificamente a "qual conhecimento" e "como" é concebido ou enfatizado, para além de "quanto" é contemplado, o que reflete, de certo modo, uma visão do próprio ensino.

Há pesquisas que focalizam tópicos convencionais da física ou das ciências, tal qual presentes nos índices e manuais didáticos tradicionais e há as que trazem e tratam de um conteúdo inovador, quer quanto à temática propriamente dita, quer quanto aos valores e competências segundo os quais esse conhecimento é inserido, ou ainda, quanto aos objetivos e finalidades almejadas. Também há pesquisas em que o conhecimento científico é, implícita ou explicitamente, assumido como um dado, unívoco, natural, inquestionável e outras no qual esse é objeto de seleção, reorganizado, problematizado, contextualizado, questionado.

Mais ainda do que na primeira categorização acima elaborada, os critérios e procedimentos de análise nesse caso não são nada triviais. De um lado, porque tais critérios não se somam ou se articulam cumulativamente, de outro, porque precisam ser contextualizados espacial e temporalmente, como comentamos a seguir. Soma-se a isso, o fato de que conteúdo e tratamento, conteúdo e habilidades, conteúdo e abordagens, conteúdo e valores, conteúdo e forma, são muitas vezes indistinguíveis, inseparáveis. Abordagens e tratamentos distintos de um mesmo conteúdo podem conferir distintas concepções, tornando-o mais ou menos convencional, mais ou menos inovador, mais ou menos naturalizado, mais ou menos técnico, mais ou menos crítico.

Exemplificando.

Quando utilizamos como critério a presença de um conteúdo "tradicional" ou "inovador", devemos levar em conta, entre outros fatores a dimensão temporal: o momento em que se apresenta. Uma pesquisa que trata de tópicos de Física Moderna pode ser muito inovadora na década de 1970, relativamente inovadora nas décadas de 1980 ou 1990 e pouco inovadora nos anos 2000. Também deve ser relativizada em outras dimensões ou contextos. Se essa Física Moderna está sendo foco do ensino no nível fundamental, médio ou superior, sua "tradicionalidade" (com a licença de criação do termo) não é a mesma. E mais, um tópico de Física Moderna pode ser ou não tratado como conteúdo dado ou como objeto de escolha crítica. 
O mesmo pode-se dizer sobre um conteúdo ou um tema "novo" do ponto de vista do ensino, como energia e ambiente, ciência e tecnologia. O novo não necessariamente é de fato renovador. Uma temática como "Energia" (recurso energético), não tradicional, pode ser inserida e desenvolvida, tal qual qualquer outra, sob uma ótica convencional, que tem em vista, ao fim e ao cabo, tão somente o aprendizado de Física, do conhecimento pelo conhecimento.

Por outro lado, se o objeto de conhecimento é um tópico tradicional da Física, tal como Mecânica, Eletricidade, Termodinâmica, Ótica, etc.. ou um conceito, particular, como força, momento, corrente elétrica ou calor, esse objeto também pode ser tradicional ou inovador, neutro ou crítico, contextualizado ou não, tratado historicamente, epistemologicamente, filosoficamente, tecnologicamente, socialmente, culturalmente, religiosamente, estetica ou eticamente... Escolhas de uma ou outra abordagem, um ou outro tratamento, também conferem a esse conteúdo concepções ou naturezas distintas, da ciência e de seu ensino.

E ainda, se um dado conhecimento é tratado de um ponto de vista histórico, ele pode ser mais ou menos crítico. Se é inserido em uma abordagem dita CTS, idem. Se é associado ao cotidiano, essa associação pode lhe conferir um caráter e uma finalidade transformadora ou conservadora. Ou seja, uma abordagem ainda que menos convencional do ponto de vista disciplinar, ou da tradição da disciplina, não necessariamente torna o objeto de ensino mais inovador ou transformador, ainda que muitas vezes se apresente enquanto tal.

Esses são alguns exemplos que mostram a complexidade envolvida em uma análise dessa natureza, de caracterizar em uma produção acadêmica, um caráter tradicional ou inovador; propedêutico ou crítico; conservador ou transformador, do ponto de vista da seleção e tratamento de conteúdos científicos. Contando, ainda, com outra dificuldade metodológica, a necessidade ainda maior, nesse caso, de realizar uma leitura mais acurada do texto completo da dissertação ou tese. Ainda assim, persistimos e nos aventuramos nessa tentativa, procurando elementos e exemplos que pudessem revelar um pouco mais do que as hipóteses iniciais sobre o problema delineado.

Um primeiro resultado dessa tentativa já nos mostrou a ineficácia do uso de um critério único de análise para pesquisas realizadas em momentos distintos. Tomandose, por exemplo, dois períodos de nossa amostra relativamente distanciados, 19891990 e 2009, a diferenciação dos trabalhos quanto a esse aspecto nos define categorias diversas, demandando investigá-los segundo as óticas acima delineadas: a tradição ou inovação quanto ao conteúdo propriamente dito (seleção do conhecimento), quanto à abordagem ou tratamento dado ao conteúdo (organização do conhecimento) e quanto o grau de problematização ou concepção de 
conhecimento (dimensão epistemológica). Para isso, selecionamos, a título de exemplo e comparação, trabalhos presentes nesses dois períodos (1989/1990 e 2009) que explicitam e utilizam um dado conhecimento científico (classificados na categoria 3 acima).

Desse modo, para identificar essas polarizações, entre "tradicional" e "novo", procuramos caracterizar esses trabalhos de acordo com esses três critérios:

(i) Os conteúdos e temas propriamente (da Física)

(ii) As abordagens de conteúdos

(iii) A problematização dos conteúdos

\section{- Conteúdos e Temas}

Como vimos no primeiro tópico do capítulo, trabalhos que abarcam tópicos ou conceitos físicos compõem um conjunto relativamente grande, nos diferentes períodos analisados. Como já sinalizamos, em alguns o conhecimento aparece tal como tradicionalmente é abordado no ensino médio ou superior, presentes na maior parte dos livros didáticos ou tratados nos cursos de física: tópicos como mecânica, eletricidade e magnetismo, gravitação, ótica, física térmica; leis e princípios tais como leis de Newton ou da Termodinâmica; conceitos mais específicos como os de força, massa, calor, luz. Em outros, o conhecimento é focalizado por meio de temas ou questões relacionadas ao mundo ou à própria ciência contemporânea, tais como energia, ambiente, transportes, nutrição, telefonia celular; ou ainda à própria ciência contemporânea, como são os casos de tópicos de física moderna, cosmologia, caos e complexidade.

Um levantamento desses conteúdos nos trabalhos situados nos dois períodos escolhidos (1989-1990 e 2009) revela que ao longo do tempo há um certo deslocamento de uns para outros: daqueles identificados como mais tradicionais, para temáticas mais novas. Especialmente a partir do final dos anos 90, início dos anos 2000, começam a aparecer mais sistematicamente essas novas temáticas, particularmente associadas a questões ambientais, recursos energéticos e novas tecnologias, bem como os trabalhos que têm como objeto de conhecimento a Física Moderna (e Contemporânea) e a Cosmologia.

No primeiro período encontramos algo próximo de $80 \%$ de investigações que abordam os tópicos mais tradicionais da física, para $20 \%$ de tópicos considerados novos. No outro período, mais recente, essa relação passa a ser algo em torno de $50 \%$ a $50 \%$, se incluídos na segunda categoria (novo) os trabalhos que tratam de Física Moderna, representantes de metade dos títulos que aqui identificamos. Se os deslocarmos para a primeira categoria, ficamos com uma parcela de $75 \%$ para $25 \%$, 
bem próxima daquela obtida em 89-90. Mais um resultado que mostra a dificuldade inerente a uma análise dessa natureza. Nesse caso, a questão de conceber a Física Moderna, à essa época, um conteúdo tradicional ou novo, independentemente de como é tratada.

A título de exemplo, selecionamos resumos de trabalhos identificados em cada um desses tipos, utilizando o critério descrito: conhecimento específico "tradicional" ou "novo".

\section{TRADICIONAL}

Concepções alternativas em eletricidade básica. UFF, 1989.

Verifica a influência do ensino formal nas concepções alternativas em eletricidade básica, de alunos dos três graus de ensino [...] Identifica diversos modelos alternativos que indicam o baixo aprendizado de eletricidade em todos os níveis de escolaridade. Em alguns casos, em que as respostas dos alunos parecem se aproximar do conhecimento científico, constata que ocorre um aprimoramento na forma de expressar suas idéias[...] Conclui que, de uma maneira geral, o atual ensino não tem contribuído para transformar as concepções espontâneas em eletricidade e que, quando os alunos mudam seus modelos alternativos, o fazem quase sempre substituindo por outro alternativo e, em raras situações, pelo modelo científico. (TRECHO DE RESUMO EXTRAÍDO DE....)

O Vetorama como ferramenta de ensino-aprendizagem de conceitos de mecânica no ensino médio. UFRPE, 2009.

O principal objetivo desta pesquisa é investigar a contribuição de um jogo didático para o ensino-aprendizagem dos conceitos de vetor e grandezas vetoriais (posição, deslocamento $e$ velocidade média). O jogo em questão é o Vetorama, que é jogado sobre uma folha de papel quadriculado, no qual são desenhadas linhas sinuosas representando uma pista de corrida, e os carros são representados por vetores, possuindo inicialmente mesma intensidade. [...]. Os resultados indicaram que o Vetorama, enquanto recurso didático,favoreceu a aprendizagem dos conceitos em questão, além de despertar maior interesse dos alunos; permitir uma maior socialização nas relações e possibilitar a identificação das dificuldades durante a realização do jogo[...]

NOVO

Física no 10. grau? USP, IF-FE, 1990.

Discute o papel do ensino de ciências no Brasil, enfatizando especialmente o conteúdo de física e sua contribuição para a educação elementar. Concretiza essa discussão, apresentando uma proposta para a física no primeiro grau, centrada em um tema extraído do universo vivencial dos alunos: a "casa". [...] O conceito de energia é utilizado como conceito unificador do conteúdo físico desenvolvido nos diferentes sub-temas [...] (TRECHO DE RESUMO EXTRAÍDO DE...]

Física ambiental e teoria da complexidade: possibilidades de ensino na educação básica. UFMT, 2009. 
Investigou-se a possibilidade de inserção de tópicos de complexidade no ensino fundamental e médio por meio de uma experiência de ensino entre professores de Ciências da Natureza e Matemática. [...] Para implementação da proposta optou-se pela elaboração de material didático que abrangesse tanto uma revisão histórico-crítica dos estudos de complexidade quanto conceitos iniciais ligados ao tema, utilizando como referência a disciplina Teoria da Complexidade Aplicada ao Estudo do Meio Ambiente, do mestrado em Física Ambiental da UFMT. Esse material foi trabalhado na forma de um curso de extensão universitária de 20 horas para professores de uma grande e tradicional escola da cidade de Cuiabá, Mato Grosso, Brasil. [...] Estes resultados e a aceitação do curso parecem indicar que a inserção de tópicos de complexidade no nível fundamental e médio é viável.

O "tradicional" ou o "novo" nesse caso referem-se essencialmente à inovação do ponto de vista de uma seleção do conteúdo propriamente dito, podendo esse ter abordagens tradicionais ou novas e sendo tratado como conteúdo problematizado ou não. Nos exemplos acima, eletricidade e cinemática são os objetos do conhecimento físico focalizado, tradicionais segundo esse critério; energia e complexidade trazem o novo.

- Abordagens de Conteúdos

Tomamos, então, como segundo critério a forma tal qual o conhecimento é apresentado, dada pelo tratamento, abordagem ou organização dos conteúdos selecionados nas investigações.

São exemplos de abordagens que estamos aqui caracterizando como não convencionais, trabalhos que buscam estratégias ou formas de organização do conhecimento que com explicitude e intencionalidade visam tratar a ciência com olhares "diferentes" dos meios mais convencionais, seja incorporando dimensões históricas e filosóficas, aspectos socioculturais, tecnológicos, valores éticos, contextualização, cotidiano, temas geradores, interdisciplinaridade.

Vistas e comparadas por esse ângulo, as produções do final dos anos 80 (1989-1990) e do final da primeira década de 2000 (2009) contemplam parcelas muito próximas. Segundo esse critério, dentre os trabalhos que contemplam um conhecimento físico explicitamente, cerca de $20 \%$ em um e em outro período foram identificados como novos: em 1989-1990, 5 em 29 títulos (17\%) e em 2009, 8 em 41 (20\%). Ou seja, cerca de $80 \%$ das pesquisas analisadas em um e outro momento têm uma abordagem tradicional.

Seguem exemplos de um e outro tipo de trabalho analisados segundo esse critério.

TRADICIONAL

Vibrações e ondas: uma proposta de ensino. UFF, 1989. 
Através de um questionário escrito, levantamos as concepções de estudantes universitários acerca de movimento ondulatório. Destacamos uma falta quase total de compreensão dos conceitos básicos envolvidos e um uso excessivo e desarticulado de termos técnicos. Pensamos, então, em elaborar atividades experimentais que permitissem a estes estudantes discutir algumas formulações básicas de ondas, utilizando conceitos já construídos, através de um trabalho prático. Depois do estudo teórico de alguns sistemas, obtivemos medidas experimentais das frequencias naturais de varias cadeias que pêndulos excitados através de uma série de atividades experimentais com o grupo de estudantes do 4․ período do curso de Física da UFF, durante o segundo semestre de 1988.

Ferramenta Didática para o Ensino de Vibrações e de Dinâmica em Engenharia. UnB, 2009.

O presente trabalho apresenta uma contribuição no desenvolvimento de uma estratégia para aperfeiçoamento do processo de ensino/aprendizagem em disciplinas do curso de Engenharia Mecânica. [...]. A ferramenta didática desenvolvida é constituída por uma seqüência de problemas envolvendo dinâmica de corpo rígido, nos quais foram apresentadas, de forma sistemática e com dificuldade progressiva, a modelagem física, matemática e numérica. Os temas abordados exploram problemas escolhidos dentre aqueles, bem conhecidos dos alunos. Tal escolha compõe uma estratégia de ensino, que deve motivar o aluno para o estudo de determinadas estruturas, cujo comportamento experimental, por vezes, já é de seu conhecimento prévio. [...] Com o propósito de testar a estratégia proposta, a mesma foi aplicada, de forma complementar, no curso de Vibrações Mecânicas, ao longo de um semestre letivo do Departamento de Engenharia Mecânica da Universidade de Brasília. Para tanto foi utilizado o software MATLAB ${ }^{\circledR}$ da MathWorks e de suas "toolboxes" devido ao seu potencial didático. Por fim, como forma de avaliação da estratégia adotada, foi adaptado e utilizado o instrumento SERVQUAL, desenvolvido por Parasuraman et al. (1988), para mensurar o desempenho do processo de ensino/aprendizagem. Os resultados alcançados neste trabalho demonstram que a estratégia de ensino é eficaz e contribui de forma positiva no processo de aprendizagem dos alunos.

NOVO

"Alfabetização técnica" na disciplina de física: uma experiência educacional dialógica. UFSC, 1990.

Descreve e analisa uma experiência educacional em física, realizada em Santa Catarina, majoritariamente com alunos trabalhadores.[...] Utiliza como referenciais teóricos a "alfabetização técnica" (de Maurice Bazin) e a concepção educacional de Paulo Freire [...] Num processo denominado "investigação participativa", e utilizando como temática central a eletricidade, parte de assuntos do cotidiano do aluno para a elaboração em sala de aula do material didático, teórico e experimental, seleção de "equipamentos geradores" e elaboração de um programa de estudos alternativo. Conclui ser possivel a operacionalização de uma concepção educacional freireana no espaço escolar formal. (TRECHO DE RESUMO EXTRAÍDO $\mathrm{DE} . .$.

Ensino de entropia: um enfoque histórico e epistemológico. UFRN, 2009

A construção racional necessária à sistematização do conhecimento científico na física acarreta dificuldades de entendimento de alguns dos seus conceitos. Um conceito que apresenta, de forma exemplar, esta dificuldade - tanto de aprender quanto de ensinar - é o conceito de entropia. Esta tese propõe a construção de um roteiro didático que se constitui num percurso 
histórico e epistemológico para a entropia, com a intenção de contribuir para o ensino deste conceito e, de maneira geral, para o ensino da física. A premissa básica para a construção do roteiro é que, através de uma revisão histórica do desenvolvimento do conceito, nos moldes sugeridos pela epistemologia de Bachelard (1884-1962), é possivel tornar mais significativo o conhecimento a ser ensinado e aprendido. [...] A estratégia para a construção do roteiro foi dividir o conteúdo usual da termodinâmica básica em três momentos de modo que estes se constituam em "unidades epistemológicas", ou seja, momentos que possam ser identificados a partir do pensamento predominante na construção do conhecimento científico [...] A forma como construí este percurso para a entropia pode contribuir para a construção de percursos outros, na física ou em outras ciências, com vistas a desvelar significados e humanizar o conhecimento científico. (TRECHO DE RESUMO EXTRAÍDO DO AUTOR)

- Problematização dos conteúdos

No terceiro critério, buscamos identificar trabalhos mais ou menos conservadores ou inovadores do ponto de vista de como ou quanto o conhecimento físico contemplado é (explicita ou implicitamente) tido como dado e natural, ou como objeto de ensino a ser problematizado e questionado, tendo em vista finalidades formativas.

Com base nessa diferenciação, situamos, no primeiro período em torno de $80 \%$ na categoria conhecimento dado e $20 \%$ na categoria conhecimento problematizado e em 2009 , respectivamente $90 \%$ e $10 \%$. Ou seja, no período mais recente, ainda que com novas temáticas, a problematização do conhecimento (nas teses em que esse é explicitamente abordado) tem representação inferior ao final dos anos 80 .

São exemplos de uma e outra categoria nesses períodos:

\section{TRADICIONAL}

Concepções alternativas em eletricidade básica. UFF-IF, 1989.

Verifica a influência do ensino formal nas concepções alternativas em eletricidade básica, de alunos dos três graus de ensino. Efetua, inicialmente, dois estudos pilotos, objetivando a formulação de uma hipótese de trabalho e a elaboração de um questionário especial. $O$ questionário envolve montagens de circuitos elétricos simples e questões descritivas que evocam o cotidiano dos alunos. Identifica diversos modelos alternativos que indicam o baixo aprendizado de eletricidade em todos os níveis de escolaridade. Em alguns casos, em que as respostas dos alunos parecem se aproximar do conhecimento cientifico, constata que ocorre um aprimoramento na forma de expressar suas idéias. Faz um estudo complementar, comparando as concepções espontâneas de estudantes universitários brasileiros e estrangeiros, verificando diferenças significativas entre as duas amostras. Conclui que, de uma maneira geral, o atual ensino não tem contribuído para transformar as concepções espontâneas em eletricidade e que, quando os alunos mudam seus modelos alternativos, o fazem quase sempre substituindo por outro alternativo e, em raras situações, pelo modelo científico.

o Vetorama como ferramenta de ensino-aprendizagem de conceitos de mecânica no ensino médio. UFRPE, 2009. 
O principal objetivo desta pesquisa é investigar a contribuição de um jogo didático para o ensino-aprendizagem dos conceitos de vetor e grandezas vetoriais (posição, deslocamento $e$ velocidade média). O jogo em questão é o Vetorama, que é jogado sobre uma folha de papel quadriculado, no qual são desenhadas linhas sinuosas representando uma pista de corrida, e os carros são representados por vetores, possuindo inicialmente mesma intensidade. [...] Os resultados indicaram que o Vetorama, enquanto recurso didático favoreceu a aprendizagem dos conceitos em questão, além de despertar maior interesse dos alunos; permitir uma maior socialização nas relações e possibilitar a identificação das dificuldades durante a realização do jogo. A principal dificuldade encontrada pelos alunos consistiu na transposição de jogadas do tabuleiro para a resolução dos exercícios usando a notação algorítmica.

NOVO

Outra óptica para o ensino de óptica. USP, 1990.

Apresenta e discute uma proposta para o ensino de física no segundo grau, relativa ao conteúdo de ótica. A proposta insere-se no projeto do Grupo de Reelaboração do Ensino de Física (GREF), sediado no Instituto de Física da USP, que vem trabalhando na reconcepção dos conteúdos de física para o segundo grau e produção de textos para o professor. A partir de uma visão crítica do atual sistema educacional brasileiro, concebe o ensino de física vinculado a uma compreensão de situações reais, presentes tanto no cotidiano do cidadão como no sistema produtivo. Defende e apresenta um tratamento para a ótica que lida com a natureza física da luz e com o caráter prático da ótica na vida contemporânea. A proposta é comparada a outros projetos educacionais e textos didáticos que abordam esse conteúdo. [...] (TRECHO DE RESUMO EXTRAÍDO DE...]

Ressalta-se, que dependendo do critério utilizado, em um mesmo trabalho, o conhecimento pode ser caracterizado como novo ou como tradicional. Como é o caso de "Outra óptica para o ensino de óptica". Do ponto de vista do conhecimento específico, o conteúdo - "Ótica" - seria um conteúdo tido como tradicional, já que se trata de tópico da física convencional, do ponto de vista da seleção de conteúdos para o ensino. Por outro lado, sua abordagem, forma de organização e perspectivas educacionais são inovadoras, especialmente à sua época. A “óptica” que investiga é reorganizada, abordada segundo concepção crítica problematizada.

Isso mostra, mais uma vez, a complexidade envolvida nesse tipo de análise. E o quanto a já referida "multi-dimensionalidade", quer na produção de conhecimento, quer nas práticas educacionais, é um elemento importante.

Uma vez traçado esse primeiro esboço, tendo como base a produção na qual identificamos a presença do objeto disciplinar como foco, procuramos olhar o outro extremo, no qual esse é parcial ou totalmente ausente, identificados nas tipologias " 0 e $1 "$. 


\section{Natureza e temáticas dos trabalhos do tipo "0 e 1"}

Uma análise dos trabalhos classificados nas categorias "Zero" ou "Um" quanto à presença do conhecimento, mostra que na primeira, ou seja, naqueles em que esse é ausente, a grande maioria (cerca de 60\%) trata da Formação de Professores, discutindo questões relativas a essa temática de um modo genérico, sem se reportar a um campo de saber específico. Destacam-se aqui, especialmente as pesquisas que procuram refletir, analisar, identificar diferentes modelos sobre práticas docentes. Dentre os demais, $10 \%$ tratam de Questões Institucionais, tais como memória de instituições de ensino e pesquisa, vestibular, evasão de cursos, sem entrar no mérito do âmbito da ciência ou de seu ensino. Outros $10 \%$ tratam de questões relacionadas à linguagem, sobretudo análise de discursos, de professores, alunos ou pesquisadores, também de modo genérico. Os demais são dispersos entre temas variados, como Ensino a Distância, Psicanálise, TIC e currículos.

Na categoria "Tipo 1", destacam-se os trabalhos que tratam das Tecnologias de Informação e Comunicação (as TICs), com participação em torno de um terço; os trabalhos sobre "Linguagem e Cognição", concentrando outro terço, seguidos da temática "Formação de Professores" (15\%), Laboratório (10\%) e outros distribuídos em temas como Avaliação, Interdisciplinaridade, Livro Didático.

Ou seja, concentram-se nessas duas categorias, sobretudo, as investigações nas linhas de Formação de professores, Processos Cognitivos e Tecnologias da Informação e Comunicação.

No que diz respeito à evolução no tempo, as pesquisas classificadas na categoria "Tipo Zero" aumentam a partir de 2000. A Linguagem (análise de discurso) em 2003, 2006 e 2009. E as TIC em 2006 e 2009.

Como síntese dessa análise, podemos esboçar algumas conclusões, ainda que considerando as dificuldades apontadas.

(A) Quanto à presença do conhecimento nas pesquisas:

Uma parcela relativamente expressiva da produção, em todos os períodos, contempla direta ou indiretamente, como foco ou como locus, algum conhecimento físico (em média, algo em torno de 80\%). Também em média, em cerca de metade do total a física é contemplada explicitamente e tratada conceitualmente. No entanto, essa média não reflete exatamente o comportamento dessas frequencias ao longo do tempo. Observamos que, tanto um conjunto como outro, apresenta uma tendência de declínio. Enquanto nos três primeiros períodos, anteriores a 2000, essa média oscila em torno dos $95 \%$, nos períodos seguintes, passa a oscilar na ordem dos $75 \%$. Ou seja, parece haver, de fato, uma redução dessa dimensão nas nossas pesquisas. 
Olhando pelo outro lado, as pesquisas que prescindem parcial ou totalmente do conhecimento científico ou físico têm cada vez mais ocupado mais espaço.

(B) Quanto à "natureza" desse conhecimento

Os diferentes critérios utilizados para caracterizar o conhecimento explicitamente desenvolvido mostram, por outro lado, que não parece haver mudanças visíveis ao longo do tempo. À exceção de uma tendência de crescimento de temáticas novas ou de substituição parcial dos tópicos mais tradicionais de física por essas temáticas, as abordagens e formas conceber o conhecimento não parecem se transformar em essência. Mas algumas transições, ainda que não acentuadas podem ser significativas. Enquanto nos idos dos anos 80 ou 90 entre os trabalhos que poderíamos caracterizar como mais inovadores, se destacam aqueles em que a inovação está, sobretudo, na abordagem ou problematização do conteúdo; nos anos mais recentes, se destacam os que tratam de novos conteúdos ou temas. Ou seja, nos períodos iniciais, tomados até o final da década de 1980, a renovação ou transformação do "convencional" em "não-convencional", quando presente, recai principalmente na forma, tratamento ou organização do conhecimento, talvez na desnaturalização do que sempre foi tido como natural. Já nos mais recentes, o inovador se dá predominantemente pelo conteúdo em si, pela presença de novas temas, o que não deixa de ser um novo olhar.

Esses resultados, conclusões e considerações certamente não estão dissociados de concepções ou finalidades educacionais, ou mesmo das transições pelas quais passa a área de pesquisa em ensino de ciências/física, seja sob uma ótica "internalista" das tendências e modismos na pesquisa acadêmica, seja sob uma ótica "externalista" que reflete influências de políticas educacionais e transformações sociais mais abrangentes. Em outras palavras, mesmo que seja possível realizarmos um esboço da presença da dimensão científica nas pesquisas, ela traz consigo as demais dimensões, particularmente a dimensão educacional que, por sua vez, também reflete questões de ordem mais ampla.

Queremos dizer com isso, que seja qual for o conhecimento contemplado e a extensão e profundidade com que o é, a essência de sua natureza, ou de seu caráter, enquanto "tradicional/conservador" ou "crítico/transformador", passa necessariamente pelos valores e competências almejados. $E$, nesse caso, de um lado estão direcionados sobretudo à aquisição de conhecimento pelo conhecimento, à Física pela Física, orientados propedeuticamente. E, de outro lado, visam uma formação para a vida, para a cidadania, ou formação humanista, ainda que mesmo nesse pólo haja modelos e visões de educação distintos, como também é fato que essas finalidades passaram a ser jargão para abrigar concepções diversas de ensino e de educação, mesmo algumas mais conservadoras. 


\subsection{A dimensão da Educação na produção}

Para caracterizar a presença da dimensão educacional nas pesquisas, ou seja, os objetivos ou finalidades educacionais, buscamos um caminho metodológico semelhante ao desenvolvido para a dimensão do conhecimento. Selecionamos os trabalhos classificados nas duas interfaces que têm como um dos eixos a Educação Educação-Conhecimento (EC) e Educação-Processos (EP) para, primeiramente "quantificar" a presença dessa perspectiva e, depois, a sua natureza, ou seja, de que forma é acenada.

Já na primeira etapa, encontramos dificuldades ainda maiores que aquelas apresentadas na análise do eixo do Conhecimento. "Contabilizar" tal presença demanda critérios muito distintos e vagos ou extremamente subjetivos. Optamos, em um primeiro momento, por usar como critério a presença ou não de uma intencionalidade em sinalizar alguma perspectiva educacional nesses trabalhos. Ainda que tenhamos obtido alguns resultados importantes nessa tentativa, concluímos que não "funciona". Por dois motivos. O primeiro, porque é difícil caracterizar o que é uma intenção nesse sentido, já que de certa forma todo trabalho numa área de ensino, explicita ou implicitamente apresenta alguma intencionalidade educacional, que pode ser concreta ou abstrata, geral ou específica, conservadora ou crítica, embasada e justificada ou não em modelos ou concepções de educação. Mais ainda, se nos baseamos nos resumos das dissertações e teses para fazer essa análise, é extremamente difícil, quando não inviável, saber se essa intenção é de fato "exercitada" e coerente com a pesquisa desenvolvida, ou seja, confrontar a declaração de intenções com a prática. O uso de referências bibliográficas e de referenciais teóricos apresenta o mesmo problema, já que a presença ou não de autores e modelos de educação não são necessariamente sinalizadoras de que orientaram ou fundamentaram de fato a pesquisa desenvolvida.

No que se refere, ainda, à natureza dessa perspectiva, ou seja, de caracterizar quais concepções, modelos, ideologias, referências, estariam alicerçando as pesquisas, quando não explicitados, a análise é igualmente muito complexa e impraticável.

Em suma, o caminho que pretendíamos percorrer na busca de caracterizar a dimensão educacional mostrou-se inadequado. No entanto, revelou um dado importante: o de que as finalidades educacionais ou as concepções de educação na nossa produção acadêmica não são foco de atenção ou de reflexão explícito. Não há, de um modo geral, uma preocupação em definir esse marco teórico, assim com não há em associar a pesquisa a uma possível demarcação ou sinalização de expectativa educacional, do ponto de vista "do quê se quer ao final", de qual a sua contribuição no final da linha, seja na escola básica, seja na formação de professores (no ensino superior) ou na formação do formador de professores (na pós-graduação em ensino). 
De todo modo, insistimos em buscar algum outro caminho para tratar dessa questão e voltamos ao nosso levantamento de dissertações e teses classificadas nas duas interfaces que contemplam o eixo da educação, Educação-Conhecimento e Educação-Processos, buscando algum indicador para melhor qualificá-las.

Um primeiro estudo nos mostrou que, no que se refere à explicitação de alguma intencionalidade educativa, mesmo que vaga ou implícita, ela aparece mais consistentemente nos trabalhos situados na interface Educação-Conhecimento do que na outra, Educação-Processos. Ou seja, dentre as pesquisas que contemplam o eixo educacional, aquelas que o fazem na intersecção com o eixo do conhecimento, sinalizam, mesmo que tímida ou vagamente mais que nas outras, alguma forma de conceber uma intencionalidade formativa.

Uma vez que os trabalhos nessa interface (EC) foram analisados sob a ótica do conhecimento, esse conjunto de certa forma já foi contemplado e a ele voltamos. A conclusão que poderia ser "natural" naquela análise só se destacou ao retornar à mesma visando essa outra face, da educação. Qual seja, a de que ao procurarmos caracterizar a natureza do conhecimento científico como tradicional ou inovador, por critérios diferentes, uma concepção de educação já lá estava implícita. Seja do ponto de vista dos conteúdos tratados, da abordagem com que são focalizados ou da sua organização e problematização, objeto e objetivos estão profundamente imbricados. O que outra vez poderia parecer "óbvio" em se tratando da natureza da área "ensino de física" ou "ensino de ciências". Mas é importante que essa obviedade seja iluminada, pois no decurso da evolução e trajetórias da área, ela pode ser perdida.

Enfim, o que podemos inferir é que a concepção de educação na produção acadêmica dessa área raramente é intencionalmente apresentada e discutida e, quando implícita, se dá por meio da forma como a dimensão do conhecimento é tratada.

\subsection{Sistematização e considerações gerais}

Entre os aspectos a serem destacados a partir da análise realizada nesse capítulo, o primeiro refere-se ao instrumento utilizado para investigar a produção. A caracterização das pesquisas por meio das interfaces que delimitam seus âmbitos e, posteriormente a natureza de seus focos de interesses se mostrou adequada e possibilitou complementar e aprofundar o quadro anteriormente delineado pelas temáticas às quais estão voltadas.

Em primeira instância, confirma, aprofunda e estende a hipótese acerca do "DNA" da área. O que já havia surgido na análise das áreas temáticas, a partir da qual identificamos a hegemonia dos focos nos Processos de Ensino e Aprendizagem, é sublinhado quando identificamos a expressiva concentração de pesquisas na 
interface Conhecimento-Processos, que reflete uma ênfase recorrente nos resultados desses processos enquanto meio de aperfeiçoar o ensino de Física. Ou ainda, a ênfase no estudo dos materiais e métodos, no "como" ensinar, no como tornar o ensino de física mais eficiente, mais motivante, mais palatável. Ou, também, como investigar de que modo se aprende mais ou menos dados conhecimentos.

Em segunda instância, a combinação eixos-interfaces nos estabeleceu parâmetros para investigar mais analítica ou criticamente de que modo o conhecimento científico vem sendo incorporado enquanto objeto de estudo nas pesquisas. Análise essa que permitiu melhor delimitar e balizar considerações encontradas nos estados da arte da PEF sobre o declínio ou não da presença da "Física", do ponto de vista conceitual. Quanto a isso, podemos afirmar que de fato está ocorrendo um distanciamento do conhecimento físico e um deslocamento desse para questões mais gerais acerca do ensino-aprendizagem em Ciências.

Ainda que com toda a complexidade ou dificuldade de identificar perspectivas e finalidades educacionais presentes (ou não) nas pesquisas, pudemos extrair indícios sobre a dimensão disciplinar, ensino de Física, enquanto relação entre conhecimento científico e perspectiva educacional.

A tradição ou o conservadorismo, evidenciados na ótica da dimensão do conhecimento, são reflexo da mesma tradição e conservadorismo na ótica da dimensão educacional. A ênfase nos processos de ensino e aprendizagem, ainda que esperada, se soma a isso. E a essência do conjunto é a forte tendência da supremacia de uma concepção tecnicista, de "ensino por resultados" que tem como valor principal o conhecimento em si mesmo e não evidencia perspectivas na direção de uma formação cidadã (autêntica).

Finalmente, não podemos deixar de observar que na relação Pesquisa-Ensino, de um lado os reflexos de políticas e iniciativas educacionais mais amplas não parecem estar amplamente incorporados pelas pesquisas, já que diretrizes, parâmetros e movimentos como LDB/..., PCN e ENEM parecem produzir poucos impactos nas pesquisas (ou particularmente nas dissertações e teses) quando observamos tendências predominantes, como tema ou objeto explícito de investigação. Por outro lado, não são nulos ou ausentes, enquanto influência em outros aspectos analisados. Por exemplo, quando passam a ser incorporadas na produção, a partir do final das anos 90 , e início da década de 2000 , as novas temáticas (do mundo contemporâneo). E mesmo que não tenhamos analisado aqui, observamos a incorporação nos discursos da pesquisa (o que não significa nas suas práticas) acenos e afirmações no sentido de "formação para cidadania", "formação para a vida", "promoção de habilidades e competências", "contextualização do conhecimento", "interdisciplinaridade", valores éticos e socioculturais. 


\section{Um novo capítulo: o mestrado profissional}

Nos anos recentes, um "novo capítulo" passou a ser incorporado na trajetória de nossa área: a implementação dos mestrados profissionais (MP), dentro de uma política geral da Coordenação de Aperfeiçoamento do Pessoal de Nível Superior (CAPES).

Desde sua criação, mas, sobretudo após sua expansão nos primeiros anos da década de 2000, o MP tornou-se alvo de discussões, entre defesas e críticas, entre incentivos e resistências. No entanto, apesar de já decorridas mais de uma década dos primeiros programas e propostas dessa modalidade na pós-graduação, o perfil, a evolução e atual situação desses mestrados estão pouco delineados. Estudos e reflexões em torno desse tema não acompanham proporcionalmente quer a expansão desses cursos, quer as novas questões que introduziram. De um modo geral, as publicações sobre os MP têm se limitado ao âmbito interno da própria CAPES, por meio de seus documentos oficiais ou de seu periódico - a Revista Brasileira de Pós-Graduação (RBPG).

Particularmente na área de Ensino de Ciências, o número de programas com mestrado profissional já supera o de mestrados acadêmicos, com expressivos impactos na área. E também nesse âmbito mais específico, os dados e as discussões acerca da formação profissional são incipientes. Por esse motivo, visando complementar o panorama até aqui desenvolvido, nesse capítulo procuramos trazer alguns dados sobre a evolução desses programas na área de Ensino de Ciências, situando-os num quadro mais abrangente dos cursos de pós-graduação recomendados pela CAPES em diferentes áreas. Investigamos, também, algumas características das produções dos mestrados profissionais em Ensino de Física, segundo os mesmos parâmetros utilizados até aqui para descrever e analisar a produção acadêmica.

O objetivo do capítulo é, pois, contribuir para o aprofundamento que se faz necessário sobre essa discussão, trazendo dados e sinalizando algumas questões em aberto, que merecem atenção, com foco nas especificidades desse modelo de pósgraduação na área de Ensino de Ciências e de Física. 


\subsection{O Mestrado Profissional: questões em pauta e panorama geral}

\subsubsection{Breve histórico, discursos e polêmicas}

A criação dos cursos de mestrado profissional no Brasil (também chamados mestrados profissionalizantes) tem origem na década de 1960 com base em documentos que justificavam a importância da criação de uma pós-graduação dirigida à formação profissional, contemplada no Parecer 977/65 do Conselho Federal de Educação, já o prevendo como grau terminal. No entanto, os primeiros cursos nessa modalidade só vão ser instituídos na segunda metade da década de 1990, quando a CAPES cria nova portaria em 1995 com recomendações para a sua implantação.

Finalmente, a partir de 2000, os MP são amplamente estimulados e cursos diversos de pós-graduação stricto sensu no país passam a enviar propostas à CAPES.

A homologação, em 2001, pelo Conselho Superior da CAPES das proposições apresentadas no documento técnico "Capes - A necessidade de desenvolvimento da pós-graduação profissional e o ajustamento do Sistema de Avaliação às características desse segmento" (MINISTÉRIO DA EDUCAÇÃO/CAPES, 1999) e, no ano seguinte, a explicitação dos instrumentos de avaliação do MP tiveram o primeiro maior impacto na implantação de cursos profissionais em diferentes áreas e, em especial na área de Ensino de Ciências.

Vale aqui destacar que o mestrado profissional (MP) não tem existência legal, com legislação aprovada pelo Congresso Nacional e sancionada pelo presidente da República. Seu reconhecimento decorre de uma portaria da CAPES de 1998 (BRASIL. MEC. CAPES, 1999) que dispõe sobre seu enquadramento e avaliação, explicitando distinções entre o mestrado profissional e o acadêmico e prevendo, por meio de aprovação do Conselho Nacional de Educação a equivalência de títulos dessas duas modalidades, impedindo qualquer discriminação entre uma e outra para diferentes fins, tal como para a seleção de candidatos aos cursos de Doutorado.

As datas referentes às normatizações do $\mathrm{MP}$, entretanto, não são muito claras e aparecem em artigos e publicações de forma desencontrada. Há inúmeros decretos, portarias, normas e resoluções. Segundo Portal da CAPES, somente em 2009 o MP foi regulamentado.

"A regulamentação que pretende incentivar essa modalidade foi publicada no dia 23 de junho no Diário Oficial da União pelo Ministério da Educação (MEC). A PORTARIA NORMATIVA N 7, DE 22 DE JUNHO DE 2009 tem como objetivo regulamentar o mestrado profissional, modalidade esta que estava sem regulamentação no país". http://www.capes.gov.br/duvidas-frequentes/62-pos- 
graduacao/2376-qual-e-a-diferenca-entre-o-mestrado-academico-e-o-mestradoprofissional (acessado em 07/02/2012)

A própria "definição" do mestrado profissional, seus objetivos e características, estão explicitados de forma fragmentada nessas diferentes "legislações". Essa mais recente portaria apresenta como objetivos do MP:

\section{PORTARIA NORMATIVA No- 7, DE 22 DE JUNHO DE 2009}

Dispõe sobre o mestrado profissional no âmbito da Fundação Coordenação de Aperfeiçoamento de Pessoal de Nível Superior - CAPES.

São objetivos do mestrado profissional:

I - capacitar profissionais qualificados para o exercício da prática profissional avançada e

transformadora de procedimentos, visando atender demandas sociais, organizacionais ou profissionais e do mercado de trabalho;

II - transferir conhecimento para a sociedade, atendendo demandas específicas e de arranjos produtivos com vistas ao desenvolvimento nacional, regional ou local;

III - promover a articulação integrada da formação profissional com entidades demandantes de naturezas diversas, visando melhorar a eficácia e a eficiência das organizações públicas e privadas por meio da solução de problemas e geração e aplicação de processos de inovação apropriados; IV - contribuir para agregar competitividade e aumentar a produtividade em empresas, organizações públicas e privadas.

Parágrafo único. A oferta de cursos com vistas à formação no Mestrado Profissional terá como ênfase os princípios de aplicabilidade técnica, flexibilidade operacional e organicidade do conhecimento técnico-científico, visando o treinamento de pessoal pela exposição dos alunos aos processos da utilização aplicada dos conhecimentos e o exercício da inovação, visando a valorização da experiência profissional.

\section{Das questões polêmicas em destaque}

Entre as controversas e problemas que vêm sendo apontados nessa discussão, destacam-se os seguintes aspectos:

- as finalidades e a natureza de um mestrado profissional como contraponto ao acadêmico;

- as contradições inerentes ao desenvolvimento dos mestrados profissionais nos moldes acadêmicos e as disputas de espaço

- as características da produção final nas duas modalidades de mestrado;

- os possíveis interesses político-econômicos e a questão de financiamento

\section{Segundo a CAPES,}

"Mestrado Profissional" é a designação do Mestrado que enfatiza estudos e técnicas diretamente voltadas ao desempenho de um alto nivel de qualificação profissional. Esta ênfase é a única diferença em relação ao acadêmico. Confere, pois, idênticos grau e prerrogativas, inclusive para o exercício da docência, e, como todo programa de pós-graduação stricto sensu, tem a validade nacional do 
diploma condicionada ao reconhecimento prévio do curso (Parecer CNE/CES 0079/2002). (grifos nossos)

Essa "única diferença", no entanto, é carregada de sentidos e interpretações, que desencadeiam muitas outras. A própria distinção entre formação acadêmica e formação profissional traz em seu seio muitas outras polaridades e falsas ou autênticas contradições: teoria e prática; produção de conhecimento e aplicação de conhecimento; formação intelectual e formação técnica. A existência ou não de contradição ou de valorização entre um e outro pólo é também questão controversa. Para alguns, especialmente para o setor oficial, vinculado à CAPES, parece não haver contradições, tampouco aspectos valorativos, apenas diferenças ou complementaridades entre um tipo de formação e outro, atendendo distintas demandas e perfis.

Janine Ribeiro (2005), diretor de Avaliação da Capes no período 2004 a 2008, faz a seguinte distinção entre os dois modelos:

"No MA, pretende-se pela imersão na pesquisa formar, a longo prazo, um pesquisador. No MP, também deve ocorrer a imersão na pesquisa, mas o objetivo é formar alguém que, no mundo profissional externo à academia, saiba localizar, reconhecer, identificar e, sobretudo, utilizar a pesquisa de modo a agregar valor a suas atividades, sejam essas de interesse mais pessoal ou mais social. Com tais características, o MP aponta para uma clara diferença no perfil do candidato a esse mestrado e do candidato ao mestrado acadêmico..." (RIBEIRO, 2005, p.15)

Em tal distinção entre o MA e o MP apresentada por Ribeiro, alguns pontos chamam atenção. O primeiro deles refere-se ao perfil ou trajetória dos alunos formados em um ou noutro mestrado. $O$ aluno egresso do mestrado acadêmico permanece na universidade (pesquisando), enquanto o egresso do mestrado profissional atua fora da academia. Parece haver aí uma contradição com a própria definição e regulamentação dos MP, já que o título de mestre profissional possibilita, tal qual o de acadêmico, lecionar em uma universidade (pública ou privada). Ou seja, tanto quanto o mestre acadêmico, o profissional teria com uma de suas perspectivas seguir uma carreira universitária. Também parece haver implícita, nessa e em outras definições e interpretações, uma cisão entre o "mundo acadêmico" e o " mundo social", como instâncias apartadas. O mestrado acadêmico seria algo que pertence à academia, cujo caráter social não é enfatizado. O profissional estaria dirigido para um mundo profissional externo à academia visando atender demandas sociais.

Outra ênfase que aparece nesse discurso (e em muitos outros) é a "agregação de valor" ao trabalho do mestre profissional. De que valor se trataria? E por que a formação acadêmica não agregaria valor ao seu formando? Estaria aqui se dizendo 
que a formação para o mercado produtivo tem valor distinto da produção de conhecimento em uma universidade? Ou, ainda, o destaque para o "valor" seria para não tirar mérito do MP diante do MA? Ou para lhe conferir um mérito distinto?

Ainda nessa direção, retomamos a citação acima da definição da CAPES na qual o MP é o "Mestrado que enfatiza estudos e técnicas diretamente voltadas ao desempenho de um alto nível de qualificação profissional." O alto nível (que agrega valor) estaria sendo enfatizado para diferenciar um mestre profissional de outro profissional sem título de mestre? Ou para diferenciá-lo do mestre acadêmico que tem alto nível, mas não é profissional?

Podemos levantar outras explícitas ou implícitas polarizações nessa distinção. Por exemplo, sobre o "pesquisar" (no MA) e o "aplicar a pesquisa" (no MP). Isso nos leva a perguntar se um "acadêmico" não aplica sua pesquisa. Como se situariam, então, os "acadêmicos aplicados" ou experimentais? Haveria aqui uma identificação da pesquisa acadêmica com pesquisa teórica?

Quanto à polarização entre teoria e prática, que estaria implícita nas diferenciações das finalidades de um e outro curso, estando o MA inserido numa produção teórica de conhecimento e o MP na sua aplicação prática, também é motivo de controversa e refutada pelos maiores "adeptos" ao MP. Em boa parte dos discursos, procura-se sublinhar a inconsistência de contradições entre esses pólos, que remetem à "velha", mas aqui recolocada questão sobre a divisão social do trabalho.

Spink (1997) aponta uma falsa contradição nas finalidades e desenhos desses modelos, remetendo-se a essa discussão.

Também parte do dilema está nas falsas separações entre as reflexões da academia e as ações no mundo, entre scholars e practitioners (para usar a distinção comum nos Estados Unidos), ou entre os intelectuais e os artesãos. Não é o momento de aprofundar a sutileza nefasta destas distinções e suas conseqüências nas múltiplas esferas da ação social; suficiente é notar sua fragilidade em face da transformação do conceito de intelectual nas mãos brilhantes de Antonio Gramsci (Hoare e Smith, 1971), ou lembrar a visão de Kurt Lewin (Spink, 1979; Thiollant, 1997) de que não há nada mais prático do que uma boa teoria e a longa e extremamente produtiva tradição de pesquisa-ação que esta expressão gerou. (SPINK, 1997. p.169)

Fisher (2005), por sua vez, propõe uma conciliação entre formação acadêmica e profissional, sugerindo um modelo de gestão institucional em que se prezem interesses e práticas de docentes, ao mesmo tempo em que uma articulação orgânica entre teoria e prática. 
Defende-se o esforço de pensar e organizar um modelo de curso para além da academia, pelas vantagens tanto para os praticantes quando para os acadêmicos. Entre outras vantagens, a fertilização cruzada entre cursos quando ocorrem nas mesmas estruturas de programas, conferindo maior ressonância social à pesquisa, e a reflexão sistemática sobre as práticas além das possibilidades oferecidas ao ensino ancorado na experiência...

...Talvez seja esse o maior desafio e fator de sedução para oferecer cursos de natureza profissionalizantes: a articulação orgânica entre a prática (que o aluno tem ou almeja ter) e a teoria que alimenta e alicerça essa prática (FISCHER, 2005, p.29)

Outra decorrência dessa polarização viria da convivência dos dois modelos de curso nos mesmos espaços e sob a mesma política. A formação profissional, dadas as suas especificidades e vocação, estaria encontrando barreiras por ter que se constituir nos moldes da academia.

... Com formato e denominação polêmicos, o MP esbarra na concepção acadêmica da pós-graduação, sedimentada por práticas e modelos tradicionais. O sistema de avaliação da Capes reflete essa realidade, concebida e estruturado para aferir o desempenho de programas e cursos voltados para a formação acadêmica, orientando-se, portanto, por parâmetros, critérios e indicadores orientados a tal propósito. Há, nesse momento, uma tendência a revisar o sistema de avaliação incorporando novos valores e critérios. (FISCHER, 2005, p.25-26)

Problema que é também apontado por Castro,

...As barreiras legais mais sérias já foram vencidas. Mas ainda há adversários ferrenhos, sejam por purismo ou por defenderem reservas de mercado. Não obstante, o que está freando o desenvolvimento do mestrado profissional é a sua estrutura atrelada à $P G$ acadêmica que Ihes tira a vida própria e os converte em prêmios de consolação ou mendigos, no Olimpo dos cursos acadêmicos. A estrutura presente condena os mestrados profissionais a uma mímica da vida acadêmica e da pesquisa "científica" totalmente inapropriada para sua índole profissional. Sem que satisfaçam a exigências muito próximas daquelas apropriadas para o mestrado acadêmico, a Capes não os aceita. Na prática, isso significa que somente uma instituição operando um mestrado acadêmico pode satisfazer às exigências do profissional. (CASTRO, 2005, p.17)

E aqui reside uma questão no mínimo curiosa, uma vez que ambos os formatos de pós-graduação são criados, geridos, regulamentados e avaliados pela mesma agência responsável pelas políticas de pós-graduação no Brasil, a CAPES. Ou seja, parece haver outra contradição entre o que se estabelece como padrão e como critério de avaliação no modelo acadêmico, com o que se espera do modelo profissional. 
Quanto a essa divisão ou sobreposição de espaços, surge outra questão, a de que a resistência de alguns setores e, mais especificamente do setor acadêmico, à entrada dos cursos profissionais se daria num confronto de interesses ou em uma disputa política e social, na qual "os acadêmicos" estariam resistindo a essa entrada para proteger interesses próprios e resguardar seu espaço de poder, especialmente nas universidades públicas.

Para Fischer,

A pós-graduação brasileira vive, desde o seu início, uma espécie de síndrome bipolar entre valores, padrões e critérios de ensino e avaliação estritamente acadêmicos e as exigências de formação do mundo do trabalho. $O$ mestrado profissional é a forma mais visível dessa disputa entre lideranças da comunidade acadêmica e das instituições que defendem tradições ou inovações como se fossem mutuamente exclusivas. (FISCHER, 2005, p.24-25)

Sobre essa disputa, Rezende Ribeiro aponta, inicialmente, motivos que datam da década de 1990, com a implantação dos primeiros mestrados profissionais.

Essa rejeição inicial pode ser encarada como um reflexo do que ocorria à época do surgimento desses primeiros mestrados profissionais: a Academia brasileira estava ainda vivenciando o impacto da então recente expansão da educação superior por meio do mercado, conduzida pelo próprio Ministério da Educação, de forma agressiva... Além desse motivo, houve também o reflexo de uma disputa social nos moldes da "distinção" de Bourdieu", isto é, os mestres "acadêmicos" (diferenciação que só se consolida em época recente) temiam que seu título se tornasse desvalorizado. (RIBEIRO, 2010, p.436)

E prossegue, trazendo questões mais profundas enraizadas nessa disputa, sobretudo no debate sobre o papel da universidade como parte integrante da produção e reprodução social.

No entanto, passada uma década, a permanência da rejeição por esse novo tipo de formação, os mestrados profissionais, pode evidenciar um outro processo social e histórico brasileiro mais profundo e com raízes históricas bem antigas: a separação entre a Academia e seu contexto social amplo, que, como muito bem demonstrou toda a obra de Freire, aparta do ensino a práxis. (RIBEIRO, 2010, p.436-437)

\footnotetext{
20 O autor refere-se aqui à citação de Boudieu que faz em seu artigo:

“O confronto de visões antagonistas que opõe a autonomia dos pesquisadores ditos 'puros' à heteronomia dos pesquisadores "aplicados" impede de ver que aquilo que se confronta; na realidade, são duas formas, ambas relativamente autônomas de pesquisa, uma voltada, antes, pelo menos na intenção, para a invenção científica e participante (bem ou mal) da lógica do campo científico, a outra voltada, antes, para a inovação, mas igualmente independente, para o melhor e para o pior, das sanções do mercado e capazes de designar, para si própria, fins igualmente universais de serviço público e de promoção do interesse geral." (BOURDIEU, 2003, p. 58)
} 
Ainda no interior dessa disputa, ou fora dele, mas nessa teia de argumentos e questionamentos, a própria formação acadêmica, seu sentido e finalidades, entram na berlinda.

A construção social do mestrado levou seu significado numa direção própria, que precisa ser explicitamente questionada. Com ênfase, de forma sutil, no papel do mestrado enquanto contribuição ao conhecimento, cria-se inevitável conflito, quando se lança a possibilidade não somente de mestrado profissional, mas também a de permitir que o mestrado profissional possa contar com uma dissertação, e que talvez esta venha a ter feições diferentes, sobretudo em um mundo onde a distinção entre teoria e prática não somente existe, mas, pior, é revestida com significados de superioridade. Ao trazer o mestrado profissional para o cenário de títulos acadêmicos, torna-se evidente a falta de discussão substantiva não sobre o mestrado profissional, mas sobre o mestrado em si, não sobre sua dissertação mas sobre a dissertação do modelo atual... ... Ao olhar-se para dentro das críticas sobre o mestrado profissional, encontra-se o significado mais amplo do modelo anterior. (SPINK, 1997, p.170)

Percebe-se, também nos diferentes discursos, outra implicação das distinções entre os dois modelos de mestrado, quanto à natureza de suas produções e no produto final almejado em cada um deles.

Antes da mais recente portaria regulamentadora do MP, em 2009, o produto final ou trabalho de conclusão exigido para atribuição do título, era uma dissertação nos moldes da dissertação do mestrado acadêmico, enquanto formato. Do ponto de vista de seu conteúdo, a principal diferença residiria na sua "aplicabilidade", ou seja, no seu valor enquanto "inovação" no mercado em que se insere o campo de conhecimento.

Mesmo tratando-se de uma dissertação, diferentes denominações e concepções desse trabalho de conclusão do MP vêm sendo dadas.

Segundo Moreira,

... o caráter do trabalho de final de curso no mestrado acadêmico é o de um relatório de pesquisa, enquanto o mestrado aqui proposto requer que se encontre naquele trabalho uma proposta de ação profissional que possa ter, de modo mais ou menos imediato, impacto no sistema a que ele se dirige. (MOREIRA, 2004, p.133). (grifos nossos)

Spink defende a ideia de que não há diferenças significativas entre esses produtos.

Se uma dissertação é essencialmente um processo de aprendizagem, de início, meio e fim - incluindo, entre outros, o porque da questão escolhida, o aprender a 
receber críticas, a ética da investigação e a sinceridade na dúvida - segue-se que uma dissertação num curso de mestrado voltado à interpretação da prática, à discussão de idéias, conceitos e teorias, e ao delineamento de linhas de ação a partir do conhecimento, deve contribuir para este objetivo, tanto em termos de instrumento de aprendizagem quanto em termos de mecanismo de avaliação. ... Conseqüentemente, não há nenhuma razão para que uma dissertação em um mestrado dito profissional seja diferente - em termos substantivos - de qualquer outra dissertação. Pode ser diferente em forma e em estilo, pode focalizar certas questões mais que outras, pode incluir e privilegiar diferentes fontes $e$ estratégias de coleção de dados, mas se ajuda a fixar o "saber como" e o "saber por que" e a avaliar a compreensão do candidato sobre seu papel neste "discurso crítico, movido pela fé na possibilidade humana do acerto", será uma dissertação. (SPINK, 1997, p.169) (grifos do Autor)

Com a nova regulamentação de 2009 , as possibilidades de formato dos trabalhos de conclusão se ampliaram, conforme descrito na Portaria da CAPES:

Agora, o 3o parágrafo da alínea IX do Artigo 7ㅇ diz o seguinte: "O trabalho de conclusão final do curso poderá ser apresentado em diferentes formatos, tais como dissertação, revisão sistemática e aprofundada da literatura, artigo, patente, registros de propriedade intelectual, projetos técnicos, publicações tecnológicas; desenvolvimento de aplicativos, de materiais didáticos $e$ instrucionais e de produtos, processos e técnicas; produção de programas de mídia, editoria, composições, concertos, relatórios finais de pesquisa, softwares, estudos de caso, relatório técnico com regras de sigilo, manual de operação técnica, protocolo experimental ou de aplicação em serviços, proposta de intervenção em procedimentos clínicos ou de serviço pertinente, projeto de aplicação ou adequação tecnológica, protótipos para desenvolvimento ou produção de instrumentos, equipamentos e kits, projetos de inovação tecnológica, produção artística; sem prejuízo de outros formatos, de acordo com a natureza da área e a finalidade do curso, desde que previamente propostos $e$ aprovados pela Capes". (CAPES, 2009)

Tal mudança, que se remete essencialmente ao "tipo" de produto, parece ser um ajuste ao MP, tendo em vista essa sua vocação de formação para o trabalho, acentuando sua distância do modelo acadêmico, e adaptando-o mais propriamente às áreas de saber técnico ou aplicado, ainda que tendo validade para todas. Uma questão que se poderia levantar aqui é o quanto essa abertura interfere na própria natureza da formação, indo além da forma e tendo implicações maiores nos conteúdos. Pois, é claro, as orientações de ensino vão refletir o que se almeja ao final do curso e forma e conteúdo estão intimamente imbricadas. Essas possíveis diferenças de formatos também poderiam criar ou acentuar diferenças entre os próprios mestrados profissionais, seja em uma mesma área ou em áreas distintas. Se isso é positivo ou não, é questão a ser avaliada. 
Finalmente, quanto ao último aspecto que apresentamos, está o debate sobre interesses em jogo na criação dos MP, de certo modo subjacente aos outros levantados. A discussão teria origem na resistência aos MP quanto a seu papel nas "defesas de mercado", que poderiam colocar as instituições de ensino superior a serviço de empresas. Fala-se de uma dupla finalidade dessa formação (contraditória para uns e conciliatória para outros) em atender interesses econômicos, do capital, ou garantir compromisso com demandas sociais.

Sobre tal polêmica Janine Ribeiro argumenta que os MP podem servir a ambos os propósitos, com vantagens, sugerindo

... modos pelos quais ele possa não apenas aumentar a produção na economia, mas também promover avanços significativos no resgate de nossa dívida social.

... que pretendemos, no ateliê de trabalho e em nossa ação na Capes, foi e é explicitar como a pós-graduação pode ajudar no desenvolvimento econômico e social - na fabricação e na práxis... O que a Capes intenciona, e os conceitos filosóficos acima expostos bem o mostram, é apostar nos dois caminhos. Ambos são importantes, o primeiro para nosso desenvolvimento econômico, o segundo para o desenvolvimento social. E é importante que o diálogo ocorra constantemente entre ambas as vertentes... (RIBEIRO, 2005, p.9).

Rezende Ribeiro (o outro Ribeiro!), em sua análise sobre o papel da universidade e sua disputa com o setor social, busca mostrar que existe uma forte tendência mercadológica do ensino superior. E nessa discussão questiona a visão, que concebe como de "senso comum", de que o mestrado profissional teria por finalidade exclusiva, atender o mercado.

[...]Portanto, o senso comum de que os mestrados profissionais seriam instrumentos que exclusivamente promovem a transformação da educação universitária em mercadoria é, no mínimo, um erro histórico. A criação desses cursos pode ser um aprofundamento das relações mercadológicas no meio acadêmico, mas isso só ocorrerá se a universidade assim o desejar, pois a criação de um novo modelo de pós-graduação pode servir, pelo contrário, como uma forma de transformação na direção de outras competências e contribuições sociais que se mostrem capazes de negar a suposta naturalidade de características tanto do indivíduo como do conjunto de seus participantes, substituindo, por exemplo, competitividade por cooperação coletiva. A disputa está em aberto e esse momento irreversível de consolidação desses novos cursos deve ser enfrentado tanto pela Academia quanto pela sociedade de forma cautelosa e corajosa. (RIBEIRO, 2010, p.441)

O que destacamos até aqui é a existência de uma diversidade relativamente grande nos discursos, concepções e linhas de argumentação acerca do MP. No entanto, quase todas as falas (ou "estados da arte") que podemos localizar, portanto 
publicadas, são de autores que buscam defender e legitimar os MP, mesmo que com eventuais críticas inerentes ao seu desenvolvimento. Estranhamente, as reflexões críticas a esse pensamento, sejam as que viriam do setor acadêmico, sejam outras, não têm sido objeto de publicações. O que poderia ser decorrente da incipiência mesmo dessas reflexões nos meios acadêmicos ou das dificuldades de espaços de reflexão e de divulgação. Lembramos que grande parte dos artigos localizados sobre o tema encontra-se no âmbito do discurso oficial da CAPES, seja em seu próprio Portal, seja por meio de seu periódico, a RBPG.

Enfatizamos também que, mesmo no interior desse discurso oficial, há focos diversos, alguns complementares outros divergentes em dados aspectos. Mas, de um modo geral, na defesa dos MP, percebe-se uma tendência de anular possíveis contradições entre a formação acadêmica e a profissional, buscando sempre mostrar conciliações entre as distintas propostas e possíveis controversas.

Sob uma ótica mais abrangente, os argumentos que vêm sendo usados na defesa dos MP foram incorporados pela área de Ensino. Porém, com adaptação para suas necessidades próprias, não apenas no que tange ao impacto em número de programas, mas também à sua natureza.

\subsubsection{Os Mestrados Profissionais em Ensino}

Até muito recentemente, os mestrados profissionais em Ensino (MPE) concentravamse plenamente na área de Ensino de Ciências e Matemática (antiga Área 46 da (APES), da qual trataremos mais detalhadamente adiante. Ainda com a extinção da mesma e substituição pela grande área de "Ensino", os programas que abrange ainda se restringem ao Ensino de Ciências e Matemática.

Moreira, um dos pioneiros na implantação dos MP, como membro da CAPES e Coordenador do primeiro mestrado profissional em ensino, define o público-alvo e natureza desses programas.

População alvo: (i) professores em exercício na educação básica (ensino fundamental e médio); (ii) professores de ensino superior que atuam nas licenciaturas ou em disciplinas básicas de outros cursos de graduação.

Natureza: o mestrado em ensino deverá ter caráter de preparação profissional na área docente focalizando o ensino, a aprendizagem, o currículo, a avaliação e o sistema escolar. Deverá, também, estar sempre voltado explicitamente para a evolução do sistema de ensino, seja pela ação direta em sala de aula, seja pela contribuição na solução de problemas dos sistemas educativos, nos níveis fundamental e médio, e no nível superior na formação de professores das licenciaturas e de disciplinas básicas. (MOREIRA,2004. p.133-134) 
Uma das principais justificativas para implantação dos mestrados profissionais em ensino (MPE) viria da constatação de uma grande demanda por "professores qualificados", tanto na escola básica como no ensino superior. Um segundo argumento, bastante recorrente, é a constatação de um "abismo" existente entre a formação acadêmica nessa área e as salas de aula. 0 mestrado acadêmico não estaria dando conta das demandas da escola, em especial do ensino básico, e dela estaria se apartando a passos largos. Desse modo, a pós-graduação profissional viria cobrir uma lacuna deixada pela formação acadêmica, provendo o "mercado educacional" de quadros com formação qualificada e específica, voltada para a solução de problemas educacionais locais ou regionais. Nas palavras de Moreira,

Nos últimos trinta anos a pós-graduação stricto sensu vem crescendo e se definindo no contexto de suas especificidades, tanto no Brasil quanto em muitos outros países. No Brasil, em particular por meio de agências de fomento à pesquisa e à formação de recursos humanos, como a Capes, surgiram comunidades de pesquisadores e produziu-se um considerável corpo de conhecimentos, em ambos os casos com o reconhecimento das comunidades internacionais correspondentes. No entanto, em que pese o esforço dessas comunidades, esse corpo de conhecimentos não teve ainda impacto significativo no sistema escolar, em particular na sala de aula, o que coloca, de forma evidente, a necessidade de ações que revertam este quadro. (MOREIRA, 2004. p.131)

A essas duas justificativas, adiciona-se o crescente "inchaço" do ensino superior e, consequentemente, a dificuldade dos cursos de pós-graduação em absorver o grande contingente de alunos graduados. Argumenta-se, ainda, que grande parte dos licenciados não teria condições ou mesmo expectativas de prosseguir na carreira acadêmica, que tem como objetivo a formação de pesquisadores e docentes de ensino superior. Ao "contrário" disso, teriam necessidades "especiais" de aperfeiçoamento da formação inicial. Os cursos stricto sensu, especialização ou extensão oferecidos em Universidades não teriam sido concebidos como cursos de formação de fato, sendo esporádicos e exigindo dos professores que a eles retornassem por vezes diversas.

Castro (2005) expõe seus argumentos acerca da implantação dos MPE, nessa direção.

Em primeiro lugar, na taxa em que está crescendo e deve continuar no futuro, não há a mais remota possibilidade de que sejam atendidos pelos atuais mestrados e doutorados que consomem, no mínimo cinco anos para produzir um graduado. Além disso, ao falar nos 30\% de mestres e doutores, estamos nos esquecendo que os outros $70 \%$ continuarão em sala de aula. Para esses, quase nada existe, exceto uma especialização desregulada e desfocalizada. (CASTRO, 2005, p.17) 
... É dramática a escassez de professores de bom nível, em todos os níveis e em todos os azimutes do mapa do Brasil. E como não há bom ensino sem bons professores, se há uma prioridade mais prioritária para a Capes é a formação de professores. (CASTRO, 2005, p.22)

...Na área da formação de professores é onde a Capes deverá concentrar todo o seu esforço. É essa área para onde devem se concentrar os mais volumosos recursos. Não é apenas a importância intrínseca da área, mas, sobretudo, o fato de que não apenas os alunos são mais pobres, mas é preciso atrair as melhores cabeças. (CASTRO, 2005, p.22)

Percebe-se, nessa justificativa, que além de cobrir lacunas do mestrado acadêmico (o abismo entre esse e as salas de aula), o MP também estaria cobrindo lacunas e deficiências da formação inicial e continuada de professores. Questão que merece atenção.

Castro esclarece, ainda a que tipo de mestrado em ensino e a que perfil de professores está se referindo.

Mestre em ensino de "alguma coisa". Mestrado em ensino, sim, mas ensino de alguma coisa bem concreta. Não precisamos de mais cursos genéricos, discutindo teorias pedagógicas da moda ou de séculos passados. Portanto, falamos de ensino de física, de administração ou o que seja. Mas tem que ter especificidade e foco. (CASTRO, 2005, p.22)

...Quando pensamos no corpo docente de um mestrado para professores, devemos pensar que tais cursos devem ter pessoal com três perfis diferentes. São necessários os mais acadêmicos, com seus conhecimentos teóricos mais profundos. Devem também haver alguns poucos que possam ensinar uma didática aplicada. E, mais importante, deve haver muitos professores que sejam os super-teachers em sala de aula. O centro de gravidade do curso deve estar pendendo em direção ao último grupo. Em um mestrado para ensinar física no ensino médio, devem estar como professores as grandes estrelas das melhores escolas de ensino médio - e por que não dos cursinhos. Em minha carreira de estudante, os melhores professores de ciências estavam nos cursinhos, ensinando de verdade, ao contrário do mito corrente de que apenas adestram. (CASTRO, 2005, p.23) (grifos nossos)

Mesmo que argumentos nessa linha não representem necessariamente um consenso entre as defesas do MPE, eles são bastante expressivos e têm se revelado presentes em diferentes instâncias e fóruns de discussão sobre a formação de professores ou sobre a pesquisa em ensino. Por um lado, destaca-se uma concepção de formação qualificada na qual o bom professor é aquele que tem bom domínio do conteúdo específico com uma boa dose de "didática". Outra concepção presente nesses discursos (que não entra em conflito com a anterior) parte do pressuposto de que a formação acadêmica em Ensino não tem vocação para responder ou visar problemas 
educacionais "reais". Ou seja, se existe um distanciamento dos mestrados acadêmicos em relação às finalidades educacionais e demandas sociais, o deslocamento dessas finalidades para os mestrados profissionais poderia estar, de certo modo, cristalizando esse abismo.

Ainda no que concerne à definição do perfil de profissional e demanda do sistema escolar, outro aspecto que vem sendo enfatizado é a necessidade de formação de um "professor reflexivo", exercendo sua prática profissional em escola e ao mesmo tempo sobre ela refletindo. Nessa linha, Moreira (2004) sugere áreas nas quais "ações em nível de pós-graduação devem contribuir para as transformações necessárias" para atender as demandas do sistema escolar, destacando a necessidade de um mestrado profissional para dar conta dessas necessidades.

É importante que se entenda que o afastamento crítico se dá no plano teórico, na construção da capacidade da reflexão crítica, e é a isto que se refere a noção de professor reflexivo, inserido em sua prática profissional. 0 mestrado aqui proposto impõe que a reflexão seja feita a partir de, e de forma concomitante com, a prática profissional do mestrando, de modo que não exista hiato ou readaptação após a conclusão do curso. Ainda, no âmbito desta visão, requer-se que o mestrando tenha experiência na área na qual quer aprofundar sua formação. (MOREIRA, 2004, p.133)

As produções finais dos cursos profissionais em ensino também apresentam um viés específico, mesmo em se tratando de dissertações nos moldes do mestrado acadêmico. Denominados também "produtos educacionais", devem tratar de responder, por distintos meios, problemas locais ou regionais de escolas. Sobre isso, voltaremos a tratar adiante, ao focalizar as especificidades da área de Ensino de Ciências.

Os dados que apresentamos a seguir, visando delinear um quadro geral dos cursos de pós-graduação nas diferentes áreas da CAPES, já revelam algumas dessas características próprias do mestrado profissionalizante em ensino.

\subsubsection{Panorama geral: Cursos e programas}

Os Cursos Recomendados pela CAPES ${ }^{21}$ estão estruturados em Grandes Áreas, cada uma das quais em Áreas. Para cada Grande Área são apresentados os totais de programas e de cursos, nas três modalidades de pós-graduação: Mestrado

\footnotetext{
21 “Programas e cursos de pós-graduação que obtiveram nota igual ou superior a 3 na avaliação da CAPES e que, portanto, atendem ao requisito básico estabelecido pela legislação vigente para serem reconhecidos pelo Ministério da Educação por meio do Conselho Nacional de Educação (CNE) e, em decorrência, expedirem diplomas de mestrado e/ou doutorado com validade nacional." (Portal da CAPES, Cursos Recomendados. http://www.capes.gov.br/cursos-recomendados. (Último acesso em 08/02/2012)
} 
Acadêmico, Doutorado e Mestrado Profissional. Com base nesses dados, sintetizamos as informações de maior interesse para traçar um perfil dos MP no país.

Na Tabela 7.1 e correspondente Gráfico 7.1(a) apresentamos a distribuição dos programas e cursos ${ }^{22}$, por modalidade, nas Grandes Áreas (GA). Na terceira coluna da tabela, apresentamos, para cada GA, a parcela de Mestrados Profissionais em relação aos totais de Programas e Cursos, com destaque para a denominada "Multidisciplinar", na qual a área de Ensino está enquadrada. O gráfico 7.2(b) mostra o percentual de cursos profissionais sobre o total de cursos nessa Grande Área.

\section{Participação dos MPs nos Programas e Cursos}

\section{GRANDES ÁREAS}

\begin{tabular}{|c|c|c|c|c|c|c|}
\hline & \multirow[t]{2}{*}{ GRANDE ÁREA } & \multirow[t]{2}{*}{$\begin{array}{c}\text { TOTAL } \\
\text { PROGRAMAS } \\
\text { (TP) }\end{array}$} & \multirow[t]{2}{*}{$\begin{array}{c}\text { TOTAL } \\
\text { CURSOS } \\
\text { (TC) }\end{array}$} & \multicolumn{3}{|c|}{$\begin{array}{l}\text { MESTRADOS } \\
\text { PROFISSIONAIS } \\
\text { (MP) }\end{array}$} \\
\hline & & & & MP & $\begin{array}{l}\text { MP/TP } \\
(\%)\end{array}$ & $\begin{array}{l}\mathrm{MP} / \mathrm{TC} \\
(\%)\end{array}$ \\
\hline 1 & CIÊNCIAS AGRÁRIAS & 371 & 586 & 22 & 5,9 & 3,8 \\
\hline II & CIÊNCIAS BIOLÓGICAS & 276 & 464 & 16 & 5,8 & 3,4 \\
\hline III & CIÊNCIAS DA SAÚDE & 537 & 849 & 75 & 14,0 & 8,8 \\
\hline IV & $\begin{array}{l}\text { CIÊNCIAS EXATAS E DA } \\
\text { TERRA }\end{array}$ & 296 & 461 & 14 & 4,7 & 3,0 \\
\hline $\mathrm{V}$ & CIÊNCIAS HUMANAS & 467 & 711 & 19 & 4,1 & 2,7 \\
\hline $\mathrm{VI}$ & CIÊNCIAS SOCIAIS APLICADAS & 409 & 558 & 70 & 17,1 & 12,5 \\
\hline VII & ENGENHARIAS & 361 & 514 & 59 & 16,3 & 11,5 \\
\hline VIII & $\begin{array}{l}\text { LINGÜÍSTICA, LETRAS E } \\
\text { ARTES }\end{array}$ & 181 & 276 & 2 & 1,1 & 0,7 \\
\hline $\mathrm{IX}$ & MULTIDISCIPLINAR & 420 & 539 & 115 & 27,4 & 21,3 \\
\hline & TOTAL & 3318 & 4958 & 392 & 11,8 & 7,9 \\
\hline
\end{tabular}

Tabela 7.1: Programas e Cursos nas grandes Áreas da CAPES

A tabela mostra que, no conjunto total dos cursos de pós-graduação, a presença do MP corresponde a $12 \%$ dos Programas e $8 \%$ dos Cursos. Mostra, ainda, como se distribuem nessas Grandes Áreas.

\footnotetext{
${ }^{22}$ Cada Programa de pós-graduação pode congregar mais de uma modalidade de Cursos (Mestrado Acadêmico, Doutorado e Mestrado Profissional). Por esse motivo há um maior número de Cursos que de Programas em cada área.
} 


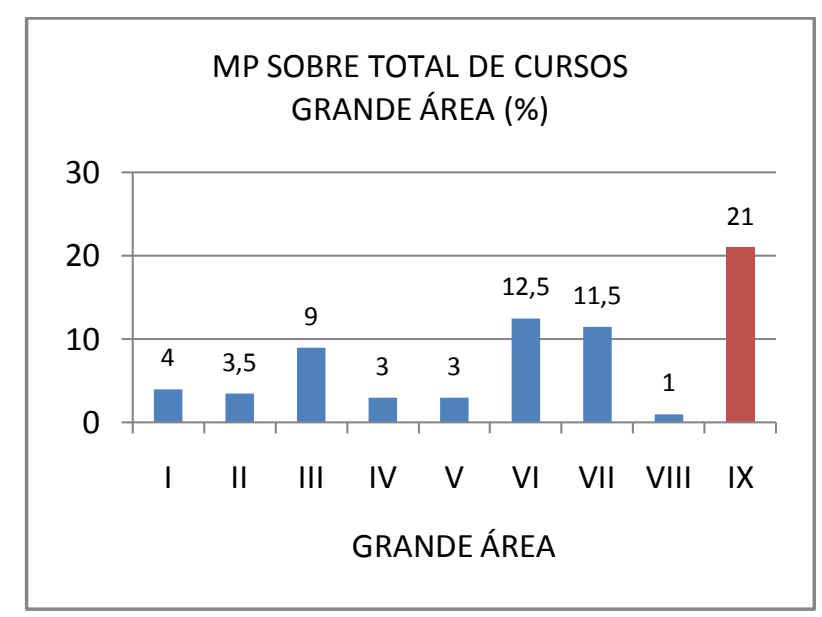

Gráficos 7.1 (a): Distribuição dos MP nas grandes Áreas

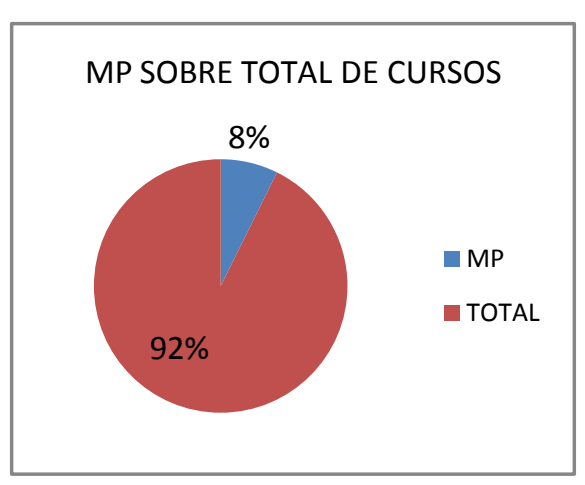

Gráfico 7.1 (b): Parcela de MP sobre Total

Já aqui chamamos atenção para a Grande Área Multidisciplinar (IX), na qual cerca de $27 \%$ dos programas têm a modalidade Mestrado Profissional, concentrando $20 \%$ dos cursos, muito acima das respectivas médias de $12 \%$ dos programas e $8 \%$ dos cursos (na soma cumulativa de todas as Grandes Áreas). É nessa GA que está inserida a área de Ensino.

Seguem a essa, as Grandes Áreas Ciências Sociais Aplicadas (VI), Engenharias (VII) e Ciências da Saúde (III), concentrando, respectivamente, cerca de $17 \%$, 62\% e 14\% dos cursos de Mestrado Profissional, parcelas próximas da média geral.

Para se ter uma ideia de quais áreas e cursos contribuem com parcelas expressivas de MP nessas grandes áreas, fizemos um levantamento de cada uma delas.

\section{GRANDE ÁREA MULTIDISCIPLINAR}

A Grande Área "Multidisciplinar" congrega as áreas de Ensino, Biotecnologia, Interdisciplinar e Materiais. A tabela 7.2 e o gráfico correspondente 7.2 mostram como se distribuem os programas e cursos de mestrado profissional nessa GA.

\begin{tabular}{|l|l|l|l|r|r|}
\hline GRANDE ÁREA: MULTIDISCIPLINAR & \multicolumn{1}{|c|}{$\begin{array}{c}\text { TOTAL PROGRAMAS } \\
\text { (TP) }\end{array}$} & \multicolumn{1}{|c|}{$\begin{array}{c}\text { TOTAL CURSOS } \\
\text { (TC) }\end{array}$} & \multicolumn{3}{|c|}{$\begin{array}{c}\text { MESTRADOS PROFISSIONAIS } \\
\text { (MP) }\end{array}$} \\
\hline ÁREA & No. Abs & No. Abs & No. Abs & MP/TP & MP/TC \\
\hline BIOTECNOLOGIA & 35 & 52 & 4 & 11,4 & 7,7 \\
\hline ENSINO & $\mathbf{7 2}$ & $\mathbf{9 1}$ & $\mathbf{3 9}$ & $\mathbf{5 4 , 2}$ & $\mathbf{4 2 , 9}$ \\
\hline INTERDISCIPLINAR & 288 & 358 & 69 & 24,0 & 19,3 \\
\hline MATERIAIS & 25 & 38 & 3 & 12,0 & 7,9 \\
\hline TOTAL & $\mathbf{4 2 0}$ & $\mathbf{5 3 9}$ & $\mathbf{1 1 5}$ & $\mathbf{2 7 \%}$ & $\mathbf{2 1 \%}$ \\
\hline
\end{tabular}

Tabela 7.2: Distribuição de Programas e Cursos na Área Multidisciplinar 


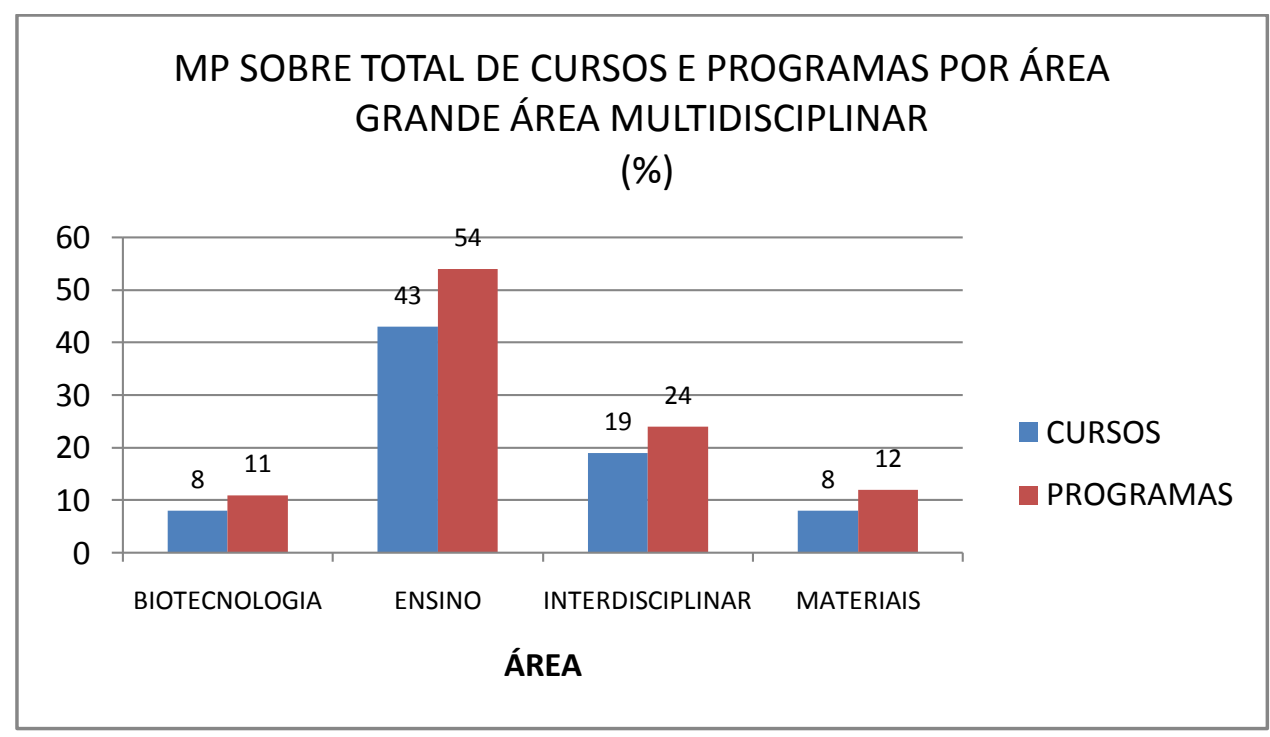

Gráfico 7.2(a): Distribuição dos MP na Grande Área "Multidisciplinar"

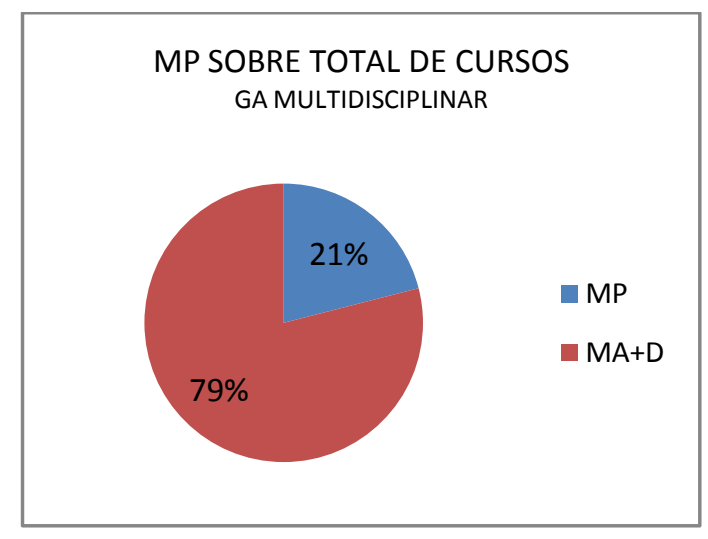

Gráfico 7.2(b): Parcela de MP sobre Total na Grande Área “Multidisciplinar"

A área de Ensino é a que tem maior parcela de mestrados profissionais, concentrando atualmente $54 \%$ dos programas e $43 \%$ dos cursos nessa modalidade, muito superiores às parcelas de MP no conjunto total da GA Multidisciplinar, $27 \%$ e $21 \%$ respectivamente.

A segunda área com participação relativamente expressiva de MP é a Interdisciplinar com 70 cursos nessa modalidade, $19 \%$ do total na GA Multidisciplinar. Engloba cursos nas áreas de Saúde (Ciência e Tecnologia em Saúde, Cuidados Primários, Educação nas Profissões da Saúde, Ciências da Saúde); Energia e Ambiente (Agroenergia, Bioenergia, Getão Ambiental, Sustentabilidade; cursos tecnológicos (Desenvolvimento de Tecnologia, Inovação Tecnológica, TV Digital), Políticas Públicas (Segurança Pública, Vigilância Sanitária, Defesa e Segurança Civil, Inclusão Social, Saúde Pública), em Gestões e Desenvolvimento ou em Áreas Culturais (Patrimônio Cultural, Memória Social). O que se observa, portanto, é que predominam aqui cursos sobretudo com vocação técnica ou prática. Os únicos casos voltados ao setor 
educacional situam-se nas Ciências da Saúde (também presentes na área de Ensino) e em Avaliação, mas ambos voltados a técnicas e práticas profissionais.

GRANDES ÁREAS: CIÊNCIAS SOCIAIS APLICADAS, ENGENHARIAS E CIÊNCIAS DA SAÚDE Nas outras três grandes áreas que seguem a Multidisciplinar em número de mestrados profissionais, Ciências Sociais Aplicadas, Engenharias e Ciências da Saúde, verificamos a mesma tendência constatada na área Interdisciplinar, de parcela dominante dos cursos com vocação técnica, prática ou de ciências aplicadas. São exemplos da primeira: Turismo, Ciências Contábeis, Demografia, Planejamento Urbano e Regional, Economia. Nas Engenharias, os MP estão presentes com maior participação na Engenharia Biomédica, Mecânica e de Produção. E nas Ciências da Saúde, os cursos com mais de 10\% na modalidade MP são Enfermagem, Odontologia e Saúde Coletiva.

\section{Distribuição das Áreas quanto à Dependência Administrativa}

Outro dado que buscamos mapear, nas áreas de maior concentração de Mestrados Profissionais, foi sua dependência administrativa, se pertencentes a instituições públicas ou privadas. Nas Grandes Áreas, conforme mostramos na Tabela 7.3 os MP nas Engenharias e na Multidisciplinar estão majoritariamente em instituições públicas (cerca de $70 \%$ e 60\%, respectivamente). Nas Ciências da Saúde e nas Ciências Sociais Aplicadas, pouco mais da metade dos cursos estão em instituições privadas.

\begin{tabular}{|l|l|l|}
\hline GRANDE ÁREA & $\begin{array}{l}\text { INST. } \\
\text { PÚBLICA }\end{array}$ & $\begin{array}{l}\text { INST. } \\
\text { PRIVADA }\end{array}$ \\
\hline ENGENHARIAS & $69 \%$ & $31 \%$ \\
\hline MULTIDISCIPLINAR & $62 \%$ & $38 \%$ \\
\hline CIÊNCIAS DA SAÚDE* & $47 \%$ & $53 \%$ \\
\hline $\begin{array}{l}\text { CIÊNCIAS SOCIAIS } \\
\text { APLICADAS* }\end{array}$ & $45 \%$ & $55 \%$ \\
\hline
\end{tabular}

Tabela 7.3: Dependência Administrativa dos MP em Grandes Áreas

*Dados incompletos

Em outras áreas com relativa concentração de MP essa distribuição mostra que a área de Ensino é a que concentra maior parcela de cursos em instituições públicas, cerca de 74\% (Tabela 7.4). Além dessa, a única área com maior parcela dos MP em instituições públicas é a Interdisciplinar.

\begin{tabular}{|l|l|l|l|l|}
\hline & \multicolumn{3}{|l|}{ PÚBLICAS } & \multicolumn{2}{l|}{ PRIVADAS } \\
\hline ENSINO & 26 & $74 \%$ & 9 & $26 \%$ \\
\hline INTERDISCIPLINAR & 39 & $60 \%$ & 26 & $40 \%$ \\
\hline ECONOMIA & 5 & $45 \%$ & 6 & $55 \%$ \\
\hline $\begin{array}{l}\text { PLANEJAMENTO } \\
\text { URBANO E REG. }\end{array}$ & 2 & $33 \%$ & 4 & $67 \%$ \\
\hline ODONTOLOGIA & 4 & $20 \%$ & 16 & $80 \%$ \\
\hline
\end{tabular}

Tabela 7.4: Dependência Administrativa dos MP em Áreas 
Em síntese, esses dados revelam que, se levarmos em conta as amplas chamadas e os incentivos da CAPES para a instauração de Mestrados Profissionais, sua participação nos Programas de Pós-Graduação no Brasil ainda é relativamente pequena, inferior a $10 \%$ na maior parte das Grandes Áreas e Áreas. No conjunto total de Cursos Recomendados, a parcela de Mestrados Profissionais é de $8 \%$ dos cursos (em 12\% dos Programas).

Revelam, ainda, que a área de Ensino é exceção a esse padrão, concentrando uma parcela de cursos nessa modalidade muito superior à média. Essa área é responsável pela predominância dos MP na grande área Multidisciplinar, líder nesse "quesito". Ao final de 2011, superou a marca dos 50\% de programas que oferecem Mestrados Profissionais. Também se destaca por ser a área em que esses programas estão majoritariamente concentrados em instituições públicas.

Finalmente, verifica-se que os mestrados profissionais estão mais frequentemente instituídos em programas de natureza técnica ou aplicada, dado que representa outro diferencial da área de Ensino em relação às demais e que merece atenção. Parece haver aqui uma contradição com a análise já feita sobre os MP de um modo geral. Tais cursos foram concebidos tendo em vista uma formação profissional predominantemente voltada para atender demandas específicas de setores ligados ao sistema produtivo, conforme pudemos perceber a partir de diferentes documentos oficiais da CAPES ou nos diversos artigos publicados na RBPG sobre os Mestrados Profissionais. Voltando a um desses documentos, segundo a Portaria de 2009 da CAPES são necessidades que o MP pretende atender ${ }^{23}$ :

- Necessidade de estimular a formação de mestres profissionais habilitados para desenvolver atividades e trabalhos técnico-científicos em temas de interesse público;

- Necessidade de identificar potencialidades para atuação local, regional, nacional e internacional por órgãos públicos e privados, empresas, cooperativas e organizações não-governamentais, individual ou coletivamente organizadas;

- Necessidade de atender, particularmente nas áreas mais diretamente vinculadas ao mundo do trabalho e ao sistema produtivo, a demanda de profissionais altamente qualificados;

- Possibilidades a serem exploradas em áreas de demanda latente por formação de recursos humanos em cursos de pós-graduação stricto sensu com vistas ao desenvolvimento socioeconômico e cultural do país;

- Necessidade de capacitação e treinamento de pesquisadores e profissionais destinados a aumentar o potencial interno de geração, difusão e utilização de conhecimentos científicos no processo produtivo de bens e serviços em consonância com a política industrial brasileira;

- Natureza e especificidade do conhecimento científico e tecnológico a ser produzido e reproduzido;

- Relevância social, científica e tecnológica dos processos de formação profissional avançada, bem como o necessário estreitamento das relações entre as universidades e o setor produtivo.

\footnotetext{
${ }^{23}$ Extraído da PORTARIA NORMATIVA No-7, de 22 de junho de 2009, publicada no Diário Oficial de 23/06/2009.
} 
Parece haver nesse conjunto de "itens de necessidade", uma ênfase no atendimento a setores produtivos, ao mundo do trabalho, às atividades técnico-científicas e tecnológicas. Poderíamos identificar a área de Ensino mais propriamente com um deles apenas - "Possibilidades a serem exploradas em áreas de demanda latente por formação de recursos humanos em cursos de pós-graduação stricto sensu com vistas ao desenvolvimento socioeconômico e cultural do país". Estranhamente, é justamente nos Programas de Ensino que parece haver maior estímulo e concentração dos mestrados profissionais. Mais um aspecto que chama atenção quanto às especificidades do Mestrado Profissional em Ensino.

\subsection{O Mestrado Profissional na área de Ensino de Ciências: um perfil emergente}

\subsubsection{A extinta "Área 46" da CAPES e a implantação dos MP}

A Área de Ensino de Ciências e Matemática na CAPES (Área 46) foi criada em setembro de 2000. Nesse ano foi constituída uma comissão de representantes dessa área, pela CAPES, para elaborar uma proposta de curso de mestrado distinto daquele até então existente (o acadêmico) visando atender necessidades específicas de professores do ensino básico e das licenciaturas, no ensino superior.

Segundo dados de Moreira (2002a), o primeiro programa (acadêmico) aprovado na área foi o Mestrado em Ensino, Filosofia e História das Ciências, desenvolvido conjuntamente pelas Universidades Federal da Bahia e Estadual de Feira de Santana. Em meados de 2001 a área contava com cinco programas aprovados (UFBA/UEFS, PUC-SP, USP, UNESP/Bauru e USU) dois em Educação Matemática e três em Ensino de Ciências, todos em nível de mestrado acadêmico. Ao final de 2001, somavam-se dez mestrados acadêmicos e quatro profissionalizantes aprovados, um doutorado aprovado e três propostas em diligência, totalizando 18 cursos (16 mestrados e 2 doutorados). ${ }^{24}$ À época, com base nesses dados, Moreira afirmava que

Tais indicadores sugerem que a Área estava em fase de crescimento, tendendo a abrigar novos programas em 2002. Tal crescimento implicava, por um lado, apoiar novos cursos e estimular aqueles em andamento e, por outro, não abrir mão de rigorosos critérios de qualidade. Nesse sentido, a qualificação do corpo docente, as atividades de pesquisa e as publicações em periódicos arbitrados, de nivel nacional e internacional, sempre estiveram entre os primeiros e mais importantes critérios a serem utilizados. Ainda nessa ocasião, foi iniciada a

\footnotetext{
${ }^{24}$ Números controversos, diferem dos apresentados em Relatórios Trienais da CAPES. Possivelmente devido a critérios de contabilizações distintos (programas aprovados, em aprovação, homologados, iniciados etc..)
} 
definição de padrões e critérios de qualidade da Área, cuja versão outubro 2002 está apresentada no Anexo I, e elaborada nova versão do documento sobre o mestrado (profissionalizante) em ensino, o qual, mais tarde, deu origem aos critérios específicos do mestrado profissional constantes no Anexo I. (MOREIRA, 2002a, p.4) (Reproduzimos no Anexo 7.1 esse Anexo de Moreira)

Nesse mesmo ano de 2002, são estabelecidos pela CAPES os instrumentos de avaliação dos mestrados profissionais e é criado o primeiro curso na área de Ensino de Ciências e Matemática, o Mestrado de Pesquisa em Ensino de Física da Universidade Federal do Rio Grande do Sul (UFRGS), o qual foi seguido por outros, como modelo de MP na área de Ensino.

Na interpretação de Moreira (2004), até esse ano somente haviam sido aprovados e implantados mestrados profissionais na área de Ensino de Ciências e Matemática, por ser essa a que tinha maior número de doutores, fruto de amplo apoio da CAPES e do CNPq para doutorados no exterior.

Em 2005, os MPE são induzidos em uma ampla chamada por meio de edital da CAPES e realização do Seminário - "Para além da Academia: A pós-graduação contribuindo para a sociedade" ${ }^{25}$ - com representantes de todas as áreas de conhecimento. Conclamava as Instituições de Ensino Superior a abrirem cursos profissionais em áreas específicas. Como consequência, os mestrados profissionais na área de Ensino de Ciências se expandem mais expressivamente a partir desse ano.

Quanto às justificativas mais específicas para implantação da pós-graduação profissional na área de ECM, com pioneirismo no Ensino de Física, destacamos nas falas de Moreira (2002a e 2002b), então membro da CAPES e Coordenador do primeiro Programa de MP na UFRGS dois argumentos. O primeiro, por ser praticamente uma condição de sobrevivência, consolidação e reconhecimento da área em dado momento de sua evolução, e o segundo, já anteriormente apresentado, pelas lacunas deixadas pela formação acadêmica:

- "A hora da vez..."

Dentro dos mestrados profissionais, os chamados "mestrados em ensino" constituem um caso especial fortemente estimulado pela CAPES. Portanto, no momento atual, uma das maneiras de inserir a pesquisa em Ensino de Física na política de pós-graduação do país é levá-la a criar Mestrados Profissionais em Ensino de Física. (MOREIRA, 2002b, p.2)

\footnotetext{
${ }^{25}$ Seminário realizado nos dias 30 e 31 de março de 2005 na Universidade Federal de São Paulo (UNIFESP), em São Paulo, promovido pela CAPES/MEC, teve como objetivo principal debater temas relativos à geração de conhecimento e sua repercussão na sociedade a partir de atividades desenvolvidas em cursos de pós-graduação.
} 
Como a pesquisa em Ensino de Física já está bastante consolidada no país, ela poderá inserir-se nessa política de pós-graduação participando da criação de Mestrados Profissionais em Ensino de Física. Esses mestrados contribuirão para o aperfeiçoamento dos professores de Física e poderão viabilizar a transferência à escola do conhecimento produzido pela pesquisa. (MOREIRA, 2002b, p.7)

- Impacto da pesquisa acadêmica no sistema escolar

Nos últimos trinta anos a pós-graduação stricto sensu vem crescendo e se definindo no contexto de suas especificidades, tanto no Brasil quanto em muitos outros países. No Brasil, em particular por meio de agências de fomento à pesquisa e à formação de recursos humanos, como a Capes, surgiram comunidades de pesquisadores e produziu-se um considerável corpo de conhecimentos, em ambos os casos com o reconhecimento das comunidades internacionais correspondentes. No entanto, em que pese $o$ esforço dessas comunidades, esse corpo de conhecimentos não teve ainda impacto significativo no sistema escolar, em particular na sala de aula, o que coloca, de forma evidente, a necessidade de ações que revertam este quadro. (MOREIRA, 2004, p.131)

Esse último aspecto é reforçado por Ostermann e Rezende (2009)

Os resultados da pesquisa em ensino de Física são abundantes em descrições de experimentos, metodologias, estratégias e materiais didáticos inovadores. Entretanto, como sugerem Rezende e Ostermann (2006), o contato do professor com as inúmeras propostas de recursos didáticos e metodologias inovadoras não tem sido suficiente, dada a desconsideração do contexto escolar e das condições de trabalho dos professores nas pesquisas. [...] Nesse sentido, os produtos educacionais desenvolvidos no contexto dos cursos de MPE deveriam tentar ganhar relevância a partir de sua inserção na realidade escolar. (OSTERMANN e REZENDE, 2009, p.72)

Sobre a natureza e identidade do Mestrado Profissional em Ensino (MPE), Moreira afirma

O mestrado acadêmico é aquele até aqui referido, com o qual estamos habituados. Este tipo de mestrado está dirigido à pesquisa e, na prática, é, ou ainda é, um passo para o doutorado. O mestrado profissional, por outro lado, tem caráter terminal e não está voltado para a pesquisa, mas sim diretamente para a ação docente, para a atividade profissional em ensino, em sala de aula, em serviço. (MOREIRA, 2002b, p.1)

Ostermann e Rezende introduzem outros aspectos que devem ser ponderados na diferenciação entre esses dois modelos. Entre as questões que colocam, uma referese às finalidades e ao sentido, o que se busca em um e outro mestrado. E a outra, 
considera as próprias questões de pesquisa, ou seja, onde estão colocados seus focos.

Quanto ao sentido e finalidades:

Na forte tradição cognitivista da área de pesquisa em ensino de Ciências, a pergunta sobre a melhoria do ensino de Física sempre esteve voltada para o processo ensino-aprendizagem, como mostram os exemplos de questões-foco mencionadas acima. Por outro lado, numa perspectiva sociocultural (LEMKE, 2001), a pergunta sobre como melhorar o ensino de Física deveria questionar também o seu próprio sentido, buscando uma visão mais crítica de quais seriam os objetivos desse ensino... As perguntas formuladas sobre o ensino de Ciências são de outra natureza nessa abordagem, pois aprender um novo conhecimento é enculturar-se processo concebido como uma segunda socialização em uma subcomunidade. (OSTERMANN e REZENDE, 2009, p.73).

Quanto aos focos de investigação:

A pergunta que projetos de desenvolvimento devem buscar responder é de natureza diversa daquela que se formula em uma pesquisa, pois seu foco deve ser a inovação didática. No MPE, podemos pensar na formulação de questõesfoco e não em questões de pesquisa, como é usual em projetos de investigação. Por exemplo, uma questão-foco deve se relacionar a formas de se conceber, implementar e avaliar inovações didáticas (estando vinculadas a metodologias de ensino, conteúdos e avaliação); já questões de pesquisa podem se reportar a práticas educativas estudadas à luz de pressupostos sustentados por referenciais teóricos, metodológicos, epistemológicos e terem como principal objetivo orientar a produção de conhecimento científico. (OSTERMANN e REZENDE, 2009, p.72).

Também nesse âmbito específico, os produtos finais esperados nos Mestrados Profissionais de Ensino são objeto de discussão. E essa tem recaído sobre a outra controversa, referente à polarização entre "projetos de desenvolvimento em ensino", que seriam característicos dos MP ou "pesquisa e produção de conhecimento", característica dos MA. Nos primeiros, espera-se como resultado "um produto educacional" que, segundo a Comissão de Avaliação da Área de Educação em 2006, "pode ser um trabalho de investigação, uma proposta de ação e/ou uma intervenção, voltado para um tema aplicado ou uma solução de problema." (OSTERMANN e REZENDE, 2009, p.70).

Sobre isso, Ostermann e Rezende (2009) ponderam e sugerem,

O fato de que o trabalho final de MPE deva incluir o desenvolvimento de um produto educacional carrega consigo uma visão tecnicista de ensino. Na tentativa de superar essa concepção, valeria a pena investir em produtos que 
não apenas contemplam a eficiência de um método de ensinar dado conteúdo, mas que envolvam uma reflexão sobre um problema educacional vivido pelo professor em uma dada realidade escolar e que levaria ao desenvolvimento de atividades curriculares alternativas (projetos interdisciplinares envolvendo toda a escola, problematização de problemas ambientais, problemas sociais, tais como questões de gênero, etc.), que exigissem a reflexão sobre as finalidades e o significado da educação em ciências na contemporaneidade...

...A posição aqui defendida em relação aos produtos educacionais é que estes devem não só ser desenvolvidos, mas também implementados e avaliados à luz de referenciais teóricos atuais sobre ensino-aprendizagem (na perspectiva de superação de abordagens comportamentalistas) e sobre avaliação, bem como estar fundamentados em epistemologias contemporâneas...

... Vê-se, portanto, que há uma fronteira tênue entre pesquisa e desenvolvimento em ensino de Ciências. Os projetos de desenvolvimento jamais podem ignorar os resultados de pesquisa, uma vez que as tendências da pesquisa em ensino acabam, muitas vezes, sendo temas de dissertações elaboradas por estudantes dos MPE, tais como a introdução da Física Moderna e Contemporânea e Tecnologias da Informação e Comunicação na educação básica; por outro lado, resultados de projetos de desenvolvimento podem colocar aos investigadores novos e relevantes objetos de estudo. (OSTERMANN e REZENDE, 2009, p.71)

O papel dos referenciais teóricos, segundo as autoras, não seria o mesmo nos trabalhos de mestrado profissional e acadêmico, como sustentam:

Os referenciais teóricos que fundamentam projetos de desenvolvimento podem ser pensados como tendo especificidades que os colocam em papel diverso daquele que desempenham no campo investigativo. Enquanto que em projetos de pesquisa esses referenciais colocam as questões de investigação e devem se integrar à metodologia, nos projetos de desenvolvimento estes devem fundamentar metodologias de ensino e sustentar a concepção do produto educacional, orientando a seleção de conteúdos e estabelecendo novas formas de avaliação. (OSTERMANN e REZENDE, 2009, p.72)

Se é que entendo essa comparação, ela também parece refletir diferenças já apontadas entre esses dois tipos de formação: o MA prescreveria as orientações (teóricas) para o MP. Ou seja, os ditos referenciais teóricos são determinados pela pesquisa acadêmica e devem ser "utilizados", "aplicados" ou "incorporados" (sem reflexões?) pelos projetos desenvolvidos nos MP. Particularmente chama atenção a "tese" de que "em projetos de pesquisa esses referenciais colocam as questões de investigação". Não estaria aqui havendo uma inversão de "bois com carroças", ou seja, referenciais colocam questões ou contribuem para respostas ou tratamentos dessas? Sobre essa particular problemática, tecemos comentários no oitavo capítulo. 


\subsubsection{Panorama geral da Área de Ensino de Ciências e Matemática: cursos e programas}

\section{Dados Gerais}

A área de Ensino da CAPES congrega, hoje, 91 cursos de Pós-Graduação reunidos em 72 Programas, sediados em 58 Instituições. No Anexo 7.2 apresentamos uma tabela com a relação dos atuais programas na área, identificando para cada um a Instituição, UF, Dependência Administrativa e as modalidades de cursos oferecidos.

Nos Quadros 7.1 e 7.2 apresentamos as distribuições dos cursos e dos programas segundo as modalidades de pós-graduações, em valores absolutos e percentuais.

\section{Modalidades}

\begin{tabular}{|c|c|c|}
\hline MODALIDADE & CURSOS & \\
\hline Mestrado Acadêmico & 32 & \\
\hline Doutorado & 20 & \\
\hline $\begin{array}{l}\text { Mestrado } \\
\text { Profissionalizante }\end{array}$ & 39 & $\begin{array}{l}\mathrm{MA} \\
\square \mathrm{D}\end{array}$ \\
\hline TOTAL & 91 & \\
\hline
\end{tabular}

Quadro 7.1: Distribuição dos Cursos da Área de Ensino nas Modalidades

\begin{tabular}{|c|c|c|}
\hline PROGRAMAS $^{26}$ & & \\
\hline Mestrado Acadêmico & 32 & \multirow[t]{2}{*}{ DISTRIBUIÇÃO DE PROGRAMAS } \\
\hline Doutorado & 20 & \\
\hline Mestrado Profissional & 39 & $\square$ \\
\hline $\begin{array}{l}\text { Mestrado Acadêmico e } \\
\text { Doutorado }\end{array}$ & 19 & MA e D \\
\hline Total & 72 & \\
\hline
\end{tabular}

Quadro 7.2: Distribuição dos Programas da Área de Ensino nas Modalidades

\footnotetext{
${ }^{26}$ O Total não corresponde à soma, uma vez que estamos contabilizando mais de uma vez os Mestrados Acadêmicos e Doutorados, nos casos de programas que oferecem ambos. Não existem Programas com as duas modalidades de mestrado, MA e MP. Existem Instituições que oferecem ambas as modalidades de mestrado, algumas delas, também o doutorado.
} 
Esses dados mostram que, ainda que instituídos posteriormente aos Acadêmicos (não apenas enquanto área da CAPES, mas como cursos de fato) atualmente os Mestrados Profissionais já superam os primeiros tanto na participação de Cursos quanto de Programas.

\section{Evolução da Área de Ensino de Ciências e Matemática}

Instituída como área na CAPES em 2000 com 7 programas ao final do triênio 20042006 contava com 28 programas e no triênio seguinte, 2007-2009, com 54 programas. Atualmente, antes do término do triênio vigente, conta com 72 programas. Também como já havíamos adiantado, mesmo com a "transição" para a recém-criada área de Ensino, todos os programas se mantêm, até o momento, no âmbito do Ensino de Ciências e Matemática. É bom lembrar também que alguns tiveram início muito antes da criação da área na CAPES, nas décadas de 1970, 1980 e 1990. No gráfico 7.3 apresentamos ano a ano essa evolução.

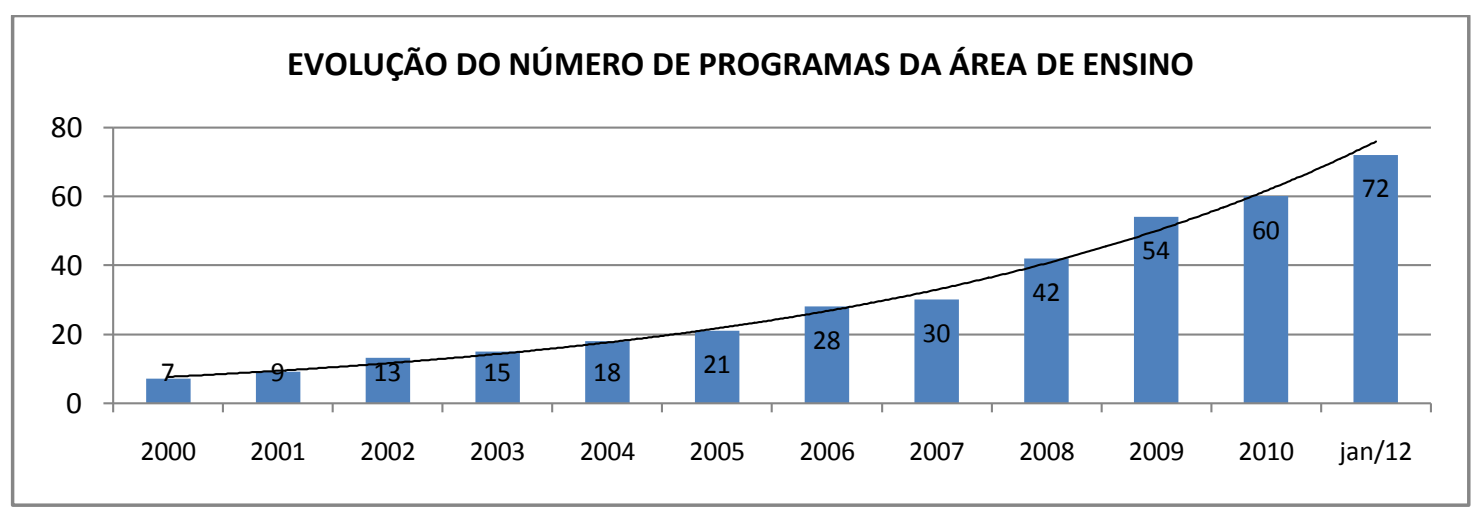

Gráfico 7.3: Evolução anual dos programas de Pós-Graduação na Área de ECM

A evolução do número de cursos de acordo com a modalidade, representada pelo Gráfico 7.4, confirma a liderança dos Mestrados Profissionais, nesse caso pelas taxas de crescimento bem mais elevadas que os Acadêmicos.

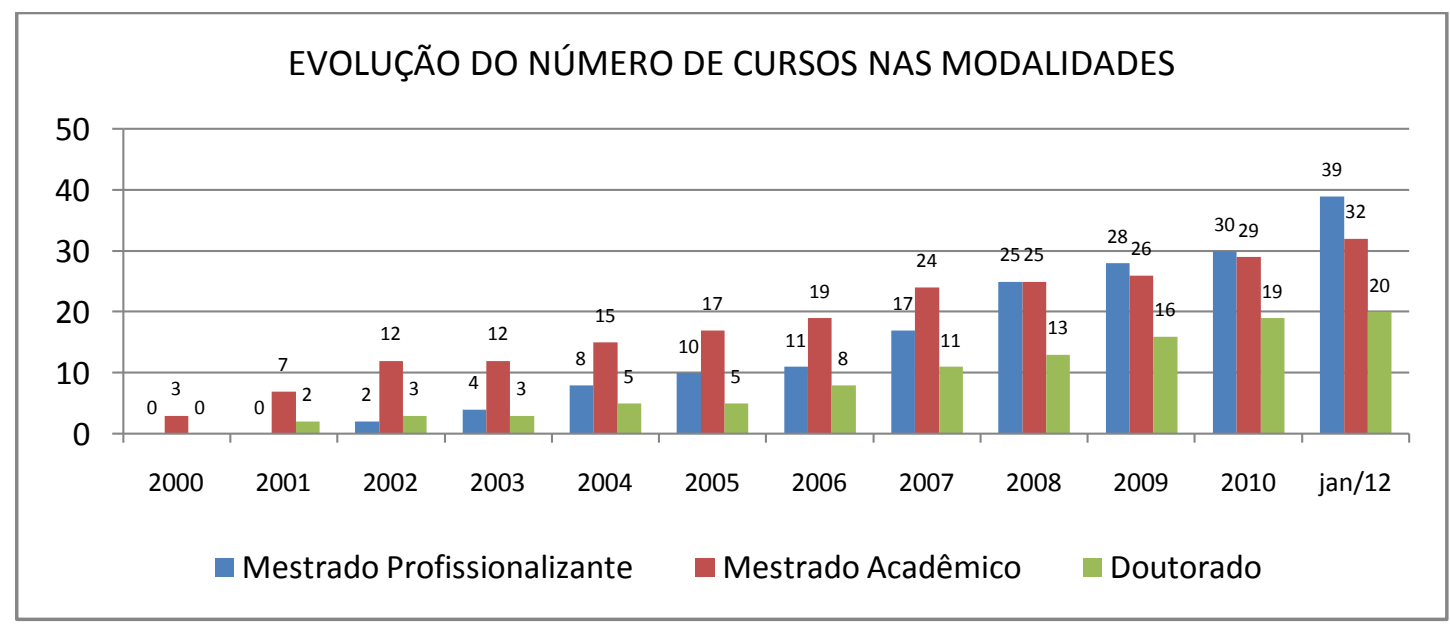

Gráfico 7.4: Evolução dos cursos na Área de ECM por modalidade 
Tomando-se o intervalo entre 2002 e 2011, o número de MP foi multiplicado por 20 (crescimento de 1900\%), enquanto o de MA por 3 (200\%).

Ainda para reforçar esse dado acerca do crescimento dos MP, comparando-se os triênios de avaliação da CAPES, 2004-2006 e 2007-2009, no primeiro os cursos de Mestrado Profissional tiveram um crescimento cerca de $40 \%$ e os de Mestrado Acadêmico de $27 \%$ e no segundo, essas taxas passam a ser, respectivamente, de $65 \%$ e $8 \%$.

\section{Região}

A distribuição dos cursos na área de Ensino nas regiões geográficas do país é apresentada na Tabela 7.5 e no gráfico 7.5.

\begin{tabular}{|l|l|l|l|l|l|l|l|l|}
\hline REGIÃO & \multicolumn{3}{|l|}{ MA } & \multicolumn{3}{l|}{ DO } & \multicolumn{3}{l|}{ MP } & \multicolumn{2}{l|}{ TOTAL } \\
\hline & abs & $\%$ & abs & $\%$ & abs & $\%$ & abs & $\mathbf{\%}$ \\
\hline CENTRO-OESTE & 2 & 6,5 & 1 & 5 & 3 & 8 & $\mathbf{6}$ & $\mathbf{6 , 5}$ \\
\hline NORDESTE & 5 & 15,5 & 2 & 10 & 4 & 10 & $\mathbf{1 1}$ & $\mathbf{1 2}$ \\
\hline NORTE & 2 & 6,5 & 1 & 5 & 3 & 7,5 & $\mathbf{6}$ & $\mathbf{6 , 5}$ \\
\hline SUDESTE & 15 & 47,0 & 10 & 50 & 19 & 49 & $\mathbf{4 4}$ & $\mathbf{4 8 , 5}$ \\
\hline SUL & 8 & 25,0 & 6 & 30 & 10 & 25,5 & $\mathbf{2 4}$ & $\mathbf{2 6 , 5}$ \\
\hline TOTAL & $\mathbf{3 2}$ & $\mathbf{1 0 0}$ & $\mathbf{2 0}$ & $\mathbf{1 0 0}$ & $\mathbf{3 9}$ & $\mathbf{1 0 0}$ & $\mathbf{9 1}$ & $\mathbf{1 0 0}$ \\
\hline
\end{tabular}

Tabela 7.5: Distribuição dos cursos nas regiões geográficas do Brasil

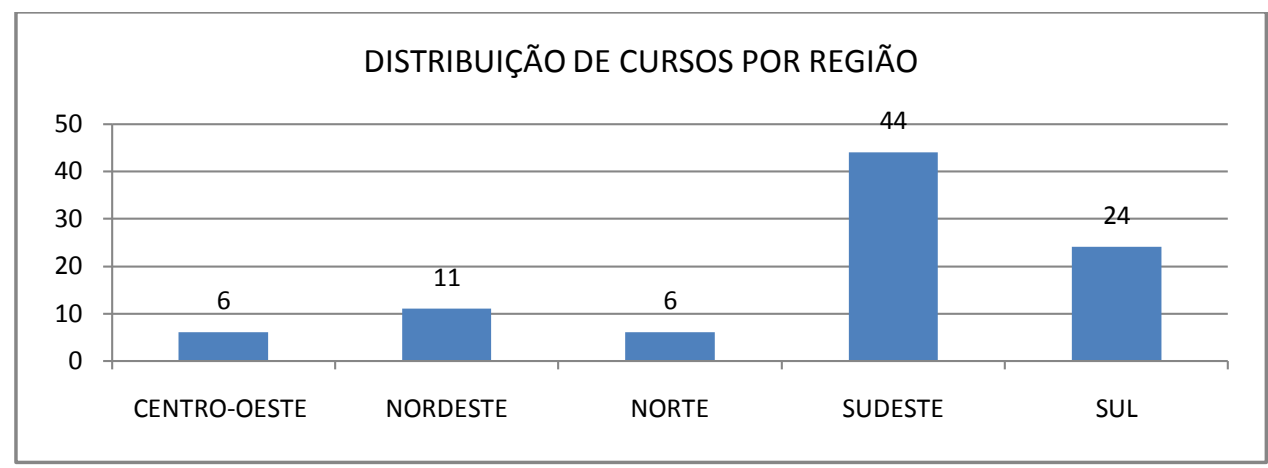

Gráfico 7.5: Distribuição do total de cursos na área de Ensino por região geográfica

Nesse caso, não há desigualdades expressivas entre os Mestrados Profissionais e os demais cursos. Contudo, verifica-se que as regiões Sul e Sudeste, com maior concentração de cursos (dado que segue tendências gerais no país, especialmente sócio-econômicas) são as que também acompanham as distribuições gerais por modalidade de curso, com maior índice de Mestrados Profissionais, como mostra o gráfico a seguir. 


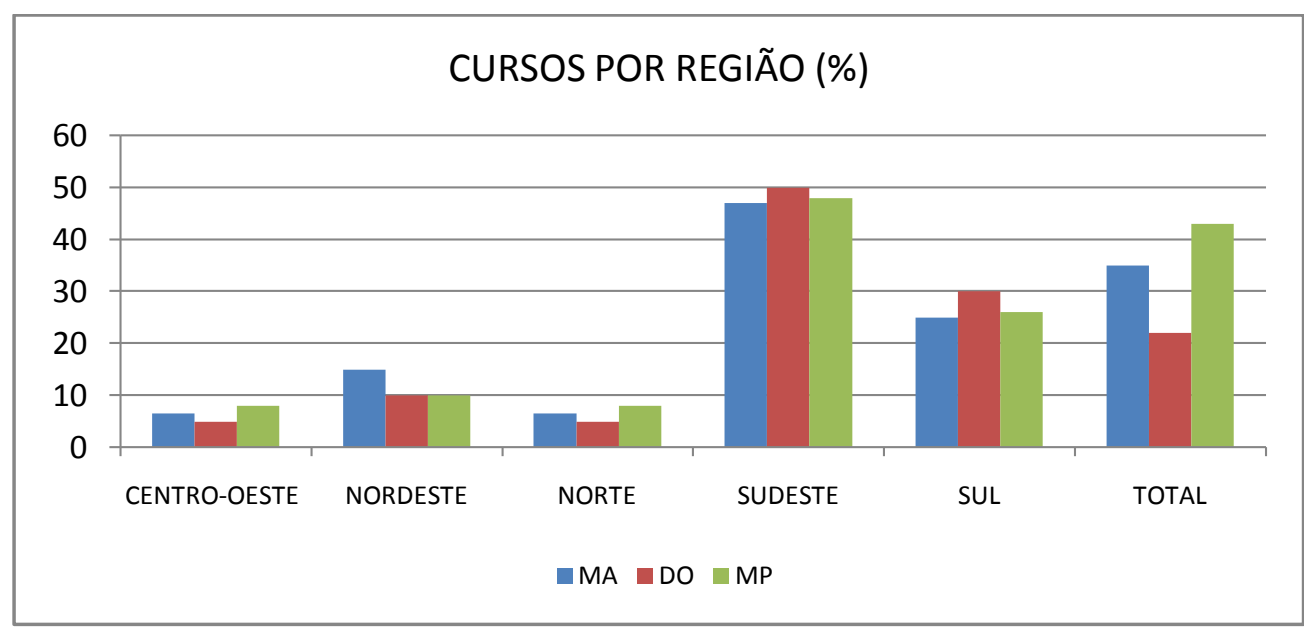

Gráfico 7.6: Distribuição relativa dos cursos na área de Ensino por modalidade e por região geográfica

\section{Dependência Administrativa}

Quanto à Dependência Administrativa, os MP também seguem tendência verificada na área de Ensino, com participação de instituições públicas muito superior à de instituições privadas.

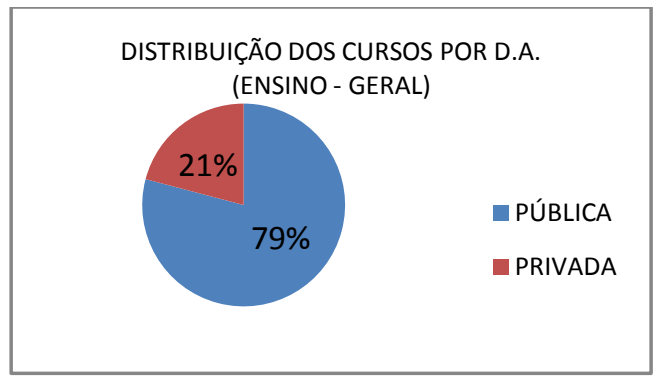

Gráfico 7.7(a)

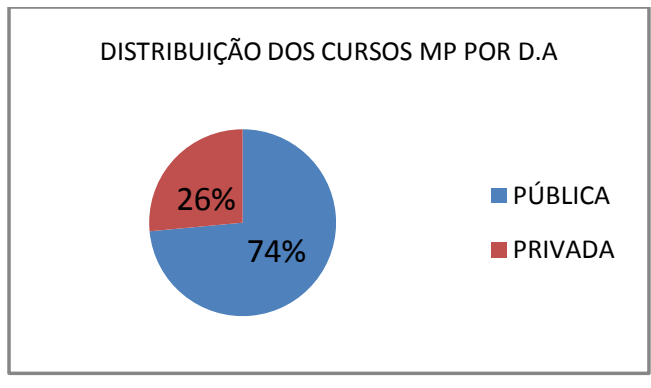

Gráfico 7.7(b)

Gráficos 7.7: Distribuição dos cursos na área de Ensino por Dependência Administrativa

(a) Distribuição Geral; (b) Distribuição dos mestrados profissionais

\section{Produção}

Dados extraídos do último relatório trienal da área de ECM (CAPES, 2010) mostram as taxas de crescimento das dissertações e teses nos dois últimos triênios avaliados, revelando, também nesse caso, a liderança dos Mestrados Profissionais. (Tabela 7.6 e Gráfico 7.8)

\begin{tabular}{|l|l|l|l|}
\hline & $2004-2006$ & $2007-2009$ & VARIAÇÃO \\
\hline DISSERTAÇÕES MA & 750 & 1053 & $40 \%$ \\
\hline TESES DOUTORADO & 39 & 142 & $264 \%$ \\
\hline DISSERTAÇÕES MP & 163 & 702 & $331 \%$ \\
\hline
\end{tabular}

Tabela 7.6: Taxas de crescimento das produções de Dissertações e Teses nos dois últimos triênios de avaliação da CAPES 


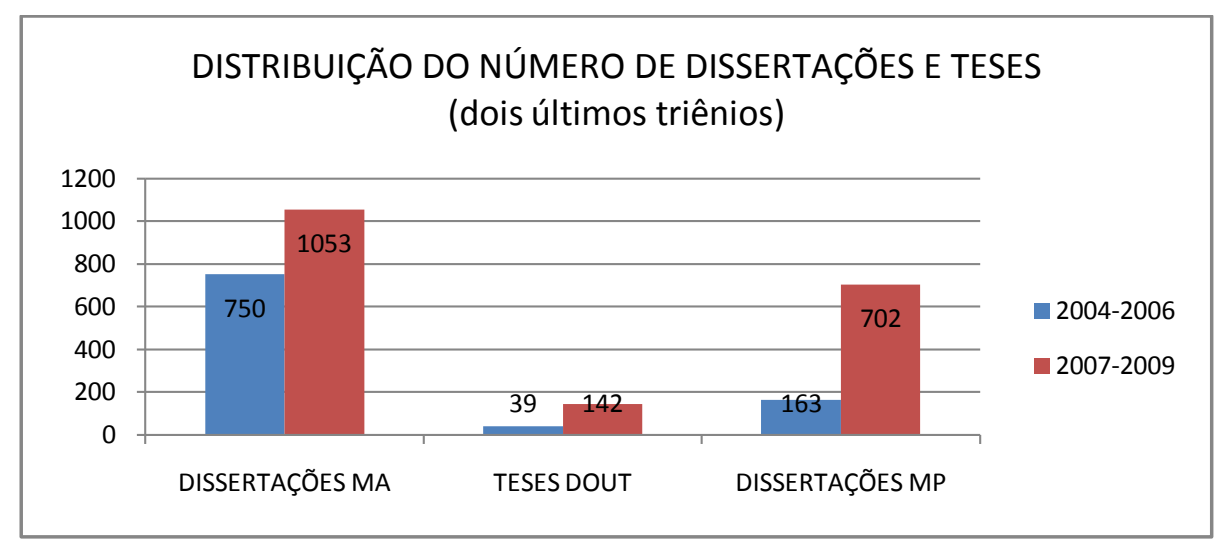

Gráfico 7.8: Número de dissertações (MA e MP) e de teses na área de Ensino nos dois últimos triênios de avaliação da CAPES

Enquanto a produção (dissertações) nos mestrados acadêmicos cresceu nos dois últimos triênios de $40 \%$, os profissionais tiveram aumento de $330 \%$. Também é significativo o crescimento dos doutorados, dado comentado no capítulo três para o caso particular do Ensino de Física.

\subsection{Produção do Mestrado Profissional em Ensino de Física}

Passamos a analisar especificamente a produção do mestrado acadêmico em Ensino de Física, tendo como referência as metodologias e os resultados obtidos para a produção acadêmica.

Por meio de levantamento realizado a partir do Portal da CAPES $^{27}$, contabilizamos 814 dissertações de mestrados profissionais na área de Ensino de Ciências e Matemática entre 2004 e 2009 (número superior aos 750 apresentados no último Relatório Trienal da CAPES). Desse total, identificamos 157 com foco no Ensino de Física, portanto cerca de $20 \%$. Fizemos, então, um recorte para análise, selecionando dois períodos dentre aqueles utilizados na análise da produção acadêmica: 2006 e 2009. Os dois anos iniciais com produção de MP na área, 2004 e 2005, foram descartados por serem resultantes dos primeiros cursos profissionais, portanto, em estágio inicial, com um número restrito de dissertações (três em 2004 e catorze em 2005) desenvolvidas em um número pequeno de programas (quatro) ${ }^{28}$. Assim,

\footnotetext{
${ }^{27}$ Esses dados foram obtidos a partir da relação de cursos recomendados na área de Ensino. Para cada um deles, são fornecidos em um "Caderno de Indicadores", entre outros dados da produção no Curso, as teses a cada ano.

(http://conteudoweb.capes.gov.br/conteudoweb/ProjetoRelacaoCursosServlet?acao=pesquisarles\&co digoArea $=90200000 \&$ descricaoArea=MULTIDISCIPLINAR+\&descricaoAreaConhecimento=ENSINO\&des cricaoAreaAvaliacao=ENSINO. Último acesso em 17/2/2012)

${ }^{28}$ Programas que tiveram primeiras dissertações de MP em Ensino de Física: UFRGS, UFRN, CEFET-RJ e UnB.
} 
tomamos o ano de 2006, com 28 dissertações, e para ter uma ideia evolutiva, o ano de 2009, com 38 dissertações, último ano com dados disponibilizados pela CAPES e também o último da nossa amostra na análise da produção acadêmica. Finalmente, subtraímos os doutorados, tendo em vista o objetivo de comparar as duas modalidades de Mestrado.

Visando comparar as características da produção no mestrado profissional com aquelas da produção acadêmica, traçadas nos últimos dois capítulos, utilizamos os mesmos objetos e parâmetros de análise: suas temáticas, as interfaces ou âmbitos (dadas pelos planos de intersecção entre os eixos da Educação, Conhecimento e Processos) e a presença e natureza do conhecimento físico contemplado.

Vale ressaltar que iremos nos ater às sínteses dos resultados mais expressivos dos MP, buscando extrair as marcas mais relevantes no que se refere a esses parâmetros de análise.

\subsubsection{Das Temáticas}

Para facilitar a leitura, reproduzimos novamente o quadro de áreas temáticas estabelecido no capítulo quatro e utilizado no capítulo cinco para análise da produção acadêmica.

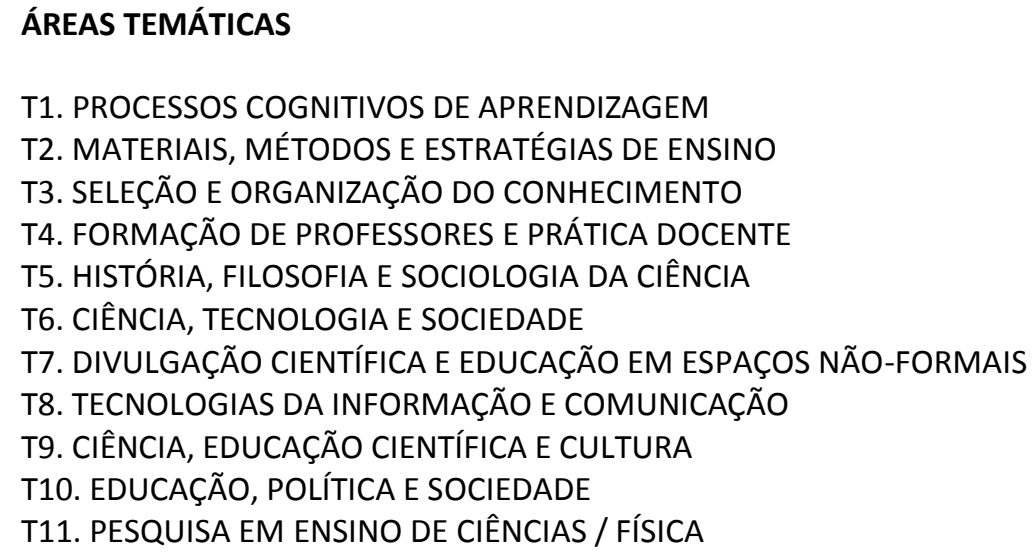

Quadro 7.3: Categorias Temáticas usadas na análise da produção acadêmica

Os resultados da análise comparativa entre as temáticas das dissertações para os dois períodos analisados, 2006 e 2009, são apresentados a seguir. 

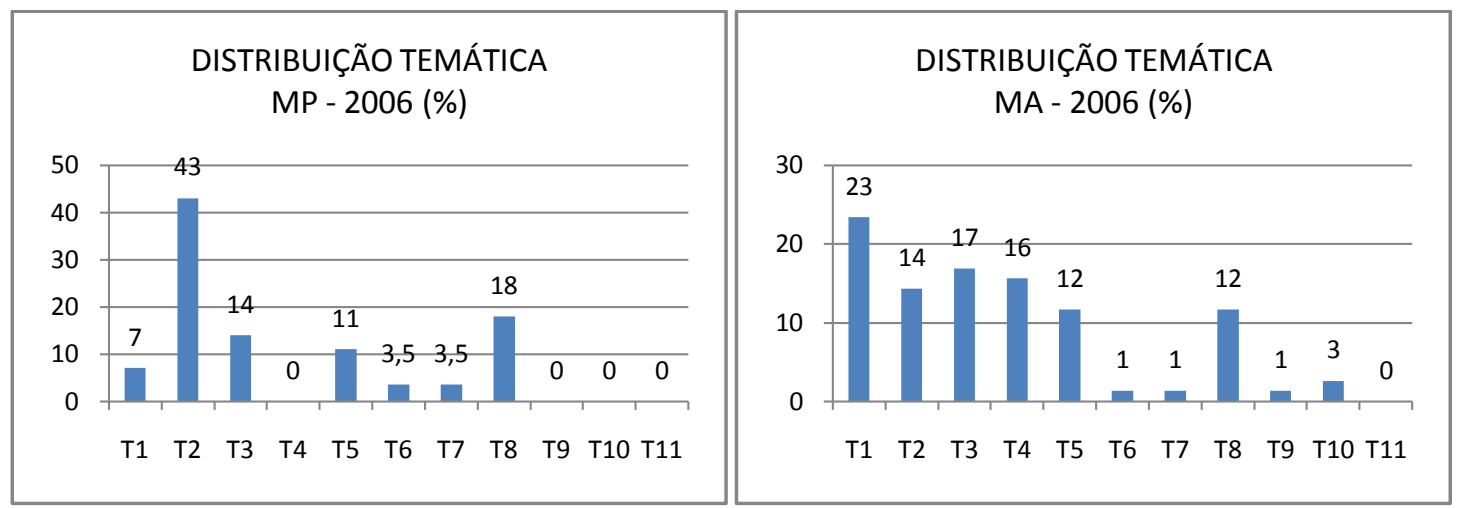

Gráficos 7.8 (1) e 7.8 (2): Comparação da distribuição de Áreas temáticas do MP e MA em 2006

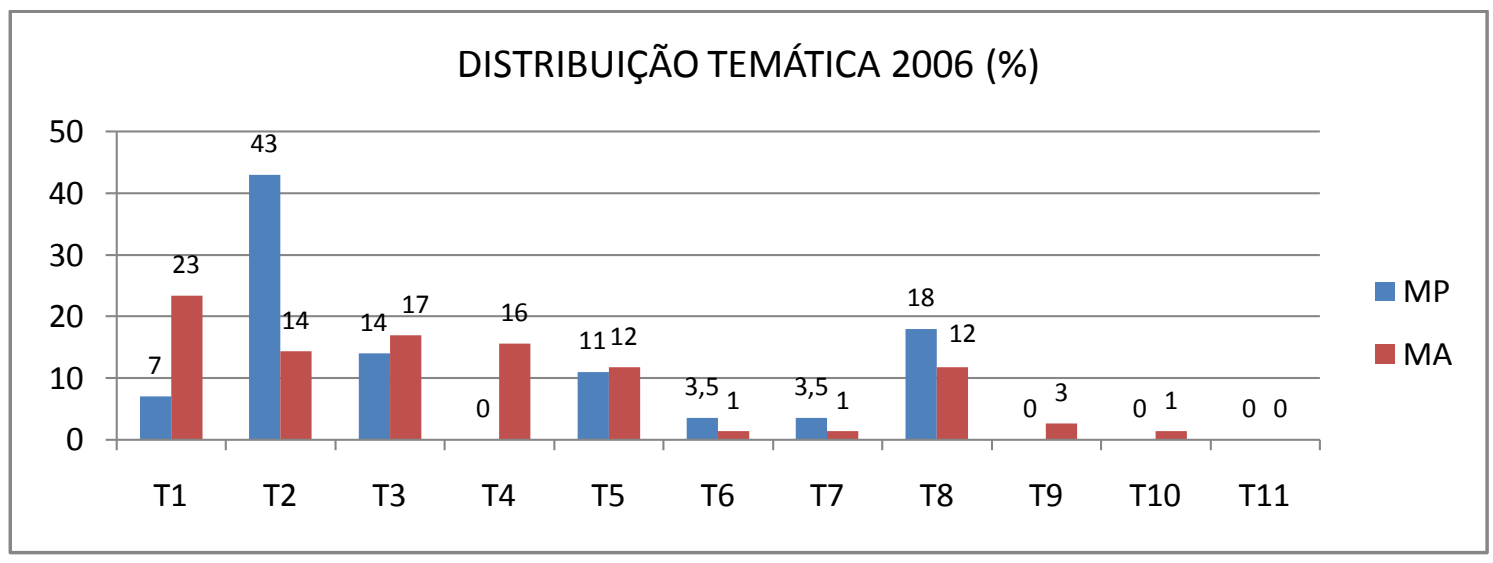

Gráfico 7.9: Participação relativa das Áreas Temáticas nos MA e MP em 2006

\section{9}
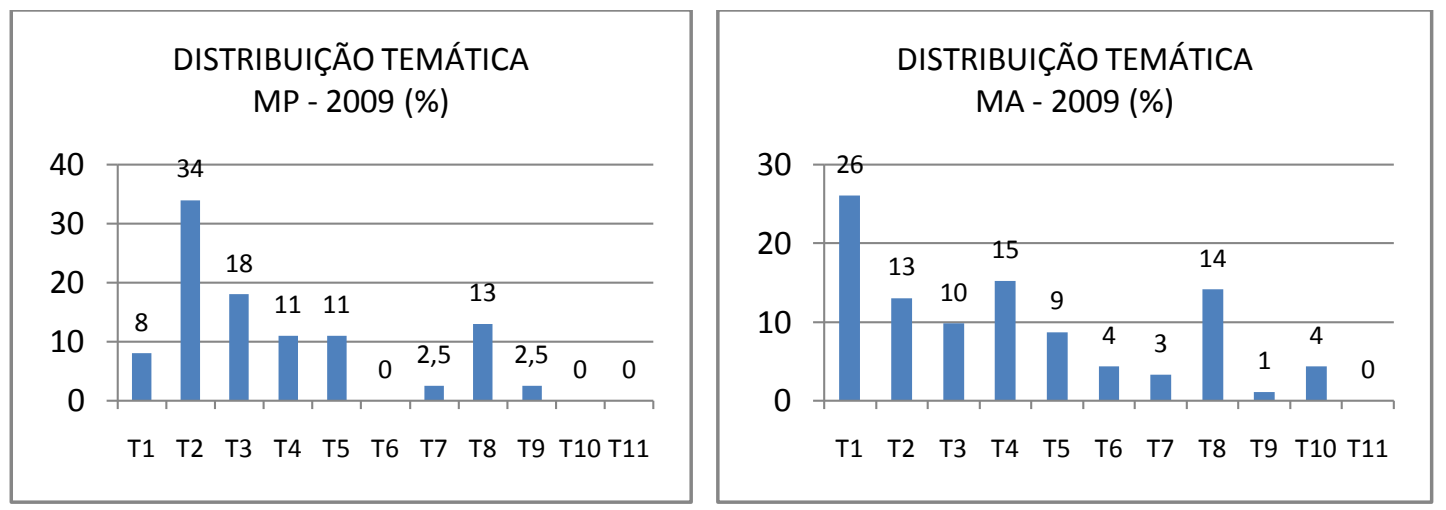

Gráficos 7.10 (a) e 7.10 (b): Comparação da distribuição de Áreas Temáticas do MP e MA em 2009 


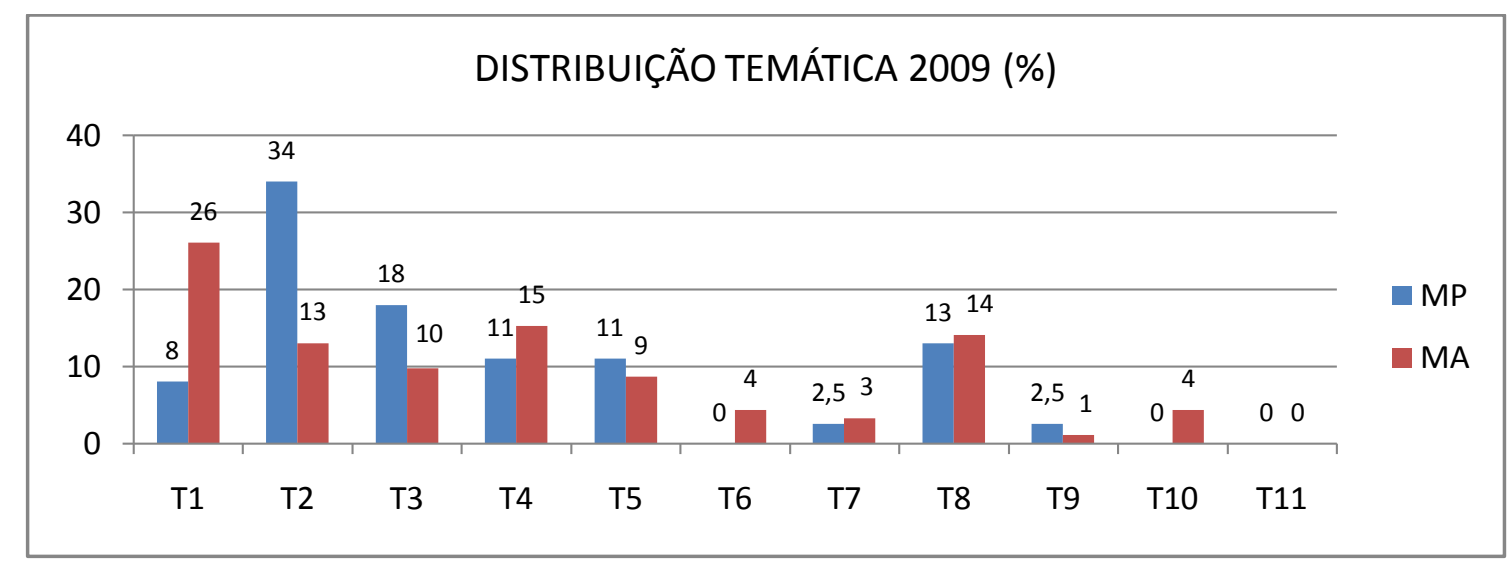

Gráfico 7.11: Participação relativa das Áreas Temáticas nos MP e MA em 2009

Das diferenças mais significativas entre o MP e o MA nesses dois períodos, destacamos:

- O MP tem maior e expressiva concentração de trabalhos, tanto em seu interior, como em relação ao MA, na temática $\mathrm{T} 2$.

- A parcela de trabalhos na Temática T1 é muito inferior no MP

- A soma das temáticas (T2+T8) é maior nos MP. Em 2006: 61\% no MP e $26 \%$ no MA. Em 2009, 47\% no MP e $27 \%$ no MA.

- A soma das temáticas $(T I+T 2+T 8)$ é também maior nos $M P$, sobretudo em 2006: $68 \%$ no MP e 49\% no MA. Em 2009, a diferença é pouco expressiva: $55 \%$ no MP e $52 \%$ no MA.

- Ausência da Temática T4 no MP, em 2006; em 2009 cerca de 10\%.

- As temáticas T5, T6, T7 E T9 não apresentam diferenças importantes na comparação entre os dois cursos.

- Ausência da temática T10 no MP nos dois anos.

Quanto a esses resultados destacamos, em primeiro lugar, a tendência já verificada na produção acadêmica de forte ênfase nas temáticas que têm como objeto de interesse central, os processos de ensino e aprendizagem. No entanto, no caso dos $\mathrm{MP}$, contribuem para essa soma as duas temáticas com foco no ensino já que a categoria $\mathrm{T} 1$, que dá conta dos processos cognitivos de aprendizagem é muito pouco representada, especialmente quando comparada aos MA. Ressaltamos que essa particular característica dos MP é semelhante à verificada na produção acadêmica nos primeiros anos de institucionalização da área, quando as pesquisas com foco na aprendizagem ainda eram incipientes, sendo largamente superadas por aquelas com foco nos métodos e estratégias de ensino, como reproduzimos nos gráfico 7.12(a) e (b). 


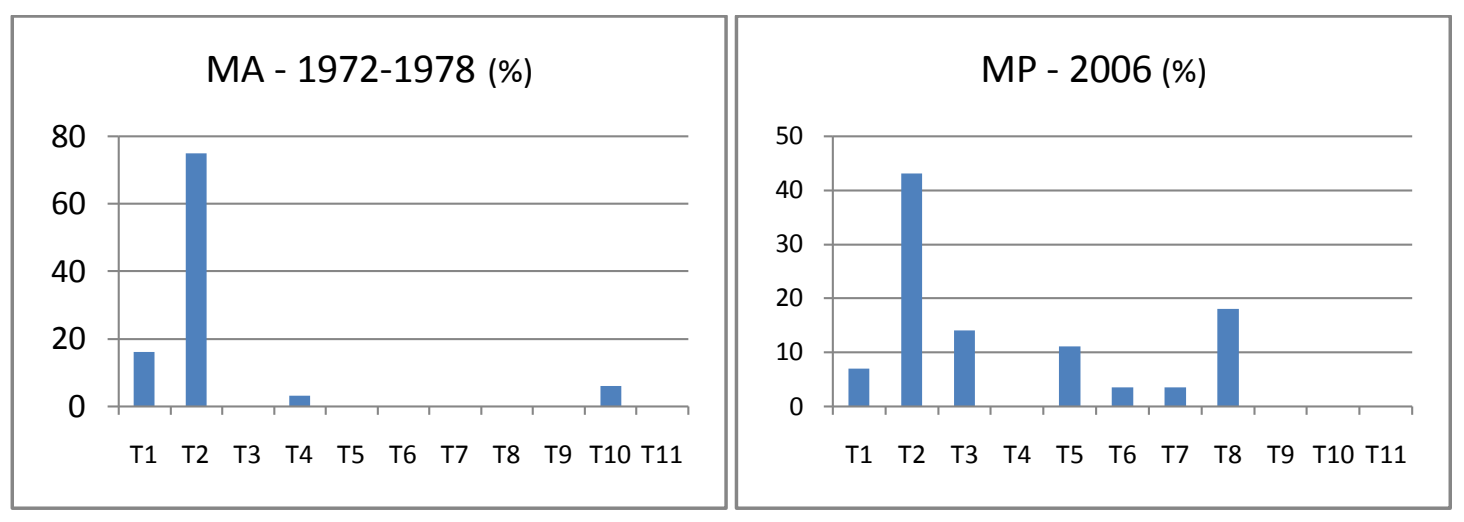

Gráficos 7.12(a) e 7.12 (b): Comparação dos mestrados acadêmicos na década de 1970 com os profissionais em meados de 2000 quanto à distribuição temática

Guardadas as diferenças, que são um reflexo da evolução na área ao longo desses 30 anos que separam um período do outro, o que se percebe é a semelhança na concentração das dissertações na área T2.

Um segundo resultado que merece atenção remete-se às investigações que tratam da Formação de Professores (T4). Em 2006, esse tema está totalmente ausente nos MP e, em 2009, aparece e alcança uma parcela não muito longe dos mestrados acadêmicos, ( $10 \%$ nos primeiros e $15 \%$ nos últimos). Isso pode ser lido como tendência dos MP, inicialmente focados nas "aplicações" do ensino em sala de aula, ou seja, com interesse predominante nos métodos, estratégias e recursos didáticos (representados por T2 e T8) sem, ainda, se voltar para a própria formação docente. No entanto, passam, mais recentemente, a ser objeto das dissertações, o que corrobora discursos também mais recentes no âmbito dos mestrados profissionais de Ensino, que vêm enfatizando a importância da reflexão sobre a própria prática e do caráter de "pesquisa-ação" que esses cursos deveriam guardar.

Chama também atenção a participação, nos MP, das investigações relativas à seleção e organização de conteúdo (T3), praticamente igual à dos MA em 2006 (14\% e 17\%, respectivamente) e superando esses em 2009 (18\% e 10\%). Verificamos que essa alta incidência nos MP deve-se aos trabalhos que tratam da inserção da Física Moderna no ensino médio. No ano de 2009, representam $70 \%$ dos trabalhos nessa categoria temática, ao passo que nos mestrados acadêmicos, $30 \%$ dos trabalhos aqui classificados tratam dessa questão.

A pequena parcela de trabalhos nos conjunto T6 a T11 (subtraindo T8) mesmo sendo dado significativo, reproduz tendência geral dos $M A$, que à exceção de T10, tem pouca representação. Quanto a esse tema, em particular (T10), as diferenças também fazem sentido, já que tal foco temático abrange investigações sobre questões institucionais ou políticas educacionais mais gerais, que não estão fortemente contempladas nos objetivos da formação profissional (a exemplo de 
estudos sobre vestibular, perfis institucionais, avaliação institucional, legislações educacionais).

Em síntese, o que se extrai de mais importante da análise das temáticas desenvolvidas nos trabalhos finais dos mestrados profissionais, em primeiro lugar, é a grande incidência de investigações que tratam de estratégias e recursos didáticos. Ao lado disso, destaca-se a reduzida presença de estudos que investigam os processos cognitivos de aprendizagem ou construção do conhecimento (Área Temática T1). Resultados que convergem apenas parcialmente com os do mestrado acadêmico, já que nesses, ainda que a soma dessas três áreas ( $\mathrm{T} 1+\mathrm{T} 2+\mathrm{T} 8)$, tal qual aqui, congregue a maioria absoluta dos focos das dissertações, a primeira, diferentemente dos MP, é hegemônica, predominante em todos os períodos. Ou seja, enquanto na produção acadêmica pudemos verificar que os processos de aprendizagem estão no centro das atenções, nos mestrados profissionais, o centro está nos processos de ensino. Dado interessante, pois revela que a grande preocupação desses cursos está na produção de meios visando o aperfeiçoamento do ensino. Como já mostramos, esse é um quadro muito semelhante ao que tínhamos no início da produção acadêmica, nos anos setenta.

Os dois outros focos temáticos que podem ser considerados relativamente contemplados, se olharmos para o ano de 2009, são a seleção de conteúdos (na temática T3) e a formação de professores (T4). O primeiro, como já assinalamos, provém de uma participação elevada de trabalhos sobre a inserção da Física Moderna no ensino médio. $O$ segundo, incipiente, porém emergente.

Finalmente, verifica-se que temáticas que dão conta das linhas de pesquisa mais recentes na área, tais como CTS, Divulgação Científica ou Ciência e Cultura estão praticamente ausentes nos MP (enquanto foco), mas também são reduzidas nos MA.

\subsection{2 Âmbitos ou Interfaces}

Como já amplamente discutimos nos capítulos 4 e 6, o outro instrumento criado para melhor identificar os objetos de estudo e de interesse na pesquisa em ensino é dado pelos âmbitos em que se situam, tomando como referência suas perspectivas predominantes: as finalidade da Educação (E), o conhecimento científico $(C)$ e os processos de Ensino e Aprendizagem (P).

Os dados obtidos da análise desses âmbitos, definidos pelas interfaces CP, EC e EP, também tendo como contraponto às dissertações dos mestrados acadêmicos nos anos de 2006 e 2009, são apresentados a seguir. 

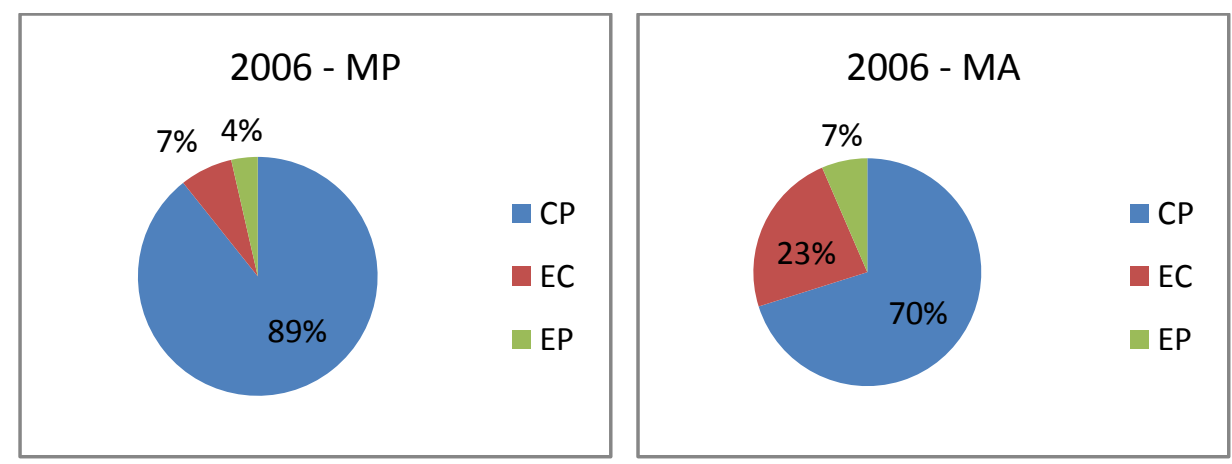

Gráficos 7.11: Distribuição das interfaces no MP e no MA em 2006
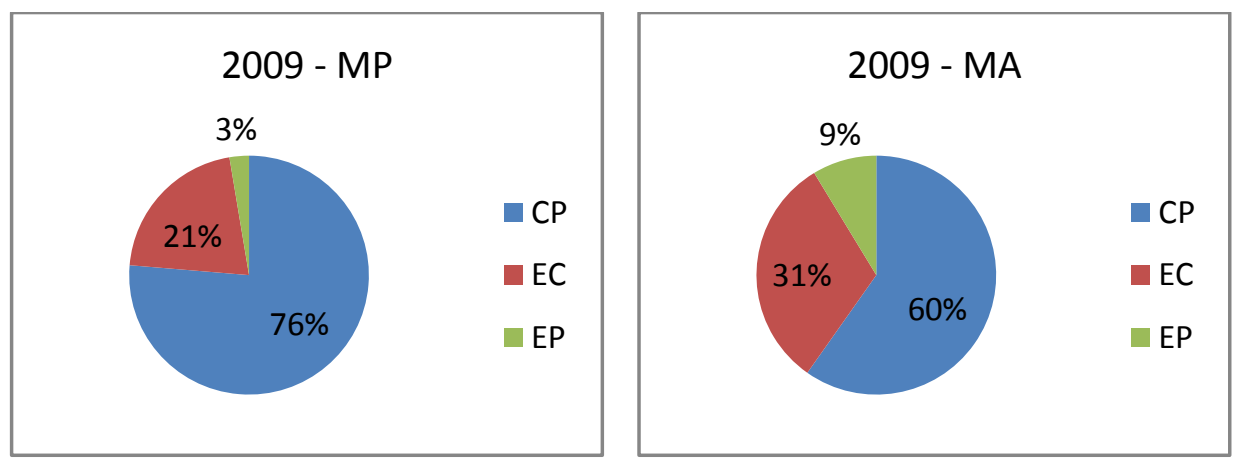

Gráficos 7.12: Distribuição das interfaces no MP e no MA em 2006

Tanto em 2006 quanto em 2009, a interface CP é significativamente maior nos mestrados profissionais, respectivamente em torno de $90 \%$ e $70 \%$ em 2006 e $80 \%$ e $60 \%$ em 2009. Tomando por base as discussões e análises já efetuadas sobre os sentidos atribuídos a essas interfaces, esses dados revelam que, mais ainda que na produção acadêmica, há uma forte prevalência da perspectiva dos "meios" e dos "como" ensinar Física.

Também se verifica um aumento relativo apreciável na interface EC, nos mestrados profissionais, entre um ano e outro (de $7 \%$ para $21 \%$ ). Dado que pode sinalizar que estariam crescendo os estudos que passam a incorporar outras perspectivas, que vão além do "como ensinar", introduzindo reflexões que se deslocam para o "o quê" e "para quê" ensinar. Os trabalhos incluídos nessa perspectiva, nesse ano de 2009, estão distribuídos em temas que trazem novos conteúdos (como consumo energético e sustentabilidade e uso de radiações) ou novas abordagens (como interdisciplinaridade, cotidiano e epistemologia da ciência).

Assim como nas temáticas, a distribuição das interfaces apresenta uma distribuição dos primeiros mestrados profissionais (em 2006) muito próxima aos primeiro mestrados acadêmicos (anos setenta). Reproduzimos essas distribuições, lado a lado. 

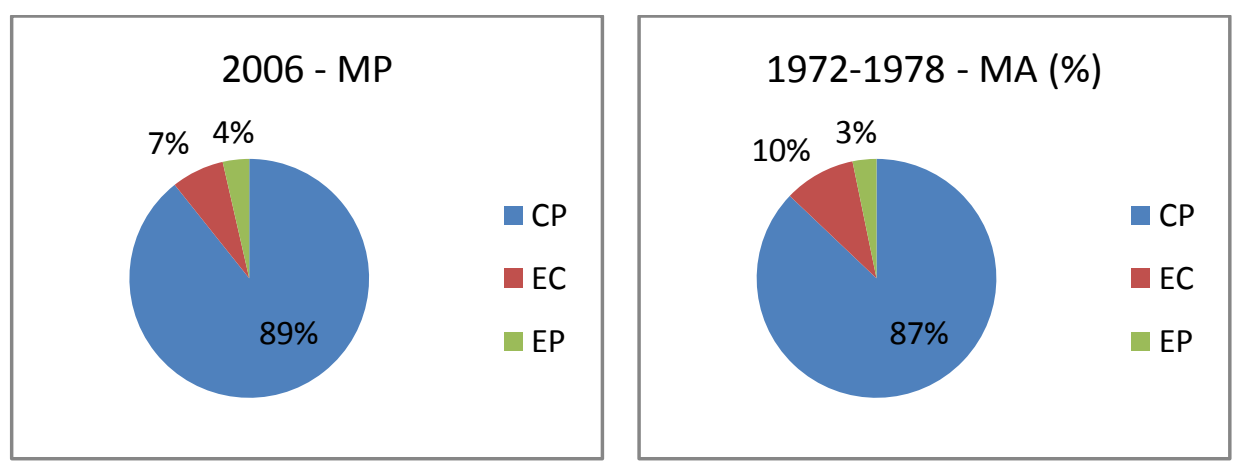

Gráfico 7.13: Comparação dos mestrados acadêmicos na década de 1970 com os profissionais em meados de 2000 quanto à distribuição de interfaces

\subsubsection{A perspectiva do conhecimento}

Como justificamos e analisamos no universo da produção acadêmica, buscamos identificar a presença e a natureza do conhecimento científico nos produtos dos mestrados profissionais.

\section{Presença do conhecimento}

No que se refere à presença do conhecimento físico, as classificações das dissertações do mestrado profissional foram feitas segundo o critério de gradações utilizado no capítulo 6 , reproduzido a seguir.

TIPO 3: Trabalhos que contemplam e utilizam um conhecimento físico explicitamente, enquanto objeto científico. A Física é foco do problema de pesquisa.

TIPO 2: Trabalhos que contemplam o conhecimento, mas sem entrar propriamente na sua estrutura conceitual, enquanto ciência. Podem tratar de questões relativas ao ensino de física, mas o conhecimento não é predominantemente o foco, mas locus da pesquisa.

TIPO 1: Trabalhos que utilizam o conhecimento físico / científico como ilustração ou exemplo para discutir ou validar um referencial teórico, para analisar uma proposição didáticometodológica, refletir sobre uma concepção educacional ou formativa no ensino de Ciências. Ainda que mencione o objeto disciplinar, prescinde do conhecimento.

TIPO ZERO: trabalhos que prescindem quase que totalmente do conteúdo científico, seja como foco ou como locus de pesquisa. Tratam de aspectos educacionais, sociais, institucionais ou outros, sem entrar no âmbito da dimensão científica ou do ensino de Física.

Nos Gráficos 7.14 e 7.15 apresentamos os resultados das classificações dos Mestrados Profissionais e Acadêmicos, em 2006 e 2009, quanto a esses critérios. 

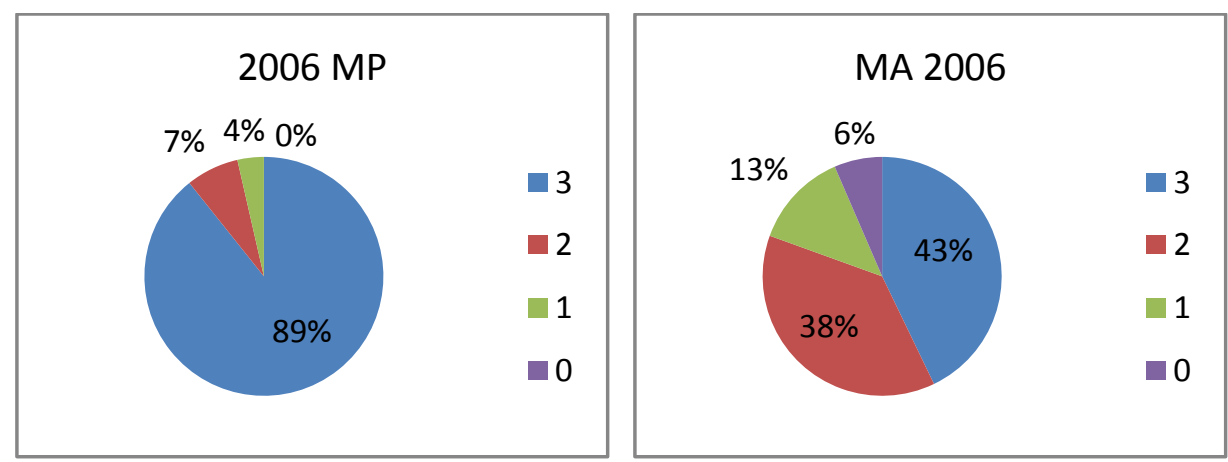

Gráficos 7.14: Grau de participação do conhecimento específico no MP e no MA em 2006
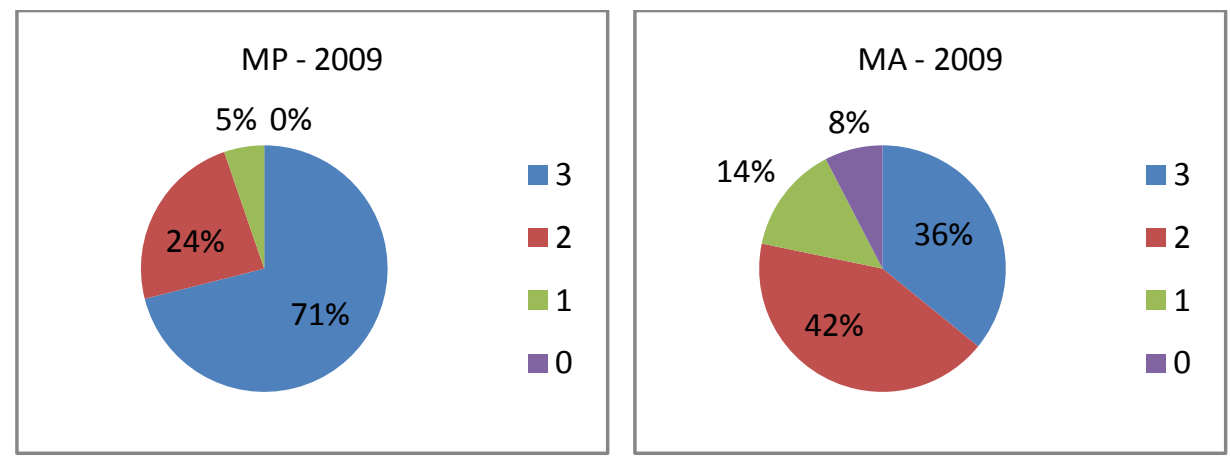

Gráficos 7.15: Grau de participação do conhecimento específico no MP e no MA em 2009

Resultados que se destacam:

- Tanto em um ano como em outro, a categoria 3 é significativamente superior nos MP, com participações duas vezes maior que no MA: cerca de $90 \%$ e $45 \%$ em 2006 e 70\% e 35\% em 2009.

- Percentuais de trabalhos do tipo 2 crescem nos MP de 2006 para 2009, de 7 para $21 \%$ (mantém-se relativamente estáveis nos MA, com parcelas em torno de $40 \%)$

- Não há diferenças muito expressivas nos percentuais de trabalhos do tipo 1, reduzidos em ambos os mestrados nos dois anos, mas ligeiramente mais freqüentes nos MA.

- Não há trabalhos na categoria tipo Zero nos MP; nos MA são poucos (6\% e 8\%) mas existem.

Em síntese. O conhecimento físico tem presença mais expressiva nos mestrados profissionais que nos acadêmicos, como foco das investigações. Mesmo na comparação com períodos iniciais do mestrado acadêmico, em que a presença de trabalhos do "Tipo 3" era maior que atualmente (de 60 a 70\%), os atuais mestrados profissionais têm maior concentração nessa categoria. Ainda assim, parece haver uma tendência de deslocamento dos trabalhos classificados no "Tipo 3" para os do "Tipo 2" nos MP, tal como vem ocorrendo na produção acadêmica. Não há, ainda, 
trabalhos nos MP que prescindem totalmente do conhecimento ("Tipo Zero") e são desprezíveis os que dele prescindem parcialmente ("Tipo 1").

\section{Natureza do Conhecimento}

A caracterização da natureza do conhecimento, feita por meio dos três critérios utilizados no capítulo seis para analisar a produção acadêmica, traz os seguintes resultados:

\section{$\underline{\text { Temas e Conteúdos }}$}

O primeiro critério empregado concerne à caracterização dos conteúdos propriamente ditos quanto à sua inovação: se tratam de tópicos tradicionais da Física, presentes nas ementas de cursos e livros didáticos tradicionais (TRADICIONAL), ou se trazem novas temáticas (NOVO), considerando o momento em que foram desenvolvidos (ver discussão a respeito no Capítulo 6).

$\mathrm{Na}$ análise dos conteúdos presentes nas dissertações dos mestrados profissionais, identificamos que em 2006, cerca de 70\% deles tratam de tópicos tradicionais da Física, portanto, 30\% de novos conteúdos. Em 2009, essa proporção é praticamente a mesma (65\% para $35 \%)$.

Nos mestrados acadêmicos, identificamos em 2006, exatamente a mesma relação obtida nos MP e, em 2009, uma relação em torno de $60 \%$ a $40 \%$, portanto também próxima dos mestrados profissionais nesse ano.

\begin{tabular}{|l|l|l|l|l|}
\hline & MP & MA \\
\hline & T & N & T & N \\
\hline 2006 & $70 \%$ & $30 \%$ & $70 \%$ & $30 \%$ \\
\hline 2009 & $65 \%$ & $35 \%$ & $60 \%$ & $40 \%$ \\
\hline \multicolumn{5}{|c}{ Tabela 7.7(a) }
\end{tabular}

Ou seja, quanto a esse critério não há diferenças expressivas entre o MP e o MA, predominando em ambos os conteúdos tipicamente convencionais em proporções em torno de $70 \%$ e $60 \%$ (em 2006 e 2009).

\section{Abordagens}

Como segundo critério, avaliamos a "inovação" dos tratamentos ou abordagens dadas aos conteúdos. Entendemos aqui como "novo" (N) ou não convencionais, aqueles em que há uma preocupação em combinar conhecimento e abordagem, conferindo ao primeiro uma perspectiva crítica, a exemplo de tratamentos históricos, abordagens sócio-culturais, ou que levem em conta aspectos do cotidiano, sociais ou tecnológicos, buscando valorizar contextos e problemas reais. 
Do ponto de vista das abordagens, em 2006 cerca de $80 \%$ das dissertações dos mestrados profissionais utilizam abordagens predominantemente tradicionais, para $20 \%$ inovadoras. Em 2009, essa relação passa a ser em torno de $70 \%$ a $30 \%$, revelando tendência de valorização em abordagens inovadoras.

Com relação aos mestrados acadêmicos, em 2006 identificamos uma parcela de aproximadamente $60 \%$ de trabalhos com abordagens tipicamente tradicionais, para 40\% novas. Relação que em 2009 passa para 75\% a 25\%. Temos, portanto, aqui, um movimento inverso ao dos MP, com um aumento, ainda que não substancioso das parcelas de dissertações com abordagens mais convencionais.

Em síntese, no ano de 2006 os mestrados acadêmicos têm produções, do ponto de vista das abordagens dadas aos conteúdos, mais inovadoras que os profissionais. Em 2009, não há diferenças consideráveis.

No conjunto, em ambos predominam os tratamentos mais convencionais.

\begin{tabular}{|l|l|l|l|l|}
\hline & \multicolumn{2}{|l|}{ MP } & \multicolumn{2}{l|}{ MA } \\
\hline & T & N & T & N \\
\hline 2006 & $80 \%$ & $20 \%$ & $60 \%$ & $40 \%$ \\
\hline 2009 & $65 \%$ & $35 \%$ & $75 \%$ & $25 \%$ \\
\hline
\end{tabular}

Tabela 7.7(b)

\section{Problematização}

O terceiro critério tem como diferenciação dos trabalhos a maneira como o conhecimento é concebido: se como dado e natural (T) ou se problematizado (N).

Quanto a esse critério, identificamos, nos mestrados profissionais, em 2006, uma reduzida parcela, em torno de $10 \%$ de trabalhos nos quais o conhecimento físico é, de algum modo, problematizado. Em 2009 essa parcela aumenta para cerca de 25\%. Comparativamente aos acadêmicos, em 2006 há uma diferença não desprezível e, em 2009 as distribuições são muito semelhantes.

\begin{tabular}{|l|l|l|l|l|}
\hline & MP & MA \\
\hline & T & N & T & N \\
\hline 2006 & $90 \%$ & $10 \%$ & $75 \%$ & $25 \%$ \\
\hline 2009 & $75 \%$ & $25 \%$ & $70 \%$ & $30 \%$ \\
\hline
\end{tabular}

No conjunto, em ambos os modelos predominam as concepções de conhecimento "naturalizado" ou "dado", sendo que nos mestrados acadêmicos há uma ligeira diferença para menos nessa relação entre dado e problematizado. Diferença que talvez seja aqui desprezível, na escala de precisão dessa análise. 
Enfim, o que podemos concluir a respeito dimensão do conhecimento científico nos mestrados profissionais é que por um lado, está mais explicita e amplamente contemplada que nos mestrados acadêmicos e, por outro lado, que não há diferenças significativas no caráter mais ou menos inovador ou crítico em sua seleção, abordagem e problematização.

\subsubsection{Outras Características}

A esses parâmetros, acrescentamos dois outros aspectos que se destacaram na análise dessas dissertações dos mestrados profissionais.

O primeiro refere-se aos chamados Referenciais Teóricos. Apesar de não entrarmos nessa discussão na análise da produção acadêmica, um dado que chamou a atenção é o papel que tais referenciais cumprem e como são explicitados nas dissertações dos mestrados profissionais. $\mathrm{Na}$ grande maioria delas, especialmente aquelas identificadas na temática T2, portanto as que tratam dos processos de ensino (métodos, estratégias, recursos), seus autores explicitam, já no resumo, os referenciais teóricos que balizam suas investigações. Pois bem, entre esses, predominam largamente referenciais vindos da psicologia cognitiva, a exemplo de Ausubel, Vigotsky, Novak, Piaget, Vergnaud, Gil- Perez e Moreira. A combinação dos referenciais "aprendizagem significativa" (Ausubel, Moreira) com a "teoria sóciointerativista" (Vigotsky) é a mais recorrente, campeã de citações.

Esse dado é muito interessante, pois mostra que enquanto na produção acadêmica as teorias de cognição são referenciais que tomam o lugar de objeto de pesquisa, nos trabalhos dos mestrados profissionais essas teorias constituem referências para a pesquisa, que se desenvolve em outra dimensão, a das proposições de alternativas para o ensino. Em outras palavras, o que é foco de investigação no mestrado acadêmico, é referencial para o profissionalizante, o que é coerente com a visão apresentada por Ostermann e Rezende (2009) sobre tal questão, já comentada nesse capítulo.

Os referenciais teóricos que fundamentam projetos de desenvolvimento podem ser pensados como tendo especificidades que os colocam em papel diverso daquele que desempenham no campo investigativo. Enquanto que em projetos de pesquisa esses referenciais colocam as questões de investigação e devem se integrar à metodologia, nos projetos de desenvolvimento estes devem fundamentar metodologias de ensino e sustentar a concepção do produto educacional, orientando a seleção de conteúdos e estabelecendo novas formas de avaliação. (OSTERMANN e REZENDE, 2009, p.72)

O segundo aspecto que também parece significativo e coerente com a concepção desses cursos diz respeito a características de seus produtos finais. Um breve 
levantamento desses produtos revela uma altíssima concentração de propostas de estratégias didático-pedagógicas e de recursos didáticos, entre esses predominando roteiros de experimentos e textos didáticos (em mídias impressas ou eletrônicas) e um grande número de sugestões de atividades didáticas também em mídias diversas, particularmente por meio das TICS (CD-ROM, sites na internet, simulações computacionais etc.). Dado que também vem confirmar proposições diversas já apresentadas sobre a natureza e objetivos dessa modalidade de curso: atender demandas ou problemas locais "das salas de aula".

\subsection{Sistematização e Considerações gerais}

No âmbito mais geral dos mestrados profissionalizantes no país, identificamos como aspecto que dá margem a polêmicas e dúvidas, a própria distinção ente formação profissional e acadêmica ou entre formar para o mundo do "trabalho" ou para o universo da pesquisa. Isso, como vimos, tem implicações de muitas naturezas, com leituras e interpretações diversas, seja no âmbito dos promulgadores e defensores do mestrado profissional, seja no âmbito da academia.

Também se expressam contradições internas à própria CAPES e às suas regulamentações e critérios de avaliação estabelecidos para esses dois modelos de pós-graduação e para a sua coexistência nos mesmos espaços. Parte dos mestrados profissionais convive com os acadêmicos em uma mesma instituição, muitas vezes tendo docentes em comum, que precisam se ajustar a formatos, demandas e finalidades distintas. Particularmente, quanto aos critérios de avaliação de um e outro programa ou curso. Hoje, a pesquisa e seus protagonistas acadêmicos estão cada vez mais pressionados por um dado tipo de demanda de produção, muito diversa da exigida ou esperada pelos cursos profissionais.

De todo modo, podemos inferir que o MP tem um caráter de especialização ou aperfeiçoamento dos cursos de graduação, mas com um viés formal e com finalidades voltadas "para fora da academia", o que traz também questões a serem refletidas, pois se assim for, estaria se concebendo os mestrados acadêmicos com formação focada na própria academia, o que, particularmente no caso do Ensino, é no mínimo duvidoso. Isso lança outra questão importante, que é a necessidade de reflexão sobre os próprios mestrados acadêmicos, uma vez que uma das grandes justificativas para implantação dos MP são lacunas e distorções por eles colocadas.

Ainda quanto ao panorama geral, destaca-se que, tendo em vista a concentração de esforços já com algum tempo, para o desenvolvimento dos cursos profissionais no país, sua participação no quadro geral da pós-graduação ainda é incipiente, representando no conjunto de cursos, menos de $10 \%$. Quadro muito diverso quando colocamos as lentes no mestrado profissional de Ensino (MPE). 
Pudemos constatar que, diferentemente desse panorama geral, os impactos da criação de cursos profissionais para a área de Ensino são grandes. Foi nesse espaço que eles nasceram e proliferaram, concentrando hoje, parcelas muito grandes que já são maiores que os mestrados acadêmicos.

Tais impactos parecem evidenciar que as demandas e finalidades dos MP na área de Ensino são muito distintas daquelas de outras áreas, para os quais teriam sido criados, tendo em vista a formação de "profissionais qualificados" especialmente para o setor produtivo. Nos parece evidente que os mestrados profissionais nos programas na área de Ensino foram motivados e têm se direcionado para cobrir lacunas no "mercado educacional", para as quais os acadêmicos não estariam se dirigindo. E, mais que isso, vieram também "sanar" deficiências da formação de professores no país. O que explica, em parte, porque é justamente na área de Ensino de Ciências e Matemática que eles estão plenamente concentrados. Por um lado, é nessa área que o mestrado acadêmico e, posteriormente os doutorados, se desenvolveram e se expandiram largamente, comparativamente a outros "Ensino de". Por outro lado, é também aqui que a demanda por professores no Brasil vem sendo cada vez mais intensa.

Novamente, a questão que se coloca, sem desmerecer necessidades específicas, é uma revisão de nossa pós-graduação acadêmica e também das nossas licenciaturas, ou seja, das instâncias de formação de professores e de formação dos formadores desses. Pois, se desviados seus objetivos para os mestrados profissionais, só tendem a cristalizar ou intensificar distorções. A produção acadêmica deve rever suas finalidades, tendo em vista demandas sociais e não "a pesquisa pela pesquisa", tanto quanto as licenciaturas devem investir na formação de professores qualificados, "reflexivos e críticos".

Disso tudo, uma observação que consideramos pertinente é que a discussão dessa temática deva ser reportada não a uma polêmica "sim ou não", mas a necessidades particulares, sejam regionais ou de campos de saber específicos. E que sejam pensados, do ponto de vista de estrutura curricular, quadros docentes, perfil de alunos etc., a partir dessas demandas específicas.

Para finalizar, nos voltamos para a análise da específica produção dos MP com foco no Ensino de Física. Dos resultados obtidos nessa análise queremos evidenciar a forte tendência das dissertações no desenvolvimento de recursos técnicos, didáticopedagógicos, com vistas ao aperfeiçoamento do ensino. Nada contra o desenvolvimento desses recursos e das suas necessidades, ao contrário, é legítimo e importante. Contudo, salientamos aqui dois aspectos que nos pareceram importantes. 
Um deles é uma espécie de volta ao "DNA" da área, à sua marca de nascença, também profundamente presente na pesquisa acadêmica, mas com mais "acentos" nos MP. De certo modo, isso mostra que os mestrados profissionais na área de "Ensino" estariam retornando a um problema que deu origem à pesquisa na área de Ensino de Ciências, diante das dificuldades e deficiências do ensino, particularmente no nível médio. $E$, particularmente diante das lacunas que a produção acadêmica vem deixando quanto a isso, entram em cena como uma espécie de "tábua de salvação".

O segundo aspecto, relacionado ao anterior, é que por trás da natureza dos produtos finais desses cursos estaria se revelando uma concepção ou tradução das deficiências do ensino escolar e de como superá-las: provendo a escola, a sala de aula e o professor de materiais e recursos didático-pedagógicos, mesmo que com "roupagens novas", com o uso de metodologias e referenciais acadêmicos e com o caráter inovador do ponto de vista da tecnologia educacional.

Enquanto, na academia, estaríamos nos aprofundando em modelos, teorias e referenciais de aprendizagem e por meio desses "colocando as questões de investigação", os cursos profissionais estariam artificialmente utilizando dessa produção para intervir na prática escolar.

Enfim, a nosso ver o foco dessa questão não estaria propriamente no debate acerca da necessidade e a legitimidade da pós-graduação profissional, mas na sua natureza enquanto resposta a demandas atuais do ensino. Tal qual se coloca para a pósgraduação acadêmica. 


\section{Retomada e Síntese}

É preciso reconhecer o imponderável, gerar o novo, tendo a dúvida como direito e condição de liberdade! (Menezes)

\section{Uma Retomada}

Ao longo desse trabalho constatamos, por meio de diferentes parâmetros, que a produção acadêmica na área de pesquisa em Ensino de Física teve um crescimento sistemático e bastante expressivo, do ponto de vista do volume de dissertações e teses, das instituições depositárias, programas de pós-graduação e orientadores. Ao mesmo tempo, verificamos uma grande diversificação das linhas de pesquisa. Tal crescimento fez com que também se intensificassem os trabalhos na linha de estado da arte ou estado do conhecimento na área, objeto de estudo de nosso primeiro capítulo.

Por meio desse primeiro estudo identificamos diferentes formas de perceber e tratar a evolução da área para então demarcar a opção que fizemos nessa pesquisa, qual seja, a de identificar por meio dos focos de estudo e natureza das investigações, algumas marcas que deram ou dão identidade ao nosso campo, visando contribuir para uma reflexão de suas tendências atuais e desafios colocados.

Com essa perspectiva, uma vez tendo situado a área em um panorama mais geral da educação no país e do Ensino de Ciências (capítulo dois); caracterizado o crescimento da produção acadêmica, tendo como universo as dissertações e teses (capítulo três); apresentado e justificado nosso instrumento de análise para estudar os conteúdos ou objetos de interesse da produção (capítulo quatro); passamos a estudar propriamente esses objetos, por meio da análise das temáticas, âmbitos e dimensões da pesquisa ao longo do tempo (capítulos cinco e seis). No capítulo sete abrimos um parêntese para analisar a implantação dos mestrados profissionais na área de Ensino de Ciências de modo a compreender seus impactos nessa dinâmica de evolução da qual tratamos.

Pretendemos, ao longo desse capítulo, sintetizar os principais resultados das análises efetuadas e situá-los ao longo de todo o período em que se deu a evolução da área, visando buscar algumas respostas às nossas principais questões de pesquisa. 


\subsection{Retomando questões da pesquisa}

$\mathrm{Na}$ introdução desse trabalho, apresentamos nossas intenções e objetivos de pesquisa, sistematizadas por meio de algumas questões centrais ou recortes de investigação. Tais questões, por sua vez, foram orientadas a partir de premissas básicas, sendo a principal delas que a gênese de nossa área no final dos anos sessenta, início dos setenta, teria se dado pelo interesse em aprimorar o Ensino das Ciências, em um momento particular da história e das demandas do país. Em função disso, instaurou-se uma linha de investigação voltada ao desenvolvimento de técnicas, recursos e métodos de ensino visando sanar deficiências e lacunas no aprendizado das ciências, especialmente no então segundo grau de ensino (ensino médio). Pois bem, partindo dessa premissa, levantamos quatro questões que conduziram nossa pesquisa e que aqui retomamos.

\section{A primeira questão}

Em primeiro lugar, nos perguntamos o quanto essa marca de nascimento da pesquisa em Ensino de Ciências teria conduzido as atenções e os focos de interesse da produção acadêmica, particularmente no Ensino de Física, desde suas origens e ao longo de seu percurso até os dias atuais. Tal como a formulamos na introdução:

O quanto essa marca, esse registro de nascimento permanece, sobrevive e predomina? Em outras palavras, seriam os meios e os processos de aperfeiçoar, aprimorar o ensino (de Física), desde as suas origens, o eixo principal motivador ou condutor de nossa trajetória, a principal razão de ser de nossa área de pesquisa?

\section{A segunda questão}

Essa mesma hipótese nos levou a questionar o quanto estaríamos nos apartando da preocupação com a dimensão educacional, ou seja, refletindo e demarcando concepções sobre as finalidades do ensino de Física tendo em vista uma contribuição à formação de estudantes e demandas escolares. Questão assim formulada:

Onde, quando, de que modo, na dinâmica de evolução da pesquisa acadêmica, a dimensão educacional se coloca, particularmente explicitando perspectivas ou finalidades do Ensino de Física?

\section{A terceira questão}

Esse "registro de nascimento" da área de Ensino de Física, somado à sua natureza interdisciplinar e, portanto, demandando estudar e articular campos diversificados de saberes, configuraria outro recorte investigativo, acerca do tratamento na pesquisa acadêmica de nosso particular campo de conhecimento científico ou objeto disciplinar: a Física. O que nos remete à terceira questão: 
De que forma e com que natureza a dimensão do conhecimento científico a preocupação com qual física ensinar, tem estado presente nas nossas pesquisas?

\section{A quarta questão}

Finalmente, um quarto recorte, de natureza um pouco distinto dos anteriores, diz respeito à demanda de reconhecimento da área, ou seja, à necessidade de ter aceitação no meio acadêmico e junto aos órgãos de fomento à pesquisa, com visibilidade nacional e internacional e, portanto, de marcar identidade. O que nos levou à quarta questão:

\section{o quanto a necessidade de reconhecimento da área institucional $e$} academicamente influencia e determina rumos e opções da pesquisa?

Entendemos que ao longo desse trabalho tais questões foram parcialmente respondidas, mas de forma dispersa e demandando uma sistematização e reflexão que incorporem e articulem os resultados obtidos até aqui com uma análise crítica e contextualizada de nossa trajetória. Para isso, um primeiro passo seria retomar esses resultados, procurando situar a dinâmica de evolução da área, tendo em conta essas questões ou parâmetros, em uma cronologia ou periodização. Para isso, tratamos inicialmente de identificar marcos importantes dessa evolução, no que concebe à produção analisada, destacando principais alternâncias e permanências. Em um segundo momento, buscamos situar essa cronologia interna em um contexto mais amplo de tendências educacionais no país, e particularmente da evolução histórica do Ensino de Ciências traçadas no capítulo dois.

\subsection{Retomando e sistematizando resultados}

\section{Do Crescimento}

No que tange ao crescimento da produção em números, pudemos verificar que, em valores absolutos, a produção de dissertações e teses passou de cerca de uma dezena de títulos nas décadas de 1970 e 1980 para duas a três dezenas na década de 1990, e para uma centena e meia no final da primeira década de 2000 . Destaca-se, particularmente, a última década (2000-2009) que concentrou $70 \%$ de toda a produção nesse período de quase quarenta anos. E mais, que se tomamos apenas essa década, constatamos um aumento superior a $100 \%$ da primeira para a segunda metade (2000-2004 para 2005-2009).

Esses dados nos levam a caracterizar cinco momentos ou períodos, extraídos com base nas taxas e médias de crescimentos obtidas no capítulo três (ver, em particular, gráficos 3.2 e 3.3). 
O primeiro momento se estende do início dos anos 70 até meados dos 80; (média anual de dissertações e teses inferior a uma dezena) o segundo de meados de 80 a meados de 90 (média anual em torno de duas dezenas); o terceiro de meados ao final da década de 90 (média anual de três dezenas); o quarto corresponde à primeira metade da década de 2000 (média anual de seis dezenas) e o quinto à segunda metade dessa década (média anual de cerca de uma centena).

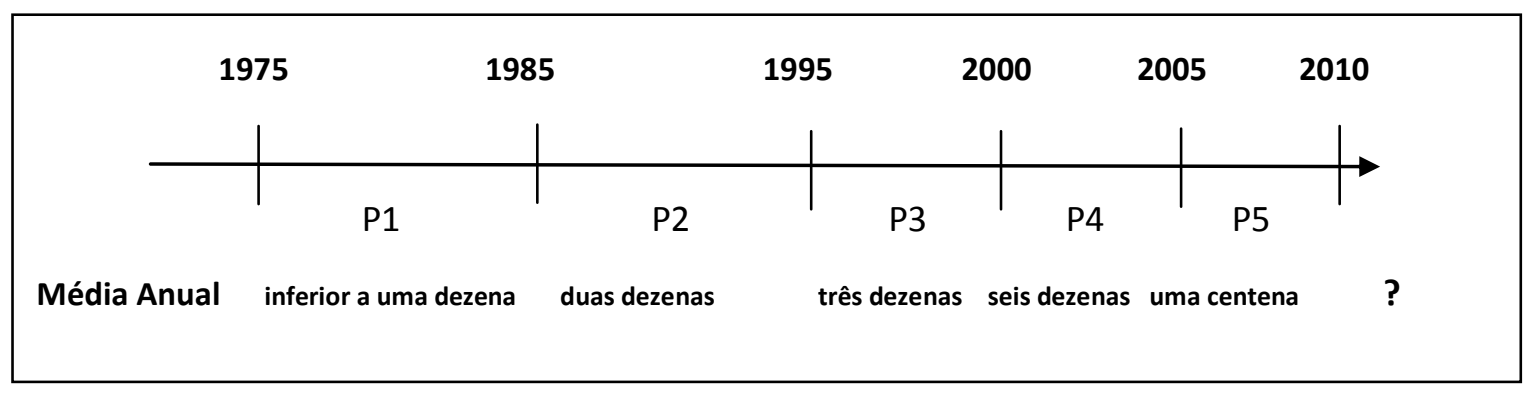

Fig. 8.1: Periodização do crescimento da produção

A análise do crescimento do número de instituições e de orientadores de certo modo acompanha essa evolução e periodização, com destaque para o fato de que esses parâmetros enquanto aumentam numericamente, se dispersam, ou seja, cada vez mais o número de trabalhos por instituição e por orientador é menor, revelando que o crescimento da produção de dissertações e teses na área tem se dado com a inserção crescente de novos programas e cursos de pós-graduação.

Quanto ao grau acadêmico, verificamos que os mestrados representam maior parte do conjunto, $75 \%$ na soma cumulativa de todos os períodos e acompanham o crescimento geral. Os doutorados crescem a taxas superiores às dos mestrados até início da primeira década de 2000, a partir de quando passam a ser inferiores. Esse particular resultado seria devido, por um lado, pelo fato de que até a virada de século a produção de doutorados crescia absorvendo o aumento do contingente de mestres na área e, por outro lado, talvez a uma inflexão ou represamento de novos concursos para doutores nas Universidades (especialmente nas Federais) nos primeiros anos da década de 2000.

Finalmente, uma questão que ressaltamos e que não temos elementos claros para responder diz respeito às tendências futuras de tal crescimento. Certamente dependem de fatores que transcendem a dinâmica interna de evolução da pesquisa, especialmente das políticas educacionais para a escola básica e nessa, dos rumos do Ensino de Ciências e do Ensino de Física, o que influencia (e é influenciado por) subvenções e prioridades do ensino superior e da pós-graduação. $\mathrm{O}$ atual contexto e possíveis perspectivas da educação básica no país, particularmente no nível médio, 
poderiam sinalizar prognósticos diversos, dentre os quais a re-unificação do Ensino de Ciências no nível médio, com extinção das disciplinas específicas de Física, Química e Biologia, o que tiraria a razão de ser da pesquisa em ensino nesses campos de conhecimento.

Outro aspecto que pode ter impacto importante na evolução da área é a entrada e crescimento dos mestrados profissionais. Ainda que já apresentando efeitos seja nos números, seja na natureza da pesquisa, é prematuro delinear orientações e possibilidades futuras.

\section{Das temáticas, âmbitos e perspectivas}

Uma síntese das análises desenvolvidas nos capítulos cinco, seis e sete, nos quais investigamos as temáticas, os âmbitos e perspectivas da produção, também revela a existência de marcos que delimitam períodos relevantes ao longo desse crescimento, os quais passamos a descrever. Ressaltamos, entretanto, que tal periodização não é precisamente demarcada, havendo sobreposições e intersecções entre os momentos identificados. Diríamos que é dada por "manchas", com características próprias na linha do tempo da evolução da área. Também observamos que estamos nesse momento destacando resultados no âmbito interno da área, com base nos dados obtidos a partir da análise da produção.

Os períodos que a seguir delimitamos são, pois, decorrentes de nossos dados sobre as evoluções das Áreas Temáticas (capítulo cinco) e dos âmbitos e perspectivas da pesquisa, embasados nas três dimensões que orientaram nossa análise - Educação, Conhecimento e Processos de Ensino-Aprendizagem - e respectivas interfaces (capítulo seis). Os resultados do capítulo sete pontuam alguns efeitos do mestrado profissional sobre esses parâmetros.

Uma das principais indicações que já obtivemos na análise desses parâmetros, é a de que enquanto a dimensão dos Processos de Ensino e Aprendizagem é dominante em todos os períodos e, por isso, mais facilmente demarcável, as outras duas dimensões, do Conhecimento e da Educação trazem dificuldades nas suas delimitações e podem ser mais bem caracterizadas no seu plano de intersecção. Por esse motivo, na análise em períodos que aqui trazemos, distinguimos esses dois conjuntos: a evolução da pesquisa no eixo do Ensino-Aprendizagem e no âmbito da interface EducaçãoConhecimento.

Esses parâmetros, somados à periodização feita no capítulo dois, definiram os seguintes períodos:

1. Os anos setenta

2. Início a meados dos anos oitenta

3. Final dos anos oitenta - início dos noventa 
4. Meados dos anos noventa

5. Primeira metade dos anos 2000

6. Segunda metade dos anos 2000

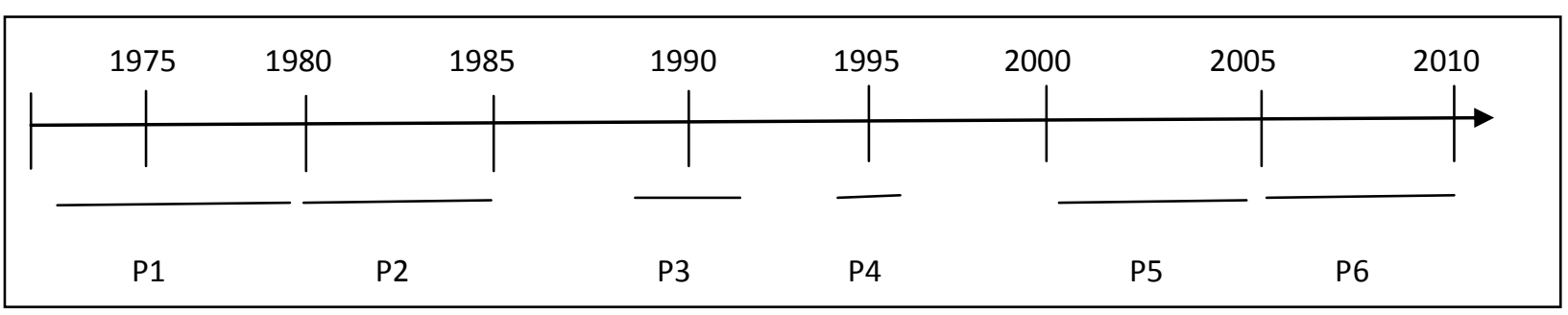

Quanto aos elementos nessa periodização, observamos que uma vez construída a partir da amostra definida para análise das temáticas e interfaces (capítulo 5 e 6), ela não é contínua, o que não desmerece os traços e atributos da cronologia desenvolvida. Ainda assim, para confirmar ou esclarecer algum resultado, em alguns momentos lançamos mão de períodos lacunares, ausentes na amostra.

Também é necessário salientar, que ao longo da análise que segue, o objetivo central é discutir tendências predominantes e, nessas, as permanências e mudanças relevantes, sem uma preocupação com parâmetros estatísticos. Ou seja, o apontamento de características desses períodos e os exemplos de pesquisa que trazemos nem sempre refletem uma totalidade ou prevalência, mas expressam atributos importantes que os particularizam.

\section{Primeiro Período: anos 70}

Quanto ao eixo Processos de Ensino-Aprendizagem

Do ponto de vista das áreas temáticas tratadas nas pesquisas em Ensino de Física nesse primeiro período que marca sua instauração, verificamos que uma enorme parcela (75\%) esteve concentrada em estudos sobre métodos e estratégias de ensino, com destaque especial para os cursos de instrução personalizada (Método Keller), instrução programada e laboratório. Também se destacam aqui as pesquisas sobre os projetos de ensino nacionais então recém desenvolvidos (FAI, PEF, PBEF). Incluem-se, ainda, estudos sobre o vestibular, com foco na análise de desempenho de estudantes nas provas de Física. Ou seja, trata-se de trabalhos que privilegiam o Ensino de Física com lentes nos meios ou técnicas para aprimorá-lo.

Nessa linha, as perspectivas ou referenciais epistemológicos e pedagógicos dominantes - as concepções positivistas da ciência e comportamentalistas do ensino têm primazia, são quase hegemônicas, quer quanto às temáticas, quer quanto às metodologias e abordagens propostas e investigadas, com particular ênfase na experimentação e nos métodos de ensino programados e individualizados. 


\section{Quanto à interface Conhecimento-Educação}

O conhecimento científico é aqui explicitamente contemplado, sendo que a Física

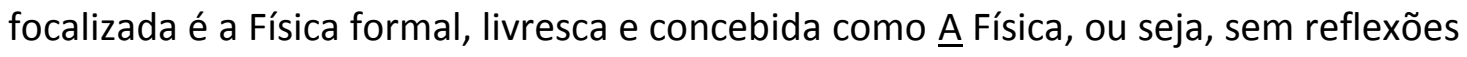
e questionamentos sobre a seleção dos conteúdos a serem tratados na escola. Ao mesmo tempo, são trabalhos bastante próximos às salas de aula, já que têm como finalidade principal a melhoria do aprendizado na escola básica.

Quanto aos objetivos educacionais, inserem-se em uma perspectiva do "ensinar pelo ensinar", via de regra desprendidos de uma preocupação do por que, para quê ou para quem ensinar Física, que transcenda o processo de transmissão-aquisição de conhecimentos científicos acumulados. E, ainda nessa concepção, o aluno, sujeito do aprendizado, é desprovido de "pessoalidade". Seus conhecimentos e vivências prévias, sua cultura e visão de mundo não têm relevância no aprendizado. Ao professor cabe transmitir conhecimentos da melhor forma possível, dominando os conteúdos, com bons métodos ou boa didática.

Processos, Conhecimento e Educação são, assim, alinhados, articulados e fundamentados com base na tradição positivista, segundo a qual o conhecimento científico é dado pelos resultados obtidos da experiência, acabado e único, e a atividade científica é autônoma e neutra, indutora do progresso social. O ensino, por sua vez, é calcado na progressão dos indivíduos (impessoais); "páginas em branco" que, submetidos a técnicas eficientes, podem adquirir conhecimento. Aspectos humanos, históricos e sociais são irrelevantes e, coerentemente, o papel do professor e sua formação profissional são subestimados.

São alguns exemplos de teses nesse período:

- Extensão para um grande número de alunos e um modelo dinâmico probabilístico para o método Keller. UnB, 1972.

- Estudo sobre os métodos Keller, audiotutorial e de estudo dirigido em física. UFRGS, 1975.

- Uma análise do Projeto de Ensino de Física: Mecânica. USP, 1977.

- Análise do projeto FAl: uma proposta de um curso auto-instrutivo para o segundo grau. USP, 1977

- Candidatos à área de matemática, ciências físicas e tecnologia: desempenho escolar no curso introdutório de física. UFBA, 1977.

\section{Segundo período: início a meados dos anos 80}

Quanto ao eixo Processos de Ensino-Aprendizagem

A entrada na década de 1980 traz algumas mudanças significativas, especialmente no que concerne à primeira área temática caracterizada pelos Processos de Ensino e Aprendizagem. Como visto, a década anterior foi marcada pela ênfase nos métodos e 
estratégias de ensino, segundo a qual o aluno, sujeito do aprendizado, não é foco de atenção privilegiado. A virada desse período para o seguinte caracteriza-se pela mudança de foco do ensino para a aprendizagem. Passa-se a considerar e investigar os conhecimentos prévios dos alunos, de modo a suprir as deficiências conceituais apresentadas, particularmente no aprendizado de Física em nível médio (então segundo grau).

Da ênfase no referencial comportamentalista, passam a fundamentar as investigações a psicologia cognitiva e, nessa, o construtivismo. O aluno é sujeito da construção do conhecimento, já que sua "bagagem" agora é elemento balizador do ensino. Piaget e Ausubel são referenciais mais recorrentes dessas pesquisas. 0 primeiro contribuindo para a compreensão de como se dá o desenvolvimento cognitivo dos alunos, tendo em vista as diferentes potencialidades ao longo de seu desenvolvimento pessoal e tendo em conta a dimensão psicogenética. O segundo, trazendo elementos que possibilitariam uma "aprendizagem significativa", tendo em consideração a estrutura conceitual quer das teorias físicas, quer do próprio aluno. É nesse âmbito que se instauram e começam a ocupar espaço nas pesquisas da área, as investigações sobre Concepções Espontâneas (também denominadas intuitivas, prévias ou alternativas).

Certamente esse "movimento das concepções alternativas" trouxe uma contribuição importante às pesquisas em Ensino de Ciências, especialmente por questionarem (mais especificamente na sua instauração) a eficiência dos processos de ensino por "transmissão" de conhecimentos, ou a própria concepção espontânea e naturalizada de ensino como algo relativamente simples, demandando um bom domínio do objeto de ensino pelo professor, com alguma experiência e recursos didáticos adequados. Abriu espaço, também, para novas questões de pesquisa e sinalizações para o ensino, entre as quais a necessidade de se investigar a própria natureza e desenvolvimento do conhecimento científico, ou seja, a dimensão epistemológica do ponto de vista do aluno, articulada à epistemologia da Ciência (estudos na linha da psicogênese de conceitos físicos). Ainda quanto a novas orientações educacionais, abriu campo para iniciativas renovadoras e mais críticas, que passaram a considerar as vivências e o cotidiano dos estudantes na organização do ensino.

Contudo, ainda que tais mudanças tenham expressão e significados importantes, com possíveis impactos na educação escolar, observa-se que os processos de ensino e aprendizagem e a ênfase na psicologia da aprendizagem permanecem como foco hegemônico da produção.

As temáticas aqui presentes ainda incluem trabalhos típicos do período anterior, particularmente sobre métodos de instrução personalizada e sobre o laboratório.

Quanto à interface Conhecimento-Educação 
$\mathrm{Na}$ perspectiva do âmbito educacional e do conhecimento, ainda predomina a concepção de que o conhecimento a ser ensinado é dado e não questionável. Com raras exceções, o objeto de ensino não é passível de discussão. Qual Física ensinar. Trata-se de se investir, talvez não mais na recepção passiva de conceitos, mas em uma apropriação dos mesmos conceitos, que abarque o desenvolvimento cognitivo do aluno. Assim, considerar o estudante significa sobretudo ter em conta seus conhecimentos prévios da Física a ser ensinada. Ou seja, não se trata de trazer para educação formal novas dimensões e perspectivas, que incorporem ou enfatizem aspectos históricos, sócio-culturais, concepções de ciência, valores ou visões de mundo desses estudantes. O objetivo principal permanece: aprimorar o ensino, o aprendizado. O conhecimento pelo conhecimento.

São exemplos de dissertações e teses nesse período:

- Uma abordagem ausubeliana ao ensino de eletricidade e magnetismo em nível universitário básico. UFRGS, 1981.

- Representações conscientes do movimento simultâneo de esferas em trilhos inclinados. USP, 1982.

- Estudo das noções espontâneas acerca de fenômenos relativos à luz em alunos de 1118 anos. USP, 1982.

- Mapas conceituais como instrumentos para investigar a estrutura cognitiva em física. UFRGS, 1983.

- Concepção problematizadora para o ensino de ciências na educação formal : relato e análise de uma prática educacional na Guiné-Bissau. USP, 1982.

- Condicionamentos históricos e sociais no surgimento da física: um guia e um guia bibliográfico para professores de física. USP, 1984.

\section{Terceiro Período: final dos anos 80, início dos 90}

\section{Quanto ao eixo Processos de Ensino-Aprendizagem}

Um curto período entre final da década de 1980 e primeiros anos da década de 1990 apresenta novas mudanças no cenário das preocupações e linhas de pesquisa. Porém, antes delas, realçamos a permanência - a hegemonia das temáticas sobre ensino-aprendizagem - ainda que com concentração inferior ao período que a antecede. Nos dois anos desse período que compuseram a amostra analisada, a linha que definimos como Construção Conceitual (capítulo cinco) ocupa 100\% dos trabalhos identificados na área temática dos "Processos de Ensino e Aprendizagem". Dentro dessa linha, as pesquisas sobre Concepções Espontâneas têm elevado crescimento e concentram a maior parcela de trabalhos. Ou seja, permanece a prevalência do foco na aprendizagem, no "como o aluno aprende".

São exemplos da produção nesse eixo: 
- Concepções alternativas em eletricidade básica. UFF, 1989.

- Gênese das noções espontâneas sobre ondas na superfície da água e influência do ensino. UFF, 1989.

- Estudo psicogenético da noção de centro de massa: uma contribuição para o ensino da física. USP, 1989.

\section{Quanto à interface Conhecimento-Educação}

Uma mudança que aqui se revela é a entrada com mais peso de duas áreas temáticas que passarão a compor o panorama das pesquisas com presença relativamente importante. São elas, a História e Filosofia da Ciência e a Formação de Professores.

Ao mesmo tempo, surgem trabalhos que começam a se preocupar com a problematização de conteúdos a serem tratados no ensino, alguns na linha freireana (Angotti, 1991 e Delizoicov, 1991) outros que já sinalizam uma perspectiva na linha das relações Ciência, Tecnologia e Sociedade (não com esse rótulo), mediada por interação dialógica, a exemplo dos trabalhos no âmbito do Projeto GREF ${ }^{29}$.

Ainda nesse conjunto, a preocupação com qual Física ensinar para dado contexto curso, disciplina ou nível de ensino - se expressa por meio de investigações na linha "Física para..." (Engenharia, Geociências, 1o. grau, Licenciatura...). É também nesse momento que aspectos históricos e culturais no ensino de Física e na formação do professor são particularmente iluminados em um trabalho que terá grande repercussão na área (Zanetic, 1989).

No que tange particularmente aos estudos na linha da História e Filosofia da Ciência (HFC), percebe-se que esses têm, em grande parte, uma preocupação em trazer para o ensino uma discussão de fundo epistemológico, com ênfase na importância dessa dimensão no ensino para uma compreensão da ciência enquanto construção humana, inserida em um processo dinâmico, histórico e social. Ou seja, são explicitadas novas concepções de ciência e de ensino que se contrapõe às visões positivistas e empiristas que dominavam até a década de 1970 com importantes impactos no ensino das Ciências. Quanto à presença das investigações que focalizam a HFC, observa-se que em 1992, vinte e cinco por cento das dissertações e teses

\footnotetext{
${ }^{29}$ O projeto GREF, com início no final dos anos 80 e desenvolvido por professores de Física do ensino médio da rede estadual de São Paulo, sob orientação de pesquisadores da área , tem como primeiro produto, uma coleção de livros para professores desse nível de ensino, com objetivo de "tornar significativo esse aprendizado científico mesmo para alunos cujo futuro profissional não dependa diretamente da Física; por outro lado, dar a todos os alunos condições de acesso a uma compreensão conceitual e formal consistente, essencial para sua cultura e para uma possivel carreira universitária." (GRUPO DE REELABORAÇÃO PARA O ENSINO DE FÍSICA, São Paulo: Editorada Universidade de São Paulo, 1999)
} 
estavam concentradas nessa área temática, único ano (que não entrou em nossa amostra, mas que aqui resgatamos) em que um tema alcançou e superou o dos Processos Cognitivos de Ensino-Aprendizagem (Área Temática T1, a primeira nos demais "rankings" e, nesse particular ano com vinte e um por cento dos trabalhos).

O papel do professor e sua formação, questão timidamente tratada até então na produção acadêmica, também aqui passam a ser motivação de reflexões. Destacamse nessa área temática os estudos sobre formação continuada de professores, o que faz sentido nesse momento em que há uma preocupação em reconceber o aprendizado do aluno. Professores precisam ser atualizados ou usando um termo da época, "reciclados", para dar conta de novas orientações.

Não por coincidência, é nesse período que a interface Conhecimento-Processos (CP) é a que tem a menor parcela de trabalhos em relação a todos os outros analisados, e a interface Educação-Conhecimento (EC) a maior, ainda que a primeira predomine sobre a segunda, como em todos os momentos. (ver tabela 6.1, Capítulo 6). E é também aqui que identificamos a maior concentração de pesquisas que contemplam o conhecimento físico explicitamente (ver Tabela 6.2, Capítulo 6).

Esse resultado vem reiterar uma hipótese já vislumbrada sobre a natureza da área. É na articulação de uma perspectiva educacional com o objeto de conhecimento que se extrapola o limiar mais restrito do âmbito ensino-aprendizagem e que se apontam caminhos "não tão lá nem tão cá" na relação entre o Ensino e a Física.

Novamente, salientamos que, mesmo não sendo expressão de parcela considerável, a entrada em cena de trabalhos dessa natureza é importante e deve ser sinalizada, pois revela um "respiro" diferente na área, no qual a produção ensaia novos ares, aponta novos olhares, não redutíveis ao eixo ensino-aprendizagem.

São exemplos da produção nessa perspectiva:

- Física no 1o. Grau? USP, 1990.

- Outra óptica para o ensino de óptica. USP, 1990.

- Goiânia, Tchernobyl e a tecnologia nuclear: a informação científica entre alunos do 20 grau. UFSC, 1991.

- Atualização de professores de física em serviço: subsídios para um programa. USP, 1989.

- Fragmentos e totalidades no conhecimento científico e no ensino de ciências. USP, 1991.

- Conhecimento, tensões e transições. USP, 1991

- Voar também é com os homens: o pensamento científico-filosófico de Mario Schenberg. USP, 1991.

- A natureza do conhecimento científico e a educação em Ciências. UFSC, 1991.

- Física também é cultura. USP, 1989. 


\section{Quarto período: meados dos anos 90}

Quanto ao eixo Processos de Ensino-Aprendizagem

Estamos agora em meados da década de 1990, com destaque para os anos de 1995 e 1996, contemplados em nossa amostra. Em primeiro lugar, esse período tem um marco particular na linha das pesquisas sobre os aspectos cognitivos da aprendizagem. Demarca o "topo" (percentualmente) das investigações sobre Concepções Espontâneas, que alcança seu auge e começa a partir de então a declinar, dando lugar às investigações sobre Mudanças Concentuais e Modelos Mentais, que aqui entram com relativa participação na produção de teses e passarão a crescer nos períodos seguintes. Trata-se, como já vimos de uma linha de pesquisa que dá continuidade e é articulada ao movimento das concepções alternativas, com orientação construtivista, e também fundamentada nos quadros teóricos da psicologia de aprendizagem. O deslocamento de uma para outra linha traz uma amplitude de enfoque, deslocando-se da constatação acerca das concepções dos alunos sobre conceitos diversos e introduzindo elementos que promoveriam o entendimento de como os alunos aprendem ou como "pensam" em contextos dados. São exemplos dessa linha de pesquisa nesse período:

- Concepções alternativas em óptica. UNICAMP, 1995.

- Mudança conceitual em sala de aula: o ensino de ciências numa perspectiva construtivista. UFMG, 1995

\section{Quanto à interface Conhecimento-Educação}

Um dado importante que caracteriza esse momento é a maior concentração de estudos na Área Temática "Seleção e Organização de Conteúdos", que também aqui alcança o seu auge. Como no período anterior, predominam nessa área temática os trabalhos identificados no sub-tema "Abordagens e critérios na organização do conhecimento", com destaque para os estudos nas linhas da Física do Cotidiano, Contextualização, Física / Ciências para... Também é nesse momento que a pesquisa acadêmica começa a contemplar as discussões sobre a inserção da Física Moderna e Contemporânea no ensino médio. São exemplos de dissertações e teses com esses enfoques:

- Que física ensinar no segundo grau? Elementos para uma reelaboração de conteúdo. USP, 1995.

- A interdependência conteúdo-contexto-metódo no ensino de Física: um exemplo em Física térmica. UFSM, 1995.

- A física no ensino técnico industrial federal: um retrato em formato A4. USP, 1995.

- Física moderna no ensino de nível médio. UFMT, 1995.

- A fragmentação do objeto pedagógico e suas implicações interdisciplinares: um olhar voltado para o ensino de Ciências. UFSC, 1996. 
Na linha da Formação de Professores, que desde o período antecedente a esse começa a se estabilizar e ganhar uma identidade específica destaca-se nesse período, particularmente as investigações que enfocam a Prática Docente. Enquanto até início dos anos 90 a ênfase dos trabalhos sobre formação de professores estava na formação inicial e continuada, surge uma nova preocupação em analisar o perfil do professor e sua prática profissional, referenciados nas teorias e proposições sobre pesquisa-ação e reflexão na ação, que começam a ganhar espaço nessa linha de pesquisa. São exemplos:

- Prática docente do professor de Física do terceiro grau. USP, 1996.

- Processo reflexivo e pesquisa-ação: apontamentos sobre uma prática dialógica em física. UFSM, 1996.

- Pesquisa-ação emancipatória e prática educacional dialógica em ciências naturais. USP, 1995.

Nas pesquisas com enfoque na História e Filosofia da Ciência ainda predominam abordagens sobre concepções e representações de Ciência, a exemplo de:

- A significação filosófica da Física Moderna: temas controversos, conflito de enfoques. UNICAMP, 1995.

- Ciência e religião: implicações do diálogo entre duas visões de mundo de ensino da cosmologia. UFSC, 1996.

- Newton e a metafísica: uma proposta para o ensino de física no segundo grau a partir do resgate das origens do conceito de força a distância. UNICAMP, 1995.

- Da vinculação entre ciência e relações sociais ao ensino de Ciências na escola pública do século XIX. UEM, 1996.

A Divulgação Científica passa aqui a integrar as pesquisas, mas muito timidamente.

De um modo geral, a marca da década de 1990, somando-se esses dois últimos períodos, é uma ampliação de horizontes na produção acadêmica com tendência (e não prevalência) a extrapolar o âmbito da aprendizagem e cognição, e do conhecimento pelo conhecimento. E nesse âmbito, o aluno, mesmo que não protagonista nos processos de ensino, passa a ser valorizado enquanto sujeito epistêmico.

\section{Quinto período: primeira metade da década de 2000}

Quanto ao eixo Processos de Ensino-Aprendizagem

Como já constatamos, nesse período começam a declinar os estudos na linha das Concepções Espontâneas para darem lugar aos Modelos Mentais e Mudanças Conceituais, passando a integrar estudos sobre Perfis Conceituais, já prenunciando as abordagens que vem sendo denominadas por sócio-históricas ou sócio- 
interacionistas. Em 2003 esses estudos (em conjunto) concentram a maior parcela nesse eixo do "Ensino-Aprendizagem".

Em sintonia com essas abordagens, começam a crescer os trabalhos que enfatizam o papel da Linguagem na construção do conhecimento.

Ainda são características relevantes desse período o surgimento e o crescimento de trabalhos na linha das Tecnologias de Informação e Comunicação (TIC) especialmente como recursos didáticos para o ensino formal. São exemplos de teses nessas perspectivas:

- Dificuldades dos alunos na aprendizagem da lei de Gauss em nível de Física Geral à luz da teoria dos modelos mentais de Johnson-Laird, UFRGS, 2000.

- Perfil conceitual: trabalhando a concepção de matéria e estados físicos dos materiais com alunos e alunas do ensino médio. UFBA, 2003.

- Uma análise exploratória do potencial das narrativas como recurso para o ensino de Física. UFMG, 2000.

- Começando a pensar com ciência: a educação pré-escolar em ciências em interações discursivas. UFF, 2003.

- O discurso do professor de ciências sobre leitura: um olhar da biblioteca. UFRJ, 2003.

- A prática de leitura e a escrita em aula de Física mediadas por textos de divulgação científica. UFMG, 2003.

- Escrevendo em aulas de Ciências. USP, 2003.

- O uso de computadores nos cursos de Física das escolas privadas de Campinas. PUCCAMP, 2000.

- Uma proposta pedagógica para uso do computador em ambientes de ensino experimental de Física. UFRJ, 2000

Quanto à interface Conhecimento-Educação

Um resultado que se destaca nesse período é a intensificação das investigações sobre a inserção da Física Moderna e Contemporânea no ensino básico e na formação de professores. Em 2003 é o tema que concentra a maior parte dos trabalhos nessa área temática.

- Tópicos de Física Contemporânea em escolas de nível médio na formação de professores de Física. UFRGS, 2000.

- Texto e contexto para o ensino de Física Moderna e Contemporânea na escola média. USP, 2003

As pesquisas que contemplam a História e Filosofia da Ciência passam a ter um enfoque mais específico, concentrando-se em abordagens que tratam de seu uso como estratégia ou aplicação didática na aprendizagem das Ciências. 
Integrada a essas perspectivas, nessa primeira década de 2000 as chamadas abordagens CTS passam a ser contempladas.

Também nessa década começa a diminuir a presença do conhecimento físico como foco explícito das pesquisas, passando-se a tratar de temáticas que extrapolam o conhecimento específico e voltam-se para investigações mais abrangentes, ainda com predominância em teorias de Aprendizagem.

Do ponto de vista do objeto de conhecimento, começam a aparecer "Novas Temáticas" que buscam integrá-lo a uma formação "voltada à cidadania" abrangendo dimensões sociais e éticas do mundo contemporâneo. Entre esses temas, destacamse questões ambientais, recursos energéticos, energia nuclear e novas tecnologias.

Exemplos:

- Análise do uso de um texto paradidático sobre energia e meio ambiente. UNESPBauru, 2000.

- Física Moderna no ensino fundamental: uma experiência com o Projeto Manhattan. UFSC, 2003.

- A Física na educação ambiental: a questão do efeito estufa. USP, 2003.

- Investigando a telefonia celular: ensinando-aprendendo com a interatividade em uma abordagem temática no ensino de Física. UFSC, 2003.

Ao mesmo tempo, as pesquisas começam a tratar de linhas e enfoques que extrapolam e, em alguns casos prescindem do conhecimento físico (enquanto conhecimento disciplinar). Ou seja, estudos em que o conhecimento científico, as ciências ou a física não têm lugar como foco (e, às vezes, nem como lócus), mas têm lugar secundário, como aplicação ou exemplo para "discutir ou validar um referencial teórico, para analisar uma proposição didático-metodológica, refletir sobre uma concepção educacional ou formativa no ensino de Ciências."

Exemplos:

- As contribuições do pensamento complexo de Edgar Morin para a formação do professor. PUC-PR, 2003.

- O discurso do professor de ciências sobre leitura: um olhar da biblioteca. UFRJ, 2003.

- O currículo do curso de formação de professor, desenvolvido na modernidade de ensino a distância, frente a emergência das tecnologias da comunicação $e$ informação: análise de uma experiência. UNEB, 2003.

- Investigação-ação: colaboração sobre práticas docentes na formação continuada de formadores. UNIMEP, 2003.

Em síntese, a marca desse período, virada de século, nas pesquisas acadêmicas é ao mesmo tempo que um esboço de mudanças nas temáticas ou conteúdos focalizados, com tendência de "abertura" no sentido de incorporarem questões sintonizadas ao 
mundo contemporâneo, também um distanciamento do conhecimento do conhecimento científico. Acrescenta-se nesse momento a forte tendência na linha das "Tecnologias de Informação e Comunicação" como recursos didáticos para o ensino formal. Ou seja, enquanto as pesquisas se abrem para orientações educacionais e formativas que seriam implicitamente dadas por uma perspectiva de "formação para a cidadania", também se abrem para referenciais e problemas que não privilegiam a dimensão científica ou o saber disciplinar. Seria uma contradição, caso se tratassem das mesmas pesquisas em ambas as direções. Mas o que observamos é que no primeiro caminho, de inclusão de temas contemporâneos, não se trata propriamente de se apartar do conhecimento científico, mas de articulá-lo com essas novas questões, ao passo que, no segundo, o afastamento da dimensão disciplinar das ciências ocorre especialmente nas investigações na linha da cognição e nessas, o enfoque na interação discursiva. Ou seja, ainda que visando situar as ideias dos estudantes num contexto mais amplo, que admite sua convivência com o saber escolar e com o saber científico, há uma tendência de afastamento do saber (escolar e científico).

É importante lembrar, ainda, que no ano 2000 foi criada a área de Ensino de Ciências e Matemática da CAPES (extinta área 46), fato com alto impacto na evolução da produção, dado o aumento de Programas e Cursos que passam a integrar os recomendados por esse órgão.

\section{Sexto período: segunda metade da década de 2000}

Finalmente, esse último período se destaca pelo crescimento mais expressivo no volume da produção, fato que se deve particularmente à entrada dos Mestrados Profissionais na área. Como vimos no capítulo sete, esse novo dado tem significativo impacto não apenas nos "números", mas também nos focos de pesquisa.

\section{Quanto ao eixo Processos de Ensino-Aprendizagem}

No interior da primeira Área Temática as abordagens sócio-culturais ou sóciointeracionistas, com uma nova vertente histórica e sócio-cultural, passam a ocupar mais atenção das pesquisas, com destaque, ainda, para a linguagem, as interações discursivas em sala de aula e a chamada negociação de significados entre diferentes culturas. Tais abordagens marcam uma nova "agenda de pesquisa" na linha cognitiva que se instaura nesses anos mais recentes.

Nesse campo, Vygotsky é o referencial teórico mais frequente no domínio da relação entre pensamento e linguagem, em uma concepção histórica do psiquismo humano, mediado pela realidade social. Lontiev é outra referência, que seguindo os passos iniciados por Vygotsky na linha histórico-social da psicologia do desenvolvimento, agrega novos elementos que integram a chamada "Teoria da Atividade". Ambos 
contrapondo-se à psicologia do desenvolvimento baseada em Piaget, calcada em mecanismos adaptativos do comportamento.

Mais recentemente, no final desse período, começam a se esboçar estudos sobre as relações entre multiculturalismo e gênero e os processos de ensino e aprendizagem nas ciências.

As pesquisas na linha das Tecnologias de Informação e Comunicação (TIC), como no período anterior, concentram parcelas relativamente expressivas, passando a contemplar, além de suas aplicações no ensino escolar presencial, o campo do Ensino a Distância, que começa a ser alvo de investigações, particularmente na formação de professores.

Alguns exemplos de trabalhos nesse período:

- Estudos dos processos interativos em aulas de física: uma abordagem segundo a teoria de Vigotski....2006.

- Eventos de letramento científico promovidos pela interação de jovens e adultos com a leitura e a escrita de textos de ficção científica. CEFET-MG, 2009.

- Protexto, narrativa poética da ciência: uma estratégia de construção do conhecimento e religação de saberes no ensino da física. UFRN, 2009.

- Ambientes distribuídos em realidade virtual como suporte à aprendizagem cooperativa para solução de problemas. UFU, 2009.

- Licenciaturas na modalidade a distância e o desafio da qualidade: uma proposta de indicadores para aferir qualidade nos cursos de física, química, biologia $e$ matemática. PUC-RS, 2009.

- Utilização do moodle no curso de Licenciatura em Física a distância da UAB/UFAL. UFAL, 2009.

- Fisíca e Masculinidade: microanálise de atividades de investigação na escola. UFMG, 2009.

\section{Quanto à interface Conhecimento-Educação}

As temáticas e focos no âmbito dessa interface apresentam mudanças muito pontuais em relação ao período anterior. Dentre essas, ressalta-se o declínio dos estudos sobre a Física Moderna e Contemporânea, na Seleção e Organização de Conteúdos e, na Formação de Professores, uma redução do enfoque na prática docente, voltando a prevalecer a ênfase na formação inicial e continuada, especialmente nessa última.

Quanto aos âmbitos e perspectivas, também não identificamos mudanças significativas em relação ao período anterior. O particular dado que chama atenção refere-se à presença e ao tratamento do conhecimento científico/físico que mantém tendência de declínio como foco explícito, ou seja, revelando um ainda maior distanciamento da produção acadêmica de seu objeto disciplinar. 
Por outro lado, os mestrados profissionais, cujas dissertações crescem muito rapidamente nesse período, voltam a reproduzir um panorama de temas e perspectivas mais próximo aos períodos iniciais da produção acadêmica, como mostramos no capítulo sete.

Finalmente, cabe observar que as tendências sinalizadas nessa periodização,

- estão sintonizadas com movimentos e agendas de pesquisas internacionais na área de Ensino de Ciências;

- extrapolam o próprio Ensino de Ciências, acompanhando também evolução de pesquisas educacionais de um modo geral e, de certo modo, das próprias "Ciências duras" em seu processo de complexificação e articulação com outros campos de saber, que passam a repensar criticamente e superar a perspectiva epistemológica positivista;

- apresentam uma defasagem entre as tendências e concepções nos âmbitos educacionais e científicos, uma vez que são resultados de projetos de pesquisas iniciados alguns anos antes de sua apresentação no formato de dissertações e teses.

\section{Síntese da síntese}

No quadro a seguir, apresentamos uma síntese dos principais elementos que extraímos da retomada cronológica no primeiro tópico desse capítulo, para situar, mais adiante, os marcos importantes da pesquisa em Ensino de Física em um panorama mais amplo. 


\begin{tabular}{|c|c|c|}
\hline PERÍODO & ENSINO-APRENDIZAGEM & CONHECIMENTO/EDUCAÇÃO \\
\hline $\begin{array}{l}10 . \\
\text { Anos } 70 .\end{array}$ & $\begin{array}{l}\text { Foco no ensino. } \\
\text { Materiais e Métodos. } \\
\text { Método Keller; estudo dirigido. } \\
\text { Projetos de Ensino: PEF, FAI, PSSC. } \\
\text { Aprendizagem receptiva; aluno não é } \\
\text { sujeito. } \\
\text { Behaviorismo / Skinner. }\end{array}$ & $\begin{array}{l}\text { Aperfeiçoamento do Ensino. } \\
\text { Conhecimento pelo conhecimento. } \\
\text { Transmissão de conhecimentos. } \\
\text { Positivismo / empirismo. } \\
\text { Conhecimento físico explícito. Tradicional; } \\
\text { dado. } \\
\text { Aluno impessoal. }\end{array}$ \\
\hline $\begin{array}{l}\text { 2o } \\
\text { Início - } \\
\text { meados } \\
\text { anos } 80 .\end{array}$ & $\begin{array}{l}\text { Foco na aprendizagem. } \\
\text { Processos mentais e habilidades cognitivas. } \\
\text { Psicologia cognitivista. Construtivismo. } \\
\text { (Início - Concepções espontâneas) } \\
\text { Piaget, Ausubel, Viennot. }\end{array}$ & $\begin{array}{l}\text { Aperfeiçoamento do Ensino. } \\
\text { Conhecimento pelo conhecimento. } \\
\text { Conhecimento físico explícito. Tradicional; } \\
\text { dado. } \\
\text { Aluno é sujeito. }\end{array}$ \\
\hline $\begin{array}{l}3 \text { o } \\
\text { Final dos } \\
\text { anos } 80- \\
\text { início } \\
\text { anos } 90 .\end{array}$ & $\begin{array}{l}\text { Foco na aprendizagem. } \\
\text { Processos mentais e habilidades cognitivas. } \\
\text { Psicologia cognitivista. Construtivismo. } \\
\text { Psicogênese. } \\
\text { Concepções Espontâneas no auge. } \\
\text { Piaget, Ausubel, Viennot. }\end{array}$ & $\begin{array}{l}\text { Acenos para educação crítica. Paulo Freire/ } \\
\text { problematização do conhecimento. } \\
\text { Predomina conhecimento físico explícito; } \\
\text { tradicional; dado. } \\
\text { Dimensão histórica, filosófica e cultural. } \\
\text { Ciência como construção. } \\
\text { Aperfeiçoamento da formação de } \\
\text { professores; papel do professor } \\
\text { Aluno é sujeito, mediado pelo objeto. }\end{array}$ \\
\hline $\begin{array}{l}40 \\
\text { Meados } \\
\text { a fim dos } \\
\text { anos } 90 .\end{array}$ & $\begin{array}{l}\text { Foco na aprendizagem, com aspectos de } \\
\text { ensino. } \\
\text { Processos mentais e habilidades cognitivas } \\
\text { Concepções Espontâneas e Mudança } \\
\text { Conceitual. }\end{array}$ & $\begin{array}{l}\text { Acenos para seleção e problematização de } \\
\text { conteúdos: Física do cotidiano, } \\
\text { contextualização. } \\
\text { Educação não formal; divulgação científica. } \\
\text { Predomina conhecimento físico explícito; } \\
\text { tradicional; dado. } \\
\text { Dimensão histórica/ filosófica no auge. } \\
\text { Formação do professor: prática docente. } \\
\text { Aluno é sujeito, mediado pelo objeto e } \\
\text { contexto. }\end{array}$ \\
\hline $\begin{array}{l}\text { 50 } \\
\text { Primeira } \\
\text { metade } \\
\text { da } \\
\text { década } \\
\text { de } 2000 .\end{array}$ & $\begin{array}{l}\text { Foco na aprendizagem, com aspectos de } \\
\text { ensino. } \\
\text { Processos mentais e habilidades cognitivas } \\
\text { Modelos mentais; Perfil conceitual. } \\
\text { Vygotsky. } \\
\text { TIC no ensino formal. }\end{array}$ & $\begin{array}{l}\text { Educação para cidadania. } \\
\text { Novas temáticas. } \\
\text { Conhecimento físico implícito. } \\
\text { (Distanciamento do conhecimento } \\
\text { específico) } \\
\text { Física Moderna e Contemporânea. } \\
\text { História da Ciência como recurso didático. } \\
\text { CTS. } \\
\text { Aluno é sujeito, mediado pelo objeto e } \\
\text { contexto }\end{array}$ \\
\hline $\begin{array}{l}\text { 60 } \\
\text { Segunda } \\
\text { metade } \\
\text { da } \\
\text { década } \\
\text { de } 2000 .\end{array}$ & $\begin{array}{l}\text { Foco na aprendizagem, com aspectos de } \\
\text { ensino. } \\
\text { Abordagens sócio-culturais e sócio- } \\
\text { interacionistas. } \\
\text { Interações discursivas / Linguagem. } \\
\text { Aprendizagem inclusiva / questões de } \\
\text { gênero. } \\
\text { Vigotsky. Lontiev. Toulmin. } \\
\text { TIC no Ensino a Distância. }\end{array}$ & $\begin{array}{l}\text { Educação para cidadania. } \\
\text { Novas temáticas. } \\
\text { Conhecimento físico implícito ou ausente. } \\
\text { (Distanciamento do conhecimento } \\
\text { específico) } \\
\text { Aluno é sujeito, mediado pelo objeto e } \\
\text { contexto sócio-cultural. } \\
\text { Mestrado profissional. }\end{array}$ \\
\hline
\end{tabular}

Quadro 8.1: Aspectos evolutivos da pesquisa em Ensino de Física 


\subsection{Respondendo às questões de pesquisa}

O conjunto da pesquisa desenvolvida até aqui, acrescido da síntese construída nesse capítulo nos permite dar algumas respostas às questões de pesquisa apresentadas na introdução do trabalho e retomadas nesse capítulo. As três primeiras estão calcadas na tríade Processos, Educação e Conhecimento, cada uma com recorte em um desses eixos. Voltemos a elas.

- Na primeira, indagamos sobre o quanto a ênfase nos Processos de EnsinoAprendizagem, marca de origem da nossa área, permanece, sobrevive e predomina; ou ainda, se essa dimensão constituiria o eixo condutor de nossa trajetória ou a principal razão de ser da pesquisa.

- $\quad$ Na segunda, buscamos compreender como a dimensão da Educação, no que se refere especialmente a perspectivas e finalidades formativas, vem sendo incorporada ou tratada nas pesquisas.

- Na terceira, o recorte é sobre o Conhecimento específico, visando examinar quanto e como é contemplado na produção.

Ao longo de todo o trabalho, essas questões vêm sendo pontuadas e respostas vislumbradas, quer na análise dos estados da arte desenvolvidos por diferentes pesquisadores na área (capítulo 1), quer na contextualização da pesquisa em um panorama mais abrangente (capítulo 2), na análise das áreas temáticas (capítulo 5), dos âmbitos de pesquisa (capítulo 6) e, finalmente, na síntese realizada no primeiro tópico desse capítulo. Pretendemos, nesse momento, retomar e reunir as indagações, dados, resultados, reflexões, interpretações e respostas já sinalizadas nesse percurso, sistematizando-os e analisando-os com um olhar de conjunto mais abrangente.

Observamos primeiramente que as três questões convergem em uma única, já que estão profundamente articuladas. Processos de Ensino-Aprendizagem, Finalidades Educacionais e Objeto de Conhecimento são facetas imbricadas, interdependentes. Do mesmo modo que Pesquisa, Ensino e Física, o campo em que se articulam essas três dimensões, são também instâncias que se combinam de modo complexo em sua unificação. Começamos tratando brevemente uma a uma, dentro das especificidades em que essa pesquisa as tratou, mas dada essa interdependência, ao discutir uma questão, estaremos adentrando nas outras duas.

\section{Primeira Questão}

Entre o Sim e o Não, a conclusão a que chegamos é afirmativa. A ênfase nos Processos de Ensino-Aprendizagem, marca de origem da nossa área... 


\section{...PERMANECE, SOBREVIVE E PREDOMINA.}

Ao longo de toda a trajetória da área, há prevalência do foco no eixo dos Processos de Ensino e Aprendizagem. É o eixo principal. Conduz e rege a pesquisa. E tanto o é que parte expressiva dos estados da arte da PEC ou da PEF a ele se reportam.

A pesquisa em Ensino de Física nasce e vive tendo essa perspectiva: como ensinar melhor, como se aprende melhor. Como combinar meios, métodos, estratégias, abordagens no ensino, questões relativas ao desenvolvimento do sujeito cognoscente (psicologia e epistemologia da aprendizagem) com o objeto de conhecimento específico. Quais esforços e investigações devem ser feitos nessa direção. Essa é a pauta.

Isso é, de certo modo, natural e previsível, característica de uma área de Ensino de "...", que tem como questão central de pesquisa buscar meios de aprimorar o ensino, visando em última instância um melhor aprendizado de “...". Ou seja, não esperaríamos das pesquisas nessa área que o foco central estivesse no tratamento de problemas da Educação, enquanto campo de conhecimento, tampouco do conhecimento específico de Física.

A questão que se coloca é como Ensino e Física se combinam na pesquisa, tendo a perspectiva de "aprimoramento" ou "melhoria" e, ao mesmo tempo, o que significa aprimorar, melhorar.

Quanto ao primeiro ponto. A questão da interdisciplinaridade típica do Ensino de Física pode ser concebida e praticada de distintos modos. E o que queremos salientar ao focalizar essa questão, é uma visão ora explícita, ora implícita, em grande parte da pesquisa acadêmica, ao enfatizar essa dimensão dos "Processos". Trata-se de um modelo concebido por uma justaposição do Ensino com a Física. Justaposição na qual o "Ensino" é representado essencialmente pelos meios e processos, pelas estratégias, métodos e recursos didático-pedagógicos. E a "Física" é predominantemente entendida como conhecimento dado, acumulado, padronizado, inequívoco. A justaposição desses dois elos resulta em uma compreensão do aprimoramento do Ensino de Física como a soma de uma boa didática (ensino) balizada por estudos sobre como o aluno aprende (aprendizagem), com o domínio do conhecimento específico. Trata-se de uma visão que prevalece na área, em diferentes linhas de pesquisa e que, ironicamente, frequentemente é usada para desvalorizar a própria pesquisa em ensino, especialmente por setores acadêmicos da área "dura" de pesquisa em física, que questionam a validade desse campo, com todas as suas linhas, metodologias e práticas. Enfim, um bom ensino de Física se reduziria à sobreposição (ou à soma) de boas técnicas, metodologias, estratégias e didáticas com um bom domínio da Física. 
Quanto ao segundo ponto: a perspectiva implícita de aprimoramento ou melhoria do ensino. Aprimorar e melhorar também são verbos que abrem um "guarda-chuva" de possibilidades e perspectivas. E dentre essas, o que vemos na produção acadêmica é uma preponderância da concepção de "ensino por resultados". Ou seja, de promover a aquisição de conhecimento pelo conhecimento; ensinar Física para que se aprenda Física. Mesmo em algumas das pesquisas que introduzem elementos "do cotidiano", da vivência dos alunos, o uso de materiais e recursos didáticos alternativos, dimensões históricas ou ainda temáticas do mundo contemporâneo, a finalidade principal é o aprendizado da Física. Trata-se de inserir "o mundo" para aperfeiçoar o conhecimento de Física. Diferentemente de se inserir a Física para melhor conhecer e interferir sobre o mundo. Trata-se de aprimorar, mas não transformar. De eficientizar, mas não promover visão crítica.

Tal visão está calcada em um modelo com tradição tecnicista que deu origem à área de pesquisa em Ensino de Física (o DNA) e, ainda que com exceções, resistências e sinalizações de novos modelos e concepções, marcou profundamente seu percurso.

Percebemos, por meio de nossa própria vivência na área, que essa é uma tendência presente não apenas nas dissertações e teses, mas na produção de um modo geral, em publicações, trabalhos apresentados em eventos, em materiais didáticos e propostas curriculares. E, como vimos, não é caso particular da pesquisa em Ensino de Ciências no Brasil, mas é modelo também dominante em âmbito internacional.

Contudo, há que se ressaltar que essa ênfase permanece, sobrevive e predomina...

\section{...MAS MUDA.}

A análise da produção também mostra que no interior desse eixo dominante, há mudanças de enfoques e referenciais. Inicialmente, nos primeiros períodos, esses passam do foco no ensino para o da aprendizagem. Enquanto nas origens da pesquisa não se reflete sobre como o aluno, sujeito do ensino, aprende, apreende, constrói, se apropria ou se relaciona com o conhecimento, logo nos períodos que sucedem essa gênese, essa passa a ser a preocupação e orientação privilegiada.

Nessa perspectiva, lança-se mão especialmente de referenciais da psicologia da aprendizagem, psicologia do desenvolvimento, psicologia cognitiva. Que vão do behaviorismo e da psicologia comportamental, com Skinner, para o cognitivismo e construtivismo, centrados no sujeito do aprendizado, com Piaget e Ausubel. Desses para a inclusão da dimensão sócio-histórica e cultural no desenvolvimento pessoal, com Vygotsky e Lontiev, integrando a relação sujeito-objeto do conhecimento, sujeito-realidade e as interações discursivas. Mudanças que como acentuamos, acompanham referências e tendências do Ensino de Ciências em geral, no Brasil e no mundo. 
Há permanência, portanto, no eixo da psicologia do desenvolvimento como referência dominante no olhar para os processos de ensino e aprendizagem. E há mudanças nos referenciais e aportes que fundamentam esse eixo. Mudanças essas que avançam no sentido de introduzirem novas dimensões filosóficas e epistemológicas, de integrarem nas teorias de aprendizagem, a natureza do ser humano (dimensão ontológica), a validade do conhecimento em função do sujeito cognoscente (dimensão gnosiológica) e aspectos valorativos e éticos (dimensão axiológica), incorporando no processo de ensino-aprendizagem aspectos históricos, epistemológicos e socioculturais.

Ou seja, queremos destacar que na prevalência desse eixo do Ensino-Aprendizagem há mudanças importantes que trazem para o campo das investigações novos olhares para o ensino de Física, que extrapolam o modelo " $A$ + B" - técnica + conhecimento no qual o ensino e o aprendizado são neutros e assépticos, desvinculados do mundo e suas transformações, assim como as transformações da própria Ciência.

Mas queremos também frisar que essa hegemonia nos "Processos" minimiza, desvaloriza e não põe em evidência perspectivas educacionais críticotransformadoras, limitando-se na essência ao "como" e não ao "por quê, para quê, para quem e o quê" ensinar-aprender. E, assim, já entramos no domínio da segunda questão, sobre como vem sendo inserida ou contemplada a perspectiva educacional nas pesquisas.

\section{Segunda Questão}

Ainda que a investigação de tal questão tenha nos apresentado dificuldades metodológicas, pudemos extrair indícios e sinais importantes. Em primeiro lugar, concepções de educação, referenciais e objetivos educacionais não são explicitados em grande parte das pesquisas. Quando são, especialmente nas introduções ou resumos dos trabalhos, não necessariamente voltam a ser contemplados ou são coerentes e condizentes com o desenvolvimento da pesquisa.

Aspecto esse que já é revelador, pois a própria ausência dessa preocupação nos leva a duas suposições. Ou se está preterindo os objetivos formativos, ou se estão subentendo alguns. Essa segunda hipótese nos parece mais pertinente. Ou seja, no desenvolvimento das pesquisas, as finalidades do ensino seriam pressupostos tácitos, que não precisam ser explicitados. Nessa linha, é de se supor que se alguma perspectiva educacional é questão dada e naturalizada ou "óbvia", não demandando reflexão, muito possivelmente trata-se da ideia de que o objetivo do ensino de física é acima de tudo "ensinar física". Trata-se, portando, do modelo ao qual nos referimos na primeira questão, de um ensino propedêutico, com vistas à aquisição de conhecimentos e a uma "formação científica" também tacitamente conceituada. 
O que não descarta a primeira suposição. A não relevância em explicitar ou conduzir a pesquisa, na direção de finalidades desejadas e de sua inserção social, também sinalizaria que sua motivação principal não é delimitar quais perspectivas pretende atender, que cidadão pretende formar, que tipo de formação pretende priorizar.

Contudo, "para não dizer que não falei das flores", há flores. Há sinalizações nessa direção. Mas são poucas e episódicas, como pudemos ver. Em todos os períodos demarcados, especialmente mais no passado que no presente, e aqui precisamos frisar nosso recorte ao objeto de estudo - dissertações e teses - verificamos a presença de produções que demarcam, explicitam e desenvolvem a pesquisa em uma perspectiva educacional crítica e transformadora, como são aquelas que se aproximam da linha freireana ou, ainda outras que estabelecem como expectativa de orientação do ensino, a formação "para a cidadania". No entanto, ao longo da evolução da área, essas orientações parecem ter sido afogadas e suplantadas pela hegemonia das tendências predominantes (questão 1) e, ousaria afirmar, por um modismo instaurado e cristalizado nas pesquisas, ao qual voltaremos adiante, no tratamento de nossa quarta questão.

Podemos sistematizar, quanto a essa dimensão, três linhas ou tendências não necessariamente seguindo ordem cronológica e não necessariamente explicitadas e justificadas.

A primeira, calcada no modelo tradicional e tecnicista já delineado, do conhecimento por ele próprio, do aprendizado de Física pela Física, do ensino propedêutico, do aprimoramento do ensino e da aprendizagem pelo maior domínio do conhecimento e eficiência dos métodos.

A segunda, na perspectiva da formação de "cidadania", que introduz a necessidade de incorporar no ensino elementos do cotidiano ou do mundo contemporâneo, de contextualizá-lo, de promover a interdisciplinaridade, de tratar de temáticas atuais. Incluem-se aqui parte dos trabalhos referenciados nas abordagens CTS(A) ou na alfabetização científica, parte dos trabalhos que se dizem baseados nos Parâmetros Curriculares Nacionais ( $\mathrm{PCN}$ e $\mathrm{PCN}+$ ), parte dos trabalhos que tratam da inserção da Física Moderna no ensino básico, parte dos trabalhos na linha da História e Filosofia da Ciência, entre outros. São pesquisas que trazem o contexto para o processo de ensino-aprendizagem, que se preocupam com o sentido ou significado do conhecimento para o aluno. Entretanto não sinalizam claramente perspectivas críticas no sentido de uma formação cidadã transformadora, restingindo-se de certa forma ao aprimoramento do aprendizado científico.

Ressalvamos aqui que se tratam de "parte" das linhas de pesquisas exemplificadas, porque não são todas. Também destacamos que, a partir de um certo momento, especialmente "pós-PCN", "pós-ENEM" ou após a LDB/96, essa tendência cresceu e 
nela há trabalhos autênticos e condizentes com essa finalidade. Há outros que a ela se reportam em resumos e apresentações, mas não "cumprem" ou são coerentemente desenvolvidos com esse aceno.

E a terceira, seria uma tendência crítico-transformadora presente em pesquisas que explicitam concepções e finalidades educacionais na direção da apropriação crítica do conhecimento, da ressignificação do ensino visando também uma formação cidadã, mas comprometida com perspectivas e transformações sociais. Explicitam a "quê" vieram, tratam de problematizar a seleção e o tratamento de conteúdos e, em alguns casos, concepções de Ciência.

No conjunto do universo analisado, a primeira é predominante em todos os períodos.

\section{Terceira Questão}

Quanto a esse aspecto, presença e natureza do conhecimento específico, pudemos constatar, em primeiro lugar, que a partir do final dos anos noventa, início da primeira década de 2000, o conhecimento científico ou físico vem sendo preterido na produção da área. Há claramente uma propensão ao distanciamento da dimensão científica enquanto objeto disciplinar. $\mathrm{Na}$ "dupla-hélice" Ensino-Física, está se focalizando sobretudo o Ensino em detrimento da Física. Na interdisciplinaridade desses dois campos, estaria havendo um deslocamento. Isso vem se manifestando por um alargamento das fronteiras na dimensão do ensino, especialmente no âmbito dos processos de ensino-aprendizagem. A produção analisada parece indicar uma sobre-atenção em reiterar e aperfeiçoar modelos, teorias e referenciais nesse âmbito, os quais dariam conta do ensino de Ciências de uma maneira geral e não só desse, mas de conhecimentos ainda mais abrangentes. Tal tendência estaria sinalizando que, ao aprofundar as teorias de aprendizagem, ao estendê-las a campos de saber da psicologia, filosofia, epistemologia, antropologia, as especificidades do conhecimento científico não teriam um peso relativo relevante, ou mais que isso, não necessariamente precisariam "compor" com a dimensão do ensino, o que reafirma a tese do "DNA" da área. Permanecemos no "como", nos afastamos do "o quê" e "para quê".

Ao mesmo tempo, verificamos que de um modo geral, quando esse conhecimento específico está contemplado, predomina a concepção do conhecimento dado, não problematizado, ou seja, a já referida visão sinalizada ao longo desse trabalho, de que Física é Física, "massa é massa", coerentemente com a tendência de não problematização das perspectivas educacionais. A naturalização do conhecimento acompanha, pois a naturalização dos objetivos do ensino.

Investigações que se orientam em outras perspectivas, que compreendem uma íntima relação entre o ensino de ciências/física com as ciências/física são 
esporádicas. Ao mesmo tempo, vez ou outra estão implícitas. É o caso, por exemplo, de pesquisas que tratam de contemplar e introduzir na seleção de conteúdos, novas temáticas do mundo contemporâneo em que a Física toma parte (nas vertentes da formação para cidadania e da educação crítica).

Essas constatações e interpretações evidenciam que "a preocupação com qual física ensinar", (quando e para quê) não é foco de investigação e reflexão relevante em quase todo o percurso da área.

Também observamos que trabalhos identificados na interface desses dois eixos Educação-Conhecimento são os que buscam uma perspectiva crítica do ensino, da pesquisa em ensino e da própria ciência ou atividade científica. Em outras palavras, a (re)significação da pesquisa em "ensino de..." , assim como o próprio "ensino de..." se dá nessa articulação das finalidades do ensino com o objeto de ensino (...). Isso não significa que a dimensão dos "processos de ensino-aprendizagem" não se articule a tais perspectivas. Ao contrário, deveriam estar articuladas, já que escolhas de abordagens, estratégias, métodos ou recursos didático-pedagógicos e investigações sobre como se dá o aprendizado ou como o conhecimento se constrói e tem sentido para o aluno, não são neutras e assépticas. Dependem de concepções de ensino, de valores humanos ou "competências" que se pretende desenvolver e, em nosso caso, da visão de ciência que se almeja construir (ou desconstruir).

Enfim...

A hegemonia dos "processos" vem preterindo dimensões educacionais e formativas, ao mesmo tempo que o próprio objeto do aprendizado, o conhecimento científico. Essas duas dimensões (educação e conhecimento), como também destacamos, caminham lado a lado, estão profundamente relacionadas. Não há como explicitar intenções formativas em um campo de saber sem privilegiar e adentrar no próprio campo. Não há como fazer escolhas na seleção dos objetos de ensino sem ter em vista tais intenções. $E$, finalmente não haveria como privilegiar meios e estratégias de ensino, assim como estudos sobre a aprendizagem sem apontar para qual objeto e objetivos de ensino.

Podemos concluir que, entre as permanências e mudanças observadas no conjunto do trabalho, a hegemonia da interface "Conhecimento-Processos", sendo o primeiro com "c" minúsculo e o segundo com " $\mathrm{P}$ " maiúsculo, evidencia que...

...as ciências são tomadas como conhecimento não problematizado, assim como os objetivos educacionais são aqueles estabelecidos pela matriz construtivista mais ampla. (MENEZES, KAWAMURA, HOSOUME, 1997) 


\section{Quarta Questão}

A quarta questão que trouxemos para investigar diz respeito à necessidade de reconhecimento e legitimação da área e como isso influencia e determina rumos e opções da pesquisa. Mesmo que de natureza diferente das questões anteriores, de certo modo a elas está vinculada.

Vejamos. É autêntica e legítima a necessidade de reconhecimento de um campo de saber, de uma área de pesquisa. Sem ele, perde-se visibilidade e espaço de penetração. Particularmente no que tange à educação, setor essencial no desenvolvimento social de um país. Porém... Porém sabemos que tal legitimação passa por atender demandas que ditam as normas e prioridades de uma Política, ou de umas Políticas. Políticas públicas, políticas sociais, políticas econômicas, políticas científicas, políticas políticas.

É interessante observar que essa é uma preocupação desde suas origens. No entanto, sua natureza e motivações vêm mudando. Na década de 1970, quando a área começava a ser institucionalizada por meio da criação de cursos de Pós-Graduação, havia uma grande necessidade de enfrentar resistências de diferentes ordens e campos. Em particular, a instauração desses cursos em Departamentos e/ou Institutos de Física trazia questionamentos à pesquisa em Ensino, especialmente por acenar uma descaracterização e um afastamento das suas tradições de pesquisa (em Física). Críticas de diferentes tipos eram apresentadas. Do ponto de vista metodológico, por exemplo, a falta de objetividade ou de rigor científico. Do ponto de vista dos focos de estudo, o "temor" de se distanciar de um conhecimento científico "sério" ou de qualidade. De outro lado, da parte dos educadores, também se apresentavam objeções quanto aos fundamentos nas teorias da educação.

Sobre esse quadro de resistências e atritos nos períodos iniciais da área, Villani (1981) destaca entre os argumentos por parte de alguns Físicos:

... Que o crescimento da área, pelo menos em alguns centros, era "anormal", e levantava a perspectiva de descaracterização dos Institutos de Física nos quais se realizava, afastando-os da sua tradição de pesquisa: uma posição mais radical negava a legitimidade da existência de um grupo de pesquisa em ensino num Instituto de Física, mesmo em se tratando de um grupo pequeno. (VILLANI, 1981, p.70-71)

E da parte dos educadores,

Não se pense que a pesquisa em Ensino de Física fosse recebida com apoio incondicional por parte dos educadores: ao contrário se frizava que as bases teóricas educacionais dos trabalhos na área eram fracas e sobretudo que faltava uma inserção desses trabalhos dentro do contexto geral das pesquisa em Educação. (VILLANI, 1981, p.71) 
Nesse momento pesquisadores na área precisaram "afinar" seus discursos e ações no enfrentamento dessas críticas e de afirmação de identidade.

Mais recentemente, ainda que esse tipo de resistência ainda esteja vivo em algumas instituições, com a expansão da área em inúmeros centros de ensino superior, com a elevada produção e uma comunidade estabelecida e, particularmente com o reconhecimento de sua existência pela CAPES, o esforço da área por se legitimar ganhou outros contornos.

Uma vez reconhecida academicamente, a questão da identidade não é central. Como vimos (no capítulo 1) há uma espécie de consenso tático (ou estratégico) de que existimos e temos identidade própria. Não necessitamos "afinar" o discurso sobre "quem somos, o que pesquisamos". Contudo, precisamos nos enquadrar em um modelo estabelecido de pesquisa acadêmica. Modelo particularmente ditado pelas políticas de fomento ao ensino superior e às pós-graduações. Políticas que orientam o quê e como direcionar a pesquisa, o quê privilegiar. Quanto a esse direcionamento, claras têm sido as evidências de incentivo ao "produtivismo", que prioriza a quantidade acima da qualidade. Volume da produção, das publicações, dos "papers", das citações. Direta ou indiretamente essa tendência tem efeitos sobre "o quê pesquisar". Ou seja, ao privilegiar a quantidade, acaba por privilegiar também linhas de pesquisa que têm sido reconhecidas e legitimadas em cada campo, nacional e sobretudo internacionalmente. Direcionamento que leva a um modismo e à importação (e exportação) acrítica de tendências globais. A "qualidade" a serviço da quantidade. E aqui, ressaltamos um particular modismo "metodológico".

Evidencia-se, nas últimas décadas a necessidade, acima de tudo, de se apresentar, citar, explicitar os chamados "referenciais teóricos". Nomes, títulos e datas. Não importa muito se condizentes com a pesquisa, se substanciados em profundidade, se criativos, dinâmicos, críticos, novos. Ao contrário, quando muito díspares do padrão instaurado no campo, são preteridos. Assim, as linhas de pesquisa na nossa particular área têm sido "amarradas" às tendências globais e predominantes, para as quais há maior espaço de publicação e participação nos eventos nacionais e internacionais.

Gamboa (1998) enfatiza esse problema com bastante propriedade.

Dentro dessa preocupação, estudos recentes identificam, problemas tais como: o formalismo acadêmico, onde a intenção não é produzir novos conhecimentos e sim cumprir uma exigência de titulação; o "ritualismo metodológico" e o modismo teórico que predominam particularmente nos Centros de PósGraduação, responsáveis pela formação de pesquisadores; a presença, progressivamente mais intensa, de tentativas ecléticas que juntam aleatoriamente técnicas, métodos e referenciais teóricos sem uma clara compreensão dos fundamentos epistemológicos e das implicações filosóficas dos 
diversos caminhos do conhecimento; a influência, ainda forte, dos manuais de pesquisa que "ensinam" técnicas de coleta, organização, análise de dados, sugerem receitas e modelos que, na sua maioria, se enquadram nos delineamentos, procedimentos e sistematizações próprios de uma concepção positivista de ciência e assumem a defesa do "método científico", rigoroso e objetivo. (GAMBOA, 1998, p. 8)

Acreditamos que o "ritualismo metodológico" e o "modismo teórico" a que se refere Gamboa têm produzido efeitos (ou defeitos) às nossas pesquisas com impactos mais negativos do que positivos, pois que estariam intensificando o mencionado distanciamento da razão de ser (ou da razão de "deveria" ser) de uma pesquisa em Ensino, isto é, de uma dimensão formativa, humana, alicerçada em uma perspectiva educacional para o nosso país.

Interessante notar como, especialmente nesse aspecto, nos aproximamos da área de Pesquisa em Física. Nas origens da Pesquisa em Ensino, esse era um parâmetro que nos diferenciava essencialmente das ditas áreas "duras". Como observa Villani (1981), no início da década de 1980, referindo-se à Pesquisa em Física.

... Quando pessoas trabalham, em lugares diferentes, no mesmo assunto e com praticamente os mesmos recursos técnicos e científicos, é fácil entender a corrida à publicação mais rápida, ao cálculo mais imediato ou ao experimento mais tranqüilo para o aumento do curriculum individual; isso porque além de uma universalização das pesquisas, existe uma universalização do critério de avaliação que, pela dificuldade e diversidade dos trabalhos e pelo grande número de pessoas envolvidas, tem que ser às vezes meramente quantitativo $e$ reduzir-se ao número de trabalhos publicados ou até ao seu número de páginas. (VILLANI, 1981, p.76)

Como contraponto no que concernia à Pesquisa em Ensino, aponta diferenças, mas já antecipa criticamente semelhanças.

Finalmente, no que diz respeito à produtividade da área, a situação é sem dúvida diferente da pesquisa em Física, pelo menos aqui no Brasil: em primeiro lugar o número de pesquisadores é muito menor; em segundo lugar as fontes de financiamento são mais limitadas, e consequentemente a possibilidade de dedicação integral 'pesquisa é bem mais precária; em terceiro lugar as pesquisas têm refletido inúmeras vezes problemas locais sem uma correspondente continuidade e com conseqüente desgaste em termos de preparação e tempo. No entanto, na medida em que se tem criado grupos de pesquisas ligados a instituições estáveis, partilhando uma metodologia e adaptando objetivos importados das universidades e centros educacionais do hemisfério norte, temse tido uma produtividade maior; resta a dúvida quanto a importância destes trabalhos e sua significação social. (VILLANI, 1981, p. 79-80) 
Ainda quanto à tendência produtivista cada vez mais instaurada de conferir mérito à quantidade, há que se ressaltar que é efeito de uma política ampla, em distintas áreas. Sobre esse "fenômeno" e, em particular na área de Educação, Kuenzer e Moraes (2005) chamam atenção.

...Por outro lado, as exigências relativas à produção acadêmica geraram o seu contrário: um verdadeiro surto produtivista em que o que conta é publicar, não importa qual versão requentada de um produto, ou várias versões maquiadas de um produto novo. A quantidade institui-se em meta. Deste modo, formas legítimas de produção, como co-autorias e organizações de coletâneas - em inúmeros casos produtos de sólidas pesquisas integradas -, banalizaram-se no âmbito de algumas áreas de conhecimento, entre elas a Educação. No caso das coletâneas, nota-se, muitas vezes, tendência a um ensaísmo que longe está do necessário avanço na construção de uma produção consolidada e orgânica acerca dos objetos de investigação. No das co-autorias, em particular a de docentes com discentes e em trabalhos completos em eventos, alguns exageros "não permitem que se possa aferir o que é resultado de investigação específica de docente, de discentes ou de efetiva co-autoria" (CAPES, Documento da área de Educação). Dessa forma, o incentivo para que orientadores e orientandos publiquem juntos, a partir de uma crescente participação do corpo discente nos projetos de pesquisa dos orientadores desvirtua-se, reduzindo-se a um incansável roteiro de sucessivas apresentações em eventos, no exterior e no país. (KUENZER e MORAES, 2005)

Enfim, respondemos a essa quarta questão afirmando que hoje, com identidade já demarcada, com comunidade estabelecida, com reconhecimento de órgãos de fomento, estamos cada vez mais nos submetendo às políticas de financiamento, vestidos em "camisas-de-força" que solicitam um produtivismo (palavra que não comparece nos dicionários de língua portuguesa, mas que pedimos licença de utilizar e sugerir, por ter um sentido diferente de produtividade) cego e, a nosso ver, improdutivo na perspectiva da criação, da inovação, da qualidade, da autonomia de pesquisa e sobretudo da contribuição social que uma pesquisa em ensino poderia (e deveria) almejar.

\subsection{Sistematização e considerações finais}

Encerramos esse capítulo (quase) final, no qual reunimos e sistematizamos dados, resultados, hipóteses, questões, respostas, análises, sínteses e outros elementos do conjunto do trabalho. Para encerrar essa retomada, apresentamos um quadro-síntese geral no qual buscamos inserir os elementos que consideramos mais significativos que caracterizam a evolução de nossa área, especialmente reunindo as primeiras sínteses, apresentadas no capítulo dois, que abarcam aspectos mais amplos dessa 
evolução, com essa última, que tratou mais especificamente da evolução das "ideias", dos focos e dimensões da pesquisa em ensino de Física.

Para melhor compreender os elementos do quadro, apresentamos as duas etapas em que foi construído. Na primeira (Quadro 8.2), apresentamos uma combinação e justaposição mais detalhada, dos quadros apresentados no capítulo dois (evolução na perspectiva histórica da educação e evolução da área de Ensino de Ciências) com a síntese apresentada nesse capítulo (Quadro 8.1). Na segunda (Quadro 8.3), apresentamos uma síntese do anterior.

Mais uma vez grifamos que se trata de um quadro com super e sobreposições, com intersecções e também contradições que são próprios de todo campo de conhecimento e, em especial desse nosso, que não apenas agrega uma ampla diversidade de saberes, mas, principalmente, tem uma vocação e natureza se não controversa, sujeita a olhares e perspectivas distintas, com protagonistas também com convicções, objetivos e vivências diversificados.

Também ressaltamos que nos diferentes períodos em que essa sistematização é feita, apresentamos aquilo que se destaca ou se apresenta como "novo" em dado momento, o que não significa ser predominante. Entendemos que elementos novos, particularmente no campo da pesquisa, ainda que pouco frequentes podem ter significados importantes, sinalizando que não estamos em um universo totalmente hegemônico, dado e imutável. É uma esperança, vontade ou necessidade de sobrevivência que alimentamos. 


\begin{tabular}{|c|c|c|c|c|c|}
\hline \multicolumn{2}{|c|}{ INÍCIO DE 70 ATÉ MEADOS DE 80} & \multirow{2}{*}{$\begin{array}{c}\text { MEADOS DOS } 80 \text { E ANOS } \\
90 \\
\begin{array}{c}\text { Meados dos anos } 80- \\
\text { início dos anos } 90\end{array}\end{array}$} & \multicolumn{2}{|c|}{$\begin{array}{c}\text { FINAL DOS } 90 \\
\text { E INÍCIO DA DÉCADA DE } 2000\end{array}$} & \multirow{2}{*}{$\begin{array}{c}\text { SEGUNDA METADE DA } \\
\text { DÉCADA DE } 2000 \\
\begin{array}{c}\text { Segunda metade da } \\
\text { década de } 2000\end{array}\end{array}$} \\
\hline Anos 70 & $\begin{array}{c}\text { Início - } \\
\text { meados dos anos } 80\end{array}$ & & $\begin{array}{l}\text { Meados a final dos anos } \\
\qquad 90\end{array}$ & $\begin{array}{l}\text { Primeira metade da } \\
\text { década de } 2000\end{array}$ & \\
\hline \multicolumn{2}{|c|}{$\begin{array}{l}\text { Segundo grau: Científico para todos. } \\
\text { Reforma Universitária. } \\
\text { Ensino Profissionalizante. } \\
\text { Lic. Curta / Ciência Integrada }\end{array}$} & $\begin{array}{l}\text { “Educação para todos” } \\
\text { Novas experiências } \\
\text { educacionais } \\
\text { Expansão do ensino } \\
\text { superior privado. } \\
\text { Centros e Associações } \\
\text { (ANPED, ANDES...) }\end{array}$ & $\begin{array}{l}\text { Modelo neo- liberal: } \\
\text { avaliações } \\
\text { Educação de Jovens e } \\
\text { Adultos } \\
\text { Ensino Profissionalizante }\end{array}$ & $\begin{array}{l}\text { LDB/96, PCNs, } \\
\text { ENEM } \\
\text { Diretrizes na Formação de } \\
\text { professores }\end{array}$ & $\begin{array}{l}\text { Novas formas de ingresso } \\
\text { no Ensino Superior } \\
\text { (“Novo ENEM”, SISU, } \\
\text { ENADE, ProUni) } \\
\text { IFETs } \\
\text { Educação tecnológica } \\
\text { Educação Especial }\end{array}$ \\
\hline \multicolumn{2}{|c|}{$\begin{array}{l}\text { Grupos de Ensino } \\
\text { Projetos de Ensino Nacionais } \\
\text { Primeiras Pós-Graduações em EF }\end{array}$} & $\begin{array}{l}\text { Núcleos de Ensino } \\
\text { Expansão das Pós- } \\
\text { Graduações (Educação) }\end{array}$ & $\begin{array}{l}\text { Expansão do número de } \\
\text { Instituições com programas } \\
\text { de PG em EF }\end{array}$ & $\begin{array}{l}\text { Criação da Área de Ensino } \\
\text { de Ciências e Matemática } \\
\text { (CAPES) }\end{array}$ & $\begin{array}{l}\text { Mestrados profissionais } \\
\text { Expansão de Programas de } \\
\text { Pós-Graduações em EF e EC }\end{array}$ \\
\hline $\begin{array}{l}\text { Seção de Ensino da RBF } \\
\text { Primeiro SNEF (70) }\end{array}$ & $\begin{array}{l}\text { REF (79/86) } \\
\text { Cad. Cat. Ens. Fis. (83) }\end{array}$ & $\begin{array}{l}\text { RBEF (87) } \\
\text { Primeiro EPEF (86) }\end{array}$ & $\begin{array}{l}\text { ABRAPEC } \\
\text { Primeiro ENPEC (1997) }\end{array}$ & $\begin{array}{l}\text { Novas Publicações } \\
\text { Cad. Bras. Ens. Fis. (2001) }\end{array}$ & $\begin{array}{l}\text { Diversificação das } \\
\text { publicações (Temáticas) } \\
\text { Encontros temáticos }\end{array}$ \\
\hline $\begin{array}{l}\text { Disciplina de } \\
\text { Instrumentação para o } \\
\text { Ensino(na Licenciatura) }\end{array}$ & & $\begin{array}{l}\text { Projetos SPECT } \\
\text { /CAPES/PADCT de } \\
\text { formação continuada } \\
\text { GREF nas FE }\end{array}$ & Didática das Ciências & $\begin{array}{l}\text { Ações de Extensão e } \\
\text { Divulgação se deslocam } \\
\text { para a Pós-Graduação }\end{array}$ & $\begin{array}{l}\text { Ensino a Distância } \\
\text { (Formação inicial e } \\
\text { continuada) }\end{array}$ \\
\hline
\end{tabular}


Predominâncias: Foco central nos processos de aprendizagem; Características do aluno contempladas; Conhecimento científico dado; Finalidades formativas e concepções de educação implícitas, não relevantes.

\begin{tabular}{|c|c|c|c|c|c|}
\hline \multicolumn{2}{|c|}{$\begin{array}{l}\text { Professor é condutor do processo de ensino, de } \\
\text { acordo com teorias de aprendizagem }\end{array}$} & \multicolumn{2}{|c|}{$\begin{array}{l}\text { Professor é figura central, detector dos procedimentos } \\
\text { da didática específica }\end{array}$} & \multicolumn{2}{|c|}{$\begin{array}{l}\text { Professor é figura central, com identidade e } \\
\text { autonomia (teórica) }\end{array}$} \\
\hline $\begin{array}{l}\text { Foco no ensino. } \\
\text { Psicologia } \\
\text { Comportamentalista/Be } \\
\text { haviorismo. Skinner. } \\
\text { Materiais e Métodos. } \\
\text { Projetos de Ensino. } \\
\text { Experimentação. }\end{array}$ & $\begin{array}{l}\text { Do Ensino para } \\
\text { Aprendizagem. } \\
\text { Psicologia cognitiva } \\
\text { Construtivismo } \\
\text { Concepções espontâneas. } \\
\text { Psicogênese. } \\
\text { (Piaget, Ausubel, Viennot) }\end{array}$ & $\begin{array}{l}\text { Foco na aprendizagem, com } \\
\text { De Concepções Espontânea } \\
\text { Conceituais. }\end{array}$ & $\begin{array}{l}\text { nelementos de ensino. } \\
\text { Is para Mudanças }\end{array}$ & $\begin{array}{l}\text { Perfil conceitual. } \\
\text { Abordagens sócio- } \\
\text { interacionistas } \\
\text { (Vygotsky) } \\
\text { TICs }\end{array}$ & $\begin{array}{l}\text { Abordagens sócio- } \\
\text { interacionistas; } \\
\text { socioculturais. } \\
\text { Linguagem, interações } \\
\text { discursivas. } \\
\text { (Vygotsky, Lontiev, } \\
\text { Toulmin) } \\
\text { Aprendizagem inclusiva; } \\
\text { questões de "gênero" }\end{array}$ \\
\hline $\begin{array}{l}\text { Conhecimento pelo } \\
\text { conhecimento. } \\
\text { Transmissão de } \\
\text { conhecimentos. } \\
\text { Positivismo/empirismo. } \\
\text { Conhecimento } \\
\text { específico explícito. } \\
\text { Tradicional; dado. } \\
\text { Aluno impessoal }\end{array}$ & $\begin{array}{l}\text { Conhecimento pelo } \\
\text { conhecimento. } \\
\text { Ciência como construção. } \\
\text { Conhecimento específico } \\
\text { explícito } \\
\text { Aluno é sujeito da } \\
\text { aprendizagem. }\end{array}$ & $\begin{array}{l}\text { Acenos para educação } \\
\text { crítica. Paulo Freire/ } \\
\text { problematização do } \\
\text { conhecimento. } \\
\text { Dimensão histórica, } \\
\text { filosófica e cultural } \\
\text { Formação de professores } \\
\text { (formação inicial; papel do } \\
\text { professor) } \\
\text { Aluno é sujeito, mediado } \\
\text { pelo objeto }\end{array}$ & $\begin{array}{l}\text { Acenos para seleção e } \\
\text { problematização de } \\
\text { conteúdos. } \\
\text { Educação não formal. } \\
\text { Dimensão histórica/ } \\
\text { filosófica no auge. } \\
\text { Formação de professores } \\
\text { (Prática docente) } \\
\text { Aluno é sujeito, mediado } \\
\text { pelo objeto e contexto. }\end{array}$ & $\begin{array}{l}\text { Educação para cida } \\
\text { Novas temáticas ( } n \\
\text { CTS } \\
\text { História da Ciência } \\
\text { Maior abrangência } \\
\text { conhecimento esp } \\
\text { Distanciamento da } \\
\text { Aluno é sujeito, me } \\
\text { cultural. }\end{array}$ & $\begin{array}{l}\text { ciência contemporâneos) } \\
\text { curso didático. } \\
\text { demandistanciamento do } \\
\text { elo objeto e contexto sócio- }\end{array}$ \\
\hline
\end{tabular}

Quadro 8.2: Aspectos evolutivos da área de Ensino de Ciências 


\begin{tabular}{|c|c|c|c|c|c|}
\hline \multicolumn{2}{|c|}{ INÍCIO DE 70 ATÉ MEADOS DE 80} & \multirow{2}{*}{$\begin{array}{l}\text { MEADOS DOS } 80 \mathrm{E} \\
\text { ANOS } 90 \\
\text { Meados dos anos } 80- \\
\text { início dos anos } 90\end{array}$} & \multicolumn{2}{|c|}{ FINAL DOS 90 E INÍCIO DA DÉCADA DE 2000} & \multirow{2}{*}{$\begin{array}{l}\text { SEGUNDA METADE DA } \\
\text { DÉCADA DE } 2000 \\
\text { Segunda metade da década } \\
\text { de } 2000\end{array}$} \\
\hline Anos 70 & $\begin{array}{l}\text { Início-meados dos } \\
\text { anos } 80\end{array}$ & & $\begin{array}{l}\text { Meados a final dos anos } \\
90\end{array}$ & $\begin{array}{l}\text { Primeira metade da } \\
\text { década de } 2000\end{array}$ & \\
\hline \multicolumn{2}{|c|}{$\begin{array}{l}\text { Segundo grau: Científico para todos. Reforma } \\
\text { Universitária. Projetos de Ensino Nacionais Grupos } \\
\text { de Ensino de Física e Primeiras Pós em EF }\end{array}$} & $\begin{array}{l}\text { Educação para todos } \\
\text { Núcleos de EF Expansão } \\
\text { PG(Educação) }\end{array}$ & $\begin{array}{l}\text { Expansão da escola } \\
\text { Modelo neoliberal } \\
\text { Avaliações Expansão da } \\
\text { PG em EF }\end{array}$ & $\begin{array}{l}\text { LDB/96, PCNs, ENEM } \\
\text { Diretr Form. de } \\
\text { Professores Criação da } \\
\text { Área na CAPES }\end{array}$ & $\begin{array}{l}\text { Expansão do acesso ao ES } \\
\text { Novo ENEM Mestrados } \\
\text { profissionais Expansão das } \\
\text { PGs }\end{array}$ \\
\hline \multicolumn{2}{|c|}{$\begin{array}{l}\text { Identidade do Ensino nas instituições de Física } \\
\text { Publicações e Encontros em EF }\end{array}$} & $\begin{array}{l}\text { Publicações e Encontros } \\
\text { em Pesquisa em EF }\end{array}$ & $\begin{array}{l}\text { Publicações e Encontros } \\
\text { em Pesquisa em EC }\end{array}$ & $\begin{array}{l}\text { Novas publicações em } \\
\text { EC }\end{array}$ & $\begin{array}{l}\text { Diversificação e publicações e } \\
\text { encontros em EC (temáticos) }\end{array}$ \\
\hline \multicolumn{2}{|c|}{$\begin{array}{l}\text { Disciplina de Instrumentação para o Ensino (nos } \\
\text { cursos de Licenciatura) }\end{array}$} & $\begin{array}{l}\text { Didática das ciências } \\
\text { Projetos SPECT } \\
\text { formação continuada, } \\
\text { GREF }\end{array}$ & \multicolumn{2}{|c|}{$\begin{array}{l}\text { Ações de Extensão e Divulgação se deslocam para a } \\
\text { Pós-Graduação }\end{array}$} & $\begin{array}{l}\text { Ensino a Distância (Formação } \\
\text { inicial e continuada) }\end{array}$ \\
\hline $\begin{array}{l}\text { Foco no ensino. Psic. } \\
\text { Comportamental. } \\
\text { Materiais e Métodos. } \\
\text { Experimentação. }\end{array}$ & $\begin{array}{l}\text { Do Ensino para } \\
\text { Aprendizagem. } \\
\text { Construtivismo } \\
\text { Concepções } \\
\text { espontâneas. }\end{array}$ & \multicolumn{2}{|c|}{$\begin{array}{l}\text { Foco na aprendizagem, com elementos de ensino. } \\
\text { De Concepções Espontâneas para Mudanças } \\
\text { Conceituais. }\end{array}$} & $\begin{array}{l}\text { Sócio-interacionismo } \\
\text { (Vygotsky) Perfil } \\
\text { conceitual TICs }\end{array}$ & $\begin{array}{l}\text { Sócio-interacionismo } \\
\text { sociocultural Aprendizagem } \\
\text { inclusiva;" }\end{array}$ \\
\hline \multicolumn{2}{|c|}{ Professor é condutor e intermediário } & \multicolumn{2}{|c|}{ Professor é central, com didática específica } & \multicolumn{2}{|c|}{ Professor é central, com identidade e autonomia } \\
\hline Aluno impessoal & $\begin{array}{l}\text { Aluno é sujeito da } \\
\text { aprendizagem }\end{array}$ & $\begin{array}{l}\text { Aluno é sujeito, mediado } \\
\text { pelo objeto }\end{array}$ & $\begin{array}{l}\text { Aluno é sujeito, mediado } \\
\text { pelo objeto e contexto }\end{array}$ & \multicolumn{2}{|c|}{$\begin{array}{l}\text { Aluno é sujeito, mediado pelo objeto e contexto sócio- } \\
\text { cultural }\end{array}$} \\
\hline $\begin{array}{l}\text { Conhecimento explícito } \\
\text { tradicional, dado } \\
\text { Transmissão de } \\
\text { conhecimentos. } \\
\text { Positivismo/empirismo. }\end{array}$ & $\begin{array}{l}\text { Conhecimento pelo } \\
\text { conhecimento. } \\
\text { Conhecimento } \\
\text { específico explícito }\end{array}$ & $\begin{array}{l}\text { Acenos para educação } \\
\text { crítica. Paulo Freire/ } \\
\text { Ciência como } \\
\text { construção Formação de } \\
\text { professores }\end{array}$ & $\begin{array}{l}\text { Acenos para seleção e } \\
\text { problematização } \\
\text { Educação não formal. } \\
\text { Dimensão hist./ } \\
\text { filosófica (Prática } \\
\text { docente) }\end{array}$ & \multicolumn{2}{|c|}{$\begin{array}{l}\text { Novas temáticas (mundo e ciência contemporâneos) } \\
\text { Educação para cidadania. CTS História da Ciência como } \\
\text { recurso didático. Maior abrangência temática com } \\
\text { distanciamento do conhecimento específico }\end{array}$} \\
\hline \multicolumn{2}{|c|}{$\begin{array}{l}\text { Institucionalização do Ensino de Física na } \\
\text { comunidade dos físicos }\end{array}$} & $\begin{array}{l}\text { Institucionalização da } \\
\text { Pesquisa em Ensino de } \\
\text { Física } \\
\end{array}$ & \multicolumn{2}{|c|}{$\begin{array}{l}\text { Institucionalização da Pesquisa em Ensino de } \\
\text { Ciências }\end{array}$} & $\begin{array}{c}\text { Diversificação e expansão da } \\
\text { Pesquisa em Ensino de } \\
\text { Ciências }\end{array}$ \\
\hline
\end{tabular}

Quadro 8.3: Quadro-Síntese - Aspectos evolutivos do Ensino de Ciências 
Entendemos que esse quadro, com elementos justapostos de contextos e âmbitos diversos, é mais que um ponto de chegada. Configura-se como ponto de partida para um possível aprofundamento, que incorpore novos olhares e contribuições.

Na linha final desse quadro, destacamos que ao longo desse percurso de quatro décadas, do ponto de vista de seu campo, comunidade e institucionalização, a área de Ensino de Física passou por três grandes momentos: nos anos setenta, com a criação dos então chamados "grupos de ensino" inseridos nos institutos ou departamentos de Física; a partir de meados a década de 80 , a pesquisa propriamente na área passa a se institucionalizar e ganhar dimensões nacionais e, a partir do final da década de 90, passa a ser parte de um campo maior que se instaura, a pesquisa em Ensino de Ciências. No período final, segunda metade da década de 2000, essa última (PEC) é consolidada, cresce e passa também a ser amplamente reconhecida como um campo de pesquisa. Nesse movimento, a pesquisa em Ensino de Física passa a ter características e focos de interesse já inseridos nesse campo mais abrangente. Paralelamente, há uma forte tendência de internacionalização dessas áreas, já de certo modo mescladas.

Finalizo essa síntese (re) citando Menezes, Kawamura, Yossume (1997) que, ao reler nesse período final de redação da pesquisa, me identifico, reitero e agradeço.

A ambição do presente trabalho é sugerir a importância de recuperar a totalidade conceitual do fazer educacional. O esforço crítico-analítico, inevitavelmente e por sua natureza, tende a seccionar alguns aspectos e variáveis, como condição mesma que viabiliza a investigação. Reconhecer isso, não significa ignorar a necessidade de se compreender a complexidade da atividade docente, como ela se apresenta na prática, por excelência multidimensional, multidisciplinar e quantos outros "multi" houver... (Menezes, Kawamura, Yossume,1997) 


\title{
Finalmente
}

\author{
E agora, José? \\ A festa acabou, \\ a luz apagou, \\ o povo sumiu, \\ a noite esfriou, \\ e agora, José?
}

(Carlos Drummond de Andrade)

Pois bem. E agora, José?

Tinha a pretensão de encerrar esse trabalho no oitavo capítulo. Mas esse se estendeu mais do que imaginava e mais do que seja uma finalização sem muitas delongas... Breve, clara e afirmativa. O que me traz enormes dificuldades. Sejam de ordem pessoal, de possibilidade de um distanciamento mais crítico ao fim e ao cabo da pesquisa, seja por um fator inerente à própria pesquisa. E aqui, diferentemente do conjunto desse texto, falo na primeira pessoa do singular. Porque vou, além de esboçar uma síntese das principais conclusões que chegamos, eu e Regina, orientadora e parceira (o "nós" na primeira pessoa do plural usado ao longo dessa tese) tentar me situar mais pessoal e informalmente.

\section{O eu nos nós}

Ao final de uma dissertação ou tese é de praxe colocar duas perguntas a seu autor:

A primeira: Que contribuições você acredita que seu trabalho esteja trazendo à produção de conhecimento nesse campo?

A segunda: Quais as suas perspectivas de continuidade a esse trabalho? ("E agora, José?")

Pois bem.

Quanto à primeira, entendo que a principal contribuição dessa pesquisa é, antes de tudo, uma sistematização e reconstrução de um panorama geral acerca da área de pesquisa em Ensino de Física. Como vem crescendo e evoluindo. Onde e com quais aportes. Com quais focos de interesse, objetos de investigação e perspectivas. Com quais estudos e linhas. Com quais agendas de pesquisa. Com quais dimensões 
privilegiadas, com quais lacunas e desafios. Com quais orientações e conduções. Com quais permanências e mudanças. Com quais avanços e retrocessos. Com quais questões em aberto...

Por mais que os trabalhos nessa linha de metapesquisa estejam crescendo e se aprofundando, procurei dar uma dimensão abrangente, tendo em conta alguns aspectos nem sempre privilegiados. Por um lado, trazendo um instrumento de pesquisa que vise (mesmo que não atinja plenamente) evidenciar a complexidade e multi-dimensionalidade que essa área encerra, por outro lado, explicitando e reunindo elementos que possibilitem um diálogo, um intercâmbio e uma reflexão sobre nossa trajetória e, sobretudo, sobre nossa razão de ser.

Quanto à segunda, da vista do meu ponto (obrigada, Ivã, por inserir essa grande expressão no nosso vocabulário) não tenho uma resposta muito afirmativa. Talvez possa indicar mais alguns não(s) do que $\operatorname{sim}(\mathrm{s})$. Não desenvolvi esse trabalho visando a aquisição (legítima) de um título na perspectiva de prosseguir na carreira acadêmica. Em parte, o longo tempo decorrido entre o mestrado e o doutorado se explica por aí. Como disse na apresentação, a motivação principal dessa pesquisa foi o fechamento de um ciclo, uma necessidade de sistematizar um acúmulo de dados e análises, fragmentados em pequenas partes e gavetas, nem sempre com visibilidade. Quase como uma obrigação em devolver ao mundo aquilo que o mundo me deu. Entendendo o mundo, nesse caso, como esse pedacinho ao qual estamos inscritos ou circunscritos. (um campo de saber/ uma instituição de pesquisa). De certo modo, considero que com esse trabalho, o ciclo se fecha. Sendo assim, espero estar contribuindo para que as questões aqui colocadas, respondidas ou não, possam ser repensadas, avaliadas ou continuadas por outros atuais e futuros pesquisadores na área. Há muitas frentes e indagações que deixei em aberto, que certamente merecem maior atenção, reflexão e investigação. E, sobretudo, ação. Nessa última, permaneço em outros ciclos já iniciados, em práticas diversas, com parcerias possíveis, enfrentando muitos dos desafios e lacunas que sinalizamos nessa pesquisa.

\section{Os nós e o nós}

No que se refere aos nós, quer seja ao plural de nó, quer seja à primeira pessoa do plural, tentarei o desafio de sintetizar (o que não significa terminar) as principais conclusões ou pontos de chegada dessa tese.

Quanto à primeira pessoa do plural: esse trabalho foi desenvolvido essencialmente no plural, não apenas pela parceria orientadora-orientada desde muito antes de tornar-se um projeto de doutorado, mas porque, em se tratando de metapesquisa, está fundado em um espaço coletivo de múltiplas produções, ideias, instituições e autorias, 
envolvendo atores e protagonistas diversos, ao longo de um período quatro décadas. Quanto ao plural de nó, a tese (ou seu próprio título) dispensa explicações...

\section{Qual a tese.}

A principal tese ou a tese, se posso abreviar em um único (grande) parágrafo...

A área de Pesquisa em Ensino de Física ocupou-se durante um longo período em dar respostas a questões de ensino e aprendizagem nesse campo de saber disciplinar, particularmente buscado aperfeiçoar os meios de promover um aprendizado eficiente, sanando dificuldades apresentadas (ou tidas como) à cada época. Nessa constante busca, passou de etapas em que os métodos e estratégias de ensino seriam o foco para a solução de problemas, para então tratar especialmente dos aspectos cognitivos da aprendizagem, onde se concentrou por décadas de sua trajetória até o momento atual. Ainda que com mudanças nesse eixo condutor, as agendas de pesquisa o privilegiaram, deixando lacunas em outras duas dimensões fundamentais, a da educação de um modo mais amplo, abarcando perspectivas e finalidades educacionais, e a do conhecimento científico, ou do próprio objeto de ensino. Como sinalizamos em diversos momentos da pesquisa, isso significa ter centrado sua atenção ao "como ensinar", preterindo o "para quê" e o "o quê". Ao mesmo tempo, nos anos mais recentes, em função de demandas políticas e acadêmicas que regulamentam e financiam a pesquisa, paralelamente à "globalização" ou internacionalização da pesquisa em ensino de Ciências, priorizou modismos nas suas questões de investigação, nos referenciais teóricos e metodologias. Trata-se de predominância e não de consenso ou de permanência. Nesse seu percurso, a área não deixou de considerar, episodicamente, ou por meio de iniciativas isoladas, questões relevantes da educação e de contextos nacionais, bem como aspectos epistemológicos, no que concerne ao conhecimento científico e sua construção histórica e social. Tal marca ou tendência coloca como um grande desafio da área, ou talvez como esperança, o encontro ou aproximação de sua razão de ser: um campo de produção de conhecimentos que tem como perspectiva a ser privilegiada, a resposta (e a colocação de perguntas) a demandas de nossas escolas, de nossos alunos e professores, em nosso país, em nossas cidades, em nossas culturas, voltadas à formação de nossas crianças, jovens e adultos. No entanto, sem desconsiderar, aliás tendo como importante consideração, que estamos todos situados em nosso mundo (planeta) à nossa época (século XXI), o que exige cada vez mais uma formação diversificada, crítica e transformadora. Uma formação que dê conta das cada vez mais rápidas e complexas mudanças pelas quais esse mundo vem passando, sociais, políticas, econômicas, científicas, tecnológicas, ambientais, culturais... Quanto a isso, como produtores de conhecimento e formadores de formadores, temos uma grande responsabilidade e um vasto campo aberto para rever práticas. E aqui, passo a palavra ao Professor Menezes... 
"É preciso reconhecer o imponderável, gerar o novo, tendo a dúvida como direito e condição de liberdade!" (MENEZES) 


\section{Referências}

ALMEIDA, M. J. P. M. de. Meio século de educação em ciências: uma leitura de recomendações ao professor de física. 2003. Tese (Livre-Docência) - Faculdade de Educação, Universidade Estadual de Campinas. 2003.

ALMEIDA JÚNIOR, João de A. A evolução do ensino de Física no Brasil. Revista de Ensino de Física, 1(2): 45-58, out/1979 fev/1980.

A evolução do ensino de Física no Brasil. Revista de Ensino de Física, 2(1): 55-73,

ALVES, Alda Judith. A "revisão da bibliografia" em teses e dissertações: meus tipos inesquecíveis. Cad. Pesq. São Paulo, n. 81, p. 53-60, maio/1992.

ARANHA, M. L. História da Educação. 3 ed. São Paulo: Moderna, 2003.

BARDIN, L. Análise de Conteúdo. Lisboa: Edições 70, 1977. NOVA EDIÇÃO: 2008.

BARROS, S. de S. Ensino de física: à procura de sua identidade. In: SIMPÓSIO NACIONAL DE ENSINO DE FISICA, XIII , Brasília, 1999. Atas... Brasília: UnB/SBF, 1999. p.7-11.

Reflexões sobre 30 anos da pesquisa em ensino de física. In: ENCONTRO NACIONAL DE PESQUISA EM ENSINO DE FÍSICA, VIII, 2002, Águas de Lindóia. Anais...2002

BORTOLETTO, Adriana et al. Pesquisa em Ensino de Física (2000-2007): áreas temáticas em eventos e revistas nacionais. In: ENCONTRO DE PESQUISA EM EDUCAÇÃO EM CIÊNCIAS, VI, 2007, Florianópolis. Atas... 2007, CDROM.

BRASIL. MEC/CESu/CFE, parecer no 977 aprovada em 3 de dezembro de 1965. Definição dos cursos de pós-graduação.

BRASIL. MEC. CAPES. Portaria no 80 de 16 de dezembro de 1998. Dispõe sobre o reconhecimento dos mestrados profissionais e dá outras providências. Diário Oficial da União, Seção I, p. 14 de 11 de janeiro de 1999.

CACHAPUZ, A. F. Investigação em didáctica das ciências em Portugal um balanço crítico. In: PIMENTA, S. G. Didática e formação de professores: percursos e perspectivas no Brasil e em Portugal. São Paulo: Cortez Editora, 2000

Do sentido actual da pesquisa em formação de professores de ciências. In: ENCONTRO DE PESQUISA EM EDUCAÇÃO EM CIÊNCIAS, IV, 2003, Bauru. Atas... 2003, CDROM.

(coord.) Proceedings of the Int. Seminar on the state of the art in Science Education Research. Aveiro, Portugal, 2004.

CACHAPUZ, A. et al. Epistemologia da didáctica das ciências: um estudo sobre o estado da arte da investigação. Enseñanza de lãs Ciencias, 2005a. Número Extra. VII CONGRESO EPISTEMOLOGIA DA DIDÁCTICA DAS CIÊNCIAS.

Do estado da arte da pesquisa em educação em ciências: linhas de pesquisa e o caso "Ciência-Tecnologia-Sociedade". Alexandria - Revista de Educação em Ciência e Tecnologia, v.1, n.1, p. 27-49, mar. 2008.

CACHAPUZ, A. The state of the art in Science Education Research. In: INTERNATIONAL SEMINAR "THE STATE OF THE ART IN SCIENCE EDUCATION RESEARCH". 2005b, Aveiro. CDROM. 
CAPES. Coordenação de Aperfeiçoamento de Pessoal de Nível Superior. Diretoria de Avaliação. RELATÓRIO DE AVALIAÇÃO 2007-2009 - TRIENAL 2010. Área de Avaliação: Ensino de Ciências e Matemática. Coordenador de Área: Prof. Dr. Roberto Nardi. Brasília, 2010

Diretoria de Avaliação. Para além da academia: a pós-graduação contribuindo para a sociedade. Seminário interno de trabalho. São Paulo, Campus da Unifesp, 29/03 a 01/04 de 2005.

CAPES. Coordenação de Aperfeiçoamento de Pessoal de Nível Superior. Serviços: Banco de teses. 2005. Disponível em: http://capes.gov.br/servicos/banco-de-teses

CARVALHO, A. M. P.; VANNUCCHI, A. O currículo de física: inovações e tendências nos anos noventa. Investigação em Ensino de Ciências, 1(a) p.3-19, 1996.

CASTRO, M; WERLE, F. Estado do conhecimento em Administração da Educação: uma análise dos artigos publicados em periódicos nacionais 1982-2000. ENSAIO. Avaliação e Políticas Públicas em Educação. Rio de Janeiro, v. 12, p. 1045-1064, out/dez. 2004.

CASTRO, C. M. A hora do mestrado profissional. R B P G, v. 2, n. 4, p. 16-23, jul. 2005.

DELIZOICOV, Demétrio et al. Sociogênese do conhecimento e pesquisa em ensino: contribuições a partir do referencial fleckiano. In: ENCONTRO NACIONAL DE PESQUISA EM EDUCAÇÃO EM CIÊNCIAS, II 1999, Valinhos, SP. CD-Rom.

DELIZOICOV, Demétrio. Pesquisa em ensino de ciências como ciências humanas aplicadas. Cad. Bras. Ens. Fis. 21(1), p. 145-75, agosto/2004.

DELIZOICOV, D.; ANGOTTI, J. A.; PERNAMBUCO, M. M. Ensino de Ciências: fundamentos e métodos. São Paulo: Cortez, 2002.

FERREIRA, Norma Sandra de Almeida. As pesquisas denominadas "Estado Da Arte". Educação \& Sociedade, Campinas, ano XXIII, no 79, p. 257-272, ago/2002.

FERNANDES, Rebeca C. Azevedo; MEGID NETO, Jorge. Pesquisas sobre o estado da arte em educação em ciências: uma revisão em periódicos científicos brasileiros. In: ENCONTRO NACIONAL DE PESQUISA EM ENSINO DE CIÊNCIAS, VI, 2007. Florianópolis. Anais... CD-ROM.

FISCHER, Tânia. Mestrado profissional como prática acadêmica. $R B P$ G, v. 2, n. 4, p. 24-29, jul. 2005.

FLECK, L. La génesis y el desarrollo de um hecho científico. Madrid: Alianza Editorial, 1986

FORQUIN, J.C. Saberes escolares, imperativos didáticos e dinâmicas sociais. In: Teoria e Educação. p. 28-49. Porto Alegre: Pannônica, 1992

FREITAS, M. C. de; BICCAS, M. História social da educação no Brasil. São Paulo: Cortez, 2009.

GAMBOA, S. S. Epistemologia da pesquisa em educação: estruturas lógicas e tendências metodológicas. 1987. Tese (Doutorado em Educação) - Faculdade de Educação-UNICAMP, Campinas, 1987.

GARCÍA, J. E. Hacia una teoría alternativa sobre los contenidos escolares. Espanha: Díada Editora S. L., 1998.

GIL-PEREZ, D. New trends in science education. International Journal of Science Education, London, 18(8), p. 889-901, 1996.

GREF - Grupo de Reelaboração do Ensino de Física. (1990). Física 1: Mecânica. São Paulo: EDUSP. 
(1991). Física 2: Fsica Térmica; Óptica. São Paulo: EDUSP.

(1993). Física 3: Eletromagnetismo. São Paulo: EDUSP.

HADDAD, Sérgio (coord). $O$ estado da arte das pesquisas em educação de jovens e adultos no Brasil: A produção discente da pós-graduação em educação no período 1986 - 1998. Ação Educativa, São Paulo, 2000. Disponível em < http://www.acaoeducativa.org.br>. Acesso em: junho/2010.

HOSOUME, Yassuko. 1998. 181 f. Dissertação (Mestrado em Ensino de Ciências - modalidade Física). Instrumento e método de análise para um curso de Física básica: uma proposta. Instituto de Física e Faculdade de Educação, Universidade de São Paulo. São Paulo, 1998.

JARDIM, Maria Inês Affonseca, ERROBIDART, Nádia Cristina Guimarães; GOBARA, Shirley Takeco. Levantamento dos trabalhos em ensino de física que investigaram ondas sonoras. In: ENCONTRO NACIONAL DE PESQUISA EM ENSINO DE FíSICA, XI, 2008. Curitiba. Anais... CDROM.

KAWAMURA, M.R. Um panorama evolutivo da educação científica e do ensino de Ciências no Brasil. (Comunicação interna). 2011.

KRASILCHIK, M. A evolução no ensino de Ciências no período 1950-1985. In: O professor e o currículo de ciências. São Paulo: EPU / Edusp, 1987.

KUENZER, Acacia Zeneida; MORAES, Maria Célia Marcondes de. Temas e tramas na pósgraduação em educação. Educ. Soc. vol.26, no.93. Campinas, Set./Dez. 2005.

LEMGRUBER, Márcio Silveira. A educação em ciências físicas e biológicas a partir das dissertações e teses (1981 a 1995): uma história de sua história. Tese (Doutorado em Educação) - Faculdade de Educação da Universidade Federal do Rio de Janeiro, 1999.

LARANJEIRA, Raymundo. Estado da arte do direito agrário no Brasil. Disponível em http://www.ucg.br/jur/palestras pdf/RaymundoLaranjeira.pdf. Acesso em 05/03/2010.

LEE, A. M.; WU B. Y.; TSAI, C. Research Trends in Science Education from 2003 to 2007: A content analysis of publications in selected journals. International Journal of Science Education, 31(15), 2009, 1-22.

LIBÂNEO, J.C. Democratização da escola pública: a pedagogia crítico-social dos conteúdos, São Paulo: Loyola, 1989

LORENZETTI, Leonir; DELIZOICOV, Demétrio. A produção acadêmica brasileira em educação ambiental. In: SIMPÓSIO FUNDAMENTOS DA EDUCAÇÃO AMBIENTAL, 2007, Bruxelas. Bruxelas: Universidade Livre de Bruxelas, 2007.

LÜDKE, M; ANDRÉ, M. E. D. A. Pesquisa em Educação: abordagens qualitativas. São Paulo: EPU, 2003.

LUNA, S.V. de. Planejamento de pesquisa: uma introdução; elementos para uma análise metodológica. São Paulo, Educ. 1997.

MARQUES, A. C.; LAMAS, C. J. E. . Taxonomia zoológica no Brasil: estado da arte, expectativas e sugestões de ações futuras. Papéis Avulsos de Zoologia (São Paulo), v. 46, p. 139-174, 2006.

MARTINS, A. F. P. Concepções de estudantes acerca do conceito de tempo: uma análise à luz da epistemologia de Gaston Bachelard. Tese (Doutorado em Educação). Faculdade de Educação, Universidade de São Paulo. São Paulo, 2004.

Tempo físico: a construção de um conceito. Natal: Editora da UFRN, 2007. 
MEGID NETO, J. Pesquisa em Ensino de Física do $2^{\circ}$ grau no Brasil: concepção e tratamento de problemas em teses e dissertações. Dissertação (Mestrado em Educação). Faculdade de Educação, UNICAMP. Campinas, 1990.

O ensino de Ciências no Brasil: catálogo analítico de teses e dissertações, 1972-1995. Campinas: UNICAMP/FE/CEDOC, 1998.

Tendências da pesquisa acadêmica sobre o ensino de ciências no nível fundamental. Tese (Doutorado em Educação). Faculdade de Educação - UNICAMP, Campinas, 1999a.

O que sabemos sobre a pesquisa em ensino de Ciências no nível fundamental: tendências de teses e dissertações defendidas entre 1972 e 1995. In: ENCONTRO NACIONAL DE PESQUISA EM EDUCAÇÃO EM CIÊNCIAS, II, 1999, Valinhos. Atas...Valinhos: ABRAPEC, 1999b. CD-ROM.

Sobre as pesquisas em ensino de Física nós podemos saber: mas ... como socializar os conhecimentos elaborados nessas pesquisas? In: ENCONTRO DE PESQUISA EM ENSINO DE FÍSICA, VII, 2000, Florianópolis. Atas... CD-ROM.

Três décadas de pesquisas em Educação em Ciências: tendências de teses e dissertações (1972-2003). In: NARDI, R. (Org.). A pesquisa em ensino de Ciências no Brasil: alguns recortes. São Paulo: Escrituras, 2007. p. 341-355.

MENEZES, Luis Carlos de; KAWAMURA, Maria Regina Dubeux; HOSOUME, Yassuko. A formação de professores e as várias dimensões da educação para as ciências. In: ENCONTRO NACIONAL DE PESQUISA EM EDUCAÇÃO EM CIÊNCIAS, I, Águas de Lindóia, 1997. Atas... CD-ROM.

MINISTÉRIO DA EDUCAÇÃO/CAPES. A necessidade de desenvolvimento da pós-graduação profissional e o ajustamento do sistema de avaliação às características desse segmento. Infocapes. Brasília, V. 10, n.1, p. 51-58, 1999.

MOREIRA Marco Antonio. O estado da arte na investigação em didática da Física. ENCONTRO IBÉRICO SOBRE ENSINO DE FÍSICA, III (Conferência inaugural). Jaca (Huesca), Espanha, 27 de setembro a 1‥ de outubro, 1993.

Ensino de Física no Brasil: retrospectiva e perspectivas. Revista Brasileira de Ensino de Física, 22 (1), p.94-9, mar, 2000.

A área de Ensino de Ciências e Matemática na CAPES: panorama 2001/2002 e critérios de qualidade. Revista Brasileira de Pesquisa em Educação em Ciências. Porto Alegre, 2 (1): 3659, 2002a.

A internacionalização da área de pesquisa em Ensino de Física. In ENCONTRO DE PESQUISA EM ENSINO DE FÍSICA, VIII, Águas de Lindóia, 2002b.

Pesquisa básica em Educação em Ciências: uma visão pessoal. Texto adaptado e revisado de La investigación en educación en Física: una visión personal. Revista de Enseñanza de la Física, Argentina, v. 1, 2003. Disponível em http://www.if.ufrgs.br/ moreira/Pesquisa.pdf último acesso em 05/03/2012.

O mestrado (profissional) em ensino. RBPG, Brasília, n.1, Jul. 2004. (Seção Debates).

MORTIMER, Eduardo Fleury. Construtivismo, mudança conceitual e ensino de ciências: para onde vamos? Investigações em Ensino de Ciências - V1(1), pp.20-39, 1996.

MORTIMER, Eduardo F.; SCOTT, Phil. Atividade discursiva nas salas de aula de ciências: uma ferramenta sociocultural para analisar e planejar o ensino. Investigações em Ensino de Ciências - V7(3), pp. 283-306, 2002. 
NARDI, Roberto. Memórias da educação em Ciências no Brasil: a pesquisa em ensino de física. Investigação em Ensino de Ciências, 10(1), março/2005a.

A área de ensino de Ciências no Brasil: fatores que determinaram sua constituição e suas características segundo pesquisadores brasileiros. Tese (Livre-Docência). UNESP, Bauru, 2005b.

NARDI, Roberto; ALMEIDA, Maria José P.M. de. Investigação em Ensino de Ciências no Brasil segundo pesquisadores da área: alguns fatores que lhe deram origem. Pro-Posições, v. 18, n. 1 (52) - jan./abr. 2007

NASCIMENTO, Tatiana Galieta; REZENDE JUNIOR, Mikael Frank. Trabalhos de divulgação científica: uma análise de tendências em eventos de ensino de Ciências e Física. In: ENCONTRO NACIONAL DE PESQUISA EM ENSINO DE FÍSICA, X, 2006. Londrina. Anais... CD-ROM

OSTERMANN, Fernanda; MOREIRA, Marco Antonio. Uma revisão bibliográfica sobre a área de pesquisa "Física Moderna e Contemporânea no Ensino Médio". Investigação em Ensino de Ciências, v5(1), pp. 23-48, 2000.

OSTERMANN, Fernanda; REZENDE, Flávia. Projetos de desenvolvimento e de pesquisa na área de ensino de ciências e matemática: uma reflexão sobre os mestrados profissionais. Cad. Bras. Ens. Fís., v. 26, n. 1: p. 66-80, abr. 2009.

PACHECO, Décio; MEGID NETO, Jorge; OLIVEIRA, Lidia M.R. Tempo de avaliação: 20 anos de teses e dissertações sobre ensino de Física no Brasil. In: SIMPÓSIO NACIONAL DE ENSINO DE FÍsICA, X, 1993. Londrina. Resumos...

PACHECO, Décio; MEGID NETO, Jorge. Propostas metodológicas para o ensino de física apresentadas em teses e dissertações defendidas entre 1972 e 1995 no Brasil. In: SIMPÓsIO NACIONAL DE ENSINO DE FÍSICA, XIII, 1999. Brasília. Resumos...

PENA, Fábio Luís Alves; FREIRE JR., Olival. Sobre a modernização do ensino de física no Brasil (1960-1979). In: ENCONTRO NACIONAL DE PESQUISA EM EDUCAÇÃO EM CIÊNCIA, IV, 2003. Bauru-SP. Anais... CD-ROM

PERNAMBUCO, M. M. Uma retomada histórica do ensino de Ciências. In: SIMPÓSIO NACIONAL DE ENSINO DE FÍSICA, VI, 1985. Niterói. Atas... p. 116-125.

PINA ET AL. Nanotecnologia e nanobiotecnologia: estado da arte, perspectivas de inovação e investimentos. Revista Gestão Industrial, Vol. 2, No.2 (2006). Disponível em http://www.pg.utfpr.edu.br/depog/periodicos/index.php/revistagi/article/viewArticle/118 Último acesso em 08/09/2011.

QUEIROZ, Salete Linhares; NASCIMENTO, Fábio Batista do; REZENDE Flávio Silva. Análise dos trabalhos apresentados nas reuniões anuais da Sociedade Brasileira de Química na seção de Ensino de Química de 1999 a 2003. In: ENCONTRO NACIONAL DE PESQUISA EM EDUCAÇÃO EM CIÊNCIAS, IV, 2003. Bauru-SP. Anais... CD-ROM.

QUEIROZ, Anita Domingues; SILVA, Cibelle Celestino. A pesquisa em ensino de física no Brasil: um balanço a partir dos eventos da Sociedade Brasileira de Física. In: ENCONTRO DE PESQUISA EM ENSINO DE FÍSICA, XI , 2008. Curitiba. Atas... 2008, CDROM.

REISKA, R. Research in Science Education: past, present and future. Dordrecht: Kluwer Academic Publish, 2001.

REZENDE, Flávia et al. Tendências da pesquisa: o que dizem os periódicos nacionais sobre o ensino e aprendizagem de física no nível médio? In: ENCONTRO NACIONAL DE PESQUISA EM EDUCAÇÃO EM CIÊNCIAS, VI , 2007. Florianópolis. Atas... 2007, CDROM 
RIBEIRO, Cláudio Rezende. A universidade como disputa da reprodução social: contribuição ao debate sobre os mestrados profissionais. $R B P G$, Brasília, v. 7, n. 14, p. 433 - 450, dezembro de 2010.

RIBEIRO, Renato Janine. O mestrado profissional na política atual da Capes. R B P G, v. 2, n. 4, p. 8-15, jul. 2005.

RODRIGUES, I. G. e HAMBURGER, E. W. O "Grupo de Ensino" do IFUSP: histórico e atividades. Instituto de Física. Universidade de São Paulo. Publicações. IFUSP/P-1035, Março/1993.

ROMANELLI, O. O. História da Educação no Brasil. Petrópolis: Vozes, 2008.

ROMANOWSKI, J. P.; ENS, R. T. As pesquisas denominadas do tipo "estado da arte" em educação. Revista Diálogo Educacional, vol. 6, núm. 19, setembro-dezembro, 2006, pp. 37-50.

SALEM, Sonia; KAWAMURA, Maria Regina. Teses na área de ensino de física. In: SIMPÓSIO NACIONAL DE ENSINO DE FÍSICA, X, 1993, Londrina. Programa e Resumos, SBF, p.78, 1993 .

Banco de Referências de Ensino de Física. Caderno Catarinense de Ensino de Física, 10(3): 247-57, Florianópolis, 1993c.

Caminhos e Tendências do Ensino de Física. In: ENCONTRO DE PESQUISA EM ENSINO DE FÍSICA, I, 1994, Florianópolis. Resumos, p.96, 1994a.

Simpósios Nacionais de Ensino de Física. In: ENCONTRO DE PESQUISA EM ENSINO DE FíSICA, IV, 1994, Florianópolis. Resumos, p.94, 1994b.

Dissertações e Teses em Ensino de Física no Brasil: 1972-1995. In: SIMPÓSIO NACIONAL DE ENSINO DE FÍSICA, XII, 1997, Belo Horizonte. Anais...

Ensino de Ciências: algumas características e tendências da pesquisa. In: ENCONTRO DE PESQUISA EM EDUCAÇÃO EM CIÊNCIAS V, 2005, Bauru. Atas...2005, CDROM.

Simpósios Nacionais de Ensino de Física: uma sistematização. In: SIMPÓSIO NACIONAL DE ENSINO DE FÍSICA, XVII, 2007, São Luis - MA. Anais... 2007, CDROM.

Dissertações e teses em ensino de Física no Brasil: um panorama do período 19722005. In: ENCONTRO DE PESQUISA EM ENSINO DE FÍSICA, XI, 2008, Curitiba. Atas...2008, CDROM.

O estado da arte do estado da arte da pesquisa em Ensino de Física no Brasil. In: ENCONTRO NACIONAL DE PESQUISA EM EDUCAÇÃO EM CIÊNCIAS, VII, 2009. Florianópolis SC. Anais... 2009a

Pesquisa em ensino de Física no Brasil: diferentes olhares sobre o estado da arte. Enseñanza de las Ciencias, Número Extra. CONGRESO INTERNACIONAL SOBRE INVESTIGACIÓN EN DIDÁCTICA DE LAS CIENCIAS, VIII, 2009. Barcelona p. 2788-2792. 2009b

SALEM, Sonia; DEL CARLO, Sandra; KAWAMURA, M. Regina. Banco de referências de ensino de física. In: SIMPÓSIO NACIONAL DE ENSINO DE FÍSICA, X, 1993, Londrina. Programa e Resumos, SBF, 1993.

SÁNCHEZ, G. S. Epistemologia da Pesquisa em Educação. Campinas: Praxis. 1998

SAVIANI, D. História das idéias pedagógicas no Brasil. Campinas, Autores Associados, 2007.

SCARPA, Daniela Lopes, MARANDINO, Martha. Pesquisa em ensino de ciências: um estudo sobre as perspectivas metodológicas. In: ENCONTRO NACIONAL DE PESQUISA EM EDUCAÇÃO EM CIÊNCIA, II, 1999. Valinhos-SP. Anais... 
SCHELBAUER, A. R. O estado da arte em história da educação no Brasil Império: mapeamento preliminar da produção do HISTEDBR nas Jornadas, Seminários e Revista On-Line. In: NAVEGANDO PELA HISTÓRIA DA EDUCAÇÃO BRASILEIRA. Campinas, SP: Graf. FE: HISTEDBR, 2006.

SCHNETZLER, R. P. A pesquisa em Ensino de Química no Brasil: conquistas e perspectivas. Química Nova, v. 25, Supl.1, p. 14-24, 2003.

SILVA, R. C. P. da; MEGID NETO, J. Formação de professores e educadores para abordagem da educação sexual na escola: o que mostram as pesquisas. Ciência \& Educação, 12(2), 2006.

SLONGO, I. I. P. 2004. 349f. A produção acadêmica em ensino de Biologia: um estudo a partir de teses e dissertações. Tese (Doutorado em Educação) - Centro de Ciências da Educação da Universidade Federal de Santa Catarina. Florianópolis, 2004.

SOUZA, R. F. de. História da organização do trabalho escolar e do currículo no século XX. (ensino primário e secundário no Brasil). São Paulo, SP: Cortez, 2008. 320p. (Coleção: Biblioteca Básica de História da Educação Brasileira, v. 2).

SOUZA FILHO, Moacyr Pereira de et al. Tendências da pesquisa em ensino de física em publicações e eventos recentes. In: ENCONTRO NACIONAL DE PESQUISA EM EDUCAÇÃO EM CIÊNCIAS, V, 2005, Bauru-SP. Anais... CD-ROM. 2005.

SPINK, Peter. A formação acadêmica e a ciência: ampliando o debate sobre o mestrado profissional. Revista de Administração Contemporânea. vol.1, no.3 Curitiba Set./Dez. 1997: 163-169.

TERRAZZAN et al. Pesquisa em ensino de física: revendo trajetórias, constatando demandas e projetando caminhos. . In: ENCONTRO NACIONAL DE PESQUISA EM ENSINO DE FÍSICA, VII, 2000, Florianópolis. Atas... CD-ROM. 2000.

THERRIEN, J. ; NÓBREGA-THERRIEN, S. Os trabalhos científicos e o estado da questão: reflexões teórico-metodológicas. Estudos em avaliação educacional, v.15, n.30, jul.-dez. 2004.

TSAI, Chin-Chung; WEN, Meichun Lydia. Research and trends in science education from 1998 to 2002: a content analysis of publication in selected journals. International Journal of Science Education, 27 (1): 3-14, 2005.

UNIVERSIDADE DE SÃO PAULO, Instituto de Física. Ensino de Física no Brasil: Catálogo Analítico de Dissertações e Teses: (1972-1992). São Paulo, 1992.

UNIVERSIDADE DE SÃO PAULO, Instituto de Física. Ensino de Física no Brasil: Catálogo Analítico de Dissertações e Teses: (1992-1995). São Paulo, 1996.

UNIVERSIDADE DE SÃO PAULO, Instituto de Física. Ensino de Física no Brasil: Catálogo Analítico de Dissertações e Teses: (1995-2006). São Paulo, 2009.

VIENNOT, L. Le raisonnnement spontané en dynamique élémentaire. Paris: Hermann, 1979.

VILLANI, A. Considerações sobre a pesquisa em ensino de ciência: A interdisciplinaridade. Revista de Ensino de Física, v. 3, n. 3, p. 68-88, setembro de 1981.

VILLANI, A. Considerações sobre a pesquisa em ensino de ciência: II. Revista de Ensino de Física, v. 4, p. 23-51, dezembro de 1982.

ZANETIC, J. Física também é cultura. 1989. 262f. Tese (Doutorado em Educação). Faculdade de Educação, Universidade de São Paulo, São Paulo. 1989. 


\begin{abstract}
ANEXO 1.1
TRABALHOS DE ESTADO DA ARTE NA PESQUISA EM ENSINO DE CIÊNCIAS
\end{abstract}




\section{TRABALHOS DE ESTADO DA ARTE - PESQUISA EM ENSINO DE CIÊNCIAS}

A. Gerais

\begin{tabular}{|c|c|c|c|c|}
\hline & AUTOR & ANO & Título & PRODUÇÃO \\
\hline 1. & BIZZO & 1997 & $\begin{array}{l}\text { Pesquisas em ensino de biologia, física e química: considerações sobre seu valor heurístico relativo e implicações para } \\
\text { a história da ciência }\end{array}$ & Trabalho em evento - I ENPEC \\
\hline 2. & CARVALHO & 2003 & Os direcionamentos das pesquisas em ensino de ciências & Mesa redonda em evento - IV ENPEC \\
\hline 3. & CARVALHO\&REZENDE & 2009 & Tendências da pesquisa na área de educação em ciências: uma análise preliminar da publicação da Abrapec & Trabalho em evento - VII ENPEC \\
\hline 4. & DELIZOICOV & 2004 & Pesquisa em ensino de ciências como ciências humanas aplicadas & $\begin{array}{l}\text { Artigo de periódico } \\
\text { Cad.Bras.Ens.Fis. v.21, ago/2004 }\end{array}$ \\
\hline 5. & DELIZOICOV & 2005 & Pesquisa em ensino de ciências como ciências humanas aplicadas & Mesa Redonda - V ENPEC \\
\hline 6. & DELIZOICOV & 2007 & O estado da arte da pesquisa em educação em ciências. & Mesa Redonda - VI ENPEC \\
\hline 7. & DELIZOICOV $(*)$ & 2005 & Resultados da pesquisa em ensino de ciências: comunicação ou extensão? & $\begin{array}{l}\text { Artigo de periódico } \\
\text { Cad.Bras.Ens.Fis. v.22, } 3 \text { dez/2005 }\end{array}$ \\
\hline 8. & $\begin{array}{l}\text { DELIZOICOV, SLONGO E } \\
\text { LORENZETTI }\end{array}$ & 2007 & ENPEC: 10 anos de disseminação da pesquisa em educação em ciências & Trabalho em Evento - VI ENPEC \\
\hline 9. & ERN \& AIRES & 2001 & O ensino de ciências naturais num programa de pós-graduação em educação & Trabalho em evento - III ENPEC \\
\hline 10. & FERES \& NARDI & 2007 & $\begin{array}{l}\text { Parâmetros utilizados para caracterização e avaliação da produção acadêmica na área de educação em ciências: } \\
\text { estudos preliminares }\end{array}$ & Trabalho em evento - VI ENPEC \\
\hline 11. & FERNANDES \& MEGID & 2007 & Pesquisas sobre o estado da arte em educação em ciências: uma revisão em periódicos científicos brasileiros & Trabalho em evento - VI ENPEC \\
\hline 12. & FERNANDES \& MEGID & 2007 & $\begin{array}{l}\text { A divulgação da produção acadêmica e as dificuldades encontradas na realização de pesquisas do tipo "estado da } \\
\text { arte" em ensino de ciências }\end{array}$ & Trabalho em evento $-16^{0}$ COLE \\
\hline 13. & FERREIRA, Márcia & 2005 & Como investigar a história da pesquisa em ensino de ciências no Brasil? Reflexões teórico-metodológicas & Mesa Redonda - V ENPEC \\
\hline 14. & FREIRE, Olival & 2007 & A área 46 da Capes e a pesquisa em educação em Ciências & Mesa Redonda - VI ENPEC \\
\hline 15. & GRECA & 2002 & Discutindo aspectos metodológicos da pesquisa em ensino de ciências: algumas questões para refletir & $\begin{array}{l}\text { Artigo de periódico- Rev. Bras. Pesq. } \\
\text { Educ. Ciências } 2,1\end{array}$ \\
\hline 16. & GRECA; COSTA \& MOREIRA & 2002 & Análise descritiva e crítica dos trabalhos de pesquisa submetidos ao III ENPEC & $\begin{array}{l}\text { Artigo de periódico- Rev. Bras. Pesq. } \\
\text { Educ. Ciências } 2,1\end{array}$ \\
\hline 17. & JUSTI, Rosária & 2007 & Publicação de Pesquisas em Periódicos Internacionais & Mesa Redonda - VI ENPEC \\
\hline 18. & KRASILCHIK & 1987 & Inovação no ensino de Ciências & Capítulo de livro \\
\hline 19. & LEMGRUBER & 1999 & $\begin{array}{l}\text { A Educação em Ciências físicas e biológicas a partir das teses e dissertações (1981 a 1995): uma história de sua } \\
\text { história }\end{array}$ & TESE (doutorado) \\
\hline 20. & LEMGRUBER & 2000 & Um panorama da educação em ciências & Artigo \\
\hline 21. & MARTINS, Isabel & 2007 & O papel dos periódicos na consolidação da identidade da pesquisa na área de Ensino de Ciências: reflexões a partir da & Mesa Redonda - VI ENPEC \\
\hline
\end{tabular}




\begin{tabular}{|c|c|c|c|c|}
\hline & & & experiência da Revista Brasileira de Pesquisa em educação em Ciências & \\
\hline 22. & MEGID & 1999 & Tendências da pesquisa acadêmica sobre o ensino de ciências no nível fundamental. & TESE (doutorado) \\
\hline 23. & MEGID & 2005 & Breve panorama das teses e dissertações em educação em ciências no Brasil: período 1972-2004 & Mesa redonda - V ENPEC \\
\hline 24. & MEGID & 2005 & Breve panorama das teses e dissertações em educação em ciências no Brasil: período 1972-2004 & Mesa Redonda - V ENPEC \\
\hline 25. & MEGID & 2007 & Três décadas de pesquisas em Educação em Ciências: tendências de teses e dissertações (1972-2003) & $\begin{array}{l}\text { Capítulo de livro. In: Nardi. A pesquisa } \\
\text { em ensino de clências no Brasil: algun } \\
\text { recortes }\end{array}$ \\
\hline 26. & MEGID \& PACHECO & 1993 & Um acervo nacional de teses e dissertações sobre ensino de Ciências & $\begin{array}{l}\text { Trabalho em Evento } \\
\text { (X SNEF) }\end{array}$ \\
\hline 27. & MEGID; ANDRADE \& CABRAL & 1999 & O que se pesquisa sobre educação em ciências no Brasil: um catálogo analítico de teses e dissertações (1972-1995) & $\begin{array}{l}\text { Trabalho em Evento } \\
\text { (XIII SNEF) }\end{array}$ \\
\hline 28. & $\begin{array}{ll}\text { MEGID; } & \text { FRACALANZA } \& \\
\text { FERNANDEZ } & \& \\
\end{array}$ & 2005 & O que sabemos sobre a pesquisa em educação em ciências no Brasil (1972-2004) & Trabalho em Evento - V ENPEC \\
\hline 29. & MOREIRA, Ildeu & 2007 & O comitê de divulgação científica do CNPq e pesquisa em educação em ciências & Mesa Redonda - VI ENPEC \\
\hline 30. & MOREIRA, M.A. & 2002 & A área de Ensino de Ciências e Matemática na CAPES: panorama 2001/2002 e critérios de qualidade & Artigo de periódico \\
\hline 31. & MOREIRA, M.A. & 2003 & Pós-Graduação e pesquisa em ensino de ciências no Brasil & $\begin{array}{l}\text { Trabalho em evento } \\
\text { IV ENPEC }\end{array}$ \\
\hline 32. & MOREIRA, M.A. & 2003 & Pesquisa básica em educação em ciências: uma visão pessoal & Texto adaptado de Conferência \\
\hline 33. & NARDI & 2005 & Memórias da educação em Ciências no Brasil: a pesquisa em ensino de física. Investigação em Ensino de Ciências & Artigo (IEC 10,1) \\
\hline 34. & NARDI & 2005 & $\begin{array}{l}\text { A área de ensino de Ciências no Brasil: fatores que determinaram sua constituição e suas características segundo } \\
\text { pesquisadores brasileiros }\end{array}$ & Tese de Livre-Docência \\
\hline 35. & NARDI & 2005 & $\begin{array}{l}\text { A área de ensino de ciências no Brasil: fatores que determinaram sua constituição e suas características, segundo } \\
\text { pesquisadores brasileiros }\end{array}$ & Mesa Redonda - V ENPEC \\
\hline 36. & NARDI & 2007 & Afinal, o que conta como pesquisa em educação em Ciências? & Mesa Redonda - VI ENPEC \\
\hline 37. & NARDI & 2007 & $\begin{array}{l}\text { A área de ensino de ciências no Brasil: fatores que determinaram sua constituição e suas características segundo } \\
\text { pesquisadores brasileiros }\end{array}$ & $\begin{array}{l}\text { Capítulo de livro. In: Nardi. A } \\
\text { pesquisa....Escrituras }\end{array}$ \\
\hline 38. & NARDI & 2009 & $\begin{array}{l}\text { A pesquisa em ensino de ciências e o ensino de sala de aula: memórias de professores que atuaram nas últimas } \\
\text { décadas }\end{array}$ & Trabalho em evento - VII ENPEC \\
\hline 39. & NARDI \& ALMEIDA & 2004 & Formação da área de ensino de Ciências: memórias de pesquisadores no Brasil & Artigo de periódico \\
\hline 40. & NARDI \& ALMEIDA & 2007 & Investigação em Ensino de Ciências no Brasil segundo pesquisadores da área: alguns fatores que lhe deram origem & Artigo de periódico (Pro-Posições) \\
\hline 41. & PERNAMBUCO & 1985 & Uma retomada histórica do ensino de Ciências & $\begin{array}{l}\text { Trabalho em evento } \\
\text { VI SNEF }\end{array}$ \\
\hline 42. & PIZZATO et al & 2009 & Concepções sobre pesquisa em ensino: categorias de análise & $\begin{array}{l}\text { Trabalho em evento } \\
\text { VII ENPEC }\end{array}$ \\
\hline 43. & SALEM \& KAWAMURA & 2005 & Ensino de ciências: algumas características e tendências da pesquisa & $\begin{array}{l}\text { Trabalho em evento } \\
\text { V ENPEC }\end{array}$ \\
\hline
\end{tabular}




\begin{tabular}{|c|c|c|c|c|}
\hline 44. & SCARPA \& MARANDINO & 1999 & Pesquisa em ensino de Ciências: um estudo sobre as perspectivas metodológicas & Trabalho em evento - II ENPEC \\
\hline 45. & VILLANI & 2007 & O CA-ED do CNPq e a pesquisa em educação em Ciências & Mesa Redonda - VI ENPEC \\
\hline 46. & ZULIANI, PIZZARRO, NARDI & & $\begin{array}{l}\text { As publicações sobre ensino de ciências em evento } \\
\text { nacional da área de educacão: a ANPED }\end{array}$ & Trabalho em evento - VI ENPEC \\
\hline
\end{tabular}

Tabela 1.1a: Trabalhos sobre "estado da arte" em Ensino de Ciências - Gerais

\section{B. Recortes Temáticos}

\begin{tabular}{|c|c|c|c|c|c|}
\hline & AUTOR & ANO & Título & PRODUÇÃO & RECORTE \\
\hline 1. & AGUIAR \& CABRAL & 2007 & $\begin{array}{l}\text { A temática saúde nas atas do ENPEC: delineando tendências e apontando demandas de investigação em } \\
\text { ciências }\end{array}$ & $\begin{array}{l}\text { Trabalho em evento - VI } \\
\text { ENPEC }\end{array}$ & Saúde \\
\hline 2. & AGUIAR JR, Orlando & 2001 & Mudanças conceituais (ou cognitivas) na educação em ciências: revisão crítica e novas direções para a pesquisa & $\begin{array}{l}\text { Artigo de periódico } \\
\text { Ensaio, 3(1), jun } 2001\end{array}$ & Mudanças conceituais \\
\hline 3. & AUGUSTO \& OLIVEIRA & 2009 & Análise dos artigos sobre educação alimentar publicados nas atas dos ENPEC & $\begin{array}{l}\text { Trabalho em evento - VII } \\
\text { ENPEC }\end{array}$ & $\begin{array}{l}\text { Saúde / educação } \\
\text { alimentar }\end{array}$ \\
\hline 4. & BOER & 2007 & $\begin{array}{l}\text { Inserção da educação ambiental nas disciplinas ciências naturais e biologia: uma análise a partir de pesquisas } \\
\text { publicadas em anais de eventos }\end{array}$ & $\begin{array}{l}\text { Trabalho em evento - VI } \\
\text { ENPEC }\end{array}$ & $\begin{array}{l}\text { Educação Ambiental } \\
\text { Em Bio e Ciências }\end{array}$ \\
\hline 5. & BRANT et al & 2009 & $\begin{array}{l}\text { Tendências de estudo na área da educação em ciências e saúde: um olhar sobre a produção científica do } \\
\text { núcleo de tecnologia educacional para saúde (nutes/ufrj) }\end{array}$ & $\begin{array}{l}\text { Trabalho em evento - VII } \\
\text { ENPEC }\end{array}$ & $\begin{array}{l}\text { BIO? } \\
\text { Saúde }\end{array}$ \\
\hline 6. & CHAVES & 2007 & Formação de professores de Ciências: O que as memórias nos ensinam? & $\begin{array}{l}\text { Mesa redonda em evento - } \\
\text { VI ENPEC }\end{array}$ & Formação de professores \\
\hline 7. & COLINVAUX, Dominique $(*)$ & 2007 & As contribuições das ciências cognitivas para a educação em ciências & $\begin{array}{l}\text { Mesa redonda em evento - } \\
\text { VI ENPEC }\end{array}$ & Ciências cognitivas \\
\hline 8. & COSTA \& CABRAL & 2009 & $\begin{array}{l}\text { Educação em saúde e ensino de ciências: panorama geral deste tema nos encontros nacionais de pesquisa em } \\
\text { educação em ciências }\end{array}$ & $\begin{array}{l}\text { Trabalho em evento - VII } \\
\text { ENPEC }\end{array}$ & $\begin{array}{l}\text { BIO } \\
\text { Saúde }\end{array}$ \\
\hline 9. & COSTA \& CABRAL & 2009 & $\begin{array}{l}\text { Linguagem, cognição e ensino de ciências: reflexões sobre esta temática nos encontros nacionais de pesquisa } \\
\text { em educação em ciências }\end{array}$ & $\begin{array}{l}\text { Trabalho em evento - VII } \\
\text { ENPEC }\end{array}$ & Linguagem \\
\hline 10. & $\begin{array}{l}\text { DELL'ARETI; } \quad \text { FRANÇA; } \\
\text { MUNFORD }\end{array}$ & 2007 & Etnografia na pesquisa em educação em ciências: uma análise dos trabalhos apresentados nos ENPECs & $\begin{array}{l}\text { Trabalho em evento - VI } \\
\text { ENPEC }\end{array}$ & Etnografia \\
\hline 11. & ELIAS \& FONSECA & 2009 & $\begin{array}{l}\text { Um Olhar sobre a Produção Científica na Área de Nutrição a Partir da Perspectiva CTS: apontamentos para a } \\
\text { formação superior em saúde }\end{array}$ & $\begin{array}{c}\text { Artigo de periódico } \\
\text { Alexandria } \\
2,1 \\
\end{array}$ & $\begin{array}{l}\text { BIO } \\
\text { Saúde / Nutrição }\end{array}$ \\
\hline 12. & FERNANDES & 2009 & Tendências da pesquisa acadêmica sobre o ensino de ciencias nas series iniciais da escolarização (1972-2005) & Dissertação de mestrado & $\begin{array}{l}\text { Ensino ciências - series } \\
\text { iniciais }\end{array}$ \\
\hline 13. & FERNANDES \& MEGID & 2009 & $\begin{array}{l}\text { Modelos educacionais nas pesquisas sobre práticas pedagógicas no ensino de ciências nos anos iniciais da } \\
\text { escolarização (1972-2005) }\end{array}$ & $\begin{array}{l}\text { Trabalho em evento - VII } \\
\quad \text { ENPEC }\end{array}$ & $\begin{array}{l}\text { Modelos sobre práticas } \\
\text { pedagógicas }\end{array}$ \\
\hline
\end{tabular}




\begin{tabular}{|c|c|c|c|c|c|}
\hline 14. & FERREIRA \& MOREIRA & 2001 & A história da disciplina escolar ciências nas dissertações e teses brasileiras no período 1981-1995 & $\begin{array}{l}\text { Artigo de periódico - } \\
\text { Revista Ensaio; v3, n2 }\end{array}$ & Disciplina - Ciências \\
\hline 15. & FERREIRA e SELLES & 2003 & & $\begin{array}{l}\text { Trabalho em evento - IV } \\
\text { ENPEC }\end{array}$ & Livro Didático \\
\hline 16. & FERREIRA, Márcia & 2001 & A história da disciplina escolar ciências & $\begin{array}{l}\text { Trabalho em evento - III } \\
\text { ENPEC }\end{array}$ & $\begin{array}{l}\text { Disciplina Escolar - } \\
\text { Ciências }\end{array}$ \\
\hline 17. & $\begin{array}{ll}\text { FONSECA, } & \text { BAHIA, } \\
\text { BAMBERG } & \\
\end{array}$ & 2007 & Tendências em educação em ciências: o que indicam as pesquisas sobre o ensino universitário? & $\begin{array}{l}\text { Trabalho em evento }-\mathrm{VI} \\
\text { ENPEC }\end{array}$ & $\begin{array}{l}\text { Ensino Ciências - nível } \\
\text { superior }\end{array}$ \\
\hline 18. & FRANCO \& SZTAJN & 2007 & $\begin{array}{l}\text { Educação em ciências e matemática: identidade e implicações para políticas de formação continuada de } \\
\text { professores }\end{array}$ & $\begin{array}{l}\text { Trabalho em evento - VI } \\
\text { ENPEC }\end{array}$ & $\begin{array}{l}\text { Formação continuada de } \\
\text { professores }\end{array}$ \\
\hline 19. & FREGUGLIA \& LIMA & 2009 & A abordagem da linguagem no ensino de ciências em teses e dissertações brasileiras & $\begin{array}{l}\text { Trabalho em evento - VII } \\
\text { ENPEC }\end{array}$ & Linguagem \\
\hline 20. & $\begin{array}{l}\text { GEHLEN; SCHROEDER E } \\
\text { DELIZOICOV }\end{array}$ & 2001 & A abordagem histórico-cultural no encontro nac. de pesquisa em ens. de ciências & $\begin{array}{l}\text { Trabalho em evento - VI } \\
\text { ENPEC }\end{array}$ & $\begin{array}{l}\text { Abordagem histórico- } \\
\text { cultural / Vygotsky }\end{array}$ \\
\hline 21. & GIORDAN & 2005 & O computador na educação em ciências: breve revisão crítica acerca de algumas formas de utilização & $\begin{array}{l}\text { Artigo de periódico } \\
\text { Ciência\&Educação } 11,2\end{array}$ & TIC \\
\hline 22. & $\begin{array}{l}\text { GUIMARÃES; MELO; } \\
\text { MUNFORD }\end{array}$ & 2009 & $\begin{array}{l}\text { Etnografia na pesquisa em ensino de ciências no Brasil: análise de dois referenciais teórico-metodológicos } \\
\text { importantes no campo }\end{array}$ & $\begin{array}{l}\text { Trabalho em evento - VII } \\
\text { ENPEC }\end{array}$ & Referenciais / Etnografia \\
\hline 23. & $\begin{array}{l}\text { IANINI; FARES; BIZERRA; } \\
\text { MARANDINO }\end{array}$ & 2007 & Pesquisa em divulgação científica: um levantamento de referenciais teóricos nacionais & $\begin{array}{l}\text { Trabalho em evento - VI } \\
\text { ENPEC }\end{array}$ & Divulgação Científica \\
\hline 24. & INVERNIZI \& FRAGA & 2007 & Estado da arte na educação em ciência, tecnologia, sociedade e ambiente no Brasil & $\begin{array}{l}\text { Artigo de Periódico } \\
\text { Ciência\&Ensino 1, esp. }\end{array}$ & CTS \\
\hline 25. & KRASILCHIK & 1996 & Formação de professores e ensino de Ciências: tendências nos anos 90 & Capítulo de livro & Formação de professores \\
\hline 26. & LINHARES \& ERTHAL & 2009 & História da ciência em sala de aula: o que tem aparecido em nossas revistas? & $\begin{array}{l}\text { Trabalho em evento - VII } \\
\text { ENPEC }\end{array}$ & $\begin{array}{l}\text { História da Ciência em sala } \\
\text { de aula }\end{array}$ \\
\hline 27. & LIOTTI \& OLIVEIRA & 2007 & Currículo de ciências e as atuais reformas: o que dizem as pesquisas? & $\begin{array}{l}\text { Trabalho em evento - VI } \\
\text { ENPEC }\end{array}$ & $\begin{array}{l}\text { Reformas curriculares / } \\
\text { Ciências }\end{array}$ \\
\hline 28. & LIPPE \& CAMARGO & 2009 & $\begin{array}{l}\text { Educação especial nas atas do ENPEC e em revistas brasileiras e espanholas relevantes na área: delineando } \\
\text { tendências e apontando demandas de investigação em ciências }\end{array}$ & $\begin{array}{l}\text { Trabalho em evento - VII } \\
\text { ENPEC }\end{array}$ & Educação Especial \\
\hline 29. & MARTINS, Isabel & 2007 & $\begin{array}{l}\text { O papel dos periódicos na consolidação da identidade da pesquisa na área de Ensino de Ciências: reflexões a } \\
\text { partir da experiência da Revista Brasileira de Pesquisa em educação em Ciências }\end{array}$ & Mesa redonda - VI ENPEC & Periódicos da área \\
\hline 30. & MEGID & 1999 & $\begin{array}{l}\text { O que sabemos sobre a pesquisa em ensino de ciências no nível fundamental: tendências de teses e } \\
\text { dissertações defendidas entre } 1972 \text { e } 1995\end{array}$ & $\begin{array}{l}\text { Trabalho em evento - II } \\
\text { ENPEC }\end{array}$ & Ensino fundamental \\
\hline 31. & MUENCHEN \& DELIZOICOV & 2009 & Pesquisas em educação em ciências na região de Santa Maria/RS: algumas características & $\begin{array}{l}\text { Trabalho em evento - VII } \\
\text { ENPEC }\end{array}$ & Santa Maria - RS \\
\hline 32. & NARDI \& GATTI & 2004 & $\begin{array}{l}\text { Uma revisão sobre as investigações construtivistas nas últimas décadas: concepções espontâneas, mudança } \\
\text { conceitual e ensino de ciências }\end{array}$ & Artigo de periódico & $\begin{array}{l}\text { Investigações } \\
\text { construtivistas / ensino de } \\
\text { física }\end{array}$ \\
\hline 33. & NOVIKOFF et al & 2009 & As racionalidades nos programas de mestrado profissional em ensino de ciências & $\begin{array}{l}\text { Trabalho em Evento } \\
\text { I SNECT, } 2009\end{array}$ & $\begin{array}{l}\text { Racionalidade / Mestrado } \\
\text { profissional }\end{array}$ \\
\hline
\end{tabular}




\begin{tabular}{|c|c|c|c|c|c|}
\hline 34. & NUNES; FERRAZ \& JUSTINA & 2007 & Estudos relativos a analogias no ensino de Ciências & $\begin{array}{l}\text { Trabalho em evento - VI } \\
\text { ENPEC }\end{array}$ & Analogias \\
\hline 35. & ODA \& BEJARANO & 2007 & O ensino de ciências nos cursos universitários: uma revisão bibliográfica & $\begin{array}{l}\text { Trabalho em evento - VI } \\
\text { ENPEC }\end{array}$ & Cursos Universitários \\
\hline 36. & PASSOS, PASSOS, ARRUDA, & 2009 & $\begin{array}{l}\text { Uma análise dos problemas de pesquisa sobre formação inicial de professores nos artigos das revistas Ensaio e } \\
\text { Revista Brasileira de Pesquisa em Educação em Ciências }\end{array}$ & $\begin{array}{l}\text { Trabalho em evento - VII } \\
\text { ENPEC }\end{array}$ & $\begin{array}{l}\text { Formação inicial de } \\
\text { professores }\end{array}$ \\
\hline 37. & PINHÃO \& MARTINS & 2009 & $\begin{array}{l}\text { Análise do discurso e a pesquisa em ensino de ciências no Brasil: um levantamento da produção em periódicos } \\
\text { entre } 1998 \text { e } 2008\end{array}$ & $\begin{array}{l}\text { Trabalho em evento-VII } \\
\text { ENPEC }\end{array}$ & Análise de discurso \\
\hline 38. & $\begin{array}{l}\text { QUEIRÓS, BATISTETI, } \\
\text { JUSTINA }\end{array}$ & 2009 & $\begin{array}{l}\text { Tendências das pesquisas em história e filosofia da ciência e ensino de ciências: o que o ENPEC e o EPEF nos } \\
\text { revelam? }\end{array}$ & $\begin{array}{l}\text { Trabalho em evento - VII } \\
\text { ENPEC }\end{array}$ & $\begin{array}{l}\text { História e Filosofia da } \\
\text { Ciência }\end{array}$ \\
\hline 39. & RAMOS \& SILVA & 2007 & $\begin{array}{l}\text { Controvérsias científicas em sala de aula: uma revisão bibliográfica contextualizada na área de ensino de } \\
\text { ciências e nos estudos sociológicos da ciência \& tecnologia }\end{array}$ & $\begin{array}{l}\text { Trabalho em evento - VI } \\
\text { ENPEC }\end{array}$ & $\begin{array}{l}\text { Controvérsias científicas } \\
\text { em s. de a. / C\&T }\end{array}$ \\
\hline 40. & RAMOS, LIMA, ROCHA Fo. & 2009 & A pesquisa como prática na sala de aula de Ciências e Matemática: um olhar sobre dissertações & $\begin{array}{l}\text { Artigo de periódico } \\
\text { Alexandria 2,3 }\end{array}$ & "Educar pela Pesquisa" \\
\hline 41. & $\begin{array}{ll}\text { REZENDE } \\
\text { CARVALHO }\end{array} \quad$ FILHO \& & 2009 & Modelos e mudanças em vídeos de educação em saúde: visão histórica de um acervo & $\begin{array}{l}\text { Trabalho em evento - VII } \\
\text { ENPEC }\end{array}$ & \begin{tabular}{|l|} 
BIO \\
Vídeos / saúde
\end{tabular} \\
\hline 42. & RIPOLL; AMARAL; SANTOS & 2007 & A pesquisa qualitativa e o ensino de ciências nos trabalhos de ENPEC: outras questões a serem discutidas & $\begin{array}{l}\text { Trabalho em evento }-\mathrm{VI} \\
\text { ENPEC }\end{array}$ & Pesquisa qualitativa \\
\hline 43. & SANTOS \& ARROIO & 2009 & A utilização de recursos audiovisuais no ensino de ciências: tendências nos ENPECS entre 1997 e 2007 & $\begin{array}{l}\text { Trabalho em evento - VII } \\
\text { ENPEC }\end{array}$ & Recursos audiovisuais \\
\hline 44. & SERRA \& ARROIO & 2007 & $\begin{array}{l}\text { Análise dos trabalhos apresentados nos Enpecs - Encontro Nacional de Pesquisa em Educação em Ciências no } \\
\text { período de } 1997 \text { a 2005, onde são abordados na temática desenvolvida o uso do microcomputador como } \\
\text { recurso para aprendizagem }\end{array}$ & $\begin{array}{l}\text { Trabalho em evento - VI } \\
\text { ENPEC }\end{array}$ & $\begin{array}{l}\text { TIC } \\
\text { Uso de microcomputador }\end{array}$ \\
\hline 45. & SILVA \& MEGID & 2006 & $\begin{array}{l}\text { Formação de professores e educadores para abordagem da Educação Sexual na Escola: O que mostram as } \\
\text { pesquisas }\end{array}$ & $\begin{array}{l}\text { Artigo de periódico } \\
\text { Ciência Educação } \\
12,2\end{array}$ & $\begin{array}{l}\text { Formação de professores, } \\
\text { Educação Sexual }\end{array}$ \\
\hline 46. & $\begin{array}{ll}\text { SILVA, } & \text { CARVALHO, } \\
\text { MUNFORD } & \end{array}$ & 2009 & Formação de professores de ciências: revisão de periódicos (2006-2007) & $\begin{array}{l}\text { Trabalho em evento - VII } \\
\text { ENPEC }\end{array}$ & Formação de professores \\
\hline 47. & $\begin{array}{ll}\text { SLONGO, } & \text { ROSSET, } \\
\text { DELIZOICOV } & \end{array}$ & 2009 & A formação de professores nas atas do ENPEC: uma análise preliminar & $\begin{array}{l}\text { Trabalho em evento - VII } \\
\text { ENPEC }\end{array}$ & Formação de professores \\
\hline 48. & TEIXEIRA \& LIRA & 2009 & Estado da arte dos trabalhos apresentados nos ENPECS sobre explicação de 1997- 2007 & $\begin{array}{l}\text { Trabalho em evento - VII } \\
\text { ENPEC }\end{array}$ & "Explicação" \\
\hline 49. & $\begin{array}{l}\text { TRACTENBERG } \\
\text { STRUCHINER }\end{array}$ & 2009 & $\begin{array}{l}\text { Revisão da literatura sobre colaboração docente no ensino superior de ciências exatas, biológicas e da saúde } \\
(1988-2008)\end{array}$ & $\begin{array}{l}\text { Trabalho em evento - VII } \\
\text { ENPEC }\end{array}$ & $\begin{array}{l}\text { Colaboração docente / } \\
\text { ensino superior }\end{array}$ \\
\hline 50. & VASCOONSELOS ET al & 2007 & Estado da arte na resolução de problemas em Educação em Ciência & Artigo & Resolução de problemas \\
\hline
\end{tabular}

Tabela 1.1b: Trabalhos sobre "estado da arte" em Ensino de Ciências - recortes específicos 
ANEXO 1.2

TRABALHOS DE ESTADO DA ARTE NA PESQUISA EM ENSINO DE FÍSICA 


\section{ESTADO DA ARTE - PESQUISA EM ENSINO DE FISICA}

\section{A. GERAIS}

\begin{tabular}{|c|c|c|c|c|c|c|}
\hline & \multicolumn{4}{|c|}{ A PRODUÇÃO } & \multicolumn{2}{|c|}{$\begin{array}{l}\text { A PRODUÇÃO ANALISADA } \\
\text { (ESTADO DA ARTE) }\end{array}$} \\
\hline & AUTOR & ANO & TítULo & $\begin{array}{l}\text { NATUREZA DO } \\
\text { TRABALHO }\end{array}$ & PERÍODO ANALISADO & PRODUÇÃO ANALISADA \\
\hline 1. & ALMEIDA & 2003 & $\begin{array}{l}\text { Meio século de educação em ciências: uma leitura de recomendações } \\
\text { ao professor de física }\end{array}$ & Tese de Livre-Docência & geral & Periódicos \\
\hline 2. & ALMEIDA & 2003 & Fundamentos da pesquisa no ensino de ciências e física & $\begin{array}{l}\text { Trabalho em Evento } \\
\text { IV EPEF }\end{array}$ & & \\
\hline 3. & BARROS & 2002 & Reflexões sobre 30 anos da pesquisa em ensino de física & $\begin{array}{l}\text { Evento Conferência - VIII } \\
\text { EPEF }\end{array}$ & Déc.1960 a 1990 & Geral \\
\hline 4. & BORTOLETTO ET AL & 2007 & $\begin{array}{l}\text { Pesquisa em ensino de física (2000-2007): áreas temáticas em } \\
\text { eventos e revistas nacionais }\end{array}$ & $\begin{array}{c}\text { Evento } \\
\text { VI ENPEC } \\
\end{array}$ & $2000-2007$ & Periódicos e Eventos \\
\hline 5. & CARVALHO & 2002 & A pesquisa no ensino, sobre o ensino & $\begin{array}{c}\text { Evento - Sessão } \\
\text { Coordenada - VIII EPEF }\end{array}$ & & Periódicos \\
\hline 6. & CARVALHO \& VANNUCCHI & 1996 & O currículo de física: inovações e tendências nos anos noventa & $\begin{array}{l}\text { Artigo } \\
\mathrm{IEC}, 1\end{array}$ & 1990-1995 & Trabalhos em eventos e artigos \\
\hline 7. & KAWAMURA & 1993 & Tendências atuais no ensino de física & $\begin{array}{l}\text { Evento - Mesa Redonda } \\
\text { X SNEF }\end{array}$ & Dec. 1970 e 1980 & Geral \\
\hline 8. & MEGID & 1990 & $\begin{array}{l}\text { Pesquisa em ensino de fisica do } 2 \text {. grau no Brasil - concepcao e } \\
\text { tratamento de problemas em teses e dissertacoes. }\end{array}$ & Dissertação de mestrado & $1972-1987$ & Dissertações e teses \\
\hline 9. & MEGID & 2000 & $\begin{array}{l}\text { Sobre as pesquisas em ensino de física nós podemos saber; mas... } \\
\text { como socializar os conhecimentos elaborados nessas pesquisas? }\end{array}$ & $\begin{array}{l}\text { Evento - Trabalho } \\
\text { VII EPEF }\end{array}$ & 1972-1995 & Dissertações e teses \\
\hline 10. & MEGID \& PACHECO & 1998 & $\begin{array}{l}\text { Pesquisas sobre o ensino de física do } 2^{\circ} \text {. Grau no Brasil: concepção e } \\
\text { tratamento de problemas em teses e dissertações }\end{array}$ & $\begin{array}{c}\text { Artigo } \\
\text { Pesq.Ens.Fis, Escrituras - } \\
\text { pg 5-20 (Nardi) }\end{array}$ & 1972-1995 & Dissertações e teses \\
\hline 11. & MOREIRA & 1993 & O estado da arte na investigação em didática da Física & $\begin{array}{l}\text { Evento - Conferência } \\
\text { III Enc. Ibérico }\end{array}$ & $1960-1990$ & Geral \\
\hline 12. & MOREIRA & 2000 & Ensino de Física no Brasil: retrospectiva e perspectivas ${ }^{* 1}$ & $\begin{array}{c}\text { Artigo } \\
\text { RBEF 22(1) }\end{array}$ & 1960-2000geral & Geral \\
\hline 13. & MOREIRA & 2002 & A internacionalização da área de pesquisa em ensino de física & VIII EPEF & Década de $70-2000$ & Geral \\
\hline 14. & NARDI & 2005 & $\begin{array}{l}\text { Memórias da educação em ciências no Brasil: a pesquisa em ensino } \\
\text { de física }\end{array}$ & $\begin{array}{c}\text { Artigo } \\
\text { (IEC 10,1) }\end{array}$ & $1970-200 x g e r a l$ & Geral \\
\hline 15. & NARDI & 2006 & $\begin{array}{l}\text { A pesquisa em ensino de física no Brasil: interpretações sobre suas } \\
\text { origens e características }\end{array}$ & $\begin{array}{l}\text { Evento - Mesa Redonda } \\
\text { XEPEF }\end{array}$ & $1970-200 x g e r a l$ & geral \\
\hline 16. & PACHECO \& MEGID & 1999 & $\begin{array}{l}\text { Propostas metodológicas para o ensino de Física apresentadas em } \\
\text { teses e dissertações defendidas entre } 1972 \text { e } 1995 \text { no Brasil }\end{array}$ & $\begin{array}{c}\text { Evento } \\
\text { XIII SNEF }\end{array}$ & 1972-1995 & Dissertações e teses \\
\hline 17. & $\begin{array}{llr}\text { PACHECO, } & \text { MEGID } \quad \& \\
\text { GOMIDE } & & \end{array}$ & 1993 & $\begin{array}{l}\text { Tempo de avaliação: } 20 \text { anos de teses e dissertações sobre ensino de } \\
\text { física no Brasil }\end{array}$ & $\begin{array}{l}\text { Evento } \\
\text { X SNEF }\end{array}$ & 1972-1991 & Dissertações e teses \\
\hline
\end{tabular}




\begin{tabular}{|c|c|c|c|c|c|c|}
\hline 18. & PENA & 2004 & $\begin{array}{l}\text { Por que, apesar do grande avanço da pesquisa acadêmica sobre } \\
\text { ensino de Física no Brasil, ainda há pouca aplicação dos resultados } \\
\text { em sala de aula? }\end{array}$ & $\begin{array}{l}\text { Artigo } \\
\text { Rev. Bras. Ens. Fis. } \\
\text { 26(4), Carta ao Editor }\end{array}$ & Dec. 70 - 2000 & geral \\
\hline 19. & PENA \& FREIRE JR & 2003 & Sobre a modernização do ensino de física no Brasil (1960 - 1979) & $\begin{array}{l}\text { Evento } \\
\text { IV ENPEC }\end{array}$ & $1960-1979$ & Geral \\
\hline 20. & PIETROCOLA & 2002 & $\begin{array}{l}\text { Visibilidade social e contatos com a área de Educação. In: Identidade, } \\
\text { sustentabilidade e visibilidade social da pesquisa em ensino de física }\end{array}$ & $\begin{array}{l}\text { Evento - Mesa Redonda } \\
\text { VIII EPEF }\end{array}$ & $1970-2000$ & Geral \\
\hline 21. & QUEIROZ \& SILVA & 2008 & $\begin{array}{l}\text { A pesquisa em ensino de física no Brasil: um balanço crítico a partir } \\
\text { dos eventos da Sociedade Brasileira de Física }\end{array}$ & $\begin{array}{l}\text { Evento } \\
\text { XI EPEF }\end{array}$ & $1997-2005$ & Trabalho em evento \\
\hline 22. & QUEIROZ \& SILVA & 2009 & $\begin{array}{l}\text { A pesquisa em ensino de física no Brasil: um balanço crítico das } \\
\text { publicações do encontro de pesquisadores em ensino de física e } \\
\text { caderno brasileiro em ensino de física }\end{array}$ & $\begin{array}{l}\text { EVENTO } \\
\text { VII ENPEC }\end{array}$ & $1996-2006$ & $\begin{array}{l}\text { Trabalhos em eventos e artigos } \\
\text { de periódicos }\end{array}$ \\
\hline 23. & SALEM \& KAWAMURA & 1993a & Teses na área de ensino de física. & $\begin{array}{l}\text { Evento } \\
\text { X SNEF }\end{array}$ & 1972-1992 & Dissertações e teses \\
\hline 24. & SALEM \& KAWAMURA & $1993 c$ & Banco de Referências de Ensino de Física. & $\begin{array}{c}\text { Artigo } \\
\text { Cad.Cat.Ens.Fis 10(3) }\end{array}$ & 1970-1992 & Geral \\
\hline 25. & SALEM \& KAWAMURA & 1994 a & Caminhos e tendências do ensino de física & $\begin{array}{l}\text { Evento } \\
\text { IV EPEF }\end{array}$ & 1970-1992 & Geral \\
\hline 26. & SALEM \& KAWAMURA & 1994b & Simpósios Nacionais de Ensino de Física & $\begin{array}{l}\text { Evento } \\
\text { IV EPEF }\end{array}$ & 1970-1993 & Trabalhos em eventos \\
\hline 27. & SALEM \& KAWAMURA & 1997 & $\begin{array}{l}\text { Dissertações e teses em ensino de física no Brasil: UM PANORMA DO } \\
\text { PERÍODO 1972-2005 }\end{array}$ & $\begin{array}{l}\text { Evento } \\
\text { XII SNEF }\end{array}$ & $1972-1995$ & Dissertações e teses \\
\hline 28. & SALEM \& KAWAMURA & 2007 & Simpósios Nacionais de Ensino de Física: uma sistematização & $\begin{array}{l}\text { Evento } \\
\text { XVII SNEF }\end{array}$ & $1972-2005$ & Trabalhos em eventos \\
\hline 29. & SALEM \& KAWAMURA & 2008 & $\begin{array}{l}\text { Dissertações e teses em ensino de física no Brasil: } \\
\text { um panorama do período 1972-2005 }\end{array}$ & $\begin{array}{l}\text { Trabalho em Evento } \\
\text { XI EPEF }\end{array}$ & $1972-2005$ & Dissertações e teses \\
\hline 30. & SALEM \& KAWAMURA & 2009 & Estado da arte dos estados da arte da pesquisa em ensino de física & $\begin{array}{c}\text { Evento } \\
\text { VII ENPEC }\end{array}$ & $1990-2005$ & \\
\hline 31. & $\begin{array}{lrrr}\text { SALEM, } & \text { DEL } & \text { CARLO } & \& \\
\text { KAWAMURA } & & \\
\end{array}$ & $1993 b$ & Banco de referências de ensino de física. & $\begin{array}{l}\text { Evento } \\
\text { X SNEF }\end{array}$ & $1972-1990$ & Geral \\
\hline 32. & SOUZA FILHO ET AL (NARDI) & 2005 & $\begin{array}{l}\text { Tendências da Pesquisa em Ensino de Física em publicações e } \\
\text { eventos recentes }\end{array}$ & $\begin{array}{l}\text { Evento } \\
\text { V ENPEC }\end{array}$ & $2000-2005$ & Publicações e eventos \\
\hline 33. & TERRAZZAN ET AL & 2000 & $\begin{array}{l}\text { Pesquisa em ensino de física: revendo trajetórias, constatando } \\
\text { demandas e projetando caminhos }\end{array}$ & $\begin{array}{c}\text { Evento (pôster) } \\
\text { VII EPEF }\end{array}$ & Geral & Periódicos e eventos \\
\hline 34. & VILLANI & 2006 & A pesquisa em ensino de Física: novas tendências e perspectivas & $\begin{array}{l}\text { Evento - Mesa Redonda } \\
\text { X EPEF }\end{array}$ & geral & Geral \\
\hline
\end{tabular}

Tabela 1.2a: Trabalhos sobre "estado da arte" em Ensino de Física - Gerais 


\section{RECORTES TEMÁTICOS}

\begin{tabular}{|c|c|c|c|c|c|c|c|}
\hline & \multicolumn{4}{|c|}{ A PRODUÇÃO } & \multicolumn{3}{|c|}{$\begin{array}{l}\text { A PRODUÇÃO ANALISADA } \\
\text { (ESTADO DA ARTE) }\end{array}$} \\
\hline & AUTOR & ANO & TítULo & $\begin{array}{l}\text { NATUREZA DO } \\
\text { TRABALHO }\end{array}$ & $\begin{array}{l}\text { PERÍODO } \\
\text { ANALISADO }\end{array}$ & $\begin{array}{l}\text { PRODUÇÃO } \\
\text { ANALISADA }\end{array}$ & FOCO / TEMA \\
\hline 1. & ARAÚJO \& VEIT & 2004 & $\begin{array}{l}\text { Uma revisão da literatura sobre estudos relativos a } \\
\text { tecnologias computacionais no ensino de física }\end{array}$ & Artigo de periódico & $1990-2003$ & artigos de periódicos & TIC \\
\hline 2. & ARAUJO et al & 2009 & $\begin{array}{l}\text { Tendências das propostas de utilização das ferramentas } \\
\text { computacionais no ensino de física no nível médio e superior }\end{array}$ & $\begin{array}{c}\text { Trabalho em evento } \\
\text { - VII ENPEC }\end{array}$ & $2000-2008$ & artigos de periódicos & TIC \\
\hline 3. & AZEVEDO et al & 2009 & $\begin{array}{l}\text { O uso do experimento no ensino da física: tendências a partir } \\
\text { do levantamento dos artigos em periódicos da área no Brasil }\end{array}$ & $\begin{array}{c}\text { Trabalho em evento } \\
\text { - VII ENPEC }\end{array}$ & $1979-2008$ & artigos de periódicos & $\begin{array}{c}\text { Atividade } \\
\text { experimental }\end{array}$ \\
\hline 4. & CARLOS et al & 2009 & $\begin{array}{l}\text { Análise de artigos sobre atividades experimentais de física nas } \\
\text { atas do encontro nacional de pesquisa em educação em } \\
\text { ciências }\end{array}$ & $\begin{array}{l}\text { Trabalho em evento } \\
- \text { VII ENPEC }\end{array}$ & $1997-2007$ & Trabalhos em eventos & $\begin{array}{c}\text { Atividade } \\
\text { experimental }\end{array}$ \\
\hline 5. & CASTRO ET AL & 2003 & $\begin{array}{l}\text { Uma visão da formação inicial de professores de física na } \\
\text { última virada de século no Brasil }\end{array}$ & $\begin{array}{c}\text { Trabalho em evento } \\
\text { - IV ENPEC } \\
\end{array}$ & $1997-2002$ & Trabalhos em eventos & $\begin{array}{c}\text { Formação de } \\
\text { professores }\end{array}$ \\
\hline 6. & D'AGOSTIN; GARCIA; LEITE & 2007 & $\begin{array}{lllll}\begin{array}{l}\text { Física moderna e contemporânea no ensino médio: } \\
\text { revisitando artigos de revistas }\end{array} & & \\
\end{array}$ & $\begin{array}{c}\text { Trabalho em evento } \\
\text { - VI ENPEC } \\
\end{array}$ & 2002 a 2007 & Artigos de periódicos & FMC \\
\hline 7. & FÁVERO \& SOUZA & 2001 & $\begin{array}{l}\text { A resolução de problemas em física: revisão de pesquisa, } \\
\text { análise e proposta metodológica }\end{array}$ & $\begin{array}{l}\text { Artigo de periódico- } \\
\text { Inv. Ens.Cien. 6,2 } \\
\end{array}$ & 1970 a 1999 & Artigos de periódicos & $\begin{array}{l}\text { Resolução de } \\
\text { problemas }\end{array}$ \\
\hline 8. & GRECA \& MOREIRA & 2001 & $\begin{array}{l}\text { Uma revisão da literatura sobre estudos relativos ao ensino } \\
\text { da mecânica quântica introdutória }\end{array}$ & $\begin{array}{l}\text { Artigo de periódico- } \\
\text { Inv. Ens.Cien. } 6,1 \\
\end{array}$ & $1970-2000$ & Periódicos & Mecânica Quântica \\
\hline 9. & $\begin{array}{ll}\text { JARDIM; } & \text { ERROBIDART; } \\
\text { GOBARA } & \\
\end{array}$ & 2008 & $\begin{array}{l}\text { Levantamento dos trabalhos em ensino de física que } \\
\text { investigaram ondas sonoras }\end{array}$ & $\begin{array}{c}\text { Trabalho em evento } \\
\text { - XI EPEF } \\
\end{array}$ & $1980-2005$ & $\begin{array}{l}\text { Dissertações e teses; } \\
\text { artigos de periódicos }\end{array}$ & TD / Ondas sonoras \\
\hline 10. & MONTEIRO \& NARDI & 2007 & $\begin{array}{l}\text { Tendências das pesquisas sobre o ensino da física moderna e } \\
\text { contemporânea apresentadas nos ENPEC }\end{array}$ & $\begin{array}{c}\text { Trabalho em evento } \\
\text { - VI ENPEC } \\
\end{array}$ & $1997-2005$ & $\begin{array}{l}\text { Trabalhos em Eventos } \\
\text { (ENPEC) }\end{array}$ & $\begin{array}{l}\text { Física Moderna e } \\
\text { Contemporânea }\end{array}$ \\
\hline 11. & MOZENA \& OSTERMANN & 2008 & $\begin{array}{l}\text { A pesquisa em ensino de física nas séries iniciais do ensino } \\
\text { fundamental: uma revisão de literatura em artigos recentes } \\
\text { de periódicos nacionais "Qualis A" }\end{array}$ & $\begin{array}{l}\text { Trabalho em evento } \\
\quad-\text { XI EPEF }\end{array}$ & 1984-2007 & Periódicos & Ensino Fundamental \\
\hline 12. & NARDI \& GATTI & 2004 & $\begin{array}{l}\text { Uma revisão sobre as investigações construtivistas nas últimas } \\
\text { décadas: concepções espontâneas, mudança conceitual e } \\
\text { ensino de ciências }\end{array}$ & $\begin{array}{l}\text { Artigo - revista } \\
\text { Ensaio }\end{array}$ & Dec $70 \ldots$ & $\begin{array}{l}\text { Publicações diversas } \\
\text { (?) }\end{array}$ & construtivismo \\
\hline & NASCIMENTO \& REZENDE JR & 2006 & $\begin{array}{l}\text { Trabalhos de divulgação científica: uma análise de tendências } \\
\text { em eventos de Ensino de Ciências e Física }\end{array}$ & $\begin{array}{l}\text { Trabalho em evento } \\
\quad-X \text { EPEF }\end{array}$ & $1997-2005$ & $\begin{array}{l}\text { Trabalhos em eventos } \\
\text { (SNEF, ENPEC, EPEF) }\end{array}$ & Divulgação Científica \\
\hline 13. & OSTERMANN \& MOREIRA & 2001 & $\begin{array}{l}\text { Uma revisão bibliográfica sobre a área de pesquisa "Física } \\
\text { Moderna e Contemporânea no Ensino Médio" }\end{array}$ & $\begin{array}{l}\text { Artigo de periódico } \\
\text { - Inv. Em Ens. De } \\
\text { Ciências 5,1 }\end{array}$ & $1970-2000 ?$ & Publicações diversas & $\begin{array}{l}\text { Física Moderna e } \\
\text { Contemporânea }\end{array}$ \\
\hline 14. & PACHECO; LIMA; QUEIROZ & 2003 & $\begin{array}{l}\text { A formação continuada do professor de física na última virada } \\
\text { de século no Brasil }\end{array}$ & $\begin{array}{l}\text { Trabalho em evento } \\
\text { - IV ENPEC }\end{array}$ & 2000 e 2001 & Trabalhos em eventos & $\begin{array}{l}\text { Formação de } \\
\text { professores }\end{array}$ \\
\hline
\end{tabular}




\begin{tabular}{|c|c|c|c|c|c|c|c|}
\hline 15. & PENA \& RIBEIRO FILHO & 2008 & $\begin{array}{l}\text { Relação entre a pesquisa em ensino de física e a prática } \\
\text { docente: dificuldades assinaladas pela literatura nacional } \\
\text { da área }\end{array}$ & $\begin{array}{l}\text { Artigo de periódico } \\
\text { Cad. Bras. Ens. Fis., } \\
\text { Dez/2008 }\end{array}$ & $1980-2006(\sim)$ & Diversos & $\begin{array}{l}\text { Pesquisa em esnino } \mathrm{x} \\
\text { prática docente }\end{array}$ \\
\hline 16. & PENA \& RIBEIRO FILHO & 2009 & $\begin{array}{l}\text { Relação entre a pesquisa em ensino de física e a prática } \\
\text { docente: dificuldades assinaladas pela literatura nacional da } \\
\text { área }\end{array}$ & $\begin{array}{l}\text { Artigo de periódico } \\
\text { Rev. Bras. Pesq. } \\
\text { Educ. Cienc. 9,1 }\end{array}$ & $1971-2006$ & Periódicos nacionais & Experimentação \\
\hline 17. & PENA \& RIBEIRO FILHO & 2009 & $\begin{array}{l}\text { O uso didático da história da ciência após a implantação dos } \\
\text { parâmetros curriculares nacionais para o ensino médio } \\
\text { (PCNEM): um estudo a partir de relatos de } \\
\text { experiênciaspedagógicas publicados em periódicos nacionais } \\
\text { especializados em ensino de física (2000-2006) }\end{array}$ & $\begin{array}{l}\text { Artigo de periódico } \\
\text { Cad. Cat. Ens. Fis. } \\
\text { abr/2009 }\end{array}$ & $2000-2006$ & Periódicos nacionais & $\begin{array}{l}\text { História da Ciência } \\
\text { /uso didático }\end{array}$ \\
\hline 18. & PEREIRA \& OSTERMANN & 2009 & $\begin{array}{l}\text { Sobre o ensino de física moderna e contemporânea: uma } \\
\text { revisão da produção acadêmica recente }\end{array}$ & $\begin{array}{l}\text { Artigo de periódico } \\
\text { Inv. Ens. Cienc, } \\
2009 \\
\end{array}$ & $2001-2006$ & Artigos de periódicos & $\begin{array}{l}\text { Física Moderna e } \\
\text { Contemporânea }\end{array}$ \\
\hline 19. & PEREIRA \& OSTERMANN & 2007 & $\begin{array}{l}\text { Uma análise da produção acadêmica recente sobre o ensino } \\
\text { de FMC no Brasil }\end{array}$ & $\begin{array}{c}\text { Trabalho em evento } \\
\text { - IV ENPEC } \\
\end{array}$ & $2001-2006$ & Artigos de periódicos & $\begin{array}{l}\text { Física Moderna e } \\
\text { Contemporânea }\end{array}$ \\
\hline 20. & PORTELA \& HIGA & 2007 & $\begin{array}{l}\text { Os estudos sobre ensino de Física nas séries iniciais do ensino } \\
\text { fundamental }\end{array}$ & $\begin{array}{c}\text { Trabalho em evento } \\
- \text { VI ENPEC }\end{array}$ & $1994-2006$ & Artigos de periódicos & $\begin{array}{l}\text { EF nas séries iniciais } \\
\text { do Ens. Fund. }\end{array}$ \\
\hline 21. & $\begin{array}{ll}\text { REZENDE; } & \text { OSTERMANN; } \\
\text { FERRAZ; }\end{array}$ & 2009 & $\begin{array}{l}\text { Ensino-aprendizagem de física no nível médio: o estado da } \\
\text { arte da produção acadêmica no século XXI }\end{array}$ & $\begin{array}{c}\text { Artigo de periódico } \\
\text { - RBEF, 31(1) } \\
\end{array}$ & $2000-2007$ & Periódicos & $\begin{array}{l}\text { EA de Física no nível } \\
\text { médio }\end{array}$ \\
\hline 22. & $\begin{array}{ll}\text { REZENDE; } & \text { OSTERMANN; } \\
\text { FERRAZ; RUBINO }\end{array}$ & 2007 & $\begin{array}{l}\text { Tendências da pesquisa: o que dizem os periódicos nacionais } \\
\text { sobre o ensino e aprendizagem de física no nível médio? }\end{array}$ & $\begin{array}{l}\text { Trabalho em evento } \\
\text { - VI ENPEC }\end{array}$ & $2000-2006$ & Periódicos & $\begin{array}{l}\text { EA de Física no nível } \\
\text { médio }\end{array}$ \\
\hline 23. & ROSA \& ALVES FILHO & 2007 & $\begin{array}{l}\text { A metacognição como estratégia de aprendizagem em Física: } \\
\text { o que mostram as pesquisas brasileiras }\end{array}$ & $\begin{array}{l}\text { Trabalho em evento } \\
- \text { VI ENPEC }\end{array}$ & $1997-2006$ & $\begin{array}{l}\text { Teses, artigos, } \\
\text { trabalhos em eventos }\end{array}$ & Metacognição \\
\hline 24. & SILVA \& REGO & 2007 & $\begin{array}{l}\text { A educação a distância na formação do professor de física: } \\
\text { análise de trabalhos publicados no período 2000-2006 }\end{array}$ & $\begin{array}{l}\text { Trabalho em evento } \\
- \text { VI ENPEC }\end{array}$ & $2000-2006$ & $\begin{array}{l}\text { Artigos de Periódicos } \\
\text { e trabalhos em } \\
\text { Eventos }\end{array}$ & $\begin{array}{l}\text { EA na formação do } \\
\text { professor }\end{array}$ \\
\hline 25. & SUTIL ET AL & 2008 & $\begin{array}{l}\text { CTS e CTSA em periódicos nacionais em ensino de } \\
\text { ciências/física (2000-2007): considerações sobre a prática } \\
\text { educacional em física }\end{array}$ & $\begin{array}{c}\text { Trabalho em evento } \\
\text { - XI EPEF }\end{array}$ & $2000-2007$ & Periódicos & CTS \\
\hline 26. & $\begin{array}{ll}\text { TONIATO; } & \text { FERREIRA; } \\
\text { FERRACIOLI } & \\
\end{array}$ & 2006 & Tecnologia no ensino de Física: uma revisão do XVI SNEF & $\begin{array}{c}\text { Trabalho em evento } \\
\text {-X EPEF }\end{array}$ & 2005 & $\begin{array}{l}\text { Trabalho em Evento - } \\
\text { XVI SNEF }\end{array}$ & TIC \\
\hline
\end{tabular}

Tabela 1.2b: Trabalhos sobre "estado da arte" em Ensino de Física - recortes específicos 


\section{ANEXO 3.1}

TABELA GERAL - DISSERTAÇÕES E TESES: 1972-2009 
TABELA GERAL - DISSERTAÇÕES E TESES: 1972-2009

AUTOR(A)

ANO

GA

ORIENTADOR(A)

INSTITUIÇÃO

1. ABDALA, Marta Ferreira

2. $A B E G G$, llse

3. $A B I B$, Maria Lucia V. dos Santos

4. ABIB, Maria Lucia V. dos Santos

5. ABRAHÃO, Thais Cortellini

6. ABRAMOF, Patricia Guimarães

7. ABRANTES, Antonio Carlos Souza de

8. ABREU, Arthur G. Fernandes

9. AGOSTINI, Sandra

10. AGRA, João Tertuliano N.

11. AGUIAR JR, Orlando Gomes de

12. AGUIAR JR, Orlando Gomes de

13. ALBINO, Maria da Glória F. do Nascimento

14. ALBUQUERQUE, Dener da Silva

15. ALBUQUERQUE, Ivone Freire $M$.

16. ALCÂNTARA FILHO, José de

17. ALENCAR, José Ricardo da Silva

18. ALLAIN, Luciana Rezende

19. ALMEIDA FILHO, Wilson Rocha

20. ALMEIDA, Fabiana Carlos P. de

21. ALMEIDA, Fabiana Ribeiro de

22. ALMEIDA, Judite Fernandes de

23. ALMEIDA, Lucia da Cruz

24. ALMEIDA, Maria José P. M. de

25. ALMEIDA, Maria José P. M. de

26. ALMEIDA, Ruy Guilherme C. de

27. ALMEIDA, Ruy Guilherme C. de

28. ALMEIDA, Sonia Maria de

29. ALMEIDA, Voltaire de Oliveira

30. ALVARENGA, Luciano Lewandoski

31. ALVARENGA, Rodrigo Gontijo de

32. ALVAREZ, Denise

33. ALVES FILHO, José de Pinho

34. ALVES FILHO, José de Pinho

35. ALVES, Deuel Bernardes

36

37. ALVES, Joao Carlos Nogueira

38. ALVES, João Carlos Nogueira

39. ALVES, Luís Augusto

40. ALVES, Rosilda Maria

41. ALVES, Valéria de Freitas

42. ALVES, Virginia Mello

43. ALVETTI, Marco Antônio Simas

44. AMADEU, Sueli Giorgini

45. AMARAL, Elisabete Aparecida do

46. AMARAL, Patrícia

47. AMARAL, Ricardo Ribeiro do

48. AMARANTE, André Ricardo Soares

\begin{tabular}{|l|l|l|l|}
\hline 2001 & M & Siomara Borba Leite & UERJ \\
\hline 2004 & M & José de Pinho Alves Filho & UFSC \\
\hline 1996 & D & Anna Maria Pessoa de Carvalho & USP \\
\hline 1983 & M & Anna Maria Pessoa de Carvalho & USP \\
\hline 2004 & M & Anna Maria Pessoa de Carvalho & USP \\
\hline 1989 & M & Amélia Império Hamburger & USP \\
\hline
\end{tabular}

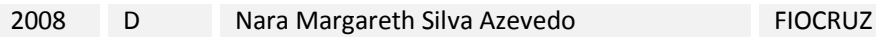

2006 M Jorge Tarcisio da Rocha Falcão $\quad$ UFPE

2008 M Eduardo Adolfo Terrazzan UFSM

1994 M Maria Carolina Nemes $\quad$ USP

1995 M João Antonio Filocre Saraiva $\quad$ CEFET/MG

2001 D João Antonio Filocre Saraiva $\quad$ UFMG

2009 P Magnólia Fernandes Florêncio de Araújo UFRN

\begin{tabular}{l|l|l|l}
2008 & $P$ & Ciclamio Leite Barreto & UFRN
\end{tabular}

1988 M Amélia Império Hamburger $\quad$ USP

2008 P Josefina Barrera Kalhil $\quad$ UEA

2006 M Licurgo Peixoto de Brito UFPA

2000 M Arnaldo de Moura Vaz $\quad$ UFMG

1992 M Luis Felippe Perret Serpa UFBA

2004 M Aguinaldo Robinson de Souza $\quad$ UNESP-Bauru

2008 M Marcos Cesar Danhoni Neves UEM

\begin{tabular}{l|l|l|l}
1977 & M & Maria A. Brandão & UFBA
\end{tabular}

$\begin{array}{llll}1987 & \text { M } & \text { Carolina M. Bori } & \text { USP }\end{array}$

\begin{tabular}{l|l|l|l}
2003 & L & ---- & UNICAMP
\end{tabular}

1987 D $\quad$ Carolina M. Bori $\quad$ USP

1997 M José J. de Alencar Alves $\quad$ UFPA

2006 D Maria Amélia M. Dantes USP

1985 M Jesuina Lopes de Almeida Pacca

2006 M Marco Antonio Moreira UFRGS

2008 P $\quad$ Silvio Luis Souza Cunha $\quad$ UFRGS

2005 M Dirceu da Silva UNICAMP

2000 D $\quad$ Mario Cesar Rodriguez Vidal $\quad$ UFRJ

$1990 \mathrm{M}$ André Valdir Zunino $\quad$ UFSC

\begin{tabular}{l|l|l|l}
2000 & D & Maurício Pietrocola P. de Oliveira & UFSC
\end{tabular}

2009 M Juan Bernardino Marques Barrio UFG

\begin{tabular}{l|l|l|l}
2009 & M & Helaine Sivini Ferreira; Heloisa F. Brasil & UFRPE
\end{tabular}

\begin{tabular}{l|l|l|l} 
& Nóbrega Bastos \\
\hline & D & Marcos da Fonseca Elia
\end{tabular}

1989 M Célia Ure; Ernesto Ure $\quad$ UFF

2004 M Vera Bohomoletz Henriques $\quad$ USP

2009 M José Vieira de Sousa UnB

2006 P Célia Maria G. Soares de Sousa UnB

1992 M $\quad$ Bernardo Buchweitz $\quad$ UFRGS

1999 M Demétrio Delizoicov UFSC

\begin{tabular}{l|l|l|l}
2007 & M & Maria da Conceição de Almeida Barbosa- & FIOCRUZ
\end{tabular}

2003 M Lima $\quad$ João Zanetic US

2008 P $\quad$ Cássio Costa Laranjeiras $\quad$ UnB

2008 M Heloisa Flora Brasil Nóbrega Bastos UFPE

2005 M Odete Pacubi Baierl Teixeira $\quad$ UNESP-Bauru 


\begin{tabular}{|c|c|c|c|c|c|}
\hline 49. & AMBRÓZIO, Maria Lucia & 1990 & M & Luis Carlos de Menezes & USP \\
\hline 50. & AMORIM, Fabrícia & 2009 & M & Carlos Alberto Marques & UFSC \\
\hline 51. & ANACLETO, Bárbara da Silva & 2007 & M & Renato Pires dos Santos & ULBRA \\
\hline 52. & ANDRADE, Cláudia Teresinha Jraige de & 2005 & $P$ & Maria Helena Steffani & UFRGS \\
\hline 53. & ANDRADE, Eugênia de Cássia & 2006 & M & Carlos Eduardo Laburú & UEL \\
\hline 54. & ANDRADE, Inez Barcellos de & 2003 & M & Isabel Gomes Rodrigues Martins & UFRJ \\
\hline 55. & ANDRADE, José Maurício de & 1995 & M & Décio Pacheco & UNICAMP \\
\hline 56. & ANDRADE, Maria Hilda de Paiva & 2000 & M & João Antonio Filocre Saraiva & UFMG \\
\hline 57. & ANDRADE, Renato Judice & 2003 & M & Sérgio Luiz Talim & UFMG \\
\hline 58. & ANDRADE, Rita de Cássia Duyprath de & 2007 & M & Simone Terezinha Bortoliero & UFBA \\
\hline 59. & ANDRADE, Solange Fonseca Santos & 2007 & M & Cesar Augusto Amaral Nunes & USP \\
\hline 60. & ANDREIS, Ulisses Antonio de & 2009 & M & João Zanetic & USP \\
\hline 61. & ANGOTTI, José André Peres & 1991 & D & Luis Carlos de Menezes & USP \\
\hline 62. & ANGOTTI, José André Peres & 1982 & M & Luis Carlos de Menezes & USP \\
\hline 63. & ANJOS, Antônio Jorge Sena dos & 1996 & M & Jandira M. R. Santos & UFBA \\
\hline 64. & ANNUNCIATO, Cristian & 2005 & M & Suzana Salem Vasconcelos & USP \\
\hline 65. & ANTUNES, Fabiano & 2007 & M & Rosana Figueiredo Salvi & UEL \\
\hline 66. & ARAMAN, Eliane Maria de Oliveira & 2006 & M & Irinéa de Lourdes Batista & UEL \\
\hline 67. & ARANTES, Alessandra Riposati & 2002 & M & Luiz Antonio de Oliveira Nunes & USP-São Carlos \\
\hline 68. & ARATO, Yara Lauriano Dias & 2006 & M & Lizete Maria Orquiza de Carvalho & UNESP-Bauru \\
\hline 69. & ARAÚJO FILHO, Walter Duarte de & 1998 & M & Norberto Cardoso Ferreira & USP \\
\hline 70. & ARAÚJO SOBRINHO, Antônio & 2005 & $P$ & Luiz Carlos Jafelice & UFRN \\
\hline 71. & ARAÚJO, Ives Solano & 2002 & M & Marco Antonio Moreira e Eliane A. Veit & UFRGS \\
\hline 72. & ARAÚJO, Ives Solano & 2005 & D & Marco Antonio Moreira & UFRGS \\
\hline 73. & ARAUJO, Jorge Fernando Silva de & 2004 & M & Marcos da Fonseca Elia & UFRJ \\
\hline 74. & ARAUJO, Jucelio Costa de & 2008 & M & Alexandre Cardoso & UFU \\
\hline 75. & ARAÚJO, Marcos Aurélio Alexandre de & 2007 & $P$ & Mauro Sérgio Teixeira de Araújo & UNICSUL \\
\hline 76. & ARAÚJO, Maria Inez Oliveira & 1996 & M & José Fernandes Lima & UFSE \\
\hline 77. & ARAÚJO, Renato Santos & 2005 & M & Flávia Rezende Valle dos Santos & UFRJ \\
\hline 78. & ARAÚJO, Sidney Maia & 2009 & M & Fabio Wellington Orlando da Silva & CEFET/MG \\
\hline 79. & ARAUJO, Valmir Henrique de & 2009 & $\mathrm{D}$ & Maria da Conceição Xavier de Almeida & UFRN \\
\hline 80. & AROCA, Silvia Calbo & 2009 & D & Cibelle Celestino Silva & USP-São Carlos \\
\hline 81. & ARRUDA, Ana Maria da Silva & 2004 & M & Maria Lúcia Vital dos S. Abib & USP \\
\hline 82. & ARRUDA, Antonio Carlos de Jesus Zanni de & 2009 & $\mathrm{D}$ & Marcelo Carbone Carneiro & UNESP-Bauru \\
\hline 83. & ARRUDA, Miguel Augusto de T. & 1983 & M & Sílvio B. Herdade & USP \\
\hline 84. & ARRUDA, Paulo Henrique Zanella de & 2009 & M & José de Souza Nogueira & UFMT \\
\hline 85. & ARRUDA, Sérgio de Mello & 2001 & D & Alberto Villani & USP \\
\hline 86. & ARRUDA, Sérgio de Mello & 1994 & M & Alberto Villani & USP \\
\hline 87. & ARTURY, Luiz Henrique Martins & 2009 & M & Luiz Orlando de Quadro Peduzzi & UFSC \\
\hline 88. & ARTUSO, Alysson Ramos & 2006 & M & Gláucia da Silva Brito & UFPR \\
\hline 89. & ASSIS, Rosângela Araújo Ábido de & 2004 & M & Glória Regina Pessoa Campello Queiroz & UFF \\
\hline 90. & ATHAYDE, Marly Ignez & 1990 & M & Marcos da Fonseca Ellia & UFRJ \\
\hline 91. & AUGÉ, Pierre Schwartz & 2004 & M & Sonia Krapas Teixeira & UFF \\
\hline 92. & AULER, Décio & 2002 & $\mathrm{D}$ & Demétrio Delizoicov & UFSC \\
\hline 93. & AULER, Décio & 1995 & M & Eduardo Adolfo Terrazzan & UFSM \\
\hline 94. & AURANI, Katya Margareth & 1985 & M & Amélia Império Hamburger & USP \\
\hline 95. & AUTH, Milton Antônio & 2002 & $\mathrm{D}$ & José André Peres Angotti & UFSC \\
\hline 96. & AUTH, Milton Antônio & 1996 & M & Eduardo Adolfo Terrazzan & UFSM \\
\hline 97. & AVANCINI, Margaret Busse & 1990 & M & Henrique Justo & PUC/RS \\
\hline 98. & AXT, Rolando & 1983 & M & John D. Rogers & UFRGS \\
\hline 99. & AZEVEDO, Hemmyle Brito de & 2009 & M & Alexandro Cardoso Tenório & UFRPE \\
\hline 100. & AZEVEDO, Maria Antonia Ramos de & 1997 & M & Eduardo A. Terrazzan & UFSM \\
\hline 101. & AZEVEDO, Maria Cristina Paternostro Stella de & 2008 & M & Mauricio Pietrocola Pinto de Oliveira & USP \\
\hline
\end{tabular}




\begin{tabular}{|c|c|c|c|c|c|}
\hline 102. & AZEVEDO, Sandra Maria Joaquim & 2006 & M & Danielle Grynszpan & FIOCRUZ \\
\hline 103. & BABICHAK, Cezar Cavanha & 1999 & M & Maria José P. M. de Almeida & USP \\
\hline 104. & BACCAGLINI, Carlos Alberto Camargo & 2000 & M & Mara Regina Lemes de Sordi & PUCCAMP \\
\hline 105. & BACCON, Ana Lúcia Pereira & 2005 & M & Sergio de Mello Arruda & UEL \\
\hline 106. & BADARÓ, Cláudio Eduardo & 2001 & M & João José Caluzi & UNESP-Bauru \\
\hline 107. & BAGGIO, André & 1997 & D & José Amalio de B. Pinheiro & UNIMEP \\
\hline 108. & BALBINOT, Alexa Maria & 2005 & M & Agostinho Serrano de Andrade Neto & ULBRA \\
\hline 109. & BALLESTERO, Henrique Cesar Estevan & 2009 & M & Sergio de Mello Arruda & UEL \\
\hline 110. & BARBOSA, João Paulino Vale & 2003 & M & Antonio Tarcisio Borges & UFMG \\
\hline 111. & BARBOSA, Joaquim de Oliveira & 1997 & M & Sérgio Roberto de Paulo & UFMT \\
\hline 112. & BARBOSA, José Isnaldo de Lima & 2008 & M & Elton Casado Fireman & UFAL \\
\hline 113. & BARBOSA, Roberto Gonçalves & 2007 & M & Luzia Marta Bellini & UEM \\
\hline 114. & BARCELLOS, Marcília Elis & 2008 & M & João Zanetic & USP \\
\hline 115. & BARCELOS, Luiz Roberto & 2008 & $P$ & Marco Antonio Barbosa Braga & CEFET/RJ \\
\hline 116. & BAROLLI, Elisabeth & 1998 & D & Alberto Villani & USP \\
\hline 117. & BAROLLI, Elisabeth & 1989 & M & Yassuko Hosoume & USP \\
\hline 118. & BARREIRO, Aguida C. de Meo & 1996 & D & Marcos Tarcísio Mazetto & USP \\
\hline 119. & BARRETO FILHO, Benigno & 2001 & M & Maria José P. M. de Almeida & UNICAMP \\
\hline 120. & BARRETO NETTO, Maria Inês & 2003 & M & Dominique Colinvaux & UFF \\
\hline 121. & BARRETO, Márcio & 1995 & M & Laymert Garcia dos Santos & UNICAMP \\
\hline 122. & BARRETO, Márcio & 2007 & D & Laymert Garcia dos Santos & UNICAMP \\
\hline 123. & BARROS FILHO, Jomar & 1999 & M & Dirceu da Silva & UNICAMP \\
\hline 124. & BARROS FILHO, Jomar & 2002 & D & Dirceu da Silva & UNICAMP \\
\hline 125. & BARROS, Antônio Moreira & 2006 & $P$ & Marcílio Colombo Oliveros & UFRN \\
\hline 126. & BARROS, João Henrique Avila de & 2008 & M & Jose de Pinho Alves Filho & UFSC \\
\hline 127. & BARROS, Marcelo Alves & 2002 & D & Alberto Villani & USP \\
\hline 128. & BARROS, Marcelo Alves & 1996 & M & Anna Maria Pessoa de Carvalho & USP \\
\hline 129. & BARROS, Pedro Renato Pereira & 2009 & $\mathrm{P}$ & Yassuko Hosoume & PUC/MG \\
\hline 130. & BARROS, Rejane Bezerra & 2008 & $P$ & Márcia Gorette Lima da Silva & UFRN \\
\hline 131. & BARUSSO, Maristela Gonzales & 2000 & M & Roberto Nardi & UNESP-Marília \\
\hline 132. & BASSO, Andrezza Cátia & 2004 & M & Luiz Orlando de Quadro Peduzzi & UFSC \\
\hline 133. & BASTOS FILHO, Ronaldo de Paula & 2009 & M & Marilia Paixão Linhares & UENF \\
\hline 134. & BASTOS, Cesar Augusto Rangel & 2005 & M & Marcos da Fonseca Elia & UFRJ \\
\hline 135. & BASTOS, Fabio da Purificação & 1990 & M & Maria Oly Pey & UFSC \\
\hline 136. & BASTOS, Fabio da Purificação & 1995 & D & José André Peres Angotti & USP \\
\hline 137. & BASTOS, Patricia Weishaupt & 2007 & M & Cristiano Rodrigues de Mattos & USP \\
\hline 138. & BATISTA, Irinea de Lourdes & 1993 & M & Maria Regina D. Kawamura & USP \\
\hline 139. & BATISTA, Irinéa de Lourdes & 1999 & D & Newton C. Affonso da Costa & USP \\
\hline 140. & BATISTA, Lúcia Maria & 2003 & M & Antonio Tarcísio Borges & UFMG \\
\hline 141. & BATISTA, Michel Corci & 2009 & M & Lilian Akemi Kato; Polonia A. Fusinato & UEM \\
\hline 142. & BATISTELLA, Carmes Ana da Rosa & 2008 & $P$ & Rejane Maria Ribeiro-Teixeira & UFRGS \\
\hline 143. & BEJARANO, Nelson Rui Ribas & 1994 & M & Carlos A. Arguello & UNICAMP \\
\hline 144. & BEJARANO, Nelson Rui Ribas & 2001 & D & Anna Maria Pessoa de Carvalho & USP \\
\hline 145. & BELMONT, Edileuza Maria Lima & 2009 & $P$ & lerecê Barbosa Monteiro & UEA \\
\hline 146. & BELO, Carolina de Lima Alves & 2008 & $\mathrm{M}$ & Eliane Brigida de Morais Falcao & UFRJ \\
\hline 147. & BEMFEITO, Ana Paula Damato & 2008 & $P$ & Deise Miranda Vianna & CEFET/RJ \\
\hline 148. & BENETI, Alysson Cristiano & 2008 & M & Odete Pacubi B. Teixeira & UNESP-Bauru \\
\hline 149. & BENEVIDES, Vagno Maia & 2009 & $P$ & Maria Inês Martins & PUC/MG \\
\hline 150. & BENITE, Claudio Roberto Machado & 2009 & M & Agustina Rosa Echeverría & UFG \\
\hline 151. & BENJAMIN, Alice Assis & 2000 & M & Odete Pacubi B. Teixeira & UNESP-Bauru \\
\hline 152. & BERALDO, Tânia Maria Lima & 1997 & M & Sérgio Roberto de Paulo & UFMT \\
\hline 153. & BERLITZ, Angela Maria Jacobus & 2009 & $P$ & Fernanda Ostermann & UFRGS \\
\hline 154. & BERNARDES FILHO, Rubens & 1992 & $\mathrm{M}$ & Dietrich Schiel & USP-São Carlos \\
\hline
\end{tabular}




\begin{tabular}{|c|c|c|c|c|c|}
\hline 155. & BERNARDES, Adriana Oliveira & 2009 & $\mathrm{M}$ & Marcelo de Oliveira Souza & UENF \\
\hline 156. & BERNARDO, José Roberto da Rocha & 2008 & D & $\begin{array}{l}\text { Deise Miranda Vianna; Helena Amaral da } \\
\text { Fontoura }\end{array}$ & FIOCRUZ \\
\hline 157. & BERNASIUK, Maria Emilia Baltar & 1989 & $\mathrm{M}$ & Maria Emília A. Engers & PUC/RS \\
\hline 158. & BERNHARD, Tania & 1994 & $\mathrm{M}$ & Eduardo Adolfo Terrazzan & UFSM \\
\hline 159. & BERTI, Valdir Pedro & 2007 & $\mathrm{M}$ & Carmen Fernandez & USP \\
\hline 160. & BETTANIN, Eleani & 2003 & $\mathrm{M}$ & José de Pinho Alves Filho & UFSC \\
\hline 161. & BEZERRA, Paulo Cesar & 1972 & $\mathrm{M}$ & Luis Carlos Gomes & UnB \\
\hline 162. & BEZERRA, Washington Carvalho & 2006 & $\mathrm{M}$ & Ernande Barbosa da Costa & UFRPE \\
\hline 163. & BIANCOLIN, Mônica Maria & 2008 & $\mathrm{M}$ & Nelson Fiedler-Ferrara Junior & USP \\
\hline 164. & BINSFELD, Silvia Cristina & 2008 & M & Lenir Basso Zanon & UNIJUI \\
\hline 165. & BISCH, Sérgio & 1998 & D & Yassuko Hosoume & USP \\
\hline 166. & BISCHOFF, Lenora & 2005 & $\mathrm{M}$ & João Bernardes da Rocha Filho & PUC/RS \\
\hline 167. & BITTENCOURT, Diomar R. S. & 1977 & $\mathrm{M}$ & Ernst W. Hamburger & USP \\
\hline 168. & BLÜMKE, Roseli Adriana & 2005 & $\mathrm{M}$ & Milton Antonio Auth & UNIJUI \\
\hline 169. & BOARETTO, Rogério & 2004 & $\mathrm{M}$ & César Augusto Amaral Nunes & USP \\
\hline 170. & BODIÃO, Idevaldo da Silva & 1993 & $\mathrm{M}$ & Jesuina Lopes de Almeida Pacca & USP \\
\hline 171. & BOECHAT, Verônica Aparecida Pereira & 2006 & M & Marcelo de Oliveira Souza & UENF \\
\hline 172. & BOLFE, Lurdes Eliane Rothmund & 2009 & $\mathrm{P}$ & Vania Elisabeth Barlette & UNIFRA \\
\hline 173. & BONAFINI, Fernanda Cesar & 2004 & M & Marcelo de Carvalho Borba & UNESP-Rio Claro \\
\hline 174. & BONETTI, Marcelo de Carvalho & 2008 & $\mathrm{M}$ & Yassuko Hosoume & USP \\
\hline 175. & BORDIGNON, Clotilde Rocha & 1995 & M & Tadeu Cristovam Mikowski & FURB \\
\hline 176. & BORGES, Mauro Duro & 2005 & $\mathrm{M}$ & Marco Antonio Moreira & UFRGS \\
\hline 177. & BORGES, Regina M. Rabello & 1991 & $\mathrm{M}$ & Arden Zylberstajn & UFSC \\
\hline 178. & BORGES, Sérgio Figueiredo & 2005 & $\mathrm{M}$ & Antonio Sérgio C. Esperidião & UFBA \\
\hline 179. & BORTOLETTO, Adriana & 2009 & M & Washington Luiz Pacheco de Carvalho & UNESP-Bauru \\
\hline 180. & BOSS, Sergio Luiz Bragatto & 2009 & M & João José Caluzi & UNESP-Bauru \\
\hline 181. & BOTELHO, Affonso Celso B. & 1988 & $\mathrm{M}$ & Balina Bello Lima & UFF \\
\hline 182. & BOZELLI, Fernanda Cátia & 2005 & M & Roberto Nardi & UNESP-Bauru \\
\hline 183. & BRAGA, Marcia de Melo & 2004 & $P$ & Rejane Maria Ribeiro Teixeira & UFRGS \\
\hline 184. & BRANDÃO, Rafael Vasques & 2008 & M & Eliane Angela Veit; Ives Solano Araújo & UFRGS \\
\hline 185. & BRANDÃO, Sonia Maria M. & 1982 & M & Circe N. Rivas & FGV \\
\hline 186. & BRANDI, Arlete Terezinha Esteves & 1999 & $\mathrm{M}$ & Célia M. do Amaral Gurgel & UNIMEP \\
\hline 187. & BRAÚNA, Rita de Cassia & 1990 & M & Menga Ludke & PUC/RJ \\
\hline 188. & BRAÚNA, Rita de Cassia & 2000 & D & Yassuko Hosoume & USP \\
\hline 189. & BRAZ, Marcia Cristina Dantas Leite & 2009 & M & Erika dos Reis Gusmao Andrade & UFRN \\
\hline 190. & BRETONES, Paulo Sérgio & 2006 & D & Maurício Compiani & UNICAMP \\
\hline 191. & BRETONES, Paulo Sérgio & 1999 & M & Maurício Compiani & UNICAMP \\
\hline 192. & BRIZZI, Maristela Luisa Stolz & 2000 & M & Otávio Aloisio Maldaner & UNIJUI \\
\hline 193. & BROCKINGTON, José Guilherme de Oliveira & 2005 & $\mathrm{M}$ & Mauricio Pietrocola P. de Oliveira & USP \\
\hline 194. & BROSS, Ana Maria Marques & 1990 & $\mathrm{M}$ & Fuad D. Saad & USP \\
\hline 195. & BUCHWEITZ, Bernardo & 1975 & M & Anildo Bristol & UFRGS \\
\hline 196. & BUCUSSI, Alessandro Aquino & 2005 & M & Fernanda Ostermann & UFRGS \\
\hline 197. & BUENO, Maria Christina Fernandes & 2009 & $\mathrm{M}$ & Jesuina Lopes de Almeida Pacca & USP \\
\hline 198. & BUENO, Murilo Nogueira & 2008 & $\mathrm{P}$ & Célia Maria Soares Gomes de Sousa & UnB \\
\hline 199. & BULEGON, Ana Marli & 2006 & $\mathrm{P}$ & Maria Arleth Pereira; Orildo Luis Battistel & UNIFRA \\
\hline 200. & BUTLAND, Valéria R. Graça & 2006 & M & Renato Pires dos Santos & ULBRA \\
\hline 201. & BUZA, Juliana Lando Canga & 2007 & $\mathrm{M}$ & Terezinha Valim Oliver Gonçalves & UFPA \\
\hline 202. & C. JÚNIOR, João Hermano Torreiro de & 2008 & M & Elton Casado Fireman & UFAL \\
\hline 203. & CABRAL, Iramaia Jorge & 1997 & M & Sérgio Roberto de Paulo & UFMT \\
\hline 204. & CAFAGNE, Anildes & 1996 & D & Jesuina Lopes de Almeida Pacca & USP \\
\hline 205. & CAFAGNE, Anildes & 1991 & M & Jesuina Lopes de Almeida Pacca & USP \\
\hline 206. & CALIL, Marcos Rogério & 2008 & M & Lilian Al-Chueyr Pereira Martins & PUC/SP \\
\hline
\end{tabular}




\begin{tabular}{|c|c|c|c|c|c|}
\hline 207. & CALISAYA, Francisco A Garcia & 1997 & $\mathrm{M}$ & Norberto Cardoso Ferreira & USP \\
\hline 208. & CAMARGO, André Luiz de & 2004 & M & Solon Pereira da Cruz Filho & PUC/RS \\
\hline 209. & CAMARGO, Antônio José & 1996 & $\mathrm{M}$ & José André Peres Angotti & UFSC \\
\hline 210. & CAMARGO, Eder Pires de & 2000 & M & Luis Vicente de A Scalvi & UNESP-Bauru \\
\hline 211. & CAMARGO, Eder Pires de & 2004 & D & Dirceu da Silva & UNICAMP \\
\hline 212. & CAMARGO, Rubens Barbosa de & 1989 & M & Luis Carlos de Menezes & UNICAMP \\
\hline 213. & CAMARGO, Sérgio & 2003 & $\mathrm{M}$ & Roberto Nardi & UNESP-Bauru \\
\hline 214. & CAMARGO, Sérgio & 2007 & D & Roberto Nardi & UNESP-Bauru \\
\hline 215. & CAMÊLO, Midori Hijioka & 2009 & D & José Luiz Goldfarb & $\mathrm{PUC} / \mathrm{SP}$ \\
\hline 216. & CAMILETTI, Giuseppi Gava & 2001 & M & Laércio Evandro Ferracioli da Silva & UFES \\
\hline 217. & CAMPOS, Celso Ribeiro & 2000 & $\mathrm{M}$ & Sonia Barbosa Camargo Igliori & $\mathrm{PUC} / \mathrm{SP}$ \\
\hline 218. & CAMPOS, Miguel Arcanjo de Lima & 2008 & M & Silvia Nogueira Chaves & UFPA \\
\hline 219. & CANALES, Renata Pereira & 2006 & $\mathrm{M}$ & Ester Buffa & UFSCar \\
\hline 220. & CANATO JUNIOR, Osvaldo & 2003 & $\mathrm{M}$ & Luis Carlos de Menezes & USP \\
\hline 221. & CANÇADO, Ivan Pontelo & 2009 & $\mathrm{M}$ & Adelson Fernandes Moreira & CEFET/MG \\
\hline 222. & CANIATO, Rodolpho & 1973 & D & José Goldenberg & UNESP-Rio Claro \\
\hline 223. & CAPECCHI, Maria Cândida V. de Morais & 2004 & D & Anna Maria Pessoa de Carvalho & USP \\
\hline 224. & CAPPELLETTO, Eliane & 2009 & $\mathrm{M}$ & Marco Antonio Moreira & UFRGS \\
\hline 225. & CARAMEL, Neusa June Carlton & 2006 & $\mathrm{M}$ & Jesuina Lopes de Almeida Pacca & USP \\
\hline 226. & CARAMELLO, Giselle Watanabe & 2008 & $\mathrm{M}$ & Maria Regina Dubeux Kawamura & USP \\
\hline 227. & CARDOSO, Denise D'Assupção & 1998 & $\mathrm{M}$ & Ernst W. Hamburger & USP \\
\hline 228. & CARLI, Enio Borba & 1988 & M & Wison C. Bueno & $\begin{array}{l}\text { Uni. Metodista } \\
\text { de SP }\end{array}$ \\
\hline 229. & CARLOS, Jairo Gonçalves & 2007 & $\mathrm{P}$ & Erika Zimmermann & UnB \\
\hline 230. & CARMO, Alex Bellucco do & 2006 & M & Anna Maria Pessoa de Carvalho & USP \\
\hline 231. & CARMO, Luis Augusto de Carvalho & 1999 & $\mathrm{M}$ & Alexandre J. G. de Medeiros & UFRPE \\
\hline 232. & CARMO, Luis Augusto de Carvalho & 2005 & D & Alberto Villani & USP \\
\hline 233. & CARNEIRO, Kelber Silvio Rios & 2007 & $\mathrm{M}$ & João Carlos Salles Pires da Silva & UFBA \\
\hline 234. & CARRASCO, Hernan David J. & 1985 & $\mathrm{M}$ & Marco Antonio Moreira; B. Buchveitz & UFRGS \\
\hline 235. & CARRILHO, Flair Jose Sobrinho & 2009 & M & Marcelo Sacardi Biudes & UFMT \\
\hline 236. & CARVALHO FILHO, José Ernane Carneiro & 2005 & M & Elyana Barbosa & UFBA \\
\hline 237. & CARVALHO JUNIOR, Gabriel Dias de & 2005 & $\mathrm{M}$ & Orlando Gomes de Aguiar Junior & UFMG \\
\hline 238. & CARVALHO JÚNIOR, José Carlos Nogueira de & 2008 & M & Sônia Pitta Coelho & $\mathrm{PUC} / \mathrm{SP}$ \\
\hline 239. & CARVALHO NETO, Rodolfo Alves de & 2006 & M & Stefano Osnaghi & UFBA \\
\hline 240. & CARVALHO, Anna Maria P. de & 1972 & D & Amélia Domingues de Castro & USP \\
\hline 241. & CARVALHO, Anna Maria P. de & 1986 & $\mathrm{~L}$ & ---- & USP \\
\hline 242. & CARVALHO, Cristiano & 2007 & $\mathrm{M}$ & Nilson Marcos Dias Garcia & UFPR \\
\hline 243. & CARVALHO, Ingrid Aline de & 2007 & M & Carlos Alberto Souza; Rejane Aurora Mion & UFSC \\
\hline 244. & CARVALHO, Lizete Maria O. de & 1994 & D & Alberto Villani & USP \\
\hline 245. & CARVALHO, Lizete Maria O. de & 1986 & $\mathrm{M}$ & Alberto Villani & USP \\
\hline 246. & CARVALHO, Marcelo Alves de & 2009 & M & Sergio de Mello Arruda & UEL \\
\hline 247. & CARVALHO, Rocine Castelo de & 1993 & M & Yassuko Hosoume & USP \\
\hline 248. & CARVALHO, Silvia Helena Mariano de & 2006 & M & João Zanetic & USP \\
\hline 249. & CARVALHO, Washington Luiz P. & 1991 & D & Joel Martins e Carlos A. Arguello & UNICAMP \\
\hline 250. & CARVALHO, Washington Luiz P. & 1985 & $\mathrm{M}$ & Jesuina Lopes de Almeida Pacca & USP \\
\hline 251. & CASSIANO, Webster Spiguel & 2002 & M & Maria Helena da Silva Carneiro & UnB \\
\hline 252. & CASTILHO, Maria Inês & 2005 & $\mathrm{P}$ & Trieste Freire dos Santos Ricci & UFRGS \\
\hline 253. & CASTINEIRA, Matheus Petricelli & 1989 & $\mathrm{M}$ & Fuad D. Saad & USP \\
\hline 254. & CASTRO, Beatriz Aparecida & 1999 & $\mathrm{M}$ & Ernst W. Hamburger & USP \\
\hline 255. & CASTRO, Giselle Faur de & 2009 & M & Glória Regina Pessôa Campello Queiroz & UFF \\
\hline 256. & CASTRO, Marcus Vasconcelos de & 2006 & $\mathrm{P}$ & Carlos Fernando de Araújo Jr. & UNICSUL \\
\hline 257. & CASTRO, Reginaldo & 2003 & $\mathrm{M}$ & Laércio Evandro Ferracioli da Silva & UFES \\
\hline 258. & CASTRO, Roberto Santos de & 2005 & $\mathrm{M}$ & Jesuina Lopes de Almeida Pacca & USP \\
\hline
\end{tabular}


259. CASTRO, Ruth Schmitz

260. CAVALCANTE, Cyntia

261. CAVALCANTI, Albérico Cony

262. CAVALCANTI, Gilberto de Holanda

263. CAZELLI, Sibele

264. CENNE, Arlindo Henrique Hoch

265. CESAR, Ruth de Oliveira

266. CHAGAS, Saionara Moreira Alves das

267. CHARRET, Heloize da Cunha

268. CHAVES, Taniamara Vizzotto

269. CHIAPETTA, Marília Gonçalves

270. CHIARELLI, Rogerio Avila

271. CHICARINO, Angélica da Graça G. Palmeira

272. CHINELLI, Maura Ventura

273. CHIRINEA, Guilherme

274. CHRISTÓFALO, Airton Acácio Castilho

275. CILURZO, Aurea Bottecchia

276. CIMA, Vanderlei André

277. CLEBSCH, Angelisa Benetti

278. CLEMENT, Luiz

279. CLEMENTE, José Eduardo Ferraz

280. COELHO, Geide Rosa

281. COELHO, João de Vasconcellos

282. COELHO, Rafael Otto

283. COIMBRA, Sandra Gonçalves

284. COLA, Cláudio dos Santos Dias

285. COLETO, Andréa Patapoff Dal

286. COLETTO, Nires Metilde

287. COMPIANI, Maurício

288. CONCEIÇÃO, Thaís

289. CONCHA HENRIQUEZ, Gaston Alberto

290. CONTI, Eliana Maceira Pires

291. CORALLO, Márcio Vinícius

292. CORDEIRO FILHO, Francisco

293. CORDEIRO, Luis Fernando

294. CORDERO, Silvina

295. CORONEL, João Alberto Carmo

296. CORRÊA, Ana Lúcia Lopes

297. CORREIA, Paulo dos Santos

298. CORTELA, Beatriz Salemme Corrêa

299. COSTA, Alice Scherer da

300. COSTA, Ana Paula Bossler da

301. COSTA, Angela Maria Souza

302. COSTA, Arlindo

303. COSTA, Frederico Vasconcellos

304. COSTA, Gilvana Benevides

305. COSTA, Giovana Galvanin da

306. COSTA, Karla Cynthia Quintanilha da

307. COSTA, Luciano Gonçalves

308. COSTA, Maria Claudia Barbosa

309. COSTA, Regina Calderipe

310. COSTA, Regina Calderipe

311. COSTA, Regina Nascimento Martins da

\begin{tabular}{|c|c|c|c|}
\hline 1993 & M & Anna Maria Pessoa de Carvalho & USP \\
\hline 2007 & M & Agostinho Serrano de Andrade Neto & ULBRA \\
\hline 2006 & M & Sérgio Roberto de Paulo & UFMT \\
\hline 2005 & M & Ernande Barbosa da Costa & UFRPE \\
\hline 1992 & M & Tania Dauster & PUC/RJ \\
\hline 2007 & $P$ & Rejane M. Ribeiro- Teixeira & UFRGS \\
\hline 1978 & M & Giorgio Moscati & USP \\
\hline 2006 & M & Isabel Gomes R. Martins & UFRJ \\
\hline 2009 & M & Sonia Krapas Teixeira & UFF \\
\hline 2002 & M & Eduardo Adolfo Terrazzan & UFSM \\
\hline 2000 & M & Maria das Mercês Ferreira Sampaio & PUC/SP \\
\hline 2007 & M & Marco Antonio Moreira & UFRGS \\
\hline 2009 & $\mathrm{D}$ & Roberto Nardi & UNESP-Bauru \\
\hline 2008 & D & Luiz Edmundo Vargas de Aguiar & FIOCRUZ \\
\hline 2006 & M & Jair Lopes Junior & UNESP-Bauru \\
\hline 2007 & M & José Roberto Boettger Giardinetto & UNESP-Bauru \\
\hline 2002 & M & Anna Maria Pessoa de Carvalho & USP \\
\hline 2007 & M & Sonia Maria Silva Corrêa de Souza Cruz & UFSC \\
\hline 2004 & M & Paulo Machado Mors & UFRGS \\
\hline 2003 & M & Eduardo Adolfo Terrazzan & UFSM \\
\hline 2005 & M & Olival Freire Jr. & UFBA \\
\hline 2007 & M & Oto Neri Borges & UFMG \\
\hline 1995 & M & Sérgio R. de Paulo; Carlos Rinaldi & UFMT \\
\hline 2002 & M & Bernardo Buchweitz & UFPEL \\
\hline 2007 & $\mathrm{P}$ & Cássio Costa Laranjeiras & UnB \\
\hline 2004 & M & Flavia Rezende Valle Dos Santos & UFRJ \\
\hline 2007 & M & Orly Zucatto Mantovani de Assis & UNICAMP \\
\hline 1982 & M & Maria Virgínia S. Silva & UFSM \\
\hline 1996 & $\mathrm{D}$ & Roseli Pacheco Schnetzler & UNICAMP \\
\hline 2005 & M & Francisco Catelli & PUC/RS \\
\hline 1999 & M & Nelio M. V. Bizzo & USP \\
\hline 2004 & M & Maria Regina D. Kawamura & USP \\
\hline 2000 & M & Norberto Cardoso Ferreira & USP \\
\hline 1992 & M & Lucia Regina Goulart Vilarinho & UFRJ \\
\hline 2003 & M & José Alberto Pedra & UFPR \\
\hline 1999 & M & Dominique Colinvaux & UFF \\
\hline 1976 & M & Neide U. Xavier & UFSM \\
\hline 2003 & M & Silvania de Souza Nascimento & UFMG \\
\hline 2008 & M & Olival Freire Junior & UFBA \\
\hline 2004 & M & Roberto Nardi & UNESP-Bauru \\
\hline 2007 & M & Ana Maria Marques da Silva & PUC/RS \\
\hline 2009 & $\mathrm{D}$ & Silvania Sousa do Nascimento & UFMG \\
\hline 2006 & M & Isabel Gomes R. Martins & UFRJ \\
\hline 1994 & M & André Valdir Zunino & UFSC \\
\hline 2009 & $P$ & Yassuko Hosoume & PUC/MG \\
\hline 2005 & $P$ & Luiz Carlos Jafelice & UFRN \\
\hline 2005 & M & Jair Lopes Júnior & UNESP-Bauru \\
\hline 2008 & M & Marilia Paixão Linhares & UENF \\
\hline 2004 & $\mathrm{D}$ & Marcos Cesar Danhoni Neves & UFRGS \\
\hline 2007 & M & Alex Sandro Gomes & UFPE \\
\hline 2001 & $\mathrm{D}$ & Valdemarina B. de Azevedo e Souza & PUC/RS \\
\hline 1980 & M & Marco Antonio Moreira & UFRGS \\
\hline 1998 & M & Dominique Colinvaux & UFF \\
\hline
\end{tabular}




\begin{tabular}{|c|c|c|c|c|c|}
\hline 312. & COSTA, Rita Zanlorensi Visneck & 1997 & M & Alberto Villani & USP \\
\hline 313. & COSTA, Sayonara S. Cabral da & 2005 & D & Marco Antonio Moreira & UFRGS \\
\hline 314. & COSTA, Sayonara S. Cabral da & 1997 & M & Marco Antonio Moreira & UFRGS \\
\hline 315. & COSTA, Valter Ferrer & 1983 & M & Karl M. Lorenz & UFPR \\
\hline 316. & COUTO, Antonio José Sampaio & 2007 & M & Evandro Faustino & USM \\
\hline 317. & COUTO, Francisco Pazzini & 2009 & M & Orlando Gomes De Aguiar-Jr & UFMG \\
\hline 318. & COVOLAN, Silvia Cristina Teodoro & 2003 & M & Dirceu da Silva & UNICAMP \\
\hline 319. & COZENDEY, Sabrina Gomes & 2008 & M & Marcelo de Oliveira Souza & UENF \\
\hline 320. & CRUZ, Ana Cristina Parente & 2007 & M & $\begin{array}{l}\text { Maria da Conceição de Almeida Barbosa- } \\
\text { Lima }\end{array}$ & FIOCRUZ \\
\hline 321. & CRUZ, Renato Antônio & 1997 & M & Euclydes Marega Júnior & USP-São Carlos \\
\hline 322. & CRUZ, Roberto Soares da & 2009 & $P$ & Andreia Guerra de Moraes & CEFET/RJ \\
\hline 323. & CRUZ, Sônia Maria S. Corrêa de Souza & 2001 & D & Arden Zylbersztajn & UFSC \\
\hline 324. & CRUZ, Wilson Gonçalves da & 2008 & $P$ & Eymar Sampaio Lopes & USC \\
\hline 325. & CUBILLOS, Sergio Pascoal Z. & 1981 & M & Marco Antonio Moreira & UFRGS \\
\hline 326. & CUNHA, Ailson Vasconcelos da & 2008 & M & Lizete Maria Orquiza de Carvalho & UNESP-Bauru \\
\hline 327. & CUNHA, Alexander Montero & 2008 & M & Dirceu da Silva & UNICAMP \\
\hline 328. & CUNHA, Altair Lorencetti & 2000 & M & Helena Maria da S. C. C. Pereira Caldas & UFES \\
\hline 329. & CUNHA, Francislene Moraes da & 2006 & M & Luciana Maria Lunardi Campos & UNESP-Bauru \\
\hline 330. & CUNHA, Márcia Borin da & 1999 & M & Eduardo Adolfo Terrazzan & UFSM \\
\hline 331. & CUNHA, Maria Bernadete de Melo & 2003 & M & Olival Freire Jr & UFBA \\
\hline 332. & CURADO, Maria Clotilde Correa & 1999 & M & Décio Pacheco & UNICAMP \\
\hline 333. & CUSTÓDIO FILHO, José Francisco & 2002 & M & Maurício Pietrocola Pinto de Oliveira & UFSC \\
\hline 334. & CUSTÓDIO FILHO, José Francisco & 2007 & D & Maurício Pietrocola Pinto de Oliveira & UFSC \\
\hline 335. & D'AGOSTIN, Aline & 2008 & M & Nilson Marcos Dias Garcia & UFPR \\
\hline 336. & DAMÁSIO, Felipe & 2007 & $\mathrm{P}$ & Maria Helena Steffani & UFRGS \\
\hline 337. & DAVID, Marciana Almendro & 2000 & M & Oto Neri Borges & UFMG \\
\hline 338. & DEL CARLO, Sandra & 2007 & D & Nelio Marco Vincenzo Bizzo & USP \\
\hline 339. & DEL CARLO, Sandra & 1997 & M & Yassuko Hosoume & USP \\
\hline 340. & DELGADO, Nely Magdalena Barrios & 2005 & M & Norberto Cardoso Ferreira & USP \\
\hline 341. & DELIZOICOV NETO, Demétrio & 1991 & D & Luis Carlos de Menezes & USP \\
\hline 342. & DELIZOICOV NETO, Demétrio & 1982 & M & Luis Carlos de Menezes & USP \\
\hline 343. & DEYLLOT, Monica Elizabete Caldeira & 2005 & M & Joaõ Zanetic & USP \\
\hline 344. & DIAS, Ângela Maria Costa & 1998 & M & Dominique Colinvaux & UFF \\
\hline 345. & DIAS, Ricardo Henrique Almeida & 2009 & M & Maria José Pereira Monteiro de Almeida & UNICAMP \\
\hline 346. & DIAS, Valéria Silva & 2008 & D & Alberto Villani & UNESP-Bauru \\
\hline 347. & DIAS, Valéria Silva & 2004 & M & Alberto Villani & USP \\
\hline 348. & DIB, Claudio Zaki & 1972 & D & Ernst W. Hamburger & USP \\
\hline 349. & DINIZ, Ana Aleixo & 2009 & M & Alice Helena Campos Pierson & UFSCar \\
\hline 350. & DIOGO, Rodrigo Claudino & 2008 & M & Shirley Takeco Gobara & UFMS \\
\hline 351. & DION, Sonia Maria & 1998 & D & Jesuina Lopes de Almeida Pacca & USP \\
\hline 352. & DION, Sonia Maria & 1992 & M & Jesuina Lopes de Almeida Pacca & USP \\
\hline 353. & DIONÍSIO, Paulo Henrique & 1976 & M & Fernando C. Zawislak & UFRGS \\
\hline 354. & DOMINGUES, Maria Eugênia & 1985 & M & Marco Antonio Moreira & UFRGS \\
\hline 355. & DOMINGUEZ, Dominique C. & 1987 & M & Franco L.P. Semineiro & FGV \\
\hline 356. & DONADELLI, Marisilvia & 2002 & M & Amélia Império Hamburger & USP \\
\hline 357. & DORNELES, Pedro Fernando Teixeira & 2005 & M & Marco Antonio Moreira & UFRGS \\
\hline 358. & DOTTI, Amanda Fogonholi & 2007 & M & Vera Teresa Valdemarin & $\begin{array}{l}\text { UNESP- } \\
\text { Araraquara }\end{array}$ \\
\hline 359. & DRUMMOND, Ângelo Fialho & 2004 & M & Olival Freire Jr & UFBA \\
\hline 360. & DRUZIAN, Aline César & 2009 & M & Renato Pires dos Santos & ULBRA \\
\hline 361. & DUARTE, Marcia Sampaio & 2007 & M & Flavia Rezende Valle dos Santos & UFRJ \\
\hline 362. & DUARTE, Maria Cristina & 2001 & M & João Zanetic & USP \\
\hline 363. & DUARTE, Róber Carlos Barbosa & 2006 & $\mathrm{P}$ & Erika Zimmermann & UnB \\
\hline
\end{tabular}




\begin{tabular}{|c|c|c|c|c|c|}
\hline 364. & DUQUE, Enoque Rinaldi & 2009 & $P$ & Andreia Guerra de Moraes & CEFET/RJ \\
\hline 365. & DUQUE, Luis Marcelo Acosta & 1999 & M & José de Souza Nogueira & UFMT \\
\hline 366. & DUSO, Leandro & 2009 & M & Regina Maria Rabello Borges & PUC/RS \\
\hline 367. & DUTRA, Glênon & 2008 & $P$ & Maria Inês Martins & PUC/MG \\
\hline 368. & EGG, Jeanine Maria & 2005 & M & Flavia Rezende V. dos Santos & UFRJ \\
\hline 369. & ELIAS, Daniele Cristina Nardo & 2006 & $P$ & Luiz Henrique Amaral & UNICSUL \\
\hline 370. & ERTHAL, João Paulo Casaro & 2006 & M & Marilia Paixão Linhares & UENF \\
\hline 371. & ESPINDOLA, Ana Cristina & 2008 & $P$ & $\begin{array}{l}\text { Ana Cristina Garcia Dias; Vania Elisabeth } \\
\text { Barlette }\end{array}$ & UNIFRA \\
\hline 372. & ESPÍNDOLA, Karen & 2005 & M & Marco Antonio Moreira & UFRGS \\
\hline 373. & EVANGELISTA, Fábio Lombardo & 2008 & M & $\begin{array}{l}\text { Jose de Pinho Alves Filho; Nelson Canzian da } \\
\text { Silva }\end{array}$ & UFSC \\
\hline 374. & FACCHINELLO, Carla Simone & 2008 & $P$ & Marco Antonio Moreira & UFRGS \\
\hline 375. & FAGUNDES, Maria Beatriz & 1997 & $\mathrm{M}$ & João Zanetic & USP \\
\hline 376. & FAHL, Deise Dias & 2003 & M & Jorge Megid Neto & UNICAMP \\
\hline 377. & FAIS, Gilson & 2002 & M & Norberto Cardoso Ferreira & USP \\
\hline 378. & FALCÃO, José Tarcisio da R. & 1987 & M & David William Carraher & UFPE \\
\hline 379. & FALEIROS, Wanda & 1999 & M & Ângela Maria Zanon & UFMS \\
\hline 380. & FARIA, Alexandre Fagundes & 2008 & M & Arnaldo Moura Vaz & UFMG \\
\hline 381. & FARIA, Lucimar Moreira & 2009 & M & Juan Bernardino Marques Barrio & UFG \\
\hline 382. & FARIAS, Antonio José Ornellas & 1982 & M & Marco Antonio Moreira & UFRGS \\
\hline 383. & FAUSTINO, Maria da Conceição & 1994 & M & Norberto Cardoso Ferreira & USP \\
\hline 384. & FAUSTINO, Maria de Fátima & 2000 & M & Jesuina Lopes de Almeida Pacca & USP \\
\hline 385. & FÁVARO, Carol Lindy Joglar & 2007 & M & Nara Regina de Souza Basso & PUC/RS \\
\hline 386. & FERES, Glória Georges & 2001 & M & Roberto Nardi & UNESP-Bauru \\
\hline 387. & FERNANDES JUNIOR, Alfredo Sotto & 2006 & $P$ & Daniel Guilherme Gomes Sasaki & CEFET/RJ \\
\hline 388. & FERNANDES, Geraldo W. Rocha & 2007 & M & Jose Andre Peres Angotti & UFSC \\
\hline 389. & FERNANDES, Luciano Massa & 2007 & M & Alberto Villani & USP \\
\hline 390. & FERNANDES, Paula M. N. Rodrigues & 2002 & M & Amélia Império Hamburger & USP \\
\hline 391. & FERNANDES, Rafael Gomes & 2000 & M & Marco Antonio Moreira & UFRGS \\
\hline 392. & FERNANDES, Simone Aparecida & 2004 & M & José Guilherme Moreira & UFMG \\
\hline 393. & FERNANDES, Simone G. Pereira & 1995 & M & Nivaldo Nale & UFSCar \\
\hline 394. & FERRAÇO, Carlos Eduardo & 1990 & M & Nilda G. Alves; Regina L. Garcia & UFF \\
\hline 395. & FERRARI, Paulo Celso & 1998 & M & Sérgio R. de Paulo; Carlos Rinaldi & UFMT \\
\hline 396. & FERRARI, Paulo Celso & 2008 & $\mathrm{D}$ & Marcelo Henrique Romano Tragtenberg & UFSC \\
\hline 397. & FERRAZ, Ademir Gomes & 2004 & M & Heloisa F. B. N. Bastos; Marcelo B. C. Leão & UFRPE \\
\hline 398. & FERREIRA, Alexandre Marcos de Mattos Pires & 2001 & M & José Luiz Goldfarb & PUC/SP \\
\hline 399. & FERREIRA, Alexandre Marcos de Mattos Pires & 2009 & $\mathrm{D}$ & José Luiz Goldfarb & PUC/SP \\
\hline 400. & FERREIRA, Andréia Alves & 2005 & M & Yassuko Hosoume & USP \\
\hline 401. & FERREIRA, Carlos Eduardo dos Reis & 2001 & M & José André Peres Angotti & UFSC \\
\hline 402. & FERREIRA, Doralice Bortoloci & 2001 & M & Alberto Villani & USP \\
\hline 403. & FERREIRA, Doralice Bortoloci & 2008 & $\mathrm{D}$ & Alberto Villani & USP \\
\hline 404. & FERREIRA, Eraldo Costa & 1980 & M & Joséph Max Cohenca & USP \\
\hline 405. & FERREIRA, Fernando Cesar & 2004 & $\mathrm{D}$ & Hercília Tavares de Miranda & USP \\
\hline 406. & FERREIRA, Fernando Cesar & 1999 & $\mathrm{M}$ & Yassuko Hosoume & USP \\
\hline 407. & FERREIRA, Josimar Miranda & 1999 & M & José de Souza Nogueira & UFMT \\
\hline 408. & FERREIRA, Margareth P. Pires & 1997 & M & Alberto Villani & USP \\
\hline 409. & FERREIRA, Mário de Jesus & 2008 & M & Olival Freire Junior & UFBA \\
\hline 410. & FERREIRA, Marli Cardoso & 2003 & M & Lizete Maria Orquiza de Carvalho & UNESP-Bauru \\
\hline 411. & FERREIRA, Nélio Oliveira & 2005 & M & Ernande Barbosa da Costa & UFRPE \\
\hline 412. & FERREIRA, Norberto Cardoso & 1985 & $\mathrm{D}$ & Myriam Krasilchik & USP \\
\hline 413. & FERREIRA, Norberto Cardoso & 1978 & M & luda D.G.V. Lejbman & USP \\
\hline 414. & FERREIRA, Rosilene Gomes da Silva & 2008 & $P$ & Elizabeth da Conceição Santos & UEA \\
\hline 415. & FERREIRA, Valter Antonio & 2005 & M & Magda Floriana Damiani & UFPEL \\
\hline
\end{tabular}




\begin{tabular}{|c|c|c|c|c|c|}
\hline 416. & FERRETTI, Cláudio & 2007 & D & Milton Antonio Zaro & UFRGS \\
\hline 417. & FERRY, Alexandre da Silva & 2008 & M & $\begin{array}{l}\text { Catia Rodrigues Barbosa; Ronaldo Luiz } \\
\text { Nagem }\end{array}$ & CEFET/MG \\
\hline 418. & FIGUEIRA, Jalves Sampaio & 2006 & $P$ & $\begin{array}{l}\text { Eliane Angela Veit e Fernando Lang da } \\
\text { Silveira }\end{array}$ & UFRGS \\
\hline 419. & FIGUEIREDO NETO, Anibal F. & 1988 & M & Yassuko Hosoume & USP \\
\hline 420. & FIGUEIREDO, M. Antonia P. de Camargo & 2000 & M & Roberto Nardi & UNESP-Bauru \\
\hline 421. & FIGUEIREDO, Warlisson Gonçalves & 2008 & M & Fabio Wellington Orlando da Silva & CEFET/MG \\
\hline 422. & FILGUEIRA, Sergio Silva & 2009 & M & Márlon Herbert Flora Barbosa Soares & UFG \\
\hline 423. & FIORAVANTE, Marco Antônio & 1997 & M & Alberto Villani & USP \\
\hline 424. & FLÔR, Cristhiane Cunha & 2005 & M & Suzani Cassiani de Souza & UFSC \\
\hline 425. & FONSECA, João Batista B. da & 1996 & M & Sérgio Roberto de Paulo & UFMT \\
\hline 426. & FONSECA, Marcia Santos & 2008 & M & Dácio Guimarães de Moura & CEFET/MG \\
\hline 427. & FONSECA, Marina Assis & 2002 & M & Oto Neri Borges & UFMG \\
\hline 428. & FONSECA, Nadia Lobo da & 2009 & M & $\begin{array}{l}\text { Vera Lucia Doyle Louzada de Mattos } \\
\text { Dodebei }\end{array}$ & UFRJ \\
\hline 429. & FONSECA, Sarah Virgínia F. L. P. da & 1996 & M & Dominique Colinvaux & UFF \\
\hline 430. & FONTANA, Altair José & 2005 & M & João Bernardes da Rocha Filho & PUC/RS \\
\hline 431. & FONTE BOA, Marcelo Cordeiro & 2008 & M & Sandra Lúcia Escovedo Selles & UFF \\
\hline 432. & FORATO, Thais Cyrino de Mello & 2009 & D & Mauricio Pietrocola Pinto de Oliveira & USP \\
\hline 433. & FORTE, Cleberson Eugenio & 2009 & M & Claudio Kirner & UNIMEP \\
\hline 434. & FORTES, Danilo Ribeiro de Sá & 2003 & M & Silvania de Souza Nascimento & UFMG \\
\hline 435. & FRAGA, Rosane Rodrigues & 2000 & M & Dácio Guimarães de Moura & UFMG \\
\hline 436. & FRANÇA, Suzane Bezerra de & 2005 & M & Helaine Sivini Ferreira & UFRPE \\
\hline 437. & FRANCO JUNIOR, Francisco C. & 1988 & M & Vera Maria F. Candau & PUC/RJ \\
\hline 438. & FREIRE JUNIOR, Olival & 1995 & D & Shozo Motoyama & USP \\
\hline 439. & FREIRE JUNIOR, Olival & 1990 & M & Amélia Império Hamburger & USP \\
\hline 440. & FREIRE, Vanda Lima Bellard & 1980 & M & Maria Angela V. Almeida & FGV \\
\hline 441. & FREITAS, Alexander de & 2003 & M & Marcos Ferreira dos Santos & USP \\
\hline 442. & FREITAS, José Guilherme de Oliveira & 2004 & M & Francisco Cordeiro Filho & UFRJ \\
\hline 443. & FRESCHI, Marcio & 2008 & M & Maurivan Güntzel Ramos & PUC/RS \\
\hline 444. & FROTA, Paulo Rômulo de Oliveira & 1995 & M & Antonio Roazzi & UFPI \\
\hline 445. & FROTA, Paulo Rômulo de Oliveira & 2000 & D & José André Peres Angotti & UFSC \\
\hline 446. & FUKUI, Ana & 2002 & M & Jesuina Lopes de Almeida Pacca & USP \\
\hline 447. & FURUKAWA, Claudio Hiroyuki & 1999 & M & Fuad D. Saad & USP \\
\hline 448. & FUSINATO, Polonia Altoe & 1985 & M & Fuad D. Saad & USP \\
\hline 449. & FUSINATO, Polônia Altoe & 1996 & D & Ernst W. Hamburger & USP \\
\hline 450. & FUTTERLEIB, José Antônio & 2006 & M & Renato Pires dos Santos & ULBRA \\
\hline 451. & GADIOLI, Nirce Pereira de S. & 1989 & M & Jesuina Lopes de Almeida Pacca & USP \\
\hline 452. & GALIAN, Claudia Valentina Assumpção & 2009 & D & Alda Junqueira Marin & PUC/SP \\
\hline 453. & GALLI, Claudio & 1977 & M & Lady L. Traldi & PUC/RS \\
\hline 454. & GALLUCH, Maria Terezinha Bellanda & 1996 & M & Zelia Leonel & UEM \\
\hline 455. & GAMA, Eduardo André Rego Moreira da & 2006 & $P$ & Marta Feijó Barroso & CEFET/RJ \\
\hline 456. & GAMA, Heleny Uccello & 1985 & M & Cláudio Z. Dib & USP \\
\hline 457. & GAMA, Liliane Castelões & 2005 & M & Maria José P. M. de Almeida & UNICAMP \\
\hline 458. & GARCIA, Ligia Valente de Sá & 2009 & M & Maria Regina Dubeux Kawamura & USP \\
\hline 459. & GARCIA, Nilson Marcos Dias & 2000 & $\mathrm{D}$ & Carmem Sylvia Vidigal & USP \\
\hline 460. & GARCIA, Nilson Marcos Dias & 1995 & M & Yassuko Hosoume & USP \\
\hline 461. & GARDELLI, Daniel & 2004 & M & Roberto de Andrade Martins & USP \\
\hline 462. & GARRIDO, Esteban A. R. & 1980 & M & Paul Shepard & UNICAMP \\
\hline 463. & GASPAR, Alberto & 1993 & $\mathrm{D}$ & Ernst W. Hamburger & USP \\
\hline 464. & GASPAR, Alberto & 1982 & M & Anna Maria Pessoa de Carvalho & USP \\
\hline 465. & GASTALDO, Luís Fernando & 2009 & $P$ & Gilberto Orengo de Oliveira & UNIFRA \\
\hline 466. & GATTI, Sandra Regina Teodoro & 2005 & D & Dirceu da Silva & UNICAMP \\
\hline
\end{tabular}




\begin{tabular}{|c|c|c|c|c|c|}
\hline 467. & GEBARA, Maria José Fontana & 2001 & M & Décio Pacheco & UNICAMP \\
\hline 468. & GEBARA, Nadia & 2005 & M & Yassuko Hosoume & USP \\
\hline 469. & GEHLEN, Simoni Tormohlen & 2006 & M & Milton Antonio Auth & UNIJUI \\
\hline 470. & GEHLEN, Simoni Tormöhlen & 2009 & $\mathrm{D}$ & Demetrio Delizoicov Neto & UFSC \\
\hline 471. & GEWANDSZNAJDER, Fernando & 1987 & M & Sérgio Luiz de C. Fernandes & FGV \\
\hline 472. & GEWANDSZNAJDER, Fernando & 1995 & $\mathrm{D}$ & Alda Judith Alves Mazzotti & UFRJ \\
\hline 473. & GHENO, Simara Rodrigues & 2008 & M & Juliana da Silva & ULBRA \\
\hline 474. & GIRALDO, Victor Ayma & 1996 & M & Norberto Cardoso Ferreira & USP \\
\hline 475. & GIRCOREANO, José Paulo & 1998 & M & Jesuina Lopes de Almeida Pacca & USP \\
\hline 476. & GIRCOREANO, José Paulo & 2008 & D & Jesuina Lopes de Almeida Pacca & USP \\
\hline 477. & GOBARA, Shirley Takeco & 1984 & M & Marco Antonio Moreira & UFRGS \\
\hline 478. & GOMES, Alessandro Damasio Trani & 2005 & M & Antonio Tarcisio Borges & UFMG \\
\hline 479. & GOMES, Alessandro Damasio Trani & 2009 & $\mathrm{D}$ & Antonio Tarciso Borges & UFMG \\
\hline 480. & GOMES, Flávia Rezende dos Santos & 1988 & M & Marcos da Fonseca Elia & UFRJ \\
\hline 481. & GOMES, José Luiz & 1986 & M & Anna Maria Pessoa de Carvalho & USP \\
\hline 482. & GOMES, Maria Cristina da Silva & 2009 & M & Cleomar Azevedo & C.U. FIEO \\
\hline 483. & GOMES, Nilzilene Ferreira & 2008 & M & Licurgo Peixoto de Brito & UFPA \\
\hline 484. & GOMES, Thieberson da Silva & 2003 & M & Laércio Evandro Ferracioli da Silva & UFES \\
\hline 485. & GOMES, Thieberson da Silva & 2008 & D & Laércio Evandro Ferracioli da Silva & UFES \\
\hline 486. & GOMIDE, Maria R. & 1995 & M & José Claudinei Lombardi & UNICAMP \\
\hline 487. & GONÇALVES, Elias & 2004 & M & Laércio Evandro Ferracioli da Silva & UFES \\
\hline 488. & GONÇALVES, Ennio Salaberry & 1979 & M & Marco Antonio Moreira & UFRGS \\
\hline 489. & GONÇALVES, Leila de Jesus & 2005 & $P$ & $\begin{array}{l}\text { Eliane Angela Veit e Fernando Lang da } \\
\text { Silveira }\end{array}$ & UFRGS \\
\hline 490. & GONCALVES, M. Elisa Rezende & 1997 & $\mathrm{D}$ & Anna Maria Pessoa de Carvalho & USP \\
\hline 491. & GONÇALVES, M. Elisa Rezende & 1991 & M & Anna Maria Pessoa de Carvalho & USP \\
\hline 492. & GONÇALVES, Marco Aurélio Clemente & 2007 & M & Sérgio Roberto de Paulo & UFMT \\
\hline 493. & GONZAGA, Edson Pereira & 2009 & $P$ & Marcos Rincon Voelzke & UNICSUL \\
\hline 494. & GONZATTI, Sônia Elisa Marchi & 2008 & $P$ & $\begin{array}{l}\text { Maria de Fátima O. Saraiva; Trieste dos } \\
\text { Santos Freire Ricci }\end{array}$ & UFRGS \\
\hline 495. & GOULART, Janice Anita Bomfim & 2008 & $P$ & Maria de Fátima da Silva Lettere Verdeaux & UnB \\
\hline 496. & GOULART, Maria Ines Mafra & 2005 & $\mathrm{D}$ & Arnaldo de Moura Vaz & UFMG \\
\hline 497. & GOULART, Paulo Ricardo Alcântara & 2008 & $P$ & $\begin{array}{l}\text { Flavia Maria Teixeira dos Santos; Marco } \\
\text { Antonio Moreira }\end{array}$ & UFRGS \\
\hline 498. & GOULART, Sílvia Moreira & 1994 & M & Hermenengarda A. Ludke & UERJ \\
\hline 499. & GOUVEIA, Amandio Augusto & 2007 & M & Carlos Eduardo Laburú & UEL \\
\hline 500. & GOUVEIA, Carlos Eduardo & 2005 & M & Nereide Saviani & UNISANTOS \\
\hline 501. & GOVEIA, Clarice de Paula & 2009 & M & Paulo Cezar Santos Ventura & CEFET/MG \\
\hline 502. & GRABALLOS JUNIOR, Edmundo & 2000 & M & Luis Carlos de Menezes & USP \\
\hline 503. & GRALA, Rita Margarete & 2006 & $P$ & Marco Antonio Moreira & UFRGS \\
\hline 504. & GRAMAJO, Maria Cecilia & 2003 & D & Jesuina Lopes de Almeida Pacca & USP \\
\hline 505. & GRECA, Ileana Maria Rosa & 1995 & M & Marco Antonio Moreira & UFRGS \\
\hline 506. & GRECA, lleana Maria Rosa & 2000 & $\mathrm{D}$ & $\begin{array}{l}\text { Marco Antonio Moreira; Victória E. } \\
\text { Herscovitz }\end{array}$ & UFRGS \\
\hline 507. & GROTTO, Eliane Maria Balcevicz & 2004 & M & Eduardo Adolfo Terrazzan & UFSM \\
\hline 508. & GUEDES, Enildo Marinho & 1999 & D & Rita Maria Diniz Zozzoli & UFAL \\
\hline 509. & GUERRA, Waldo Ahumada & 1983 & M & Marco Antonio Moreira & UFRGS \\
\hline 510. & GUILARDI JÚNIOR, Felício & 2002 & M & Dietrich Schiel & UNESP-Bauru \\
\hline 511. & GUIMARÃES, Luciana Faustino & 2009 & M & Alberto Villani & USP \\
\hline 512. & GUIMARÃES, Luiz Alberto M. & 1987 & M & Balina Bello Lima & UFF \\
\hline 513. & GURGEL, Ivã & 2006 & M & Maurício Pietrocola Pinto de Oliveira & USP \\
\hline 514. & GURIDI, Veronica Marcela & 2007 & $\mathrm{D}$ & Alberto Villani & USP \\
\hline 515. & GUTIERREZ, Arsenio J. Carmona & 2002 & $\mathrm{D}$ & Norberto Jacob Etges & UFSC \\
\hline 516. & HANSEN, Michele Facin & 2006 & M & Terezinha de Fátima Pinheiro & UFSC \\
\hline
\end{tabular}




\begin{tabular}{|c|c|c|c|c|c|}
\hline 517. & HARRES, João Batista Siqueira & 1990 & M & Maria Emilia A. Engers & PUC/RS \\
\hline 518. & HARRES, João Batista Siqueira & 1999 & D & Juracy Cunegatto Marques & PUC/RS \\
\hline 519. & HECKLER, Valmir & 2004 & $P$ & $\begin{array}{l}\text { Kepler de S. Oliveira Filho e M.de Fátima O. } \\
\text { Saraiva }\end{array}$ & UFRGS \\
\hline 520. & HENRIQUE, Kátia Ferreira & 1996 & M & Jesuina Lopes de Almeida Pacca & USP \\
\hline 521. & HERNANDES, Cláudio Luis & 2002 & M & Eduardo Adolfo Terrazzan & UFSM \\
\hline 522. & HERZOG, Zilk Malta & 2009 & $P$ & Maria Helena Steffani & UFRGS \\
\hline 523. & HESSEL, Roberto & 1981 & M & Dietrich Schiel & USP-São Carlos \\
\hline 524. & HIGA, Ivanilda & 2005 & D & Yassuko Hosoume & USP \\
\hline 525. & HIGA, Ivanilda & 1997 & M & Giorgio Moscati & USP \\
\hline 526. & HIGA, Terezinha Teruko & 1988 & M & Amélia Império Hamburger & USP \\
\hline 527. & HIGINO, Anderson Fabian & 2002 & M & Dácio Guimarães de Moura & CEFET/MG \\
\hline 528. & HILDEBRANDT, Dulce de Magalhães & 1990 & M & Maria Vitória Teixeira de Carvalho & UFRJ \\
\hline 529. & HILGER, Thaís Rafaela & 2009 & M & Marco Antonio Moreira & UFRGS \\
\hline 530. & HOHENFELD, Dielson Pereira & 2008 & M & Maria Cristina Penido Martins & UFBA \\
\hline 531. & HOSOUME, Yassuko & 1986 & D & Alberto Villani & USP \\
\hline 532. & HOSOUME, Yassuko & 1978 & M & Alberto Villani & USP \\
\hline 533. & HÜLSENDEGER, Margarete Jesus V. Centeno & 2004 & M & Regina Maria Rabello Borges & PUC/RS \\
\hline 534. & IACHEL, GUSTAVO & 2009 & M & Roberto Nardi & UNESP-Bauru \\
\hline 535. & IANNINI, Ana Maria Navas & 2008 & M & Martha Marandino & USP \\
\hline 536. & IRAMINA, Alice Sizuko & 1991 & M & Fuad D. Saad & USP \\
\hline 537. & ISTCHUK, Maria Eutêmia & 2007 & M & Ademir José Rosso & UEPG \\
\hline 538. & JACOBUCCI, Daniela Franco Carvalho & 2006 & D & Jorge Megid Neto & UNICAMP \\
\hline 539. & JACQUES, Vinicius & 2008 & M & Jose de Pinho Alves Filho & UFSC \\
\hline 540. & JORGE NETO, Miguel & 2009 & M & José de Souza Nogueira & UFMT \\
\hline 541. & JORGE, Maria Tereza Soler & 1995 & M & Roseli Pacheco Schnetzler & UNICAMP \\
\hline 542. & JULIÃO, Gerson dos Santos & 2004 & M & João Zanetic & USP \\
\hline 543. & JULIO, Josimeire Meneses & 2007 & M & Arnaldo Moura Vaz & UFMG \\
\hline 544. & JULIO, Josimeire Meneses & 2009 & D & Arnaldo Moura Vaz & UFMG \\
\hline 545. & JUSTO, Mônica Pagliusi Lopes & 2005 & M & Lizete Maria Orquiza de Carvalho & UNESP-Bauru \\
\hline 546. & KAMIOJI, Marly lyo & 1995 & M & Amélia Império Hamburger & USP \\
\hline 547. & KANBACH, Bruno Gusmão & 2005 & M & Carlos Eduardo Laburú & UEL \\
\hline 548. & KANTOR, Carlos Aparecido & 2001 & M & Luis Carlos de Menezes & USP \\
\hline 549. & KARAN, Ricardo A. Sotomaior & 2005 & M & Sônia M. S. C. de Souza Cruz & UFSC \\
\hline 550. & KAWAZOE, Elisabete Favoretto & 2009 & M & Luzia Marta Bellini & UEM \\
\hline 551. & KESSLER, Sérgio Luís & 2008 & M & João Bernardes da Rocha Filho & PUC/RS \\
\hline 552. & KILLNER, Gustavo Isaac & 1993 & M & Norberto Cardoso Ferreira & USP \\
\hline 553. & KILPP, Guilherme Germano & 2009 & $\mathrm{P}$ & leda Maria Giongo & UNIVATES \\
\hline 554. & KISHINAMI, Roberto Isao & 1982 & M & Alberto Villani & USP \\
\hline 555. & KLEIN, Alberto Eduardo & 2009 & M & Sergio de Mello Arruda & UEL \\
\hline 556. & KNEUBIL, Fabiana Botelho & 2006 & M & Manoel Roberto Robilotta & USP \\
\hline 557. & KOCK, Raquel Aparecida Akinaga & 1997 & M & Luiz Fernando de Lara Campos & PUCCAMP \\
\hline 558. & KÖHNLEIN, Janete Francisca Klein & 2003 & M & José André Peres Angotti & UFSC \\
\hline 559. & KREY, Isabel & 2009 & D & Marco Antonio Moreira & UFRGS \\
\hline 560. & KREY, Isabel & 2000 & M & Marco Antonio Moreira & UFRGS \\
\hline 561. & KROETZ, Danusa Ariete & 2006 & M & Agostinho Serrano de Andrade Neto & ULBRA \\
\hline 562. & KRUMMENAUER, Wilson Leandro & 2009 & $\mathrm{P}$ & $\begin{array}{l}\text { Sayonara Salvador C. da Costa; Fernando } \\
\text { Lang da Silveira }\end{array}$ & UFRGS \\
\hline 563. & KULESZA, Wojciech & 2002 & D & Pedro Laudinor Goergen & UNICAMP \\
\hline 564. & KULESZA, Wojciech & 1985 & M & Luis Carlos de Menezes & USP \\
\hline 565. & LABURU, Carlos Eduardo & 1993 & D & Anna Maria Pessoa de Carvalho & USP \\
\hline 566. & LABURU, Carlos Eduardo & 1987 & M & Anna Maria Pessoa de Carvalho & USP \\
\hline 567. & LACERDA NETO, Jurandyr Carneiro Nobre de & 2002 & M & Dirceu da Silva & UNICAMP \\
\hline 568. & LACERDA NETO, Jurandyr Carneiro Nobre de & 2008 & D & Dirceu da Silva & UNICAMP \\
\hline
\end{tabular}


569. LAGO, Elsa Marisa Muguruza dal

570. LAGRECA, Maria do Carmo Baptista

571. LAMEIRA, Leocadio José C. Ribas

572. LANÇA, Tatiana

573. LANGHI, Rodolfo

574. LANGHI, Rodolfo

575. LAPA, Jancarlos Menezes

576. LARA, Ana Elisa

577. LARANJEIRAS, Cassio Costa

578. LAVAQUI, Vanderlei

579. LAZZAROTTO, Aquiles

580. LEAL, Christiano Carvalho

581. LEITE FILHO, Ivo

582. LEITE FILHO, IVo

583. LEITE, Álvaro Emílio

584. LEITE, Cristina

585. LEITE, Cristina

586. LEITE, Sérgio Corrêa

587. LEMGRUBER, Márcio Silveira

$588 . \quad$ LEODORO, Marcos Pires

589. LEODORO, Marcos Pires

590. LEVANDOWSKI, Carlos Ernesto

591. LIBANORE, Ana Cristina Leandro da Silva

592. LIMA JUNIOR, Paulo Roberto Menezes

593. LIMA, Adriel Roberto Ferreira de

594. LIMA, Augusto Otávio Galvão de

595. LIMA, Everaldo José Machado de

596. LIMA, Geraldo Francisco Correa Alves

597. LIMA, Gielton Barros

598. LIMA, Maria da Conceição A. Barbosa

599. LIMA, Maria da Conceição de A. Barbosa

600. LIMA, Maria Luciene de Souza

601. LIMA, Miguel Salustiano de

602. LIMA, Paulo Alves de

603. LIMA, Sergio Ferreira de

604. LINS, Suzana Maria de Castro

605. LOCATELLI, Rogério José

606. LONGUINI, Marcos Daniel

607. LOPES, Alice Ribeiro Casimiro

608. LOPES, Bruno Bernardo Galindo

609. LOPES, Cesar Valmor Machado

610. LOPES, Cláudia Costa

611. LOPES, Fábio

$612 . \quad L O P E S$, Frederico José Andries

613. LOPES, Gláucia

614. LOPES, Gláucia

615. LOPES, Janice Pereira

616. LOPES, José Junio

617. LORENZETTI, Leonir

618. LOUREIRO, Solange Maria

619. LOZADA, Claudia de Oliveira

620. LUCION, Cibele da Silva

621. LUZ, Lydia Cristina Q. Pereira da

\begin{tabular}{|c|c|c|c|}
\hline 2006 & M & Waldomiro José da Silva Filho & UFBA \\
\hline 1997 & M & Marco Antonio Moreira & UFRGS \\
\hline 1987 & M & Ayrton Dutra Correia & UFSM \\
\hline 2005 & M & Maria José P. M. de Almeida & UNICAMP \\
\hline 2004 & M & Roberto Nardi & UNESP-Bauru \\
\hline 2009 & D & Roberto Nardi & UNESP-Bauru \\
\hline 2008 & M & Maria Cristina Penido Martins & UFBA \\
\hline 2007 & $P$ & Célia Maria Soares Gomes de Sousa & UnB \\
\hline 1994 & M & João Zanetic & USP \\
\hline 2004 & M & Irinéa de Lourdes Batista & UEL \\
\hline 1995 & M & Mariley Simões Floria Gouveia & UNICAMP \\
\hline 2006 & M & Marilia Paixão Linhares & UENF \\
\hline 1997 & M & Angela Maria Zanon & UFMS \\
\hline 2003 & D & Ernst Wolfgang Hamburger & USP \\
\hline 2008 & M & Nilson Marcos Dias Garcia & UFPR \\
\hline 2006 & D & Yassuko Hosoume & USP \\
\hline 2002 & M & Yassuko Hosoume & USP \\
\hline 2003 & M & João Zanetic & USP \\
\hline 1999 & D & José Silvério Baia Horta & UFRJ \\
\hline 2005 & D & Hercilia Tavares de Miranda & USP \\
\hline 2001 & M & Hercilia Tavares de Miranda & USP \\
\hline 1975 & M & Ialo R. Bonilla & UFRGS \\
\hline 2007 & M & Ana Tiyomi Obara & UEM \\
\hline 2009 & M & Fernanda Ostermann e Flávia Rezende & UFRGS \\
\hline 2008 & M & Francimar Martins Teixeira Machado & UFPE \\
\hline 1981 & M & Marco Antonio Moreira & UFRGS \\
\hline 2006 & M & Rute Helena Trevisan & UEL \\
\hline 2008 & M & Fabio Wellington Orlando da Silva & CEFET/MG \\
\hline 2004 & M & Silvania Sousa do Nascimento & UFMG \\
\hline 1993 & M & Maria Aparecida C. M. Neves & PUC/RJ \\
\hline 2001 & $\mathrm{D}$ & Anna Maria Pessoa de Carvalho & USP \\
\hline 2006 & $P$ & Luiz Carlos Jafelice & UFRN \\
\hline 2008 & $P$ & Gilvan Luiz Borba & UFRN \\
\hline 1976 & M & Ernst W. Hamburger & USP \\
\hline 2008 & $P$ & Daniel Guilherme Gomes Sasaki & CEFET/RJ \\
\hline 2002 & M & Zélia Maria Soares Jófili & UFRPE \\
\hline 2006 & M & Anna Maria Pessoa de Carvalho & USP \\
\hline 2001 & M & Roberto Nardi & UNESP-Bauru \\
\hline 1996 & D & Antônio Flavio Barbosa Moreira & UFRJ \\
\hline 2007 & M & Jorge Megid Neto & UNICAMP \\
\hline 2009 & $\mathrm{D}$ & Lilian Al-Chueyr Pereira Martins & PUC/SP \\
\hline 1992 & M & Maria Célia D. Ure & UFF \\
\hline 2006 & $P$ & Maria Delourdes Maciel & UNICSUL \\
\hline 2002 & D & Ubiratan D'Ambrosio & UNESP-Rio Claro \\
\hline 2009 & D & Maria José Pereira Monteiro de Almeida & UNICAMP \\
\hline 2001 & M & Norberto Cardoso Ferreira & USP \\
\hline 2004 & M & José André Peres Angotti & UFSC \\
\hline 1995 & M & Moacyr R. do Valle Filho & USP \\
\hline 2000 & M & Demétrio Delizoicov & UFSC \\
\hline 1996 & M & Arden Zylbersztajn & UFSC \\
\hline 2007 & $P$ & Mauro Sérgio Teixeira de Araújo & UNICSUL \\
\hline 2009 & M & Paulo Romulo de Oliveira Frota & UNESC \\
\hline 1990 & M & Analucia Dias Schliemann & UFPE \\
\hline
\end{tabular}




\begin{tabular}{|c|c|c|c|c|c|}
\hline 622. & LUZ, Sérgio Luis Correa da & 2008 & $\mathrm{P}$ & Mauro Sérgio Teixeira de Araújo & UNICSUL \\
\hline 623. & LYRA, Maria Alice Farias de Morais & 2006 & M & Ernande Barbosa da Costa & UFRPE \\
\hline 624. & MACCIONE, Luiz & 1989 & M & Anna Maria Pessoa de Carvalho & USP \\
\hline 625. & MACEDO, Josué Antunes de & 2009 & $P$ & Adriana Gomes Dickman & PUC/MG \\
\hline 626. & MACÊDO, Marcos Antonio Rodrigues & 2003 & M & Ernande Barbosa da Costa & UFRPE \\
\hline 627. & MACHADO, Carlos Alberto & 2000 & M & Alex Alves Freitas & UFPR \\
\hline 628. & MACHADO, Daniel Iria & 2006 & D & Roberto Nardi & UNESP-Bauru \\
\hline 629. & MACHADO, Daniel Iria & 2000 & M & Plácida Leopoldina V. A. da Costa Santos & UNESP-Marília \\
\hline 630. & MACHADO, João Felisardo & 2006 & $P$ & Gilvan Luiz Borba & UFRN \\
\hline 631. & MACHADO, José Luis Michinel & 2001 & D & Maria José P. M. de Almeida & UNICAMP \\
\hline 632. & MACHADO, Juliana & 2009 & M & Sonia Maria Silva Corrêa de Souza Cruz & UFSC \\
\hline 633. & MACHADO, Marcelo Araujo & 2005 & M & Fernanda Ostermann & UFRGS \\
\hline 634. & MACHADO, Vinicius & 2009 & $P$ & Nilcéia Aparecida Maciel Pinheiro & UTF-PR \\
\hline 635. & MAGALHÃES JUNIOR, Carlos Alberto de Oliveira & 2007 & M & Mauricio Pietrocola Pinto de Oliveira & USP \\
\hline 636. & MAGALHÃES, Maria Elisa & 2002 & M & Helena Maria da S. C. C. Pereira Caldas & UFES \\
\hline 637. & MAGALHÃES, Mônica J. de Menezes & 1997 & M & Dietrich Schiel & USP-São Carlos \\
\hline 638. & MAGALHÃES, Mônica J. de Menezes & 2004 & D & Dietrich Schiel & USP-São Carlos \\
\hline 639. & MAl, Ivo & 2008 & $P$ & João Edgar Schmidt; Naira Maria Balzaretti & UFRGS \\
\hline 640. & MAIA, Dayane Rejane Andrade & 2008 & M & Rejane Aurora Mion & UEPG \\
\hline 641. & MALACARNE, Vilmar & 2007 & D & Nelio Marco Vincenzo Bizzo & USP \\
\hline 642. & MALUF, Vitérico Jabur & 2000 & M & José Adolfo Rodríguez Rodríguez & UFMT \\
\hline 643. & MALUF, Vitérico Jabur & 2006 & D & Vera Teresa Valdemarin & $\begin{array}{l}\text { UNESP- } \\
\text { Araraquara }\end{array}$ \\
\hline 644. & MANGIERI, Regina Helena Corsi & 1999 & M & Maria Benedita de Lima Pardo & UFSCar \\
\hline 645. & MANTOVANI, Katia Cristina Cota & 2002 & M & Dietrich Schiel & UNESP-Bauru \\
\hline 646. & MANZINI, Neiva Irma Jost & 1997 & M & Maria Augusta Salin Gonçalves & UNISINOS \\
\hline 647. & MANZINI, Neiva Irma Jost & 2003 & D & Maria Augusta Salin Gonçalves & UNISINOS \\
\hline 648. & MARCHEZINI, Ronaldo & 2008 & $P$ & Lev Vertchenko & PUC/MG \\
\hline 649. & MARCIAL CASTILLO, Joaquim & 1983 & M & José F.B. Lamonaco & USP \\
\hline 650. & MARDEGAN, Luiz Augusto & 1991 & M & Amélia Império Hamburger & USP \\
\hline 651. & MARIANI, Maria Cristina & 1987 & M & Alberto Villani & USP \\
\hline 652. & MARIN,Francis Carlos Morelato & 2009 & M & Laércio Evandro Ferracioli da Silva & UFES \\
\hline 653. & MARINELI, Fabio & 2007 & M & Jesuina Lopes de Almeida Pacca & USP \\
\hline 654. & MARQUES, Leandro dos Reis & 2008 & M & Natalina Aparecida Laguna Sicca & $\begin{array}{l}\text { C.U. Moura } \\
\text { Lacerda }\end{array}$ \\
\hline 655. & MARQUES, Nelson Luiz Reyes & 2009 & $\mathrm{P}$ & Ives Solano Araújo & UFRGS \\
\hline 656. & MARQUES, Simone Machado & 2009 & M & Shirley Takeco Gobara & UFMS \\
\hline 657. & MARRONE JUNIOR, Jayme & 2007 & M & Rute Helena Trevisan & UEL \\
\hline 658. & MARTIN, George Francisco Santiago & 2005 & M & Irinéa de Lourdes Batista & UEL \\
\hline 659. & MARTINELLI, Liliam Maria Born & 2003 & M & Bortolo Valle & PUC/PR \\
\hline 660. & MARTINEZ, Carmen Lidia Pires & 2009 & D & Lizete Maria Orquiza De Carvalho & UNESP-Bauru \\
\hline 661. & MARTINI, Maria da Glória de Andrade & 2006 & M & Maria Regina Dubeux Kawamura & USP \\
\hline 662. & MARTINS, Alisson Antonio & 2008 & M & Ivanilda Higa & UFPR \\
\hline 663. & MARTINS, André Ferrer Pinto & 2004 & D & Jesuina Lopes de Almeida Pacca & USP \\
\hline 664. & MARTINS, André Ferrer Pinto & 1998 & M & João Zanetic & USP \\
\hline 665. & MARTINS, Carlos Alberto Gomes & 2008 & $\mathrm{P}$ & $\begin{array}{l}\text { Ana Cristina Garcia Dias; Vania Elisabeth } \\
\text { Barlette }\end{array}$ & UNIFRA \\
\hline 666. & MARTINS, Claudio Souza & 2009 & M & Juan Bernardino Marques Barrio & UFG \\
\hline 667. & MARTINS, Daniel Gadelha & 2009 & M & Julio Wilson Ribeiro & UFC \\
\hline 668. & MARTINS, Douglas Aparecido Nacci & 2005 & M & Célia Maria Carolino Pires & PUC/SP \\
\hline 669. & MARTINS, José Eduardo & 1996 & M & Norberto Cardoso Ferreira & USP \\
\hline 670. & MARTINS, Lorena Fernandes & 2009 & M & Isabel Gomes Rodrigues Martins & UFRJ \\
\hline 671. & MARTINS, Maria Cristina M. & 1995 & D & Ernst W. Hamburger & USP \\
\hline 672. & MARTINS, Maria Cristina M. & 1989 & M & Myriam Krasilchik & USP \\
\hline
\end{tabular}


673. MARTINS, Renata Lacerda Caldas

674. MASSONI, Neusa

675. MATOS, Ageu de Almeida

676. MATTASOGLIO NETO, Octavio

677. MATTASOGLIO NETO, Octavio

678. MATTOS, Cristiano R. de

679. MAURÍCIO, Luiz Alberto

680. MAURINA, Keli Cristina

681. MAZZILLI, Maria Aparecida

682. MEDEIROS, Alexandre José G.

683. MEDEIROS, Amauri Fragoso

684. MEDEIROS, Geneci C. Moura

685. MEDEIROS, Rodrigo de Miranda Henrique

686. MEDINA, Márcio Nasser

687. MEES, Alberto Antonio

688. MEGID NETO, Jorge

689. MEGID NETO, Jorge

690. MEIRA, Vanildo Silva

691. MELCHIOR, Sandra Cristina Licerio

692. MELEIRO, Alessandra

693. MELHORANÇA, Silvia Regina Lomberti

694. MELO, Ana Carolina Staub de

695. MELO, Décio da Silva

696. MELO, Énery Gislayne de Souza

697. MELO, Luiz Arlindo Ramos de

698. MELO, Wolney Candido de

699. MENDES FILHO, Josué

700. MENDES SOBRINHO, José Augusto de Carvalho

701. MENDES, Janduí Farias

702. MENDES, Maria Isabel Porazza

703. MENDES, Maria Isabel Porazza

704. MENEGAT, Tania Marlene Costa

705. MENEGOTTO, José Carlos

706. MENEZES, Ana Paula Sá

707. MENEZES, Cleber Silva de

708. MENEZES, Luis Carlos de

709. MENEZES, Paulo Henrique Dias

710. MEZALIRA, Sandra Mara

711. MICHELENA, Juleane Boeira

712. MILANI, Raquel

713. MILEO FILHO, Pedro Romano

714. MION, Rejane Aurora

715. MION, Rejane Aurora

716. MIQUELIN, Awdry Feisser

717. MIQUELIN, Awdry Feisser

718. MIRANDA JÚNIOR, Moacir Rosa

719. MIRANDA, Ailton Lima

720. MIRANDA, Antonio Carlos de

721. MIRANDA, Antônio Carlos de

722. MIRANDA, Elenita dos Santos

723. MOISÉS, Adriana Cássia Freitas de

724. MONERO, Carlos Alberto Ribeiro

725. MONTEIRO, Isabel Cristina de Castro

\begin{tabular}{|c|c|c|c|}
\hline 2006 & $P$ & Maria de Fátima da Silva Lettere & UnB \\
\hline 2005 & M & Marco Antonio Moreira & UFRGS \\
\hline 2006 & M & Ernande Barbosa da Costa & UFRPE \\
\hline 1998 & $D$ & Alberto Villani & USP \\
\hline 1990 & M & Fuad D. Saad & USP \\
\hline 1991 & M & Amélia Império Hamburger & USP \\
\hline 1992 & M & Fuad D. Saad & USP \\
\hline 2008 & M & Jose de Pinho Alves Filho & UFSC \\
\hline 1994 & M & Mere Abramowicz & PUC/SP \\
\hline 1984 & M & Luis Carlos de Menezes & USP \\
\hline 1995 & M & Alberto Villani & USP \\
\hline 2005 & $P$ & Luiz Carlos Jafelice & UFRN \\
\hline 2006 & M & Helaine Sivini Ferreira & UFRPE \\
\hline 2009 & $P$ & Marco Antonio Barbosa Braga & CEFET/RJ \\
\hline 2004 & M & Maria Helena Steffani & UFRGS \\
\hline 1990 & M & Decio Pacheco & UNICAMP \\
\hline 1999 & $\mathrm{D}$ & Hilario Fracalanza & UNICAMP \\
\hline 2003 & M & Manoel Eusébio de Lima & UFRPE \\
\hline 2004 & M & Jesuina Lopes de Almeida Pacca & USP \\
\hline 1998 & M & Marcius Cesar Soares Freire & UNICAMP \\
\hline 2006 & M & Mauricéa Nunes & UFMT \\
\hline 2005 & M & Luiz Orlando de Quadro Peduzzi & UFSC \\
\hline 2008 & M & Ernande Barbosa da Costa & UFRPE \\
\hline 2007 & M & Alexandro Cardoso Tenório & UFRPE \\
\hline 2007 & M & Maria de Fátima Vilhena da Silva & UFPA \\
\hline 2006 & M & Yassuko Hosoume & USP \\
\hline 1973 & M & Luis Carlos Gomes & UnB \\
\hline 1998 & D & Demétrio Delizoicov & UFSC \\
\hline 2009 & $P$ & Ivan Ferreira da Costa & UnB \\
\hline 2006 & D & Silvia Fernanda de Mendonça Figueirôa & UNICAMP \\
\hline 2001 & M & Silvia Fernanda de Mendonça Figueirôa & UNICAMP \\
\hline 2007 & $P$ & Rosane Carneiro Sarturi & UNIFRA \\
\hline 2006 & M & João Bernardes da Rocha Filho & PUC/RS \\
\hline 2009 & $P$ & Josefina Barrera Kalhil & UEA \\
\hline 2006 & M & João Carlos Nogueira Alves & CEFET/RJ \\
\hline 1988 & $\mathrm{~L}$ & ----- & USP \\
\hline 2003 & M & Arnaldo de Moura Vaz & UFMG \\
\hline 2008 & M & Maria Cristina Pansera de Araújo & UNIJUI \\
\hline 2008 & $P$ & Paulo Machado Mors & UFRGS \\
\hline 2002 & M & Roberto Ribeiro Baldino & UNESP-Rio Claro \\
\hline 1994 & M & Norberto Cardoso Ferreira & USP \\
\hline 2002 & D & José André Peres Angotti & UFSC \\
\hline 1996 & M & Fabio Da Purificação De Bastos & UFSM \\
\hline 2009 & D & Jose Andre Peres Angotti & UFSC \\
\hline 2003 & M & Fábio da Purificação de Bastos & UFSM \\
\hline 2005 & $P$ & Naira Maria Balzaretti & UFRGS \\
\hline 2004 & M & Luiz Marconi Fortes Magalhaes & UFPA \\
\hline 1989 & M & Cosimo Damião de Avila & UFF \\
\hline 1998 & $\mathrm{D}$ & Maria Elizabete Sampaio Prado Xavier & UNICAMP \\
\hline 2007 & M & Ana Maria Marques da Silva & PUC/RS \\
\hline 2007 & $P$ & André Ferrer Pinto Martins & UFRN \\
\hline 2007 & M & José Silvério Edmundo Germano & ITA \\
\hline 2002 & M & Alberto Gaspar & UNESP-Bauru \\
\hline
\end{tabular}




\begin{tabular}{|c|c|c|c|c|c|}
\hline 726. & MONTEIRO, Isabel Cristina de Castro & 2006 & $\mathrm{D}$ & Alberto Gaspar & UNESP-Bauru \\
\hline 727. & MONTEIRO, Marco Aurélio Alvarenga & 2002 & M & Odete Pacubi Baierl Teixeira & UNESP-Bauru \\
\hline 728. & MONTENEGRO, Anisabel da Glória P. de M & 2005 & M & Maria José P. M. de Almeida & UNICAMP \\
\hline 729. & MONTENEGRO, Patricia Peregrino & 2008 & M & Erika Zimmermann & UnB \\
\hline 730. & MONTENEGRO, Roberto Luiz & 2000 & M & Osvaldo Frota Pessoa Júnior & USP \\
\hline 731. & MORAES, Andreia Guerra & 2002 & D & Carlos B. G. Koehler; Roberto C. Martins & UFRJ \\
\hline 732. & MORAES, Andreia Guerra & 1993 & M & Roberto Cintra Martins & UFRJ \\
\hline 733. & MORAES, Maria Beatriz dos Santos Almeida & 2005 & $P$ & Rejane Maria Ribeiro Teixeira & UFRGS \\
\hline 734. & MORAES, Roque & 1991 & D & Maria das Graças F. Feldens & UFRGS-FE \\
\hline 735. & MORAIS, Francisco Valdomiro & 2004 & $P$ & Gilvan Luiz Borba & UFRN \\
\hline 736. & MORAIS, Welerson Rezende & 2009 & M & Ronaldo Luiz Nagem & CEFET/MG \\
\hline 737. & MOREIRA, Adelson Fernandes & 1999 & M & Oto Neri Borges & UFMG \\
\hline 738. & MOREIRA, Adelson Fernandes & 2003 & D & Oto Neri Borges & UFMG \\
\hline 739. & MOREIRA, Augusto César Lima & 2003 & M & Ernande Barbosa da Costa & UFRPE \\
\hline 740. & MOREIRA, Claudinei Aparecido Oliveira & 2009 & M & Marcelo Giordan & USP \\
\hline 741. & MOREIRA, Cláudio & 2008 & M & Renato Eugenio da Silva Diniz & UNESP-Bauru \\
\hline 742. & MOREIRA, Ernani Fernandes & 2005 & M & Anna Maria Pessoa de Carvalho & USP \\
\hline 743. & MOREIRA, Marco Antonio & 1972 & M & Fernando C. Zawislak & UFRGS \\
\hline 744. & MOREIRA, Silvia Goulart & 1993 & M & Hermengarda A. Ludke & UERJ \\
\hline 745. & MORET, Artur de Souza & 1994 & M & Alberto Villani & USP \\
\hline 746. & MORINI, Lizandra Botton Marion & 2009 & $P$ & $\begin{array}{l}\text { Eliane Angela Veit; Fernando Lang da } \\
\text { Silveira }\end{array}$ & UFRGS \\
\hline 747. & MORTIMER, Eduardo Fleury & 1994 & $\mathrm{D}$ & Anna Maria Pessoa de Carvalho & USP \\
\hline 748. & MOTA, Luzia Matos & 2000 & M & Arden Zylbersztajn & UFSC \\
\hline 749. & MOURA, Breno Arsioli & 2008 & M & Cibelle Celestino Silva & USP \\
\hline 750. & MOURA, Dácio Guimarães de & 1993 & D & Ernst W. Hamburger & USP \\
\hline 751. & MOURA, Dácio Guimarães de & 1985 & M & Ernst W. Hamburger & USP \\
\hline 752. & MOURA, Mauricio Silva de & 2008 & M & Waldomiro José da Silva Filho & UFBA \\
\hline 753. & MOUTINHO, Pedro Estevão da Conceição & 2007 & M & Adilson Oliveira do Espírito Santo & UFPA \\
\hline 754. & MOZENA, Érika Regina & 2003 & $\mathrm{M}$ & João Zanetic & USP \\
\hline 755. & MOZZER, Nilmara Braga & 2008 & M & Rosária da Silva Justi & UFMG \\
\hline 756. & MÜLLER, Marcos A.Torres & 2006 & M & Luis Gallego Martinez & UFES \\
\hline 757. & MUNDIM, Juliana Viégas & 2009 & M & Wildson Luiz Pereira Dos Santos & UnB \\
\hline 758. & MUNIZ, Paulo Pereira & 1977 & M & Celia Luci M. Castro & UFF \\
\hline 759. & MURAMATSU, Mikiya & 1976 & M & Ernst W. Hamburger & USP \\
\hline 760. & MÜTZENBERG, Luiz André & 2005 & $P$ & $\begin{array}{l}\text { Eliane Angela Veit e Fernando Lang da } \\
\text { Silveira }\end{array}$ & UFRGS \\
\hline 761. & NAGOSKI, Rosemeire & 2008 & M & Wanda Maria Junqueira de Aguiar & $\mathrm{PUC} / \mathrm{SP}$ \\
\hline 762. & NARDI, Roberto & 2005 & $\mathrm{~L}$ & ----- & UNESP-Bauru \\
\hline 763. & NARDI, Roberto & 1989 & D & Anna Maria Pessoa de Carvalho & USP \\
\hline 764. & NASCIMENTO, Benjamin Gomes do & 2007 & $P$ & Tereza Maria Rolo Fachada Levy Cardoso & CEFET/RJ \\
\hline 765. & NASCIMENTO, Cláudia Santos do & 2009 & $\mathrm{P}$ & Shirley Takeco Gobara & UFMS \\
\hline 766. & NASCIMENTO, Fabrício do & 2003 & D & Nivaldo Nale & UFSCar \\
\hline 767. & NASCIMENTO, Silvania S. do & 1990 & M & Ernst W. Hamburger & USP \\
\hline 768. & NASCIMENTO, Viviane Briccia do & 2003 & M & Anna Maria Pessoa de Carvalho & USP \\
\hline 769. & NASSARALA, Nair Leite Ribeiro & 2001 & M & José Misael Ferreira do Vale & UNESP-Bauru \\
\hline 770. & NASSIF, Luiz Alberto de Lima & 1976 & M & Joel Martins & $\mathrm{PUC} / \mathrm{SP}$ \\
\hline 771. & NEITZEL, Clifford Luciano Vinícius & 2006 & $\mathrm{P}$ & Basilio Xavier Santiago & UFRGS \\
\hline 772. & NERO, Harnye del & 2007 & $P$ & Solange Binotto Fagan & UNIFRA \\
\hline 773. & NERY, Marcos de Abreu & 2007 & M & Oto Neri Borges & UFMG \\
\hline 774. & NEVES, Graziela das & 2003 & M & Yassuko Hosoume & USP \\
\hline 775. & NEVES, Marcos Cesar Danhoni & 1991 & $\mathrm{D}$ & Joel Martins & UNICAMP \\
\hline 776. & NEVES, Marcos Cesar Danhoni & 1986 & $\mathrm{M}$ & Carlos A. Arguello & UNICAMP \\
\hline 777. & NEVES, Marcos Rogério & 2002 & $\mathrm{M}$ & Alice Helena Campos Pierson & UFSCar \\
\hline
\end{tabular}




\begin{tabular}{|c|c|c|c|c|c|}
\hline 778. & NEVES, Maria Luiza Rodrigues da Costa & 2002 & M & Oto Neri Borges & UFMG \\
\hline 779. & NICIOLI JUNIOR, Roberto Bovo & 2007 & M & Cristiano Rodrigues de Mattos & USP \\
\hline 780. & NISHITANI, Eduardo Yoshikazu & 2007 & M & Elsa Garrido & $\begin{array}{l}\text { Uni. Pres. } \\
\text { Mackenzie }\end{array}$ \\
\hline 781. & NOBRE, Francisco de Assis Fernandes & 2006 & $P$ & Ciclamio Leite Barreto & UFRN \\
\hline 782. & NOBRE, Maria Cristina Dal Pian & 1981 & M & Ernst W. Hamburger & USP \\
\hline 783. & NÓBREGA, Mayane Leite da & 2009 & M & $\begin{array}{l}\text { Olival Freire Junior; Suani Tavares Rubim de } \\
\text { Pinho }\end{array}$ & UFBA \\
\hline 784. & NOGUEIRA, Ana Lúcia Figueiredo de Souza & 2008 & $P$ & Adriana Gomes Dickman & PUC/MG \\
\hline 785. & NOGUEIRA, Christiano & 2004 & M & Izaura Hiroko Kuwabara & UFPR \\
\hline 786. & NOGUEIRA, Dalton Costa & 2003 & M & Arnaldo de Moura Vaz & UFMG \\
\hline 787. & NONENMACHER, Sandra Elisabet Bazana & 2000 & M & Mário Osório Marques & UNIJUI \\
\hline 788. & NUERNBERG, Celito & 2009 & $\mathrm{P}$ & Amarildo Menezes Gonzaga & UEA \\
\hline 789. & NUNES, Albano Oliveira & 2006 & $P$ & Ciclamio Leite Barreto & UFRN \\
\hline 790. & NUNES, Eliana dos Reis & 1991 & M & Arden Zylberstajn & UFSC \\
\hline 791. & NUNES, Sérgio Luiz Pereira & 2005 & M & Verno Kruger & UFPEL \\
\hline 792. & OHIRA, Marcio Akio & 2006 & M & Irinéa de Lourdes Batista & UEL \\
\hline 793. & OHL,Wilson José & 2009 & M & Júlio Celso Ribeiro de Vasconcelos & UFBA \\
\hline 794. & OLGUIN, Giuliano Salcas & 2005 & M & Luis Carlos de Menezes & USP \\
\hline 795. & OLIVEIRA, Ana Maria de & 2001 & M & Amélia Império Hamburger & USP \\
\hline 796. & OLIVEIRA, Andrea T. de Siqueira & 2003 & D & Sonia Krapas Teixeira & UFF \\
\hline 797. & OLIVEIRA, Andrea T. de Siqueira & 1999 & M & Roberto Cintra Martins & UFRJ \\
\hline 798. & OLIVEIRA, Ariane Braga & 2009 & M & Jesuina Lopes de Almeida Pacca & USP \\
\hline 799. & OLIVEIRA, Carla M. Alvarenga de & 2003 & M & Anna Maria Pessoa de Carvalho & USP \\
\hline 800. & OLIVEIRA, Carloney Alves de & 2009 & M & Elton Casado Fireman & UFAL \\
\hline 801. & OLIVEIRA, Cristiane Barbosa Pinheiro De & 2009 & M & $\begin{array}{l}\text { Fabio Ferrentini Sampaio; Marcos da } \\
\text { Fonseca Elia }\end{array}$ & UFRJ \\
\hline 802. & OLIVEIRA, Elrismar Auxiliadora Gomes & 2008 & $P$ & Yassuko Hosoume & PUC/MG \\
\hline 803. & OLIVEIRA, Eraldo Rizzo de & 2005 & M & Yassuko Hosoume & USP \\
\hline 804. & OLIVEIRA, Ethel Silva de & 2009 & $\mathrm{P}$ & Amarildo Menezes Gonzaga & UEA \\
\hline 805. & OLIVEIRA, Fábio Ferreira de & 2006 & M & Reuber Gerbassi Scofano & UFRJ \\
\hline 806. & OLIVEIRA, Flavia José & 2004 & M & Laércio Evandro Ferracioli da Silva & UFES \\
\hline 807. & OLIVEIRA, Glauco Reinaldo Ferreira de & 2007 & D & Heloísa Flora Brasil Nóbrega Bastos & UFPE \\
\hline 808. & OLIVEIRA, Jorge Henrique Lopes de & 2006 & M & Marcos Cesar Danhoni Neves & UEM \\
\hline 809. & OLIVEIRA, Lídia M. L.P. Ribeiro & 1995 & M & José Claudinei Lombardi & UNICAMP \\
\hline 810. & OLIVEIRA, Lídia Maria L.P. Ribeiro de & 2002 & D & José Paulo Netto & UNICAMP \\
\hline 811. & OLIVEIRA, Luciano Denardin de & 2009 & $P$ & Paulo Machado Mors & UFRGS \\
\hline 812. & OLIVEIRA, Manoel de Araujo & 2008 & $P$ & Luiz Henrique Amaral & UNICSUL \\
\hline 813. & OLIVEIRA, Margareth M. de & 1993 & M & Amélia Império Hamburger & USP \\
\hline 814. & OLIVEIRA, Maria de Fátima Alves de & 1996 & M & Maria Ines G.F.M. de Souza & UERJ \\
\hline 815. & OLIVEIRA, Mario Conceição & 2008 & M & Jesuina Lopes de Almeida Pacca & USP \\
\hline 816. & OLIVEIRA, Mauricio Pietrocola P. de & 2004 & L & ----- & USP \\
\hline 817. & OLIVEIRA, Mauricio Pietrocola P. de & 1988 & M & Manoel Roberto Robilotta & USP \\
\hline 818. & OLIVEIRA, Monica Abrantes Galindo de & 2007 & M & Maria Lucia V. S. Abib & USP \\
\hline 819. & OLIVEIRA, Neusa Raquel de & 2004 & M & João Zanetic & USP \\
\hline 820. & OLIVEIRA, Odisséia Boaventura de & 2001 & M & Maria José P. M. de Almeida & UNICAMP \\
\hline 821. & OLIVEIRA, Rebeca Vilas Boas Cardoso de & 2006 & D & Yassuko Hosoume & USP \\
\hline 822. & OLIVEIRA, Rebeca Vilas Boas Cardoso de & 1999 & M & Yassuko Hosoume & USP \\
\hline 823. & OLIVEIRA, Ricardo Bastos de & 2005 & M & Marilia Paixão Linhares & UENF \\
\hline 824. & OLIVEIRA, Ricardo Vescovi de & 2006 & $P$ & Naira Maria Balzaretti & UFRGS \\
\hline 825. & OSTERMANN, Fernanda & 1991 & M & Marco Antonio Moreira & UFRGS \\
\hline 826. & OSTERMANN, Fernanda & 2000 & $\mathrm{D}$ & Marco Antonio Moreira & UFRGS \\
\hline 827. & OTA, Maria Ines Nobre & 1997 & $\mathrm{D}$ & Yassuko Hosoume & USP \\
\hline 828. & OTA, Maria Ines Nobre & 1985 & M & Manoel Roberto Robilotta & USP \\
\hline
\end{tabular}




\begin{tabular}{|c|c|c|c|c|c|}
\hline 829. & PACCA, Jesuina L. de Almeida & 1983 & $\mathrm{D}$ & Giorgio Moscatti & USP \\
\hline 830. & PACCA, Jesuina L. de Almeida & 1994 & L & ----- & USP \\
\hline 831. & PACCA, Jesuina L. de Almeida & 1976 & M & Giorgio Moscatti & USP \\
\hline 832. & PACHECO, Décio & 1979 & M & Lafayette de Moraes & UNICAMP \\
\hline 833. & PACHECO, Décio & 1985 & D & Fermino F. Sisto & UNICAMP \\
\hline 834. & PACHECO, Marcia Maria Dias Reis & 2008 & D & Marli Eliza Dalmazo Afonso de André & PUC/SP \\
\hline 835. & PADILHA, Jackson Neo & 2008 & M & Anna Maria Pessoa de Carvalho & USP \\
\hline 836. & PAES, Fernanda Depizzol & 2005 & M & Maria Terezinha da C. F. Monteiro & USM \\
\hline 837. & PAGLIARINI, Cassiano Rezende & 2007 & M & Cibelle Celestino Silva & USP-São Carlos \\
\hline 838. & PAIVA, Alfonso Gómez & 2008 & M & Maria Lucia Vital dos Santos Abib & USP \\
\hline 839. & PALADINI, Suenoni & 2008 & M & Joao Bosco da Mota Alves & UFSC \\
\hline 840. & PALMEIRA, Márcio Freire & 2005 & M & Robinson Moreira Tenório & UFBA \\
\hline 841. & PANZERA, Arjuna Casteli & 1989 & M & Maria Rita N. S. Oliveira & UFMG \\
\hline 842. & PASSOS, Angela Meneghello & 2009 & M & Sergio de Mello Arruda & UEL \\
\hline 843. & PASSOS, Antonio Maria Freire & 1981 & M & Marco Antonio Moreira & UFRGS \\
\hline 844. & PAULA E SOUZA, Gilberto Morel de & 2007 & $P$ & Gilvan Luiz Borba & UFRN \\
\hline 845. & PAULA, Helder Figueiredo de & 2004 & D & Antonio Tarciso Borges & UFMG \\
\hline 846. & PAULA, Mônica Marques de & 2007 & M & Sueli Mazzilli & UNICSUL \\
\hline 847. & PAULA, Ronaldo César de Oliveira & 2006 & $P$ & Cássio Costa Laranjeiras & UnB \\
\hline 848. & PAZ, Alfredo Müllen da & 1999 & M & Francisco Antônio Pereira Fialho & UFSC \\
\hline 849. & PAZ, Alfredo Muller da & 2007 & D & Jose de Pinho Alves Filho & UFSC \\
\hline 850. & PEDROSO, Luiz Eduardo & 2004 & D & Maria José P. M. de Almeida & UNICAMP \\
\hline 851. & PEDROSO, Luiz Eduardo & 1989 & M & Luis Carlos de Menezes & USP \\
\hline 852. & PEDUZZI, Luiz Orlando de Q. & 1980 & M & Marco Antonio Moreira & UFRGS \\
\hline 853. & PEDUZZI, Luiz Orlando de Q. & 1998 & D & Arden Zylbersztajn & UFSC \\
\hline 854. & PEDUZZI, Sonia Silveira & 1981 & M & Marco Antonio Moreira & UFRGS \\
\hline 855. & PENA, Fábio Luís Alves & 2008 & M & Aurino Ribeiro Filho & UFBA \\
\hline 856. & PEÑA, Miriam Haydee Romero & 1996 & M & Maria Regina D. Kawamura & USP \\
\hline 857. & PENHA, Sidnei Percia da & 2006 & $\mathrm{P}$ & Deise Miranda Vianna & CEFET/RJ \\
\hline 858. & PERDIGÃO, Ana Luiza R. Vieira & 2000 & D & Nivaldo Nale & UFSCar \\
\hline 859. & PEREIRA, Alexsandro Pereira de & 2008 & M & $\begin{array}{l}\text { Fernanda Ostermann; Trieste dos Santos } \\
\text { Freire Ricci }\end{array}$ & PUC/RS \\
\hline 860. & PEREIRA, Antonio Jose Miranda & 2006 & M & Guaracira Gouvea de Sousa & UFRJ \\
\hline 861. & PEREIRA, Cléverson Mota & 2004 & M & Roberto Nardi & UNESP-Bauru \\
\hline 862. & PEREIRA, Edenise Alves & 2009 & M & Agostinho Serrano de Andrade Neto & ULBRA \\
\hline 863. & PEREIRA, Francielle Amâncio & 2008 & M & Ivan Amorosino do Amaral & UNICAMP \\
\hline 864. & PEREIRA, Grazielle Rodrigues & 2007 & M & Robson Coutinho-Silva & FIOCRUZ \\
\hline 865. & PEREIRA, Jairo Alves & 1995 & M & Yassuko Hosoume & USP \\
\hline 866. & PEREIRA, José Alexandre de A. & 2008 & M & Heloisa Flora Brasil Nóbrega Bastos & UFRPE \\
\hline 867. & PEREIRA, Jose Everaldo & 2009 & M & Isauro Beltran Nuñez & UFRN \\
\hline 868. & PEREIRA, Marcia Regina Santana & 1999 & M & Laércio Evandro Ferracioli da Silva & UFES \\
\hline 869. & PEREIRA, Marcus Vinicius da Silva & 2007 & $P$ & Tereza Maria Rolo Fachada Levy Cardoso & CEFET/RJ \\
\hline 870. & PEREIRA, Ozimar da Silva & 1997 & M & Ernst W. Hamburger & USP \\
\hline 871. & PEREIRA, Ricardo Francisco & 2008 & M & $\begin{array}{l}\text { Cesar Danhoni Neves; Polonia Altoé } \\
\text { Fusinato }\end{array}$ & UEM \\
\hline 872. & PEREIRA, Vagner & 1993 & M & Dácio R. Hartwig & UFSCar \\
\hline 873. & PEREIRA, Yara Christina Cesário & 2004 & D & José André Peres Angotti & UFSC \\
\hline 874. & PERES, Maria Regina & 1993 & M & Décio Pacheco & UNICAMP \\
\hline 875. & PEREZ, Carmem Alice & 2008 & M & Maria Inês Nogueira & USP \\
\hline 876. & PEREZ, José Rafael Boesso & 2004 & M & João José Caluzi & UNESP-Bauru \\
\hline 877. & PERNAMBUCO, Marta M. C. A. & 1994 & $\mathrm{D}$ & Luis Carlos de Menezes & USP \\
\hline 878. & PERNAMBUCO, Marta M. C. A. & 1981 & M & Ernst W. Hamburger & USP \\
\hline 879. & PERRELLI, Maria Aparecida de Souza & 1996 & M & Edel Ern & UFSC \\
\hline 880. & PERROTTA, Suzete Geraldi Montenegro & 2001 & $M$ & Ana Paula Jahn & PUC/SP \\
\hline
\end{tabular}


881. PERUZZI, Hilda Beti Ukstin

882. PESSANHA, Márlon Caetano Ramos

883. PESSOA, Luiz Gonzaga Pontes

884. PIASSI, Luís Paulo

885. PIASSI, Luiz Paulo de Carvalho

886. PIERSON, Alice Helena Campos

887. PIERSON, Alice Helena Campos

888. PIMENTEL, Erizaldo Cavalcanti Borges

889. PIMENTEL, Naida Lena

890. PINHEIRO, Cíntia Garrido

891. PINHEIRO, Terezinha de Fatima

892. PINHEIRO, Terezinha de Fatima

893. PINTO NETO, Pedro da Cunha

894. PINTO, Adriano de Oliveira

895. PINTO, Alexandre Custódio

896. PINTO, Gisnaldo Amorim

897. PINTO, Inês Mendes

898. PINTO, José Antônio

899. PINTO, José Luiz Martins

900. PINTO, Ricardo Guedes Ferreira

901. PINTO, Simone Pinheiro

902. PINTO, Sonia Maria da Conceição

903. PINZON, Victoria Elvira Moreno

904. PIRANI, Renato

905. PIRES, Marcelo Antônio

906. PIUBELI, Umbelina Giacometti

907. PIZARRO, Washington Armando Garcia

908. PONCZEK, Roberto Leon Inacio

909. PONTONE, Renato

910. PORTELA, Caroline Dorada Pereira

911. PORTELA, Sebastião Ivaldo Carneiro

912. PORTO, Antonio Vicente Lima

913. PORTO, Franco de Salles

914. PRADO, Fernando Dagnoni

915. PRADO, Fernando Dagnoni

916. PRADO, Francisco de B. Lopes

917. PREGNOLATTO, Yukimi $\mathrm{H}$.

918. PRESTES, Michely

919. PRESTES, Rosangela Ferreira

920. PUCCI, Luis Fábio Simões

921. PUREZA, Odifax Quaresma

922. PUZZO, Deolinda

923. QUEIROZ, Alex Sander Barros

924. QUEIROZ, Glória Regina Pessoa Campello

925. QUEIROZ, Vanessa

926. QUESADO, Mirna de Almeida

927. QUINTAL, João Ricardo

928. QUINTAS, José Silva

929. RABONI, Paulo César de Almeida

930. RABONI, Paulo César de Almeida

931. RADÉ, Tane da Silva

932. RAFAEL, Francisco Josélio

933. RAMOS, Eugênio Maria de F.

\begin{tabular}{|c|c|c|c|}
\hline 1999 & M & Guiomar Carneiro Tomazello & UNIMEP \\
\hline 2009 & M & Marcelo de Oliveira Souza & UENF \\
\hline 2003 & D & Betania Leite Ramalho & UFRN \\
\hline 2007 & D & Maurício Pietrocola P. de Oliveira & USP \\
\hline 1995 & M & Yassuko Hosoume & USP \\
\hline 1997 & D & Yassuko Hosoume & USP \\
\hline 1990 & M & Luis Carlos de Menezes & USP \\
\hline 2007 & $P$ & Maria de Fátima da Silva Lettere Verdeaux & UNB \\
\hline 2001 & M & Eduardo Adolfo Terrazzan & UFSM \\
\hline 2000 & M & Laércio Evandro Ferracioli da Silva & UFES \\
\hline 1996 & M & Maurício Pietrocola Pinto de Oliveira & UFSC \\
\hline 2003 & $\mathrm{D}$ & Maurício Pietrocola Pinto de Oliveira & UFSC \\
\hline 2001 & D & Mansur Lutfi & UNICAMP \\
\hline 2000 & M & Marco Antonio Moreira & UFRGS \\
\hline 2003 & M & João Zanetic & USP \\
\hline 2007 & D & Maurício Pietrocola P. de Oliveira & USP \\
\hline 2001 & M & Oto Neri Borges & UFMG \\
\hline 2006 & M & Marcelo Shoey de Oliveira Massunaga & UENF \\
\hline 1989 & M & Lyra Paixão & UFRJ \\
\hline 1978 & M & & IUPERJ \\
\hline 2005 & M & Deise Miranda Vianna & FIOCRUZ \\
\hline 2003 & M & Jacques Jules Sonneville & UNEB \\
\hline 1980 & M & Aurea Vasconcelos & UNICAMP \\
\hline 2004 & M & João José Caluzi & UNESP-Bauru \\
\hline 2005 & $P$ & Eliane Angela Veit & UFRGS \\
\hline 1989 & M & Maria Celia D. Ure & UFF \\
\hline 2003 & M & José J. Queiróz & UNINOVE \\
\hline 2005 & D & Dante Augusto Galeffi & UFBA \\
\hline 2003 & M & Sérgio Luiz Talim & UFMG \\
\hline 2009 & M & Ivanilda Higa & UFPR \\
\hline 2006 & $P$ & Cássio Costa Laranjeiras & UnB \\
\hline 1983 & M & Marco Antonio Moreira; M. Epstein & UFRGS \\
\hline 2008 & $P$ & Erika Zimmermann & UnB \\
\hline 1990 & D & Ernst W. Hamburger & USP \\
\hline 1980 & M & Ernst W. Hamburger & USP \\
\hline 1987 & M & Oder J. Santos & UFMG \\
\hline 1994 & D & Luis Carlos de Menezes & USP \\
\hline 2008 & M & Arion de Castro Kurtz dos Santos & UFRGS \\
\hline 2008 & M & Ana Maria Marques da Silva & PUC/RS \\
\hline 2007 & M & Carlos Bauer de Souza & UNINOVE \\
\hline 2004 & M & Luiz Marconi Fortes Magalhães & UFPA \\
\hline 2005 & M & Rute Helena Trevisan & UEL \\
\hline 2005 & $P$ & Luiz Carlos Jafelice & UFRN \\
\hline 2000 & D & Francisco Creso Junqueira Franco Jr. & PUC/RJ \\
\hline 2008 & M & Rute Helena Trevisan & UEL \\
\hline 2005 & M & Isabel Gomes Rodrigues Martins & UFRJ \\
\hline 2008 & $P$ & Andreia Guerra de Moraes & CEFET/RJ \\
\hline 1975 & M & Carlos Alberto S. Lima & UnB \\
\hline 1993 & M & Maria José P. M. de Almeida & UNICAMP \\
\hline 2002 & D & Maria José P. M. de Almeida & UNICAMP \\
\hline 2005 & M & Renato Pires dos Santos & ULBRA \\
\hline 2007 & $P$ & André Ferrer Pinto Martins & UFRN \\
\hline 1997 & D & Moacyr Ribeiro do Valle Filho & USP \\
\hline
\end{tabular}




\begin{tabular}{|c|c|c|c|c|c|}
\hline 934. & RAMOS, Eugênio Maria de F. & 1990 & M & Norberto Cardoso Ferreira & USP \\
\hline 935. & RAMOS, Tiago Clarimundo & 2009 & $\mathrm{P}$ & Lev Vertchenko & PUC/MG \\
\hline 936. & RANCHE, Priscila Machado & 2006 & M & Jandira Liria Biscalquini Talamoni & UNESP-Bauru \\
\hline 937. & RANGEL, Ana Jussema & 2002 & M & Robert Kenyon Walker & UnB \\
\hline 938. & REAL, Conceição de Maria Campinho R. Corte & 2008 & M & Carlos Henrique Medeiros de Souza & UENF \\
\hline 939. & REBELLO, Lúcia Helena de Souza & 2001 & M & Sônia Krapas Teixeira & UFF \\
\hline 940. & REGIS, Marcio Trindade Duque Estrada & 2009 & M & Flavia Rezende Valle dos Santos & UFRJ \\
\hline 941. & REGISTRO, Erisaura Leomil & 1999 & $M$ & Euclydes Marega Júnior & USP-São Carlos \\
\hline 942. & REGO, Sheila Cristina Ribeiro & 2004 & $\mathrm{M}$ & Christina Marilia Teixeira da Silva & UFRJ \\
\hline 943. & REID, Marilene de Almeida Vianna & 2009 & $\mathrm{M}$ & Liéte de Oliveira Accácio & UENF \\
\hline 944. & REIS, Ernesto Macedo & 2008 & $\mathrm{D}$ & Marilia Paixão Linhares & UENF \\
\hline 945. & REIS, Ernesto Macedo & 2001 & M & $\begin{array}{l}\text { Cláudia L. R. da Motta; Flavia R. V. dos } \\
\text { Santos }\end{array}$ & UFRJ \\
\hline 946. & REIS, Jose Claudio de Oliveira & 2002 & $\mathrm{D}$ & Carlos B. G. Koehler; Roberto C. Martins & UFRJ \\
\hline 947. & REIS, José Cláudio de Oliveira & 1991 & M & Pedro B. Garcia & PUC/RJ \\
\hline 948. & REIS, Mari Aurora Fávero & 2003 & M & Agostinho Serrano de Andrade Neto & ULBRA \\
\hline 949. & RESENDE, Geralda Lopes de & 2002 & $M$ & Itamar José Moraes & UFG \\
\hline 950. & RESQUETTI, Silvia Oliveira & 2007 & $\mathrm{M}$ & Marcos Cesar Danhoni Neves & UEM \\
\hline 951. & REY, Renato Casal del & 2000 & M & Anna Maria Pessoa de Carvalho & USP \\
\hline 952. & REZENDE JUNIOR, Mikael Frank & 2006 & D & Frederico Firmo de Souza Cruz & UFSC \\
\hline 953. & REZENDE JUNIOR, Mikael Frank & 2001 & M & Frederico Firmo de Souza Cruz & UFSC \\
\hline 954. & RIBEIRO, Adelino Antônio da Silva & 2007 & M & Luiz Carlos Cerquinho de Brito & UFAM \\
\hline 955. & RIBEIRO, Amanda Amantes Neiva & 2005 & M & Oto Neri Borges & UFMG \\
\hline 956. & RIBEIRO, Amanda Amantes Neiva & 2009 & $\mathrm{D}$ & Oto Neri Borges & UFMG \\
\hline 957. & RIBEIRO, Elinete Oliveira Raposo & 2004 & $M$ & Licurgo Peixoto de Brito & UFPA \\
\hline 958. & RIBEIRO, Jocemar Regina Cotrim & 2000 & $M$ & Ricardo José Horowicz & USP \\
\hline 959. & RIBEIRO, Júlio Cezar & 2000 & $M$ & José Humberto Dias da Silva & UNESP-Bauru \\
\hline 960. & RIBEIRO, Luciane Francielli & 2009 & M & $\begin{array}{l}\text { Geraldo Lucio Tiago Filho; Rita de Cássia M. } \\
\text { T. Stano }\end{array}$ & UF Itajubá \\
\hline 961. & RIBEIRO, Marco Antonio Cipriano & 2001 & M & Jacques Therrien & UFC \\
\hline 962. & RIBEIRO, Monica Norris & 2008 & $M$ & Mirian Struchiner & UFRJ \\
\hline 963. & RIBEIRO, Osmando Barbosa da Silva & 2007 & $M$ & Eduardo de Campos Valadares & UFMG \\
\hline 964. & RIBEIRO, Renata Alves & 2007 & $M$ & Maria Regina Dubeux Kawamura & USP \\
\hline 965. & RIBEIRO, Ruth Marina Lemos & 2000 & M & Isabel Gomes R. Martins & UFMG \\
\hline 966. & RIBEIRO, Tiago Nery & 2009 & M & Maria Inêz Oliveira Araújo & UFSE \\
\hline 967. & RIBEIRO, Verenice dos S. Leite & 1981 & M & Fermino F. Sisto & PUC/SP \\
\hline 968. & RICARDO, Elio Carlos & 2001 & $M$ & Arden Zylbersztajn & UFSC \\
\hline 969. & RICARDO, Elio Carlos & 2005 & $\mathrm{D}$ & Arden Zylbersztajn & UFSC \\
\hline 970. & RINALDI, Carlos & 1989 & $M$ & Maria Célia D. Ure & UFF \\
\hline 971. & ROBERTO, Edson Valentim & 2009 & M & Tomaz Catunda & USP-São Carlos \\
\hline 972. & ROBERTO, Lúcia Helena Sasseron & 2005 & M & Anna Maria Pessoa de Carvalho & USP \\
\hline 973. & ROBERTO, Lúcia Helena Sasseron & 2008 & D & Anna Maria Pessoa de Carvalho & USP \\
\hline 974. & ROCHA, Laurentino Gonçalves da & 2005 & $M$ & Heloisa F. B. N. Bastos & UFRPE \\
\hline 975. & ROCHA, Marcelo Borges & 2003 & $\mathrm{M}$ & Isabel Gomes Rodrigues Martins & UFRJ \\
\hline 976. & RODRIGUES JÚNIOR, Edmundo & 2008 & $P$ & Adriana Gomes Dickman & PUC/MG \\
\hline 977. & RODRIGUES, Andre Machado & 2009 & M & Cristiano Rodrigues de Mattos & USP \\
\hline 978. & RODRIGUES, Bruno Augusto & 2008 & M & Antonio Tarciso Borges & UFMG \\
\hline 979. & RODRIGUES, Carlos Daniel Ofugi & 2001 & M & Maurício Pietrocola Pinto de Oliveira & UFSC \\
\hline 980. & RODRIGUES, Cristiane Rodrigues de & 2008 & M & Suzana Maria Coelho & PUC/RS \\
\hline 981. & RODRIGUES, Elton & 2008 & M & José Luiz Goldfarb & PUC/SP \\
\hline 982. & RODRIGUES, Elvis Vilela & 2008 & $P$ & Erika Zimmermann & UnB \\
\hline 983. & RODRIGUES, Gizella Menezes & 2005 & M & Helaine Sivini Ferreira & UFRPE \\
\hline 984. & RODRIGUES, Idely Garcia & 1988 & M & Amélia Império Hamburger & USP \\
\hline 985. & RODRIGUES, Marcia Helena Freitas & 2009 & $P$ & Jaime Sandro da Veiga & UNICSUL \\
\hline
\end{tabular}




\begin{tabular}{|c|c|c|c|c|c|}
\hline 986. & RODRIGUES, Maria de Fátima D. & 1993 & M & Arden Zylberstajn & UFSC \\
\hline 987. & RODRIGUES, Maria de Lourdes Bandeira & 2007 & $\mathrm{M}$ & José Augusto de Carvalho Mendes Sobrinho & UFPI \\
\hline 988. & RODRIGUES, Maria Inês Ribas & 2001 & $\mathrm{M}$ & Anna Maria Pessoa de Carvalho & USP \\
\hline 989. & ROSA, Dalva Eterna Gonçalves & 2003 & D & Roseli Pacheco Schnetzler & UNIMEP \\
\hline 990. & ROSA, Daniela Corrêa da & 2002 & $\mathrm{M}$ & Eduardo Adolfo Terrazzan & UFSM \\
\hline 991. & ROSA, Katemari Diogo da & 2006 & $\mathrm{M}$ & Maria Cristina Mesquita Martins & UFBA \\
\hline 992. & ROSA, Maria Inês de F. P. dos Santos & 2000 & D & Roseli Pacheco Schnetzler & UNICAMP \\
\hline 993. & ROSA, Marlusa Benedetti da & 2005 & $\mathrm{M}$ & João Bernardes da Rocha Filho & PUC/RS \\
\hline 994. & ROSA, Paulo Ricardo da S. & 1987 & $\mathrm{M}$ & Marco Antonio Moreira & UFRGS \\
\hline 995. & ROSELLA, Marcelo Luis Aroeira & 2004 & $\mathrm{M}$ & João José Caluzi & UNESP-Bauru \\
\hline 996. & ROVIGATTI, Rodinei Lourenço & 1987 & $\mathrm{M}$ & Alberto Villani & USP \\
\hline 997. & RUBIM, Juliana & 2007 & $\mathrm{M}$ & Lizete Maria Orquiza de Carvalho & UNESP-Bauru \\
\hline 998. & RUFATTO, Carlos Alberto & 2008 & D & Marcelo Carbone Carneiro & UNESP-Bauru \\
\hline 999. & RUGGIERO, Maurício Carlos & 1979 & $\mathrm{M}$ & Fermino F. Sisto & UNICAMP \\
\hline 1000. & RUI, Laura Rita & 2006 & $\mathrm{P}$ & Basilio Xavier Santiago & UFRGS \\
\hline 1001. & SÁ, Eliane Ferreira de & 2003 & $\mathrm{M}$ & Oto Neri Borges & UFMG \\
\hline 1002. & SÁ, Eliane Ferreira de & 2009 & D & $\begin{array}{l}\text { Maria Emília Caixeta de C. Lima; Orlando G. } \\
\text { de Aguiar-Jr }\end{array}$ & UFMG \\
\hline 1003. & SÁ, Karlla Karollina de & 2009 & $\mathrm{M}$ & Carlito Lariucci & UFG \\
\hline 1004. & SÁ, Luiz Fernando Nunes & 1990 & M & Terezinha V. Flores & UFRGS \\
\hline 1005. & SAAD, Fuad Daher & 1983 & D & Nélio Parra & USP \\
\hline 1006. & SAAD, Fuad Daher & 1990 & $\mathrm{~L}$ & $-\cdots--$ & USP \\
\hline 1007. & SAAD, Fuad Daher & 1977 & M & Ivan C. Nascimento & USP \\
\hline 1008. & SALAMI, Marcos Alfredo & 2004 & M & João Bernardes da Rocha Filho & PUC/RS \\
\hline 1009. & SALÉM, Sonia & 1986 & M & Manoel Roberto Robilotta & USP \\
\hline 1010. & SALES, Dirceu Reis de & 2009 & M & Carlos Eduardo Laburú & UEL \\
\hline 1011. & SALOMÃO, M. Rejane & 1977 & M & & UFRGS \\
\hline 1012. & SALVETTI FILHO, Antonio Paulo & 1983 & M & Anna Maria Pessoa de Carvalho & USP \\
\hline 1013. & SALVIANO FILHO, Paulo de Tarso & 2009 & M & Mario Olavo Magno de Carvalho & UnB \\
\hline 1014. & SALVIATO, Giselle Midori Simizu & 2009 & $\mathrm{M}$ & Carlos Eduardo Laburú & UEL \\
\hline 1015. & SAMAGAIA, Rafaela Rejane & 2003 & M & Luiz Orlando de Quadro Peduzzi & UFSC \\
\hline 1016. & SAMBA , Kilwangy Kya Kapitango-a- & 2005 & M & Marcia Helena Mendes Ferraz & $\mathrm{PUC} / \mathrm{SP}$ \\
\hline 1017. & SAMPAIO, Fátima Cruz & 1998 & D & Jesuina Lopes de Almeida Pacca & USP \\
\hline 1018. & SANCHES, Mônica Bordim & 2006 & M & Marcos Cesar Danhoni Neves & UEM \\
\hline 1019. & SANCHEZ, Rafael Urbaneja & 2002 & M & Alberto Villani & USP \\
\hline 1020. & SANTANA, Anderson de Sousa & 2008 & M & Eugenia Coelho Paredes & UFMT \\
\hline 1021. & SANTANA, Dulceval Andrade de & 2003 & M & Alberto Villani & USP \\
\hline 1022. & SANTANA, Osvaldo & 1990 & M & Fuad D. Saad & USP \\
\hline 1023. & SANTANA, Walker Antonio Lins de & 2006 & M & Olival Freire Jr. & UFBA \\
\hline 1024. & SANTANDER, Vicente Caro & 1980 & M & Sérgio Goldemberg & UNICAMP \\
\hline 1025. & SANTINI, Nestor Davino & 2005 & M & Eduardo Adolfo Terrazzan & UFSM \\
\hline 1026. & SANTOS NETO, Estevam Rouxinol dos & 2007 & M & Mauricio Pietrocola Pinto de Oliveira & USP \\
\hline 1027. & SANTOS, Alessandra Guida dos & 2008 & M & Eliane Brigida de Morais Falcao & UFRJ \\
\hline 1028. & SANTOS, Arion de C. Kurtz dos & 1985 & M & Marco Antonio Moreira; C. Levandowski & UFRGS \\
\hline 1029. & SANTOS, Carlos Alberto dos & 1978 & M & Marco Antonio Moreira & UFRGS \\
\hline 1030. & SANTOS, Célia Regina Silva & 2001 & M & Roseli Pacheco Schnetzler & UNIMEP \\
\hline 1031. & SANTOS, César Sátiro dos & 2002 & M & João José Caluzi & UNESP-Bauru \\
\hline 1032. & SANTOS, Cláudio José & 2004 & M & Sergio de Mello Arruda & UEL \\
\hline 1033. & SANTOS, Clodogil Fabiano Ribeiro dos & 2002 & M & Luis Vicente de Andrade Scalvi & UNESP-Bauru \\
\hline 1034. & SANTOS, Edilson Duarte dos & 2001 & M & Jorge Megid Neto & UNICAMP \\
\hline 1035. & SANTOS, Emerson Isidoro dos & 2003 & M & Norberto Cardoso Ferreira & USP \\
\hline 1036. & SANTOS, Flávia Maria Teixeira dos & 1996 & M & Maurício Pietrocola Pinto de Oliveira & UFSC \\
\hline 1037. & SANTOS, Flávia Rezende Valle dos & 1996 & D & Vera Maria F. Candau & PUC/RJ \\
\hline
\end{tabular}




\begin{tabular}{|c|c|c|c|c|c|}
\hline 1038. & SANTOS, Fred Ferreira dos & 2004 & M & Monica Rabello de Castro & UESA \\
\hline 1039. & SANTOS, Giovanni Lima dos & 1997 & M & Edil Vasconcellos de Paiva & UERJ \\
\hline 1040. & SANTOS, Gustavo Henrique dos & 2006 & M & Marcelo Albano Moret Simões Gonçalves & $\begin{array}{l}\text { Fund. Vde. de } \\
\text { Cairu }\end{array}$ \\
\hline 1041. & SANTOS, Henriette dos & 2002 & M & Flavia Rezende Valle dos Santos & UFRJ \\
\hline 1042. & SANTOS, José Renan Gomes Dos & 2009 & M & Elton Casado Fireman & UFAL \\
\hline 1043. & SANTOS, Kelsen André Melo dos & 2008 & M & Fabio Wellington Orlando da Silva & CEFET/MG \\
\hline 1044. & SANTOS, Lilian Cristiane Almeida dos & 2003 & M & Maria Regina D. Kawamura & USP \\
\hline 1045. & SANTOS, Luciana Tavares dos & 2001 & M & Luis Carlos de Menezes & USP \\
\hline 1046. & SANTOS, Marcos Antônio Barros & 2006 & M & Heloisa F. B. N. Bastos & UFRPE \\
\hline 1047. & SANTOS, Marilda Ines C. dos & 1980 & M & Lafayette de Moraes & UNICAMP \\
\hline 1048. & SANTOS, Marly da Silva & 1986 & M & Terezinha de J.G. Lankenau & UFF \\
\hline 1049. & SANTOS, Marly da Silva & 1993 & $\mathrm{D}$ & Anna Maria Pessoa de Carvalho & USP \\
\hline 1050. & SANTOS, Nelma Ferreira dos & 2004 & M & Edil Vasconcellos de Paiva & UERJ \\
\hline 1051. & SANTOS, Paulo Roberto & 2004 & M & Marcos Barbosa de Oliveira & USP \\
\hline 1052. & SANTOS, Plinio Ugo M. dos & 1976 & M & Ernst W. Hamburger & USP \\
\hline 1053. & SANTOS, Rita de Cássia Bortoletto & 2006 & M & Alice Helena Campos Pierson & UFSCar \\
\hline 1054. & SANTOS, Rogerio Vogt Cardoso dos & 2007 & M & Nelson Fiedler-Ferrara Junior & USP \\
\hline 1055. & SANTOS, Rosilene Maria dos & 2008 & M & Filomena Maria de Arruda Monteiro & UFMT \\
\hline 1056. & SANTOS, Rosiméri dos & 2006 & M & Maurivan Güntzel Ramos & PUC/RS \\
\hline 1057. & SANTOS, Zanoni Tadeu Saraiva dos & 2009 & D & Marta M. C. A. Pernambuco & UFRN \\
\hline 1058. & SÃO PAULO, Colbert Francisco & 2004 & M & Aurino Ribeiro Filho; Olival Freire Jr. & UFBA \\
\hline 1059. & SARAIVA, João Antonio Filocre & 1991 & D & Jesuina Lopes de Almeida Pacca & USP \\
\hline 1060. & SARAIVA, João Antonio Filocre & 1986 & M & Jesuina Lopes de Almeida Pacca & USP \\
\hline 1061. & SARTORI, Ademilde Silveira & 1993 & M & Maurice Bazin & UFSC \\
\hline 1062. & SATIRO, Maria Sumie Watanabe & 1989 & M & Luis Carlos de Menezes & USP \\
\hline 1063. & SAVERWEIN, Inés Pietro Schmidt & 2008 & D & Demetrio Delizoicov Neto & UFSC \\
\hline 1064. & SCALA, Sergio Brasil N. & 1995 & D & Alberto Villani & USP \\
\hline 1065. & SCALA, Sérgio Brasil N. & 1980 & M & Alberto Villani & USP \\
\hline 1066. & SCARINCI, Anne Louise & 2006 & M & Jesuina Lopes de Almeida Pacca & USP \\
\hline 1067. & SCARPARI, Deivi de Oliveira & 2009 & $\mathrm{P}$ & $\begin{array}{l}\text { Fernando Lang da Silveira; Sandra Denise } \\
\text { Prado }\end{array}$ & UFRGS \\
\hline 1068. & SCHEIN, Zenar Pedro & 2004 & M & Suzana Maria Coelho & PUC/RS \\
\hline 1069. & SCHIMIN, Eliane Strack & 1997 & M & Décio Pacheco & $\begin{array}{l}\text { UNICAMP- } \\
\text { Unicentro }\end{array}$ \\
\hline 1070. & SCHIMITZ, César & 2004 & M & José de Pinho Alves Filho & UFSC \\
\hline 1071. & SCHMALL, Alice Vianna & 2009 & M & Suzani Cassiani de Souza & UFSC \\
\hline 1072. & SCHMIDT, Inés Prieto & 1995 & M & Maria Regina D.Kawamura & USP \\
\hline 1073. & SCHMITT, Cesar Eduardo & 2006 & $P$ & Basilio Xavier Santiago & UFRGS \\
\hline 1074. & SCHREINER, Wido Herwig & 1973 & M & Anildo Bristol & UFRGS \\
\hline 1075. & SCHROEDER, Carlos & 2004 & M & Marco Antonio Moreira & UFRGS \\
\hline 1076. & SCOARIS, Raquel Carmen de Oliveira & 2007 & M & Ana Maria Teresa Benevides Pereira & UEM \\
\hline 1077. & SCRIPTORI, Carmen Campoy & 1998 & D & Orly Z. Mantovani de Assis & UNICAMP \\
\hline 1078. & SEPKA, Fábio Heberton & 2004 & M & Arden Zylbersztajn & UFSC \\
\hline 1079. & SEPULVEDA, Luis Dario & 2002 & M & Kasumi Munakata & $\mathrm{PUC} / \mathrm{SP}$ \\
\hline 1080. & SERPA, Bela S. Perret & 1985 & M & Fausto Alvin Junior & UnB \\
\hline 1081. & SERZEDELLO, Marcos & 1997 & M & Fernando Dagnoni Prado & UNESP-Marília \\
\hline 1082. & SERZEDELLO, Marcos & 2001 & $\mathrm{D}$ & Fernando Dagnoni Prado & UNESP-Marília \\
\hline 1083. & SESSA, Patrícia da Silva & 2006 & M & Rosália Maria Ribeiro de Aragão & UNIMEP \\
\hline 1084. & SEVERINO, Elizabeth Zaki Gonçalves & 2006 & M & Maria Regina Dubeux Kawamura & USP \\
\hline 1085. & SHINOMIYA, George Kouzo & 2003 & M & Mikiya Muramatsu & USP \\
\hline 1086. & SIAS, Denise Borges & 2006 & $P$ & Rejane Maria Ribeiro Teixeira & UFRGS \\
\hline 1087. & SICA, Carla Maria Simões & 2009 & M & Beatriz Maria Atrib Zanchet & UFPEL \\
\hline 1088. & SILVA FILHO, Lourival Gomes da & 2006 & M & Maria Marly de Oliveira & UFRPE \\
\hline
\end{tabular}


1089. SILVA JÚNIOR, Adahir Gonzaga da

1090. SILVA JUNIOR, Walter Luiz da

1091. SILVA JÚNIOR, Walter Romero Ramos e

1092. SILVA NETO, Jader da

1093. SILVA, Adriana Aparecida da

1094. SILVA, Alcina Maria T. Braz de

1095. SILVA, Alexandre Afrânio Hokama da

1096. SILVA, Andreia Pires da

1097. SILVA, Ângela Maria Araújo da

1098. SILVA, Aparecida Valquiria P. da

1099. SILVA, Aparecida Valquíria P. da

1100. SILVA, Artur Cézar Alves da

1101. SILVA, Carla Mahomed Gomes da

1102. SILVA, Carlos Francisco da

1103. SILVA, Carlos Magno Lima Fernandes e

1104. SILVA, Cassia Aparecida Barion da

1105. SILVA, Cassio Alberto Dias da

1106. SILVA, Cássio Alberto Dias da

1107. SILVA, Cesar José da

1108. SILVA, Cláudia Adriana de Sousa

1109. SILVA, Daniela Fiorini da

1110. SILVA, Daniela Rodrigues da

1111. SILVA, Denys Brasil Rodrigues

1112. SILVA, Diego Aurino da

1113. SILVA, Dirceu da

1114. SILVA, Dirceu da

1115. SILVA, Djalma Nunes da

1116. SILVA, Douglas Falcão

1117. SILVA, Élcio Oliveira da

1118. SILVA, Elifas Levi da

1119. SILVA, Elifas Levi da

1120. SILVA, Fabiane A. de S.S. da

1121. SILVA, Fabio Ramos da

1122. SILVA, Ferdinand Martins da

1123. SILVA, Fernanda Duarte A.

1124. SILVA, Gilmar da

1125. SILVA, Glauco dos Santos Ferreira da

1126. SILVA, Henrique César da

1127. SILVA, Henrique César da

1128. SILVA, Hilda M. Fajardo da

1129. SILVA, Hosana Salete Curtt da

1130. SILVA, lara da Glória Marcos da

1131. SILVA, Indianara Lima

1132. SILVA, Isilda Sampaio

1133. SILVA, Jadson Augusto de Almeida da

1134. SILVA, Jales de Aquino

1135. SILVA, João Freitas da

1136. SILVA, José Alves da

1137. SILVA, José Fernandes da

1138. SILVA, Joselina Conceição da

1139. SILVA, Laércio E. Ferracioli

1140. SILVA, Leandro Londero da

1141. SILVA, Lenilda Austrilino

\begin{tabular}{|c|c|c|c|}
\hline 2006 & M & Alexandro Cardoso Tenório & UFRPE \\
\hline 2008 & $\mathrm{P}$ & Antonio Carlos de Miranda & UNIPLI \\
\hline 2007 & $\mathrm{P}$ & Ciclamio Leite Barreto & UFRN \\
\hline 2008 & $P$ & Fernanda Ostermann; Sandra Denise Prado & UFRGS \\
\hline 2007 & M & Marcio Silveira Lemgruber & UFJF \\
\hline 1998 & D & Tarso Bonilha Mazzotti & UFRJ \\
\hline 2006 & M & Maria Regina D. Kawamura & USP \\
\hline 2008 & M & Ana Maria de Oliveira Cunha & UFU \\
\hline 2009 & M & Silvia Nogueira Chaves & UFPA \\
\hline 1989 & M & Fuad D. Saad & USP \\
\hline 1996 & D & Nivaldo Nale & UFSCar \\
\hline 2003 & M & Marco Antonio Moreira e Eliane A. Veit & UFRGS \\
\hline 2004 & M & Dominique Colinvaux & UFF \\
\hline 2008 & $\mathrm{P}$ & Maria Inês Martins & PUC/MG \\
\hline 2006 & $\mathrm{P}$ & Marcílio Colombo Oliveros & UFRN \\
\hline 2009 & $\mathrm{P}$ & Jaime Sandro da Veiga & UNICSUL \\
\hline 2008 & D & Dirceu da Silva & UNICAMP \\
\hline 2002 & M & Dirceu da Silva & UNICAMP \\
\hline 1993 & M & Norberto Cardoso Ferreira & USP \\
\hline 2008 & $\mathrm{P}$ & Maria Inês Martins & PUC/MG \\
\hline 2009 & M & Maria Lucia Vital dos Santos Abib & USP \\
\hline 2009 & M & José Cláudio Del Pino & UFRGS \\
\hline 2006 & M & Alice Ribeiro Casimiro Lopes & UERJ \\
\hline 2009 & M & Luiz Orlando de Quadro Peduzzi & UFSC \\
\hline 1995 & D & Anna Maria Pessoa de Carvalho & USP \\
\hline 1988 & M & Anna Maria Pessoa de Carvalho & USP \\
\hline 2009 & M & Jesuina Lopes de Almeida Pacca & USP \\
\hline 1999 & M & Henrique Lins de Barros & UFRJ \\
\hline 1996 & M & José André Peres Angotti & UFSC \\
\hline 2004 & M & Jesuina Lopes de Almeida Pacca & USP \\
\hline 2009 & D & Jesuina Lopes de Almeida Pacca & USP \\
\hline 2002 & M & Luiz Orlando de Quadro Peduzzi & UFSC \\
\hline 2007 & M & Marcelo Alves Barros & UEL \\
\hline 1999 & M & Norberto Cardoso Ferreira & USP \\
\hline 2007 & M & Ana Maria de Oliveira Cunha & UFU \\
\hline 2007 & $\mathrm{P}$ & Célia Maria Soares Gomes de Sousa & UnB \\
\hline 2008 & M & Alberto Villani & USP \\
\hline 1997 & M & Maria José P. M. de Almeida & UNICAMP \\
\hline 2002 & D & Maria José P. M. de Almeida & UNICAMP \\
\hline 1995 & M & Ligia Gomes Elliot & UFRJ \\
\hline 2003 & M & Jorge Megid Neto & UNICAMP \\
\hline 2007 & M & Helaine Sivini Ferreira & UFRPE \\
\hline 2009 & M & Ana Paula Bispo da Silva; Olival Freire Junior & UFBA \\
\hline 1999 & M & Yassuko Hosoume & USP \\
\hline 2003 & M & Jorge Tarcisio da Rocha Falcão & UFRPE \\
\hline 2009 & $\mathrm{P}$ & Célia Maria Soares Gomes de Sousa & UnB \\
\hline 2009 & M & Anna Maria Pessoa de Carvalho & USP \\
\hline 2002 & M & Maria Regina D. Kawamura & USP \\
\hline 2006 & $\mathrm{P}$ & Ciclamio Leite Barreto & UFRN \\
\hline 1998 & M & João Zanetic & USP \\
\hline 1986 & M & Marco Antonio Moreira & UFRGS \\
\hline 2006 & M & Eduardo Adolfo Terrazzan & UFSM \\
\hline 1999 & D & Marcos Tarciso Masetto & PUC/SP \\
\hline
\end{tabular}




\begin{tabular}{|c|c|c|c|c|c|}
\hline 1142. & SILVA, Lucia Forgiarini da & 2005 & $P$ & Eliane Angela Veit & UFRGS \\
\hline 1143. & SILVA, Luciana da Cruz Machado da & 2009 & $\mathrm{P}$ & Joice de Aguiar Baptista & UnB \\
\hline 1144. & SILVA, Luciano Fernandes & 2001 & M & Luiz Marcelo de Carvalho & $\begin{array}{l}\text { UNESP- } \\
\text { Araraquara }\end{array}$ \\
\hline 1145. & SILVA, Luciano Fernandes & 2007 & D & Luiz Marcelo de Carvalho & $\begin{array}{l}\text { UNESP- } \\
\text { Araraquara }\end{array}$ \\
\hline 1146. & SILVA, Luciano Ferreira & 2006 & M & Alexandre Cardoso & UFU \\
\hline 1147. & SILVA, Luciano Ferreira & 2009 & D & Alexandre Cardoso & UFU \\
\hline 1148. & SILVA, Luis Carlos da & 2009 & M & Renato Borges Guerra & UFPA \\
\hline 1149. & SILVA, Márcio José da & 2005 & M & Sônia Maria S. C. de Souza Cruz & UFSC \\
\hline 1150. & SILVA, Marcos Corrêa da & 2006 & M & Sonia Krapas Teixeira & UFF \\
\hline 1151. & SILVA, Marcos José da & 2004 & M & Ernande Barbosa da Costa & UFRPE \\
\hline 1152. & SILVA, Marcus Pinto Soares e & 2003 & M & Isabel Gomes Rodrigues Martins & UFRJ \\
\hline 1153. & SILVA, Maria de Fátima da & 1989 & M & Antônio M. Figueiredo Neto & USP \\
\hline 1154. & SILVA, Maria Luzia Rocha da & 2009 & M & Luis Paulo Leopoldo Mercado & UFAL \\
\hline 1155. & SILVA, Marine Terezinha & 1987 & M & Maria Alzira Nobre & UFSM \\
\hline 1156. & SILVA, Mário José Van Thienen da & 2003 & M & José André Peres Angotti & UFSC \\
\hline 1157. & SILVA, Milton Soares da & 2009 & $P$ & Célia Maria Soares Gomes de Sousa & UnB \\
\hline 1158. & SILVA, Osmar Henrique Moura da & 2003 & M & Carlos Eduardo Laburú & UEL \\
\hline 1159. & SILVA, Osmar Henrique Moura da & 2008 & D & Roberto Nardi & UNESP-Bauru \\
\hline 1160. & SILVA, Otto Henrique Martins da & 2006 & M & Nilson Marcos Dias Garcia & UFPR \\
\hline 1161. & SILVA, Paulo Sérgio Araújo da & 2007 & M & Silvia Nogueira Chaves & UFPA \\
\hline 1162. & SILVA, Raimundo Nonato Alves da & 2009 & M & Agostinho Serrano de Andrade Neto & ULBRA \\
\hline 1163. & SILVA, Selma Gonzaga & 2002 & M & Graça Aparecida Cicillini & UFU \\
\hline 1164. & SILVA, Valéria Cristina Lima da & 2009 & $P$ & $\begin{array}{l}\text { Célia Maria S. G. de Sousa; Maria de Fátima } \\
\text { da S. L. Verdeaux }\end{array}$ & UnB \\
\hline 1165. & SILVA, Walkiria Reche da & 2002 & M & Osvaldo Frota Pessoa Junior & USP \\
\hline 1166. & SILVA, Wallesandra Araújo & 2009 & M & Sueli Maria Pessagno Caro & UNISAL \\
\hline 1167. & SILVA, Washington Luiz Raposo da & 2009 & $P$ & Andreia Guerra de Moraes & CEFET/RJ \\
\hline 1168. & SILVA, William Costa da & 2008 & $P$ & Amarildo Menezes Gonzaga & UEA \\
\hline 1169. & SILVEIRA, Aires Vinicius Correia da & 2008 & M & Marco Antonio Moreira & UFRGS \\
\hline 1170. & SILVEIRA, Anete Cristina Reis & 2009 & $P$ & Yassuko Hosoume & PUC/MG \\
\hline 1171. & SILVEIRA, Fernando Lang da & 1992 & D & Juracy C. Marques & PUC/RS \\
\hline 1172. & SILVEIRA, Fernando Lang da & 1976 & M & Bernardo Liberman & UnB \\
\hline 1173. & SILVEIRA, Lucillana de Moraes & 2001 & M & Eduardo Adolfo Terrazzan & UFSM \\
\hline 1174. & SILVEIRA, Tomás de Aquino & 2008 & $P$ & Yassuko Hosoume & PUC/MG \\
\hline 1175. & SIMÕES, Armando Amorim & 1994 & M & João Zanetic & USP \\
\hline 1176. & SIMÕES, Cleonir Coelho & 2009 & $P$ & Yassuko Hosoume & PUC/MG \\
\hline 1177. & SIQUEIRA, Ana Maria de Paula & 2008 & $\mathrm{D}$ & Antonio Carlos Caruso Ronca & $\mathrm{PUC} / \mathrm{SP}$ \\
\hline 1178. & SIQUEIRA, Ana Paula Dias & 2004 & M & Maria Regina D. Kawamura & USP \\
\hline 1179. & SIQUEIRA, Maxwell Roger da Purificação & 2006 & M & Mauricio Pietrocola Pinto de Oliveira & USP \\
\hline 1180. & SOARES, Mirele Sousa & 2009 & $P$ & $\begin{array}{l}\text { Célia Maria S. G. de Sousa; Maria de Fátima } \\
\text { da S. L. Verdeaux }\end{array}$ & UnB \\
\hline 1181. & SOARES, Reginaldo Ribeiro & 2007 & $P$ & Paulo de Faria Borges & CEFET/RJ \\
\hline 1182. & SOARES, Sabrina Maria & 2008 & $P$ & Marco Antonio Moreira & UFRGS \\
\hline 1183. & SOARES, Vera Lúcia Lemos & 1977 & M & Ernst W. Hamburger & USP \\
\hline 1184. & SOCORRO, Marlene Santos & 2008 & M & Sonia Maria Silva Corrêa de Souza Cruz & UFSC \\
\hline 1185. & SODRÉ, Fernanda Cavaliere Ribeiro & 2008 & M & Cristiano Rodrigues de Mattos & USP \\
\hline 1186. & SOL, Elena Lidia & 2002 & M & Bernardo Buchweitz & UFPEL \\
\hline 1187. & SONZA, Aline Picoli & 2007 & $P$ & Solange Binotto Fagan & UNIFRA \\
\hline 1188. & SORPRESO, Thirza Pavan & 2008 & M & Maria José Pereira Monteiro de Almeida & UNICAMP \\
\hline 1189. & SOUSA, Carlos Nereu & 1994 & D & Lúcia Maria M. Moysés & UFF \\
\hline 1190. & SOUSA, Guaracira Gouvêa de & 2000 & D & Henrique Lins de Barros & UFRJ \\
\hline 1191. & SOUSA, Guaracira Gouveia de & 1985 & M & Zilah Xavier de Almeida & FGV \\
\hline
\end{tabular}




\begin{tabular}{|c|c|c|c|c|c|}
\hline 1192. & SOUSA, Paula Fernanda Ferreira de & 2005 & M & Maria Regina D. Kawamura & USP \\
\hline 1193. & SOUSA, Wellington Batista de & 2009 & M & Elio Carlos Ricardo & USP \\
\hline 1194. & SOUZA FILHO, Moacir Pereira de & 2004 & M & Carlos Roberto Grandini & UNESP-Bauru \\
\hline 1195. & SOUZA FILHO, Moacir Pereira de & 2009 & $\mathrm{D}$ & João José Caluzi & UNESP-Bauru \\
\hline 1196. & SOUZA FILHO, Osvaldo Melo & 1987 & M & Manoel Roberto Robilotta & USP \\
\hline 1197. & SOUZA JÚNIOR, Jonas Pereira de & 2006 & M & José Luis Vieira de Almeida & UNINOVE \\
\hline 1198. & SOUZA, Adao Jose de & 2009 & $P$ & Mauro Sérgio Teixeira de Araújo & UNICSUL \\
\hline 1199. & SOUZA, Carla Simone Bittencourt Netto de & 2009 & M & Lucia Maria Martins Giraffa & PUC/RS \\
\hline 1200. & SOUZA, Carlos Alberto & 1996 & M & José André Peres Angotti & UFSC \\
\hline 1201. & SOUZA, Carlos Alberto & 2004 & $\mathrm{D}$ & José André Peres Angotti & UFSC \\
\hline 1202. & SOUZA, Carlos Alberto Loiola de & 2006 & D & Eduardo Rodrigues da Cruz & PUC/SP \\
\hline 1203. & SOUZA, Célia Maria Soares G. de & 1980 & M & Marco Antonio Moreira & UFRGS \\
\hline 1204. & SOUZA, Célia Maria Soares G. de & 2001 & D & Maria Helena Fávero & UnB \\
\hline 1205. & SOUZA, Esdras Viggiano de & 2008 & M & Cristiano Rodrigues de Mattos & USP \\
\hline 1206. & SOUZA, Gilberto Morel de Paula e & 2007 & $P$ & Gilvan Luiz Borba & UFRN \\
\hline 1207. & SOUZA, Helson Ferreira de & 1981 & $\mathrm{M}$ & Marco Antonio Moreira & UFRGS \\
\hline 1208. & SOUZA, Ilza Fernandes de & 2004 & M & Maria Lúcia Vital dos S. Abib & USP \\
\hline 1209. & SOUZA, José de Arimater de & 2008 & $\mathrm{P}$ & André Ferrer Pinto Martins & UFRN \\
\hline 1210. & SOUZA, Jossyl A. Ribeiro de & 1990 & $\mathrm{M}$ & Luis Carlos de Menezes & USP \\
\hline 1211. & SOUZA, Luciana Sedano de & 2005 & M & Anna Maria Pessoa de Carvalho & USP \\
\hline 1212. & SOUZA, Marcos Aurélio de & 2005 & M & Sônia Maria S. C. de Souza Cruz & UFSC \\
\hline 1213. & SOUZA, Paulo Fernando Lima de & 2009 & M & Romildo de Albuquerque Nogueira & UFRPE \\
\hline 1214. & SOUZA, Paulo Henrique de & 2008 & M & João Zanetic & USP \\
\hline 1215. & SOUZA, Pedro de & 1997 & M & Demétrio Delizoicov Neto & UFSC \\
\hline 1216. & SOUZA, Salete de & 2007 & $P$ & Vania Elisabeth Barlette & UNIFRA \\
\hline 1217. & SOUZA, Sandro Aléssio Vidal de & 2008 & M & Danilo Teixeira Alves & UFPAs \\
\hline 1218. & SOUZA, Wagner de & 2007 & $P$ & Tereza Maria Rolo Fachada Levy Cardoso & CEFET/RJ \\
\hline 1219. & SPIES, Áurea Inês & 2006 & M & Roque Moraes & PUC/RS \\
\hline 1220. & SPOHR, Carla Beatriz & 2008 & $\mathrm{P}$ & Fernanda Ostermann; Paulo Pureur Neto & UFRGS \\
\hline 1221. & SPONTON, Fabiane Grossi & 2000 & M & José Humberto Dias da Silva & UNESP-Bauru \\
\hline 1222. & SQUINCA, Luzia Helena Castro & 2006 & M & Angela Fernandes Campos & UFRPE \\
\hline 1223. & STEFFENS, Cesar Augusto & 2008 & $P$ & $\begin{array}{l}\text { Eliane Angela Veit; Fernando Lang da } \\
\text { Silveira }\end{array}$ & UFRGS \\
\hline 1224. & STENSMANN, Berenice Helena Wiener & 2005 & $P$ & Marco Antonio Moreira & UFRGS \\
\hline 1225. & STREHL, Paulo Ludwig & 1996 & M & José André Peres Angotti & UFSC \\
\hline 1226. & STRIEDER, Dulce Maria & 1998 & M & Eduardo Adolfo Terrazzan & UFSM \\
\hline 1227. & STRIEDER, Dulce Maria & 2007 & $\mathrm{D}$ & Anna Maria Pessoa de Carvalho & USP \\
\hline 1228. & STRIEDER, Roseline Beatriz & 2008 & M & Maria Regina Dubeux Kawamura & USP \\
\hline 1229. & STUCHI, Adriano Marcus & 2002 & M & Norberto Cardoso Ferreira & USP \\
\hline 1230. & SUTIL, Noemi & 2006 & M & Rejane Aurora Mion & UEPG \\
\hline 1231. & TAGIKU, Armando Massao & 2001 & M & Maria Regina D. Kawamura & USP \\
\hline 1232. & TAGLIATI, José Roberto & 1991 & M & Jesuina Lopes de Almeida Pacca & USP \\
\hline 1233. & TANCREDI, Regina M.S. & 1995 & D & Myrtes Alonso & UFSCar \\
\hline 1234. & TAVARES, Luciano de Abreu & 2005 & M & Maria Helena Roxo Beltran & PUC/SP \\
\hline 1235. & TAVARES, Sued Teixeira & 1982 & M & Henry G. Wetzler & UNICAMP \\
\hline 1236. & TEIXEIRA, Cícero Marcos & 1979 & M & Juracy C. Marques & UFRGS \\
\hline 1237. & TEIXEIRA, Elder Sales & 2003 & M & Olival Freire Jr. & UFBA \\
\hline 1238. & TEIXEIRA, Jonny Nelson & 2007 & M & Mikiya Muramatsu & USP \\
\hline 1239. & TEIXEIRA, Maria Amélia & 2005 & M & Olival Freire Jr & UFBA \\
\hline 1240. & TEIXEIRA, Odete Pacubi Baierl & 1992 & D & Anna Maria Pessoa de Carvalho & USP \\
\hline 1241. & TEIXEIRA, Odete Pacubi Baierl & 1985 & M & Anna Maria Pessoa de Carvalho & USP \\
\hline 1242. & TEIXEIRA, Sonia Krapas & 1989 & $\mathrm{D}$ & Jesuina Lopes de Almeida Pacca & USP \\
\hline 1243. & TEIXEIRA, Sonia Krapas & 1982 & $\mathrm{M}$ & Anna Maria Pessoa de Carvalho & USP \\
\hline
\end{tabular}




\begin{tabular}{|c|c|c|c|c|c|}
\hline 1244. & TEODORO, Sandra Regina & 2000 & M & Roberto Nardi & UNESP-Bauru \\
\hline 1245. & TERRAZZAN, Eduardo A. & 1994 & $\mathrm{D}$ & Luis Carlos de Menezes & USP \\
\hline 1246. & TERRAZZAN, Eduardo A. & 1985 & M & Jesuina Lopes de Almeida Pacca & USP \\
\hline 1247. & TESTONI, Leonardo André & 2004 & M & Maria Lúcia Vital dos S. Abib & USP \\
\hline 1248. & THOBIAS, Maria Aline Lemos Silva & 2000 & M & Aguinaldo Robinson de Souza & UNESP-Bauru \\
\hline 1249. & TIMM, Rita Mara Bueno & 2008 & M & Valderez Marina do Rosário Lima & PUC/RS \\
\hline 1250. & TINOCO, Sandra Carpinetti & 2000 & M & Anna Maria Pessoa de Carvalho & USP \\
\hline 1251. & TINOCO, Sandra Carpinetti & 2005 & $\mathrm{D}$ & Anna Maria Pessoa de Carvalho & USP \\
\hline 1252. & TOFOLI, Marcos Rogério & 2003 & M & Yassuko Hosoume & USP \\
\hline 1253. & TOLENTINO NETO, Luiz Caldeira Brant de & 2008 & $\mathrm{D}$ & Nelio Marco Vincenzo Bizzo & USP \\
\hline 1254. & TONDIM, Jose Egidio Marin & 2009 & M & Marina Beatriz Agostini Vasconcellos & USP-IPEN \\
\hline 1255. & TONIAL, Carla Mara & 2008 & M & Milton Antonio Auth & UNIJUI \\
\hline 1256. & TORRES, Juliana Rezende & 2002 & M & Demétrio Delizoicov & UFSC \\
\hline 1257. & TORRES, Mariana Cassab & 2003 & M & Isabel Gomes Rodrigues Martins & UFRJ \\
\hline 1258. & TORRES, Renato Kerley Lage & 2008 & $\mathrm{P}$ & Lev Vertchenko & PUC/MG \\
\hline 1259. & TOSCANO, Carlos & 1991 & M & Maria da Graça N. Mizukami & UFSCar \\
\hline 1260. & TOSCANO, Carlos & 2005 & $\mathrm{D}$ & Sueli Mazzilli & UNIMEP \\
\hline 1261. & TOTI, Frederico Augusto & 2007 & M & Alice Helena Campos Pierson & UFSCar \\
\hline 1262. & TRAN?, Luciana Breder Peres & 2008 & $\mathrm{P}$ & Paulo de Faria Borges & CEFET/RJ \\
\hline 1263. & TRENTIN, Elizabeth & 2003 & M & Jesuina Lopes de Almeida Pacca & USP \\
\hline 1264. & TRENTIN, Marco Antonio S. & 2004 & M & Marie Jane Soares Carvalho & UFRGS \\
\hline 1265. & TRINDADE, Diamantino Fernandes & 2002 & M & Sylvia Helena Souza da Silva Batista & UNICID \\
\hline 1266. & TRINDADE, Inez Leal & 2004 & M & Silvia Nogueira Chaves & UFPA \\
\hline 1267. & UEMA, Soraya Noriko & 2005 & M & Nelson Fiedler-Ferrara Junior & USP \\
\hline 1268. & UENO, Michele Hidemi & 2004 & $\mathrm{M}$ & Sérgio de Mello Arruda & UEL \\
\hline 1269. & UHR, Andréia Pessi & 2007 & $\mathrm{P}$ & Maria de Fátima Oliveira Saraiva & UFRGS \\
\hline 1270. & USTRA, Sandro Rogerio Vargas & 1997 & M & Eduardo Adolfo Terrazzan & UFSM \\
\hline 1271. & USTRA, Sandro Rogério Vargas & 2006 & D & Jesuina Lopes de Almeida Pacca & USP \\
\hline 1272. & UTGES, Graciela Rita & 1999 & $\mathrm{D}$ & Jesuina Lopes de Almeida Pacca & USP \\
\hline 1273. & VALADARES, Juarez Melgaço & 2002 & M & Alberto Villani & USP \\
\hline 1274. & VALENTE, José Alexandre da Silva & 2007 & M & Cícero Roberto Teixeira Régis & UFPA \\
\hline 1275. & VALLE FILHO, Moacyr Ribeiro do & 1989 & $\mathrm{D}$ & Anna Maria Pessoa de Carvalho & USP \\
\hline 1276. & VALLE FILHO, Moacyr Ribeiro do & 1982 & M & Giorgio Moscati & USP \\
\hline 1277. & VALLE, Marta Maria Cola & 2000 & M & Helmuth Ricardo Krüger & UCP \\
\hline 1278. & VANNUCCHI, Andréa Infantosi & 1997 & M & Anna Maria Pessoa de Carvalho & USP \\
\hline 1279. & VASCONCELOS, Francisco Herbert Lima & 2008 & M & $\begin{array}{l}\text { José Aires de Castro Filho; Mauro } \\
\text { Cavalcante Pequeno }\end{array}$ & UFC \\
\hline 1280. & VASNIZI, Renata & 2006 & M & Mikiya Muramatsu & USP \\
\hline 1281. & VAZ, Arnaldo de Moura & 1989 & M & Maria Regina D. Kawamura & USP \\
\hline 1282. & VENDRAMETO, Oduvaldo & 1987 & M & Fuad D. Saad & USP \\
\hline 1283. & VENEZUELA, Osvaldo Dias & 2008 & M & Osvaldo Frota Pessoa Júnior & USP \\
\hline 1284. & VERAS, Alcione da Anunciação Caetano Lobao & 2007 & M & Orlando Gomes de Aguiar-Jr & UFMG \\
\hline 1285. & VETTORI, Marcelo & 2006 & M & Roque Moraes & PUC/RS \\
\hline 1286. & VIANNA, Deise Miranda & 1998 & D & Anna Maria Pessoa de Carvalho & USP \\
\hline 1287. & VICENZI, Scheila & 2007 & $\mathrm{P}$ & Silvio Luis Souza Cunha & UFRGS \\
\hline 1288. & VICTORINO, Alfiado & 2006 & M & Fernando José de Almeida & PUC/SP \\
\hline 1289. & VIDAL, Eloisa Maia & 2000 & $\mathrm{D}$ & André Haguette & UFC \\
\hline 1290. & VIDOTTO, Luiz Carlos & 2004 & M & Carlos Eduardo Laburú & UEL \\
\hline 1291. & VIEIRA, Eulália Soares & 2008 & M & Rosália Maria Ribeiro de Aragão & UFPA \\
\hline 1292. & VIEIRA, Kátia Regina Cunha Flor & 2006 & M & Jose de Pinho Alves Filho & UFSC \\
\hline 1293. & VIEIRA, Marlete & 2003 & M & Edel Ern & UFSC \\
\hline 1294. & VIEIRA, Rodrigo Drumond & 2007 & M & Silvania Sousa do Nascimento & UFMG \\
\hline 1295. & VIEIRA, Rui Manoel de Bastos & 2005 & M & Norberto Cardoso Ferreira & USP \\
\hline
\end{tabular}




\begin{tabular}{|c|c|c|c|c|c|}
\hline 1296. & VILLAÇA, Jaqueline da Silva & 2007 & M & Cláudio Bertolli Filho & UNESP-Bauru \\
\hline 1297. & VILLANI, Alberto & 1987 & L & ----- & USP \\
\hline 1298. & VILLANI, Carlos Eduardo Porto & 2002 & M & Silvania de Souza Nascimento & UFMG \\
\hline 1299. & VILLANI, Carlos Eduardo Porto & 2007 & $\mathrm{D}$ & Silvania Sousa do Nascimento & UFMG \\
\hline 1300. & VILLATORRE, Aparecida Magalhães & 2004 & M & $\begin{array}{l}\text { Maria Cristina M. Martins e Nilson Marcos } \\
\text { Dias Garcia }\end{array}$ & UFBA \\
\hline 1301. & VINHA, Maria Lucia & 2007 & D & Mauricio Pietrocola Pinto de Oliveira & USP \\
\hline 1302. & VIOLIN, Antonio Geraldo & 1976 & M & Ernst W. Hamburger & USP \\
\hline 1303. & VITIRITTI, Ana Beatriz Godoy & 2006 & M & Myriam Krasilchik & USP \\
\hline 1304. & VIVIAN, Nanci Miksza & 2006 & M & Marcos Rodrigues da Silva & UEL \\
\hline 1305. & WALVY, Ophelio Walkyrio de Castro & 2008 & $\mathrm{D}$ & Glória Regina Pessôa Campello Queiroz & UFF \\
\hline 1306. & WATANABE, Kazuo & 1980 & M & Yashiro Yamamoto & USP \\
\hline 1307. & WEBBER, Márcia Cândida Montano & 2006 & $P$ & Marco Antonio Moreira & UFRGS \\
\hline 1308. & WEISS, Josiane Maria & 2006 & $P$ & Agostinho Serrano de Andrade Neto & ULBRA \\
\hline 1309. & WERKAIZER, Fernando Eustáquio & 2008 & $P$ & Lev Vertchenko & PUC/MG \\
\hline 1310. & WERLANG, Rafhael Brum & 2007 & $\mathrm{P}$ & Ruth de Souza Schneider & UFRGS \\
\hline 1311. & WERLICH, Raquel & 2008 & M & Tales Leandro Costa Martins & ULBRA \\
\hline 1312. & WETSPHAL, Murilo & 2006 & M & Edel Ern & UFSC \\
\hline 1313. & WOLFF, Jeferson Fernando de Souza & 2005 & $P$ & Paulo Machado Mors & UFRGS \\
\hline 1314. & WUO, Wagner & 1999 & M & Nereide Saviani & PUC/SP \\
\hline 1315. & WUO, Wagner & 2005 & $\mathrm{D}$ & Maria das Mercês Ferreira Sampaio & PUC/SP \\
\hline 1316. & WYKROTA, Jordelina Laje Martins & 2007 & D & Oto Neri Borges & UFMG \\
\hline 1317. & XAVIER, Alexandre A. Barbosa & 2003 & M & Antonio Tarcísio Borges & UFMG \\
\hline 1318. & XAVIER, Maria Emília Rehder & 2007 & M & Américo A. F. S. Kerr & USP \\
\hline 1319. & XAVIER, Rosaly Soalheiro & 2001 & M & Yara Lygia Nogueira Sáes Cerri & UNIMEP \\
\hline 1320. & YAMAMURA, Paulo & 1980 & M & Yashiro Yamamoto & USP \\
\hline 1321. & YAMAZAKI, Sérgio Choiti & 1998 & M & Alberto Villani & USP \\
\hline 1322. & ZAMBIASI, José Luiz & 2000 & M & Ari Paulo Jantsch & UFSC \\
\hline 1323. & ZANETIC, João & 1989 & D & Luis Carlos de Menezes & USP \\
\hline 1324. & ZANOLLA, Jaime José & 2008 & M & Rejane Aurora Mion & UEPG \\
\hline 1325. & ZAPPAROLI, Ferdinando Vinicius Domenes & 2005 & M & Sergio de Mello Arruda & UEL \\
\hline 1326. & ZAWISLAK, Beatriz M. Mikusinski & 1976 & M & Juracy C. Marques & UFRGS \\
\hline 1327. & ZIMMERMANN, Licia & 2005 & M & Vicente Hillebrand & PUC/RS \\
\hline 1328. & ZULIANI, Renata Duarte & 2009 & M & Fernando Bastos & UNESP-Bauru \\
\hline 1329. & ZWIRTES, Ari & 2001 & $M$ & Otavio Aloisio Maldaner & UNIJUI \\
\hline 1330. & ZYLBERSZTAJN, Arden & 1976 & M & Maria B. C. Barbosa & INPE \\
\hline
\end{tabular}




\begin{abstract}
ANEXO 3.2
INSTITUIÇÕES COM DISSERTAÇÕES E TESES NA ÁREA NO PERÍODO

1972-2009
\end{abstract}




\section{INSTITUIÇÕES COM DISSERTAÇÕES E TESES NA ÁREA NO PERÍODO 1972-2009}

\begin{tabular}{|c|c|c|c|c|c|c|c|c|c|c|c|c|c|c|c|c|c|c|c|c|c|c|c|c|c|c|c|c|c|c|c|c|c|c|c|c|c|c|}
\hline $\begin{array}{ll} & \text { ANO } \\
\text { INST } & \end{array}$ & 72 & 73 & 74 & 75 & 76 & 77 & 78 & 79 & 80 & 81 & 82 & 83 & 84 & 85 & 86 & 87 & 88 & 89 & 90 & 91 & 92 & 93 & 94 & 95 & 96 & 97 & 98 & 99 & 00 & 01 & 02 & 03 & 04 & 05 & 06 & 07 & 08 & 09 \\
\hline CEFET/MG & & & & & & & & & & & & & & & & & & & & & & & & $\mathrm{X}$ & & & & & & & $\mathrm{X}$ & & & & & & $\mathbf{x}$ & $x$ \\
\hline CEFET/RJ & & & & & & & & & & & & & & & & & & & & & & & & & & & & & & & & & & & $\mathrm{x}$ & $\mathrm{x}$ & $\mathrm{x}$ & $\mathrm{x}$ \\
\hline $\begin{array}{l}\text { C.UNIV. } \\
\text { FIEO }\end{array}$ & & & & & & & & & & & & & & & & & & & & & & & & & & & & & & & & & & & & & & $x$ \\
\hline $\begin{array}{l}\text { C. UNIV. M. } \\
\text { LAC. }\end{array}$ & & & & & & & & & & & & & & & & & & & & & & & & & & & & & & & & & & & & & $\mathrm{x}$ & \\
\hline $\begin{array}{l}\text { C. UNIV. P. } \\
\text { LEITE }\end{array}$ & & & & & & & & & & & & & & & & & & & & & & & & & & & & & & & & & & & & & $x$ & \\
\hline FGV-IEAE & & & & & & & & & $\mathrm{x}$ & & $\mathrm{x}$ & & & $\mathrm{x}$ & & $\mathrm{x}$ & & & & & & & & & & & & & & & & & & & & & & \\
\hline FIOCRUZ & & & & & & & & & & & & & & & & & & & & & & & & & & & & & & & & & & $\mathbf{x}$ & $\mathrm{x}$ & $\mathrm{x}$ & $\mathrm{x}$ & \\
\hline FURB & & & & & & & & & & & & & & & & & & & & & & & & $\mathrm{x}$ & & & & & & & & & & & & & & \\
\hline FVC & & & & & & & & & & & & & & & & & & & & & & & & & & & & & & & & & & & $\mathrm{x}$ & & & \\
\hline ITA & & & & & & & & & & & & & & & & & & & & & & & & & & & & & & & & & & & & $\mathrm{x}$ & & \\
\hline IUPERJ & & & & & & & $\mathrm{x}$ & & & & & & & & & & & & & & & & & & & & & & & & & & & & & & & \\
\hline PUC/MG & & & & & & & & & & & & & & & & & & & & & & & & & & & & & & & & & & & & & $x$ & $x$ \\
\hline PUC/PR & & & & & & & & & & & & & & & & & & & & & & & & & & & & & & & & $\mathbf{x}$ & & & & & & \\
\hline PUC/RJ & & & & & & & & & & & & & & & & & $\mathrm{X}$ & & $x$ & $x$ & $\mathrm{X}$ & $\mathrm{x}$ & & & $\mathrm{x}$ & & & & $\mathrm{x}$ & & & & & & & & & \\
\hline PUC/RS & & & & & & $\mathbf{x}$ & & & & & & & & & & & & $x$ & $x$ & & $\mathrm{x}$ & & & & & & & $\mathbf{x}$ & & $\mathrm{x}$ & & & $x$ & $\mathbf{x}$ & $\mathrm{x}$ & $\mathrm{x}$ & $\mathrm{x}$ & $\mathrm{x}$ \\
\hline PUC/SP & & & & & $\mathrm{x}$ & & & & & $\mathrm{x}$ & & & & & & & & & & & & & $x$ & & & & & $x$ & $\mathrm{x}$ & $x$ & $x$ & & & $x$ & $\mathrm{x}$ & & $\mathrm{x}$ & $\mathrm{x}$ \\
\hline PUCCAMP & & & & & & & & & & & & & & & & & & & & & & & & & & $x$ & & & $x$ & & & & & & & & & \\
\hline UCB & & & & & & & & & & & & & & & & & & & & & & & & & & & & & & & $\mathrm{x}$ & & & & & & & \\
\hline UCP & & & & & & & & & & & & & & & & & & & & & & & & & & & & & $\mathrm{x}$ & & & & & & & & & \\
\hline UNICSUL & & & & & & & & & & & & & & & & & & & & & & & & & & & & & & & & & & & $\mathrm{X}$ & $\mathrm{x}$ & $x$ & $x$ \\
\hline
\end{tabular}




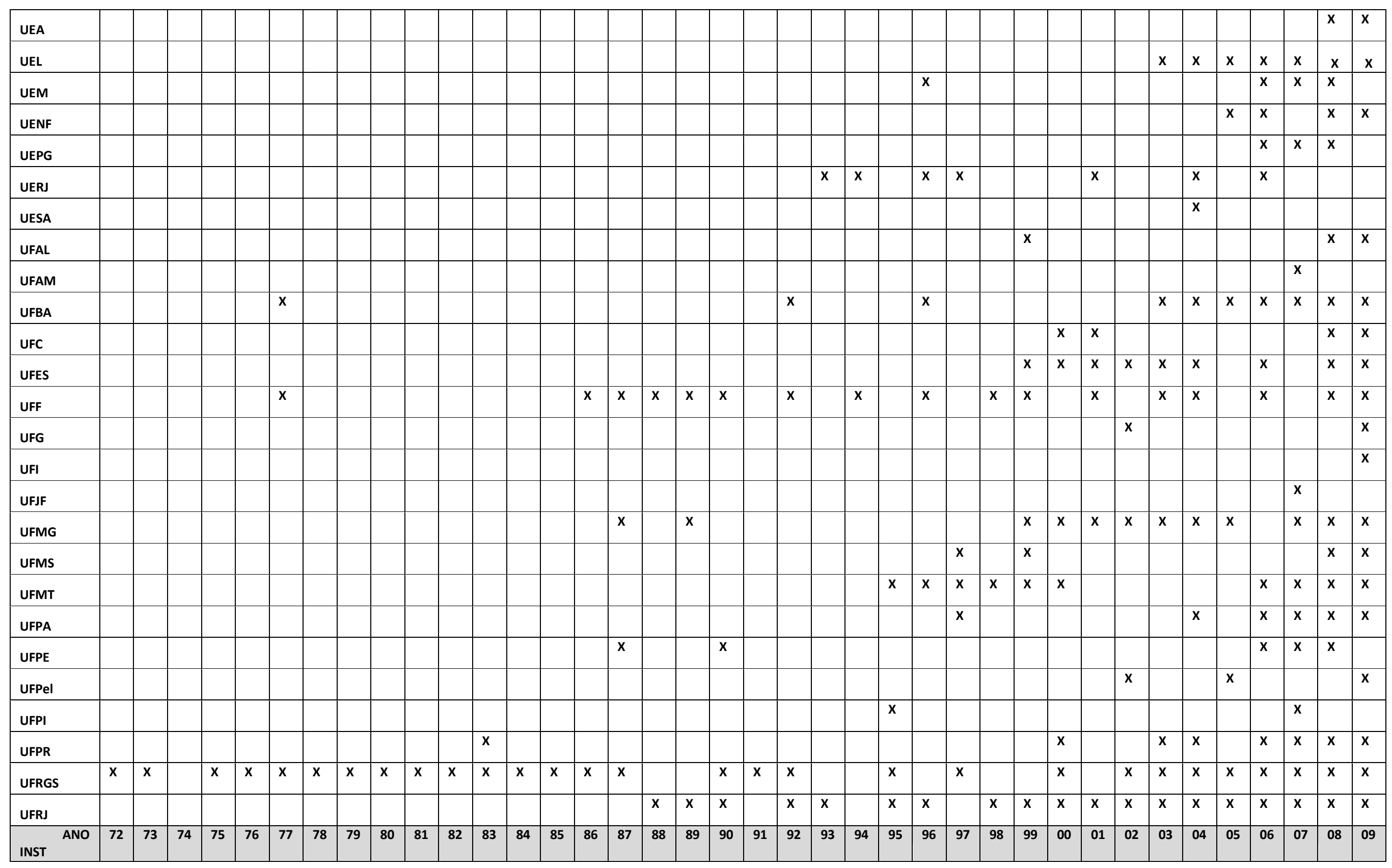




\begin{tabular}{|c|c|c|c|c|c|c|c|c|c|c|c|c|c|c|c|c|c|c|c|c|c|c|c|c|c|c|c|c|c|c|c|c|c|c|c|c|c|c|}
\hline UFRN & & & & & & & & & & & & & & & & & & & & & & & & & & & & & & & & $x$ & $x$ & $x$ & $x$ & $\mathbf{x}$ & $x$ & $x$ \\
\hline UFRPE & & & & & & & & & & & & & & & & & & & & & & & & & & & & $\mathrm{x}$ & & & $\mathrm{x}$ & $x$ & $x$ & $x$ & $x$ & $\mathrm{x}$ & $x$ & $x$ \\
\hline UFSC & & & & & & & & & & & & & & & & & & & $x$ & $x$ & & $x$ & $x$ & & $x$ & $x$ & $x$ & $x$ & $x$ & $x$ & $x$ & $x$ & $x$ & $x$ & $x$ & $x$ & $x$ & $x$ \\
\hline UFSCar & & & & & & & & & & & & & & & & & & & & $x$ & & $x$ & & $x$ & $x$ & & & $x$ & $\mathrm{x}$ & & $x$ & $x$ & & $\mathrm{x}$ & $x$ & $x$ & & $x$ \\
\hline UFSE & & & & & & & & & & & & & & & & & & & & & & & & & $x$ & & & & & & & & & & & & & $x$ \\
\hline UFSM & & & & & $x$ & & & & & & $\mathrm{x}$ & & & & & $\mathrm{x}$ & & & & & & & $x$ & $x$ & $x$ & $x$ & $x$ & $x$ & & $x$ & $x$ & $x$ & $x$ & $\mathrm{x}$ & $x$ & & $x$ & \\
\hline ULBRA & & & & & & & & & & & & & & & & & & & & & & & & & & & & & & & & $x$ & & $x$ & $x$ & $x$ & $x$ & $x$ \\
\hline UnB & $x$ & $x$ & & $x$ & $x$ & & & & & & & & & $x$ & & & & & & & & & & & & & & & & $x$ & $x$ & & & & $x$ & $x$ & $x$ & $x$ \\
\hline UNEB & & & & & & & & & & & & & & & & & & & & & & & & & & & & & & & & $x$ & & & & & & \\
\hline UNESC & & & & & & & & & & & & & & & & & & & & & & & & & & & & & & & & & & & & & & $x$ \\
\hline $\begin{array}{l}\text { UNESP- } \\
\text { Araraq. }\end{array}$ & & & & & & & & & & & & & & & & & & & & & & & & & & & & & & $x$ & & & & & $x$ & $x$ & & \\
\hline $\begin{array}{l}\text { UNESP- } \\
\text { Bauru }\end{array}$ & & & & & & & & & & & & & & & & & & & & & & & & & & & & & & $\mathrm{x}$ & $\mathrm{x}$ & $\mathrm{x}$ & $x$ & $\mathrm{x}$ & $x$ & $x$ & $x$ & $x$ \\
\hline $\begin{array}{l}\text { UNESP- } \\
\text { Marília }\end{array}$ & & & & & & & & & & & & & & & & & & & & & & & & & & $x$ & & & $x$ & $x$ & & & & & & & & \\
\hline $\begin{array}{l}\text { UNESP- } \\
\text { R.Claro }\end{array}$ & & $x$ & & & & & & & & & & & & & & & & & & & & & & & & & & & & & $x$ & & $x$ & & & & & \\
\hline UNICAMP & & & & & & & & $x$ & $\mathrm{x}$ & & $\mathrm{x}$ & & & $x$ & & & & $x$ & $x$ & $x$ & & $x$ & $x$ & $x$ & $x$ & $x$ & $x$ & $x$ & $x$ & $x$ & $x$ & $\mathrm{x}$ & $x$ & $x$ & $x$ & $x$ & $x$ & $x$ \\
\hline UNICID & & & & & & & & & & & & & & & & & & & & & & & & & & & & & & & $x$ & & & & & & & \\
\hline UNIFRA & & & & & & & & & & & & & & & & & & & & & & & & & & & & & & & & & & & $x$ & $x$ & $x$ & $x$ \\
\hline UNIJUI & & & & & & & & & & & & & & & & & & & & & & & & & & & & & $\mathbf{x}$ & $x$ & & & & $x$ & $x$ & & $x$ & \\
\hline UNIMEP & & & & & & & & & & & & & & & & & & & & & & & & & & $x$ & & $\mathrm{x}$ & & $x$ & & $x$ & & $x$ & $x$ & & & \\
\hline UNINOVE & & & & & & & & & & & & & & & & & & & & & & & & & & & & & & & & $x$ & & & $x$ & $x$ & & \\
\hline UNISAL & & & & & & & & & & & & & & & & & & & & & & & & & & & & & & & & & & & & & & $x$ \\
\hline $\begin{array}{ll} & \text { ANO } \\
\text { INST } & \end{array}$ & 72 & 73 & 74 & 75 & 76 & 77 & 78 & 79 & 80 & 81 & 82 & 83 & 84 & 85 & 86 & 87 & 88 & 89 & 90 & 91 & 92 & 93 & 94 & 95 & 96 & 97 & 98 & 99 & 00 & 01 & 02 & 03 & 04 & 05 & 06 & 07 & 08 & 09 \\
\hline
\end{tabular}




\begin{tabular}{|c|c|c|c|c|c|c|c|c|c|c|c|c|c|c|c|c|c|c|c|c|c|c|c|c|c|c|c|c|c|c|c|c|c|c|c|c|c|c|}
\hline UNIVATES & & & & & & & & & & & & & & & & & & & & & & & & & & & & & & & & & & & & & & $x$ \\
\hline $\begin{array}{l}\text { UNIV. SAG. } \\
\text { CORAÇÃO }\end{array}$ & & & & & & & & & & & & & & & & & & & & & & & & & & & & & & & & & & & & & $x$ & \\
\hline $\begin{array}{l}\text { UNIV. P. } \\
\text { MACK }\end{array}$ & & & & & & & & & & & & & & & & & & & & & & & & & & & & & & & & & & & & $x$ & & \\
\hline USM & & & & & & & & & & & & & & & & & & & & & & & & & & & & & & & & & & $x$ & & 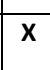 & & \\
\hline USP & $x$ & & & & $x$ & $\mathbf{x}$ & $\mathrm{X}$ & & $x$ & $\mathbf{X}$ & $x$ & $x$ & $x$ & $x$ & $x$ & $x$ & $x$ & $x$ & 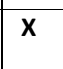 & $x$ & $x$ & $x$ & $x$ & $x$ & $x$ & $x$ & $x$ & $x$ & $x$ & $x$ & $x$ & $x$ & $x$ & $x$ & $x$ & $x$ & $x$ & $\mathrm{X}$ \\
\hline UTF-PR & & & & & & & & & & & & & & & & & & & & & & & & & & & & & & & & & & & & & & $\mathrm{X}$ \\
\hline
\end{tabular}

\begin{tabular}{|c|c|c|c|c|c|c|c|c|c|c|c|c|c|c|c|c|c|c|c|c|c|c|c|c|c|c|c|c|c|c|c|c|c|c|c|c|c|c|}
\hline ANO & 72 & 73 & 74 & 75 & 76 & 77 & 78 & 79 & 80 & 81 & 82 & 83 & 84 & 85 & 86 & 87 & 88 & 89 & 90 & 91 & 92 & 93 & 94 & 95 & 96 & 97 & 98 & 99 & 00 & 01 & 02 & 03 & 04 & 05 & 06 & 07 & 08 & 09 \\
\hline $\begin{array}{l}\text { TOTAL } \\
\text { GERAL }\end{array}$ & 3 & 3 & 0 & 2 & 6 & 5 & 3 & 2 & 4 & 3 & 5 & 3 & 3 & 5 & 2 & 6 & 4 & 6 & 9 & 6 & 7 & 6 & 7 & 9 & 12 & 12 & 7 & 16 & 16 & 16 & 20 & 20 & 20 & 22 & 34 & 30 & 38 & 41 \\
\hline
\end{tabular}


ANEXO 4.1

ÁREAS TEMÁTICAS DOS EVENTOS 


\section{ÁREAS TEMÁTICAS DOS EVENTOS}

EPEF

\section{EPEF (2010)}

1. ENSINO/ APRENDIZAGEM/ AVALIAÇÃO EM FÍSICA

2. FORMAÇÃO E PRÁTICA PROFISSIONAL DO PROFESSOR DE FÍSICA

3. FILOSOFIA, HISTÓRIA E SOCIOLOGIA DA CIÊNCIA E O ENSINO DE FÍSICA

4. FÍSICA E COMUNICAÇÃO EM PRÁTICAS EDUCATIVAS FORMAIS, INFORMAIS E NÃO-FORMAIS

5. TECNOLOGIAS DA INFORMAÇÃO E COMUNICAÇÃO E O ENSINO DE FÍSICA

6. DIDÁTICA, CURRÍCULO E INOVAÇÃO EDUCACIONAL NO ENSINO DE FÍSICA

7. LINGUAGEM E COGNIÇÃO NO ENSINO DE FÍSICA

8. CIÊNCIAS, TECNOLOGIA, SOCIEDADE E AMBIENTE E O ENSINO DE FÍSICA

9. POLÍTICAS PÚBLICAS EM EDUCAÇÃO E O ENSINO DE FÍSICA

10. QUESTÕES TEÓRICO-METODOLÓGICAS E NOVAS DEMANDAS NA PESQUISA EM ENSINO DE FÍSICA

\section{EPEF (2008)}

1. ENSINO-APRENDIZAGEM DE FÍSICA

2. FORMAÇÃO E PRÁTICA PROFISSIONAL DE PROFESSORES DE FÍSICA

3. FILOSOFIA, HISTÓRIA E SOCIOLOGIA DA CIÊNCIA E O ENSINO DE FÍSICA

4. DIDÁTICA, CURRÍCULO E AVALIAÇÃO NO ENSINO DE FÍSICA

5. FÍSICA E DIVULGAÇÃO CIENTÍFICA EM ESPAÇOS EDUCATIVOS FORMAIS E NÃO FORMAIS

6. TECNOLOGIAS E NOVAS ABORDAGENS NO ENSINO DA FÍSICA

7. COGNIÇÃO, ALFABETIZAÇÃO E LETRAMENTO EM FÍSICA

8. POLÍTICAS PÚBLICAS E O ENSINO DE FÍSICA

9. QUESTÕES TEÓRICO-METODOLÓGICAS DA PESQUISA EM ENSINO DE FÍSICA

10. CTSA E O ENSINO DE FÍSICA

\section{$X$ EPEF (2006)}

1. FORMAÇÃO E PRÁTICA PROFISSIONAL DE PROFESSORES DE FÍSICA

2. APRENDIZAGEM EM FÍSICA

3. FILOSOFIA, HISTÓRIA E SOCIOLOGIA DA CIÊNCIA E O ENSINO DE FÍSICA

4. LINGUAGEM E COGNIÇÃO NO ENSINO DE FÍSICA

5. DIDÁTICA, CURRÍCULO E AVALIAÇÃO NO ENSINO DE FÍSICA

6. DIVULGAÇÃO E COMUNICAÇÃO DE FÍSICA EM ESPAÇOS FORMAIS E NÃO FORMAIS

7. TECNOLOGIA DA INFORMAÇÃO, DIFUSÃO TECNOLÓGICA E O ENSINO DE FÍSICA

8. POLÍTICAS PÚBLICAS E O ENSINO DE FÍSICA

9. QUESTÕES TEÓRICO-METODOLÓGICAS DA PESQUISA EM ENSINO DE FÍSICA

10. CIÊNCIA, TECNOLOGIA E SOCIEDADE E O ENSINO DE FÍSICA

\section{EPEF (2004)}

1. ENSINO E APRENDIZAGEM DE FÍSICA

2. FORMAÇÃO E PRÁTICA PROFISSIONAL DE PROFESSORES

3. FILOSOFIA, HISTÓRIA E SOCIOLOGIA DA CIÊNCIA NO ENSINO DE FÍSICA

4. DIVULGAÇÃO E COMUNICAÇÃO DE CIÊNCIAS: FÍSICA EM ESPAÇOS ESCOLARES E NÃO ESCOLAR

5. TECNOLOGIA DA INFORMAÇÃO E INSTRUMENTAÇÃO NO ENSINO DE FÍSICA

6. CIÊNCIAS, TECNOLOGIA E SOCIEDADE

7. ALFABETIZAÇÃO E LETRAMENTO EM FÍSICA E TECNOLOGIA

8. DIDÁTICA, CURRÍCULO E AVALIAÇÃO NO ENSINO DE FÍSICA

9. POLÍTICAS PÚBLICAS E ENSINO DE FÍSICA

10. LINGUAGEM E COGNIÇÃO NO ENSINO DE FÍSICA E TECNOLOGIA

VIII EPEF (2002)

1. ENSINO/APRENDIZAGEM DE FÍSICA

2. FORMAÇÃO DO PROFESSOR DE FÍSICA 
3. FILOSOFIA, HISTÓRIA E SOCIOLOGIA DA CIÊNCIA NO ENSINO DE FÍSICA

4. EDUCAÇÃO EM ESPAÇOS NÃO-FORMAIS E DIVULGAÇÃO CIENTÍFICA

5. TECNOLOGIA DA INFORMAÇÃO, INSTRUMENTAÇÃO E DIFUSÃO TECNOLÓGICA

6. CIÊNCIAS, TECNOLOGIA E SOCIEDADE

7. ALFABETIZAÇÃO CIENTÍFICA E TECNOLÓGICA E ENSINO DE FÍSICA

8. DIDÁTICA, CURRÍCULO E AVALIAÇÃO NO ENSINO DE FÍSICA

9. COMUNIDADE, PRÁTICAS E POLÍTICAS EDUCACIONAIS

\section{EPEF (2000)}

1. ENSINO - APRENDIZAGEM - AVALIAÇÃO: ESPAÇOS FORMAIS E NÃO FORMAIS

2. FORMAÇÃO DO PROFESSOR DE FÍSICA

3. CURRÍCULO E INOVAÇÃO EDUCACIONAL

4. BALANÇO CRÍTICO DAS PESQUISAS E NOVAS DEMANDAS DE INVESTIGAÇÃO

5. CIÊNCIA, SOCIEDADE E ENSINO DE FÍSICA

\section{EPEF (1998)}

Sessões de Painéis:

1. FILOSOFIA E HISTÓRIA DA CIÊNCIA: IMPLICAÇÕES E DECORRÊNCIAS PARA O ENSINO DE FÍSICA

2. FORMAÇÃO INICIAL E CONTINUADA DE PROFESSORES PARA A ÁREA DE FÍSICA E DE CIÊNCIAS

3. REPRESENTAÇÕES E COGNIÇÃO: RELAÇÃO ENTRE LINGUAGEM E FORMAÇÃO DE CONCEITOS

4. A CIÊNCIA E A FÍSICA EM ESPAÇOS NÃO FORMAIS DE ENSINO

5. INOVAÇÕES CURRICULARES E O ENSINO DE FÍSICA: FUNDAMENTOS E AVALIAÇÃO

6. INOVAÇÕES DIDÁTICO-PEDAGÓGICAS PARA O ENSINO DE FÍSICA: FUNDAMENTOS E AVALIAÇÃO

Sessões de Comunicações Orais:

1. ENSINO E APRENDIZAGEM EM FÍSICA

2. FORMAÇÃO INICIAL E CONTINUADA DE PROFESSORES DE FÍSICA

3. RESOLUÇÃO DE PROBLEMAS NO ENSINO DE FÍSICA

4. HISTÓRIA E FILOSOFIA NO ENSINO DE FÍSICA

5. CURRÍCULO NO ENSINO DE FÍSICA

6. O USO DE LABORATÓRIO NO ENSINO DE FÍSICA

7. DIDÁTICA DA FÍSICA

\section{EPEF (1996)}

1. SISTEMAS CONCEITUAIS E HISTÓRIA DA CIÊNCIA

2. FORMAÇÃO DE PROFESSORES E POLÍTICAS INSTITUCIONAIS

3. METODOLOFIA E CURRÍCULO

IV EPEF (1994)

1. FUNDAMENTOS DA PESQUISA EM ENSINO DE FÍSICA

2. OBJETIVOS DA PESQUISA E CONHECIMENTO

3. METODOLOGIAS DE PESQUISA

4. RELAÇÃO ENTRE AS PESQUISAS E O ENSINO DE FÍSICA/CIÊNCIAS NA EDUCAÇÃO ESCOLAR

\section{EPEF}

FUNDAMENTOS DA PESQUISA EM ENSINO DE FÍSICA

METAPESQUISA

OBJETIVOS DA PESQUISA E CONHECIMENTO

METODOLOGIAS DE PESQUISA

RELAÇÃO ENTRE AS PESQUISAS E O ENSINO DE FÍSICA/CIÊNCIAS NA EDUCAÇÃO ESCOLAR

OUTROS

III EPEF (1990)

$-$

\section{EPEF (1988)}

Sessões de Apresentação Oral: 
1. FORMAÇÃO DO PROFESSOR

2. CONCEITOS ALTERNATIVOS/INTUITIVOS/HISTÓRICOS/CIENTÍFICOS

SNEF

XIX SNEF (2011)

1. FORMAÇÃO E PRÁTICA PROFISSIONAL DE PROFESSORES DE FÍSICA

2. APRENDIZAGEM EM FÍSICA

3. FILOSOFIA, HISTÓRIA E SOCIOLOGIA DA CIÊNCIA E O ENSINO DE FÍSICA

4. LINGUAGEM E COGNIÇÃO NO ENSINO DE FÍSICA

5. DIDÁTICA, CURRÍCULO E AVALIAÇÃO NO ENSINO DE FÍSICA

6. DIVULGAÇÃO E COMUNICAÇÃO DE FÍSICA EM ESPAÇOS FORMAIS E NÃO FORMAIS

7. TECNOLOGIA DA INFORMAÇÃO, DIFUSÃO TECNOLÓGICA E O ENSINO DE FÍSICA

8. POLÍTICAS PÚBLICAS E O ENSINO DE FÍSICA

9. QUESTÕES TEÓRICO-METODOLÓGICAS DA PESQUISA EM ENSINO DE FÍSICA

10. CIÊNCIA, TECNOLOGIA E SOCIEDADE

11. ENSINO DE FÍSICA E EXPERIÊNCIAS EM ENSINO E APRENDIZAGEM EM CIÊNCIAS NATURAIS E

MATEMÁTICA NA AMAZÔNIA

\section{SNEF (2009)}

1. DIDÁTICA DA FÍSICA: MATERIAIS, MÉTODOS, ESTRATÉGIAS E AVALIAÇÃO

2. O ENSINO DE FÍSICA PARA A GRADUAÇÃO: FÍSICA, QUIIMICA, BIOLOGIA, OCEANOGRAFIA, ENGENHARIAS, ARQUITETURA, ARTE E ÁREAS A FINS

3. FORMAÇÃO INICIAL E CONTINUADA DO PROFESSOR EM TODOS OS NÍVEIS DE ESCOLARIDADE

4. EDUCAÇÃO CIENTÍFICA E FORMAÇÃO PROFISSIONAL

5. HISTÓRIA, FILOSOFIA E SOCIOLOGIA DA CIÊNCIA E O ENSINO DE FÍSICA

6. TECNOLOGIAS DA INFORMAÇÃO E COMUNICAÇÃO NO ENSINO TEÓRICO E EXPERIMENTAL DE FÍSICA

7. FÍSICA MODERNA E CONTEMPORÂNEA E A ATUALIZAÇÃO CURRICULAR

8. INTERDISCIPLINARIDADE E ENSINO DE FÍSICA

9. ARTE, CULTURA E EDUCAÇÃO CIENTÍFICA

10. ALFABETIZAÇÃO CIENTÍFICA E TECNOLÓGICA E ENSINO DE FÍSICA

11. DIVULGAÇÃO CIENTIIFICA E COMUNICAÇÃO NO ENSINO DE FÍSICA

12. ENSINO DE FÍSICA E ESTRATÉGIAS PARA PORTADORES DE NECESSIDADES ESPECIAIS

13. POLÍTICAS PÚBLICAS E QUESTÕES INSTITUCIONAIS PARA O ENSINO DE CIÊNCIA E DE TECNOLOGIA

\section{SNEF (2007)}

1. DIDÁTICA DA FÍSICA: MATERIAIS, MÉTODOS, ESTRATÉGIAS E AVALIAÇÃO

2. FORMAÇÃO DO PROFESSOR DE FÍSICA (TODOS OS NÍVEIS DE ESCOLARIDADE)

3. EDUCAÇÃO CIENTÍFICA E FORMAÇÃO PROFISSIONAL

4. O ENSINO DE FÍSICA PARA A GRADUAÇÃO (FÍSICA, ENGENHARIAS, QUÍMICA, BIOLOGIA, ARQUITETURA, ARTE, ETC.)

5. ALFABETIZAÇÃO CIENTÍFICA E TECNOLÓGICA E ENSINO DE FÍSICA

6. FILOSOFIA, HISTÓRIA E SOCIOLOGIA DA CIÊNCIA E ENSINO DE FÍSICA

7. TECNOLOGIAS (LABORATÓRIO, VÍDEO E INFORMÁTICA) NO ENSINO DE FÍSICA

8. INTERDISCIPLINARIDADE E ENSINO DE FÍSICA

9. POLÍTICAS PARA O ENSINO DE CIÊNCIA E DE TECNOLOGIA

10. ARTE, CULTURA E EDUCAÇÃO CIENTÍFICA

11. DIVULGAÇÃO CIENTÍFICA E COMUNICAÇÃO NO ENSINO DE FÍSICA.

12. FÍSICA MODERNA E CONTEMPORÂNEA E A ATUALIZAÇÃO CURRICULAR.

13. ENSINO DE FÍSICA E ESTRATÉGIAS PARA PORTADORES DE NECESSIDADES ESPECIAIS

\section{SNEF (2005)}

1. DIDÁTICA DA FÍSICA: MATERIAIS, MÉTODOS, ESTRATÉGIAS E AVALIAÇÃO

2. FORMAÇÃO DO PROFESSOR DE FÍSICA (TODOS OS NÍVEIS DE ESCOLARIDADE)

3. EDUCAÇÃO CIENTÍFICA E FORMAÇÃO PROFISSIONAL

4. O ENSINO DE FÍSICA PARA A GRADUAÇÃO (FÍSICA, ENGENHARIAS, QUÍMICA, BIOLOGIA, ARQUITETURA, ARTE, ETC.) 
5. ALFABETIZAÇÃO CIENTÍFICA E TECNOLÓGICA E ENSINO DE FÍSICA

6. FILOSOFIA, HISTÓRIA E SOCIOLOGIA DA CIÊNCIA E ENSINO DE FÍSICA

7. TECNOLOGIAS (LABORATÓRIO, VÍDEO E INFORMÁTICA) NO ENSINO DE FÍSICA

8. INTERDISCIPLINARIDADE E ENSINO DE FÍSICA

9. POLÍTICAS PARA O ENSINO DE CIÊNCIA E DE TECNOLOGIA

10. ARTE, CULTURA E EDUCAÇÃO CIENTÍFICA

11. DIVULGAÇÃO CIENTÍFICA E COMUNICAÇÃO NO ENSINO DE FÍSICA

12. FÍSICA MODERNA E CONTEMPORÂNEA E A ATUALIZAÇÃO CURRICULAR

13. ENSINO DE FÍSICA E ESTRATÉGIAS PARA PORTADORES DE NECESSIDADES ESPECIAIS

\section{SNEF (2003)}

1. DIDÁTICA DA FÍSICA: MATERIAIS, MÉTODOS, AVALIAÇÃO

2. FORMAÇÃO DO PROFESSOR DE FÍSICA

3. EDUCAÇÃO CIENTÍFICA E FORMAÇÃO PROFISSIONAL

4. ALFABETIZAÇÃO CIENTÍFICA E TECNOLÓGICA E ENSINO DE FÍSICA

5. FILOSOFIA, HISTÓRIA E SOCIOLOGIA DA CIÊNCIA E ENSINO DE FÍSICA

6. TECNOLOGIA DA INFORMAÇÃO E ENSINO DE FÍSICA

7. INTERDISCIPLINARIDADE E ENSINO DE FÍSICA

8. POLÍTICAS PARA O ENSINO DE CIÊNCIA E TECNOLOGIA

9. ARTE, CULTURA E EDUCAÇÃO CIENTÍFICA

10. DIVULGAÇÃO CIENTÍFICA

\section{SNEF (2001)}

(não tem Atas; não tem áreas no Programa)

\section{SNEF (1999)}

Sessões de Painéis

1. INFORMÁTICA NO ENSINO DE FÍSICA

2. HISTÓRIA E FILOSOFIA NO ENSINO DE FÍSICA

3. CURRÍCULOS E O ENSINO SUPERIOR DE FÍSICA

4. FORMAÇÃO CONTINUADA DE PROFESSORES DE FÍSICA E DE CIÊNCIAS

5. MATERIAIS E MÉTODOS PARA O ENSINO DE FÍSICA

6. APRENDIZAGEM INFORMAL E DIVULGAÇÃO CIENTÍFICA

7. ENSINO DE FÍSICA: PRESSUPOSTOS TEÓRICOS

8. ENSINO DE ASTRONOMIA

\section{SNEF (1997)}

\section{SNEF (1995)}

Eixos Temáticos

A. ENFOQUES CURRICULARES

B. ENSINO-APRENDIZAGEM

C. FORMAÇÃO DO PROFESSOR E DO PESQUISADOR EM ENSINO DE FÍSICA

D. DIVULGAÇÃO

Sessões de Painéis

A1. ASTRONOMIA

A2. ENSINO DE FÍSICA NO 30. GRAU

B1. PROPOSTA DE INTERVENÇÃO NO ENSINO DE FÍSICA

B2. EXPERIÊNCIAS E INOVAÇÕES NO ENSINO DE FÍSICA

B3. INOVAÇÕES CURRICULARES E DIDÁTICAS

C1. A PESQUISA E O ENSINO DE FÍSICA

C2. EXPERIÊNCIAS E INOVAÇÕES NO ENSINO DE FÍSICA

Sessões de Comunicações Orais

A1. CONTEÚDOS CURRICULARES 

A2. ASTRONOMIA
B1. O CONHECIMENTO CIENTÍFICO EM DISCUSSÃO
B2. RELATOS DE EXPERIÊNCIAS DE ENSINO
B3. RECURSOS DIDÁTICOS PARA O ENSINO DE FÍSICA
C1. CONCEPÇÕES PEDAGÓGICAS DOS PROFESSORES
C2. FORMAÇÃO DE PROFESSORES

\section{SNEF (1993)}

\section{Sessões de Comunicações Orais}

1. PESQUISA EM ENSINO DE FÍSICA: PROCESSOS DE APRENDIZAGEM

2. EXPERIÊNCIAS DIDÁTICAS

3. ENSINO DE CIÊNCIAS NO 10. GRAU

4. PESQUISA EM ENSINO DE FÍSICA: ASPECTOS HISTÓRICO-SOCIAIS

5. ENSINO DE FÍSICA MODERNA

6. PROPOSTAS CURRICULARES DE CURSOS DE GRADUAÇÃO EM FÍSICA

7. TRABALHOS EXPERIMENTAIS

8. HISTÓRIA E EPISTEMOLOGIA NO ENSINO DA FÍSICA

9. PESQUISA E AVALIAÇÃO EM ENSINO DE FÍSICA

10. GRUPOS DE ENSINO DE CIÊNCIAS

11. ATUALIZAÇÃO DE PROFESSORES

12. SIMULAÇÃO COMPUTACIONAL NO ENSINO DE FÍSICA

\section{Sessão de Painéis}

1. O LABORATÓRIO NO ENSINO DE FÍSICA

2. ENSINO DE CIÊNCIAS NO 1O. GRAU

3. EXPERIÊNCIAS DIDÁTICAS

4. PESQUISA EM ENSINO DE FÍSICA

5. HISTÓRIA E FILOSOFIA NO ENSINO DA FÍSICA

6. FORMAÇÃO DE PROFESSORES: AVALIAÇÃO

7. EXPOSIÇÕES E SIMULAÇÃO COMPUTACIONAL

8. AVALIAÇÃO DE CURSO DE FÍSICA

9. CURRÍCULOS E ENSINO DO 30. GRAU

10. AVALIAÇÃO

\section{SNEF (1991)}

1. ENSINO E APRENDIZAGEM DE FÍSICA

2. FORMAÇÃO E PRÁTICA PROFISSIONAL DE PROFESSORES DE FÍSICA

3. FILOSOFIA, HISTÓRIA E SOCIOLOGIA DA CIÊNCIA NO ENSINO DE FÍSICA

4. DIVULGAÇÃO E COMUNICAÇÃO DE CIÊNCIAS - FÍSICA EM ESPAÇOS ESCOLARES E NÃO ESCOLAR

5. TECNOLOGIA DA INFORMAÇÃO E INSTRUMENTAÇÃO NO ENSINO DE FÍSICA

6. CIÊNCIAS, TECNOLOGIA E SOCIEDDE

7. ALFABETIZAÇÃO E LETRAMENTO EM FÍSICA E TECNOLOGIA

8. DIDÁTICA, CURRÍCULO E AVALIAÇÃO NO ENSINO DE FÍSICA

9. POLÍTICAS PÚBLICAS E ENSINO DE FÍSICA

10. LINGUAGEM E COGNIÇÃO NO ENSINO DE FÍSICA E TECNOLOGIA

\section{SNEF (1989)}

1. INFORMÁTICA NO ENSINO DE FÍSICA

2. HISTÓRIA E FILOSOFIA NO ENSINO DE FÍSICA

3. CURRÍCULOS E O ENSINO SUPERIOR

4. FORMAÇÃO CONTINUADA DE PROFESSORES DE FÍSICA E CIÊNCIAS

5. MATERIAIS E MÉTODOS PARA O ENSINO DE FÍSICA

6. APRENDIZAGEM INFORMAL E DIVULGAÇÃO CIENTÍFICA

7. ENSINO DE FÍSICA: PRESSUPOSTOS TEÓRICOS

8. ENSINO DE ASTRONOMIA 


\section{ENPEC}

I ENPEC (1997)

\section{ENPEC (1999)}

III ENPEC (2001)

\section{ENPEC (2003)}

1. ENSINO / APRENDIZAGEM DE CIÊNCIAS

2. FORMAÇÃO DE PROFESSORES DE CIÊNCIAS

3. FILOSOFIA, HISTÓRIA E SOCIOLOGIA DA CIÊNCIA NO ENSINO DE CIÊNCIAS

4. EDUCAÇÃO EM ESPAÇOS NÃO-FORMAIS E DIVULGAÇÃO CIENTÍFICA

5. TECNOLOGIA DA INFORMAÇÃO, INSTRUMENTAÇÃO E DIFUSÃO TECNOLÓGICAS

6. AS RELAÇÕES ENTRE CIÊNCIA, TECNOLOGIA, SOCIEDADE E AMBIENTE NO NO ENSINO DE CIÊNCIAS

7. LINGUAGEM, COGNIÇÃO E ENSINO DE CIÊNCIAS

8. ALFABETIZAÇÃO CIENTÍFICA E TECNOLÓGICA E ENSINO DE CIÊNCIAS

9. COMUNIDADE, PRÁTICAS E POLÍTICAS EDUCACIONAIS

\section{$\checkmark$ ENPEC (2005)}

(idem IV ENPEC)

\section{ENPEC (2007)}

\section{ENPEC (2009)}

1. APRENDIZAGEM DE CONCEITOS CIENTÍFICOS

2. FORMAÇÃO DE PROFESSORES DE CIÊNCIAS

3. HISTÓRIA, FILOSOFIA E SOCIOLOGIA DA CIÊNCIA NO ENSINO DE CIÊNCIAS

4. EDUCAÇÃO EM ESPAÇOS NÃO-FORMAIS E DIVULGAÇÃO CIENTÍFICA

5. TECNOLOGIA DA INFORMAÇÃO E COMUNICAÇÃO E ENSINO DE CIÊNCIAS

6. EDUCAÇÃO AMBIENTAL E ENSINO DE CIÊNCIAS

7. EDUCAÇÃO EM SAÚDE E ENSINO DE CIÊNCIAS

8. LINGUAGEM, COGNIÇÃO E ENSINO DE CIÊNCIAS

9. ALFABETIZAÇÃO CIENTÍFICA E TECNOLÓGICA, ABORDAGENS CTS E ENSINO DE CIÊNCIAS

10. CURRÍCULOS E POLÍTICAS EDUCACIONAIS NO ENSINO DE CIÊNCIAS

11. MODELOS E MODELAGEM NA EDUCAÇÃO EM CIÊNCIAS

12. AVALIAÇÃO NA EDUCAÇÃO EM CIÊNCIAS

13. DIVERSIDADE, MULTICULTURALISMO E EDUCAÇÃO EM CIÊNCIAS

14. ENSINO POR INVESTIGAÇÃO, EXPERIMENTAÇÃO E APRENDIZAGEM DE HABILIDADES CIENTÍFICAS 


\section{ANEXO 4.2 \\ ÁREAS TEMÁTICAS DOS EPEFS}




\section{ÁREAS TEMÁTICAS DOS EPEFS}

\begin{tabular}{|c|c|c|c|c|c|c|c|c|c|c|c|c|c|c|c|}
\hline \multirow{2}{*}{\multicolumn{4}{|c|}{$\begin{array}{l}\text { EPEFS: } \\
\text { TEMÁTICA X EDIÇÃO }\end{array}$}} & \multicolumn{12}{|c|}{ EDIÇÃO / ANO } \\
\hline & & & & \multirow{2}{*}{$\begin{array}{c}\text { I } \\
1986 \\
X\end{array}$} & \multirow{2}{*}{$\begin{array}{c}\text { II } \\
1988\end{array}$} & \multirow{2}{*}{$\begin{array}{c}\text { III } \\
1990 \\
-\end{array}$} & \multirow{2}{*}{$\begin{array}{c}\text { IV } \\
1994\end{array}$} & \multirow{2}{*}{$\begin{array}{c}V \\
1996\end{array}$} & \multirow{2}{*}{$\begin{array}{l}\text { VI } \\
1998 \\
X\end{array}$} & \multirow{2}{*}{$\begin{array}{c}\text { VII } \\
2000 \\
X\end{array}$} & \multirow{2}{*}{$\begin{array}{c}\text { VIII } \\
2002 \\
X\end{array}$} & \multirow{2}{*}{$\begin{array}{c}\text { IX } \\
2004 \\
X\end{array}$} & \multirow{2}{*}{$\begin{array}{c}x \\
2006 \\
X\end{array}$} & \multirow{2}{*}{$\begin{array}{c}\begin{array}{c}X I \\
2008\end{array} \\
X\end{array}$} & \multirow{2}{*}{$\begin{array}{c}\text { XII } \\
2010 \\
X X\end{array}$} \\
\hline \multirow{3}{*}{$\begin{array}{l}\text { Á } \\
R \\
E \\
A\end{array}$} & 1 & 1 & $\begin{array}{l}\text { ENSINO - APRENDIZAGEM - AVALIAÇÃO } \\
\text { (geral) }\end{array}$ & & & & & & & & & & & & \\
\hline & & 2 & $\begin{array}{l}\text { CONCEPÇÕES ALTERNATIVAS / ENSINO } \\
\text { DIAGNÓSTICO }\end{array}$ & $\mathrm{x}$ & $\mathrm{x}$ & - & & & & & & & & & \\
\hline & & 3 & $\begin{array}{l}\text { LINGUAGEM E COGNIIÇ̃̃O NO ENSINO DE } \\
\text { FÍSICA }\end{array}$ & & & - & & & $\mathrm{x}$ & $\mathrm{x}$ & & $\mathrm{x}$ & $\mathrm{x}$ & & $\mathrm{x}$ \\
\hline \multirow{5}{*}{$\begin{array}{l}\mathrm{T} \\
\mathrm{E} \\
\mathrm{M} \\
\mathrm{A} \\
\mathrm{T} \\
\mathrm{I} \\
\mathrm{C} \\
\mathrm{A}\end{array}$} & II & 4 & $\begin{array}{l}\text { DIDÁTICA, CURRÍCULO E INOVAÇÃO } \\
\text { EDUCACIONAL NO ENSINO DE FÍSICA }\end{array}$ & $\mathrm{x}$ & & - & & $\mathrm{x}$ & $\mathrm{x}$ & $\mathrm{x}$ & $\mathrm{x}$ & $\mathrm{x}$ & $\mathrm{x}$ & $\mathrm{x}$ & $\mathrm{x}$ \\
\hline & III & 5 & FORMAÇÃO DE PROFESSORES & & $\mathrm{x}$ & - & & $\mathrm{x}$ & $\mathrm{x}$ & $\mathrm{x}$ & $x$ & $\mathrm{x}$ & $x$ & $x$ & $x$ \\
\hline & IV & 6 & $\begin{array}{l}\text { FILOSOFIA, HISTÓRIA E SOCIOLOGIA DA } \\
\text { CIÊNCIA NO ENSINO DE FÍSICA }\end{array}$ & & & - & & $\mathrm{x}$ & $\mathrm{x}$ & $\mathrm{x}$ & $\mathrm{x}$ & $\mathrm{x}$ & $\mathrm{x}$ & $\mathrm{x}$ & $\mathrm{x}$ \\
\hline & $\mathrm{V}$ & 7 & $\begin{array}{l}\text { EDUCAÇÃO EM ESPAÇOS NÃO-FORMAIS E } \\
\text { DIVULGAÇÃO CIENTÍFICA }\end{array}$ & & & - & & & & $\mathrm{x}$ & $\mathrm{x}$ & $\mathrm{x}$ & $\mathrm{x}$ & $\mathrm{x}$ & $\mathrm{x}$ \\
\hline & $\mathrm{VI}$ & 8 & $\begin{array}{l}\text { TECNOLOGIAS DA INFORMAÇÃO E } \\
\text { COMUNICAÇÃO E O ENSINO DE FÍSICA }\end{array}$ & & & - & & & & & $\mathrm{x}$ & $\mathrm{x}$ & $\mathrm{x}$ & $\mathrm{x}$ & $\mathrm{x}$ \\
\hline & VII & 9 & CTSA E O ENSINO DE FÍSICA & & & - & & & & & $x$ & $\mathrm{x}$ & $x$ & $x$ & $x$ \\
\hline & VIII & 10 & $\begin{array}{l}\text { ALFABETIZAÇÃO CIENTíFICA E TECNOLÓGICA } \\
\text { E ENSINO DE FÍSICA }\end{array}$ & & & - & & & & & $\mathrm{x}$ & $\mathrm{x}$ & & $\mathrm{x}$ & \\
\hline & IX & 11 & $\begin{array}{l}\text { COMUNIDADE, PRÁTICAS E POLÍTICAS } \\
\text { EDUCACIONAIS }\end{array}$ & & & - & & & & $\mathrm{x}$ & $\mathrm{x}$ & $\mathrm{x}$ & $\mathrm{x}$ & $\mathrm{x}$ & $X$ \\
\hline & $\mathrm{x}$ & 12 & PESQUISA EM ENSINO DE FÍSICA & & & - & $\mathrm{x}$ & & & $\mathrm{x}$ & & & $\mathrm{x}$ & $\mathrm{x}$ & $\mathrm{x}$ \\
\hline
\end{tabular}


ANEXO 7.1

(MOREIRA, 2002) 
Anexo de MOREIRA, 2002.

Em 2001

- Mestrado em Ensino, Filosofia e História das Ciências da UFBA/UEFS. Aprovado conceito 3.

- Mestrado em Educação Matemática da PUCSP. Aprovado, conceito 4.

- Mestrado em Ensino de Ciências, modalidades Física e Química, da USP. Aprovado, conceito 4.

- Mestrado em Educação Matemática da USU. Aprovado, conceito 3.

- Mestrado em Educação para a Ciência da UNESP/Bauru. Aprovado, conceito 4.

- Mestrado em Ensino de Ciências e Matemática da UFPA. Aprovado, conceito 3.

- Mestrado Profissionalizante em Ensino de Matemática da PUCSP. Aprovado, conceito 3.

- Mestrado Profissionalizante em Ensino de Ciências e Matemática da PUCRS. Aprovado, conceito 3.

- Doutorado em Educação Matemática da PUCSP. Em diligência.

- Mestrado Profissionalizante em Ensino de Física da UFRGS. Aprovado, conceito 4.

- Mestrado em Ensino de Ciências e Matemática da ULBRA. Aprovado, conceito 3.

- Mestrado em Ensino de Ciências e Educação Matemática da UEL. Aprovado, conceito 3.

- Mestrado em Ensino de Ciências da UFRPE. Aprovado, conceito 3.

- Mestrado Profissionalizante em Ensino de Ciências Naturais e Matemática da UFRN. Aprovado, conceito 3.

- Mestrado Profissionalizante em Ensino de Matemática da UNINOVE. Em diligência.

- Mestrado em Educação Científica e Tecnológica da UFSC. Aprovado, conceito 4.

- Doutorado em Educação Científica e Tecnológica da UFSC. Aprovado, conceito 4.

- Mestrado Profissionalizante em Ensino de Ciências e Matemática do CEFET-RJ. Em diligência.

- Mestrado em Ensino de Ciências da Saúde da UNIFESP. Conceito 3.

- Mestrado Profissionalizante em Ensino de Ciências da Saúde da UNIFESP. Conceito 3.

- Doutorado em Educação para a Ciência da UNESP/Bauru. Conceito 4.

- Mestrado Profissionalizante em Ensino de Ciências e Matemática do CEFET-RJ. Conceito.

Tais recomendações foram acatadas pelo CTC da CAPES, nas reuniões de novembro e dezembro, de modo que a Área concluiu 2002 com 11 mestrados acadêmicos, 06 mestrados profissionais e 03 doutorados, conforme indicado a seguir.

- Mestrado em Ensino, Filosofia e História das Ciências da UFBA/UEFS. Conceito 3.

- Mestrado em Educação Matemática da PUCSP. Conceito 4.

- Mestrado em Ensino de Ciências, modalidades Física e Química, da USP. Conceito 4.

- Mestrado em Educação Matemática da USU. Conceito 3.

- Mestrado em Educação para a Ciência da UNESP/Bauru. Conceito 4.

- Mestrado em Ensino de Ciências e Matemática da UFPA. Conceito 3.

- Mestrado Profissionalizante em Ensino de Matemática da PUCSP. Conceito 3.

- Mestrado Profissionalizante em Ensino de Ciências e Matemática da PUCRS. Conceito 3.

- Doutorado em Educação Matemática da PUCSP. Conceito 4.

- Mestrado Profissionalizante em Ensino de Física da UFRGS. Conceito 4. 
- Mestrado em Ensino de Ciências e Matemática da ULBRA. Conceito 3.

- Mestrado em Ensino de Ciências e Educação Matemática da UEL. Conceito 3.

- Mestrado em Ensino de Ciências da UFRPE. Conceito 3.

- Mestrado Profissionalizante em Ensino de Ciências Naturais e Matemática da UFRN. Conceito 3.

- Mestrado em Educação Científica e Tecnológica da UFSC. Conceito 4.

- Doutorado em Educação Científica e Tecnológica da UFSC. Conceito 4.

- Mestrado em Ensino de Ciências da Saúde da UNIFESP. Conceito 3.

- Mestrado Profissionalizante em Ensino de Ciências da Saúde da UNIFESP. Conceito 3.

- Doutorado em Educação para a Ciência da UNEPS/Bauru. Conceito 3.

- Mestrado Profissionalizante em Ensino de Ciências e Matemática do CEFET-RJ. Conceito 3. 


\begin{abstract}
ANEXO 7.2
RELAÇÃO DE PROGRAMAS NA ÁREA DE ENSINO DE CIÊNCIAS E MATEMÁTICA DA CAPES
\end{abstract}


RELAÇÃO DE PROGRAMAS NA ÁREA DE ENSINO DE CIÊNCIAS E MATEMÁTICA DA CAPES

\begin{tabular}{|c|c|c|c|c|c|c|c|}
\hline & INSTITUIÇÃO & PROGRAMA & UF & $\begin{array}{l}\text { DEPENDÊNCIA } \\
\text { ADMNISTRATIVA* }\end{array}$ & $\begin{array}{l}\text { Mestrado } \\
\text { Acadêmico }\end{array}$ & Doutorado & $\begin{array}{l}\text { Mestrado } \\
\text { Profissional }\end{array}$ \\
\hline 1. & CEFET/MG & EDUCAÇÃO TECNOLÓGICA & MG & PUB-F & $x$ & & \\
\hline 2. & CEFET/RJ & $\begin{array}{l}\text { CIÊNCIA TECNOLOGIA E } \\
\text { EDUCAÇÃO }\end{array}$ & RJ & PUB-F & $\mathrm{x}$ & & \\
\hline 3. & CEFET/RJ & $\begin{array}{l}\text { ENSINO DE CIÊNCIAS E } \\
\text { MATEMÁTICA }\end{array}$ & RJ & PUB-F & & & $\mathrm{x}$ \\
\hline 4. & FIOCRUZ & $\begin{array}{l}\text { ENSINO EM BIOCIÊNCIAS E } \\
\text { SAÚDE }\end{array}$ & RJ & PUB-F & $\mathrm{x}$ & $x$ & \\
\hline 5. & FUFSE & $\begin{array}{l}\text { ENSINO DE CIÊNCIAS E } \\
\text { MATEMÁTICA }\end{array}$ & SE & PUB-F & $\mathrm{x}$ & & \\
\hline 6. & FURB & $\begin{array}{l}\text { ENSINO DE CIÊNCIAS } \\
\text { NATURAIS E MATEMÁTICA }\end{array}$ & SC & PUB-M & & & $x$ \\
\hline 7. & IFES & $\begin{array}{l}\text { EDUCAÇÃO EM CIÊNCIA E } \\
\text { MATEMÁTICA }\end{array}$ & ES & PUB-F & & & $x$ \\
\hline 8. & IFRJ & ENSINO DE CIÊNCIAS & RJ & PUB-F & & & $x$ \\
\hline 9. & PUC/MG & ENSINO & MG & PRI-CONF & & & $x$ \\
\hline 10. & PUC/RS & $\begin{array}{l}\text { EDUCAÇÃO EM CIÊNCIAS E } \\
\text { MATEMÁTICA }\end{array}$ & RS & PRI-CONF & $x$ & & \\
\hline 11. & $\mathrm{PUC} / \mathrm{SP}$ & EDUCAÇÃO MATEMÁTICA & SP & PRI-CONF & $x$ & $x$ & \\
\hline 12. & PUC/SP & EDUCAÇÃO MATEMÁTICA & SP & PRI-CONF & & & $x$ \\
\hline 13. & UEA & $\begin{array}{l}\text { EDUCAÇÃO EM CIÊNCIAS } \\
\text { NA AMAZÔNIA }\end{array}$ & AM & PUB-E & $\mathrm{x}$ & & \\
\hline 14. & UEA & $\begin{array}{l}\text { ENSINO DE CIÊNCIAS NA } \\
\text { AMAZÔNIA }\end{array}$ & AM & PUB-E & & & $\mathrm{x}$ \\
\hline 15. & UEL & $\begin{array}{l}\text { ENSINO DE CIÊNCIAS E } \\
\text { EDUCAÇÃO MATEMÁTICA }\end{array}$ & $P R$ & PUB-E & $\mathrm{x}$ & $x$ & \\
\hline 16. & UEM & $\begin{array}{l}\text { EDUCAÇÃO PARA A } \\
\text { CIEÊNCIA E A } \\
\text { MATEMÁTICA }\end{array}$ & $P R$ & PUB-E & $\mathrm{x}$ & $x$ & \\
\hline 17. & UEPA & $\begin{array}{l}\text { ENSINO EM SAÚDE NA } \\
\text { AMAZÔNIA }\end{array}$ & AM & PUB-E & & & $\mathrm{x}$ \\
\hline 18. & UEPB & $\begin{array}{l}\text { ENSINO DE CIÊNCIAS E } \\
\text { MATEMÁTICA }\end{array}$ & PB & PUB-E & & & $\mathrm{x}$ \\
\hline 19. & UERR & ENSINO DE CIÊNCIAS & $\mathrm{RR}$ & PUB-E & & & $x$ \\
\hline 20. & UESB & $\begin{array}{l}\text { EDUCAÇÃO CIENTÍFICA E } \\
\text { FORMAÇÃO DE } \\
\text { PROFESSORES }\end{array}$ & $\mathrm{BA}$ & PUB-E & $\mathrm{x}$ & & \\
\hline 21. & UFABC & $\begin{array}{l}\text { ENSINO, FILOSOFIA E } \\
\text { HISTÓRIA DAS CIÊNCIAS E } \\
\text { MATEMÁTICA }\end{array}$ & SP & PUB-F & $x$ & & \\
\hline 22. & UFAL & $\begin{array}{l}\text { ENSINO DE CIÊNCIAS E } \\
\text { MATEMÁTICA }\end{array}$ & $\overline{\mathrm{AL}}$ & PUB-F & & & $\mathrm{x}$ \\
\hline 23. & UFBA & $\begin{array}{l}\text { ENSINO, FILOSOFIA E } \\
\text { HISTÓRIA DAS CIÊNCIAS }\end{array}$ & $\mathrm{BA}$ & PUB-F & $x$ & $x$ & \\
\hline 24. & UFC & $\begin{array}{l}\text { ENSINO DE CIÊNCIAS E } \\
\text { MATEMÁTICA }\end{array}$ & CE & PUB-F & & & $\mathrm{x}$ \\
\hline 25. & UFES & ENSINO DE FÍSICA & ES & PUB-E & & & $\mathrm{x}$ \\
\hline 26. & UFF & $\begin{array}{l}\text { ENSINO DE CIÊNCIAS DA } \\
\text { NATUREZA }\end{array}$ & RJ & PUB-F & & & $x$ \\
\hline 27. & UFG & $\begin{array}{l}\text { EDUCAÇÃO EM CIÊNCIAS E } \\
\text { MATEMÁTICA }\end{array}$ & GO & PUB-F & $\mathrm{x}$ & & \\
\hline 28. & UFJF & EDUCAÇÃO MATEMÁTICA & MG & PUB-F & & & $\mathrm{x}$ \\
\hline 29. & UFMS & EDUCAÇÃO MATEMÁTICA & MS & PUB-F & $\mathrm{x}$ & & \\
\hline 30. & UFMS & ENSINO DE CIÊNCIAS & MS & PUB-F & & & $x$ \\
\hline
\end{tabular}




\begin{tabular}{|c|c|c|c|c|c|c|c|}
\hline 31. & UFMT & $\begin{array}{l}\text { ENSINO DE CIÊNCIAS } \\
\text { NATURAIS }\end{array}$ & MT & PUB-F & & & $x$ \\
\hline 32. & UFMT & $\begin{array}{l}\text { EDUCAÇÃO EM CIÊNCIAS E } \\
\text { MATEMÁTICA }\end{array}$ & MT & PUB-F & & $x$ & \\
\hline 33. & UFOP & EDUCAÇÃO MATEMÁTICA & MG & PUB-F & & & $x$ \\
\hline 34. & UFPA & $\begin{array}{l}\text { EDUCAÇÃO EM CIÊNCIAS E } \\
\text { MATEMÁTICAS }\end{array}$ & PA & PUB-F & $x$ & $x$ & \\
\hline 35. & UFPE & $\begin{array}{l}\text { EDUCAÇÃO MATEMÁTICA } \\
\text { E TECNOLÓGICA }\end{array}$ & $\mathrm{PE}$ & PUB-F & $\mathrm{x}$ & & \\
\hline 36. & UFPEL & $\begin{array}{l}\text { ENSINO DE CIÊNCIAS E } \\
\text { MATEMÁTICA }\end{array}$ & RS & PUB-F & & & $\mathrm{x}$ \\
\hline 37. & UFPR & $\begin{array}{l}\text { EDUCAÇÃO EM CIÊNCIAS E } \\
\text { EM MATEMÁTICA }\end{array}$ & PR & PUB-F & $\mathrm{x}$ & & \\
\hline 38. & UFRGS & $\begin{array}{l}\text { EDUCAÇÃO EM CIÊNCIAS } \\
\text { QUÍMICAS DA VIDA E } \\
\text { SAÚDE }\end{array}$ & RS & PUB-F & $x$ & $x$ & \\
\hline 39. & UFRGS & ENSINO DE FÍSICA & RS & PUB-F & $\mathrm{x}$ & $x$ & \\
\hline 40. & UFRGS & ENSINO DE FÍSICA & RS & PUB-F & & & $\mathrm{x}$ \\
\hline 41. & UFRGS & ENSINO DE MATEMÁTICA & RS & PUB-F & & & $\mathrm{x}$ \\
\hline 42. & UFRJ & $\begin{array}{l}\text { EDUCAÇÃO EM CIÊNCIAS E } \\
\text { SAÚDE }\end{array}$ & RJ & PUB-F & $x$ & $x$ & \\
\hline 43. & UFRJ & ENSINO DE MATEMÁTICA & RJ & PUB-F & $\mathrm{x}$ & & \\
\hline 44. & UFRJ & ENSINO DE FÍSICA & RJ & PUB-F & & & $x$ \\
\hline 45. & UFRN & $\begin{array}{l}\text { ENSINO DE CIÊNCIAS } \\
\text { NATURAIS E MATEMÁTICA }\end{array}$ & $\mathrm{RN}$ & PUB-F & & & $x$ \\
\hline 46. & UFRPE & ENSINO DAS CIÊNCIAS & $\mathrm{PE}$ & PUB-F & $\mathrm{x}$ & $x$ & \\
\hline 47. & UFSC & $\begin{array}{l}\text { EDUCAÇÃO CIENTÍFICA E } \\
\text { TECNOLÓGICA }\end{array}$ & SC & PUB-F & $x$ & $x$ & \\
\hline 48. & UFSCAR & $\begin{array}{l}\text { ENSINO DE CIÊNCIAS } \\
\text { EXATAS }\end{array}$ & SP & PUB-F & & & $x$ \\
\hline 49. & ULBRA & $\begin{array}{l}\text { ENSINO DE CIÊNCIAS E } \\
\text { MATEMÁTICA }\end{array}$ & RS & PRI & $\mathrm{x}$ & $x$ & \\
\hline 50. & UNAERP & SAÚDE E EDUCAÇÃO & SP & PRI & & & $x$ \\
\hline 51. & UNB & ENSINO DE CIÊNCIAS & DF & PUB-F & & & $x$ \\
\hline 52. & UNESP/BAURU & $\begin{array}{l}\text { EDUCAÇÃO PARA A } \\
\text { CIÊNCIA }\end{array}$ & SP & PUB-E & $x$ & $\mathrm{x}$ & \\
\hline 53. & UNESP/RC & EDUCAÇÃO MATEMÁTICA & SP & PUB-E & $x$ & $x$ & \\
\hline 54. & UNIBAN & EDUCAÇÃO MATEMÁTICA & SP & PRI & $\mathrm{x}$ & $\mathrm{x}$ & \\
\hline 55. & UNICAMP & $\begin{array}{l}\text { ENSINO E HISTÓRIA DE } \\
\text { CIÊNCIAS DA TERRA }\end{array}$ & SP & PUB-E & $x$ & $x$ & \\
\hline 56. & UNICAMP & $\begin{array}{l}\text { MULTIUNIDADES EM } \\
\text { ENSINO DE CIÊNCIAS E } \\
\text { MATEMÁTICA }\end{array}$ & SP & PUB-E & $\mathrm{x}$ & $\mathrm{x}$ & \\
\hline 57. & UNICSUL & ENSINO DE CIÊNCIAS & SP & PRI & $x$ & $x$ & \\
\hline 58. & UNICSUL & $\begin{array}{l}\text { ENSINO DE CIÊNCIAS E } \\
\text { MATEMÁTICA }\end{array}$ & SP & PRI & & & $x$ \\
\hline 59. & UNIFEI & ENSINO DE CIÊNCIAS & MG & PUB-F & & & $\mathrm{x}$ \\
\hline 60. & UNIFESP & $\begin{array}{l}\text { ENSINO EM CIÊNCIAS DA } \\
\text { SAÚDE }\end{array}$ & SP & PUB-F & $x$ & & \\
\hline 61. & UNIFESP & $\begin{array}{l}\text { ENSINO EM CIÊNCIAS DA } \\
\text { SAÚDE }\end{array}$ & SP & PUB-F & & & $x$ \\
\hline 62. & UNIFOA & $\begin{array}{l}\text { ENSINO EM CIÊNCIAS DA } \\
\text { SAÚDE E DO MEIO } \\
\text { AMBIENTE }\end{array}$ & RJ & PUB-F & & & $x$ \\
\hline 63. & UNIFRA & $\begin{array}{l}\text { ENSINO DE FÍSICA E } \\
\text { MATEMÁTICA }\end{array}$ & RS & PRI & & & $x$ \\
\hline
\end{tabular}




\begin{tabular}{|c|c|c|c|c|c|c|c|}
\hline 64. & UNIGRANRIO & ENSINO DAS CIÊNCIAS & RJ & PRI & & & $\mathrm{x}$ \\
\hline 65. & UNIPAMPA & ENSINO DE CIÊNCIAS & RS & PUB-F & & & $x$ \\
\hline 66. & UNIPLI & $\begin{array}{l}\text { ENSINO DE CIÊNCIAS DA } \\
\text { SAÚDE E DO AMBIENTE }\end{array}$ & RJ & PRI & & & $x$ \\
\hline 67. & UNIVATES & $\begin{array}{l}\text { ENSINO DE CIÊNCIAS } \\
\text { EXATAS }\end{array}$ & RS & PRI & & & $x$ \\
\hline 68. & URI & $\begin{array}{l}\text { ENSINO CIENTÍFICO E } \\
\text { TECNOLGICA }\end{array}$ & RS & PRI & & & $\mathrm{x}$ \\
\hline 69. & USP & $\begin{array}{l}\text { ENSINO DE CIÊNCIAS } \\
\text { (MODALIDADES FÍSICA, } \\
\text { QUÍMICA E BIOLOGIA) }\end{array}$ & SP & PUB-E & $\mathrm{x}$ & $\mathrm{x}$ & \\
\hline 70. & USS & EDUCAÇÃO MATEMÁTICA & RJ & PRI & & & $\mathrm{x}$ \\
\hline 71. & UTFPR & $\begin{array}{l}\text { ENSINO DE CIÊNCIA E } \\
\text { TECNOLOGIA }\end{array}$ & $P R$ & PUB-F & & & $\mathrm{x}$ \\
\hline 72. & UTFPR & $\begin{array}{l}\text { FORMAÇÃO CIENTÍFICA, } \\
\text { EDUCACIONAL E } \\
\text { TECNOLÓGICA }\end{array}$ & $P R$ & PUB-F & & & $\mathrm{x}$ \\
\hline
\end{tabular}

* PRI - Privada; PRI-CONF - Privada Confessional; PUB-F - Pública-Federal; PUB-E - Pública-Estadual; PUB-M - Pública-Municipal 